\title{
Coal Geology and Assessment of Coal Resources and Reserves in the Powder River Basin, Wyoming and Montana
}

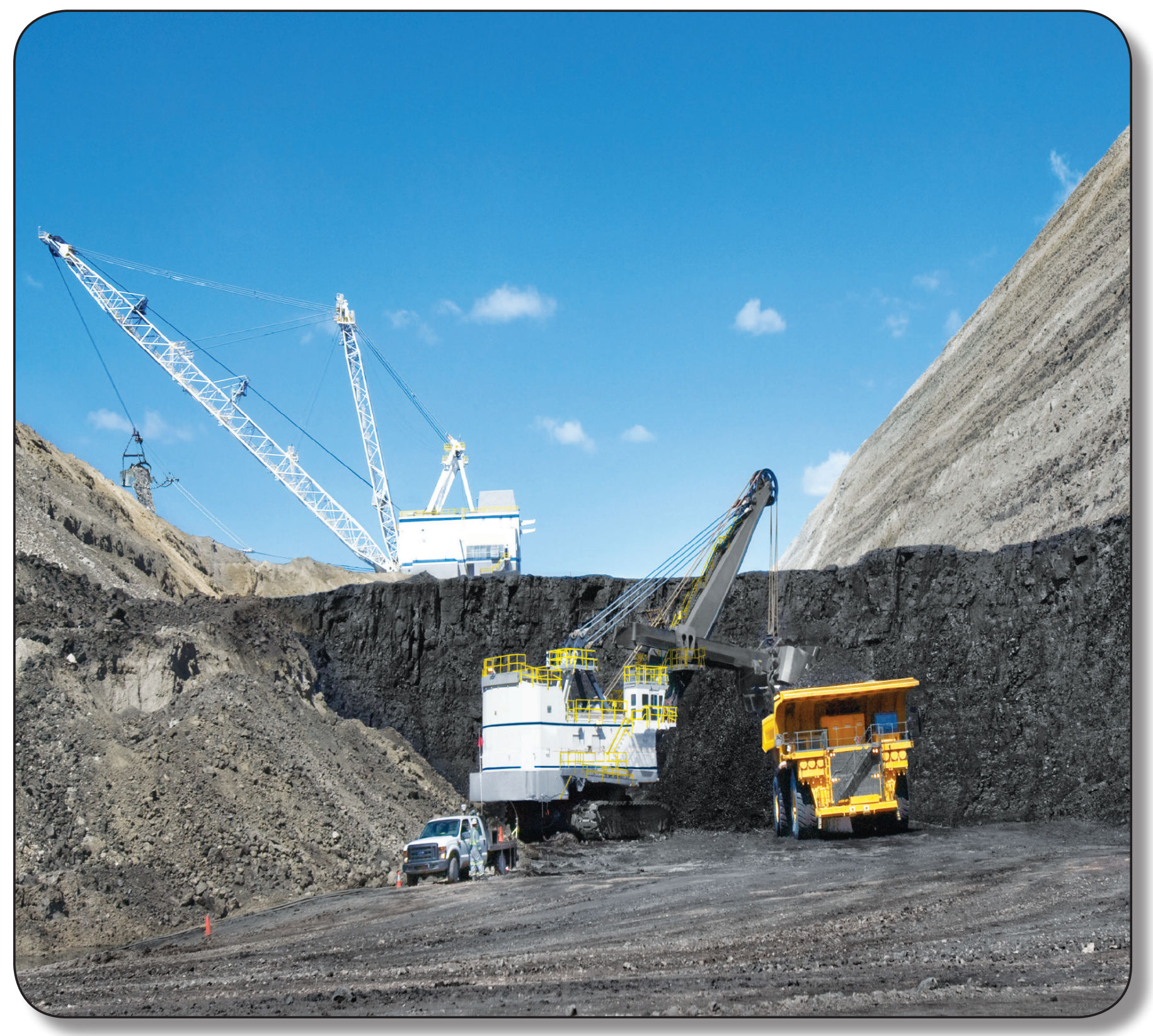

Professional Paper 1809 
Cover: Photograph showing surface coal mining in the Powder River Basin. 


\section{Coal Geology and Assessment of Coal Resources and Reserves in the Powder River Basin, Wyoming and Montana}

By James A. Luppens, David C. Scott, Jon E. Haacke, Lee M. Osmonson, and Paul E. Pierce

Professional Paper 1809 


\title{
U.S. Department of the Interior SALLY JEWELL, Secretary
}

\section{U.S. Geological Survey \\ Suzette M. Kimball, Acting Director}

\author{
U.S. Geological Survey, Reston, Virginia: 2015
}

For more information on the USGS — the Federal source for science about the Earth, its natural and living resources, natural hazards, and the environment, visit http://www.usgs.gov or call 1-888-ASK-USGS.

For an overview of USGS information products, including maps, imagery, and publications, visit http://www.usgs.gov/pubprod

To order this and other USGS information products, visit http://store.usgs.gov

Any use of trade, firm, or product names is for descriptive purposes only and does not imply endorsement by the U.S. Government.

Although this information product, for the most part, is in the public domain, it also may contain copyrighted materials as noted in the text. Permission to reproduce copyrighted items must be secured from the copyright owner.

Suggested citation:

Luppens, J.A., Scott, D.C., Haacke, J.E, Osmonson, L.M., and Pierce, P.E., 2015, Coal geology and assessment of coal resources and reserves in the Powder River Basin, Wyoming and Montana: U.S. Geological Survey Professional Paper 1809, 218 p., http://dx.doi.org/10.3133/pp1809.

\section{Library of Congress Cataloging-in-Publication Data}

Luppens, James A. (James Alan), 1946-

Coal geology and assessment of coal resources and reserves in the Powder River Basin, Wyoming and Montana / by James A. Luppens, David C. Scott, Jon E.

Haacke, Lee M. Osmonson, and Paul E. Pierce.

pages cm. -- (Professional paper ; 1809)

Includes bibliographical references and index. ISBN 978-1-4113-3875-3 (pbk. : alk. paper)

1. Coal reserves--Powder River Basin (Wyo. and Mont.) 2. Coal--Geology--Powder

River Basin (Wyo. and Mont.) I. Title.

TN805.W8L87 2015

553.2'4097871--dc23 


\section{Contents}

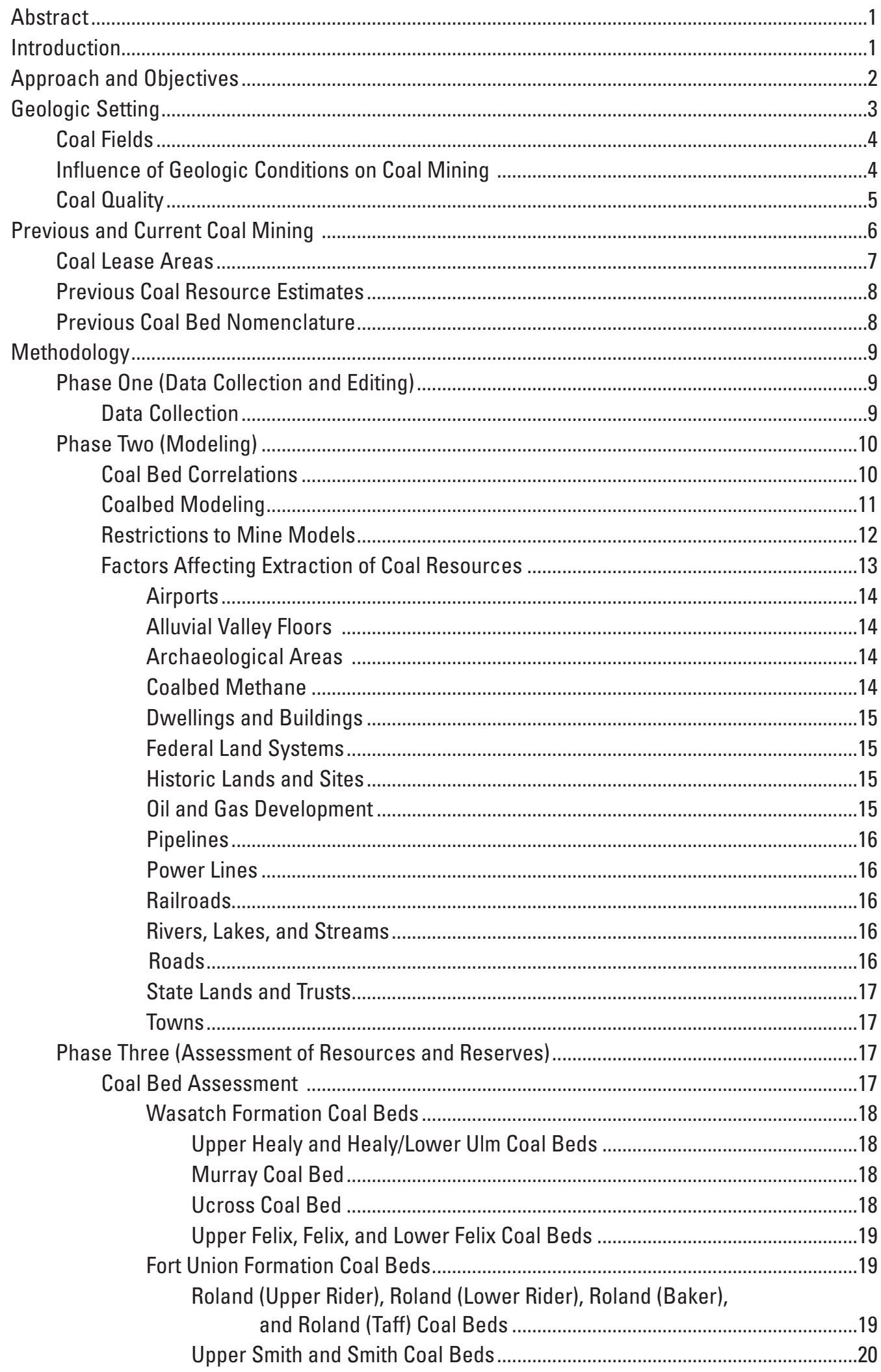


Anderson Upper Rider, Anderson Lower Rider, Anderson,

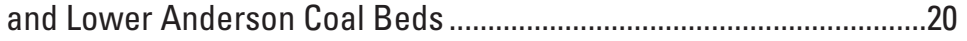

Dietz 1, Dietz 2, Dietz 3, and Dietz 4 Coal Beds ..............................................21

Upper Canyon/Cox, Canyon, and Lower Canyon Coal Beds.............................22

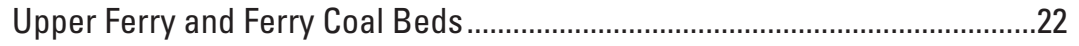

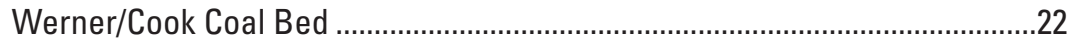

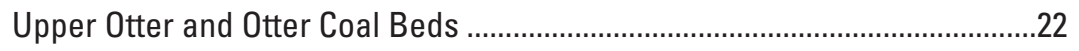

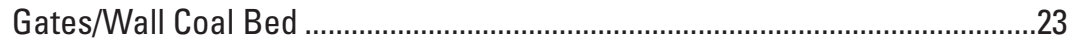

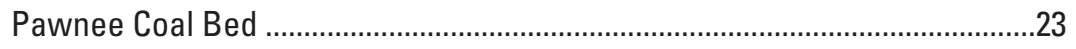

Brewster-Arnold Coal Bed ..........................................................................23

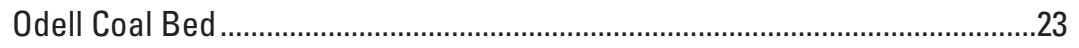

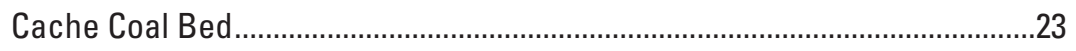

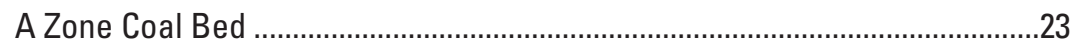

Upper Rosebud and Rosebud/Knobloch Coal Beds....................................24

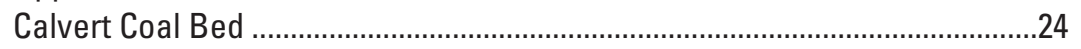

McKay/Nance and Lower McKay Coal Beds .................................................24

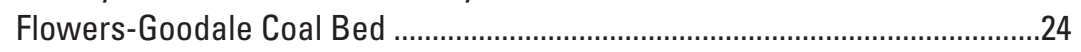

Upper Witham and Robinson/Witham Coal Beds .........................................25

Roberts/Terret Coal Bed ...............................................................................25

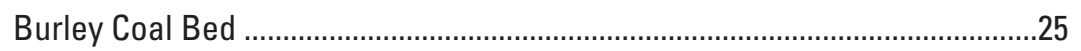

Upper Stag and Lower Stag Coal Beds..........................................................25

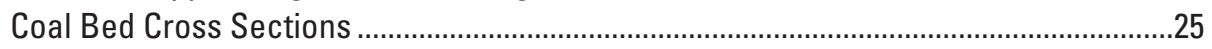

In-Place Coal Resource Volumetrics............................................................................26

Perspectives on Environments of Deposition .............................................................27

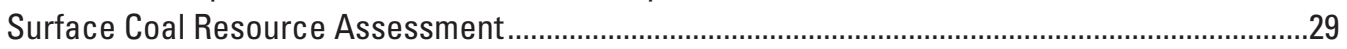

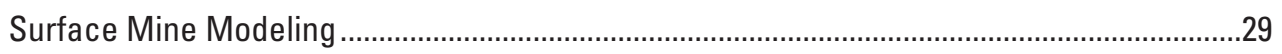

Geologic Aspects of Surface Mine Model Development .............................................29

Modeling Stratigraphic Sequence for Surface Mining ..................................................30

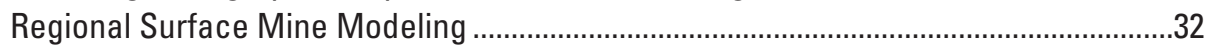

Surface Mine Model Design Assumptions...........................................................32

Surface Mine Plant Facilities......................................................................................33

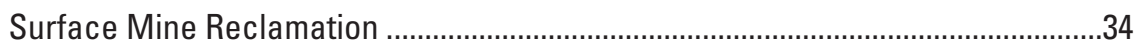

Surface Mine Supplies and Utilities .....................................................................

Surface Mine Reserve and Recoverable Resource Evaluation Results ..........................34

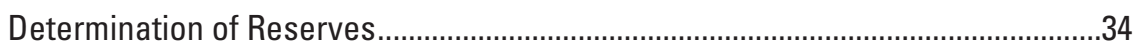

Gillette Coal Field Assessment Area ...............................................................34

Northern Wyoming PRB Assessment Area.....................................................35

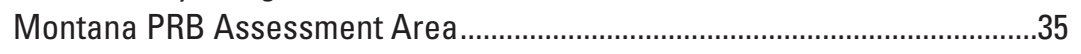

Combined PRB Reserve and Recoverable Resource Summary .......................36

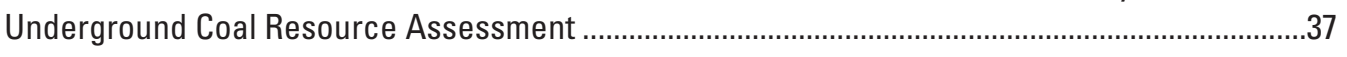

Underground Mine Model Design ...................................................................................37

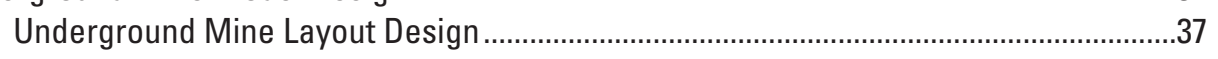

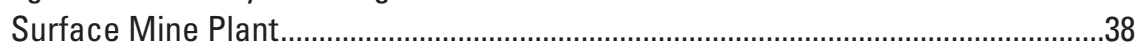

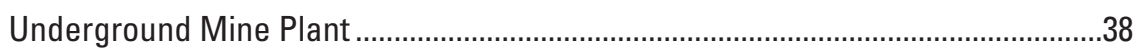

Underground Mine Development Excavation ............................................................38

Longwall Panel and Pillar Recovery ....................................................................38

Underground Coal Resources Results ................................................................................39

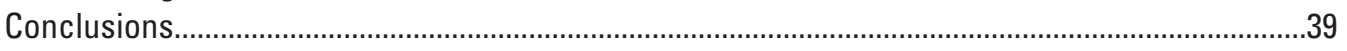

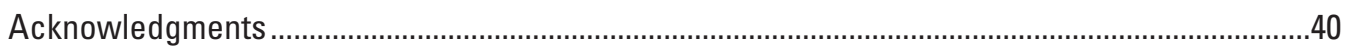

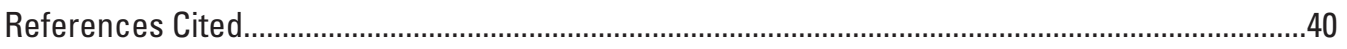

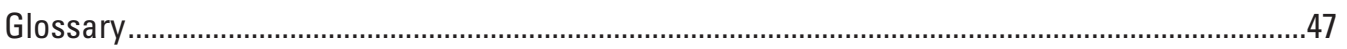




\section{Figures}

1. Map showing location of the Powder River Basin, Wyoming and Montana

2. Map showing location of individual assessment areas in the Powder River Basin, Wyoming and Montana

3. Map showing structure contours drawn on the top of the Tullock Member of the Fort Union Formation

4. Map showing generalized surface geology of the Powder River Basin, Wyoming and Montana.

5. Generalized stratigraphic column for the Powder River Basin, Wyoming and Montana

6. Map showing location of coal fields in the Powder River Basin, Wyoming and Montana

7. Map showing location of significant clinker in the Powder River Basin, Wyoming and Montana.

8. West-east cross section $A-A^{\prime}$ showing subsurface distribution of significant coal beds through the southern part of the Powder River Basin, Wyoming

9. West-east cross section $B-B$ ' showing subsurface distribution of significant coal beds through the central part of the Powder River Basin, Wyoming

10. North-south cross section $C-C^{\prime}$ showing subsurface distribution of significant coal beds through the Powder River Basin, Wyoming and Montana .

11. Map showing approximate location of faults within the Powder River Basin, Wyoming and Montana.

12. Map showing locations of mines, lease areas, and average coal quality basis within the Powder River Basin, Wyoming and Montana

13. Coal bed and coal zone names used in this assessment and previous publications in the Powder River Basin, Wyoming and Montana

14. Flow chart showing generalized U.S. Geological Survey methodology used for coal resource and reserve assessment.

15. Map showing mines and nonproprietary drill holes and paleochannels within the Anderson coal bed in the Powder River Basin, Wyoming and Montana

16. Cross section $A-A$ 'showing correlations used in the U.S. Geological Survey Miscellaneous Investigations Series Map I-1959-D by Molnia and Pierce (1992)

17. Cross section $B-B^{\prime}$ showing comparison of coal bed correlations made in the Gillette coal field report to the U.S. Geological Survey Miscellaneous Investigations Series Map I-1959-D by Molnia and Pierce (1992)...

18. Isopach map showing combined thickness of the Smith, Anderson, and Canyon coal beds and areas of thin or absent coal ("want area" after Flores and others, 2010) within the Powder River Basin, Wyoming and Montana.

19. Map showing land-use restrictions in the Powder River, Wyoming and Montana.............71

20. Map showing coal mineral estate ownership in the Powder River Basin, Wyoming and Montana

21. Illustration showing the effect of coal-bed depth upon restricted resource because of mine-pit highwall setback requirements

22. Map showing location of areas of low, moderate, and high coalbed methane potential in the Powder River Basin, Wyoming and Montana

23. Coal bed stratigraphy, original and available resources, and maximum and average thicknesses for coal beds in the Powder River Basin, Wyoming and Montana. 
24. Isopach map of the Upper Healy coal bed showing extent of coal at least 1.0 foot thick within the Powder River Basin

25. Map showing depth to the top of the Upper Healy coal bed within the Powder River Basin.

26. Isopach map of the Healy/Lower Ulm coal bed showing extent of coal at least 1.0 foot thick within the Powder River Basin

27. Map showing depth to the top of the Healy/Lower Ulm coal bed within the Powder River Basin

28. Isopach map of the Murray coal bed showing extent of coal at least 1.0 foot thick within the Powder River Basin

29. Map showing depth to the top of the Murray coal bed within the Powder River Basin.

30. Isopach map of the Ucross coal bed showing extent of coal at least 1.0 foot thick within the Powder River Basin

31. Map showing depth to the top of the Ucross coal bed within the Powder River Basin.

32. Isopach map of the Upper Felix coal bed showing extent of coal at least 1.0 foot thick within the Powder River Basin

33. Map showing depth to the top of the Upper Felix coal bed within the Powder River Basin

34. Isopach map of the Felix coal bed showing extent of coal at least 1.0 foot thick within the Powder River Basin

35. Map showing depth to the top of the Felix coal bed within the Powder River Basin....

36. Isopach map of the Lower Felix coal bed showing extent of coal at least 1.0 foot thick within the Powder River Basin

37. Map showing depth to the top of the Lower Felix coal bed within the Powder River Basin.

38. Isopach map of the Roland (Upper Rider) coal bed showing extent of coal at least 1.0 foot thick within the Powder River Basin

39. Map showing depth to the top of the Roland (Upper Rider) coal bed within the Powder River Basin

40. Isopach map of the Roland (Lower Rider) coal bed showing extent of coal at least 1.0 foot thick within the Powder River Basin

41. Map showing depth to the top of the Roland (Lower Rider) coal bed within the Powder River Basin

42. Isopach map of the Roland (Baker) coal bed showing extent of coal at least 1.0 foot thick within the Powder River Basin ....

43. Map showing depth to the top of the Roland (Baker) coal bed within the Powder River Basin

44. Isopach map of the Roland (Taff) coal bed showing extent of coal at least 1.0 foot thick within the Powder River Basin

45. Map showing depth to the top of the Roland (Taff) coal bed within the Powder River Basin.....

46. Isopach map of the Upper Smith coal bed showing extent of coal at least 1.0 foot thick within the Powder River Basin

47. Map showing depth to the top of the Upper Smith coal bed within the Powder River Basin. 
48. Isopach map of the Smith coal bed showing extent of coal at least 1.0 foot thick within the Powder River Basin

49. Map showing depth to the top of the Smith coal bed within the Powder River Basin

50. Isopach map of the Anderson Upper Rider coal bed showing extent of coal at least 1.0 foot thick within the Powder River Basin

51. Map showing depth to the top of the Anderson Upper Rider coal bed within the Powder River Basin

52. Isopach map of the Anderson Lower Rider coal bed showing extent of coal at least 1.0 foot thick within the Powder River Basin

53. Map showing depth to the top of the Anderson Lower Rider coal bed within the Powder River Basin

54. Isopach map of the Anderson coal bed showing extent of coal at least 1.0 foot thick within the Powder River Basin .106

55. Map showing depth to the top of the Anderson coal bed within the Powder River Basin

56. Isopach map of the Lower Anderson coal bed showing extent of coal at least 1.0 foot thick within the Powder River Basin

57. Map showing depth to the top of the Lower Anderson coal bed within the Powder River Basin.

58. Isopach map of the Dietz 1 coal bed showing extent of coal at least 1.0 foot thick within the Powder River Basin

59. Map showing depth to the top of the Dietz 1 coal bed within the Powder River Basin

60. Isopach map of the Dietz 2 coal bed showing extent of coal at least 1.0 foot thick within the Powder River Basin

61. Map showing depth to the top of the Dietz 2 coal bed within the Powder River Basin

62. Isopach map of the Dietz 3 coal bed showing extent of coal at least 1.0 foot thick within the Powder River Basin

63. Map showing depth to the top of the Dietz 3 coal bed within the Powder River Basin

64. Isopach map of the Dietz 4 coal bed showing extent of coal at least 1.0 foot thick within the Powder River Basin

65. Map showing depth to the top of the Dietz 4 coal bed within the Powder River Basin

66. Isopach map of the Upper Canyon (Cox) coal bed showing extent of coal at least 1.0 foot thick within the Powder River Basin

67. Map showing depth to the top of the Upper Canyon (Cox) coal bed within the Powder River Basin

68. Isopach map of the Canyon coal bed showing extent of coal at least 1.0 foot thick within the Powder River Basin

69. Map showing depth to the top of the Canyon coal bed within the Powder River Basin

70. Isopach map of the Lower Canyon coal bed showing extent of coal at least 1.0 foot thick within the Powder River Basin

71. Map showing depth to the top of the Lower Canyon coal bed within the Powder River Basin. 
72. Isopach map of the Upper Ferry coal bed showing extent of coal at least 1.0 foot thick within the Powder River Basin

73. Map showing depth to the top of the Upper Ferry coal bed within the Powder River Basin.

74. Isopach map of the Ferry coal bed showing extent of coal at least 1.0 foot thick within the Powder River Basin.

75. Map showing depth to the top of the Ferry coal bed within the Powder River Basin.

76. Isopach map of the Werner/Cook coal bed showing extent of coal at least 1.0 foot thick within the Powder River Basin

77. Map showing depth to the top of the Werner/Cook coal bed within the Powder River Basin.

78. Isopach map of the Upper Otter coal bed showing extent of coal at least 1.0 foot thick within the Powder River Basin

79. Map showing depth to the top of the Upper Otter coal bed within the Powder River Basin.

80. Isopach map of the Otter coal bed showing extent of coal at least 1.0 foot thick within the Powder River Basin ...

81. Map showing depth to the top of the Otter coal bed within the Powder River Basin.

82. Isopach map of the Gates/Wall coal bed showing extent of coal at least 1.0 foot thick within the Powder River Basin

83. Map showing depth to the top of the Gates/Wall coal bed within the Powder River Basin.

84. Isopach map of the Pawnee coal bed showing extent of coal at least 1.0 foot thick within the Powder River Basin

85. Map showing depth to the top of the Pawnee coal bed within the Powder River Basin.

86. Isopach map of the Brewster-Arnold coal bed showing extent of coal at least 1.0 foot thick within the Powder River Basin

87. Map showing depth to the top of the Brewster-Arnold coal bed within the Powder River Basin

88. Isopach map of the Odell coal bed showing extent of coal at least 1.0 foot thick within the Powder River Basin

89. Map showing depth to the top of the Odell coal bed within the Powder River Basin.

90. Isopach map of the Cache coal bed showing extent of coal at least 1.0 foot thick within the Powder River Basin

91. Map showing depth to the top of the Cache coal bed within the Powder River Basin

92. Isopach map of the A Zone coal bed showing extent of coal at least 1.0 foot thick within the Powder River Basin

93. Map showing depth to the top of the A Zone coal bed within the Powder River Basin.

94. Isopach map of the Upper Rosebud coal bed showing extent of coal at least 1.0 foot thick within the Powder River Basin

95. Map showing depth to the top of the Upper Rosebud coal bed within the Powder River Basin 
96. Isopach map of the Rosebud/Knobloch coal bed showing extent of coal at least 1.0 foot thick within the Powder River Basin .148

97. Map showing depth to the top of the Rosebud/Knobloch coal bed within the Powder River Basin

98. Isopach map of the Calvert coal bed showing extent of coal at least 1.0 foot thick within the Powder River Basin

99. Map showing depth to the top of the Calvert coal bed within the Powder River Basin

100. Isopach map of the McKay/Nance coal bed showing extent of coal at least 1.0 foot thick within the Powder River Basin.

101. Map showing depth to the top of the McKay/Nance coal bed within the Powder River Basin.

102. Isopach map of the Lower McKay coal bed showing extent of coal at least 1.0 foot thick within the Powder River Basin.

103. Map showing depth to the top of the Lower McKay coal bed within the Powder River Basin.

104. Isopach map of the Flowers-Goodale coal bed showing extent of coal at least 1.0 foot thick within the Powder River Basin

105. Map showing depth to the top of the Flowers-Goodale coal bed within the Powder River Basin.

106. Isopach map of the Upper Witham coal bed showing extent of coal at least 1.0 foot thick within the Powder River Basin

107. Map showing depth to the top of the Upper Witham coal bed within the Powder River Basin.

108. Isopach map of the Robinson/Witham coal bed showing extent of coal at least 1.0 foot thick within the Powder River Basin

109. Map showing depth to the top of the Robinson/Witham coal bed within the Powder River Basin

110. Isopach map of the Roberts/Terret coal bed showing extent of coal at least 1.0 foot thick within the Powder River Basin

111. Map showing depth to the top of the Roberts/Terret coal bed within the Powder River Basin.

112. Isopach map of the Burley coal bed showing extent of coal at least 1.0 foot thick within the Powder River Basin

113. Map showing depth to the top of the Burley coal bed within the Powder River Basin

114. Isopach map of the Upper Stag coal bed showing extent of coal at least 1.0 foot thick within the Powder River Basin

115. Map showing depth to the top of the Upper Stag coal bed within the Powder River Basin

116. Isopach map of the Lower Stag coal bed showing extent of coal at least 1.0 foot thick within the Powder River Basin

117. Map showing depth to the top of the Lower Stag coal bed within the Powder River Basin

118. Pie diagram showing tonnages and percentages of individual coal beds in relation to the total 1.16 trillion short tons of original resources in the Powder River Basin, Wyoming and Montana 
119. Isopach map of the Flowers-Goodale coal bed showing extent of resources at least 1.0 foot thick and location of lineaments described by Jones, 2010a, in the Powder River Basin, Wyoming and Montana ...

120. Isopach map of the Roberts/Terret coal bed showing extent of resources at least 1.0 foot thick and location of lineaments described by Jones, 2010a, in the Powder River Basin, Wyoming and Montana

121. Isopach map of the Smith, Anderson, and Canyon coal beds showing extent of resources at least 5 feet thick and location of lineaments described by Jones, 2010a in the Powder River Basin, Wyoming and Montana

122. Isopach map showing interburden thickness between the Anderson and Canyon coal beds in the Gillette coal field and location of lineaments described by Jones, 2010a in the Powder River Basin, Wyoming

123. Generic cost curve showing 12.8 billion short tons (BST) reserve estimate at $\$ 13.20$ per ton for the Powder River Basin, Wyoming and Montana.

124. Map showing areal extent for the composite stripping ratio of the Roland (Baker), Smith, Upper Anderson, Anderson, Dietz, and Canyon coal beds in the Gillette coal field, Wyoming Powder River Basin.....

125. Cost curve showing reserve estimates at $\$ 10.47$ per short ton (as of January 2007) and $\$ 14.00$ per short ton (as of March 2008) for the Gillette coal field, Wyoming

126. Map showing areal extent for the composite stripping ratio of the Roland (Baker), Smith, Anderson, Dietz 3, Canyon, Lower Canyon, and Werner/Cook coal beds where the stripping ratios are from 1:1 to 10:1, thicknesses are equal to at least 5.0 feet, and the overburden is less than or equal to 500 feet thick, in the Wyoming Powder River Basin

127. Cost curve showing 1.5 billion ton reserve estimate at $\$ 9.30$ per short ton (as of February 2010) for the Northern Wyoming Powder River Basin assessment area

128. Map showing areal extent for the composite stripping ratio of the Roland (Baker), Smith, Anderson, Dietz 2, and Dietz 3 coal beds where the stripping ratios are from 1:1 to 10:1, thicknesses are equal to at least 5.0 feet, and the overburden is less than or equal to 500 feet thick, in the Montana Powder River Basin

129. Map showing areal extent for the stripping ratio of the Canyon coal bed where the stripping ratios are from 1:1 to 10:1, thicknesses are equal to at least 5.0 feet, and the overburden is less than or equal to 500 feet thick, in the Montana Powder River Basin

130. Map showing areal extent for the stripping ratio of the Werner/Cook coal bed where the stripping ratios are from 1:1 to 10:1, thicknesses are equal to at least 5.0 feet, and the overburden is less than or equal to 500 feet thick, in the Montana Powder River Basin

131. Map showing areal extent for the stripping ratio of the Pawnee coal bed where the stripping ratios are from 1:1 to 10:1, thicknesses are equal to at least 5.0 feet, and the overburden is less than or equal to 500 feet thick, in the Montana Powder River Basin

132. Map showing areal extent for the stripping ratio of the Rosebud/Knobloch coal bed where the stripping ratios are from 1:1 to 10:1, thicknesses are equal to at least 5.0 feet, and the overburden is less than or equal to 500 feet thick, in the Montana Powder River Basin 
133. Map showing areal extent for the stripping ratio of the Flowers-Goodale coal bed where the stripping ratios are from 1:1 to 10:1, thicknesses are equal to at least 5.0 feet, and the overburden is less than or equal to 500 feet thick, in the Montana Powder River Basin.

134. Graph showing cost curve for the Montana Powder River Basin assessment area showing estimated recoverable coal resources compared to sales price per ton of coal

135. Bar graph showing resource and reserve summary in the Powder River Basin, Wyoming and Montana

136. Graph showing cumulative cost curve for the Powder River Basin, Wyoming and Montana (Gillette coal field, Northern Wyoming Powder River Basin, and Montana Powder River Basin assessment areas).

\section{Tables}

1. 2012 and cumulative coal production from the Powder River Basin, Wyoming and Montana .

2. Typical proximate analysis on an as-received basis of coal from mines in the Powder River Basin, Wyoming and Montana

3. Typical proximate analysis on an as-received basis of coal beds reporting sodium as percent of ash, percent sulfur, percent ash, and calorific value, in coal beds in the Wyoming Powder River Basin compared to the Montana Powder River Basin.

4. Coal resources and restrictions for 47 beds greater than or equal to 2.5 feet thick, reported in millions of short tons by reliability category for the Powder River Basin, Wyoming and Montana.

5. Coal resources and restrictions for 47 beds greater than or equal to 2.5 feet thick, reported in millions of short tons by overburden depth for the Powder River Basin, Wyoming and Montana

6. Coal resources and restrictions for 47 beds greater than or equal to 2.5 feet thick, reported in millions of short tons, by coal ownership categories for the Powder River Basin, Wyoming and Montana

7. Coal resources and restrictions for 47 beds greater than or equal to 2.5 feet thick, reported in millions of short tons by assessment area.

8. Summary of coal resources by reliability, depth, ownership, and assessment area categories in the Powder River Basin, Wyoming and Montana

9. Summary of resources by reliability categories for all 47 coal beds assessed in the Powder River Basin and comparison of reliability of previous assessment of the Wyodak-Anderson zone in the Gillette coal field to the current Powder River Basin assessment

10. Example of a regional mine model stratigraphic sequence used in the economic evaluation of the Northern Wyoming Powder River Basin assessment area, River Wyoming .....

11. Estimated impacts of compositing the originally excluded shale, pyrite, and other high-ash parting material with the coal analyses for the USGS-1 core hole from the Lake DeSmet coal area, Wyoming.

12. Coal resources and reserves for beds greater than or equal to 5.0 feet thick in each assessment area in the Powder River Basin, Wyoming and Montana .216

13. Underground resources for coal beds 10-20 feet thick and greater than 500 feet deep in the Powder River Basin, Wyoming and Montana. 


\section{Conversion Factors}

\begin{tabular}{lll}
\hline Multiply & \multicolumn{1}{c}{ By } & To obtain \\
\hline & \multicolumn{1}{c}{ Length } & \\
\hline foot $(\mathrm{ft})$ & 0.3048 & meter $(\mathrm{m})$ \\
mile $(\mathrm{mi})$ & 1.609 & kilometer $(\mathrm{km})$ \\
square mile $\left(\mathrm{mi}^{2}\right)$ & 2.590 & square kilometer $\left(\mathrm{km}^{2}\right)$ \\
square feet $\left(\mathrm{ft}^{2}\right)$ & 0.0929 & square meters $\left(\mathrm{m}^{2}\right)$ \\
\hline & \multicolumn{1}{c}{ Mass } & \\
\hline pounds $(\mathrm{lbs})$ & 0.4536 & kilograms $(\mathrm{kg})$ \\
short tons $(2,000 \mathrm{lbs})$ & 0.90718474 & metric tons $(2,204.6 \mathrm{lbs})$ \\
\hline
\end{tabular}

Vertical coordinate information is referenced to the North American Vertical Datum of 1988 (NAVD 88).

Horizontal coordinate information is referenced to the Universal Transverse Mercator (UTM) map projection, using the following parameters: map units = meters; $z$ zone $=13$; datum = NAD83; and spheroid $=$ Clarke, 1866 .

\section{Abbreviations and Acronyms Used in This Report}

$\begin{array}{ll}\text { BST } & \text { billion short tons } \\ \text { Btu/lb } & \text { British thermal unit per pound } \\ \text { CARS } & \text { coal availability and resource studies } \\ \text { CBM } & \text { coalbed methane } \\ \text { DRB } & \text { demonstrated reserve base } \\ \text { EIA } & \text { U.S. Energy Information Administration } \\ \text { ERR } & \text { estimated recoverable reserve base } \\ \text { Esri } & \text { Environmental Systems Research International } \\ \text { ft } & \text { feet } \\ \mathrm{ft}^{2} & \text { square feet } \\ \text { hr } & \text { hour } \\ \text { GIS } & \text { geographic information system } \\ \text { in } & \text { inch } \\ \text { MBMG } & \text { Montana Bureau of Mines and Geology } \\ \text { mi } & \text { mile } \\ \text { mi } & \text { square mile } \\ \text { MST } & \text { million short tons } \\ \text { MST/yr } & \text { million short tons per year } \\ \text { MTPRB } & \text { Montana Powder River Basin assessment area } \\ \text { NCRA } & \text { National Coal Resource Assessment } \\ \text { NCRDS } & \text { USGS National Coal Resources Database System } \\ \text { NWPRB } & \text { Northern Wyoming Powder River Basin assessment area } \\ \text { PRB } & \text { Powder River Basin (both Wyoming and Montana) }\end{array}$




$\begin{array}{ll}\text { PRLAs } & \text { preference right lease applications } \\ \text { RAP } & \text { resource allocation planning } \\ \text { SMCRA } & \text { Surface Mining Control and Reclamation Act } \\ \mathrm{SO}_{2} / \mathrm{lb} & \text { sulfur dioxide per pound } \\ \text { SWPRB } & \text { Southwestern Powder River Basin assessment area } \\ \text { USBLM } & \text { U.S. Bureau of Land Management } \\ \text { USFS } & \text { U.S. Forest Service } \\ \text { USGS } & \text { U.S. Geological Survey } \\ \text { UTM } & \text { Universal Transverse Mercator } \\ \text { WSGS } & \text { Wyoming State Geological Survey } \\ \text { WOGCC } & \text { Wyoming Oil and Gas Conservation Commission } \\ \text { yd } & \text { cubic yards } \\ \text { yr } & \text { year }\end{array}$





\title{
Coal Geology and Assessment of Coal Resources and Reserves in the Powder River Basin, Wyoming and Montana
}

\author{
By James A. Luppens, David C. Scott, Jon E. Haacke, Lee M. Osmonson, and Paul E. Pierce
}

\section{Abstract}

This report presents the final results of the first assessment of both coal resources and reserves for all significant coal beds in the entire Powder River Basin, northeastern Wyoming and southeastern Montana. The basin covers about 19,500 square miles, exclusive of the part of the basin within the Crow and Northern Cheyenne Indian Reservations in Montana. The Powder River Basin, which contains the largest resources of low-sulfur, low-ash, subbituminous coal in the United States, is the single most important coal basin in the United States. In 2012, almost 420 million short tons were produced from this basin, which was about 42 percent of the total coal production in the United States.

Prior resource assessments relied on net coal thickness maps for only selected beds. Although net thickness maps are sufficient for estimating in-place (remaining) resources, the mapping of all individual beds is necessary for conducting economic studies to determine the coal reserve base for the Powder River Basin. The coal reserve base includes those resources that are currently (October 2014) economic (reserves), but also may encompass those parts of a resource that have a reasonable potential for becoming economically available. Thus, the coal reserve base provides a more realistic estimate of the portion of in-place resources that are potentially recoverable, which is important from a national energy standpoint. A key to the success of this current assessment was incorporating as much data as practical from the recent, extensive coalbed methane development in the basin. The interpretation of these new data proved critical to the development of a comprehensive geologic model needed for estimating coal resources and reserves in the Powder River Basin. A total of 29,928 drill holes were used for this assessment, of which 21,393 are in the public domain.

The U.S. Geological Survey used a geology-based assessment methodology to estimate an original coal resource of about 1.16 trillion short tons for 47 coal beds in the Powder River Basin; in-place (remaining) resources are about 1.15 trillion short tons. The most significant resources are within the Tertiary (Paleocene) Tongue River Member of the Fort Union Formation and include the Roland (Baker, 1929), Smith, Anderson, Dietz 3, Canyon, Lower Canyon, Werner/Cook, Otter, Gates/ Wall, Rosebud/Knobloch, Flowers-Goodale, and Roberts/Terret coal beds. These resources represent about 944 billion short tons (81.5 percent) of the total 1.16 trillion short tons of original coal resource estimated for the Powder River Basin.

Not all 47 coal beds were included in the mining economics evaluation. Only those beds that exceeded $5.0 \mathrm{ft}$ in thickness and had a significant areal extent with a stripping ratio of 10:1 or less were included. A total of 162 billion short tons of recoverable coal resources (coal reserve base) are estimated at a 10:1 stripping ratio or less. An estimated 25 billion short tons of that coal reserve base met the definition of reserves, which are resources that can be economically produced at or below the current sales price at the time of the evaluation. This reserve estimate does not mean that the total amount of coal left in the Powder River Basin could be produced by surface mining technologies. The costs of mining and coal sales prices are not static as both tend to increase over time if supported by demand. If future market prices exceed mining costs, portions of the coal reserve base would be elevated to reserve status (and the converse).

There are no active underground mining operations in the Powder River Basin, nor are any anticipated in the foreseeable future. However, there are significant deeper coal resources in the basin that could be produced with current underground mining technologies. Therefore, a preliminary estimate of coal with thicknesses amenable for longwall mining was conducted. The total underground coal resource in coal beds 10-20 feet thick is estimated at 304 billion short tons.

\section{Introduction}

The U.S. Geological Survey (USGS) is responsible for providing objective scientific information to support decisions regarding land management, environmental quality, energy, and strategic policy. Therefore, the USGS periodically assesses the Nation's endowment of various energy resources, including coal. The objective of the United States Coal Resources and 
Reserves Assessment Project is to conduct regional-scale coal resource $^{1}$ and coal reserve assessments of coal beds in major coal basins. Coal resource and reserve estimates are essential for planning local, State, and Federal energy and land-use policy decisions now and for the foreseeable future. These estimates are also necessary to determine possible socioeconomic effects on a region as coal resources and reserves are developed and approach depletion (Luppens and others, 2008).

From 1999 to 2009, the USGS completed the first digital National Coal Resource Assessment (NCRA) of in-place (remaining) coal resources (Pierce and Dennen, 2009); however, these estimates did not provide all the information needed for resource planning. Calculations of the portion of in-place coal resources that are economically recoverable (coal reserves) are equally important (Luppens and others, 2009). Since the NCRA study, USGS methodology to calculate resources and reserves has been refined to take advantage of improvements in computer hardware, geologic and mine model software, and availability of data. As a result, the scope of coal resource and especially reserve assessment capabilities has grown in geographic size from a single topographic quadrangle to entire coal fields and geologic basins.

The first U.S. coal basin evaluated in the coal assessment project is the Powder River Basin (PRB) Wyoming and Montana (fig. 1). In this report, the abbreviation PRB refers to the entire Powder River Basin (Wyoming and Montana); Wyoming PRB refers only to the Wyoming portion of the basin, and Montana PRB refers only to the Montana portion of the basin. The PRB contains some of the most significant deposits of low-sulfur, low-ash, subbituminous coal in the world (Molnia and Pierce, 1992). In 2012, coal production from 16 mines in the basin totaled almost 420 million short tons (MST) (42 percent of the total coal production in the United States), making it the single most important coalproducing basin in the Nation (table 1). About 388 MST (93 percent of the total PRB coal production) came from the Gillette coal field, located in the eastern part of the Wyoming PRB (fig. 2, table 1).

There is often confusion regarding the use of the terms coal resources and coal reserves as they relate to assessments. Although the two terms have been used interchangeably, there are significant differences between the definitions. Coal resources include those in-place tonnage estimates determined by summing the volumes for identified resources and hypothetical resources, using coal zones of a minimum thickness and within certain depth limits (commonly 0-2,000 feet [ft] deep) (Pierce and Dennen, 2009). Coal reserves are a subset of coal resources and are considered economically minable at the time of classification (Wood and others, 1983).

Results presented in this report include not only an assessment of coal resources and reserves, but also the most current and comprehensive correlation of individual coal beds throughout the PRB. Other coal stratigraphers have attempted

\footnotetext{
${ }^{1}$ Technical terms used in this report requiring additional explanation are italicized when used for the first time and their definitions are given in the Glossary section at the end of the report.
}

to correlate the entire PRB (Flores and others, 2010); however, that assessment did not include all of the Montana PRB assessment area, nor did it include deeper coal beds in the PRB. This assessment is based on data from the entire PRB and correlates coal beds based on their stratigraphic position.

The Powder River Basin is a structural and sedimentary basin that is generally defined by Tertiary-age (Paleocene) rocks that crop out along the margins of the basin. The basin covers about 19,500 square miles $\left(\mathrm{mi}^{2}\right)$ exclusive of the part of the basin within the Crow and Northern Cheyenne Indian Reservations in the Montana PRB (fig. 1). The basin extends north-south from Miles City, Montana to Douglas, Wyoming; the west-east extent in the Wyoming PRB is from about Sheridan to Moorcroft and from about Decker to Broadus, in the Montana PRB (fig. 1).

The PRB was divided into five geographic areas to keep databases and modeled areas to a manageable size and permit timely publication of assessment results (fig. 2). Four of those areas are in the Wyoming PRB and one is in the Montana PRB: (1) Luppens and others (2008) reported on the first assessment area, summarizing geology, coal resources, and reserves for the Gillette coal field; (2) Scott and others (2010) summarized the second assessment area and presented results on geology, coal resources, and reserves for the Northern Wyoming Powder River Basin assessment area (NWPRB assessment area); (3) Osmonson and others (2011) summarized the third assessment area and presented results on geology and coal resources in the Southwestern Powder River Basin assessment area (SWPRB assessment area); and (4) Haacke and others (2013) summarized the fourth assessment area and presented results on geology, coal resources, and reserves for the Montana Powder River Basin assessment area (MTPRB assessment area). The fifth area (East Gillette coal field extension) extends east from the Gillette coal field and was evaluated for this report specifically to provide a more comprehensive mapping of coal beds below the WyodakAnderson coal zone and to complete the assessment of the entire PRB (fig. 2). This publication supersedes the four OpenFile Reports and presents estimates of coal resources and reserves for the entire PRB. Supplemental to this report are the geographic information system (GIS) data created using Environmental Systems Research International (Esri) ArcGIS (Environmental Systems Research International, 2006) that can be used to show the PRB boundary in map view along with other pertinent data layers (Kinney and others, 2015).

\section{Approach and Objectives}

To provide a meaningful estimate of the amount of coal that is potentially recoverable, the USGS and the former U.S. Bureau of Mines conducted initial coal availability and recoverability Studies (CARS) in the late 1980s (Luppens and others, 2009). These studies included both mine planning and economic studies that were used to derive estimates of the coal reserves for limited areas. The CARS methodology evolved 
from single 7.5-minute quadrangle maps containing an area of about 56 square miles $\left(\mathrm{mi}^{2}\right)$ (145.0 square kilometers $\left.\left[\mathrm{km}^{2}\right]\right)$ to entire coal fields containing greater than 2,000 $\mathrm{mi}^{2}$ (greater than $5,180 \mathrm{~km}^{2}$ ). These advances became feasible largely because of advances in computer hardware and software and the availability of digital information regarding geology, geography, and societal data and infrastructure.

One of the objectives of the USGS CARS project has been to provide data to update the U.S. Energy Information Administration (EIA) demonstrated coal reserve base (DRB), the only publicly available, nationwide summary of the quantities of minable coal conforming to a unified set of criteria (EIA, 1997). The EIA has obtained valuable accessibility and recoverability data for recent coal reserve estimates from the USGS coal availability studies and from the former U.S. Bureau of Mines coal recoverability studies. The EIA use of revised CARS data in New Mexico, Illinois, and Eastern Kentucky document the increasing cooperation among EIA, the U.S. Geological Survey, and State geological agencies in order to share data and coordinate efforts in their coal resource and reserve programs (EIA, 1997).

Regardless of the size or generation of the particular CARS area, the methodology to estimate coal resources and reserves has remained standardized and consistent throughout the assessment process. For CARS assessments, coal beds must be correlated and modeled individually. Another key component is the systematic inventory of restrictions to mining to yield the volume of coal that could be potentially recovered.

Previous USGS resource assessments in the PRB have relied on the correlation of coal bed zones and overburden depths based on depth to the uppermost coal bed in a zone (for example, Ellis and others, 1999, and Flores and others, 2010). Flores and others (1999) defined a coal zone (WyodakAnderson) in the Gillette coal field that is within an interval almost $900 \mathrm{ft}$ thick that consists of 11 coal beds totaling more than $200 \mathrm{ft}$ thick. However, by reporting only the overburden to the top of the uppermost coal bed in a coal zone, as much as $700 \mathrm{ft}$ of interburden was unaccounted for assuming a 900-ftthick coal zone and a net coal bed thickness of $200 \mathrm{ft}$. Furthermore, there is a significant difference in terms of the cost of mining a single 200 -ft-thick coal bed compared to mining seven coal beds (ranging in thickness from 3 to $50 \mathrm{ft}$ ) totaling $200 \mathrm{ft}$ over a 900 -ft-thick stratigraphic zone. Although a methodology based on coal zone correlations is suitable for calculating net inplace resources, it does not provide the comprehensive bed by bed geometry required for a mining and economic assessment of reserve potential. Therefore, another objective of the PRB coal assessment project was developing a correlated drill-hole database used to generate a multibed model that included all individual coal beds in the Powder River Basin.

Historically, the CARS project relied on interpretation of both existing oil and gas well and coal drilling data; however, because of the recent development of coalbed methane (CBM) in the PRB, an abundance of new data are now available. The interpretation of these new data proved critical to the development of a comprehensive geologic model needed for calculating coal resources and reserves in the PRB.
The principal objectives of this assessment are as follows:

1. Update the stratigraphic database, correlate individual coal beds, and unify coal bed names throughout the PRB.

2. Develop a comprehensive, multi-coal bed geological model for the PRB with the geological assurance to support regional resource and reserve estimates.

3. Complete an economic mining evaluation that incorporates the environmental and technological restrictions to mining for the PRB.

4. Summarize coal resources and reserves for all four coal resource and reserve assessment areas in the PRB, including the East Gillette extension.

5. Supply the EIA with updated coal availability and recoverability results.

\section{Geologic Setting}

The geologic history of the PRB has been extensively discussed by Flores and others (2010) and Jones (2010a); therefore, an in-depth discussion of geology and depositional history of coal beds in the PRB was not a primary objective of this assessment. However, the public available downhole data generated during this assessment does provide a foundation for future geologic studies (Haacke and Scott, 2013).

The PRB is an elongated, north-northwest-trending sedimentary and structural basin that forms a broad asymmetric syncline (depression) with a gently dipping east limb and a steeply dipping west limb. A structure contour map (sea level datum) drawn on top of the Tullock Member reveals the asymmetrical nature of the PRB, with the axis near the west margin of the basin (Ayers, 1986a) (fig. 3). Along the west margin of the $\mathrm{PRB}$, rocks dip between $20^{\circ}$ and $25^{\circ}$ to the east, whereas rocks dip only about $2^{\circ}$ to $5^{\circ}$ to the west along the east margin of the basin (Flores and others, 1999). The synclinal axis of the basin is closer to the basin's west margin, trending north-northwest in the Wyoming PRB, and gradually turning north-northeast in the Montana PRB (Lopez, 2005) (fig. 4). In the Montana PRB, the basin is bounded by structural uplifts - the Bighorn Mountains to the west, and the Black Hills to the east - and becomes shallow to the north against the southern flank of the Miles City arch, located northeast of the PRB.

Geologic strata exposed at the surface in the PRB consist almost entirely of lower Tertiary (Paleocene) Fort Union and (Eocene) Wasatch Formations with the (Oligocene) White River Formation (Oligocene) present in stream drainages (figs. 4 and 5). The Lebo Shale Member and Tullock Members of the Fort Union Formation underlie the Tongue River Member of the Fort Union and are present along the margins of the basin (fig. 4).

The Wasatch Formation conformably overlies the Fort Union Formation in the center of the basin and unconformably overlies it along the basin margins. The Wasatch Formation covers about three fourths of the Wyoming PRB (fig. 4) and 
extends north into the southernmost part of the Montana PRB where it crops out along topographic highs that occur between river valleys, including the Tongue River, Hanging Woman Creek, and Otter Creek drainages (Vuke and others, 2001a). The underlying Fort Union Formation is exposed along the basin margins in the Wyoming PRB and throughout most of the Montana PRB (fig. 4).

The Fort Union Formation covers about one-fourth of the surface area in the PRB, mostly in the Montana PRB, and underlies the Wasatch Formation in the Wyoming PRB (fig. 4). The Fort Union Formation is composed of three members; from oldest to youngest they are the Tullock, Lebo, and Tongue River (fig. 5). Together, these members form a thick sequence of interbedded sands, gravels, silts, shales, and coals. These strata incorporate some of the thickest and most extensive deposits of low-sulfur, low-ash, subbituminous coal in the world (Molnia and Pierce, 1992). Most of the coal is contained in the Wyodak-Anderson coal zone in the Tongue River Member (Ellis and others, 1999). The Fort Union Formation ranges in thickness from a few hundred feet along the north margin of the Montana PRB, to approximately 4,000 ft at the Montana-Wyoming border (Jay Gunderson, Montana Bureau of Mines and Geology, written commun., 2011).

Underlying the Fort Union Formation in the Montana PRB, delta-plain sands and shales of the Upper Cretaceous Hell Creek Formation (equivalent to the Lance Formation in Wyoming) grade upward into fluvial-dominated sediments of the lowermost Tullock Member of the Fort Union Formation (fig. 5). The top of the Hell Creek Formation is generally placed at the base of the lowest coal bed found in the Tullock Member and generally corresponds to an upward change in sedimentary character from cross-bedded to planar-bedded sandstones (Vuke and others, 2001b). The GIS layer of geology for the PRB is available using Esri ArcGIS 9.3.1 (Environmental Systems Research International, 2006) (Kinney and others, 2015).

\section{Coal Fields}

The Powder River Basin has been segregated into named coal fields based on geographic features or nearby towns. Previous investigations in the PRB often referred to areas of coal production and coal resources by coal field name; therefore, a map of all the coal fields in the PRB is included in this report (fig. 6). The Ashland, Birney-Broadus, Coalwood, Forsyth, Miles City, Mizpah, Moorhead, northward extension of the Sheridan, and Rosebud coal fields are all within the Montana PRB (Averitt, 1966; McLellan and others, 1990) (fig. 6). The Barber, Buffalo, Dry Cheyenne, Gillette, Glenrock, Little Powder River, Lost Spring, Powder River, Pumpkin Buttes, Sheridan, Spotted Horse, and Sussex coal fields are all within the Wyoming PRB (Glass, 1976) (fig. 6). The area east of the Gillette coal field is referred to as the East Gillette Extension coal field for this report (fig. 6).

\section{Influence of Geologic Conditions on Coal Mining}

Almost everywhere in the PRB, coal beds greater than $5 \mathrm{ft}$ thick show evidence of burning. The heat from the burning coal on the overlying rock produces a reddish colored material known as clinker. The thickness of clinker is roughly 2-3 times the thickness of the original coal that has burned; therefore, clinker thickness can be used in exploration as a relative indicator of the approximate thickness of a coal bed. A coal bed 5-10 ft thick can produce a clinker zone 10-30 ft thick, whereas a coal bed $50 \mathrm{ft}$ thick may produce a clinker zone 100-200 ft thick (Matson and Blumer, 1973).

Large areas of original near-surface coal resources of the Tongue River Member of the Fort Union Formation have been destroyed by burning at the outcrop and beneath shallow cover (fig. 7). Approximately $1,000 \mathrm{mi}^{2}$ of the surface area in the Montana PRB is affected by clinker (Coates and Heffern, 1999; Roberts and others, 1999a, b, c) (fig. 7). Roberts and others (1999c) outlined large areas of clinker in the Spring Creek and Decker Mine areas (fig. 2) affecting the Anderson, Dietz 2, and Dietz 3 coal beds. At the Rosebud Mine, near Colstrip, Montana (fig. 2), where the Rosebud and McKay beds have merged to a single bed, clinker deposits have been reported to attain a thickness of as much as $120 \mathrm{ft}$ (Tudor, 1975). In the Wyoming PRB, large areas of original near-surface coal resources have been burned at their outcrop and beneath shallow cover along the east margin of the basin; approximately $750 \mathrm{mi}^{2}$ in the Wyoming PRB is affected by clinker.

The structural dip of coal beds can affect the mining method. A dip of $5^{\circ}$ or less is optimal for both surface and underground mining. A dip of $20^{\circ}$ or greater negatively affects both types of mining. Rocks along the west margin of the PRB dip steeply to the east ( $20^{\circ}$ or more) towards the axis of the basin, whereas rocks along the east margin of the basin dip about $2-5^{\circ}$ to the west, towards the axis of the basin. Surface coal mining has been more prevalent along the east margin of the Wyoming PRB because of the shallower dip, whereas underground mining was more prevalent along the west margin of the basin, in the area north of Sheridan, Wyoming. Figures 8 and 9 illustrate the relatively gentle dip of coal beds along the east margin of the PRB in contrast to the steeper dip of the same beds along the west margin of the basin. The stratigraphic sequence of significant coal beds in the subsurface geology of the PRB is shown in three cross sections (figs. 8-10).

In the northwest portion of the Wyoming PRB and southwest portion of the Montana PRB, numerous northeasttrending faults are present (fig. 11). The faults, most of which are downthrown on the east, postdate coal bed formation. Faults shown on figure 11 are based on Ellis and others (1999) and Roberts and others (1999a, b, c), or they were identified during the correlation phase of this assessment from observations of stratigraphic offset between drill holes. The faults range $0.5-6.0 \mathrm{mi}$ long, with displacements of as much as $140 \mathrm{ft}$ (Robinson and Van Gosen, 1986). In most cases, 
fault displacement is not much more than $100 \mathrm{ft}$. Areas where numerous high-angle faults are present are not conducive to either surface or underground mining operations. One such example in the PRB is near the abandoned Big Horn Mine (fig. 12), north of Sheridan, Wyoming, where previous underground mining in a highly faulted area has produced significant subsidence.

Faults in coal beds also have an important effect on the selection of mining methods and on productivity. Major faults with vertical displacements greater than $65 \mathrm{ft}$ commonly are used to delineate mine plan boundaries. Numerous minor faults are generally associated with and trend almost parallel to major faults. The adverse effects of faulting are greater on underground mining operations. A fault with a vertical displacement of 3-16 ft may not pose much of a problem in a surface mine, whereas it could be a serious impediment in underground mining (Thomas, 2002). For this report faults were not considered a restriction to mining.

The method of underground mining can affect the amount of resources lost because of faulting. If the method is longwall mining, a larger resource loss will occur, because longwall operations need hazard-free runs in a designated panel of coal. Longwall panels are typically 5,000-10,000 ft in length and $750-1,500 \mathrm{ft}$ in width; thus, a large, relatively unfaulted block of coal is required. If coal panels between faults are too small, then whole blocks may be lost to mining (Thomas, 2002).

\section{Coal Quality}

Coal quality is a major factor in its marketability and also an important input parameter for coal reserve estimations. Coal is sold based on its calorific value expressed in British thermal units per pound of coal (Btu/lb). Quality parameters, such as increased ash content that lowers the calorific value, negatively affect the operating and maintenance costs at coal-fired power plants. Therefore, coals with lower ash and sulfur content and higher calorific values command a premium selling price.

A single set of typical coal quality values based on available data was estimated for each assessment area. The typical coal quality values were then used to determine the current freight on board (FOB) sales prices. Various trade publications publish periodic coal sales prices based on coal quality, primarily by gross calorific value measured in Btu/lb and sulfur dioxide per pound $\left(\mathrm{SO}_{2} / \mathrm{lb}\right)$. Typically, the higher the gross calorific content and the lower the sulfur dioxide values, the higher the sales price. For example, for the week ending October, 5, 2012, the average price for Powder River Basin coal with $8,800 \mathrm{Btu} / \mathrm{lb}$ and $0.8 \mathrm{SO}_{2} / \mathrm{lb}$ was $\$ 10.20 /$ ton, whereas at $8,400 \mathrm{Btu} / \mathrm{lb}$ and $0.8 \mathrm{SO}_{2} / \mathrm{lb}$, the price was only $\$ 8.60 /$ ton (Platts, 2012.) After the sales price for an assessed area was established, the volume of reserves could be determined. All recoverable coal resources that could be produced at or below the current sales price at the time of the evaluation (discounted cash flow (DCF) cost per ton basis), by definition, are reserves.
The amendments of the Clean Air Act of 1990 (42 U.S.C. 765d) enforced emission limits at coal-fired power plants to reduce certain air pollutants, such as sulfur dioxide. Sulfur dioxide emission limits for all new coal-fired power plants built after 1976 were capped at $1.2 \mathrm{lbs}$ sulfur dioxide per million Btu (U.S. Environmental Protection Agency, 1980). Any coal that could be burned and meet the sulfur dioxide emission standards for air quality (emit $0.6 \mathrm{lbs}$ or less sulfur per million Btu or $1.2 \mathrm{lbs}$ sulfur dioxide per million Btu) without the need for flue-gas desulfurization was designated "compliance coal," also known as low-sulfur coal (EIA, 2011). Subsequent phases of the Clean Air Act amendments have further restricted sulfur dioxide emissions. Currently, New Source Performance Standards establish uniform national Environmental Protection Agency air-emission standards that limit the amount of pollution allowed from new sources or from modified existing sources. Under New Source Performance Standards, Best Available Control Technology emission limitations are based on the maximum degree of reduction of each pollutant (U.S. Environmental Protection Agency, 2005). The current minimum Best Available Control Technology standard for sulfur dioxide emissions is 90 percent reduction regardless of the sulfur content.

Former compliance coals still have a competitive advantage because the cost to meet the 90 percent emission reductions is typically lower than higher sulfur coals. The abundance of low-sulfur and low-ash coal in the PRB has been a significant factor in the steadily growing demand for coal from this region.

Coal quality information has been available since the early 1970s for most of the mines in the PRB. Figure 12 shows the average coal quality for five areas in the PRB where significant mining is current or has been proposed (averages calculated from mine averages in table 2). Table 2 summarizes coal quality for all mines in the PRB, as well as the Otter Creek lease area in the Montana PRB (fig. 12). In comparison to coal in the Wyoming PRB, coal in the Montana PRB is generally greater in sodium content (table 3 ). The Smith, Anderson, and Dietz 3 coal beds in the Decker and Spring Creek Mine areas generally have higher sodium content than the Rosebud/Knobloch coal bed in the Rosebud and Absaloka Mine areas in the Montana PRB (table 3, fig. 12). Increased sodium content in coal can cause excessive slagging and fouling in power plants and requires boilers specifically designed to successfully burn coal with higher sodium contents (Thomas, 2002).

In-place coal quality varies significantly within the Gillette coal field. The north, middle, and south areas (fig. 12) were defined on the basis of variations in coal quality which permitted estimates of sales price using averaged coal quality data for each area. From figure 12, the in-place coal quality trends by bed may be observed. The Btu is highest in the south area and lowest in the north area. Sulfur and ash generally increase from the south area to the north area. 
In general, the apparent rank of coals in the PRB range from subbituminous $\mathrm{C}$ to subbituminous $\mathrm{A}$. The lower rank subbituminous $\mathrm{C}$ coal is located primarily in the shallower part of the basin along the east margin of the PRB (Stricker and others, 2007). Subbituminous B ranked coal is found in the Sheridan and North Extension Sheridan coal fields (fig. 6) on the west side of the basin as well as at intermediate depths (Luppens, 2011). Subbituminous A ranked coal is generally found in the deeper parts of the basin (greater than 1,600 ft depth) (Luppens, 2011). Because the PRB contains subbituminous coal, all resource and reserve volumes were calculated using an average density factor of 1,770 tons per acre foot of coal (Wood and others, 1983).

\section{Previous and Current Coal Mining}

In 2012, about 42 percent (420 million short tons) of the total coal production in the United States came from the PRB, distinguishing it as the most prolific coal basin in the United States (EIA, 2013). Coal production from the PRB from 1969 to 2012 has been almost 10 billion short tons (BST) (table 1). There are five areas within the PRB where current (December 2012) or previous coal mining has been significant (fig. 12): (1) Colstrip, Montana (includes the Rosebud, Absaloka, and abandoned Big Sky Mine); (2) Decker, Montana (includes the Decker and Spring Creek Mines); (3) Sheridan coal field, Wyoming (includes the abandoned Big Horn Mine); (4) Gillette coal field, Wyoming (includes the Antelope, Belle Ayr, Black Thunder, Buckskin, Caballo, Coal Creek, Cordero Rojo, Dry Fork, Eagle Butte, Jacobs Ranch, North Antelope/ Rochelle, Rawhide, and Wyodak Mines); and (5) Glenrock coal field, Wyoming (includes the abandoned Dave Johnston Mine and the Stevens lease areas).

On July 28, 1806, Captain William Clark of the Corps of Discovery observed coal beds as he floated down the Yellowstone River along the north margin of the Montana PRB (Moulton, 2001). Less than a year later, Manuel Lisa built a trading post at the confluence of the Bighorn and Yellowstone Rivers and used lignite coal from nearby outcrops to heat buildings during the winter months (Morgan, 1966). Despite the early discovery and use of coal in the Montana PRB, it was more than 100 years later that coal was commercially mined. In 1923, the first modern-day strip mine (Rosebud Mine) in the western United States was opened near Colstrip, Montana (fig. 2). The coal was mined by Northern Pacific Railroad Company and used to fuel steam locomotives. In the mid-1940s, coal production from the Rosebud Mine reached production of just more than 4 MST per year. However, by 1957 the mine was closed after a decade-long decrease in coal demand as steam locomotives were gradually replaced by diesel locomotives (Morgan, 1966). Total coal production from 1923 to1968 for the Montana PRB was less than 45 MST (Department of Labor and Industry, Safety and Health Bureau, State of Montana, written commun., 2011).
Montana Power Company acquired the Rosebud Mine in 1968 and formed a subsidiary, Western Energy Company, to manage and develop the Colstrip properties (U.S. Office of Surface Mining, 1983). Western Energy Company began mining coal at the Rosebud Mine near Colstrip Montana in 1968. One year later, Peabody Coal began operations at the Big Sky Mine just south of Colstrip, but closed operations in 2003 (figs. 2 and 12). The Absaloka Mine, located 10-12 mi west of the Rosebud Mine, began production in 1974 and is owned and operated by Westmoreland Resources, Inc. (figs. 2 and 12). Total production from the Colstrip area is about 708 MST (table 1).

The Decker East, West, and North Mines near Decker, Montana (figs. 2 and 12), began operating in 1972 after development of a 19-mi-long railroad spur from Sheridan, Wyoming. Total production from the Decker/Spring Creek area is about 642 MST (table 1). The Spring Creek Mine, also near Decker, Montana, opened in 1979 and is operated by Spring Creek Coal, LLC (figs. 2 and 12).

Coal in the Wyoming PRB was first documented in 1859-60 by Ferdinand V. Hayden, a member of Captain W.F. Raynolds' expedition exploring the Lower Yellowstone River. Hayden reported extensive lignite coal between the North Platte River and Pumpkin Butte area northwest of Gillette, Wyoming (Bryans, 1987). Traveling through the Powder River Basin in 1865, James A. Sawyer observed sizeable coal deposits south of Gillette, Wyoming (Gardner and Flores, 1989).

In the Wyoming PRB, coal mining began about 1883 near the towns of Glenrock and Douglas, Wyoming (fig. 1); however, it was the development of railroad lines in 1886 and 1887 that greatly affected significant growth in coal mining activity (Gardner, and Flores, 1989). The first underground coal mines in 1888 were the Mine near Douglas, Wyoming, and the Deer Creek Mine near Glenrock, Wyoming (fig. 1), each with production of about 13,000 short tons of coal (Gardner and Flores, 1989).

In the Sheridan coal field area (fig. 12), the Buffalo Fuel Company No. 1 underground mine was developed in 1888 (Gardner and Flores, 1989). The nearby Dietz Mine opened about 1890 and by 1925, 17 additional underground mines opened in close proximity to the Dietz Mine (Gardner and Flores, 1989). In 1905, mine production in Sheridan County was about 550,000 short tons of coal annually (Trumbull, 1905). The first surface mine (Peerless) near Gillette, Wyoming opened in 1924, where a 90-ft-thick coal bed was mined (Gardner and Flores, 1989). The Wyodak Coal and Manufacturing Company opened a large surface mine and produced about 33,600 short tons of coal in 1925. By the mid-1900s, advancements in mining equipment and mining techniques made surface mining much more profitable. Most underground mines closed or the companies switched from underground to surface mining methods.

Until 1978, most of the coal production in the Sheridan coal field area was from underground mines. Of the Sheridan County cumulative coal tonnage of about 62 MST through 1978, underground mining accounted for about 48 MST 
(78 percent). This production came from about 70 underground mines, most of which are about 10 mi north of Sheridan, Wyoming (fig. 12). Surface subsidence pits and troughs mark locations of many of the abandoned underground mine workings (Glass, 1978). The Dietz 3 and Canyon coal beds in the Sheridan coal field area were surface mined at the Big Horn Mine from 1962 to 2000 (Ellis and others, 1999); more than 47 MST of coal were produced from the mine (fig. 12). Total recorded production from the entire Sheridan coal field area is estimated at about 100 MST of coal (Nick Jones, Wyoming State Geological Survey, written commun., 2009) (table 1).

The need for coal increased dramatically in the mid1960s because of the increased demand for electricity from coal-fired power plants. For example, the Dave Johnston Mine in the Glenrock coal field opened in 1958 to supply coal to the adjoining power plant (fig. 12). Production from the Dave Johnston Mine from 1958 to 2000 totaled about 104 MST (Nick Jones, written commun., 2010). The Dave Johnston Mine marked the beginning of large surface mines in the Gillette coal field in the Wyoming PRB. In response to the need for low-sulfur, low-ash coal, production from the Gillette coal field increased: 623,000 short tons in 1972 (Keystone Coal Industry Manual, 1973); 81 MST in 1982 (Keystone Coal Industry Manual, 1983); 151 MST in 1992 (Keystone Coal Industry Manual, 1993); 360 MST in 2002 (Keystone Coal Industry Manual, 2003); and 388 MST in 2012 (Mine Safety and Health Administration, 2012).

Although coal production in the Gillette coal field came from 15 surface mines, only 11 are currently active (December 2012): Antelope, Belle Ayr, Black Thunder, Buckskin, Caballo, Cordero Rojo (Cordero Mine), Dry Fork, Eagle Butte, North Antelope/Rochelle, Rawhide, and Wyodak (fig. 12). Coal production is from the Anderson and Canyon coal beds (fig. 13), which when combined in some areas, attains more than $100 \mathrm{ft}$ in thickness. Production in 2012 from the Gillette coal field totaled more than 388 MST (table 1) with almost 52 percent of that total from two mines, the North Antelope Rochelle and the Black Thunder (EIA, 2013). Production from these two mines alone represents about 20 percent of the total U.S. coal production in 2012 (EIA, 2013). Total production (through 2012) from the Gillette coal field is about 8 BST (table 1).

\section{Coal Lease Areas}

In 1983, a report was submitted to the Bureau of Land Management (BLM) for the lease acquisition of Preference Right Lease Applications (PRLA) known as the Stevens North (W-12767, W-14390, W-14392) and the Stevens South (PRLA W-14355) (Western Fuels Association, Inc., 1983). The lease applications are north of the Dave Johnston Mine, in the Dry Cheyenne and Glenrock coal fields in the Wyoming PRB (figs. 2 and 12). These four PRLAs form one unit and are collectively known as the Stevens Project Area. Although no mining has taken place, in-place coal resources were estimated to be 625.3 MST (Western Fuels Association, Inc., 1983).
A report detailing the final Environmental Assessment of a lease area known as the Belco-BLM Coal Lease Exchange indicated that the Belco lease area located southeast of Buffalo, Wyoming (figs. 2 and 12) contained between 137 and 185 MST of minable coal at a stripping ratio of 5:1 or less. The minable coal beds in the Belco area are the Healy and the Ucross, in the Wasatch Formation (Bureau of Land Management, 1999).

In 2003, Pittsburg and Midway Coal Mining Company proposed a land exchange with the Federal government for lands within the Sheridan coal field in the Wyoming PRB. This land, which encompasses about 2,500 acres in sections $20,21,22,23,27,28,29,33$, and 34 , T. 58 N., R. 84 W., is referred to as the PSO lease area (figs. 2 and 12) and is located in the NE $1 / 4$ sec. 22, T. 58 N., R. 84 W. (Bureau of Land Management, 2003).

Pittsburg and Midway Coal Mining Company estimated that the PSO lease area contains about 112.5 MST of minable Federal coal, of which 107 MST was classified as recoverable. The projected mining rate was estimated at one MST for the first year with subsequent production increasing to 10 MST per year by year five. Within the PSO lease area, the Dietz 1 and Dietz 3 coal beds would be surface mined using a strip ratio of about 2.5:1. The Dietz 1 coal bed is present in the northern one-half of the lease area and is 5-20 ft thick. The Dietz 3 coal bed is present throughout the lease area and averages $41 \mathrm{ft}$ thick. Overburden above the Dietz 1 coal bed is as much as $275 \mathrm{ft}$ thick, whereas overburden above the Dietz 3 where the Dietz 1 is not present, is $20-120 \mathrm{ft}$ thick. The interburden thickness between the Dietz 1 and Dietz 3 beds is $20-140 \mathrm{ft}$, with a thickening trend from east to west. Two northeast-trending faults approximate the northwest and southeast boundaries of the lease area. Although these faults are known to be present, their exact locations and displacements have not been accurately defined by drilling. The displacements across each of these two major faults are estimated to be 60-180 ft. Generally, the stratigraphic dip is to the northeast at approximately four degrees. There are local areas where the shallow strata dip at higher angles, generally because of local folding or faulting (Bureau of Land Management, 2003).

Pittsburg and Midway Coal Mining Company entered into a joint venture agreement with CONSOL Energy Inc. to develop the PSO lease area (Lynn Manning, CONSOL Energy, oral commun., 2009). CONSOL of Wyoming LLC, and Chevron NPRB, LLC, formed a new company, Youngs Creek Mining Company, LLC, to develop and operate the proposed mine (Lynn Manning, CONSOL Energy, oral commun., 2009). The PSO lease area contains coal reserves totaling approximately 315 MST with an estimated heat content of 9,350 Btu/lb and an average sulfur content of 0.47 percent. In July 2012, the PSO lease area was sold to Cloud Peak Energy (Bob Green, Cloud Peak Energy, oral commun., September 2012).

In 2010, Arch Coal Inc. acquired the right to mine 572 MST of Montana State-owned coal in Otter Creek, south of Ashland, Montana (figs. 1 and 12); Arch Coal Inc. already controlled 731 MST of privately owned coal in the Otter Creek area (Dennison, 2010). The life-of-mine area includes areas known as Tracts I, II, and III. The proposed 
mine area (Tract II) is owned by Otter Creek Coal, LLC and encompasses approximately 7,640 acres, of which about 4,100 acres would be disturbed under the proposed mine plan; tracts I and III total about 10,580 acres. The proposed project, Tract II, would have production of about $20 \mathrm{MST} / \mathrm{yr}$ for a 20-year period (Montana Department of Environmental Quality, 2013). Mining has not commenced at the Otter Creek lease area as of October 2014.

\section{Previous Coal Resource Estimates}

Estimates on coal resources and reserves in the Powder River Basin have been published since 1927 (Dobbins and others, 1927). These estimates were based on different coal beds, coal zones, reliability categories, and geographic boundaries. Differences in minimum coal thickness, maximum overburden depth, and minimum areal extent of coal beds have been used for calculations of coal tonnages. Nevertheless, these studies form the foundation for most of the coal resource compilations that followed. Detailed lists of references can be found in U.S. Geological Survey reports on the four assessment areas (Luppens and others, 2008; Scott and others, 2010; Osmonson and others, 2011; and Haacke and others, 2013). The following list contains some of the more significant estimates for coal resources and reserves in different portions of the PRB as well as the entire PRB.

The earliest published estimate of coal resources in the PRB was by Dobbin and others (1927) for the Gillette coal field (fig. 6). Their estimate, based on an area of about $3,000 \mathrm{mi}^{2}$, was about 14.4 BST; however, they were limited to outcrop measurements for their calculation because little subsurface data were available.

Combo and others (1949) published a detailed report summarizing Montana coal resources by county, rank, reliability category, and thickness. Their estimate for coal resources in the Montana PRB was 126 BST. This included reliability categories of measured resources, indicated resources, inferred resources, and hypothetical resources based on distance from drill holes or outcrop and depths up to 2,000 ft. The measured and indicated coal reserves for the Montana PRB were estimated to be $47 \mathrm{BST}$ for coal beds greater than $2.5 \mathrm{ft}$ thick.

Berryhill and others (1950) provided a calculation of total original reserves of subbituminous coal in Wyoming by township, overburden thickness, and coal bed thickness. Coal tonnage estimates given for 86 townships entirely or partly within the Gillette coal field totaled about 45 BST (fig. 6). Their estimate was made for all coal beds more than $2.5 \mathrm{ft}$ thick and overburden less than 2,000 ft thick. Those estimates were the sum of measured, indicated, and inferred reserve tonnages.

Mapel (1954) estimated 3 BST of coal reserves in the Buffalo-Lake DeSmet area in the Wyoming PRB, in beds more than $2.5 \mathrm{ft}$ thick and under less than $1,000 \mathrm{ft}$ of overburden (fig. 6). Several years later, Mapel (1959) estimated total coal reserves in the Buffalo-Lake DeSmet area in beds more than $2.5 \mathrm{ft}$ thick and under less than $1,000 \mathrm{ft}$ of overburden at about 6.4 BST.
Mapel (1958) estimated about 193 BST of coal was present in coal beds greater than $2.5 \mathrm{ft}$ thick in the entire PRB. The estimate was based on 87 BST in the Montana PRB and 106 BST in the Wyoming PRB.

Ayers (1986a) provided an estimate of 1.06 TST of coal greater than $2 \mathrm{ft}$ thick to a depth of 3,000 ft within the Tongue River Member of the Fort Union Formation in the Wyoming PRB (fig. 4).

Glass (2001) published an estimate of 1.03 TST of coal for the Wyoming PRB, which included coal beds of any thickness and to all depths, even greater than $6,000 \mathrm{ft}$. The remaining strippable coal reserve base for the Wyodak coal bed was reported to be $17.9 \mathrm{BST}$, using a $200-\mathrm{ft}$ cutoff depth for overburden.

Ellis and others (2002) estimated 136.1 BST of original coal resource for five coal beds in the Gillette coal field (fig. 6). These resources were calculated for an area of the Gillette coal field encompassing about 1,500 $\mathrm{mi}^{2}$. The estimates showed that the available coal resource already defined represents about 89 percent of the original coal resource.

As documented in these various estimates, coal resource and reserve estimates change as more data become available. Therefore, new estimates provided in this report prove the usefulness of periodically recalculating coal resources and reserves. Estimates of coal resources and coal reserves in this report are a significant refinement of previous coal resource and reserve studies in the PRB.

\section{Previous Coal Bed Nomenclature}

Various names for individual coal beds and coal zones in the PRB have been used since the early 1980s (fig. 13). In fact, as many as 60 different bed names have been used throughout the basin. Historically, coal beds in Wyoming and Montana were named on the basis of a geographic location or the person who identified or described the bed.

A report by Kent and others (1980) described the northern part of the Gillette coal field and established a coal bed nomenclature system that has become the standard for much of the PRB in Wyoming (fig. 13). In that report, Kent used the name "Wyodak" from Mapel (1973) to describe a thick sequence of coals in the PRB. Pierce and others (1990) followed most of the same coal bed nomenclature of Kent and others (1980); however, they mapped the Wyodak coal bed splitting it into the Upper and Lower Wyodak beds and used the Roland bed name in place of the Smith bed (fig. 13). Although Flores and others (1999) followed the Pierce and others (1990) nomenclature, they introduced the concept of the Wyodak-Anderson coal zone, which includes the Smith, Badger, School, Sussex, Big George, Wyodak, Anderson, Dietz, Canyon, and Werner coal beds (fig. 13). A more detailed review of the historical coal geology and stratigraphy is provided in Flores and others (2010). 


\section{Methodology}

A three-phase methodology for calculating coal resources and reserves in the PRB is outlined on the flow chart in figure 14. This methodology has been used consistently for the previous four PRB assessments: (1) Gillette coal field by Luppens and others (2008), (2) Northern Wyoming Powder River Basin assessment area (NWPRB) by Scott and others (2010), (3) Southwestern Powder River assessment area (SWPRB) by Osmonson and others (2011), and the (4) Montana Powder River Basin assessment area (MTPRB) by Haacke and others (2013). The first phase involved data collection and editing. The second phase consisted of modeling, including final coal bed correlations and creation of an inventory of land-use and technical restrictions. The data entry and coal bed correlations tasks collectively represented the most man-hour-intensive effort of this assessment, representing about eight man-years. The third and final phase involved coal resource and reserve analysis.

\section{Phase One (Data Collection and Editing)}

Data pertaining to coal bed geology, extent and thickness of coal beds, interburden thickness, parting thickness, overburden thickness, structure, factors affecting coal extraction, coal ownership, coal quality, coal sales price, and tax information were gathered during the initial phase of the assessment (fig. 14). The following summaries provide more detail on the collection and editing processes.

\section{Data Collection}

The tremendous growth of CBM development since the early 1990s has facilitated a unique perspective of the subsurface coal stratigraphy in the PRB. The potential to more accurately delimit and correlate individual coal beds has been greatly enhanced with the completion of more than 27,000 CBM wells with corresponding geophysical logs. The Wyoming Oil and Gas Conservation Commission (WOGCC) Web site contains digital images of the geophysical logs of wells drilled in Wyoming (Wyoming Oil and Gas Conservation Commission, 2011). Initially, images for 694 logs were downloaded from that Web site to develop preliminary coal bed correlations throughout the Gillette coal field. These images were then used to construct both north-south and east-west hard copy geophysical log framework cross sections on approximately six-mile spacing. During the correlation of the framework cross sections, it was realized that the amount of data from these cross sections was insufficient to resolve the complex coal bed stratigraphy. More closely spaced data would be needed, which resulted in an intensive data entry program (Luppens and others, 2008).

A preliminary map of the overburden depth to the top of the Anderson coal bed was generated. Based on this overburden map, additional in-fill drill-hole logs were then selected for data entry at a spacing of about $0.25 \mathrm{mi}$ for areas less than $500 \mathrm{ft}$ of overburden, $0.5 \mathrm{mi}$ for areas of $500-1,000 \mathrm{ft}$ of overburden, and $1 \mathrm{mi}$ for areas of greater than 1,000 $\mathrm{ft}$ of overburden. Additional data were added in areas of particularly complex correlations. A 3-mile-wide buffer zone surrounding the Gillette coal field was added to extend the stratigraphic correlations and minimize edge effects when modeling the coal beds. A data collection process similar to this was used for subsequent PRB assessment areas, where thick coal beds incurred closely spaced CBM development.

Well logs for oil and gas and CBM wells were obtained from the WOGCC and MJ Systems (2009, 5085 Oakland St., Denver, CO 80239). USGS personnel completed data entry for 6,387 wells of the total 10,210 data points for the Gillette coal field assessment. Subsequently, USGS personnel entered data for 2,821 points for the NWPRB assessment area, 3,161 points for the SWPRB assessment area, 1,956 points for the MTPRB assessment area, and 276 points for the East Gillette coal field extension area, bringing the total number of data entry points to 14,601 .

Data from an additional 15,327 drill holes were supplied by the Montana Bureau of Mines and Geology (MBMG) (accessed 2012 at http:/www.mbmg.mtech.edu/gis/ gis-datalinks.asp), Wyoming State Geological Survey (WSGS), and the USGS National Coal Resources Database System (NCRDS). All of the drill-hole data were entered or imported into the StratiFact database program (GRG Corporation, 1998). A total of 29,928 drill holes (of which 21,393 holes were nonproprietary) were used in the PRB assessment (fig. 15). The database for the 21,393 nonproprietary drill holes was published by the USGS in 2013 (Haacke and Scott, 2013).

Gamma-ray geophysical logs were available for most of the wells and were the basis for most of the lithologic interpretation. Normally, oil and gas wells are logged in detail primarily for deeper target formations. The upper intervals were either not logged or only gamma-logged through the surface casing. Geophysical log data in older oil and gas wells usually consisted of a combination of spontaneous potential, resistivity, or conductivity logs. The most reliable log suite for coal interpretation consisted of natural gamma, gamma-gamma density, and resistivity traces; however, many coalbed methane wells were logged with gamma-ray only, either in open hole or through steel drill pipe or casing. Additionally, some of the coalbed methane wells were logged only to the top of the target coal bed which required consulting production records for the coal bed thicknesses.

Noncoal lithology was not essential for the coal resource assessment of the PRB; consequently, much of the noncoal lithology was coded generically as rock. It is estimated that the interpretation of all the noncoal intervals would have doubled or tripled the time needed to complete the total data entry effort. Parting intercepts within coal beds and interburden between coal beds were also coded as rock. Intervals that were not logged by geophysical methods, such as the shallow portion of an oil well or CBM well, were designated as "No Log." However, if the thickness of the methane-producing interval was available from production records for those CBM wells not completely logged, that interval was entered as "coal, CBM perf." 
Data on various restrictions to mining were gathered and incorporated into GIS. Additionally, information required for the mining and economic evaluation, such as tax information, lease royalty costs, and updated costs for equipment, supplies, and manpower wage scales were assembled. Site visits to operating mines in the PRB were conducted during this initial phase and were an important activity to help ensure that the mine models developed for the coal recoverability analyses reflected current mining practices and approaches.

\section{Phase Two (Modeling)}

Phase two involved the correlation of individual coal beds, creating integrated, multi-coal-bed models, creating land-use and technical restrictions to mining (fig. 14). The coal bed correlation process is included in the modeling section because the bed nomenclature had to consider some limitations of coal bed modeling to avoid making the models too complex.

\section{Coal Bed Correlations}

Coal bed stratigraphy in the PRB is often complicated because of complex channel systems that controlled coal deposition. Thus, the geology alone makes the task of correlating individual coal beds in the PRB a significant challenge. In cases where thick partings split coal beds into distinct beds, the coal bed is correlated as a "lower" or "upper" bed of the primary bed. Further complicating the correlation effort was the fact that coal beds extending from Wyoming into Montana often had different names. Also, thick, shallow coal beds in the eastern Gillette coal field and the western PRB, coupled with a lack of substantial subsurface data early in the reporting of the basin, led to a proliferation of local coal bed nomenclature.

Flores and others (2010) believed that there is confusion, basinwide, over the names, correlation, and distribution of individual coal beds that requires resolution in order to make meaningful estimates of both coal and CBM resources in the PRB. Because of the existing uncertainties in the correlation of individual thick coal beds, Flores and others (1999) suggested that coal resource estimates should be performed according to coal-zone intervals. However, meaningful coal resources, and especially reserve assessments, must be founded on geological models of individual coal beds, not by coal zones. Flores and others (2010) attempted to resolve some of the correlation confusion by publishing a database containing 1,715 well logs, with a network of 17 cross sections. The primary objectives of the Flores and others (2010) report were to revise and improve the mapping of coal beds in the Fort Union and Wasatch Formations. There were, however, numerous coal bed nomenclature conflicts with tie wells in the database between the north-south and east-west cross sections. The use of multiple bed names for identical coal bed intervals in the Flores and others (2010) report database precluded accomplishing the study's objectives. Consequently, the only coal bed maps in the Flores and others (2010) report were based solely on the net thickness of coal beds within the Wyodak-Anderson coal zone, rather than individual coal bed isopach maps.

The Gillette coal field report (Luppens and others, 2008) was the first assessment to take advantage of recent CBM drilling, which provided sufficient data control to correlate and map individual beds on a regional scale (fig. 2). Extension of the coal bed correlations northward from the Gillette coal field to the Montana State line and westward across the Wyoming PRB to the Sheridan coal field was accomplished in the NWPRB assessment area report (Scott and others, 2010). Completion of the correlation and mapping of the coal beds in the remaining Wyoming portion of the basin was accomplished in the SWPRB assessment area (Osmonson and others, 2011) (fig. 2). The MTPRB assessment area (Haacke and others, 2013) report was the completion of the correlation and mapping of coal beds in the Montana PRB (fig. 2).

The initial correlation and coal bed nomenclature stratigraphically below the Wyodak-Anderson coal zone were guided by five USGS cross sections: (1) McLellan and others (1990); (2) Pierce and others (1990); (3) Hardie (1991); (4) Molnia and Pierce (1992); and (5) McLellan (1991). Following data entry by USGS personnel for the Gillette coal field assessment, final correlations were refined from the preliminary framework cross sections.

A graphical interface to the StratiFact (GRG Corporation, 1998) database was a critical tool for managing the interpretation of large amounts of new stratigraphic data. Using StratiFact, cross sections were selected, edited, and correlations were completed onscreen. Both linear and circular cross sections were constructed to correlate coal beds across the PRB. Circular cross sections that verified closure were especially valuable when coal beds either split or thinned adjacent to channels systems. With this process, the beginning and ending drill holes of the cross section are the same, assuring that the coal beds align stratigraphically with each other and provide closure to the section.

Figures 16 and 17 show that with new data and circular cross sections, previous correlations can be verified or refined. As seen in figure 16, there is a 9-mi gap between drill holes API 49-005-24358 and API 49-005-33013. Both drill holes contain thick coal beds that were assumed to be the Upper Wyodak coal bed (Anderson coal bed in this assessment) (Molnia and Pierce, 1992). In the Gillette coal field assessment, nine additional drill holes were added between those two drill holes, demonstrating that the new data were essential in revising and improving the confidence in the correlations (fig. 17). Figure 17 shows that the Anderson and Canyon (Lower Wyodak) coal beds do not split and that the thick upper coal bed in API 49-005-24358 is actually the Smith coal bed, not the Anderson (Upper Wyodak) as shown in figure 16. 
The Anderson and Canyon coal beds split and thin as they extend towards the NWPRB assessment area from the northern part of the Gillette coal field (fig. 10) (Scott and others, 2013). Channel areas where coal beds are thin or absent (referred to as "want areas" by Flores and others, 2010) posed challenges for extending coal bed correlations west and north from the Gillette coal field. Figure 18 illustrates a significant "want area" in eastern Sheridan County, Wyoming. Not only were many of the coal beds thin or absent, but drilling data were relatively sparse because of a lack of sufficiently thick CBM development targets (fig. 15). To correlate around these "want areas," the coal bed correlation process proceeded north through the east margin of the NWPRB assessment area and then westward through the southernmost townships in Montana. The coal beds remained relatively thick enough to extend correlations across the NWPRB assessment area (fig. 18) (Scott and Luppens, 2013).

Although correlations focused on the Wyodak-Anderson coal zone in the Gillette coal field, coal beds from the Felix to the Pawnee were correlated (fig. 13). Three relatively persistent deeper coal beds below the Pawnee bed were informally correlated to the Deep 1,2, and 3, rather than trying to sort out the various local bed names. Figure 13 shows coal bed nomenclature used for the Gillette coal field, NWPRB assessment area, SWPRB assessment area, and MTPRB assessment area, and this report, as well as their relations to the coal bed names used in previous studies.

For the NWPRB assessment area, the Odell and Roberts coal beds, stratigraphically below the Pawnee coal bed, had significant areas $10-\mathrm{ft}$ thick or greater in thickness and were therefore correlated and assessed. The Deep 1, 2, and 3 coal beds were also correlated, but these beds remained relatively thin and insignificant from a resource standpoint. In the SWPRB assessment area, the Deep 1, 2, and 3 coal beds had significant areas greater than $10 \mathrm{ft}$ in thickness. For the MTPRB assessment report, local names were used for coal beds stratigraphically lower than the Pawnee bed such as the Knobloch (fig. 13). A "dash" was used for formal hyphenated names such as the Flowers-Goodale. Beds with equivalent local names were separated with a virgule (/) for example, the Rosebud/Knobloch bed.

The final task of the correlation process was to unify the coal bed nomenclature of the four assessment areas into a single database to support coal bed mapping on a basinwide scale. The first step in this process was to complete the correlations for deeper coal beds below the Pawnee bed which were not originally assessed in the Gillette coal field report (Luppens and others, 2008). The eastern limit of the Gillette coal field assessment was the subcrop of the thick Anderson and Canyon beds; therefore, the area east of the depth where the deeper coals would crop out was not evaluated.

To complete the evaluation of these deeper coal beds, the East Gillette coal field extension was assessed (fig. 2). Setting the east boundary of the extension area at the limit of Tertiaryage rocks in the basin also coincided with the NWPRB and
SWPRB assessment area eastern boundaries (fig. 2). The East Gillette coal field extension assessment required supplementing limited drilling information from the original Gillette coal field database with data entry of additional oil and gas wells. With these additional data, the correlation of the deeper coal beds from the Gillette coal field was expanded towards the east margin of the basin (fig. 8).

The last step in developing a unified, correlated database for the PRB was melding the Wyoming and Montana coal bed correlations into a single nomenclature. Since the Wasatch Formation is essentially confined to the Wyoming PRB, there are no significant State-to-State nomenclature issues. The principal coal beds within the Wyodak-Anderson coal zones were also straightforward as bed names such as the Smith, Anderson, and Canyon are used in both Wyoming and Montana. The coal bed nomenclature below the Wyodak-Anderson coal zone is especially problematic. Using StratiFact to display onscreen cross sections effectively resolved equivalent coal beds. Dual bed names separated by a virgule (/) were adopted where it made sense to keep ties to the regional nomenclature. For example, the Deep 3 bed in Wyoming correlated with the Flowers-Goodale bed in Montana. The final name used for this coal bed was the Flowers-Goodale. Figure 13 summarizes how the coal bed names evolved through the four assessment areas and the resultant coal bed nomenclature used for this summary report.

As a result of the correlations and unification of coal bed nomenclature, many coal bed names used in other reports were not used in this report. Names eliminated include: Badger, Broadus, Carney, Carlson, Carson, Elk, Kendrick, Kennedy, King, Mackin-Walker, Poker-Jim, Sawyer, Swartz, and Waddle.

\section{Coalbed Modeling}

The next step of Phase two of the assessment (fig. 14) was the creation of digital coal bed models to determine the original resources for all 47 beds. Preliminary coal isopach maps were created using the single-bed modeling program Surfer (Golden Software, 2002) to review coal bed areal extent. The basic assumption used to qualify coal beds for potential coal resource evaluation was a thickness of at least $2.5 \mathrm{ft}$ (Wood and others, 1983).

The integrated multibed modeling program $\mathrm{PC} /$ Cores (Mentor Consultants, 2005) was used to produce gridded coal bed models for the 47 coal beds identified in the PRB assessment (fig. 13). This modeling program is designed for coal and mineral assessments and is especially effective for coal bed modeling because of the capability to simultaneously grid multiple beds. The program provides a considerable reduction in total modeling time compared to other programs that grid only one parameter at a time. Grids must be made for coal thickness, parting thickness, coal height (coal plus parting), roof and floor structures, and overburden and interburden 
thicknesses for each bed. The roof grid for each coal bed must be individually subtracted from the surface grid or the floor grid for the next stratigraphically higher coal bed.

Most multiple coal bed modeling programs are highly automated with a sophisticated subroutine that uses individual coal bed structure grids to check for drill holes too shallow to penetrate a given bed. This feature produces more accurate digital models without the need for extensive manual editing. The PC/Cores ${ }^{\circledR}$ program code was further modified to allow correlations to pass through the sections of the drill holes that were not logged to reduce the generation of "false zero" thickness values.

Quality control methods to verify coal bed correlations and coal bed areal distributions were essential to this assessment. This was accomplished by generating preliminary isopach and structure contour maps for each modeled bed to check for "bull's eye" anomalies. Also, a routine within the $\mathrm{PC} /$ Cores modeling program was used to identify anomalous locations by comparing collar elevations to the digital elevation model (DEM) of the Earth's surface; many location errors were resolved using this technique.

Methods to reduce the effects of projected contours were also devised to limit erroneous data projections. A circle with a 0.75 -mi radius was generated around every data location with at least one coal bed intercept. A line was then digitized through the updip sides of the circles using the locations closest to the basin margins. This digitized line was used as a gridding boundary to prevent gridding projections where coal data were insufficient. The boundary line was especially important on the west margin of the basin where the strata are steeply dipping and coal beds are thinning or pinching out (figs. 3 , 8 , and 9).

To generate isopach grids for coal bed geometries, the use of an option in the PC/Cores modeling program known as "pinching" was used. While extracting $\mathrm{X}, \mathrm{Y}$, and $\mathrm{Z}$ coal bed thickness files to be gridded, the pinching option caused a negative thickness to be generated for a hole where the bed was missing. This resulted in the zero thickness value placed halfway between the nearest positive thickness data point and the actual zero value location. Therefore, use of the pinching function provided a slightly more conservative projection of coal bed areal extent, particularly where data points were more widely spaced.

For the final coal bed model, 5 grids including thickness, roof, floor, bed height, and parting, were generated for each coal bed for a total of 235 grids for the 47 coal beds modeled. The coal bed models were gridded at a resolution of 150 meters (m) (about $500 \mathrm{ft}$ ) with a total of about 3,954,000 cells in a single grid. The file size of individual grids ranged from about 25 to 45 megabytes.

The grids for the coal resource model (coal thickness, parting thickness, roof elevation, floor elevation, and bed height) for each of the 47 coal beds were converted in $\mathrm{PC} /$ Cores to a generic ASCII grid format. These ASCII grids were then exported to ArcView (Environmental Systems Research International, 2006) to perform the last step in Phase two of the assessment, modeling restrictions to mining.

\section{Restrictions to Mine Models}

The final step in Phase two of the assessment was to create grids of land-use and technical restrictions to mining by coal bed. The objective of this step in resource planning is to determine the amount of available coal resources. This process is accomplished by first subtracting the amount of mined coal and clinker from the amount of original resources; the result is remaining resources. Subtracting the amount of landuse restrictions and technical restrictions from the amount of remaining resources yields available resources. The following discussion details the methodology used in determining available resources.

The coal bed model files created in PC/Cores were imported into GIS. The GIS was used to allocate coal resources, by first subtracting amounts of various restrictions to mining (fig. 19) (for example, mined coal, towns, National forests, alluvial valley floors) in order to calculate the amount of available coal.

ArcView and the ArcView Spatial Analyst extensions (Environmental Systems Research Institute, Inc., 2006) were used to perform the various GIS analyses and ultimately calculate the amount of coal resources. In addition, ArcGIS (Environmental Systems Research Institute, Inc., 2006) was used to project digital coverages, shapefiles, and grids to the assessment area's base map projection. The geographic referencing base for the digital data used for the GIS analysis was the Universal Transverse Mercator (UTM) map projection, using the following parameters: map units $=$ meters; zone $=13$; datum $=$ NAD27; and spheroid $=$ Clarke, 1866 .

For this GIS assessment, a grid cell size of $30 \mathrm{~m}$ (about $100 \mathrm{ft}$ ) was chosen. This smaller grid size was required to better define restrictions to mining. All grids used for the GIS analysis were either originally created with a grid cell size of $30 \mathrm{~m}$ or resampled to $30 \mathrm{~m}$ from another cell size. In the case of the digital coal model grids, the cell size was resampled from $150 \mathrm{~m}$ to $30 \mathrm{~m}$.

The first task in the GIS process involved the creation of ArcView (Environmental Systems Research Institute, Inc., 2006) grids from ASCII data representing files for coal, parting, and overburden isopach grids that were created from the digital coal models. These ArcView grids were then used to create a total thickness (coal plus parting) grid, and the areal extent grid for each coal bed to be evaluated. Grids were then created to categorize an extent of a specific theme for the entire PRB. These grid themes consisted of mined-out areas, burned coal areas, land-use restrictions, technical restrictions, overburdento-coal-bed ratios, counties, mineral ownership, stripping ratios, resource reliability categories, and coal bed depth. 
The grid theme for burned coal areas was developed from digital surface clinker information obtained from the Montana Bureau of Mines and Geology Geographic Information Systems Lab (2012) and Coates and Heffern (1999) (fig. 7). To estimate the amount of coal within the PRB that has been burned, it was assumed that there is up to a 3:1 ratio of clinker thickness to burned coal thickness (Coates and Heffern, 1999). Consequently, to estimate the areas of coal within each bed that has been burned, a combination of surface clinker extent, coal overburden thickness, and coal bed thickness was used during the assessment. Specifically, wherever surface clinker is present over a coal bed and the thickness of the overburden is three times (or less) the thickness of the coal, the coal within the bed was considered to be completely burned. This calculation produces a conservative estimate of the amount of burned coal throughout the PRB.

The grid theme for mineral ownership was obtained from the USGS (2012, available at http://pubs.er.usgs.gov/ publication/ofr981) (fig. 20). The grid themes for mined coal, land-use restrictions, and counties, were derived from digital information obtained from the Natural Resource Information System GIS Data List of the Montana Bureau of Mines and Geology Geographic Information Systems Lab (2011) and the Wyoming Spatial Data Clearinghouse (2009) (fig. 19). The remaining grid themes were developed internally within the USGS using ArcView (Environmental Systems Research International, 2006).

The grid of land-use restrictions includes various buffer zones that surround each restricted area. The location and width of these buffers are typically mandated by State or Federal regulations. One of the important improvements in this USGS assessment methodology was revising a technique for defining surface restrictions at depth. Previous economic assessments applied a standard vertical projection downward through the coal beds when applying regulatory surface buffers (such as a 300-ft buffer around an inhabited house) below the surface. Because of the additional setback distance required to maintain a safe mining-pit highwall angle, a restricted area actually widens with depth when surface-mining operations are considered. Figure 21 illustrates the effect of depth on overall land-use restriction size. For example, a circular restriction having a diameter of $600 \mathrm{ft}$ at the surface encompasses an area of about 282,600 square feet $\left(\mathrm{ft}^{2}\right)$, or approximately 6.5 acres. However, at a depth of $200 \mathrm{ft}$, this same restriction has a diameter of $858 \mathrm{ft}$ and encompasses an area of about $577,900 \mathrm{ft}^{2}$, or approximately 13 acres. At a depth of $500 \mathrm{ft}$, the same restriction has a diameter of 2,144 ft and encompasses an area of about 3,608,400 $\mathrm{ft}^{2}$, or approximately 83 acres.

The grid for mined coal accounts for all prior mining within the PRB including those mines shown in figure 12. The coal mineral ownership grid was divided into Federal, State, and private ownership categories (fig. 20). The resource reliability grids were divided into measured, indicated, inferred, and hypothetical coal categories (Wood and others, 1983). The overburden grids were reported in 5 depth categories: $0-500 \mathrm{ft}$;
$500-1,000 \mathrm{ft} ; 1,000-2,000 \mathrm{ft} ; 2,000-3,000 \mathrm{ft}$; and greater than $3,000 \mathrm{ft}$. For this assessment, overburden depth is calculated where the coal bed is $2.5 \mathrm{ft}$ thick or greater.

The next step in the methodology was to combine individual grids into one composite theme grid. The composite theme grid was then combined with each respective coal bed areal-extent grid. This was done in order to define the PRB resources on a bed-by-bed basis, using all attributes of the grid. Areas within each coal bed that represented mined coal, land-use, and technical restrictions were removed from consideration. Supplemental to this report are GIS data created using Esri ArcGIS 9.3.1 (Environmental Systems Research International, 2006) that can be used to show mineral ownership, mined out areas, land-use and technical restrictions for all 47 coal beds in map view, along with other pertinent data layers (Kinney and Scott, 2015).

Although coal resources were calculated using a minimum thickness of $2.5 \mathrm{ft}$, coal beds less than $5.0 \mathrm{ft}$ thick were considered technically restricted, for surface mining operations. Consequently, separate $\mathrm{PC} / \mathrm{Cores}^{\circledR}$ models were produced for coal beds that excluded areas where the coal resources were less than $5.0 \mathrm{ft}$ thick. Coal resources were allocated to separate stripping ratios for coal beds included in the economic evaluation.

\section{Factors Affecting Extraction of Coal Resources}

Many factors affect the availability of coal for mining and a four-step screening process defined in the 43 Code of Federal Regulations (CFR) 3420.1-4 was used to determine which areas of Federal coal are acceptable for leasing (Office of the Federal Register, 2003). The following 20 coal-leasing unsuitability criteria are listed in the Code of Federal Regulations, Title 43 Subpart 3461.5 (43 CFR 3461.5).

\footnotetext{
Alluvial valley floors

Bald and golden eagle roost and concentration areas

Bald or golden eagle nests

Critical habitat for threatened or endangered plants

Critical habitat for animal species

Dwellings, roads, cemeteries, and public buildings

Federal lands containing active falcon cliff nesting site

Federal land systems

Floodplains

Fish and wildlife habitat for resident species

Habitat for migratory bird species

Historic lands and sites

Lands used for scientific study

Lands with outstanding scenic quality

Municipal watersheds

National resource waters

Natural areas

State listed threatened or endangered species

State or Indian tribe proposed criteria

Rights-of-way and easements (for example, railroads)

Wilderness study areas
} Unsuitability criteria 
These criteria are used to determine if an area is unsuitable for leasing and surface mining and were originally established by the Surface Mining Control and Reclamation Act (SMCRA) of 1977 (30 U.S.C. 1201et seq.). Although developed for lands owned by the Federal government, many of the unsuitability criteria are also applicable to State owned and privately owned lands (fig. 20). For example, areas containing threatened or endangered plant or animal species are protected from destruction wherever they occur. Municipal watersheds are also protected from detrimental actions regardless of land ownership. Not all criteria in the Unsuitable Criteria list affect mining development within the PRB. Other potential land-use restrictions to mining include airports, archaeological areas, coalbed methane wells, oil and gas wells, pipelines, power lines, rivers, lakes, streams, and towns.

Restrictions to mining vary with location and local land management regulations. This report follows practices governing restrictions to mining in the PRB. In addition, BLM personnel in Casper, Wyoming, and Billings, Montana, provided guidance concerning restrictions to mining and the distances to be buffered around specific features. Required buffer distances can change through time; however, buffer distances for this assessment were selected based on current regulations (October 2014). A more detailed determination of restrictions and other availability considerations would be necessary as part of the leasing and mine-planning phases for any mining operation. Figure 19 shows areas of land-use restrictions within the PRB; a discussion of identified mining restrictions follows.

\section{Airports}

The Broadus airport is located near the town of Broadus, Montana, about $2.5 \mathrm{mi}$ northwest of the central business district (fig. 19). For this assessment, the airport (including a $300-\mathrm{ft}$ buffer surrounding the airport) is considered a restriction to mining. The Colstrip airport is located about 4 mi southwest of the central business district of Colstrip, Montana, and is located on reclamation land that is surrounded by adjacent mining areas of the Rosebud Mine. Therefore, the Colstrip airport is not considered to represent a separate restriction to mining for this assessment.

The Sheridan County airport is adjacent to the city of Sheridan, Wyoming, and is included within the town of Sheridan restriction buffer area (fig. 19). The Johnson County airport is adjacent to the city of Buffalo, Wyoming, and is included in the town of Buffalo restriction buffer area (fig. 19). The Campbell County airport is adjacent to the city of Gillette, Wyoming, and is included within the town of Gillette restriction buffer area (fig. 19).

\section{Alluvial Valley Floors}

Areas identified as alluvial valley floors, where mining would interrupt, discontinue, or preclude farming, are considered restrictions to mining, according to the Surface Mining Control and Reclamation Act of 1977 (30 U.S.C. 1201 et seq.) (fig. 19). In addition, areas outside the alluvial valley floors may also be designated unsuitable where mining might damage the quantity or quality of water supplying the alluvial valley floors. This assessment did not include these specific areas in the delineation of restrictions.

\section{Archaeological Areas}

No major archaeological areas that would prevent mining have been identified in the PRB. However, there are several minor archaeological and historic sites within the PRB. A mitigation plan would need to be developed before coal mining disturbed any of these areas. Therefore, coal within these known sites was not excluded from this resource assessment.

\section{Coalbed Methane}

Disputes over ownership of CBM resources have arisen between coal mining and CBM development companies as to whether the CBM resources belong to the owner of the oil and gas estate or the owner of the coal estate. Determination of the ownership of CBM resources was resolved by the U.S. Supreme Court in 1999, ruling that CBM resources are part of the oil and gas estate (Supreme Court of the United States, Amoco Production Co. v. Southern Ute Tribe (98-830), 526, U.S. 865 (1999). In addition, the court specified the owner of a CBM lease has the right to gain access and to develop its estate, and owners of the land surface should be adequately compensated for damage to their property resulting from CBM extraction. The BLM has established Conflict Administration Zones to guide development of CBM leases in the path of near-term coal mining (Bureau of Land Management, 2013). In these zones, standard guidelines offer a process for settling conflicts and scheduling development of each resource under a Federal mineral estate.

The production of CBM produces large volumes of groundwater that is pumped from the coal bed. The groundwater is generally discharged to holding ponds for consumption by livestock, discharged to existing drainage systems, released into the atmosphere through the use of misting towers, or reinjected into another stratigraphic unit. Rice and others (2000) investigated concerns over potential environmental effects of CBM development including possible contamination of surface water, water quality in holding ponds, formation of saline crust on the ground surfaces, lowering of the water table, and possible groundwater contamination or depletion of existing aquifers.

Since the early 1980 s, more than 27,000 new CBM wells have been drilled in the Wyoming PRB (Wyoming Oil and Gas Conservation Commission, 2011) (fig. 15). Production of CBM is mostly from the Wyodak-Anderson coal zone (Smith, Anderson, and Canyon coal beds). The area of high CBM potential in Wyoming is controlled by the distribution of thick coal beds (fig. 22). In 2008, about 535 billion cubic ft of CBM was produced from 24 unique coal deposits in 10 Tongue River Member coal zones that occur in the Wyoming PRB (Jones, 2010a). The CBM resource in the Wyoming PRB is estimated to be 37 trillion cubic $\mathrm{ft}$ assuming 65 cubic $\mathrm{ft}$ of CBM per ton of in-place coal (De Bruin, 2009; Nick Jones, Wyoming Geological Survey, oral commun., 2009). The production life 
of CBM wells is estimated to be about $10-12$ years, although production from multiple beds can extend the life of the well by an additional 10-30 years (De Bruin and others, 2004).

CBM development in the Montana PRB began in about 1991, but has proceeded at a much slower pace than in the neighboring Wyoming PRB. Approximately 1,100 wells have been drilled near the Decker Mine, along the MontanaWyoming border (Montana Board of Oil and Gas, accessed June 2011, at http://www.bogc.dnrc.mt.gov). CBM development in the Montana PRB is restricted to a relatively small area in Big Horn County that includes T. 8-9 S., R. 39-41 W. (fig. 15). Although current (October 2014) CBM production is from the Smith, Anderson, Dietz 2, Dietz 3, Canyon, Werner/ Cook, and Gates/Wall coal beds, there may be additional potential for production from deeper coal beds in the Montana PRB. Van Voast and Thale (2001) identified areas of high, moderate, and low CBM potential for the MTPRB (fig. 22).

The lack of CBM expansion in the Montana PRB is because of a combination of less favorable coal bed targets and increased distance from existing infrastructure. Coal beds in the Montana PRB are not as well suited to CBM development as coal beds in the Wyoming PRB because they lack the overall depth and thickness when compared to the central and southern PRB coal beds. Coal beds become shallower and eventually crop out to the northern portion of the MTPRB in response to structural and topographic control. Although this may be advantageous for surface mining, it is not beneficial for CBM development. Coal beds at shallow depths or near outcrop are likely to have lower hydrodynamic pressures (the pressures necessary to retain the adsorbed methane). Under reduced pressures, methane gas in coal beds can migrate towards the outcrop and eventually escape.

Although there are thousands of CBM wells within the PRB, designating all of these wells and their accompanying pipeline infrastructure as being restrictive to mining would exclude a significant volume of coal resource from mining consideration. For the purpose of this assessment, it is assumed that coal within any part of the PRB will be mined after CBM operations have ceased in that area; therefore, the wells and accompanying pipeline infrastructure are not considered a restriction to mining.

\section{Dwellings and Buildings}

Individual dwellings and buildings that exist outside of incorporated areas (such as Colstrip, Montana) are not considered restrictions to mining within the PRB. These structures are typically purchased by a coal company, which could move or raze them in order to proceed with mining.

\section{Federal Land Systems}

Almost 86 percent of the coal in the PRB is owned by the Federal government and must be leased in order to be mined. The largest contiguous parcel of Federal-owned land in the PRB is the Custer National Forest, in the Montana PRB (fig. 19). The Custer National Forest covers an area of about
$783 \mathrm{mi}^{2}$ in western Powder River County and extends into southern Rosebud County. The same unsuitability criteria and land-use conflicts discussed earlier in this report apply to coal mining in the Custer National Forest. Therefore, the national forest is a restriction to surface coal mining, and the restriction includes a buffer that extends $300 \mathrm{ft}$ beyond the forest's boundary. However, the BLM could develop coal leasing and mining stipulations in cooperation with the U.S. Forest Service (USFS) for underground coal mining. Federal subsurface coal ownership is shown in figure 20.

Fort Keogh National Wildlife Refuge is located immediately southwest of Miles City, Montana, at the northern boundary of the Montana PRB (fig. 19). A national refuge is typically a restriction to mining. Because the mapped coal beds do not extend into the refuge, the Fort Keogh refuge did not restrict any assessed resources.

The southern part of the Gillette coal field is part of the Thunder Basin National Grassland that includes scattered Federal lands under the jurisdiction of the USFS. The same unsuitability criteria and land-use conflicts discussed in this report apply to coal mining on the Thunder Basin National Grassland. Where the mineral ownership is Federal, the BLM develops coal leasing and mining stipulations in cooperation with the USFS. Therefore, the Thunder Basin National Grassland is not considered a restriction to mining.

\section{Historic Lands and Sites}

The site of the "Battle of Wolf Mountains" is about $3 \mathrm{mi}$ southwest of Birney, Montana, along the valley of the Tongue River (figs. 1 and 19). This site is the location of the last major battle of the Great Sioux War of 1876-1877 (National Park Service, 2012) and was added to the National Register of Historic Places in 2001. In 2008, the site became a National Historic Landmark; therefore, the 1,300-acre site is a restriction to mining.

\section{Oil and Gas Development}

The Hilight gas plant is approximately 7 mi northeast of the town of Wright, Wyoming, and connects to several major pipelines for gas and crude oil, as well as a pipeline for gas processing products (fig. 19). This installation, with a $100-\mathrm{ft}$ buffer is considered a restriction to mining. The Kitty gas plant also connects to several major pipelines for gas and crude oil, and gas processing products. However, the plant is within the jurisdiction of the buffer zone restriction surrounding the town of Gillette, Wyoming.

Current infrastructure for production and transport of oil and gas in the area includes roads, pipelines, compressor stations, and separators. Generally, there is little conflict between coal development and conventional oil and gas development in the PRB, as oil and gas reservoirs are primarily in stratigraphic units below minable coal beds. Where oil and gas development and coal mining occur in the same areas, mining is confined to areas outside a specified buffer distance from wells, pipelines, and other oil and gas related structures. Resolution of land-use 
conflicts between coal mining and the oil and gas field development will depend on economic conditions, regulations, and negotiations between oil developers and coal developers.

Thousands of oil and gas wells are located throughout the PRB. An area around a major cluster of active wells might be eliminated from mining activities until these wells are no longer actively producing, or mining activities might proceed around individual active wells that are given a buffer zone. Conversely, specific wells might be plugged and then reestablished after mining. For this assessment, it was assumed that the wells will no longer be actively producing when mining operations affect them; they are not considered to be restrictions to mining.

\section{Pipelines}

There is a network of underground oil and gas pipelines throughout the entire PRB. Most of these pipelines could be moved so that surface mining could proceed. However, moving and restoring them would represent an added economic cost to mining. In any case, pipelines were not considered to be restrictions to mining for this assessment.

\section{Power Lines}

All power lines within the PRB could be moved to accommodate surface mining operations and are not considered a restriction to mining in the PRB.

\section{Railroads}

There are two main railroad routes through the Gillette coal field in the Wyoming PRB (fig. 19). The generally eastwest route in the north part of the Gillette coal field is a rail line of the Burlington Northern Santa Fe Railway that runs northwesterly through Sheridan, Wyoming. The north-south route in the eastern part of the Gillette coal field is a combination of rail lines of both the Burlington Northern Santa Fe Railway and the Union Pacific Railroad. This combination of rail lines is referred to in this report as the "Joint Line" and runs from Gillette, Wyoming, south to Douglas, Wyoming. In addition to the main rail lines, a number of additional spur rail lines serve existing coal mines. However, these spur lines can be moved as the mining operations progress, and they are not considered a restriction to mining. Although it is conceivable that the main lines of the existing rail routes could also be relocated to allow mining to proceed, it is assumed that these main rail lines would not be moved and are restrictions to mining. The total restricted width for each main rail line, including the right-of-way and a 100-ft buffer along each side, is $600 \mathrm{ft}$.

The main railroad route through the Montana PRB is an east-west rail section of the Burlington Northern Santa Fe Railway that is in the extreme northern part of the basin. It is not considered a restriction because coal beds do not extend into this area (fig. 19). In addition to the main rail line, there are three spur rail lines that exist over coal resource areas within the Montana PRB. Two of the spur lines connect to this main rail line and extend south to Absaloka and Rosebud
Mines. The third spur rail line connects to the main rail line of the Burlington Northern Santa Fe Railway south of the assessment area (near Sheridan, Wyoming) and extends north to the Decker and Spring Creek Mines. It is assumed that the spur lines would be moved as necessary for mining. They are not considered to be restrictions to mining.

\section{Rivers, Lakes, and Streams}

The most significant rivers in the PRB are the Powder and the Tongue. All of the rivers and tributaries in the PRB are shallow and slow moving. Surface mining operations could temporarily relocate the courses of smaller streams and then return them to their pre-mining locations during mine reclamation. Only the parts of these water courses that have been designated by the State Land Quality Division as alluvial valley floors significant to farming would need to be preserved with no modification. In contrast, the Yellowstone River is a more prominent water course and is considered to be a restriction to mining (fig. 19). However, like the main rail line and Interstate Highway 94, the Yellowstone River lies in the extreme northern part of the PRB beyond the extent of coal beds and subsequently has no restriction effect.

The North Platte River flows through a small part of the southern end of the Wyoming PRB (fig. 19). This prominent water course is considered a restriction to mining. In addition to the width of the river, the restriction includes a $100-\mathrm{ft}$ buffer on each side. The most significant body of flowing water in the Gillette coal field is the Belle Fourche River. It is shallow and slow moving; therefore, surface mining operations could relocate the course of this river and return it to the pre-mining location during reclamation.

Shallow lakes and small ponds that exist within the PRB could either be temporarily moved during mining or simply reformed after the mining operation ceased. However, the Tongue River Reservoir, a recreational site and water supply source located about $2.5 \mathrm{mi}$ northeast of Decker, Montana, is considered to be a restriction to mining for this assessment (fig. 19). The restriction includes a 100-ft buffer surrounding the reservoir. Lake DeSmet, a recreational site and water supply source located about 6 mi north of Buffalo, Wyoming, is considered a restriction to mining and includes a $100-\mathrm{ft}$ buffer surrounding the lake (fig. 19).

\section{Roads}

County roads within the PRB are not considered to be a restriction to mining because they could be relocated or temporarily blocked off to allow mining to proceed. A number of State and U.S. highways including Interstate Highway 94, Interstate Highway 90, and Interstate Highway 25, are present within the area (fig. 19). For this assessment, it is assumed that any State highway could be relocated to allow for mining. The Interstate highways are considered a restriction to mining. The total restricted width is $450 \mathrm{ft}$, including the highway right-ofway and a 100-ft buffer on each side. 


\section{State Lands and Trusts}

Two State parks are within the Montana PRB: the Rosebud Battlefield State Park and the Tongue River Reservoir State Park (fig. 19); both parks are considered to be restrictions to mining. The Rosebud Battlefield State Park is about 15 mi northwest of Decker, Montana, and the Tongue River Reservoir State Park is about $6 \mathrm{mi}$ northeast of Decker. The restriction for each park includes a buffer that extends out to a distance of $300 \mathrm{ft}$ beyond the park boundary.

Also within the Montana PRB are a fishing access site (Twelve Mile Dam) and two conservation easements (fig. 19). The fishing access site and one of the easements are under the jurisdiction of the Montana Fish, Wildlife \& Parks. The other conservation easement is overseen by the Montana Land Reliance. These lands are considered to be restrictions to mining; however, they have no restriction effect on the coal beds because the coals do not extend into their locations.

\section{Towns}

The municipalities of Colstrip and Broadus are within the PRB and are permanent restrictions to mining (fig. 19). In addition to the actual incorporated area, the mining restriction for each municipality includes a buffer that extends $300 \mathrm{ft}$ beyond the municipality limits (extraterritorial jurisdiction).

The entire municipalities of Buffalo, Clearmont, Gillette, Ranchester, Sheridan, and Wright, and parts of Douglas and Rolling Hills are within the Wyoming PRB (fig. 19). In addition to the actual incorporated area for each municipality, the mining restriction includes a buffer that extends beyond the municipality limit.

\section{Phase Three (Assessment of Resources and Reserves)}

The methodology for resource assessment in the geologically complex PRB was accomplished in two stages. The PRB was divided into five geographic areas to manage database size and publish more timely results. Four of those areas are in the Wyoming PRB and one is in the Montana PRB: (1) Luppens and others (2008) reported on the first assessment area, summarizing geology, coal resources, and reserves for the Gillette coal field; (2) Scott and others (2010) summarized the second assessment area and presented results on geology, coal resources, and reserves for the Northern Wyoming Powder River Basin assessment area (NWPRB assessment area); (3) Osmonson and others (2011) summarized the third assessment area and presented results on geology and coal resources in the Southwestern Powder River Basin assessment area (SWPRB assessment area); and (4) Haacke and others (2013) summarized the fourth assessment area and presented results on geology, coal resources, and reserves for the Montana Powder River Basin assessment area (MTPRB assessment area). The fifth area (East Gillette coal field extension) extends east from the Gillette coal field and was evaluated for this report specifically to provide a more comprehensive mapping of coal beds below the Wyodak-Anderson coal zone and to complete the assessment of the entire PRB. The Gillette coal field was assessed first, followed in order by the NWPRB assessment area, the SWPRB assessment area, and the MTPRB assessment area. This report represents the final stage of the PRB assessment, which includes the results of the four regional studies and the east extension of the Gillette coal field. This report provides the first published maps of individual coal beds for the entire PRB.

Two factors critical to this accomplishment were: (1) completion of the correlation of coal beds stratigraphically lower than the Wyodak-Anderson coal zone, including additional data entry in the east Gillette coal field extension (fig. 2) and (2) resolution of the proliferation of local bed names throughout the entire basin. Figure 13 illustrates the progressive inclusion of deeper coal beds through the four assessment reports. It was anticipated that minor revisions to coal bed correlations and names would be encountered between assessment areas. Correlations within the WyodakAnderson coal zone remained essentially consistent throughout each of the three Wyoming assessments; however, there were revisions in names for beds stratigraphically lower, especially from Wyoming into Montana. The discussion of the coal bed correlation process under the Phase two section of the Methodology section of this report addresses the conventions used to derive a uniform coal bed nomenclature for the entire PRB (fig. 13).

The data entry and correlation effort to produce this report represents approximately 14 man-years of work with more than 250,000 digital well logs and multiple onscreen cross sections viewed. The completed database was used to generate the final geologic model which included coal thickness, roof, and floor grids for each modeled coal bed.

The following sections provide a brief description of each assessed coal bed, including a discussion of cross sections to illustrate the regional coal geology trends, a summary of coal resource volumes, and perspectives on the depositional history provided by the geometry of the individual beds. The economic analyses for each of the assessment areas provides estimates of the volumes of available coal (after all restrictions to mining are subtracted) that are currently classified as reserves or potentially recoverable to a 10:1 stripping ratio.

\section{Coal Bed Assessment}

Coal resources were classified according to geologic assurances (certainty of existence) or reliability, which are directly dependent on the density of geologic data points (fig. 15). The different reliability categories are: (1) measured (0.25 mi from point of measurement); (2) indicated (0.250.75 mi from point of measurement); (3) inferred (0.75-3.0 mi from point of measurement); and (4) hypothetical (greater than $3.0 \mathrm{mi}$ from point of measurement) (Wood and others, 1983). Supplemental to this report are the GIS 
data created using Esri ArcGIS 9.3.1 (Environmental System Research International, 2000) that can be used to show reliability categories in map view for all 47 coal beds, along with other pertinent data layers (Kinney and Scott, 2015).

Original, remaining, and available resources were calculated for all 47 coal beds in the PRB and are reported by reliability category (table 4 ), overburden category (table 5), ownership category (table 6), and assessment area name (table 7). Tables 4-7 also show tonnages for burned coal (clinker), mined coal, land-use restrictions, and technical restrictions for each coal bed.

In this report, the areal extent for overburden depth maps match the areal extent of the $1.0 \mathrm{ft}$ (or greater) thickness isopach maps. The greatest depth to the top of the coal for most coal beds is along the axis of the basin. A typical surface mining sequence begins at the ground surface; therefore, the following descriptions of coal beds in the PRB are discussed from youngest to oldest. Seven coal beds occur in the Wasatch Formation (Upper Healy, Healy/Lower Ulm, Murray, Ucross, Upper Felix, Felix, Lower Felix); the remaining 40 beds are in the Tongue River Member of the Fort Union Formation (fig. 23).

\section{Wasatch Formation Coal Beds}

The Buffalo-Lake DeSmet area contains Wasatch Formation coal beds that have been previously evaluated for potential mining (fig. 12) (Osmonson and others, 2011). These coal beds are collectively known as the Lake DeSmet coal zone (fig. 13) and are estimated to be $250 \mathrm{ft}$ thick (Mapel, 1959; Obernyer, 1978, 1980). Obernyer $(1978,1980)$ suggested that the Lake DeSmet coal zone represents the coalescing of several major coal beds, possibly in response to basin-margin faulting in Eocene time. To calculate resources for this assessment area, the Lake DeSmet coal zone was divided into four coal beds (Upper Healy, Healy/Lower Ulm, Murray, and Ucross).

Despite the fact, that the Lake DeSmet coal zone is the thickest known coal in the United States (Jones, 2010b), no significant, large-scale mining has occurred in the area. The largest coal resource in the Lake DeSmet coal zone is within the Upper Healy and Healy/Lower Ulm coal beds, which have a composite stripping ratio greater than 5:1, making it unfavorable from a mining standpoint. Land-use restrictions for Buffalo, Lake DeSmet, and Interstate Highway 90, negatively affect the availability of the coal beds for mining (fig. 19). Also, the upper portions of these coal beds have been burned or baked over much of the area (Smith and others, 1972; Glass, 1997). The extent of the resulting clinker can be seen in figure 7. Finally, the coal quality in the Lake DeSmet coal zone is significantly inferior to coal quality currently being produced from the PRB, which would pose a competitive disadvantage for developing these resources (Luppens, 2011; Osmonson and others, 2011).

\section{Upper Healy and Healy/Lower UIm Coal Beds}

The Upper Healy is the uppermost (youngest) coal bed in the Wasatch Formation and is areally limited to the westcentral part of the Wyoming PRB (fig. 24). This bed is the uppermost bed that composes the Lake DeSmet coal zone of
Obernyer $(1978,1980)$. The Upper Healy, which was identified on 186 geophysical well logs, has a maximum thickness of $77 \mathrm{ft}$ and averages $12 \mathrm{ft}$ (fig. 23). Of the 6.9 BST of original resource, about 5.3 BST are considered as available resources (tables 4-7). Depth to the top of the coal bed ranges from shallow subcrop along the eastern extent of the bed to about $1,000 \mathrm{ft}$ along the western extent of the bed. About 98 percent of the available resource is at a depth less than $500 \mathrm{ft}$ (fig. 25 , table 5). Of these available resources, about 69 percent of the coal mineral estate is owned by the Federal government (table 6).

The Healy/Lower Ulm coal bed identified in this assessment correlates to the Healy coal bed of Mapel (1959). This bed has approximately the same areal extent as the Upper Healy coal bed and is known as the Healy in the Lake DeSmet area and the Lower Ulm in the central part of the Wyoming PRB (fig. 26). Both areal extents are defined by outcrop and clinker. More than 50 percent of the area of coal bed thickness exceeds $20 \mathrm{ft}$ with one small area of thickness more than $40 \mathrm{ft}$. The bed, which was identified on 658 geophysical well logs, has a maximum thickness of $83 \mathrm{ft}$ and an average thickness of $14 \mathrm{ft}$ (fig. 23). Of the 13.0 BST of original resource, about 10.7 BST are considered as available resources (tables 4-7). Depth to the top of the coal bed ranges from shallow subcrop along the eastern extent of the bed to about $1,000 \mathrm{ft}$ along the western extent of the bed. About 87 percent of the available resource is at a depth less than $500 \mathrm{ft}$ (fig. 27, table 5). Of these available resources, about 65 percent of the coal mineral estate is owned by the Federal government (table 6).

\section{Murray Coal Bed}

The Murray coal bed was correlated in this report with the Murray coal bed of Mapel (1959) and is present only in the west-central Wyoming PRB (fig. 28). The coal bed has approximately the same areal extent as both the Healy/Lower Ulm and Upper Healy coal beds. Identified on 785 geophysical well logs, the Murray has a maximum thickness of $14 \mathrm{ft}$ and an average thickness of $3 \mathrm{ft}$ (fig. 23). Of the $2.7 \mathrm{BST}$ of original resource, about 0.6 BST are considered as available resources (tables 4-7). Depth to the top of the coal bed ranges from shallow subcrop along the eastern extent of the bed, to about $1,000 \mathrm{ft}$ along the western extent of the bed. About 62 percent of the available resource is at a depth less than $500 \mathrm{ft}$ (fig. 29, table 5). Of these available resources, about 63 percent of the coal mineral estate is owned by the Federal government (table 6).

\section{Ucross Coal Bed}

Equivalent to the Ucross coal bed of Mapel (1959), this bed is the lowest coal bed in the Lake DeSmet coal zone and is limited to the west-central Wyoming PRB (figs. 13 and 30). As seen in the isopach maps of the Upper Healy/Lower Ulm, Healy, Murray, and Ucross coal beds, (figs. 24, 26, 28, and 30 ) the areal extent of all four beds is similar. The Ucross was identified on 591 geophysical well logs, has a maximum thickness of $40 \mathrm{ft}$, and an average thickness of $7 \mathrm{ft}$ (fig. 23). Of the 
6.8 BST of original resource, about 4.5 BST are considered as available resources (tables 4-7). Depth to the top of the coal bed ranges from shallow subcrop along the eastern extent of the bed, to about $1,500 \mathrm{ft}$ along the western extent of the bed. About 34 percent of the available resource is at a depth less than $500 \mathrm{ft}$ (fig. 31, table 5). Of those available resources, about 53 percent of the coal mineral estate is owned by the Federal government (table 6).

\section{Upper Felix, Felix, and Lower Felix Coal Beds}

The Upper Felix coal bed is an upper split of the Felix coal bed and is geographically limited to the central Wyoming PRB (fig. 32). This coal bed, which was identified on 1,989 geophysical well logs, has a maximum thickness of $19 \mathrm{ft}$ and an average thickness of $4 \mathrm{ft}$ (fig. 23). Of the 2.1 BST of original resource, about 1.2 BST are considered as available resources (tables 4-7). Depth to the top of the coal bed ranges from shallow subcrop along the eastern extent of the bed, to about $1,000 \mathrm{ft}$ along the western extent of the bed. About 95 percent of the available resource is at a depth less than $500 \mathrm{ft}$ (fig. 33, table 5). Of those available resources, about 94 percent of the coal mineral estate is owned by the Federal government (table 6).

The Felix coal bed has a larger areal extent than the Upper Felix and is limited to the central Wyoming PRB (fig. 34). The coal bed, identified in 4,444 geophysical well logs, has an average thickness of $12 \mathrm{ft}$ and a maximum thickness of $55 \mathrm{ft}$ (fig. 23). Of the 18.8 BST of original resource, about 16.8 BST are considered as available resources (tables 4-7). Depth to the top of the coal bed ranges from shallow subcrop along the eastern extent of the bed, to about 1,500 ft where the coal bed is thickest; about 85 percent of the available resource is at a depth less than $500 \mathrm{ft}$ (fig. 35, table 5). Of those available resources, about 93 percent of the coal mineral estate is owned by the Federal government (table 6).

The Lower Felix is the lowest coal bed identified in the Wasatch Formation and is present in two large areas in the central and northwestern Wyoming PRB (fig. 36). Identified on 4,109 geophysical well logs, this bed has an average thickness of $7 \mathrm{ft}$ and a maximum thickness of $53 \mathrm{ft}$ (fig. 23) along the western margin of the Wyoming PRB. Of the 19.4 BST of original resource, about 14.9 BST are considered available resources (tables 4-7). Depth to the top of the coal bed ranges from shallow subcrop along the eastern extent of the bed, to about $2,000 \mathrm{ft}$ along the axis of the basin; about 23 percent of the available resource is at a depth less than $500 \mathrm{ft}$ (fig. 37, table 5). Of the total available resource, about 69 percent of the coal mineral estate is owned by the Federal government (table 6).

Available coal resources in the Wasatch Formation coal beds (Upper Healy, Healy/Lower Ulm, Murray, Ucross, Upper Felix, Felix, and Lower Felix) in the PRB total about 54 BST (tables 4-7). Of the total available coal resource, about 75 percent of the coal mineral estate is owned by the Federal government. Available coal resources less than $500 \mathrm{ft}$ in depth total about 64 percent (tables 4-7).

\section{Fort Union Formation Coal Beds}

Although coal beds can be present in all three members of the Fort Union Formation, minable beds in the PRB are limited to the Tongue River Member (fig. 5). Forty coal beds occur within this formation with some attaining a thickness of over $200 \mathrm{ft}$ (fig. 23). Coal beds exposed at the surface in the PRB are progressively older in the northern part of the basin because of the south-dipping structure of the Montana PRB, combined with a decrease in topography. The Fort Union Formation contains some of the thickest and most extensive deposits of subbituminous coal in the world (Molnia and Pierce, 1992). Most of this coal is in the Wyodak-Anderson coal zone in the Gillette coal field in the Wyoming PRB (Flores and others, 1999). Generally, coal beds below the Wyodak-Anderson coal zone that are present in the Montana PRB tend to be thinner and more discontinuous, with the exception of the Pawnee, Rosebud/Knobloch, and FlowersGoodale beds (fig. 23).

Roland (Upper Rider), Roland (Lower Rider), Roland (Baker), and Roland (Taff) Coal Beds

The Roland (Upper Rider) coal bed is an upper split of the Roland (Baker, 1929) bed and is present in the central and northern Wyoming PRB, where it reaches a maximum thickness of $32 \mathrm{ft}$ (figs. 23 and 38). The bed, which was identified on 5,710 geophysical well logs, has an average thickness of $4 \mathrm{ft}$ (fig. 23). Although most of this bed is less than $10 \mathrm{ft}$ thick, it is significant because it marks the contact between the Wasatch and Fort Union Formations. Of the 13.5 BST of original resource, about 8.3 BST are considered as available resources (tables 4-7). Depth to the top of the coal bed ranges from shallow subcrop along the eastern extent of the bed, to about $2,000 \mathrm{ft}$ along the axis of the basin. Only about 30 percent of the available resource is at a depth less than $500 \mathrm{ft}$ (fig. 39, table 5). Of the total available resource, about 90 percent of the coal mineral estate is owned by the Federal government (table 6).

Identified on 1,619 geophysical well logs, the Roland (Lower Rider) bed has a maximum thickness of $20 \mathrm{ft}$ and an average thickness of $4 \mathrm{ft}$ (fig. 23). Although less continuous extent than the Roland (Upper Rider), it is present in several small areas in the central and northwestern Wyoming PRB (fig. 40). Of the $3.3 \mathrm{BST}$ of original resource, about 1.7 BST are considered as available resources (tables 4-7). Depth to the top of the coal bed ranges from shallow subcrop along the eastern extent of the bed, to about 2,000 ft along the axis of the basin; only about 7 percent of the available resource is at a depth less than $500 \mathrm{ft}$ (fig. 41, table 5). Of the total available resource, about 87 percent of the coal mineral estate is owned by the Federal government (table 6).

For this assessment, the Roland of Baker (1929) is referred to as the Roland (Baker) coal bed. The bed was identified in 9,987 drill holes, has a maximum thickness of $40 \mathrm{ft}$, and averages $10 \mathrm{ft}$ thick (fig. 23). The coal bed is present in a large area in the central and northwest Wyoming PRB 
extending into the Montana PRB near the Decker and Spring Creek Mines (figs. 12 and 42). It crops out to the north and east and thickens to the northwest. The largest coal resource is in the northwestern part of the Wyoming PRB, where it attains a thickness of $40 \mathrm{ft}$. Of the $47.8 \mathrm{BST}$ of original resource, about $43.3 \mathrm{BST}$ are considered as available resources (tables 4-7). Depth to the top of the coal bed ranges from shallow subcrop along the eastern extent of the bed, to about 2,000 ft south of the Decker and Spring Creek Mines; about 35 percent of the available resource is at a depth less than $500 \mathrm{ft}$ (fig. 43, table 5). Of the total available resource, about 83 percent of the coal mineral estate is owned by the Federal government (table 6). The Roland (Baker) was included for the economic analysis to determine the coal reserve base.

The Roland of Taff (1909) is the oldest bed of the Roland coal bed sequence. Hereafter the Roland of Taff (1909) will be referred to as the Roland (Taff) coal bed. The areal extent of the Roland (Taff) is limited to the northwest Wyoming PRB, extending into the southwest Montana PRB (fig. 44). This coal bed was identified in 953 geophysical well logs, has an average thickness of $3 \mathrm{ft}$ and a maximum thickness of $27 \mathrm{ft}$ (fig. 23). One small area along the western extent of the bed contains coal that exceeds a thickness of $20 \mathrm{ft}$. Of the 3.4 BST of original resource, about 1.3 BST are considered as available resources (tables 4-7). Depth to the top of the coal bed ranges from shallow subcrop along the eastern extent of the bed, to about $1,500 \mathrm{ft}$ over the areas of the thickest areas the coal bed; about 52 percent of the available resource is at a depth less than $500 \mathrm{ft}$ (fig. 45, table 5). Of the total available resource, about 78 percent of the coal mineral estate is owned by the Federal government (table 6).

\section{Upper Smith and Smith Coal Beds}

For this assessment, the Upper Smith, Smith, Anderson Upper Rider, Anderson Lower Rider, Anderson, Lower Anderson, Dietz 1, Dietz 2, Dietz 3, Dietz 4, Upper Canyon, Canyon, Lower Canyon, Upper Ferry, Ferry, and Werner/Cook coal beds constitute the Wyodak-Anderson coal zone (figs. 13 and 23). The Upper Smith is stratigraphically the uppermost bed in the Wyodak-Anderson coal zone. The Upper Smith bed is present in small areas in the southwestern part of the Wyoming PRB and in the southwestern part of the Montana PRB (fig. 46). This coal bed was identified on 326 geophysical well logs, has a maximum thickness of $36 \mathrm{ft}$, and an average thickness of $3 \mathrm{ft}$ (fig. 23). This coal attains a thickness of about $20 \mathrm{ft}$ in a small area near the abandoned Dave Johnston Mine (fig. 12). Of the 1.0 BST of original resource, about 0.4 BST are considered as available resources (tables 4-7). Depth to the top of the coal bed ranges from shallow subcrop along the eastern extent of the bed, to about $2,500 \mathrm{ft}$ along the axis of the basin; about 46 percent of the available resource is at a depth less than $500 \mathrm{ft}$ (fig. 47, table 5). Of the total available resource, about 81 percent of the coal mineral estate is owned by the Federal government (table 6).
The Upper Smith coal bed has approximately the same areal extent as the Roland (Baker) bed (fig. 42) in the western one-half of the Wyoming PRB, extending into the southwestern part of the Montana PRB near the Decker and Spring Creek Mines (figs. 12 and 48). The limits of the bed gradually thin and eventually pinch out. To the northwest, interburden between the Smith and the Anderson becomes very thin; however, the Smith does not merge with the Anderson in any drill holes. The bed thickens dramatically west of Wright, Wyoming, towards the center of the basin where it is locally referred to as the "Big George" coal bed (fig. 8). Jones (2010a) also verified that the Smith and Anderson do not merge by showing an angular relation between the Roland coal beds (Baker and Taff) and the lower Wyodak Rider coal zone (Smith Rider and Smith/Big George coal beds).

The largest coal resource in the Smith bed occurs in the central to southern part of the extent of the coal bed, where the bed attains a thickness of over $200 \mathrm{ft}$ (fig. 48). The Smith coal bed, as interpreted from 9,334 drill holes, has a maximum thickness of $278 \mathrm{ft}$, and averages $24 \mathrm{ft}$ thick (fig. 23). Of the 126.4 BST of original resource, about 122.9 BST are considered as available resources (tables 4-7). Depth to the top of the bed ranges from shallow subcrop along the eastern extent of the bed, to about 2,500 ft along the axis of the basin (fig. 49); only about 4 percent of the available resource is at a depth less than $500 \mathrm{ft}$ making the strip ratio of coal to rock undesirable for surface mining. Therefore, despite the thickness of the Smith coal bed, most of the resource would be considered too deep for surface mining, but is a potential resource for future underground mining. Of the total available resource, about 88 percent of the coal mineral estate is owned by the Federal government (table 6). The Smith bed was included in the economic analysis to determine the coal reserve base.

\section{Anderson Upper Rider, Anderson Lower Rider, Anderson, and Lower Anderson Coal Beds}

The Anderson Upper Rider bed is the uppermost of two splits above the Anderson coal bed and is present only in small, isolated areas in the central part of the Wyoming PRB (figs. 23 and 50). This coal bed was identified in 343 drill holes, has an average thickness of $3 \mathrm{ft}$, and a maximum thickness of $18 \mathrm{ft}$ (fig. 23). Of the $0.3 \mathrm{BST}$ of original resource, about $0.04 \mathrm{BST}$ are considered as available resources (tables 4-7). Depth to the top of the coal bed ranges from shallow subcrop along the eastern extent, to about $1,500 \mathrm{ft}$ over the thickest portion of the coal bed; about 59 percent of the available resource is at a depth less than $500 \mathrm{ft}$ (fig. 51, table 5). Of the total available resource, about 71 percent of the coal mineral estate is owned by the Federal government (table 6). The Anderson Upper Rider was included in the economic analysis to determine the coal reserve base.

The Anderson Lower Rider bed is the lower of two splits above the Anderson coal bed. This coal bed was identified in 480 drill holes, has a maximum thickness of $20 \mathrm{ft}$, and 
averages $8 \mathrm{ft}$ thick (fig. 23). The coal bed is only present in one small area in the south-central Wyoming PRB (fig. 52). Of the $0.8 \mathrm{BST}$ of original resource, about $0.5 \mathrm{BST}$ are considered as available resources (tables 4-7). Depth to the top of the coal bed ranges from shallow subcrop along the eastern extent of the bed, to about 3,000 ft over the thickest portion of the coal bed; about 96 percent of the available resource is at a depth less than $500 \mathrm{ft}$ (fig. 53, table 5). Of the total available resource, about 94 percent of the coal mineral estate is owned by the Federal government (table 6).

The Anderson is the principal minable coal bed in the Wyodak-Anderson coal zone in the Gillette coal field and also a principal CBM production target coal bed in the Wyoming PRB. The bed is present in much of the Wyoming PRB and extends into the Decker and Spring Creek Mine areas in the southwest Montana PRB (figs. 12 and 54). A large area of thin coal separates the bed into two thick pod-like areas in the northwestern part of the Wyoming PRB (about T. 56 N., R. 78 W.) (fig. 54). A channel area in T. 46 N., R. 70 W. bisects the thickest part of the Anderson bed where the bed thins or is absent. The Anderson, Dietz 2, and Dietz 3 coal beds are presently mined at the Decker and Spring Creek Mines in the Montana PRB (fig. 12).

The Anderson coal bed was first correlated by Baker (1929) as the Dietz 1 bed. It was also referred to as the Dietz 1 by the Pittsburg and Midway Coal Mining Company in the PSO lease area in the Sheridan coal field (figs. 2 and 12). However, the Anderson and the Dietz 1 are correlated as separate beds for this report. Identified in 11,774 drill holes, the Anderson bed has an average thickness of $24 \mathrm{ft}$, and a maximum thickness of $225 \mathrm{ft}$ near the Jacobs Ranch Mine (figs. 12 and 23). The Anderson bed crops out to the east and defines the eastern boundary of the Gillette coal field (Luppens and others, 2008). Of the 125.5 BST of original resource, about 101.8 BST is considered as available resources (tables 4-7). Depth to the top of the coal bed ranges from shallow subcrop along the eastern extent of the bed, to about 2,000 ft near the axis of the basin; about 40 percent of the available resource is at a depth less than $500 \mathrm{ft}$ (fig. 55, table 5). The available resource percentage doubles to 89 percent for depths less than $1,000 \mathrm{ft}$. Of the total available resource, about 89 percent of the coal mineral estate is owned by the Federal government (table 6). The Anderson was included in the economic analysis to determine the coal reserve base.

The Lower Anderson bed splits from the base of the Anderson coal bed. It is interpreted from 883 drill holes, has a maximum thickness of $44 \mathrm{ft}$ and an average thickness of $4 \mathrm{ft}$ (fig. 23). The coal bed is present in the north-central Wyoming PRB as small isolated areas extending into the south-central Montana PRB (fig. 56). Of the 3.4 BST of original resource, about 2.0 BST are considered as available resources (tables 4-7). Depth to the top of the coal bed ranges from shallow subcrop along the eastern extent of the bed, to about 2,000 ft near the axis of the basin; about 42 percent of the available resource is at a depth less than $500 \mathrm{ft}$ (fig. 57 , table 5). Of the total available resource, about 90 percent of the coal mineral estate is owned by the Federal government (table 6).

\section{Dietz 1, Dietz 2, Dietz 3, and Dietz 4 Coal Beds}

The Dietz 1 coal bed was identified on 672 geophysical well logs, has a maximum thickness of $29 \mathrm{ft}$, and averages $4 \mathrm{ft}$ thick (fig. 23). Dietz 1 coal thickness greater than $20 \mathrm{ft}$ is limited to a small area in the northwest Wyoming PRB and small areas in the southwest Montana PRB (fig. 58). Of the 1.1 BST of original resource, only about 0.5 BST are considered as available resources (tables 4-7). Depth of the Dietz 1 coal bed ranges from shallow subcrop along the eastern extent of the bed, to about 2,500 ft along the axis of the basin (fig. 59, table 5).

Identified in 930 drill holes, the Dietz 2 coal bed has a maximum thickness of $37 \mathrm{ft}$, and averages $6 \mathrm{ft}$ thick (fig. 23). It is present in a small area in the Decker and Spring Creek Mines (fig. 12) in the Montana PRB, where it is mined along with the Dietz 3 (fig. 60). The Dietz 2 is also present in a small area in the north-central part of the Wyoming PRB. Of the 3.0 BST of original resource, about 2.0 BST are considered as available resources (tables 4-7). The Dietz 2 coal bed ranges in depth from shallow subcrop along the eastern extent of the bed, to more than 1,500 ft near the Decker and Spring Creek Mines (fig. 61, table 5). The Dietz 2 was included in the economic analysis to determine the coal reserve base.

The Dietz 3 coal bed is the thickest and most areally extensive of the Dietz coal beds. Interpreted from 4,816 drill holes, the Dietz 3 has a maximum thickness of $119 \mathrm{ft}$ and an average thickness of $13 \mathrm{ft}$ (fig. 23). The bed is present in two distinct areas; one near the Decker and Spring Creek Mines in the Montana PRB, where it exceeds a thickness of more than $40 \mathrm{ft}$, and the other in the north-central Wyoming PRB, where the bed attains a thickness of about $119 \mathrm{ft}$ (fig. 62). Both northeast-trending and northwest-trending channels can be defined by observing where the bed thins and disappears, thus separating the bed into several pod-like areas. The combined Smith, Anderson, and Dietz 3 coal beds formed the most significant minable sequence of coals in the Decker and Spring Creek Mines (fig. 12). The Dietz 3 bed is a primary minable coal bed for the PSO lease area of Pittsburg and Midway Coal Mining Company (fig. 12). Of the 50.9 BST of original resource, about 45.1 BST are considered as available resources (tables 4-7). Of the total available resource, about 85 percent of the coal mineral estate is owned by the Federal government (table 6). Depth ranges from shallow subcrop along the eastern extent of the bed, to about 3,000 ft near the axis of the basin; about 29 percent of the available resource is at a depth less than $500 \mathrm{ft}$ (fig. 63, table 5). The Dietz 3 was included in the economic analysis to determine the coal reserve base.

The Dietz 4 coal bed is present in relatively small, isolated areas in the northwest part of the Wyoming PRB and in the area surrounding the Decker and Spring Creek Mines (fig. 12) in the Montana PRB (fig. 64). This bed was identified 
on 624 geophysical well logs, reaches a maximum thickness of $20 \mathrm{ft}$ and has an average thickness of $3 \mathrm{ft}$ (fig. 23). Of the $1.8 \mathrm{BST}$ of original resource, about $0.8 \mathrm{BST}$ are considered as available resources (tables 4-7). Depth ranges from shallow subcrop along the eastern extent of the bed, to more than $3,000 \mathrm{ft}$ along the axis of the basin (fig. 65, table 5).

\section{Upper Canyon/Cox, Canyon, and Lower Canyon Coal Beds}

The Upper Canyon coal bed is an upper split of the Canyon coal bed and correlates to the Cox coal bed identified by Haacke and others (2013) in the Montana PRB. Figure 66 shows that the subsurface extent is limited mostly to one large area in the west-central Wyoming PRB and small, isolated areas are in the south-central Montana PRB. The coal bed was identified on 725 geophysical well logs, has a maximum thickness of $31 \mathrm{ft}$, and averages $7 \mathrm{ft}$ thick (fig. 23). Of the 6.0 BST of original resource, about 4.7 BST ( 86 percent) are considered as available resources and about 4.0 BST has Federal mineral ownership (tables 4-7). Depth of the coal bed ranges from shallow subcrop along the eastern extent of the bed, to more than $3,000 \mathrm{ft}$ along the axis of the basin (fig. 67, table 5).

The Canyon coal bed, originally named the Monarch in 1909, is equivalent to the Canyon coal bed of Baker (1929) (Law and others, 1979). Since 1929, it has been referred to as both the Canyon and the Monarch. The coal bed is present in much of the Wyoming PRB, extending northward into the southwest Montana PRB (fig. 68). The Canyon, along with the Anderson, is one of the principal CBM production targets in the Gillette coal field in the Wyoming PRB. Where the Anderson bed exceeds $60 \mathrm{ft}$ thick in the Gillette coal field is where the Anderson and Canyon beds are a single thick bed (fig. 54).

The Canyon bed was identified in 9,353 drill holes and reaches a maximum thickness of $183 \mathrm{ft}$, with an average thickness of $21 \mathrm{ft}$ (fig. 23). Of the 147.4 BST of original resource, about 135.4 BST are considered as available resources (tables 4-7). Of the total available resource, about 89 percent (120.3 BST) of the coal mineral estate is owned by the Federal government (table 6). Depth from the top of the coal bed ranges from shallow subcrop along the eastern extent of the bed to more than $3,000 \mathrm{ft}$ along the axis of the (fig. 69). About 19 percent of the available coal resource is at a depth of less than $500 \mathrm{ft}$ (table 5). For the economic analysis, the Canyon was used in determining reserves.

The Lower Canyon coal bed is a lower split of the Canyon coal bed. It was identified in 4,374 drill holes, has a maximum thickness of $85 \mathrm{ft}$, and averages $11 \mathrm{ft}$ thick (fig. 23). The coal bed is present in a large area in the west-central Wyoming PRB and extends into the Decker and Spring Creek Mine area in the Montana PRB (fig. 70). About 52.0 BST of the $59.5 \mathrm{BST}$ of original resource are considered as available resources (tables 4-7). Only about 12 percent of the available coal resource is at a depth less than $500 \mathrm{ft}$ (fig. 71, table 5). Of the total available resource, about 83 percent ( 44.8 BST) of the coal mineral estate is owned by the Federal government (table 6). Depth ranges from shallow subcrop to more than $3,000 \mathrm{ft}$ near along the axis of the basin (fig. 71). The Lower Canyon bed was included in the economic analysis to determine the coal reserve base.

\section{Upper Ferry and Ferry Coal Beds}

The Upper Ferry bed is an upper split of the Ferry coal bed and is present in a small area in the north-central Wyoming PRB (fig. 72). Based on 145 drill holes, it reaches a maximum thickness of $10 \mathrm{ft}$ and has an average thickness of $4 \mathrm{ft}$ (fig. 23). About 0.5 BST of the $0.8 \mathrm{BST}$ of original resource are considered as available resources (tables 4-7). Depth to the top of the coal bed ranges from shallow subcrop to more than $1,500 \mathrm{ft}$ near the center of the basin; about 0.1 percent of the available coal resource is at a depth less than $500 \mathrm{ft}$ (fig. 73, table 5).

The Ferry coal bed was identified in 744 drill holes and is limited in areal extent to the northwest part of the Wyoming PRB and the southwest Montana PRB (fig. 74). The bed has a maximum thickness of $28 \mathrm{ft}$ and an average thickness of $5 \mathrm{ft}$ (fig. 23). About 4.3 BST of the 6.4 BST of original resource are considered as available resources (tables 4-7). Of the total available resource, about 84 percent (3.4 BST) of the coal mineral estate is owned by the Federal government (table 6). Depth to the top of the coal bed ranges from shallow subcrop along the eastern extent of the bed, to more than $3,000 \mathrm{ft}$ along the axis of the (fig. 75). About 16 percent of the available coal resource is at a depth less than $500 \mathrm{ft}$ (table 5).

\section{Werner/Cook Coal Bed}

The Werner/Cook bed, identified in 4,459 drill holes, has a maximum thickness of $90 \mathrm{ft}$ and averages $13 \mathrm{ft}$ thick (fig. 23). This is the oldest coal bed in the Wyodak-Anderson coal zone and is present in much of the Wyoming PRB, extending five townships northward into the Montana PRB (fig. 76). The Werner/Cook bed is known as the Werner coal bed in the Wyoming PRB and is equivalent to the Cook coal bed of Montana. The thickest part of the coal bed is present north of the Decker and Spring Creek Mines in the Montana PRB, where it exceeds a thickness of $60 \mathrm{ft}$. About $63.3 \mathrm{BST}$ of the approximately $74 \mathrm{BST}$ of original resource are considered as available resources (tables 4-7). Of the total available resource, about 88 percent (55.7 BST) of the coal mineral estate is owned by the Federal government (table 6). Depth to the top of the coal bed ranges from shallow subcrop along the eastern extent of the bed, to about 2,500 ft along the axis of the basin (fig. 77). About 26 percent of the available coal resource is at a depth of less than $500 \mathrm{ft}$ (table 5). The Werner/ Cook was included in the economic analysis to determine the coal reserve base.

\section{Upper Otter and Otter Coal Beds}

The Upper Otter bed is an upper split of the Otter coal bed and is present in small, isolated areas in the north-central Wyoming PRB (fig. 78). Based on 328 drill holes, it reaches a 
maximum thickness of $21 \mathrm{ft}$ and has an average thickness of $4 \mathrm{ft}$ (fig. 23). About 0.6 BST of the 0.9 BST of original resource are considered as available resources (tables 4-7). Of the total available resource, about 84 percent $(0.5 \mathrm{BST})$ of the coal mineral estate is owned by the Federal government (table 6). Depth to the top of the coal bed ranges from shallow subcrop along the eastern extent of the bed, to about 2,500 ft along the axis of the basin (fig. 79). About 0.6 percent of the available coal resource is at a depth less than $500 \mathrm{ft}$ (table 5).

Distribution of the Otter coal bed is shown in figure 80. Based on 3,642 drill holes, the bed reaches a maximum thickness of $170 \mathrm{ft}$ and has an average thickness of $14 \mathrm{ft}$ (fig. 23). Areas of greatest thickness occur in the center of the Wyoming PRB where the depth to the top of the bed is more than $1,500 \mathrm{ft}$. The Otter crops out along its northern extent and thins and eventually pinches out to the south and east. About 64.3 BST of the 71.0 BST of original resource are considered as available resources (tables 4-7). Of the total available resource, about 90 percent (58.0 BST) of the coal mineral estate is owned by the Federal government (table 6). Depth to the top of the coal bed ranges from shallow subcrop along the eastern extent of the bed, to about 2,500 ft along the axis of the basin (fig. 81). Only about 5.5 percent of the available coal resource is at a depth less than $500 \mathrm{ft}$ (table 5).

\section{Gates/Wall Coal Bed}

Known as the Gates bed in Wyoming and the Wall bed in Montana, this bed is present in a large area in the central and northern Wyoming PRB, extending into the southwestern Montana PRB (fig. 82). The Gates/Wall crops out along its northern extent and thins and pinches out to the south and east. Identified in 3,412 drill holes, the coal has a maximum thickness of $125 \mathrm{ft}$, and averages $9 \mathrm{ft}$ thick (fig. 23). About 57.9 BST of the 66.4 BST of original resource are considered as available resources (tables 4-7). Of the total available resource, about 86 percent (49.8 BST) of the coal mineral estate is owned by the Federal government (table 6). The top of the coal bed ranges from shallow subcrop along the eastern extent of the bed, to more than 3,000 ft along the axis of the basin (fig. 83). About 8 percent of the available coal resource is at a depth less than $500 \mathrm{ft}$ (table 5).

\section{Pawnee Coal Bed}

The Pawnee coal bed is present in the northern Wyoming PRB and extends into the southern one-half of the Montana PRB (fig. 84). The Pawnee crops out along its northern extent and thins and pinches out to the south and east. The coal bed was identified in 1,368 drill holes, has a maximum thickness of $34 \mathrm{ft}$, and averages $7 \mathrm{ft}$ thick (fig. 23). About 17.0 BST of the 24.5 BST of original resource are considered as available resources (tables 4-7). Of the total available resource, about 85 percent (14.5 BST) of the coal mineral estate is owned by the Federal government (table 6). Depth to the top of the coal ranges from shallow subcrop along the eastern extent of the bed, to more than $3,000 \mathrm{ft}$ near the axis of the basin.
About 30 percent of the available coal resource is at a depth less than $500 \mathrm{ft}$ (fig. 85, table 5). In the Montana PRB there is significant area of thick coal less than $500 \mathrm{ft}$ in depth, which is potentially surface minable (fig. 85).

\section{Brewster-Arnold Coal Bed}

The Brewster-Arnold coal bed, identified in 110 drill holes, has a maximum thickness of $19 \mathrm{ft}$ and averages $5 \mathrm{ft}$ thick (fig. 23). This coal bed is present mostly in the central Montana PRB and small isolated areas in the Wyoming PRB (fig. 86). About 0.5 BST of the approximate 2.0 BST of original resources are considered as available resources (tables 4-7). Of the total available resource, about 0.3 BST of the coal mineral estate is owned by the Federal government (table 6). Depth to the top of the coal ranges from shallow subcrop along the eastern extent of the bed, to more than $1,500 \mathrm{ft}$ along the axis of the basin (fig. 87, table 5).

\section{Odell Coal Bed}

Identified in 1,052 drill holes, the Odell bed is present in the northern Wyoming PRB and extends into the southern Montana PRB (fig. 88). The bed has a maximum thickness of $26 \mathrm{ft}$, and averages $4 \mathrm{ft}$ thick (fig. 23). Of the $11.7 \mathrm{BST}$ of original resource, about 6.6 BST are considered as available resources (tables 4-7). Of the total available resource, about 85 percent (5.7 BST) of the coal mineral estate is owned by the Federal government (table 6). Depth to the top of the coal ranges from shallow subcrop along the eastern extent of the bed, to more than 3,000 ft along the axis of the basin (fig. 89, table 5).

\section{Cache Coal Bed}

The Cache bed is present primarily in the southern Montana PRB (fig. 90). The bed, which was identified on 247 drill holes, reaches a maximum thickness of $26 \mathrm{ft}$, and has an average thickness of $3 \mathrm{ft}$ (fig. 23). Of the $3.3 \mathrm{BST}$ of original resource, about $0.8 \mathrm{BST}$ are considered as available resources (tables 4-7). Of the total available resource, about 0.7 BST of the coal mineral estate is owned by the Federal government (table 6). Depth to the top of the coal ranges from shallow subcrop along the eastern extent of the bed, to more than 2,000 ft along the axis of the basin (fig. 91, table 5).

\section{A Zone Coal Bed}

The A Zone bed is correlated in several drill holes in a cross section by McLellan and others (1990) and is present only in small isolated areas in the Montana PRB (fig. 92). The bed, identified in 24 drill holes, has a maximum thickness of $9 \mathrm{ft}$ and averages $3 \mathrm{ft}$ thick (fig. 23). Of the 0.1 BST of original resource, about $0.01 \mathrm{BST}$ are considered as available resources (tables 4-7). Depth ranges from shallow subcrop along the eastern extent of the bed, to about 1,000 ft along the axis of the (fig. 93, table 5). 
Coal Geology and Assessment of Coal Resources and Reserves in the Powder River Basin, Wyoming and Montana

\section{Upper Rosebud and Rosebud/Knobloch Coal Beds}

Identified in 44 drill holes, the Upper Rosebud is an upper split of the Rosebud/Knobloch coal bed and is present in a small area near the Absaloka Mine (fig. 12) in the Montana PRB (fig. 94). The Upper Rosebud is referred to as the S1 coal bed by the Westmoreland Resources, Inc. Mining Company (J. Speake, Jr., Westmoreland Resources, Inc., oral commun., 2010). The bed has a maximum thickness of $15 \mathrm{ft}$ and averages $3 \mathrm{ft}$ thick (fig. 23). Of the $0.2 \mathrm{BST}$ of original resource, about 0.05 BST are considered as available (tables 4-7).

Depth to the top of the bed ranges from shallow subcrop along the eastern extent of the bed, to about $1,000 \mathrm{ft}$ along the axis of the basin (fig. 95, table 5).

The Rosebud/Knobloch coal bed is one of the thickest minable coal beds in the Montana PRB. The bed is known as the Rosebud west of Rosebud Creek and as the Knobloch east of Rosebud Creek (fig. 96) (Haacke and others, 2013). The Rosebud/Knobloch is equivalent to the Deep 1 coal bed in the SWPRB (Osmonson and others, 2011) and correlates to the Rosebud coal bed of Roberts and others (1999c) and the Sawyer coal bed of McLellan and others (1990). Near the town of Ashland, the Rosebud/Knobloch correlates to the Calvert and the McKay/Nance coal beds of Roberts and others, (1999a). This coal is mined in the Rosebud and Absaloka Mines and was also mined at the abandoned Big Sky Mine (fig. 12).

Identified in 2,203 drill holes, the coal bed has a maximum thickness of $73 \mathrm{ft}$, and averages $12 \mathrm{ft}$ thick (fig. 23). Some of the thickest coal is located under the Custer National Forest (fig. 19). This bed is the minable bed target for the Otter Creek lease area (fig. 12). In the Montana PRB, the Rosebud/ Knobloch crops out along Otter Creek and pinches out to the east and west. About 47.1 BST of the 64.4 BST of original resource are considered as available resources (tables 4-7). Of the total available resource, about 80 percent (37.4 BST) of the coal mineral estate is owned by the Federal government (table 6). Depth to the top of the coal bed ranges from shallow subcrop along the eastern extent of the bed, to about $1,500 \mathrm{ft}$ in the Montana PRB and about 4,000 ft along the axis of the basin in the Wyoming PRB. About 27 percent of the available coal resource is at a depth less than $500 \mathrm{ft}$ (fig. 97, table 5).

The Rosebud/Knobloch was included in the economic analysis to determine the coal reserve base.

\section{Calvert Coal Bed}

Present only in the Montana PRB, the Calvert coal bed was identified in 86 drill holes, has a maximum thickness of $18 \mathrm{ft}$ and averages $3 \mathrm{ft}$ thick (fig. 23). Near the town of Ashland (fig. 1) the bed is part of the base of the Rosebud/ Knobloch (fig. 98) (Roberts and others, 1999a). About 0.2 BST of the 1.2 BST of original resource are considered as available resources (tables 4-7). Depth to the top of the coal ranges from shallow subcrop along the eastern extent of the bed, to about 2,000 ft deep along the axis of the basin (fig. 99, table 5).
McKay/Nance and Lower McKay Coal Beds

The McKay/Nance coal bed is a lower split of the Rosebud/Knobloch coal bed. The thickest portion of the Rosebud/Knobloch coal bed east and south of the town of Ashland (figs. 1 and 96) reflects the area where the Rosebud/ Knobloch and McKay/Nance coal beds form a single bed. The McKay/Nance coal bed splits off the Rosebud/Knobloch coal bed peripherally from the thickest area of the Rosebud/ Knobloch coal bed (fig. 100). This split results in a corresponding thinning of the Rosebud/Knobloch coal bed in all directions. In the Montana PRB, the McKay/Nance coal bed is known as the McKay coal bed west of Rosebud Creek and the Nance coal bed east of Rosebud Creek (Roberts and others, 1999c). The bed is present in both the Rosebud and Absaloka Mines, and the abandoned Big Sky Mine areas (figs. 12 and 100). The McKay/Nance crops out along its northern extent and thins to the east, south and west (fig. 100).

The coal bed is also present throughout the Wyoming $\mathrm{PRB}$, but at considerably greater depth. The McKay/Nance coal bed is equivalent to the Deep 2 coal bed identified in the SWPRB (Osmonson and others, 2011). The coal bed was identified in 2,499 drill holes, has a maximum thickness of $36 \mathrm{ft}$, and averages $5 \mathrm{ft}$ thick (fig. 23). Of the 33.3 BST of original resource, about 22.6 BST are considered as available resources (tables 4-7). Of the total available resource, about 78 percent (17.7 BST) of the coal mineral estate is owned by the Federal government (table 6). Because of a topographic high (Little Wolf Mountains) (fig. 101), depth to the coal bed ranges from shallow subcrop along the eastern extent of the bed, to more than 2,000 $\mathrm{ft}$ between the Absaloka and Rosebud Mines (figs. 12 and 101). About 20 percent of the available coal resource is at a depth less than $500 \mathrm{ft}$ (fig. 101, table 5).

The Lower McKay bed, identified in 63 drill holes, has a maximum thickness of $7 \mathrm{ft}$ and averages $3 \mathrm{ft}$ (fig. 23). The coal bed is present only in small areas near the Absaloka Mine in the Montana PRB (figs. 12 and 102). The Lower McKay is also referred to as the $\mathrm{S} 2$ coal bed by Westmoreland Resources, Inc. (J. Speake, Jr., Westmoreland Resources, Inc., oral commun., 2010). Of the 0.2 BST of original resource, about $0.01 \mathrm{BST}$ are considered as available resources (tables 4-7). Depth to the top of the coal bed ranges from shallow subcrop along the eastern extent of the bed, to more than $1,500 \mathrm{ft}$ (fig. 103, table 5).

\section{Flowers-Goodale Coal Bed}

The areal extent of the Flowers-Goodale is present in both the Montana and Wyoming PRB assessment areas (fig. 104). In the Montana PRB, the Flowers-Goodale bed crops out along the northern and eastern limits of its extent. Several lenticular pods of the bed are present in the central Wyoming PRB. In Wyoming, this bed is equivalent to the Deep 3 coal bed (Osmonson and others, 2011).

Identified in 2,752 drill holes, this bed occurs in a large area in the southern one-half of the Montana PRB and throughout the central part of the Wyoming PRB (fig. 104). 
The bed has a maximum thickness of $40 \mathrm{ft}$ and averages $8 \mathrm{ft}$ thick (fig. 23). Of the $60.5 \mathrm{BST}$ of original resource, about 51.0 BST are considered as available resources (tables 4-7). Of the total available resource, about 85 percent (43.4 BST) of the coal mineral estate is owned by the Federal government (table 6). Depth to the top of the coal bed ranges from shallow subcrop along the eastern extent of the bed, to more than $3,000 \mathrm{ft}$ in depth near the axis of the basin. About 12 percent of the available coal resource is at a depth less than $500 \mathrm{ft}$ (fig. 105, table 5). The Flowers-Goodale was included in the economic analysis to determine the coal reserve base.

\section{Upper Witham and Robinson/Witham Coal Beds}

The Upper Witham coal bed has limited areal extent and is present only in the Montana PRB near the abandoned Big Sky Mine (fig. 106). Identified in 150 drill holes, the bed reaches a maximum thickness of $29 \mathrm{ft}$ and has an average thickness of $4 \mathrm{ft}$ (fig. 23). Of the $0.1 \mathrm{BST}$ of original resource, about $0.07 \mathrm{BST}$ are considered as available resources (tables 4-7). Depth to the top of the coal bed ranges from shallow subcrop along the eastern extent of the bed, to about $500 \mathrm{ft}$ near the abandoned Big Sky Mine (figs. 12 and 107, table 5).

The Robinson/Witham is known as the Robinson coal bed west of Rosebud Creek and as the Witham coal bed east of Rosebud Creek in the Montana PRB (fig. 108). The bed crops out north of the Rosebud Mine (fig. 12), was identified in 1,491 drill holes, has a maximum thickness of $41 \mathrm{ft}$, and averages $7 \mathrm{ft}$ thick (fig. 23). The bed is also found in a large area in the west-central part of the Wyoming PRB and correlates with the Robinson coal bed of Roberts and others (1999c). Of the approximate 20.7 BST of original resource, about 15.0 BST are considered as available resources (tables 4-7). Of the total available resource, about 65 percent (9.9 BST) of the coal mineral estate is owned by the Federal government (table 6). Because of a topographic high (Little Wolf Mountains) (fig. 108), depth to the top of the coal bed ranges from shallow subcrop to more than 3,000 ft between the Absaloka and Rosebud Mines (fig. 12). About 30 percent of the available coal resource is at a depth less than $500 \mathrm{ft}$ (fig. 109, table 5).

\section{Roberts/Terret Coal Bed}

The Roberts/Terret coal bed, identified in 1,768 drill holes, is present throughout much of the central part of both the Montana and Wyoming PRB (fig. 110). This bed correlates with the Roberts coal bed in Wyoming (Molnia and Pierce, 1992) and in the NWPRB assessment area of Scott and others (2010). The bed reaches a maximum thickness of $42 \mathrm{ft}$, and averages $8 \mathrm{ft}$ thick (fig. 23). Of the 51.9 BST of original resource, about 44.5 BST are considered as available resources (tables 4-7). Of the total available resource, about 84 percent (37.1 BST) of the coal mineral estate is owned by the Federal government (table 6). Depth to the top of the Roberts/Terret coal bed ranges from shallow subcrop along the eastern extent of the bed, to more than $4,000 \mathrm{ft}$ near the axis of the basin (table 5, fig. 111).
Burley Coal Bed

Identified in 50 drill holes, the Burley coal bed is present in two small areas in the Montana PRB and one isolated area in the Wyoming PRB. The largest area in the Montana PRB is near the Otter Lease, the other is south of the Rosebud Mine (figs. 12 and 112). The bed has a maximum thickness of $10 \mathrm{ft}$ and averages $3 \mathrm{ft}$ thick (fig. 23). Of the 1.6 BST of original resource, about $0.7 \mathrm{BST}$ are considered as available resources (tables 4-7). The depth to the top of the coal bed ranges from shallow subcrop along the eastern extent of the bed, to more than 2,000 ft along the axis of the basin (fig. 113, table 5).

\section{Upper Stag and Lower Stag Coal Beds}

The Stag coal bed is correlated in several drill holes in a cross section in McLellan (1991). The name was expanded in this report to include an Upper and Lower Stag for correlating two minor coal beds. The Upper Stag bed is limited in areal extent to the northern Wyoming PRB extending into the southern Montana PRB (fig. 114). The bed, which was identified on 91 well logs, reaches a maximum thickness of $13 \mathrm{ft}$, and has an average thickness of $3 \mathrm{ft}$ (fig. 23). Of the approximate 1.9 BST of original resource, about 0.8 BST are considered as available resources (tables 4-7). Depth to the top of the coal bed ranges from shallow subcrop along the eastern extent of the bed, to more than $3,000 \mathrm{ft}$ along the axis of the basin (fig. 115, table 5).

The Lower Stag bed is present in small, isolated areas in the southern Montana PRB (fig. 116); this bed is the lowest (oldest) coal bed evaluated in the PRB. The bed, which was identified on 8 well logs, reaches a maximum thickness of $6 \mathrm{ft}$ and has an average thickness of $3 \mathrm{ft}$ (fig. 23). Of the $0.2 \mathrm{BST}$ of original resource, about $0.01 \mathrm{BST}$ are considered as available resources (tables 4-7). Depth to the top of the coal bed ranges from shallow subcrop to more than $2,000 \mathrm{ft}$ along the axis of the basin (fig. 117, table 5).

\section{Coal Bed Cross Sections}

Three cross sections (figs. 8-10) illustrate some of the more important features of the coal bed geometry in the PRB. The west-east, dip-oriented section labeled $A-A$ ' (fig. 8) illustrates the stratigraphic relation between the thick Anderson/ Canyon beds in the Gillette coal field to the thick Smith bed in the SWPRB area and the rapid splitting and thinning of the coal beds towards the western edge of the basin. In response to the Bighorn Mountains uplift along the western margin of the basin, several northeast-trending faults developed and terminated the coal beds from cropping out along the western margin of the basin (Ellis and Colton, 1994). Previous studies (Molnia and Pierce, 1992; Flores and others, 2010) correlated the Anderson/Canyon beds with the Smith coal bed; however, the large volume of new data for the current assessment provided sufficient control to confirm that these two coal beds are not equivalent (Luppens and others, 2008; figs. 16 and 17). A comparison of the Anderson bed isopach maps from the 2002 
and 2008 coal assessments (Ellis and others, 2002; Luppens and others, 2008) illustrate the substantial differences in coal bed correlations afforded by the abundance of additional data.

This revised interpretation is supported by several other recent studies. Ashley (2005) and Jones (2010b) have both correlated the Anderson/Canyon and the Smith (Big George) as separate coal beds. Cross section $C-C^{\prime}$ from Jones (2010b) is remarkably similar the $\mathrm{A}-\mathrm{A}^{\prime}$ cross section in this report (fig. 8). The revisions of the thick coal bed correlations within the Wyodak-Anderson coal zone have several ramifications. Rather than the Anderson and Smith beds (Big George) being a single continuous, thick bed as shown in figure 17, there is an interval in figure 8 where the Smith, Anderson, and Canyon coal beds are all relatively thin. The new correlations effectively result in a downdip, geological barrier to westward advances of surface mining of the thick Anderson/Canyon beds in the Gillette coal field (Luppens and others, 2008).

Several other important features of coal bed geometry in the PRB can also be observed in these three cross sections (figs. 8-10). The west-east, dip-oriented section $B-B^{\prime}$ (fig. 9) through the northern portion of the NWPRB assessment area illustrates both the asymmetric nature of the basin and the thickening of the Wyodak-Anderson coal zone northward relative to the $A-A^{\prime}$ cross section (fig. 8) through the Gillette coal field and SWPRB assessment area. In addition to the thickening of the Wyodak-Anderson coal zone, the thick coal beds in the Gillette coal field and the SWPRB assessment area split farther northward. Thinner coal beds spread over a larger stratigraphic interval and present a different set of mining conditions than currently found in the Gillette coal field where the thick, relatively shallow Anderson and Canyon beds are currently mined.

The northwest-southeast, strike-oriented section $C-C^{\prime}$ (fig. 10) demonstrates the splitting and thinning of the thick Anderson and Canyon coal beds and an overall increase in thickness in the Wyodak-Anderson coal zone northward from the Gillette coal field into the NWPRB and MTPRB assessment areas. The Wyodak-Anderson coal zone is limited to the southernmost portion of the MTPRB where these beds crop out. Locally, thicker parts of coal beds below the WyodakAnderson coal zone (Rosebud/Knobloch, Flowers-Goodale, and Pawnee) crop out farther to the north.

Another important factor in the coal bed geometry is that any differences in the hydrochemistry of produced water may be explained by the updated correlations described in this report. For example, the Anderson (Big George) was previously assumed to be the same thick coal bed; however, in this assessment it was determined that the Anderson and the Big George are separate thick coal beds (Luppens and others, 2008) (figs. 8, 17, and 18).

\section{In-Place Coal Resource Volumetrics}

Calculation of coal resource volumetrics first requires converting the surface topography and coal thickness, roof, and floor grids for each coal bed from the final PRB geological model to ASCII grids. Using ArcView (Environmental Systems Research Institute, 2006), USGS in-house GIS resource allocation planning (RAP) scripts were developed to apply the appropriate density value to the coal thickness grids to calculate the tonnage of coal contained within each assessed area. Finally, additional RAP scripts were used to apply the original, remaining, and available coal tonnages to the grids of coal ownership, reliability categories, depth to coal, and assessment areas to create an even more detailed analysis of the assessment area's coal resources. Original coal resources were calculated for all coal beds at least $2.5 \mathrm{ft}$ thick and with no restrictions applied. Remaining resources were calculated using the volume of the original resource minus the volume of coal that had been mined. Land-use environmental) and technical restrictions were then calculated and subtracted from the remaining resource to determine available resources.

A total of 47 coal beds were identified during this final assessment. With no restrictions applied, the total original resource for these 47 beds was calculated to be about 1.16 trillion short tons (TST) (fig. 23, tables 4-7). Available coal resources, which are part of the original coal resource after subtracting restrictions to mining and areas of burned coal, were calculated to be 975 BST. Restrictions included railroads, Federal Interstate highways, urban areas, alluvial valley floors, State parks, national forests, and mined coal areas.

Figure 118 provides the amount and percent of original coal resources for 12 significant coal beds with about $50 \mathrm{BST}$ resources or greater. Of these 12 beds, 6 are within the Wyodak-Anderson coal zone (Smith, Anderson, Dietz 3, Canyon, Lower Canyon, and Werner/Cook). Collectively, the Wyodak-Anderson coal zones represent 50 percent of the total original in-place resources. The 12 major coal beds total about 81 percent of the original resources with the remaining 35 assessed beds totaling about 19 percent of the original resources. These 12 beds offer the most potential for recoverable coal resources. The total coal resource number of $1.16 \mathrm{TST}$ is about 0.09 TST greater than the sum of 1.07 TST of original resources of the four assessment areas (Scott and Luppens, 2013). The inclusion of deeper coal beds below the WyodakAnderson coal zone for this report, especially in the Gillette coal field, East Gillette coal field extension, and NWPRB assessment areas, accounted for the increase in this final inplace resource estimate.

Tables 4-7 provide resource summaries based on reliability, overburden thickness, coal ownership, and assessment area categories. Table 8 presents the summary results of tables 4-7 to facilitate comparisons of the different coal resource categorizations. About 6.5 BST of the original resource was estimated to be burned (clinker) and 6.4 BST was previously mined, leaving a remaining resource of about 1.15 TST. Approximately 174 BST (15 percent) of the original resource is affected by restrictions (mined coal, too thin, land use, and technical). Subtraction of these restrictions from the 1.15 TST leaves about 975 BST ( 84 percent) of the original resource available for potential development in the PRB (tables 4-7). The same set of coal resource summaries are included in each of the four 
PRB area assessments if more detailed information is needed (Luppens and others, 2008, Scott and others, 2010, Osmonson and others, 2011, Haacke and others, 2013).

Coal resources for the 47 assessed coal beds are reported by reliability categories in tables 4,8 , and 9 . The resources were classified according to geologic assurance of existence or reliability, which are dependent on the density of geologic data points. The different reliability categoriesmeasured $(0.25 \mathrm{mi}$ from point of measurement); indicated (0.25-0.75 mi from point of measurement); inferred (0.75-3.0 mi from point of measurement); and hypothetcal (greater than $3.0 \mathrm{mi}$ from point of measurement) - were established on the basis of distance from a data point (Wood and others, 1983).

About 76 percent of the original resources for all assessed beds can be classified as measured or indicated (table 9). About 99 percent of the original resources are in the measured, indicated, or inferred categories (table 9). This reflects a much higher relative degree of confidence than previous studies as a result of the substantial amount of new data incorporated into this assessment. Table 9 compares PRB resources in Ellis and others (1999) with resources in this assessment as well as a comparison of the total resources and reliability categorizes. The resources in the measured and indicated categories increased from 38 to 78 percent with a corresponding threefold decrease in the inferred and hypothetical categories from the 1999 assessment to the current assessment. It is interesting to note that the difference between the total estimated resource volumes for the two PRB assessments of the Wyodak-Anderson coal zone (table 9) was only about 16 BST. Thus, reasonable total coal resources can be estimated with less data using a net thickness isopach for a coal zone. However, more data were needed to confidently correlate the individual coal beds given the complex coal geology within the PRB if estimates of recoverable coal are required. An example of this revised coal bed correlation is shown in figures 16 and 17. Although the net total resources for the area represented in the two figures are similar, figure 17 represents a significantly different stratigraphic and mining economics scenario than figure 16.

Coal resources for the 47 assessed coal beds are reported by overburden depth categories in tables 5 and 8 . Nearly 90 percent of the available resources are less than 2,000 ft in depth. Only 22 percent of the resources are less from 0 to $500 \mathrm{ft}$ in depth, which is the interval where most of the current coal resources in the reserves category would be expected.

Coal resources for the 47 assessed coal beds are reported by ownership categories in tables 6 and 8 . Eighty-six percent of the available coal resources are under Federal coal ownership for the greater PRB. South of T. 4 S. in Montana, the Federal coal ownership exceeds 90 percent (fig. 20). North of T. 4 S. in Montana, Federal coal ownership is less than 50 percent in most townships.

In July 1864, the Northern Pacific Railroad was chartered (Malone and others, 1991) and the U.S. Government used a portion of the public domain (Federally owned land) to assist and encourage the building of transcontinental railroads. This land was granted in alternate sections, creating a checkerboard pattern, within an area lying $40 \mathrm{mi}$ on either side of the proposed Northern Pacific Railroad right of way (fig. 20).

Coal resources for the 47 assessed coal beds are reported by assessment area in tables 7 and 8 . Of the four assessment areas, the MTPRB assessment area contains the least amount of available resources. The dominant Wyodak-Anderson coal zone is limited to the southernmost four townships in Montana. Coal beds in the Wyodak-Anderson coal zone are much thinner in Montana relative to those beds in the Gillette coal field and SWPRB assessment area. The Werner/Cook bed, at the base of the Wyodak/Anderson coal zone, crops out in the southern one-half of Big Horn and Powder River Counties (fig. 76).

\section{Perspectives on Environments of Deposition}

The primary goal of this assessment was to quantify and evaluate coal resources in the Powder River Basin. However, it is difficult to assess the coal beds in the PRB without speculating on the depositional history of such thick, extensive coal beds. Mapping of individual beds for the first time throughout the entire PRB was required to complete the economic assessment of in-place as well as recoverable coal resources. The correlation of the discrete coal beds in this assessment offers more information than simply the coal bed isopach maps needed for the coal resource inventory. The individual bed maps also enable the generation of interburden isopach maps between adjacent coal beds which provides the ability to investigate patterns of clastic deposition between periods of peat accumulation. The purpose of this section was not to revise depositional models, but to review several theories and to briefly discuss how the results of this assessment may provide new perspectives regarding depositional environments of the extraordinary PRB coal province.

Several depositional models have been proposed to explain the origin of the thick coal beds in the PRB. These models attribute the development of accommodation and the nature of coal splitting (parting geometry) to sedimentary processes (differential compaction, channel switching, and crevasse splay deposits) within specific depositional environments (raised mires, deltas, and basinwide wetlands) (Jones, 2010a). Most of these models are based on peat-to-coal compaction ratios ranging from $3: 1$ to $20: 1$ (3-20 ft of peat compacts to form $1.0 \mathrm{ft}$ of coal). Jones (2010a), however, proposes that sequence stratigraphy of coal beds and basement-related structural effects explain the origin of these thick coal deposits.

Flores and others (1999) proposed that the coal in the Fort Union Formation formed from peats that accumulated in swamps of northeast flowing fluvial systems. The sediments that formed these rocks were deposited in channels, overbank floodplains, floodplain lakes, and crevasse channel splays drained by meandering, anastomosing, and braided streams. Thick, low-ash, low-sulfur coal beds of the Tongue River Member formed in raised swamps that developed in 
interfluvial environments and on abandoned stream deposits. The regional paleogeographic patterns of the merged coal zones appear to be affected by peat deposition on noncompactable, sandstone-dominated, alluvial-belt deposits superimposed on paleotectonic platforms. The lateral migration, avulsion, and abandonment of these platforms resulted in random distribution of the merged coal bodies (Flores and others, 2010). Several of these channel systems were mapped in the Gillette coal field by Luppens and others (2008). Some channel locations can be seen on the drill hole location map (fig. 15) as areas of less dense drilling, because of relatively thin or absent coal beds in these channel areas. Examination of geophysical logs delineated a major basin-axis channel system. This channel system extends northward from T. 40 N., R. $73 \mathrm{~W}$. (fig. 15). A relatively narrow, east-west trending channel can also be seen by the lack of drilling from T. 46 N., R. $71 \mathrm{~W}$., west about three townships until it intersects the north-south channel system on the west side of the Gillette coal field (fig. 15).

Ayers (1986b) proposed a fluvial deltaic model where sediments filled the basin, primarily from the eastern margin, in a series of northeast southwest-trending delta systems with thick coal beds forming in an interdeltaic setting. Ayers and Kaiser (1984) stated that there is no evidence for a basin-axis fluvial system, as suggested by previous research (Flores, 1982), as sand percentages are lowest along the axis of the basin. However, using geophysical logs, Luppens and others (2008) defined a channel system parallel to the basin axis. Furthermore, the split line between the Canyon and Anderson beds, especially in the south portion of the Gillette coal field, is also oriented to the basin axis with the split thickening westward. This basin-axis fluvial system and associated split geometry is perpendicular to the deltaic sand body framework geometry which trends northeast southwest (Ayers, 1986b).

An important factor regarding the deltaic models is the concept of peat compaction (Jones, 2010a). The raised mires model and the interdeltaic wetlands model both need tremendous amounts of accommodation to allow for great thicknesses of peat to accumulate. These models are based on the concept of peat-to-coal compaction ratios, wherein a given amount of peat is compressed to form a given thickness of coal.

An alternate hypothesis has been proposed to explain the genesis of the thick PRB coal sequences, based on chronostratigraphic correlation (sequence stratigraphy) of coal beds, basement-related structural effect on differential development of accommodation within the basin, and the coalification process (not compaction) (Jones, 2010a). Recurrent movement along postulated basement faults resulted in stacked organic deposits, alternating organic and clastic deposits, and heterogeneous clastic deposits. Subtle changes in surface topography resulting from structural movement of these basement blocks disrupt the process of peat accumulation by changing the water table, shifting fluvial systems, and affecting the stabilization of shorelines.
Jones (2010a) provides evidence that the thick PRB coal deposits are not a result of organics that accumulated in single, long-lived, stable wetlands; rather, these coal deposits are composed of numerous, stratigraphically adjacent coal beds that developed intermittently between periods of organic accumulation and periods of nondeposition and weathering. A key to this depositional concept is the coalification process. As peat accumulates, it undergoes progressive aerobic to anaerobic bacterial decay with depth. The end product of this bacterial reduction of accumulated plant material is a dark brown to black, semi-amorphous, organic-rich gel, known as gytta. During periods of subaerial exposure, the layer of partially decomposed peat is readily oxidized and prone to erosion when dried and thus, is often not preserved. Data that support subaerial exposure of the gytta include thin paleosols such as fusain layers (discrete horizons of oxidized coal), evaporate minerals (for example gypsum and anhydrite), and variable ash content of the coal above and below the thin oxidized surfaces. The bottom and top of these paleosols mark periods between different depositional facies, and the spacing of these chronostratigraphic surfaces (time lines) represents equal amounts of time. These time lines are important because they indicate that thick coal deposits did not form from a singularly thick deposit of peat, but that thick coal deposits actually formed from numerous, stacked, thinner accumulations of gytta. The thickness of a coal bed generally corresponds to the final cumulative thickness of the relatively incompressible gytta layers. The heat-driven process (thermogenesis) converts the gytta to various grades of coal (Jones, 2010a).

A lineament-based depositional model is summarized in figures A and B contained in a report by Jones (2010a). In this model, organic accumulation in a lower energy wetland environment supported subaqueous reducing conditions. Subsequent development of differential accommodation because of fault reactivation of basement blocks occurred along split lines. A period of high energy, localized clastic deposition occurred in the downthrown blocks, while topographically higher blocks were subjected to subaerial exposure and oxidation of the gytta surface. Repetition of the differential development of the accommodation process resulted in the unique geometry of coal deposits in the Tongue River Member of the Fort Union Formation in the PRB (fig. B in Jones, 2010a).

To test this model, several individual coal bed isopach maps, a combined isopach map of the major Wyodak-Anderson zone beds (Canyon, Anderson, and Smith), and an isopach of the interburden between the Anderson and Canyon coal beds were examined to see if there is a relation between coal thickness trends and lineament orientation trends in the basin. The isopach maps for the Flowers-Goodale and Roberts/Terret coal beds and superimposed lineaments are shown in figures 119 and 120. Interburden between these two beds ranges from about 125 to 200 in thickness. Flores (2010) States that the thicker (merged) coal bodies are randomly distributed. 
However, several of the thicker areas of coal in both beds overlie each other. They are generally bounded by the northwest-trending Buffalo/Douglas, Lightning Creek, and Black Butte lineaments, and the southwest-trending Casper/Bill, Fiddler Creek, South Coyote Creek, and Rozet lineaments, suggesting some structural effect.

The isopach map of the Smith, Anderson, and Canyon coal beds, with superimposed lineaments, is shown in figure 121. The thickness distribution appears to be controlled by the northwest-trending Buffalo/Douglas, Lightning Creek, and Black Butte lineaments, and the southwest-trending Fiddler Creek, Rozet, Tensleep/Harding, and Big Horn/Custer lineaments, which again suggests some structural influence. There also seems to be structural control affecting areas of little or no coal accumulation or "want areas" (Flores, 2010). This want area, bounded by the southwest-trending Tensleep/ Harding and Big Horn/Custer lineaments (fig. 121), coincides with the marked thickening of the Wyodak-Anderson coal zone interval, as well as the splitting and thinning of the coal beds within that zone just south of the Montana State line.

By mapping individual coal beds rather than net coal isopachs, the generation of interburden isopachs can be accomplished by subtracting the roof elevation grid of a lower bed from the floor elevation grid of an upper bed. When a coal bed splits, the net thickness of the two splits may be similar to the unsplit coal bed. Therefore, relying on net coal isopachs may mask the split line orientation of the parting between the two coal beds. Interburden isopachs can define the parting geometry. The interburden isopach between the Anderson and Canyon beds in the Gillette coal field (Luppens and others, 2008) and the superimposed lineaments is shown in figure 122. The parting orientation in the southern portion of the coal field is parallel to the northwest-trending Lightning Creek lineament. The parting split line in the northern part of the coal field coincides with the Rozet lineament. The east-west parting in the central part of the coal field (T. $46 \mathrm{~N}$. and T. $47 \mathrm{~N}$.) is a fluvial channel system that splits the merged coal bed. This channel system is parallel to the Sussex/Osage lineament (fig. 122). Flores (2010) stated that this east-west "want" area was not parallel to lineament trends. However, that appraisal was based on a net coal isopach map with less data control than the current assessment, which precluded definitive orientation of the channel system.

\section{Surface Coal Resource Assessment}

The objective of the USGS Coal Assessment Project is to refine the Nation's coal resource estimates and conduct the systematic determination of the coal reserve base on a regional basis in the major coal provinces in the Nation. The final and most important step in the coal assessment process is to derive estimates of that portion of in-place resources that can currently be classified as reserves and those resources that are potentially recoverable based on economic analyses. Regional estimates of coal reserves can provide energy planners a more meaningful appraisal of the amount of coal that is potentially recoverable in the foreseeable future. Therefore, the development of a regional mining economics model for each of the four assessment areas is essential to accomplish the goals of the PRB coal assessment.

\section{Surface Mine Modeling}

Developing regional mine models is challenging because there are significant differences in the coal geology between the Gillette coal field (Luppens and others, 2008) and the other assessment areas within the PRB, which can appreciably affect the economic analysis. Mine engineering practices must be adapted to specific geologic conditions. Therefore, the mine modeling methodology was customized for each of the four PRB assessment areas. Despite geologic variations between assessment areas, a common methodology was followed (fig. 14). Replicating all assessment methodologies in this report would be impractical, but the individual PRB assessment reports include specific mine modeling details (Luppens and others, 2008; Scott and others, 2010; Osmonson and others, 2011; Haacke and others, 2013).

The USGS developed both surface and underground regional mine models for the assessment areas because there are significant areas within the PRB that are underlain by thick, deep, coal beds that are not amenable to surface mining recovery. Although no coal in the PRB is currently nor is anticipated to be recovered by underground mining in the foreseeable future, it was determined that for a holistic assessment of the coal resources in the PRB, underground mining should be evaluated at least on a preliminary basis.

\section{Geologic Aspects of Surface Mine Model Development}

Bed thickness is one of the most important factors affecting coal recoverability; thin coal beds may be unrecoverable. There is a significant inverse relationship between bed thickness and the mining disturbance area (Luppens and others, 2009). A 4-ft bituminous coal bed requires $22.1 \mathrm{mi}^{2}$ for a 100 million-ton resource block, whereas a 50 -ft bed requires only $1.8 \mathrm{mi}^{2}$. Clearly, it would be preferable to recover the thickest coal bed. However, coal bed thickness is not the only important criterion affecting coal recoverability.

The depth of a coal bed also affects coal recovery economics, especially for surface minable resources. The most important cost component in surface mining is the expense of removing the volume of rock above a minable coal bed (overburden) (Luppens and others, 2009). The cost of surface coal mining increases with increased depth because of the greater volume of material that needs to be removed per unit of coal. The relation between coal bed depth and thickness is 
referred to as the stripping ratio, which is the most significant economic factor in the evaluation of surface mining potential (Luppens and others, 2009). This ratio represents the volume of rock both above and within (parting) coal beds expressed by the number of cubic yards that must be mined to obtain one ton of coal. Although not an exact conversion, the stripping ratio can be estimated by dividing the thickness of the rock above the coal bed by the coal thickness. For example, given a 10-ft-thick coal bed and a 50 -ft-thick bed, both at $100 \mathrm{ft}$ depth, the approximate stripping ratios would be 10:1 and $2: 1$, respectively. Therefore, for the 2:1 stripping ratio area only 2 cubic yards $\left(\mathrm{yd}^{3}\right)$ of rock would have to be removed per ton of coal produced, compared to $10 \mathrm{yd}^{3}$ for the 10:1 area. Obviously, the 2:1 ratio area would have a significant production cost advantage. It is the combination of extensive, thick, relatively low stripping ratio resources, coupled with relatively low-sulfur and low-ash content in the PRB that has stimulated the rapid development in this region during the past 40 years. A maximum stripping ratio of 10:1 was used for the economic analyses. While a stripping ratio of 10:1 is higher than current (October 2014) average mining conditions in the PRB (typically less than $4: 1$ or less ratio), mining to 10:1 stripping ratios have been reported elsewhere in the United States (Schobert, 1995; Kaiser, 1999).

\section{Modeling Stratigraphic Sequence for Surface Mining}

The first step in conducting a mining economic evaluation is deciding which coal beds to include in the mine models and then parsing out the coal resources by composite stripping-ratio increments. The criteria used to select coal beds for the mine models were depth, thickness, and areal extent. Generally, only beds with an areal extent of at least several townships, thicknesses $5.0 \mathrm{ft}$ or greater, and depths less than $500 \mathrm{ft}$ were evaluated. The minimum thickness of $5.0 \mathrm{ft}$ (Bureau of Land Management, 1986) and the maximum incremental stripping ratio of 4:1 criteria for beds below the Anderson or Canyon were selected on the basis of current mining practices in the Gillette coal field (Luppens and others, 2008). Subsequent to bed selection for the mining economic evaluation, a composite stripping-ratio map was generated and the recoverable coal resources for each stripping increment from 1:1 to 10:1 were calculated.

For the Gillette coal field assessment, the exceptionally thick Anderson and Canyon bed sequence dominated the economic evaluation. These two coal beds are generally close to each other stratigraphically with little or no separation by parting material. The Roland and Smith coal beds stratigraphically above the Anderson and Canyon beds were also included in the Gillette coal field mine models. No coal beds below the Canyon bed were economically assessed. The Anderson and Canyon beds accounted for about 82 percent of the total recoverable coal resources in the Gillette coal field (Luppens and others, 2008). Additionally, this thick coal interval represented more than 90 percent of the resources to the 6:1-7:1 stripping-ratio interval. Use of the USGS CoalVal program (Rohrbacher and McIntosh, 2010), which aggregates all coal beds into a single composited bed mine model provided an appropriate regional mine model for the Gillette coal field.

In the northern portion of the Gillette coal field, the Anderson and Canyon beds begin to separate and thin significantly to the north and northwest into the NWPRB assessment area continuing into the MTPRB assessment area. Similarly, the Canyon bed separates into the Canyon and Lower Canyon beds in these directions. Typically, mining costs are higher for the recovery of multiple beds as opposed to a single bed scenario, which was used in the Gillette coal field assessment. To address the mining conditions in the NWPRB and MTPRB assessment areas, a new surface mine model program was developed to evaluate multibed sequences, rather than the CoalVal program used for the Gillette coal field assessment (Scott and others, 2010). For the NWPRB assessment area, DCF mining costs were as much as $\$ 6 /$ ton higher than the costs for the same stripping ratio increment for the Gillette coal field (Luppens and others, 2008).

The same methodology to parse out coal resources by composite stripping ratio increments in the Gillette coal field assessment (Luppens and others, 2008) was used for the NWPRB assessment area. However, with more beds having thinner average thicknesses throughout a larger stratigraphic interval, the approach to the coal reserve evaluation model for the NWPRB assessment area had to be modified. The Roland (Baker), Smith, Anderson, Dietz 3, Canyon, Lower Canyon, and Werner beds were selected for the economic evaluation. However, not all beds are present everywhere in the NWPRB, further complicating the development of a regional mine model for this area. This is especially true for lower stripping ratios. For example, in the 2:1 ratio areas, some areas contain the Werner and Lower Canyon or Lower Canyon and Canyon, or other bed combinations. For stripping ratios of 5:1 or greater, five or six of these assessed beds are typically present. Interburden thicknesses between the beds are also variable. Developing a single regional model with bed and interburden variability represented a challenge. A straightforward modeling approach was needed that still addressed the multibed situations in this area.

The regional mine models for the Wyodak-Anderson coal zone for the NWPRB and MTPRB assessment areas were formulated on a representative model-bed section based on approximate average thicknesses for the coal beds and average interburden intervals assessed for reserves. An example of a regional mine model stratigraphic sequence used for the economic evaluation of the NWPRB assessment area is shown in table 10. All strata in this model are assumed to be near horizontal. One coal bed is modeled at the 1:1 ratio, and additional coal beds are added from the 2:1 through 4:1 ratios. Because the coal beds in lower 
ratio models are highly variable, the coal beds are labeled beds $1-4$, rather than using specific bed names. For the 5:1 through 10:1 stripping ratios, six coal beds are modeled (table 10). To simplify the models, interburden thicknesses remain constant and overburden is increased for the 5:1-10:1 ratio models. Although the mine model used is a simplification of the actual conditions, this approach still provided a more realistic representation than the single-bed model scenario used in the Gillette coal field assessment (Luppens and others, 2008).

Active coal mining in Montana occurs in two stratigraphic zones (Haacke and others, 2013). Coal mines near Decker, Montana, (figs. 2 and 12) are recovering coal from the upper Wyodak-Anderson coal zone (Anderson to the Dietz 3 beds) (fig. 13). For the MTPRB assessment area, a representative regional model was developed based on approximate average thicknesses of five coal beds (Roland (Baker), Smith, Anderson, Dietz 2, and Dietz 3 ) (Haacke and others, 2013). The first coal bed was modeled at the 1:1 stripping ratio; additional coal beds were added for stripping ratios from 2:1 through $4: 1$. To simplify the models, interburden thicknesses remained relatively constant and overburden was increased for the 5:1-10:1 stripping ratio models.

Currently, coal beds in the lower part of the WyodakAnderson coal zone are not mined in the MTPRB assessment area. However, there are areas where the Canyon and Werner/ Cook coal beds are relatively thick and occur at shallow depth with stripping ratios less than 10:1 (figs. 129 and 130). Therefore, in addition to the regional mine model sequence, single bed mine models of the Canyon and Werner/Cook coal beds were evaluated for reserve potential.

Active mining below the Wyodak-Anderson coal zone is unique to the MTPRB assessment area (Haacke and others, 2013). Several mines are recovering coal from the Rosebud/ Knobloch coal bed (fig. 13) near Colstrip, Montana (figs. 2 and 12). In addition to the Rosebud/Knobloch bed, the Pawnee and Flowers-Goodale coal beds locally contain thicker pods of coal below the Wyodak-Anderson coal zone at stripping ratios less than 10:1 (figs. 131-133). Therefore, single bed mine models of the Pawnee, Rosebud/Knobloch, and FlowersGoodale coal beds were also evaluated for reserve potential (Haacke and others, 2013).

For the SWPRB assessment area, a number of adverse geological factors were encountered. The most important factor was the thinning and splitting of the deep WyodakAnderson coal zone towards the southern and western flanks of the PRB shown on figures 8 and 9. Relatively steep dips $\left(10-25^{\circ}\right)$ (Flores and others, 1999) of coal beds on the western flank of the PRB, such as in the Sussex coal field (fig. 6), are also a limiting factor. Thin coal beds combined with relatively steep dips severely limit the potential for mining (Osmonson and others, 2011).

Coal quality is an additional adverse factor in the SWPRB assessment area. Associated with the thinning and splitting of the coal beds in this area is the presence of numerous thin, high-ash partings within individual coal beds. These partings negatively affect coal quality by increasing ash content and lowering calorific values (Luppens, 2011). The potential for even lower grade coal quality was a factor in the decision to close the Dave Johnston Mine in 2000, the only large commercial mine developed in the SWPRB (fig. 12). Factors contributing to the mine closure were an increase in the stripping ratio, coupled with inherent adverse geologic conditions and deteriorating coal quality (PACIFICORP, 2008). Closure of this mine reflects the trend of decreasing coal quality along the shallow southern and western flanks of the SWPRB assessment area.

The lack of extensive, thick, shallow coal bed exploration targets coupled with poor coal quality has resulted in a lack of sufficient drilling (both conventional coal exploration holes and coalbed methane) in this area. Additional drilling is necessary to adequately assess surface recoverable coal resources for the SWPRB assessment area on a regional basis. No economic analysis of surface recoverable Fort Union Formation coals-Roland (Baker) and Smith-was performed for the SWPRB assessment area.

The Wasatch Formation in the SWPRB assessment area locally contains thick coal beds (fig. 23), but these typically have higher ash and sulfur contents and lower gross calorific values (table 2) (Luppens, 2011; Osmonson and others, 2011). The Lake DeSmet area in the SWPRB assessment area contains thick Wasatch Formation coals that have been commercially evaluated a number of times for potential mining. Despite the fact that the Lake DeSmet coal zone in the Wyoming PRB is the thickest known coal zone in the contiguous United States, no significant, large-scale mining has occurred in the Wasatch coal beds in the PRB.

Luppens (2011) noted that published coal quality values for the Lake DeSmet area (Mapel and others, 1953) were overly optimistic as all partings greater than $3 / 8$ inch were included from the core samples prior to analysis. Furthermore, at least one of the cores (Bureau of Reclamation core) from Mapel and others (1953), experienced unaccounted moisture loss, which resulted in anomalously high calorific values. The results from the USGS-1 core hole (Mapel and others, 1953) were evaluated to estimate the effects on reported coal analyses using more likely moisture levels and with the estimated impacts of compositing the originally excluded shale, pyrite, and other high-ash parting material. The predicted moisture increased about 1.5 percent. More importantly, the predicted ash contents increased to a range of 12.9-15.6 percent with a corresponding decrease in calorific values with a range of 6,986-6,694 Btu/lb depending on volumetric or mass weighting (table 11). The predicted quality is significantly lower than the original reported ash and calorific values of 5.0 percent and 7,970 Btu/lb, respectively (Luppens, 2011). It is suspected that the relatively inferior predicted coal quality may be a contributing factor to the lack of development in the area. 
A surface mining reserve analysis was not performed for the Upper Healy or the Healy coal beds due to a combination of negative factors within the Lake DeSmet area including unfavorable stripping ratios, restrictions to mining including extensive areas of clinker, and predicted inferior coal quality. Although limited areas of these beds could possibly be mined in the future, this scenario was not addressed because of the regional scope of this assessment and the lack of sufficient data necessary to outline specific small areas for potential surface mining (Osmonson and others, 2011).

\section{Regional Surface Mine Modeling}

Once a simplified geologically based mining sequence was developed for an assessment area, the USGS estimated potential recoverable coal resources and evaluated the cost of developing and operating a typical coal mine. For each of the four assessment areas, a regional surface mine model was developed to calculate expected mining costs based on the bulk volume and mass excavation of overburden and coal, respectively. However, the Gillette coal field was an exception. Field mine plans from recently filed State mining permits and discussions with mine operators in the southern part of the coal field indicated that mining progress could be affected by the joint Burlington Northern Santa Fe and Union Pacific Railroad (Joint Line) (fig. 19) within 10-12 years (Luppens and others, 2008). In 2006, two coal lease-by-applications (West Jacobs Ranch and West Hilight Field) confirmed that coal mining companies were planning to develop new mining pits west of the Joint Line (fig. 19) (Bureau of Land Management, 2013). Mining west of the railroad would require a deep box cut to extract the coal resources. The expense of this box cut would significantly affect the cost of mining west of the railroad, which would require a separate mine plan. Additionally, leaving the Joint Line intact produced two new restrictions to mining. One restriction accounted for the amount of coal resources affected beneath the Joint Line right-of-way, and the second estimated the amount of coal resources affected by the box cut development west of the Joint Line for overburden storage and mine facilities.

USGS regional modeling is different from evaluation of specific mining properties. With a single basinwide approach, some generalizations must be made. Certainly, customizing mine plans for each unique property within an assessment area would be better, but prohibitive in terms of time and manpower requirements. The regional mine models are used to produce a prefeasibility or conceptual level evaluation to determine which portion of the recoverable coal resources (reserves) could be economically extracted at the time of the determination. A conceptual economic study should have error limits of 30 to 50 percent (Rupprecht, 2004). The USGS assessment methodology is also consistent with EIA DRB criteria. Some USGS coal availability studies have already been used to update the EIA Agency coal resource and reserve data (U.S. EIA Agency, 1997).
The regional mine model developed for the Gillette coal field is a set of 10 mine models, one for each stripping ratio from 1:1 to 10:1. The 10:1 ratio was chosen based on geological constraints. The 10:1 stripping ratio limit in the Gillette coal field approximately coincides with a north-southtrending distributary channel against which the Anderson and Canyon coal beds thin and pinch out. This channel effectively poses a down dip barrier to surface mining in the Gillette coal field (Luppens and others, 2008). The USGS CoalVal program (Rohrbacher and McIntosh, 2010) was used to evaluate the regional mine model for the Gillette coal field assessment. This program combined total coal bed and burden thicknesses. To better address the thinner coal beds and larger interburden intervals for the NWPRB and MTPRB assessment areas, multibed regional mine models were created by USGS personnel using Microsoft EXCEL (2007) spreadsheets.

Both mining programs were used to calculate recoverable coal resources and capital and operating costs on a DCF basis. The DCF cost to produce a ton of coal is applied to all available coal resources within each stripping ratio increment of the ratio model. The breakeven cost is compared to the current (December 2013) sales price of coal on a per ton basis. The coal is economically minable when the DCF is less than the sales price and is uneconomical when the DCF cost is greater than the sales price.

\section{Surface Mine Model Design Assumptions}

Oral communication with existing PRB coal mining companies was valuable to the development of the regional mine models. Although many PRB mines have been in operation for 30 years or more, a 20 -year economic life was used for all assessment models. Production rates were chosen for each assessment area based on a reasonable tonnage rate between the minimum and maximum yearly production rates for several mines within an assessment area. For the Gillette coal field, a production rate of 35 million short tons per year (MST/yr) for the regional mine model was used. A nominal production rate of $10 \mathrm{MST} / \mathrm{yr}$ was selected from numerous mine models as being most representative for mining cases for the NWPRB and MTPRB assessment areas.

Overburden removal for the Gillette coal field consisted of a large dragline used together with truck-shovel pre-stripping. This cost effective overburden removal system takes advantage of dragline efficiencies and the flexibility of the truck-shovel operation to strategically place the spoils near final reclamation grade. The dragline operation uses cast-blasting to move a portion of the overburden into its final location across the open pit rather than using mining equipment. Cast-blasting is more cost effective than moving the same volumes by dragline or dozers. The dragline and associated stripping dozer operation is scheduled to remove $140 \mathrm{ft}$ of overburden directly above the Anderson coal bed. This schedule allows the dragline and its associated equipment and manning requirements to remain constant from model to model. As the stripping ratio increases, more equipment and 
manning requirements were added to the model. The mine models were designed to assume that new, optimally-sized equipment would be purchased and operated on a 24-hoursper-day, 7-days-per-week schedule. Except for the dragline, 10 holidays were scheduled for all equipment operations. The amount of stripping equipment and coal production equipment was determined from truck-haulage simulations, shovel productivities, and reported dragline productivities at existing mines in the Gillette coal field (oral communication with various mine managers).

For the southern one-half of the Gillette coal field, where the Joint Line Railroad is located on available coal resources, a new box cut would be required to access the coal west of the railroad (fig. 19). This box cut is a challenge both economically and logistically (Luppens and others, 2008). The projected time required to open a box cut using truck shovel equipment could vary from more than one year for a 3:1 ratio box cut, to nearly three years for a box cut at a 9:1 ratio (Luppens and others, 2008). Such operations would require additional equipment separate from the mining operations east of the Joint Line, which exacerbates the financial effects of the new box cut. During development of the new box cut, coal production would continue in the pits east of the Joint Line, as no coal would be produced during the new box cut construction. The long lead times necessary for box cut development presents a major timing challenge. Production in the new box cut west of the Joint Line must be ready to start as production east of the of the Joint Line finishes. When the dragline overburden removal operations east of the Joint Line are finished, the equipment would have to be moved across the railroad to begin overburden removal in the next cut. Back-filling the eastern pit with spoil from the box cut pit would not be possible, leaving an out-of-pit overburden dump immediately west of the Joint Line as the only feasible option for the box cut spoil.

Conventional truck-shovel operations were used for the NWPRB and MTPRB assessment area models, which facilitated more complex, multibed mining scenarios. The multibed model considered each bed in the stratigraphic sequence as a separate mining operation with the uppermost bed recovered before the next lower bed. A load-out capacity was calculated for each mining pass or bench. Equipment for overburden and interburden stripping and coal loading and hauling was sized for a $10 \mathrm{MST} / \mathrm{yr}$ mining operation. Shovel loading and rear dump-truck haulage were used to provide a common basis for the comparative modeling results produced in this assessment. Stripping shovels were sized for operating at 89 percent availability and 95 percent utilization for 6,300 hours per year. Coal-loading shovels were sized for operating at 89 percent availability and 85 percent utilization for 5,633 hours per year. These efficiencies allowed the calculated stripping volume to remain in advance of coal loading. Both operations were conducted on a two shift per day, 350-days-per-year basis. Stripping and coal-loading shovels have a range of 15-60 cubic yards in bucket capacity. Mining support equipment costs were included for haul-road maintenance, night illumination, in-pit water handling, and transportation.
In addition to the multibed model for the MTPRB assessment, single bed mine models were evaluated for five coal beds below the Dietz beds, including the Canyon, Werner/ Cook, Pawnee, Rosebud/Knobloch, and Flowers-Goodale coal beds. The same surface mining assumptions and parameters used for both the multibed and single-bed models. The singlebed models were comparatively simple as the logistics for the overburden stripping operations for multiple beds are more complex.

All coal beds in the Gillette coal field are blasted before loading. In the NWPRB and MTPRB assessment areas coal beds are ripped and heaped before loading. The mine models include initial capital, replacement capital, and operating costs for each major operational activity. Operational activities included overburden and interburden removal, coal loading and hauling, reclamation, general mine equipment application, and facilities use. Equipment and staffing costs and productivities were obtained from a variety of sources including the Society of Mining Engineers of The American Institute of Mining, Metallurgical, and Petroleum Engineers, Inc. (1973), Caterpillar, Inc. (2012), InfoMine USA, Inc. (2010), and discussions with coal companies (oral commun., 2006, with various PRB coal companies).

\section{Surface Mine Plant Facilities}

The mine plant contains those facilities essential for supporting mining. The mine plant facilities include an administration building, change house, maintenance shop, warehouse, laboratory building, emergency building, utility building, and guard house.

This assessment includes several mining scenarios (stripping ratios of 1:1-10:1) for which different plant space requirements are anticipated, and the buildings were sized accordingly. Coal handling at the mine plant includes truck scales, inclined and horizontal belt conveyors, stacking tubes, scalping screen, coal breaker, coal silo, belt sampler, belt scales, rail loop or spur, railcar mover, and associated equipment. The mine plant also includes multiple elevated steel structures, enclosures, and concrete foundations. Preliminary designs for a truck dump to accommodate a wide range of large rear-dump truck capacities and a railroad loop were developed, from which unit costing was performed.

The cost of a typical mine plant for the mining models were calculated for all case studies, which included costs for the following items:

- land improvements

- buildings

- coal handling equipment and structures

- truck dump

- railroad loop and access

- miscellaneous structures

- mobile and stationary equipment 


\section{Surface Mine Reclamation}

Reclamation is an additional ongoing function and significant cost factor in the surface mine model. A fleet of earthmoving and farm-type equipment perform a variety of activities from removal of vegetation and topsoil through contouring spoil piles, seedbed preparation, and planting. Scrapers remove and transport top soil to temporary storage piles and later transport top soil to contoured spoil piles for covering. Bulldozers remove brush, trees, and other debris during land clearing, rip topsoil, and assist scraper loading. Motor graders contour and scarify bare spoil piles for revegetation. Farm tractors with disc and seeder apparatus reestablish vegetation and mulch blowers are used to cover spoil piles.

\section{Surface Mine Supplies and Utilities}

Additional costing items in the surface mine model include equipment operating items, personnel wages, explosives, mulch, and seed. Utilities include electricity and natural gas/propane.

\section{Surface Mine Reserve and Recoverable Resource Evaluation Results}

All current mining operations in the Wyoming PRB recover coal from beds in the Wyodak-Anderson coal zone of the Fort Union Formation. The Wyodak-Anderson coal zone represents about one-half of the total remaining available coal resources in the PRB (fig. 118). The coal beds within this zone dominate the recoverable resource analyses. All coal beds in the Wyoming assessment areas that have been economically evaluated were within the Wyodak-Anderson coal zone. Several beds below the Wyodak-Anderson zone were evaluated in the Montana PRB.

Some additional data entry, coal bed correlation work, and consolidation of local bed names were completed for this final PRB assessment report. This work was essentially limited to beds stratigraphically below the Wyodak-Anderson coal zone in the three Wyoming PRB assessment areas and were not included in the reserve analyses for the four regional assessment reports. No significant recoverable coal resources were found in the East Gillette extension area, which was completed following the four PRB regional assessments. Therefore, revised reserves analyses for this report were not necessary.

\section{Determination of Reserves}

Once the available coal resources were allocated and economic mine models completed for an assessment area for each stripping ratio mine model (1:1-10:1), reserves were estimated from a portion of the total in-place (remaining) coal resources. The term "reserves" relates to that portion of demonstrated resources that can be recovered economically with the application of extraction technology available currently or in the foreseeable future (EIA Agency, 1997).
Furthermore, the term "reserves" need not signify that extraction facilities are in place or operative (Woods and others, 1983).

To derive a reserve estimate for each assessment area, a composite cost curve was developed for the total recoverable coal resources by incremental DCF costs. Cost curves provide a straightforward method of relating recoverable tons of coal to current (December 2013) sales prices (for example, see figure 123). All of the recoverable tons of coal to a 10:1 stripping ratio in a given area are sorted from lowest to highest DCF costs per ton and plotted against DCF cost. If the current (December 2013) market price for coal is $\$ 12.00 /$ ton (fig. 123), 30 BST tons by definition would be considered reserves (potentially produced at or below market price). Because a coal reserve estimate is based on a single reference point in time, the use of cost curves is particularly useful given typical fluctuations in the market price. From the cost curve, the relation between changes in the sales price and estimated reserves can readily be demonstrated. If the market price increases to $\$ 18.00 /$ ton, the estimated reserves would double to $60 \mathrm{BST}$, assuming mining costs were similar.

Because reserves refer to that portion of the recoverable coal resource that can be mined at a profit at the time of the assessment, it was necessary to determine the current (December 2013) FOB market price. The sale of coal is normally based on heating value (Btu/lb, as-received basis); therefore, the average regional coal heating value for each PRB assessment area was required. On the basis of publicly available data, an average heating value $(\mathrm{Btu} / \mathrm{lb})$ was derived. Average coal quality was used because the lack of specific data for every coal bed precluded development of more precise coal quality models. For the Gillette coal field and MTPRB assessments, an average heating value of $8,800 \mathrm{Btu} / \mathrm{lb}$ was used; an $8,400 \mathrm{Btu} / \mathrm{lb}$ average was used for the NWPRB assessment area.

The following sections provide a synopsis of the economic analyses for three of the four assessment reports and a summary of reserves and total recoverable coal resources for the entire PRB (table 11). As previously discussed, no economic analysis was conducted for the SWPRB assessment area because of a combination of negative factors. The individual PRB coal assessment reports (Luppens and others, 2008; Scott and others, 2010; Haacke and others, 2013) can be reviewed for more detailed information. The DCF costs used a common 8 percent rate of return (ROR) for all assessment areas.

\section{Gillette Coal Field Assessment Area}

Six coal beds selected for the economic analyses in the Gillette coal field are listed in table 12. Four of these are of minor importance (Roland [Baker], Smith, Anderson Upper Rider, and Dietz 3). The total recoverable coal resources are dominated by the thick Anderson and Canyon bed sequence, which represents 83 percent of the total recoverable coal resources in the Gillette coal field (Luppens and others, 2008). 
The combination of extensive, thick, coal beds at shallow depth, with low-ash and low-sulfur content, makes the Gillette coal field the most important coal field in the United States.

All current coal production in the Gillette coal field is from the Anderson and Canyon coal beds along the eastern margin of the basin. As mining continues down dip from the east margin, progressively younger beds (Smith and Roland [Baker]) that lie above the primary Anderson-Canyon target beds would be exploited (fig. 10). The combination of extensive, thick, coal beds and relatively moderate topography resulted in broad areas in the Gillette coal field with stripping ratios of 10:1 or less (fig. 124) (Luppens and others, 2008).

With a January 2007 sales price of $\$ 10.47$ per ton for the $8,800 \mathrm{Btu} / \mathrm{lb}$ coal from the Gillette coal field for the Anderson and Canyon beds (Platts, 2007), an estimated 10.1 BST of the total 77 BST of recoverable coal resources are considered coal reserves (fig. 125). As of March 2008, the sales price for the Gillette coal field had increased to $\$ 14.00$ per ton (Platts, 2008). Assuming that operating costs remained essentially unchanged during the 15-month period since the reserve study was completed there would be approximately 18.5 BST of reserves (fig. 125). Thus, an increase in the sales price of only approximately $\$ 3.50 /$ ton nearly doubled the reserves estimate.

\section{Northern Wyoming PRB Assessment Area}

Northward from the Gillette coal field, the coal beds split and thin presenting a different mining scenario. The Roland (Baker) and six beds from the Wyodak Anderson coal zone (table 12) were selected for the economic evaluation (Scott and others, 2010). There are two regions of shallow coal with cumulative stripping ratios of 10:1 or less (fig. 126). The more extensive of the two areas is found on the eastern side of the NWPRB assessment area where the regional dip is relatively low (fig. 9). The area of 10:1 ratios or less north of Sheridan, Wyoming, is much more restricted areally because of steeper dips on the west side of the basin. The most noteworthy aspect of figure 126 is the limited extent of areas less than a 5:1 stripping ratio, where resources considered reserves would be found. Although mining has occurred in the NWPRB assessment area, there are no active mining operations in this assessment area.

With a January 2010 sales price of $\$ 9.30$ per ton for the $8,400 \mathrm{Btu} / \mathrm{lb}$ coal from the PRB (Platts, 2010), an estimated 1.5 BST of the total $50 \mathrm{BST}$ of recoverable coal resources are considered as coal reserves (table 12). The relatively low reserve estimate is directly related to the limited areal extent of resources found at less than a 5:1 stripping ratio (fig. 126).

The mining costs for the NWPRB assessment area are higher than those for the Gillette coal field assessment (Scott and others, 2010) because of the more complex coal geology and multibed mine models that are inherently more costly than the simpler single-bed model used for the Gillette assessment. Also, the mine model for the NWPRB assessment area used truck-shovel operations exclusively for more coal beds with thicker interburden intervals. For the Gillette coal field, a dragline operation combine with truck-shovel operations for prestripping was used to take advantage of the lower unit stripping costs that a dragline offers.

The cost curve (fig. 127) readily demonstrates the relation between sales price and estimated reserves. On January 5, 2009, the sales price per ton for the $8,400 \mathrm{Btu} / \mathrm{lb}$ coal from the PRB was $\$ 11.00$ per ton (Platts, 2009a). An estimated 3 BST would be a reserves equivalent at this price. The $\$ 11.00$ per ton price held steady through April 6, 2009, then suddenly dropped to $\$ 8.00$ per ton in one week (Platts, 2009 b, c). By November 23, 2009, the sales price had bottomed out at $\$ 7.65$ per ton (Platts, 2009d), which would be a reserves equivalent of $0.8 \mathrm{BST}$ at this price. The sales price as of January 2010, for 8,400 Btu/lb coal from the PRB was $\$ 9.30$ per ton (Platts, 2010) (fig. 127). The changes in the sale price during the 10-month period corresponded to a 1.9 BST swing in reserves estimates from a maximum of 3 BST to a low of $0.8 \mathrm{BST}$, emphasizing the value of preparing cost curves.

\section{Montana PRB Assessment Area}

The coal geology in the Montana PRB differs from the Wyoming PRB. The coal bed thicknesses in the MTPRB assessment area are more variable than in the NWPRB assessment area of Wyoming (Scott and others, 2010). Areas of thicker coal (greater than $20 \mathrm{ft}$ thick) are more pod-like as illustrated by the isopach maps of the Dietz 3, Canyon, Lower Canyon, Werner/Cook, Pawnee, and Flowers-Goodale coal beds (figs. 62, 68, 69, 76, 84, and 104). Deeply-dissected drainages limit the areal extent of shallow, surface-minable coal beds in the MTPRB assessment area. Figure 10 illustrates the more deeply incised topography in Montana. The MTPRB assessment area is the only area in the PRB that contains potentially minable coal beds, below the Wyodak-Anderson coal zone (fig. 13) (Pawnee, Rosebud/Knobloch, and FlowersGoodale beds), that are both sufficiently thick and have a significant areal extent at stripping ratios at or less than 10:1 (figs. 128-133).

Ten of the 18 coal beds had sufficient areal extent and thickness to be further evaluated for recoverable coal resources (Haacke and others, 2013). Five of these beds, the Roland (Baker), Smith, Anderson, Dietz 2, and Dietz 3 were combined into a regional, multibed mine model. Portions of this sequence are currently being mined at the Decker and Spring Creek Mines in the southwestern portion of the MTPRB assessment area (fig. 12). The stripping ratio map for this mine model sequence is shown in figure 128.

In addition to the regional mine model sequence, the Canyon, Werner/Cook, Pawnee, Rosebud/Knobloch, and Flowers-Goodale coal beds were evaluated for reserve potential (table 12). Of these five beds, only the Rosebud/Knobloch bed is currently being mined in the Colstrip area (figs. 1 and 12). Additionally, the Rosebud/Knobloch bed is the primary target in the Otter Creek lease area (fig. 12). The stripping ratio maps for these coal beds are shown in figures 128-133. 
The individual coal bed stripping ratio maps demonstrate the relation between the deeply-dissected surface morphology and coal thickness. A comparison of the isopach map and stripping ratio map for a given bed illustrates this relation. For example, the more extensive area of less than a 10:1 ratio in R. $39 \mathrm{E}$. to R. 41 E. for the Werner/Cook bed (fig. 130) corresponds to the thickest portion of the Werner/Cook bed (fig. 76). Elsewhere, the less than 10:1 ratio areas for the thinner portions of the Werner/Cook bed are confined to narrow bands along drainages.

A total of $39 \mathrm{BST}$, at a stripping ratio of 10:1 or less, remains in the 10 beds assessed for reserves. After mining and processing losses were subtracted, about 35 BST of coal were considered recoverable coal resources (table 12). To derive a reserve estimate for the MTPRB assessment area, a composite cost curve was developed for the cumulative total 35 BST of recoverable coal resources using the November 2011 FOB sales price for $8,800 \mathrm{Btu} / \mathrm{lb}$ coal from the PRB of $\$ 13.20$ per ton (Platts, 2011a). The reserve estimate for the MTPRB was about 13 BST (table 12, fig. 134).

\section{Combined PRB Reserve and Recoverable Resource Summary}

Resources and reserves of the Gillette coal field, NWPRB, SWPRB, and MTPRB assessment area as well as total PRB resources and reserves are summarized graphically (fig. 135). The total coal reserves estimate for the PRB is 24.5 BST from the three areas assessed for surface minable coal. The most striking feature of these bar graphs is that the reserves are a small fraction (about 2.3 percent) of the total, original in-place resources. A significant amount of coal affected by all restrictions to mining (coal too thin, depth, towns, and other restrictions) and mining losses precludes recovery of most of the original in-place coal resources. The relation of original resources to reserves is consistent with previous USGS coal assessments, which typically determine the reserve fraction to be less than 20 percent (Luppens and others, 2009). The value of economic-based assessments is to provide resource planners with realistic estimates of resources that are recoverable and an understanding of the importance of differentiating between in-place resources and reserves. The PRB assessments were completed sequentially and consequently market prices were different at the time the cost curve for each study was generated. To simplify the process of generating a single, unified reserve estimate for the entire $\mathrm{PRB}$, all recoverable coal resources needed to be evaluated on a common market sales price basis. The DCF costs for all the individual stripping ratio mine models from the Gillette coal field, NWPRB assessment area, and MTPRB assessment areas were combined into a single cost curve.

The result of the aggregation of mine model costs is the cost curve shown in figure 136. Using the FOB sales price of $\$ 10.90$ per ton as of July 15, 2013 for PRB 8,800 Btu/lb coal (Platts, 2013), the coal reserve estimate for the entire PRB is about 23 BST (fig. 136). This is slightly lower than the simple addition of the reserve estimates from the Gillette coal field, NWPRB assessment area, and MTPRB assessment area reports because of a small decrease in market price in June 2013. This difference in reserve estimate underscores the fact that reserve estimates are a constantly moving target, as sales prices continually fluctuate, responding to variations in market demand. For example, in November 2009, the sales price for PRB $8,800 \mathrm{Btu} / \mathrm{lb}$ coal had dropped to $\$ 8.90$ per ton (Platts, 2009c), and subsequently increased to $\$ 15.15$ per ton in December 2011 (Platts, 2011b). The effect of this market price variation on the range of reserve estimates was a low of $10 \mathrm{BST}$ to a maximum of $43 \mathrm{BST}$ (fig. 136). The use of cost curves provides flexibility to adjust the reserves estimates to fluctuations in market price. Single estimate results are essentially frozen in time based on the economic conditions at the time of the assessment.

While the estimates of reserves are important, the relation between reserves and recoverable coal resources is equally significant, especially in light of the fundamental mission of the USGS Coal Assessment Project which is to determine the coal reserve base in all major U.S. coal basins. The coal reserve base includes identified resources that meet specified minimum criteria related to current mining and production practices, including those for quality, depth, thickness, and rank (Woods and others, 1983).

These recoverable coal resources are essentially equivalent to coal resource categories included in the EIA-estimated recoverable reserves (ERR) database (Energy Information Administration, 1997). The ERR, which is updated by the EIA periodically, is currently the only published national summary of potentially recoverable coal in the United States. The ERR is the portion of the DRB coal that may be recoverable, based on regional estimates of coal resource accessibility and mining recovery rates. It is especially important to understand that the coal reserve base may encompass those parts of a resource that have a reasonable potential for becoming economically recoverable within planning horizons that extend beyond those which assume proven technology and current economics (Energy Information Administration, 1997). The ERR includes those resources that currently are classified as reserves and recoverable coal resources that may be mined in the future.

It is a common misconception that any given estimate of reserves implies that the volume of coal in the reserves category is all that is left to recover. From figure 136, it can be seen that as market prices increase, the reserve estimate increases while the amount of remaining currently uneconomic recoverable coal resources decreases and vice versa. Reserve estimates are by nature a moving target.

Typically, as mining progresses in a basin, resources become progressively more expensive to produce. Sale prices generally increase as long as demand supports higher prices. With continued favorable sales prices and increased productivity and advances in mining technology that positively affect economics, resources once considered to be subeconomic may be elevated to the reserve status. For example, typical average stripping ratios in the Gillette coal field in 1990 were about 2:1 or less; therefore, resources greater than a 2:1 ratio would have 
been placed in the recoverable coal resources category. PRB coal reserves currently mined include coal resources up to ratios ranging from 3:1 to 4:1 Reserve studies should be considered a cyclic process and models should be adjusted periodically using the most recent data and reassessed using the most current recovery technology and economics.

\section{Underground Coal Resource Assessment}

A significant volume of coal resources in the PRB are contained in relatively thick coal beds at depths that may be impractical for surface mining. While no coal in the PRB is currently recovered by underground mining methods, nor expected to be in the near future, significant resources at depths of 2,000 ft or less are easily within the range of current underground mining technology. An evaluation of potential underground coal resources was also conducted to determine a preliminary estimate of the magnitude of underground resources.

There are precedents for transitioning from surface to underground mining operations. Several other surface coal mines in western United States basins have converted to underground longwall systems as surface coal reserves were depleted. For example, the San Juan operation near Farmington, New Mexico, consists of an underground mine accessed via the high wall of a closed strip mine (Mercier, 2010). The underground longwall operation has successfully extended coal extraction in a location where increasing overburden created unfavorable economics for further surface operations (Mercier, 2010). A similar situation developed at the Jim Bridger Mine near Rock Springs, Wyoming (PACIFICORP, 2011). The life of the mine was extended by developing an underground mine as surface minable reserves were nearing depletion to continue to provide fuel to the power plant for an additional 20 years (PACIFICORP, 2011). Underground longwall mining methods are used in a coal bed that has as much as $1,000 \mathrm{ft}$ of overburden (PACIFICORP, 2011).

The assessment of underground resources consisted of two parts. First, a mining method was selected and then a mine model was selected to generate estimated DCF cost per ton. This cost could then be compared to the cost of surface mining. The amount of deep coal in the PRB that was amenable to development by the selected mining system was inventoried.

Two principal underground mining systems are used in the United States: continuous mining (commonly referred to as room and pillar) and longwall mining. The longwall mining system was chosen as the preferred method for several reasons. Although a longwall system requires higher capital and installation costs, it has higher productivity and recovery rate than the continuous mining system. Additionally, the longwall system offers safety improvements, and offers the best opportunity for automation (U.S. EIA Agency, 1995).

The minable coal bed thickness for longwall systems ranges from 5 to $13 \mathrm{ft}$ (Thomas, 2002). Although longwall shearers are commonly used for bed thicknesses between 5 and $20 \mathrm{ft}$ (Myszkowski and Paschedag, 2009), a 10-ft minimum was used as a more conservative estimate of potential underground resources for longwall operations. For portions of coal beds that exceeded $20 \mathrm{ft}$ in thickness, only a $20-\mathrm{ft}$ slice of those beds was included to the underground resources estimate. All of the coal beds greater than $20 \mathrm{ft}$ were considered unrecoverable by current underground technology.

As with other coal basins, only a fraction of the total underground resource is typically recoverable. Factors such as adverse roof, floor conditions, slope of the coal beds, and essential safety barriers are restrictions to mining. Although recovery in multiple bed areas is generally most efficient by mining from the uppermost bed downward, that situation is impossible to control. Interburden between beds must be thick enough to prevent interbed structural problems.

\section{Underground Mine Model Design}

A preliminary underground mine model provides a reasonable estimate of the economic tipping point where underground mining might be a more viable alternative to surface mining, which establishes a limit on recoverable coal resources by surface mining. No underground mines are currently operating in the PRB as discussed in the NWPRB (Scott and others, 2010), SWPRB (Osmonson and others, 2011), and MTPRB assessment areas (Haacke and others, 2013). For each of these assessments, a separate underground mine model was developed. The NWPRB assessment area model was based on a production rate of $11 \mathrm{MST} / \mathrm{yr}$ and the SWPRB assessment area model was based on a production rate of $6 \mathrm{MST} / \mathrm{yr}$. The SWPRB assessment expanded the scope of both the NWPRB and the MTPRB assessments, by considering the effects of coal thickness and depth.

Potential underground coal reserves in the PRB assessment area were evaluated using a conventional, single-pass, continuous, longwall mining methodology. Current face shearer and roof support design are available for mining up to $20 \mathrm{ft}$ thick (Myszkowski and Paschedag, 2009), which is a reasonable thickness in portions of the PRB. With the exception of the Gillette coal field, underground mine models were developed for all the PRB assessment areas to estimate potential deep, recoverable coal resources. To provide an example of the level of detail in the conceptual underground mine model, the following sections describe the underground mine design used for the MTPRB assessment area.

\section{Underground Mine Layout Design}

The underground mine model incorporates longwall technology, which includes four primary components: (1) surface mine plant; (2) underground mine plant; (3) development excavation; and (4) longwall panel. All openings, support pillars, and longwall panel dimensions were sized to provide an annual production of $6 \mathrm{MST} / \mathrm{yr}$ which is an average size for currently operating longwall mines (Paul Pierce, oral commun., 2013). This average annual production is acquired 
through development, production, and pillar recovery operations. The model can be used to evaluate mining thicknesses that vary from 8 to $20 \mathrm{ft}$ and depths from less than 500 to $3,000 \mathrm{ft}$. The model can also be used to evaluate a wide range of annual production rates with some adjustment to longwall panel access openings and pillar sizes.

The mine model was designed for primary entry to the longwall panel through five parallel main drifts. Additional excavation included a three-entry headgate for incoming airway and main access to longwall mining and two entry tailgates for return airway and supplies. Both the headgate and tailgate openings extend perpendicular from the main entries to the full panel length and are separated by the width of the longwall panel. An initial longwall face opening is excavated at the far end of the longwall panel that connects the headgate and tailgate.

Annual production for the underground mine model is the sum of coal mined from main access, headgate, and tailgate excavation, longwall production, and pillar recovery. Physical dimensions of the longwall panel and associated mine openings are adjusted to maintain $6 \mathrm{MST} / \mathrm{yr}$ of production. The effects of increased mining height and depth have been correlated with variable panel barrier-pillar size and overall pillar recovery. The longwall panel width varies only with mining height and the panel length and is adjusted to provide the overall annual production from entries, panel, and pillars.

\section{Surface Mine Plant}

Coal handling facilities are the primary purpose of the surface mine plant. The surface mine plant for the underground mine are those facilities essential for supporting mining, including buildings, coal handling equipment, rail loading facilities, and mobile and stationary equipment. The mine model surface plant includes an administration building, change house, maintenance shop, warehouse, laboratory building, emergency building, utility building, guard house and tool sheds, and hoisting and ventilation facilities to support underground operations.

Other facilities include a stacking tube, horizontal and inclined belt conveyors, scalping screens, coal breaker, coal silo, waste bin, rail loadout structure, rail loop, various elevated steel structures and housings, preparation plant, and concrete foundations. The inclined belt conveyor is included with the surface mine plant and the excavation for the incline is included with the underground mine plant. The use of a tandem ramp and shaft arrangement is assumed for medium mine depths. Shallow underground mines will likely use ramps and deep mines will use shafts. All stationary coal handling facilities have been oversized to move in excess of the $6 \mathrm{MST} / \mathrm{yr}$ production rate.

Hoisting facilities are included in the surface mine plant and shaft excavation and furnishing are included in the underground mine plant component of the mine model. One dedicated ventilation shaft is included in the mine plant, but hoisting facilities have not been provided. Ventilation facilities include two 10-ft-diameter 800-horsepower surface mine fans, ducting, concrete foundation, electrical controls and switchgear, and appropriate enclosures. Ventilation facilities are constructed adjacent to a dedicated shaft for primary incoming airflow.

\section{Underground Mine Plant}

Three excavations (men-and-materials shaft, ventilation shaft, and ramp) connect surface and underground mine plants. A nominal depth of $1,000 \mathrm{ft}$ has been used for shafts and an inclined length of 2,280 ft for a ramp. Both shafts have been excavated with large-diameter drilling equipment and lined with concrete. The ramp is excavated with a continuous mining machine and lined with rock bolts, wire mesh, and shotcrete.

Primary excavations at the bottom of the underground mine plant at the men-and-materials shaft include a warehouse, shop, lunchroom, refuge chambers, water sump, electrical substation, and connecting runaround access way. The bottom of the ramp is located some distance away and has excavations for refuge chambers, electrical substation, and runabout access way. Both the shaft and ramp stations are lighted. Stationary equipment in the shaft station includes air compressors and centrifugal water pumps. Both the shaft and ramp stations include concrete flooring, steel equipment bases, and electrical cable distribution.

Fresh air provided by surface fans supplies the secondary air distribution using rigid ventilation ducts, which are boosted with auxiliary ventilation fans. This secondary system is used throughout the underground mine.

\section{Underground Mine Development Excavation}

Underground excavation that extends some distance beyond the shaft and ramp stations occurs prior to production mining as described for the production unit section of this assessment and is performed as a construction activity. Coal removed during this project phase is transported to the surface and disposed as a waste product.

Development excavation includes five parallel headings with connecting crosscut openings. These headings extend to the edge of the mine plant barrier pillar. This barrier pillar is sufficiently sized for underground mine plant facilities protection from structural instability because of mining production. All excavation during this phase is performed by a continuous miner and supporting mobile equipment.

\section{Longwall lanel and lillar 3ecovery}

The production unit is generally centered near the longwall panel. All pre-longwall mining following development excavation is considered production and transported offsite for sale. The production unit includes the main access way extending from the initial development excavation, gateway excavation, longwall opening, and longwall panel.

Gateway excavation starts at the main access way and extends to the full length of the longwall panel. A three-entry arrangement is developed for the headgate and two entries for the tailgate. A single longwall opening is excavated to connect the ends of the gateways. A longwall panel that is $1,000-\mathrm{ft}$ 
wide is included in the underground mine model design. This panel size is estimated to provide sufficient coal for a continuous year of operation without moving to a new area. A complete suite of standard equipment is included in the model (face shearer, roof supports, armored face conveyor, and supporting systems).

Pillar recovery provides substantial coal production as a final activity in the typical production unit. This operation involves trimming single pillars to an extent that coal can be produced without collapsing the immediate roof area during the activity. Pillar recovery is included in the underground coal mine model for chain pillars, panel barrier, and main access pillars for the typical longwall unit.

High vertical stresses are applied to the lateral edges of the longwall panel as the shearer cuts across the face of the longwall and progresses toward the end of the panel. These stresses tend to concentrate over the rib line of the opening adjacent to the panel. The forward edge of the first row of support pillars in the gateways on either side of the panel, are expected to partially collapse. This collapse is likely to cause a yield zone that extends some distance into the pillar interior. The remaining portion of the pillar is expected to be competent enough to allow significant recovery by a continuous miner. The vertical stress concentration over the outer pillar line in the headgate should be less than the stress over the longwall panel periphery, and a higher pillar extraction rate can be expected.

All the coal on the panel side of the barrier pillar is expected to be unrecoverable. Pillar recovery will need to be conducted from the main access way. Excavation of the barrier pillar will be conducted in concert with main access-way pillar recovery. Only partial recovery will occur to leave sufficient natural support for retreating from the area.

\section{Underground Coal Resources Results}

Eleven coal beds within the PRB were assessed as potentially minable by underground operations. These coal beds, which have favorable thicknesses, depths, and areal extents for possible underground extraction in the future are the Roland (Baker), Smith, Anderson, Dietz 3, Canyon, Lower Canyon, Werner, Otter, Pawnee, Rosebud/Knobloch, and FlowersGoodale. Total resources in beds between 10 and $20 \mathrm{ft}$ in thickness and $500 \mathrm{ft}$ or greater in depth are about 304 BST (table 13). About 99 percent of the resources assessed were less than 2,000 ft in depth. Almost one-half (48 percent) of those deep resources are found in just two of the coal beds (Smith and Canyon) (table 13). Two-thirds of the deep resources are found within the SWPRB assessment area. This is not surprising given the extraordinary thickness of the Smith and Canyon beds in the deeper portions of the PRB.

Because of slightly different geological conditions and mining assumptions used in the three assessment areas evaluated for underground resources, the breakeven cost per ton ranged from \$20 per short ton to about \$31 short ton (Scott and others, 2010; Osmonson and others, 2011; and Haacke and others, 2013). Given the current sales price of about
\$11 per short ton for 8,800 BTU/lb for PRB coal (Platts, 2013); the estimated cost of underground mining is about 2-3 times the current (December 2013) FOB sales price. Therefore, none of the coal resources in the 11 deep coal beds in the PRB can currently be classified as reserves. A factor that will improve underground coal mining economics is that the heating value of coal increases with depth. The estimated calorific values of the deep coals range from about 9,300 Btu/lb at 1,000 ft depth to 10,000 Btu/lb at 2,000 ft depth (Luppens, 2011; Osmonson and others, 2011). The higher cost of underground mining might be partially offset by progressively higher quality coal with depth. Various restrictions, such as the geotechnical constraints of adverse roof and floor conditions, local coal bed thinning, and hydrology issues, would reduce the amount of coal resources ultimately recovered. The deep, thick coal beds in the PRB represent a significant future, long-term resource. The longwall model analyses demonstrate that as the surface mining depths continue to increase in other parts of the PRB, underground exploitation of deep, thick coal, in the SWPRB assessment area may become an increasingly viable alternative as long as the demand for coal supports higher prices.

\section{Conclusions}

This report presents the final results of an 8-year effort to collect sufficient data to map and model 47 significant coal beds individually for the entire PRB. Previous resource assessments in the PRB have relied on net coal isopach maps, which provide reasonable estimates of in-place resources, but are insufficient for conducting economic analyses to derive reserve estimates and the total amount of recoverable coal. The tremendous amount of CBM development in the PRB during the last 10 years has provided a wealth of new, publicly available data, especially in the Gillette coal field. Because the PRB is the single most important coal basin in the United States in terms of yearly coal production, incorporating as much of these data as practical was warranted. Some of the key results of this assessment are:

- The total number of holes in the final PRB database increased to 29,928 , about 13,700 holes entered and interpreted by USGS personnel. In the Gillette coal field alone, the original database was expanded from about 2,391 to 10,210 data points. Additional data and support were provided by the Wyoming State Geological Survey and the Montana Bureau of Mines and Geology.

- The increased data control significantly improved the geological interpretation, including revision of coal bed correlations and increased geological assurance for the resource and reserve estimates.

- This report is groundbreaking as it provides the first published maps of the individual coal beds for the entire PRB. Unification of local bed names was crucial to this achievement. 
- The new geologic coal bed models provide a more robust assessment of recoverable coal resources and also facilitate other resource planning, such as developing CBM and evaluating the environmental effects of energy-related production.

- The methodology for assessing the restrictions to mining was improved from the previous "cookie cutter" approach to allow for safety setbacks needed to maintain stable highwalls in the mined coal beds rather than simple surface-only expressions around identified buffers.

- An additional relatively deep box cut will be required in the southern one-half of the Gillette coal field to recover coal resources west of the Joint Line Railroad. The need for this additional box cut will result in a significant increase in overall mining costs for coal resources in that area.

- An important distinction of the SWPRB assessment area compared to the other PRB assessment areas is the absence of the extensive, thick, shallow WyodakAnderson coal zone.

- While no coal in the PRB is currently recovered by underground mining methods, nor is it expected to be in the near future, there are significant deep resources within the range of current underground mining technology. Underground resources for coal beds $10-20 \mathrm{ft}$ thick and 500-2,000 deep were estimated at 304 BST.

- The mapping of individual coal beds for the first time throughout the entire PRB was required to complete an economic assessment of both available and recoverable coal resources and offers a unique perspective compared to previous work, which relied on less effective net coal isopach maps. This in turn may provide new viewpoints regarding depositional environments of this extensive, exceptionally thick, coal sequence.

- Regional prefeasibility mine models were developed to conduct mining economic evaluations to estimate the portion of the available resources that meet the definition of reserves and recoverable coal.

- Estimates of reserves and resources are important, however, the relation between reserves and recoverable coal resources is equally significant in understanding the potential coal reserve base of the United States. The coal reserve base provides estimates of coal resources that are currently economic (reserves), and those recoverable resources that may become economic using current technologies. This information is important from a national energy security and policy standpoint regardless of time frames.

- The cumulative results from the four PRB assessment areas are 24.5 BST of coal reserves and a total recoverable coal resource (coal reserve base) of $162 \mathrm{BST}$ in coal beds greater than $5 \mathrm{ft}$ in thickness and less than a 10:1 stripping ratio.
With continued favorable sales prices, increased productivity, and technological advances in mining that positively affect economics, resources once considered to be subeconomic may be elevated to the status of reserves. Therefore, reserve studies should be considered a cyclic process and models should be adjusted and assessed periodically using the most recent data, which uses the most current recovery technology and economics.

\section{Acknowledgments}

This report was produced through the efforts and cooperation of many people. Susan Tewalt, Michael Brownfield, Tom Judkins, and David Ferderer, all presently or formerly of the USGS, provided in-depth technical reviews of the manuscript. Nicholas Jones (formerly with the Wyoming State Geological Survey), the staff of the Wyoming State Geological Survey, and Jay A. Gunderson of the Montana Bureau of Mines and Geology, supplied data and information pertaining to the Powder River Basin. Ed Heffern, formerly with the Bureau of Land Management in Cheyenne, Wyoming, supplied the digital files that show the extent of clinker within the Powder River Basin.

\section{References Cited}

Ashley, M., 2005, Wyodak Coal, Tongue River Member of the Fort Union Formation, Powder River Basin, Wyoming: "No-coal zones" and their effects on coalbed methane production: Rocky Mountain Section American Association of Petroleum Geologists Annual Meeting, September 24-26, 2005, Jackson, Wyo., 33 p.

Association for the Advancement of Cost Engineering 1997, Cost Estimate Classification System-As applied in engineering, procurement, and construction for the process industries, Association for the Advancement of Cost Engineering International Recommended Practice No. 18R-97: 209 Prairie Avenue, Suite 100, Morgantown, WV, 26501, $7 \mathrm{p}$.

Association for the Advancement of Cost Engineering, 1999, Skills and knowledge of cost engineering (4th ed.): Morgantown, W. Va., 7 p.

Averitt, Paul, 1966, Coal in Proceedings of the first Montana coal resources symposium: Montana Bureau of Mines and Geology, Special Publication 36, March 1966, 89 p.

Ayers, W.B., Jr., and Kaiser, W.R., 1984, Lacustrineinterdeltaic coal in the Fort Union Formation (Paleocene), Powder River Basin, Wyoming and Montana, in Rahmani, R., and Flores, R.M., eds., Sedimentology of coal and coalbearing sequences: International Association of Sedimentologists, Special Publication, no. 7, p. 61-84. 
Ayers, W.B. Jr., 1986a, Coal resources of the Tongue River Member, Fort Union Formation (Paleocene), Powder River Basin, Wyoming and Montana: Wyoming Geological Survey, Report of Investigations, no. 35, 22 p.

Ayers, W.B. Jr., 1986b, Lacustrine and fluvial-deltaic depositional systems, Fort Union Formation (Paleocene), Powder River Basin, Wyoming and Montana: American Association of Petroleum Geologists Bulletin, v. 70, no. II, November 1986, p. 1651-1673.

Baker, A.A., 1929, The northward extension of the Sheridan Coal Field, Big Horn and Rosebud Counties, Montana: U.S. Geological Survey Bulletin 806-B, p. 15-67.

Berryhill, H.L., Jr., Brown, D.M., Brown, Andrew, and Taylor, D.A., 1950, Coal resources of Wyoming: U.S. Geological Survey Circular 81, 78 p.

Bryans, W.S., 1987, A history of transcontinental railroads and coal mining on the Northern Plains to 1920: University of Wyoming, Ph.D. thesis, 159 p.

Bureau of Land Management, 1986, Implementation of procedures for verification of recoverable coal reserves: Bureau of Land Management Instruction Memorandum no. 86323, $7 \mathrm{p}$.

Bureau of Land Management, 1999, Final environmental impact assessment WY-070-EA-9-191 for the proposed Enron (Belco)-BLM coal lease exchange, Casper, Wyoming Field Office, 187 p.

Bureau of Land Management, 2003, Final environmental impact Statement for the Pittsburg and Midway Coal Mining Company Coal exchange proposal (WYW148816), Casper, Wyoming, Field Office, 187 p.

Bureau of Land Management, 2013, Powder River Basin coal leases by application, accessed December 2013, at http:/www.blm.gov/wy/st/en/programs/energy/ Coal_Resources/PRB Coal/lba title.html.

Carter, M.D., and Gardner, N.K., 1989, An assessment of coal resources available for development: U.S. Geological Survey Open-File Report 89-362, 52 p.

Caterpillar, Inc., 2012, Products, accessed June 2012, at http://www.cat.com/equipment.

Coates, D.A., and Heffern, E.L., 1999, Origin and geomorphology of clinker in the Powder River Basin, Wyoming and Montana, in Miller, W.R., ed., Coal bed methane and the Tertiary geology of the Powder River Basin: Wyoming Geological Association 50th Annual Field Conference Guidebook, p. 211-229.

Combo, J.X., Brown, D.M., Pulver, H.F., and Taylor, D.A., 1949, Coal Resources of Montana: U.S. Geological Survey Circular 53, 28 p.

De Bruin, R.H., Lyman, R.M., Jones, R.W., and Cook, L.W., 2004, Coal bed methane in Wyoming: Wyoming State Geological Survey, Information Pamphlet 7, second revision, $24 \mathrm{p}$.
Dennison, Mike, 2010, The Billings Gazette, March 16, 2010; Otter Creek, accessed June 2012, at http://billingsgazette.com/news/State-and-regional/ Montana/articledce41c8a-3163-11df-b2.

Department of Labor and Industry Safety and Health Bureau, 2012, State of Montana.

Dobbin, C.E., Barnett, V.H., and Thom, W.T., Jr., 1927, The Gillette coal field, northeastern Wyoming: U.S. Geological Survey Bulletin 796-A, 64 p.

Eggleston, J.R., Carter, M.D., and Cobb, J.C., 1990, Coal resources available for development - A methodology and pilot study: U.S. Geological Survey Circular 1055, 15 p.

Ellis, M.S., and Colton, R.B., 1994, Geologic map of the Powder River Basin and surrounding area, Wyoming, Montana, South Dakota, North Dakota, and Nebraska: U.S. Geological Survey Miscellaneous Investigations Series, Map I-2298, 1 sheet, scale 1:500,000.

Ellis, M.S., Flores, R.M., Ochs, A.M., Stricker, G.D., Gunther, G.L., Rossi, G.S., Bader, L.R., Schuenemeyer, J.H., and Power, H.C., 1999, chap. PG, Gillette coalfield, Powder River Basin: Geology, coal quality, and coal resources, 24 p., chap. PH, Sheridan coalfield, Powder River Basin: Geology, coal quality, and coal resources, 19 p., in 1999 resource assessment of selected Tertiary coal beds and zones in the northern Rocky Mountains and Great Plains Region: U.S. Geological Survey Professional Paper 1625-A, 2 CD-ROMs.

Ellis, M.S., Molnia, C.L, Osmonson, L.M., Ochs, A.M., Rohrbacher, T.J., Mercier, T.J.,, and Roberts, N.R., 2002, Evaluation of economically extractable coal resources in the Gillette coal field, Powder River Basin, Wyoming: U.S. Geological Survey Open-File Report 2002-180, 48 p.

Environmental Systems Research International, Incorporated, 2006, Environmental Systems Research International, Incorporated, Redlands, California, available at http://www.esri.com.

Flores, R.M., 1982, Coal deposition in fluvial paleoenvironments of the Paleocene Tongue River Member of the Fort Union Formation in the Powder River-Clear Creek area, Wyoming in Glass, G.B., ed., Guidebook to the coal geology of the Powder River Coal Basin, Wyoming: American Association Petroleum Geologists, Energy Minerals Division Field Trip, v. 5, p. 67-90.

Flores, R.M., and Bader, L.R., 1999, chap. PS, Fort Union coal in the Powder River Basin, Wyoming and Montana: a synthesis, ,49 p., in 1999 resource assessment of selected Tertiary coal beds and zones in the Northern Rocky Mountains and Great Plains Region: U.S. Geological Survey Professional Paper 1625-A, 2 CD-ROMs. 
Flores, R.M., Ochs, A.M., Bader, L.R., Johnson, R.C., and Vogler, D., 1999, chap. PF, Framework geology of the Fort Union coal in the Powder River Basin, 17 p., in 1999 resource assessment of selected Tertiary coal beds and zones in the northern Rocky Mountains and Great Plains Region: U.S. Geological Survey Professional Paper 1625-A, 2 CD-ROMs.

Flores, R.M., Spear, B.D., Kinney, S.A., Purchase, P.A., and Gallagher, C.M., 2010, After a century—Revised Paleogene coal stratigraphy, correlation, and deposition, Powder River Basin, Wyoming and Montana: U.S. Geological Survey Professional Paper 1777, 97 p., CD-ROM in pocket.

Gardner, A.D. and Flores, V.R., 1989, Forgotten Frontier, a history of Wyoming coal mining: Boulder, Colo., Westview Press, 243 p.

Glass, G.B., 1976, Update on the Powder River coal basin, in Wyoming Geological Association Guidebook: Annual Field Conference, 28, Casper, Wyo., p. 209-220.

Glass, G.B., 1978, Coal, in Porter, F.H., and Grasso, D.N., eds., Sheridan County, Wyoming: Wyoming Geological Survey, Resource Series 5, 9 plates.

Glass, G.B., 1997, Coal geology of Wyoming: Wyoming State Geological Survey, Reprint No. 63, 21 p.

Glass, G.B., 2001, Coal geology of Wyoming, in 2001, Keystone Coal Industry Manual: Intertec Publishing Company, Chicago, Ill., p. 654-674.

Golden Software, Inc., 2002, Surfer8 software: Golden Software, Inc., Golden, Colo.

GRG Corporation, 1998, StratiFact software version 4.57: GRG Corporation, Wheatridge, Colo.

Guide to Coal Mines, 2010, Coal business unit, BNSF Railway Company: BNSF Railway Company, Fort Worth, Tex.

Haacke, J.E., and Scott, D.C., 2013, Drill hole data for coal beds in the Powder River Basin, Montana and Wyoming: U.S. Geological Survey Data Series 713, 15 p., available at http://pubs.usgs.gov/ds/713.

Haacke, J.E., Scott, D.C., Osmonson, L.M., Luppens, J.A., Pierce, P.E., and Gunderson, J.A., 2013, Assessment of coal geology, resources and reserves in the Montana Powder River Basin: U.S. Geological Survey Open-File Report 2012-1113, 133 p., http://pubs.usgs.gov/of/2012/1113/.

Hardie, J.K., 1991, Cross sections showing coal stratigraphy of the southwestern Powder River basin, Wyoming: U.S. Geological Survey Miscellaneous Investigations Series Map I-1959-C, 1 sheet, scale 1:500,000.

InfoMine USA, Inc., 2010, Mining Cost Service, InfoMine USA, Inc., Spokane Valley, Wash.

Intertec Publishing, 1997-2000, Keystone Coal Industry Manual: Chicago, Ill., Intertec Publishing, various pagination.
Primedia Business Magazines and Media, Inc., 2003, Keystone Coal Industry Manual, Chicago, Ill., Primedia Business Magazines and Media, Inc., various pagination.

Jackson, Julia A., ed., 1997, Glossary of geology, (4th ed.): American Geological Institute, Alexandria, Va., 769 p.

Jones, N.R., 2010a, Genesis of thick coal deposits and their unique angular relationships, Powder River Basin, Wyoming: Wyoming State Geological Survey, Report of Investigation No. 60, 58 p.

Jones, N.R., 2010b, Coal geology of Wyoming in 2010, Keystone Coal Industry Manual, Mining Media International, Jacksonville, Fla.

Kaiser, W.R., 1999, Gulf Coast lignite abstract—A status report: Gulf Coast Association of Geological Societies Transactions, v. 29, p. 405.

Kent, B.H., Berlage, L.J., and Boucher, E.M., 1980, Stratigraphic framework of coal beds underlying the western part of the Recluse $1 \times 1 / 2$-degree quadrangle, Campbell County, Wyoming: U.S. Geological Survey Coal Investigations Map C-81C, 2 plates, scale 1:100,000.

Kinney, S.A., Scott, D.C., Osmonson, L.M., and Luppens, J.A., 2015, Geospatial data for coal beds in the Powder River Basin, Wyoming and Montana: U.S. Geological Data Series 912, 7 p., GIS database, https://dx.doi.org/10.3133/ ds912.

Law, B.E., Barnum, B.E., and Wollenzien, T.P., 1979, Coal bed correlations in the Tongue River Member of the Fort Union Formation, Monarch, Wyoming, and Decker, Montana, areas: U.S. Geological Survey Miscellaneous Investigations Series Map I-1128, scale 1:24,000.

Lopez, D.A., 2005, Structure contour map: Top of Lebo Shale and Bear Paw Shale, Powder River Basin, SE Montana: Montana Bureau of Mines and Geology Report of Investigation 16, 3 sheets, 1:25,000 scale.

Luppens, J.A., 2011, A critical review of published coal quality data from the southwestern part of the Powder River Basin, Wyoming: U.S. Geological Survey, Open-File Report 2011-1148, 40 p., available at http://pubs.usgs.gov/of/2011/1148/.

Luppens, J.A., Scott, D.C., Haacke, J.E., Osmonson, L.M., Rohrbacher, T.J., and Ellis, M.S., 2008, Assessment of coal geology, resources, and reserves in the Gillette coal field, Powder River Basin, Wyoming: U.S. Geological Survey Open-File Report 2008-1202, 127 p., available at http://pubs.usgs.gov/ofr/2008/1202.

Luppens, J.A., Rohrbacher, T.J., Osmonson, L.M., and Carter, M.D., 2009, Coal resource availability, recoverability, and economic evaluations in the United States-A summary, in Pierce, B.S., and Dennen, K.O., eds., The national coal resource assessment overview: U.S. Geological Survey Professional Paper 1625-F, chap. D, 17 p. 
Maclean Hunter Mining and Construction Group, 1988-1996, Keystone coal industry manual, Maclean Hunter Mining and Construction Group, Chicago, Ill., various pagination.

Malone, M.P., Roeder, R.B., and Lang, W.L., 1991, MontanaHistory of two centuries (2d ed.): Seattle, Wash., University of Washington Press, $467 \mathrm{p}$.

Mapel, W.J., 1954, Geology and coal resources of the Lake DeSmet area, Johnson county, Wyoming: U.S. Geological Survey Coal Investigations Map C23, scale 1:50,000.

Mapel, W.J., 1958, Coal in the Powder River Basin: Wyoming Geological Association Guidebook, 13th Annual Field Conference, p. 218-224.

Mapel, W.J., 1959, Geology and coal resources of the BuffaloLake DeSmet area, Johnson and Sheridan Counties, Wyoming: U.S. Geological Survey Bulletin 1078, 148 p.

Mapel, W.J., 1973, Preliminary geologic map of the Rawhide School quadrangle, Campbell County, Wyoming: U.S. Geological Survey Open-File Report 73-177, scale 1:24,000.

Mapel, W.J., Schopf, J.M., and Gill, J.R., 1953, A thick coal bed near Lake DeSmet, Johnson County, Wyoming: U.S. Geological Survey Circular 228, 47 p.

Matson, R.E., and Blumer, J.W., 1973, Quality and reserves of strippable coal, selected deposits, southeastern Montana: Montana Bureau of Mines and Geology, December 1973, Bulletin 91, 135 p.

McLellan, M.W., 1991, Cross section showing the reconstructed stratigraphic framework of Paleocene rocks and coal beds in the central Powder River basin from Decker to Bear Skull Mountain, Montana: U.S. Geological Survey Miscellaneous Investigations Series Map I-1959-E, 1 sheet, no scale.

McLellan, M.W., Biewick, L.R., Molnia, C.L., and Pierce, F.W., 1990, Cross sections showing the reconstructed stratigraphic framework of Paleocene rocks and coal beds in the northern and central Powder River Basin, Montana, and Wyoming: U.S. Geological Survey Miscellaneous Investigations Series Map I-1959-A, 2 sheets, scale 1:500,000.

Mentor Consultants, 2005, PC/Cores, P.O. Box 3147, Glen Ellyn, IL, 60137.

Mercier, J.M., 2010, Coal mining in the western San Juan Basin, San Juan County, New Mexico: New Mexico Geological Society Guidebook, 61st Field conference, Four Corners County, p. 173-180, accessed June 2012, at http://nmgs.nmt.edu/publications/guidebooks/ downloads/61/61_p0173_p0180.pdf.

Microsoft, 2007, Excel spreadsheet software, v. Office 2007: Microsoft Corporation, Redman, Wash.

Minerals Management Service 1982, Tract summary report for the Northwest Otter Creek coal lease: Memorandum, accessed June 2012, at http://www.dnrc.mt.gov/Trust/ MMB/Otter Creek/Default.asp.
Mine Safety and Health Administration, online database, accessed June 2012, at http://www.msha.gov/drs/ASP/Mine Action.

Mining Information Services, 1969-1987, Keystone coal industry manual, McGraw-Hill, Inc., New York, NY, various pagination.

Molnia, C.L., and Pierce, F.W., 1992, Cross sections showing coal stratigraphy of the Central Powder River Basin, Wyoming and Montana: U.S. Geological Survey Miscellaneous Investigations Series Map I-1959-D, 1 sheet, scale 1:500,000.

Molnia, C.L., Osmonson, L.M., Wilde, E.M., Biewick, L.R.H., Rohrbacher, T.J., and Carter, M.D., 1999, chap. PAR, Coal availability and recoverability studies in the Powder River Basin, Wyoming and Montana, in 1999 resource assessment of selected Tertiary coal beds and zones in the northern Rocky Mountains and Great Plains Region: U.S. Geological Survey Professional Paper 1625-A, 119 p.

Montana Department of Environmental Quality, 2013, Proposed Otter Creek coal mine environmental impact Statement, scoping report: Helena, Mont., Montana Department of Environmental Quality, Directors Office, 22 p.

Morgan, Thomas, 1966, History of coal mining in Montana in Proceedings of the First Montana Coal Resources Symposium: Montana Bureau of Mines and Geology, Special Publication 36, $89 \mathrm{p}$.

Moulton, G.E., ed., 2001, The Journals of the Lewis and Clark Expedition: University of Nebraska Press, Lincoln, Nebr., accessed June 2009, at http://lewisandclarkhournals.unl.edu.

Myszkowski, M., and Paschedag, U., 2009, Longwall mining in seams of medium thickness - Comparison of plow and shearer performance under comparable conditions: Milwaukee, Wis., Bucyrus, 34 p., accessed June 2009, at http://www.bucyrus.com/media/5712/longwall_extraction of_medium_thickness_coal_seams.pdf.

National Park Service, 2012, National historic landmarks program, accessed June 2012, at http://tps.cr.nps.gov/nhl/ detail.cfm:ResourceID=1926966093\&Resource.

Natural Resource Information System, 2011, GIS data list of the Montana Bureau of Mines and Geology Geographic Information Systems Lab, accessed June 2012, at http://nris.mt.gov/gis/gisdatalib/gisDataList.aspx.

Obernyer, S.L., 1978, Basin-margin depositional environments of the Wasatch Formation in the Buffalo-Lake DeSmet area, Johnson County, Wyoming, in Proceedings of the second symposium on the geology of Rocky Mountain coal-1977: Colorado Geological Survey Resource Series 4, p. 49-65.

Obernyer, S.L., 1980, The Lake DeSmet coal seam in Guidebook to the coal geology of the Powder River Coal Basin, Wyoming: Geological Survey of Wyoming Public Information Circular 14, p. 31-70. 
Osmonson, L.M., Scott, D.C., Haacke, J.E., Luppens, J.A., and Pierce, P.E., 2011, Assessment of coal geology, resources, and reserves in the southwestern Powder River Basin, Wyoming: U.S. Geological Survey Open-File Report 2011-1134, 135 p., available at http://pubs.usgs.gov/ ofr/2011/1134.

PACIFICORP, 2008, Dave Johnston Power Plant 50th anniversary and Glenrock Wind Farm community celebration: Portland, Oregon, PACIFICOR, accessed June 2012, at http://www.pacificorp.com/about/newsroom/2008nrl/ djpp5aagwfcc.html.

PACIFICORP, 2011, Jim Bridger Plant fact sheet, PACIFICOR, Portland, Oregon, accessed June 2012, at http://www.pacificorp.com/content/dam/pacificorp/doc/ Energy_Sources/EnergyGeneration_FactSheets/RMP_GFS Bridger.pdf.

Pierce, B.S., and Dennen, K.O., eds., 2009, The national coal resource assessment overview: U.S. Geological Survey Professional Paper 1625-F, 402 p.

Pierce, F.W., Johnson, E.A., Molnia, C.L., Sigleo, W.R., 1990, Cross sections showing coal stratigraphy of the southeastern Powder River basin, Wyoming: U.S. Geological Survey Miscellaneous Investigations Series Map I-1959, 2 sheets, scale 1:500,000.

Platts, 2007, Coal-dat database: Platts, McGraw-Hill companies, Inc., Boulder, Colo., 1 CD-ROM.

Platts, 2008, Coal outlook: New York, Platts, a division of The McGraw-Hill Companies, March 3, 2008, v. 32, no. 9, 10 p.

Platts, 2009a, Coal outlook: New York, Platts, a division of The McGraw-Hill Companies, March 3, 2008, v. 33, no. 01, March 3, 2008, 10 p.

Platts, 2009b, Coal outlook: New York, Platts, a division of The McGraw-Hill Companies, April 06, 2009, v. 33, no. 14, $14 \mathrm{p}$.

Platts, 2009c, Coal outlook: Platts: New York, a division of

The McGraw-Hill Companies, April 13, 2009, v. 33, no. 15, $12 \mathrm{p}$.

Platts, 2009d, Coal outlook: New York, Platts, a division of The McGraw-Hill Companies, November 23, 2009, v. 33, no. $47,16 \mathrm{p}$.

Platts, 2010, Coal outlook: New York, Platts, a division of The McGraw-Hill Companies, January 11, 2010, v. 34, no. $2,12 \mathrm{p}$.

Platts, 2011a, Coal outlook: New York, Platts, a division of The McGraw-Hill Companies, November 14, 2011, v. 35, no. $46,16 \mathrm{p}$.

Platts, 2011b, Coal outlook: New York, Platts, a division of The McGraw-Hill Companies, December 5, 2011, v. 35, no. $49,16 \mathrm{p}$.
Platts, 2012, Coal outlook: New York, Platts, a division of The McGraw-Hill Companies, October 8, 2012, v. 36, no. $41,12 \mathrm{p}$.

Platts, 2013, Coal outlook: New York, Platts, a division of The McGraw-Hill Companies, July 8, 2013, v. 37, no. 27, 10 p.

Public Law 95-87, 1977, Surface Mining Control and Reclamation Act of 1977 (30 U.S.C. 1201 et seq.), 115 p., accessed June 2012, at http://www.osmre.gov/smcra.html.

Rice, C.A., Ellis, M.S., and Bullock, J.H., 2000, Water coproduced with coalbed methane in the Powder River Basin, Wyoming-Preliminary compositional data: U.S. Geological Survey Open-File Report 2000-372, 20 p.

Roberts, S.B., Wilde, E.M., Rossi, G.S., Blake, D., Ellis, M.S., Stricker, G.D., Ochs, A.M., Gunther, G.L., Schuenemeyer, J.H., and Power, H.C., 1999a, chap. PA, Ashland coal field, Powder River Basin, Montana: Geology, coal quality, and coal resources, in 1999 resource assessment of selected Tertiary coal beds and zones in the Northern Rocky Mountains and Great Plains Region: U.S. Geological Survey Professional Paper 1625-A, 2 CD-ROMs.

Roberts, S.B., Wilde, E.M., Rossi, G.S., Blake, D., Bader, L.R., Ellis, M.S., Stricker, G.D., Gunther, G.L., Ochs, A.M., Kinney, S.A., Schuenemeyer, J.H., and Power, H.C.,1999b, Colstrip, Powder River Basin, Montana: Geology, coal quality, and coal resources, chap. PC, in 1999 resource assessment of selected Tertiary coal beds and zones in the Northern Rocky Mountains and Great Plains Region: U.S. Geological Survey Professional Paper 1625-A, 2 CD-ROMs.

Roberts, S.B., Gunther, G.L., Taber, T.T., Ochs, A.M., Blake, D., Ellis, M.S., Stricker, G.D., Wilde, E.M., Schuenemeyer, J.H., and Power, H.C., 1999c, chap. PD, Decker coal field, Powder River Basin, Montana: Geology, coal quality, and coal resources, in 1999 resource assessment of selected Tertiary coal beds and zones in the Northern Rocky Mountains and Great Plains Region: U.S. Geological Survey Professional Paper 1625-A, 2 CD-ROMs.

Robinson, L.N., and Van Gosen, B.S., 1986, Maps showing the coal geology of the Sarpy Creek area, Big Horn and Treasure Counties, Montana: U.S. Geological Survey Miscellaneous Field Studies Map MF-1859, scale 1:24,000.

Rohrbacher, T.J., and McIntosh, G.E., 2010, CoalVal—A coal resource valuation program: U.S. Geological Survey OpenFile Report 2009-1282, 265 p.

Rupprecht, S., 2004, Establishing the feasibility of your proposed mining venture: International Platinum Conference, The South African Institute of Mining and Metallurgy, p. 243-247.

Schobert, H.H., 1995, Lignites of North America-Coal Science Technology 23: The Netherlands, Elsevier Science, Amsterdam, 696 p. 
Scott, D.C., Haacke, J.E., Osmonson L.M., Luppens, J.A., Pierce, P.E., and Rohrbacher, T.J., 2010, Assessment of coal geology, resources, and reserves in the Northern Wyoming Powder River Basin, Wyoming: U.S. Geological Survey Open-File Report 2010-1294, 136 p., available at http://pubs.usgs.gov/of/2010/1294/.

Scott, D.C., and Luppens, J.A., 2013, Assessment of coal geology, resources, and coal reserve base in the Powder River Basin, Wyoming and Montana: U.S. Geological Survey Fact Sheet 2012-3143, 6 p., available at http://usgs.gov/science/cite-view.php?cite=3074.

Smith, J.B., Ayler, M.F., Know, C.C., and Pollard, B.C., 1972, Strippable coal reserves of Wyoming: U.S. Bureau of Mines Information Circular IC 8538, $51 \mathrm{p}$.

Stermole, F.J., 1974, Economic evaluation and investment decision methods; second edition: Investment Evaluations Corporation, Golden, Colo., p. 14.

Society of Mining Engineers of The American Institute of Mining, Metallurgical, and Petroleum Engineers, Inc., 1973, SME Mining Engineering Handbook: New York, Arthur B. Cummins and Ivan A. Given, eds., 2 v., 35 chapters.

Stricker, G.D., Flores, R.M., Trippi, M.H., Ellis, M.S., Olson, C.M., Sullivan, J.E., and Takahashi, K.I., 2007, Coal quality and major, minor, and trace elements in the Powder River, Green River, and Williston Basins, Wyoming and North Dakota: U.S. Geological Survey Open-File Report 2007-1116, $31 \mathrm{p}$.

Supreme Court of the United States, 1999, Amoco Production Co. v. Southern Ute Tribe (98-830), 526, U.S. 865.

Taff, J.A., 1909, The Sheridan coal field, Wyoming in Coal and lignite, pt 2: U.S. Geological Survey Bulletin 341, p. $123-150$.

Thomas, Larry, Dargo Associates Ltd., 2002, Coal geology: West Sussex, England, John Wiley and Sons, LTD., 365 p.

Thrush, P.W., and the Staff of the Bureau of Mines, 1968, A dictionary of mining, mineral, and related terms: U.S. Bureau of Mines, 1,269 p.

Trumbull, L.W., 1905, Coal resources of Wyoming: University of Wyoming, School of Mines Bulletin no. 7, 98 p.

Tudor, M.S., 1975, Geologic exploration and development of coal in the Sarpy Creek area, Big Horn County, Montana, in Doroshenko, J., Miller, W.R., Thompson, E.E., Jr., and Rawlins, J.H., eds., Energy resources of Montana: Montana Geological Society 22nd Annual Publication, p. 159-164.

U.S. Energy Information Administration, 2011, available at http://www.eia.gov/tools/glossary/index.cfm.

U.S. Energy Information Administration, 2013, available at http://www.eia.gov/tools/glossary/index.cfm.
U.S. Energy Information Administration, 1997, U.S. coal reserves - 1997 update: EIA Administration, Office of Coal, Nuclear, Electric and Alternate Fuels Office of Integrated Analysis and Forecasting, DOE/EIA-0529(97), 60 p., available at ftp://ftp.eia.doe.gov/pub/pdf/coal.nuclear/052997.pdf.

U.S. Energy Information Administration, 1995, EIA Report, Longwall Mining: U.S. Department of Energy, DOE/EIA TR-0588, March 1995, 60 p.

U.S. Environmental Protection Agency, 1980, Standards of performance for new stationary source-A compilation as of July 1, 1980: Washington, D.C., U.S. Environmental Protection Agency, Office of General Enforcement, Division of Stationary Source Enforcement, 868 p., accessed June 2012, at http://nepis.epa.gov/Exe/ZyNET.exe/2000WROU.txt.

U.S. Environmental Protection Agency, 2005, AirControl NET Documentation report: Pechan Report No. 05.09.009/9010.463, H.E., Pechan \& Associates, Springfield, Va., 1,685 p., accessed June 2012, at http://www.epa.gov/air/ozonepollution/SIPToolkit/ documents/DocumentationReport.pdf.

U.S. Office of Surface Mining, 1983, Draft environmental impact Statement for Western Energy Company's Rosebud Mine, OSM 83-10, 11 p.

Van Voast, W., and Thale, P., 2001, Anderson and Knobloch coal horizons and potential for methane development, Powder River Basin, Montana: Montana Bureau of Mines and Geology Geologic Map 60, scale 1:250,000.

Vuke, S.M., Heffern, E.L., Bergantino, R.N., and Colton, R.B., 2001a, Geologic map of the Lame Deer 30' $\times 60^{\prime}$ quadrangle, eastern Montana: Montana Bureau of Mines and Geology Open-File Report 428, 8 p., 1 sheet, scale 1:100,000.

Vuke, S.M., Heffern, E.L., Bergantino, R.N., and Colton, R.B., 2001b, Geologic map of the Birney 30' x 60' quadrangle, eastern Montana: Montana Bureau of Mines and Geology Open-File Report 431, 12 p., 1 sheet, scale, 1:100,000.

Western Fuels Association, Inc., 1983, Final showing report Stevens properties prospecting permits, Converse County, Wyoming: Denver, Colo., Western Fuels Association, Inc., $25 \mathrm{p}$.

Wood, G.H., Jr., Kehn, T.M., Carter, M.D., and Culbertson, W.C., 1983, Coal resource classification system of the U.S. Geological Survey: U.S. Geological Survey Circular 891, 65 p.

Wyoming Oil and Gas Conservation Commission, 2011, Wyoming Spatial Data Clearinghouse, 2009, available at http://wgiac2.State.wy.us. 



\section{Glossary}

The present study includes determinations of original, available, and recoverable coal resources; reserves, and reserves, which are economically recoverable coal resources. This terminology has been used in many USGS coal studies (see Wood and others, 1983; Carter and Gardner, 1989; Eggleston and others, 1990; and Molnia and others, 1999). The following definitions were applied in this resource evaluation:

\section{A}

Alluvial Pertains to or composed of alluvium (sediments) deposited by a stream (Jackson, 1997).

Available coal resources Remaining coal resources that are thick and shallow enough to be mined by either surface or underground methods and that are unencumbered by land-use, environmental, societal, regulatory, or technologic restrictions as they may apply in a specific State or region (Carter and Gardner, 1989).

\section{B}

Box cut The initial cut driven in a property, where no open side exists; this results in a highwall on both sides of the cut (Thrush, 1968).

\section{C}

Chronostratigraphic The organization of rock strata into units on the basis of their age or time of origin (Jackson, 1997).

Coalbed methane (CBM) Primary coal bed gas collected from unmined coal beds (Clarkeenergy, http//:Clarke-energy.com/gas-type/coalgas, accessed on May 7, 2013).

Coal reserves Virgin or accessed parts of a coal reserve base which could be economically extracted or produced at the time of determination considering environmental, legal, and technologic constraints. The term "reserves" need not signify that extraction facilities are in place or operative. Reserves include only recoverable coal; thus, terms such as "extractable reserves" are redundant and are not a part of the classification system. Reserves can be categorized as "measured" and "indicated," as underground or surface minable, by thickness of overburden, by thickness of coal in the bed, and by various quality factors (Wood and others, 1983).

Coal reserve base The tonnage estimate for coal consisting of the sum of the estimates for measured and indicated reserves, marginal reserves, and a part of the measured and indicated subeconomic resources (Wood and others, 1983).
Coal resources Naturally occurring concentrations or deposits of coal in the Earth's crust, in such forms and amounts that economic extraction is currently or potentially feasible (Wood and others, 1983).

Continuous mining Mining in which the continuous miner machine cuts or rips coal from the face and loads it onto conveyors or into shuttle cars in a continuous operation (Thrush, 1968).

\section{D}

Delta The low, nearly flat, alluvial tract of land at or near the mouth of a river, commonly forming a triangular or fan-shaped plain of considerable area (Jackson, 1997).

Deltaic Pertaining to or characterized by a delta (Jackson, 1997).

\section{Demonstrated coal reserve base (DBR)}

Includes publicly available data on coal mapped to measured and indicated degrees of accuracy and found at depths and in coalbed thickness considered technologically minable at the time of determinations (U.S. Department of Energy, 2013).

Dip (dipping) The angle at which a bed, stratum, or vein is inclined from the horizontal (Thrush, 1968).

Discounted cash flow (DCF) The stream of the net after-tax cash flows where the cash outlays include all operating costs, taxes, and investment costs, and where revenues include cash payments of product sales (Association for the Advancement of Cost Engineering, 1997).

\section{$\mathbf{F}$}

Facies The aspect, appearance, and characteristics of a rock unit, usually reflecting the conditions of its origin, especially as differentiating the unit from adjacent or associated units (Jackson, 1997). 
Fault(s) A fracture or fracture zone along which there has been displacement of the two sides relative to one another parallel to the fracture (Thrush, 1968).

Fluvial Of or pertaining to a river or rivers (Jackson, 1997).

Freight on Board (FOB) A reference to the place where purchased goods will be shipped without transportation charge.

\section{G}

Gytta A dark, pulpy, freshwater mud characterized by abundant organic matter that is more or less cohesive, and deposited or precipitated in a marsh or in a lake whose waters are rich in nutrients and oxygen (Jackson, 1997).

H

Headgate The primary roadway access and egress through which equipment, personnel, and supplies are provided to a longwall face, through which coal is conveyed to the surface, and through which fresh air flows (Stermole, 1974).

Hypothetical resources Tonnage estimates computed by extrapolation of thicknesses of coal for a radius beyond $3.0 \mathrm{mi}(4.8 \mathrm{~km})$ from a point of measurement. Hypothetical resources are a class of undiscovered resources that are either similar to known coal deposits which may be reasonably expected to exist in the same region under analogous geologic conditions, or are an extension from inferred resources (Wood and others, 1983).

I

Identified resources Resources whose locations, rank, quality, and quantity are known or estimated from specific geologic evidence. Identified coal resources include economic, marginally economic, and subeconomic components. To reflect varying distances from points of control or reliability, these subdivisions can be divided into demonstrated and inferred, or preferably into measured, indicated, and inferred (Wood and others, 1983).

Indicated resources Tonnage estimates computed by extrapolation of thicknesses of coal for a radius of 0.25 to $0.75 \mathrm{mi}$ ( 0.4 to 1.2 kilometers $[\mathrm{km}]$ ) from a point of measurement (Wood and others, 1983).

Inferred resources Tonnage estimates computed by extrapolation of thicknesses of coal for a radius of 0.75 to $3.0 \mathrm{mi}$ ( 1.2 to $4.8 \mathrm{~km}$ ) from a point of measurement (Wood and others, 1983).
In-place resources Resources that currently exist within a geographic area. The term inplace resources is equal to the term available resources in this report.

Interburden The rock between two coal beds. When two potentially minable coal beds occur within a minimum acceptable distance above or below one another, one will not be mined-often the thinner of the two (Carter and Gardner, 1989).

Interdeltaic A term used by Ayers and Kaiser (1984) to describe coal beds forming between deltas.

\section{L}

Land-use restrictions Constraints placed upon mining by societal policies to protect those surface features or entities that could be harmed by mining. Since laws and regulations can be modified or repealed, the restrictions, including industrial and environmental restrictions, may change. Land use restrictions include railroads, cities, and towns, airports, and Interstate highways.

Longwall mining A system of underground mining on straight faces 80 yards $(73 \mathrm{~m})$ or more in length (Thrush, 1968).

\section{M}

Measured resources Tonnage estimates computed by extrapolation of thicknesses of coal for a radius of $0.25 \mathrm{mi}(0.4 \mathrm{~km})$ from a point of measurement (Wood and others, 1983).

Mined coal Coal that has already been extracted from a deposit (Association for the Advancement of Cost Engineering, 1999).

Mire(s) A small piece of marshy, swampy, or boggy ground (wet spongy earth) (Jackson, 1997).

\section{0}

Original coal resource The total amount of coal in-place before production. Where mining has occurred, the total of original resources is the sum of the identified resources, undiscovered resources, coal produced, and coal lost in mining (Wood and others, 1983).

Overburden Rock including coal or unconsolidated material that overlies a specified coal bed. Overburden is reported in feet or meters and is used to classify the depth to an underlying coal bed (Wood and others, 1983).

Outcrop(s) That part of a rock formation (coal bed) that appears at the surface of the ground (Thrush, 1968). 
Paleosol(s) A soil that formed on a landscape in the past with distinctive morphological features resulting from a soil-forming environment that no longer exists at the site (Jackson, 1997).

Parting(s) A thin layer of stratum or noncoaly material within a coal bed which does not exceed the thickness of coal in either the directly underlying or overlying benches (Wood and others, 1983).

Peat(s) An unconsolidated deposit of semicarbonized plant remains in a water-saturated environment, such as a bog or fen (Jackson, 1997).

\section{$\mathbf{R}$}

Recoverable coal resource Coal that is or can be extracted from a coal bed during mining. The term "recoverable" should be used in combination with "resources" and not with "reserves" (Wood and others, 1983).

Reliability categories Based on the distance from points of measurement or sampling. The measured, indicated, inferred, and hypothetical resource categories, as defined, indicate the relative reliability of tonnage estimates as related to distance from points of thickness control of particular parts of a coal deposit. The reliability categories are not indicative of the reliability of the basic data (that is, the accuracy of coal measurements, or the accuracy of location of the coal outcrop). It is assumed that all basic data used in resource estimation have been judged reliable by the estimator and that unreliable data have been discarded (Wood and others, 1983).

Remaining resources Represent resources in the ground after subtracting coal that has been previously mined from the original resource (Carter and Gardner, 1989).

Restrictions to mining Include land use restrictions, technical limitations, and unsuitability criteria that would prohibit mining.

Royalty A lease by which the owner or lessor grants to the lessee the privilege of mining and operating the land in consideration of payment (Thrush, 1968).

\section{S}

Strip (stripping) ratio Represents the ratio of the volume of overburden or interburden (waste) that must be removed to gain access to a unit amount of coal. For this assessment, the ratio is expressed as cubic yards of overburden to tons of coal. The stripping ratio can be approximated by dividing the total thickness of waste by the total thickness of coal. For example, given a coal bed, $10.0 \mathrm{ft}$ thick, at 100 $\mathrm{ft}$ in depth, the stripping ratio would be 10:1 (in cubic yards to a ton of coal) (Thrush, 1968).

Subaerial Means conditions and processes, such as erosion, existing or operating in the open air on or immediately adjacent to the land surface (Jackson, 1997).

Subbituminous coal Rank class of nonagglomerating coals having a heat value content of more than 8,300 Btu and less than 11,500 Btu on a moist, mineral-matter-free basis (Wood and others, 1983).

Surface coal mining (strip) Mining at or near the ground surface and is generally done where the overburden can be removed economically. A strip mine is a surface mine in which the overburden is removed from a coalbed before the coal is removed (Thrush, 1968).

\section{T}

Tailgate The secondary roadway access or egress from a longwall face and through which return air flows (Society of Mining Engineers, 1973).

Technical restrictions Constraints, relating to economics and safety, placed upon mining by the state of technology or prescribed by law. These restrictions can change with advances in science and technology, or modifications in the law. In the report, some geologic factors are included as technologic restrictions. Technical restrictions include coal between $2.5 \mathrm{ft}$ and $5.0 \mathrm{ft}$ thick and areas of clinker.

\section{U}

Unsuitability criteria Specific legal constraints used to determine if an area can be mined by surface mining methods. These include, but are not limited to, Federal land systems, dwellings, and alluvial valley floors. 

Figures 



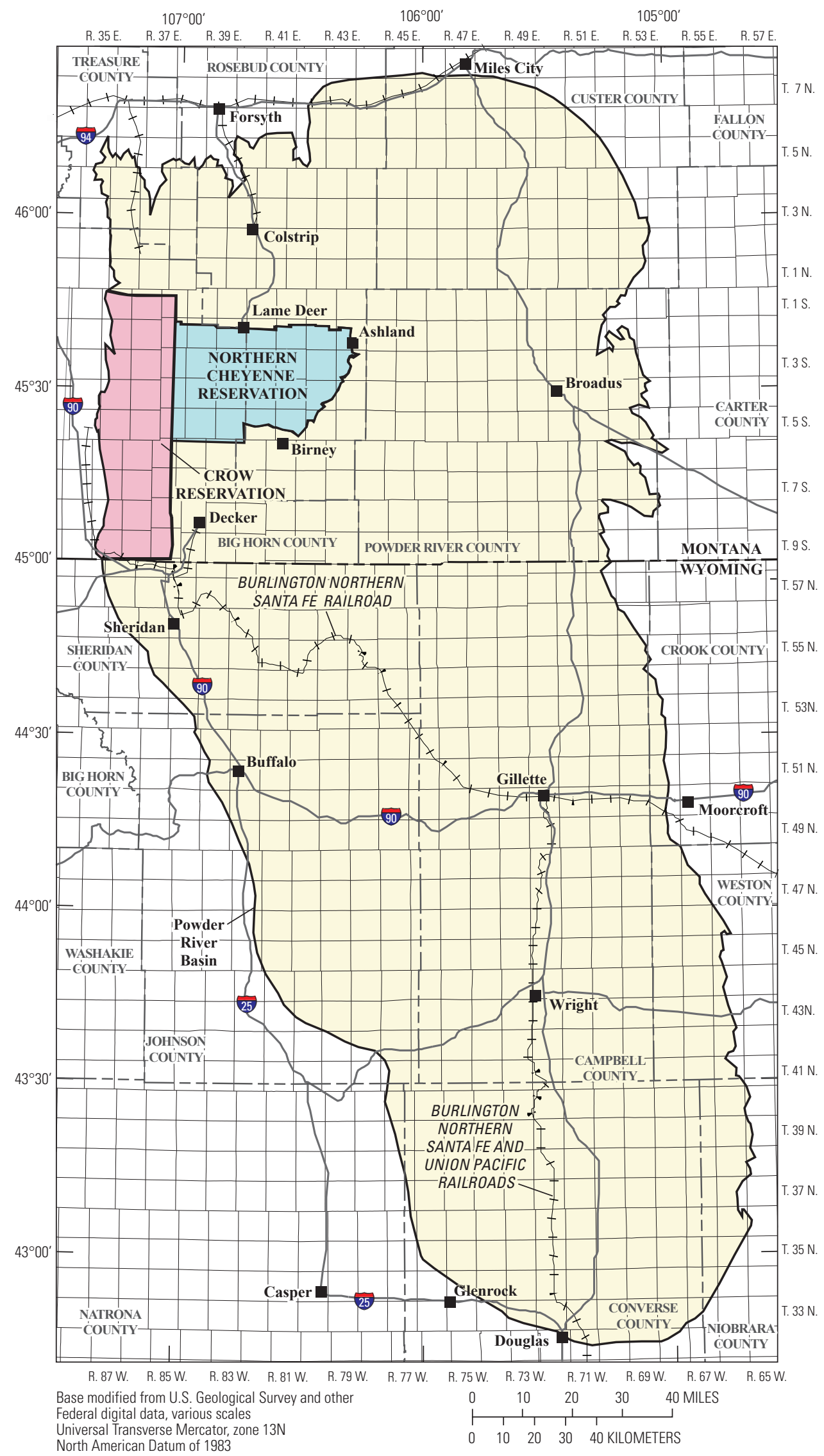

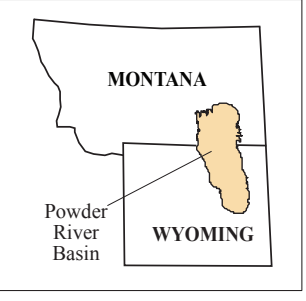

LOCATION MAP

Figure 1. Map showing location of the Powder River Basin, Wyoming and Montana. 


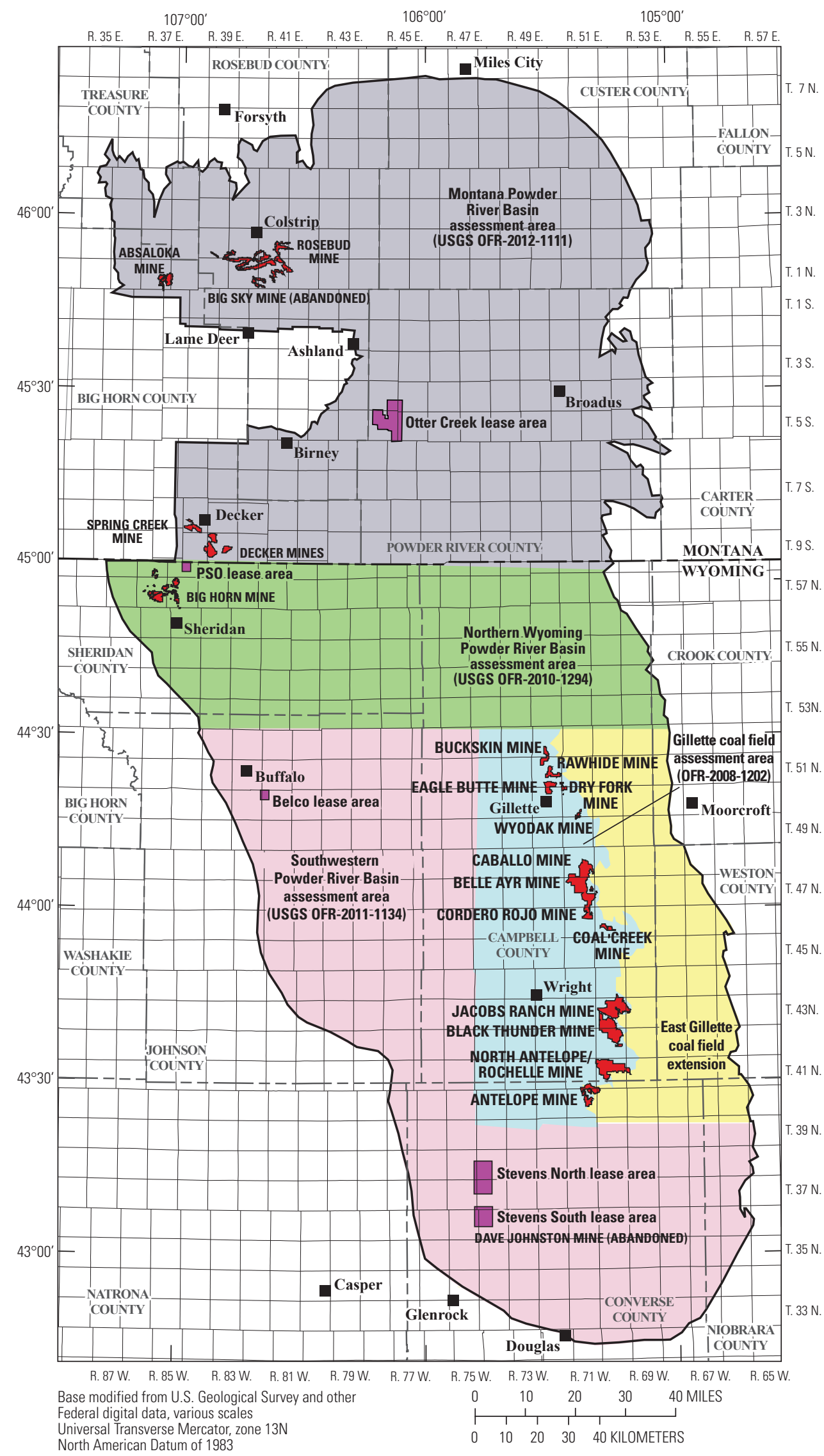

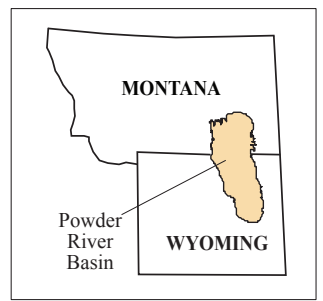

LOCATION MAP

Figure 2. Map showing location of individual assessment areas in the Powder River Basin, Wyoming and Montana. 



Contour interval $\mathbf{=} \mathbf{2 5 0}$ feet (76 meters)

Figure 3. Map showing structure contours drawn on the top of the Tullock Member of the Fort Union Formation. 


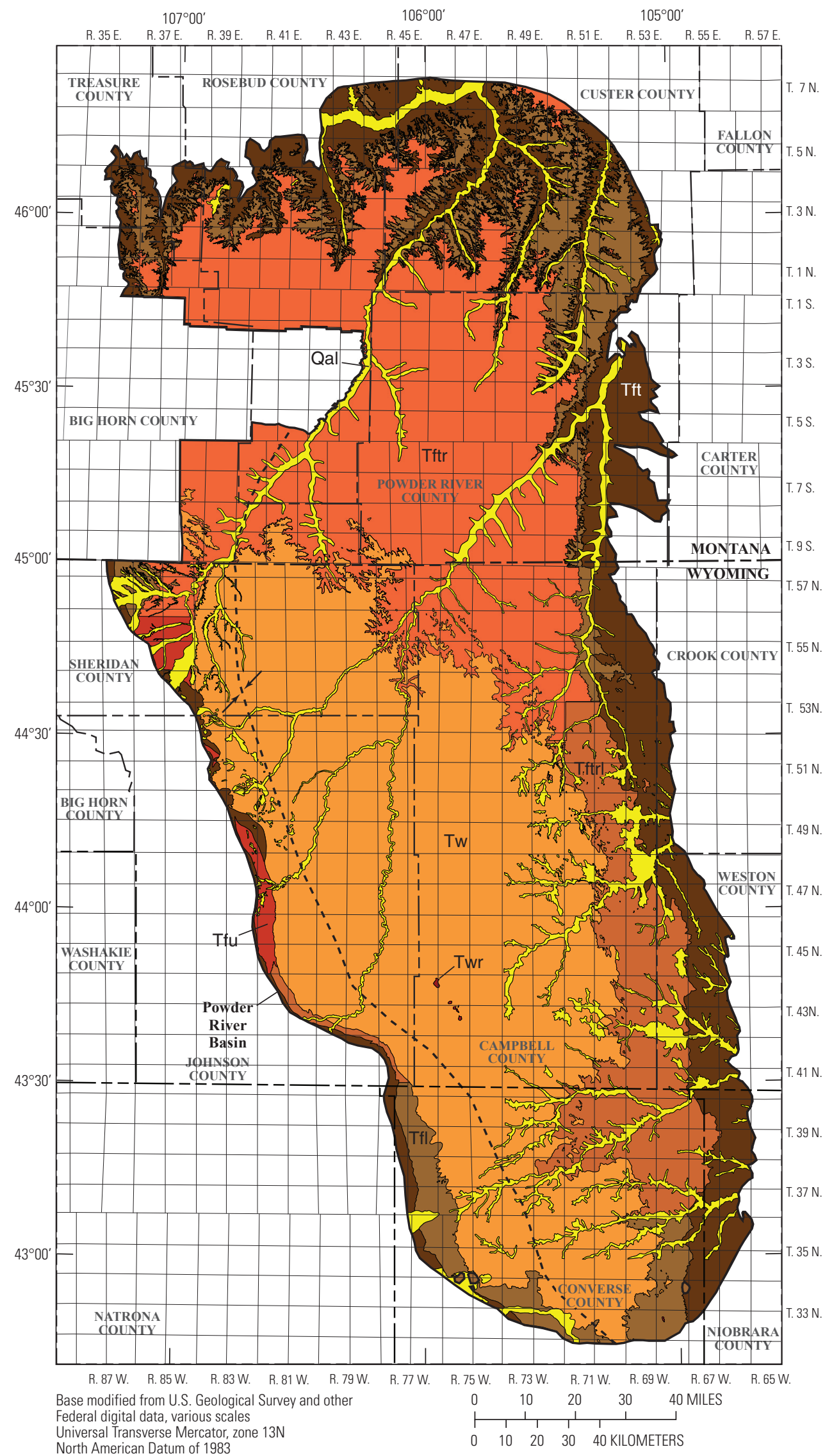

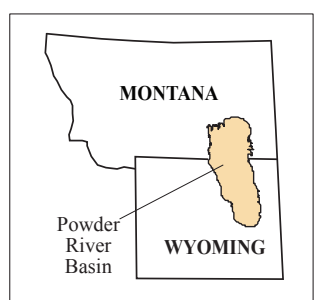

LOCATION MAP

\section{EXPLANATION}

Qal Quaternary alluvium and terrace deposits

Twr Tertiary White River Formation

Tw Tertiary Wasatch Formation

Tfu Tertiary Fort Union Formation (undifferentiated)

Tftr Tongue River Member

Tftrl Tongue River and Lebo Shale Members

Tfl Lebo Shale Member

Tft Tullock Member

$--\downarrow-$ Basin axis (approximately where dashed)

Figure 4. Map showing generalized surface geology of the Powder River Basin, Wyoming and Montana. 


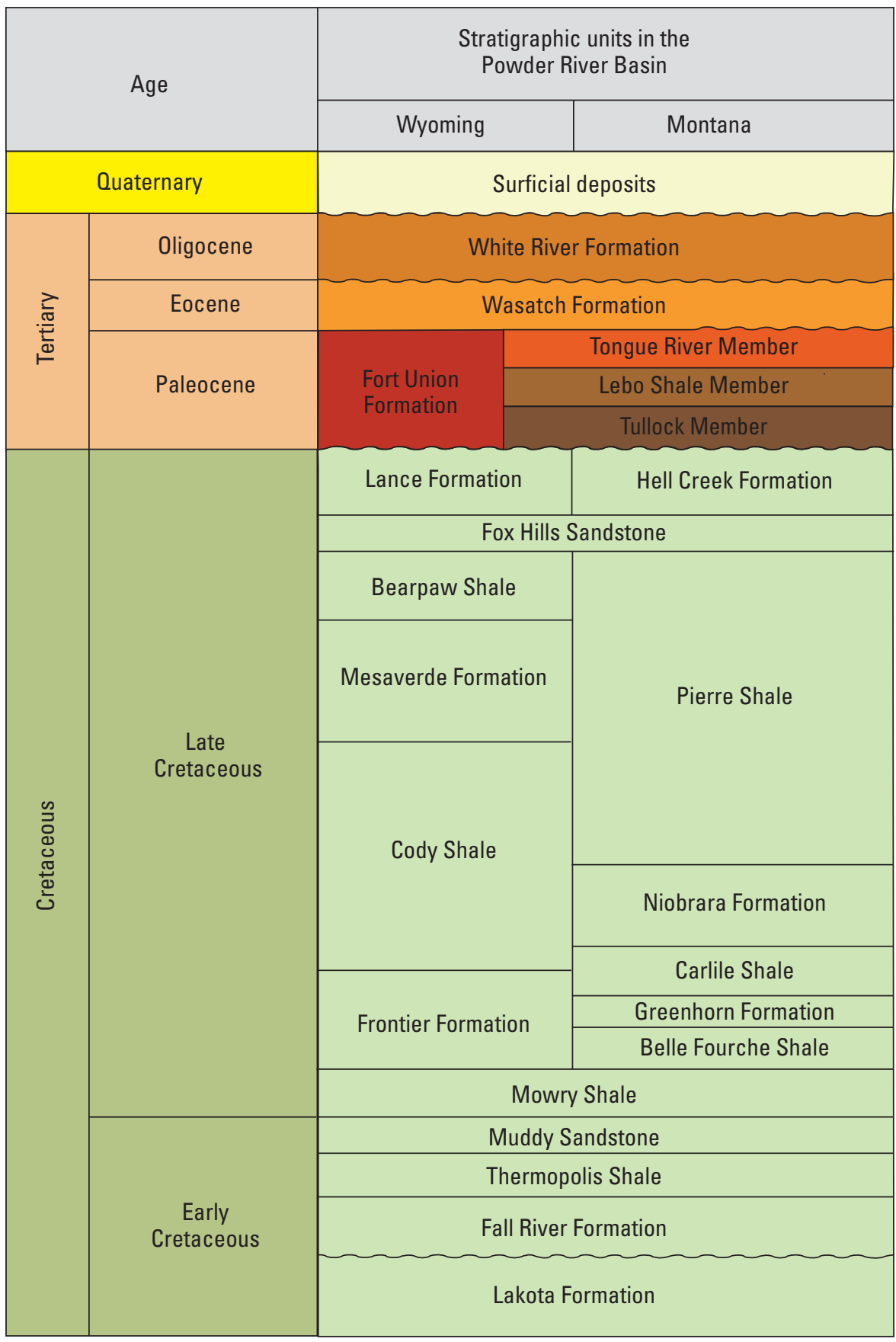

Figure 5. Generalized stratigraphic column for the Powder River Basin, Wyoming and Montana. 

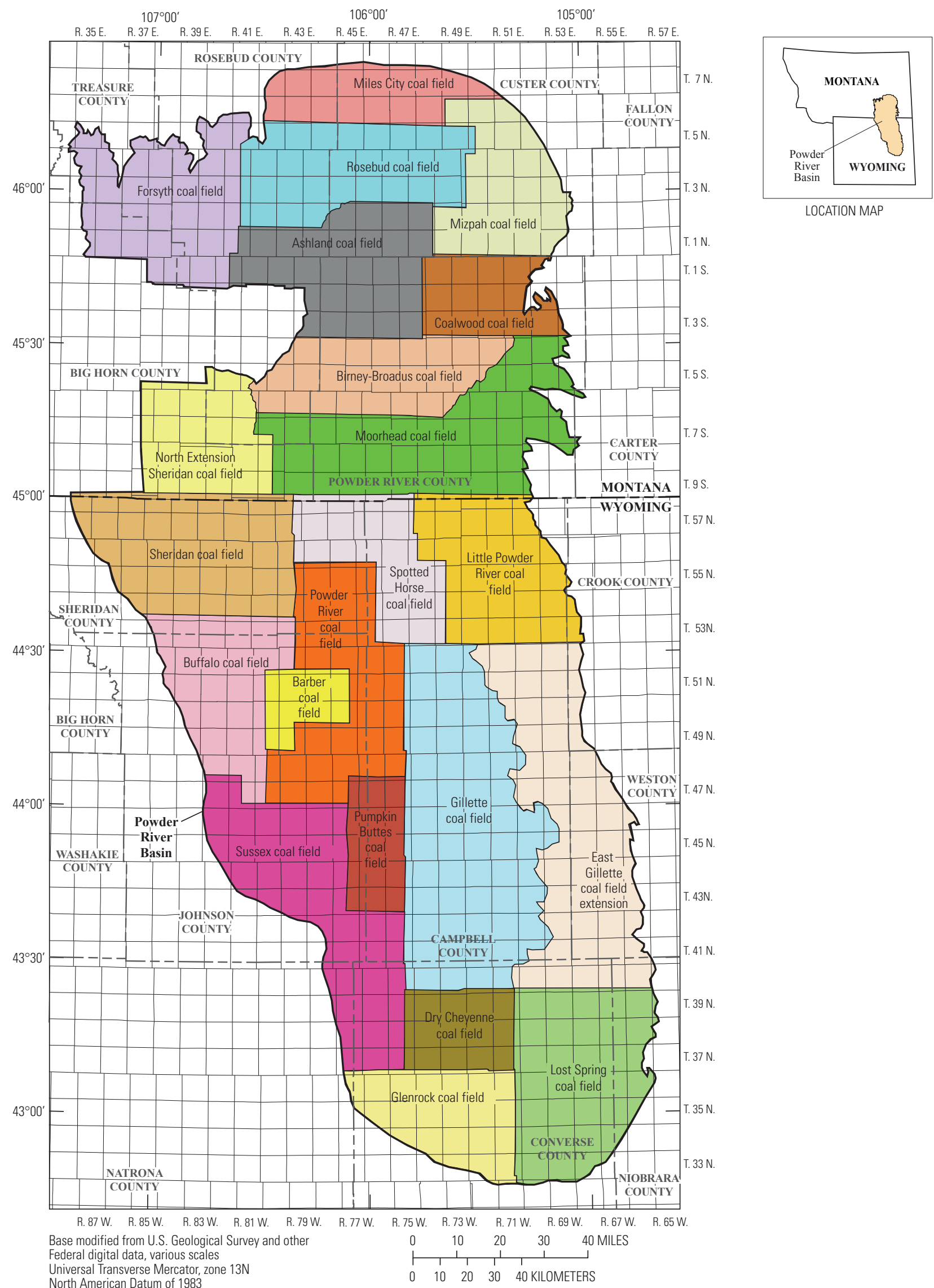

LOCATION MAP

Figure 6. Map showing location of coal fields in the Powder River Basin, Wyoming and Montana. 


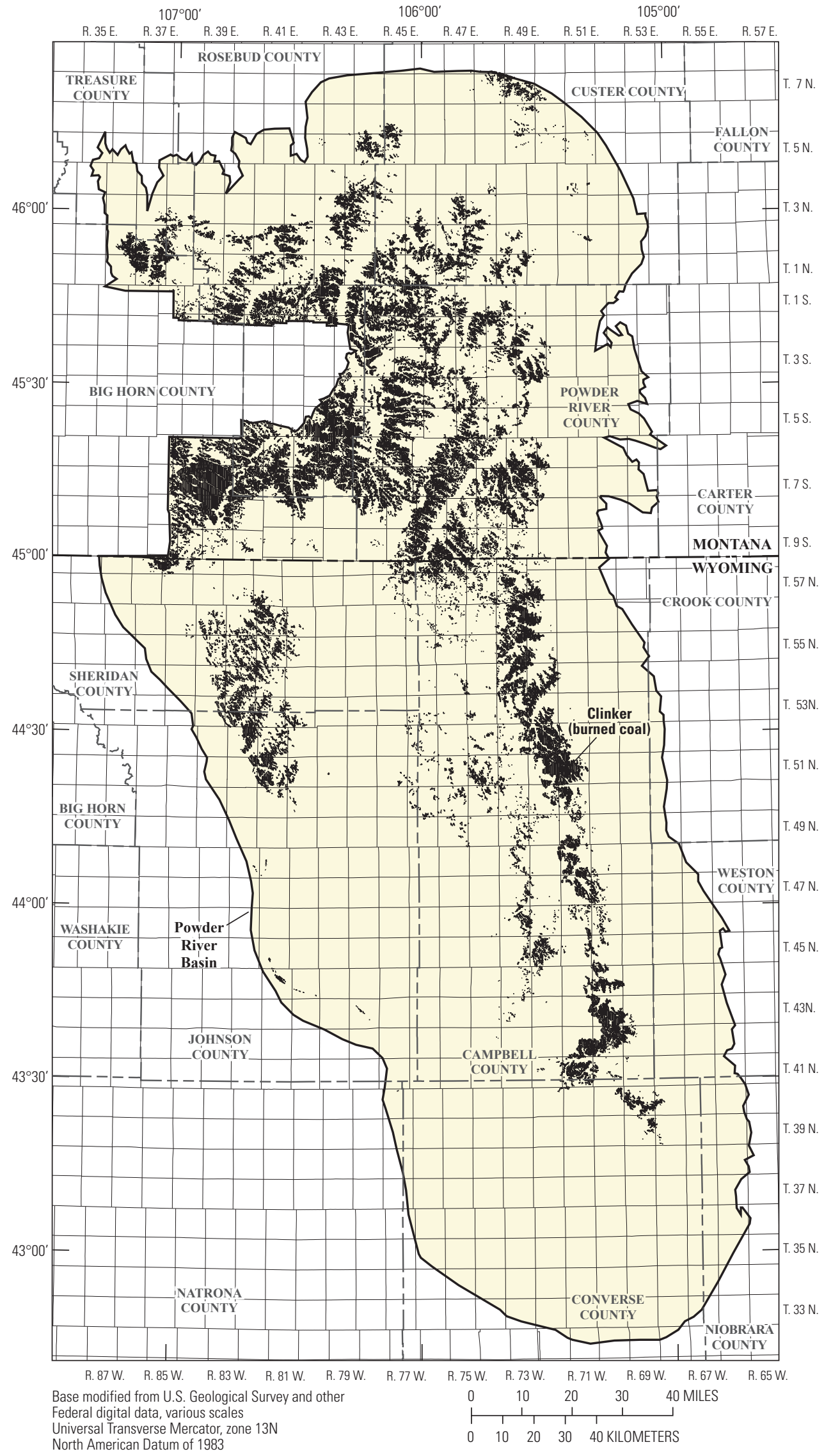

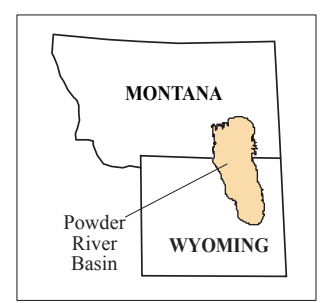

LOCATION MAP

Figure 7. Map showing location of significant clinker in the Powder River Basin, Wyoming and Montana. 


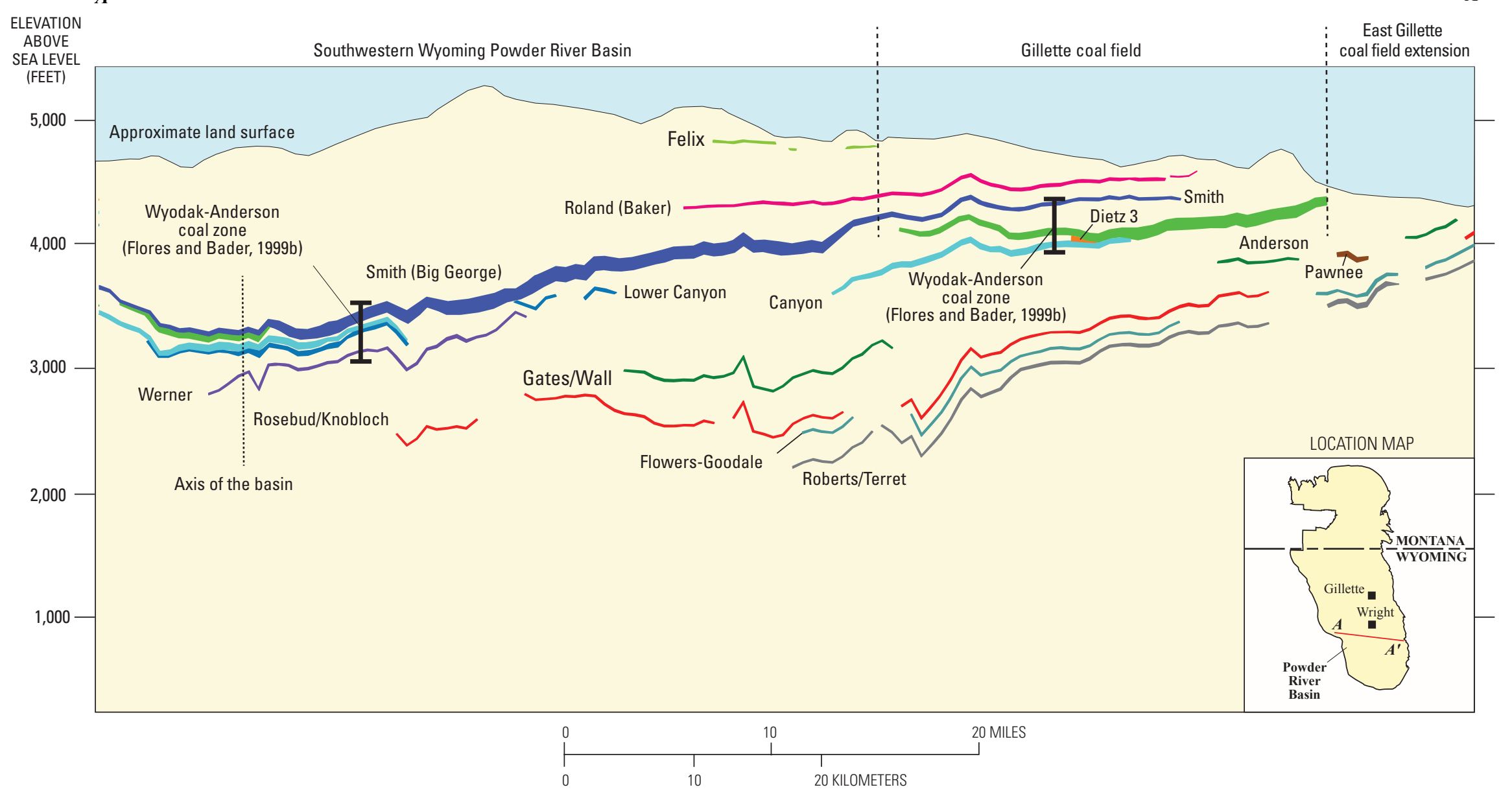

Figure 8. West-east cross section $A-A^{\prime}$ showing subsurface distribution of significant coal beds through the southern part of the Powder River Basin, Wyoming. 


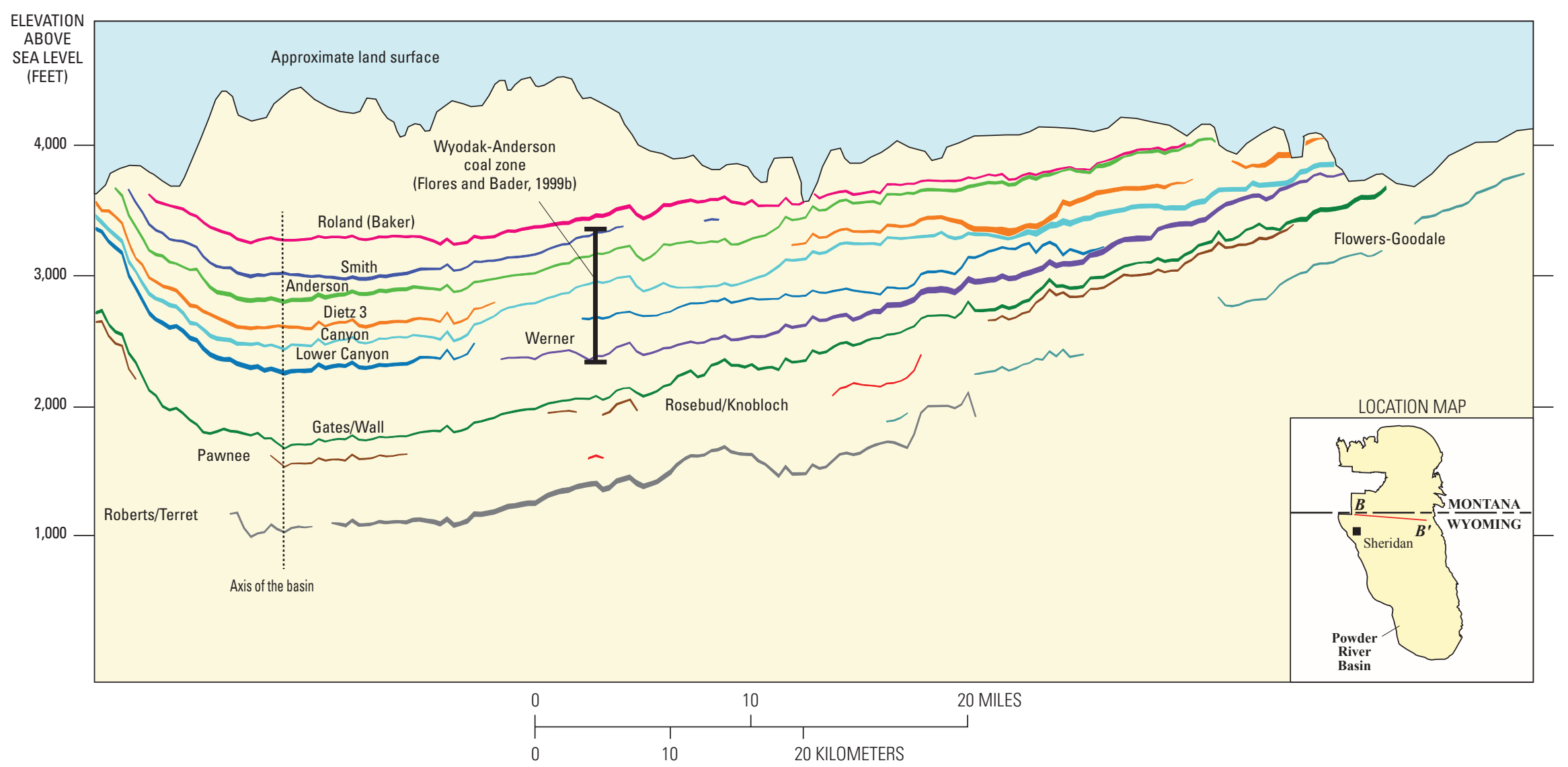

Figure 9. West-east cross section $B-B^{\prime}$ showing subsurface distribution of significant coal beds through the central part of the Powder River Basin, Wyoming. 

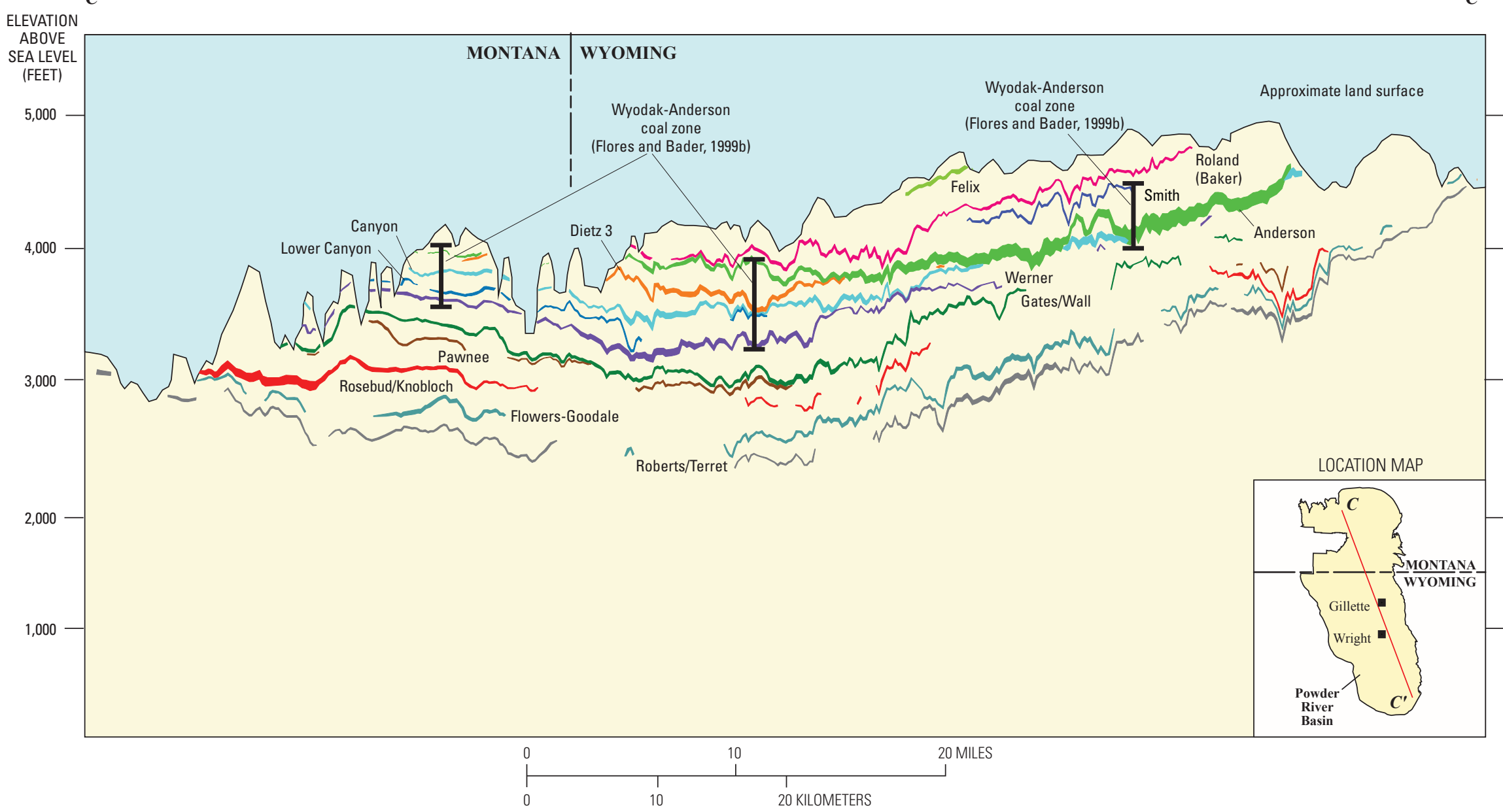

20 MILES

Figure 10. North-south cross section $C-C$ showing subsurface distribution of significant coal beds through the Powder River Basin, Wyoming and Montana. 


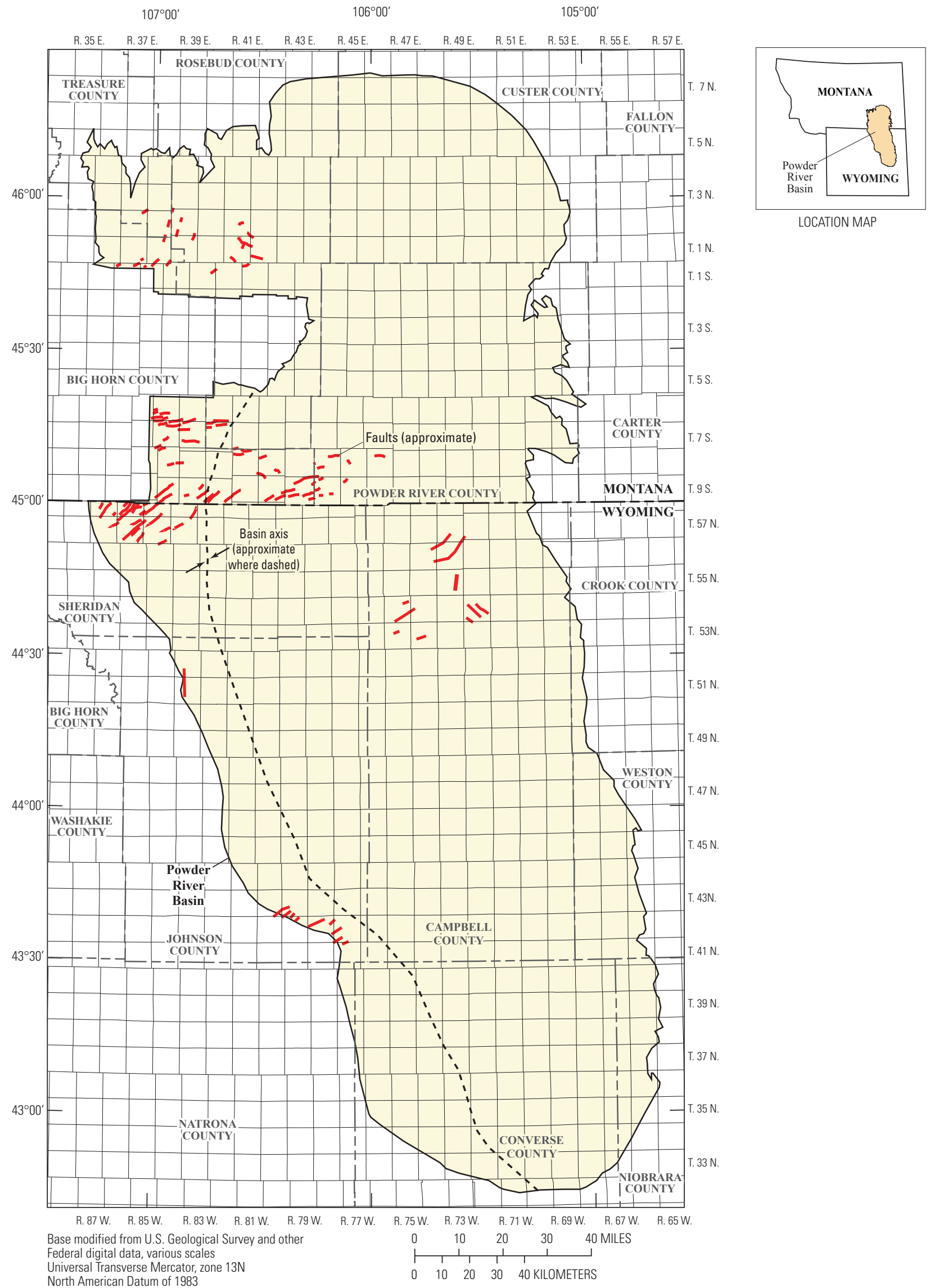

Figure 11. Map showing approximate location of faults within the Powder River Basin, Wyoming and Montana. 


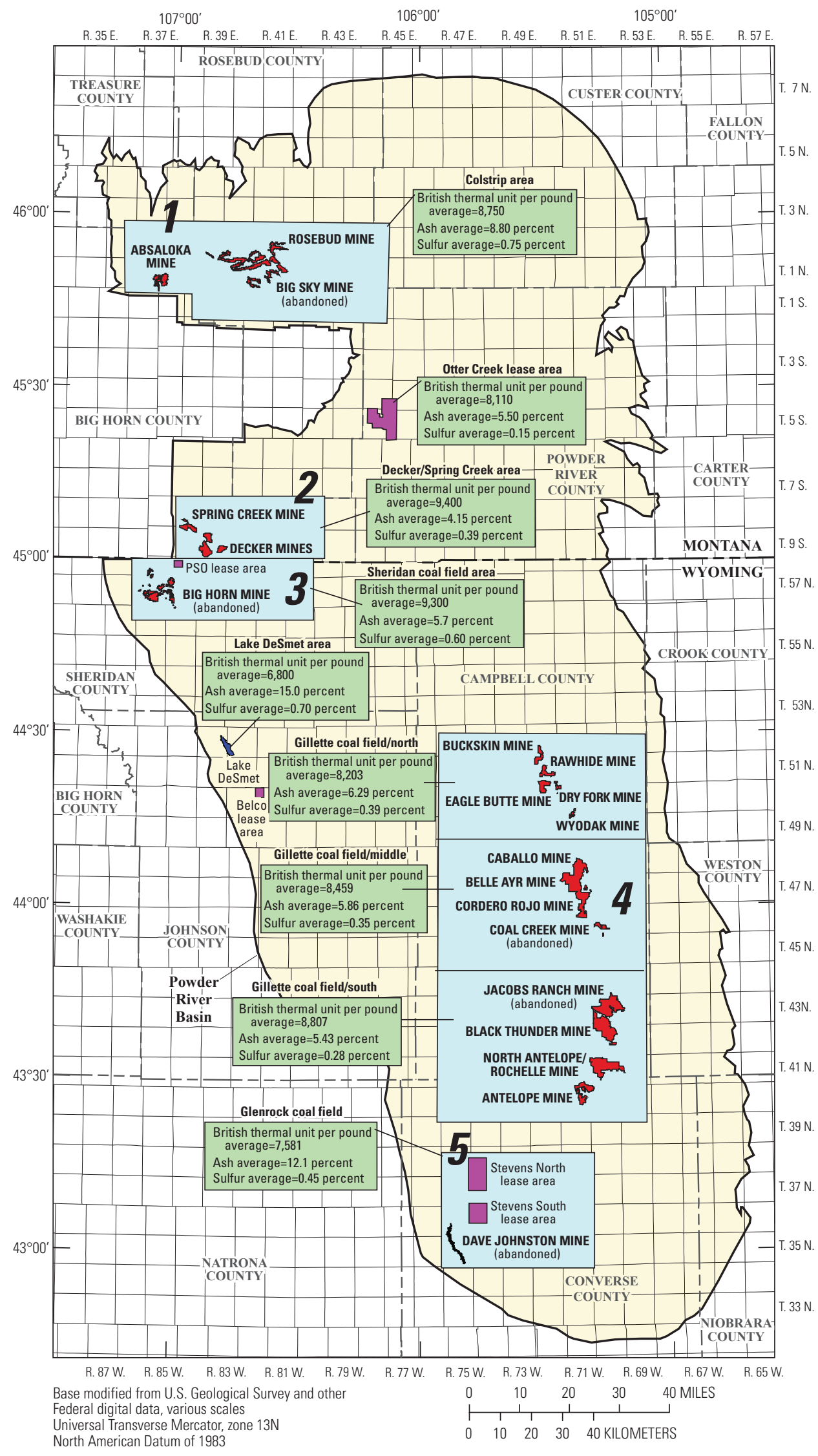

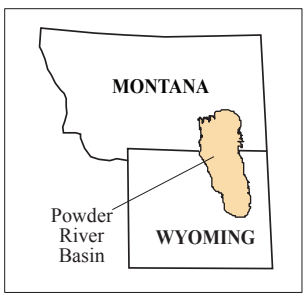

LOCATION MAP

Figure 12. Map showing locations of mines, lease areas, and average coal quality basis within the Powder River Basin, Wyoming and Montana. 


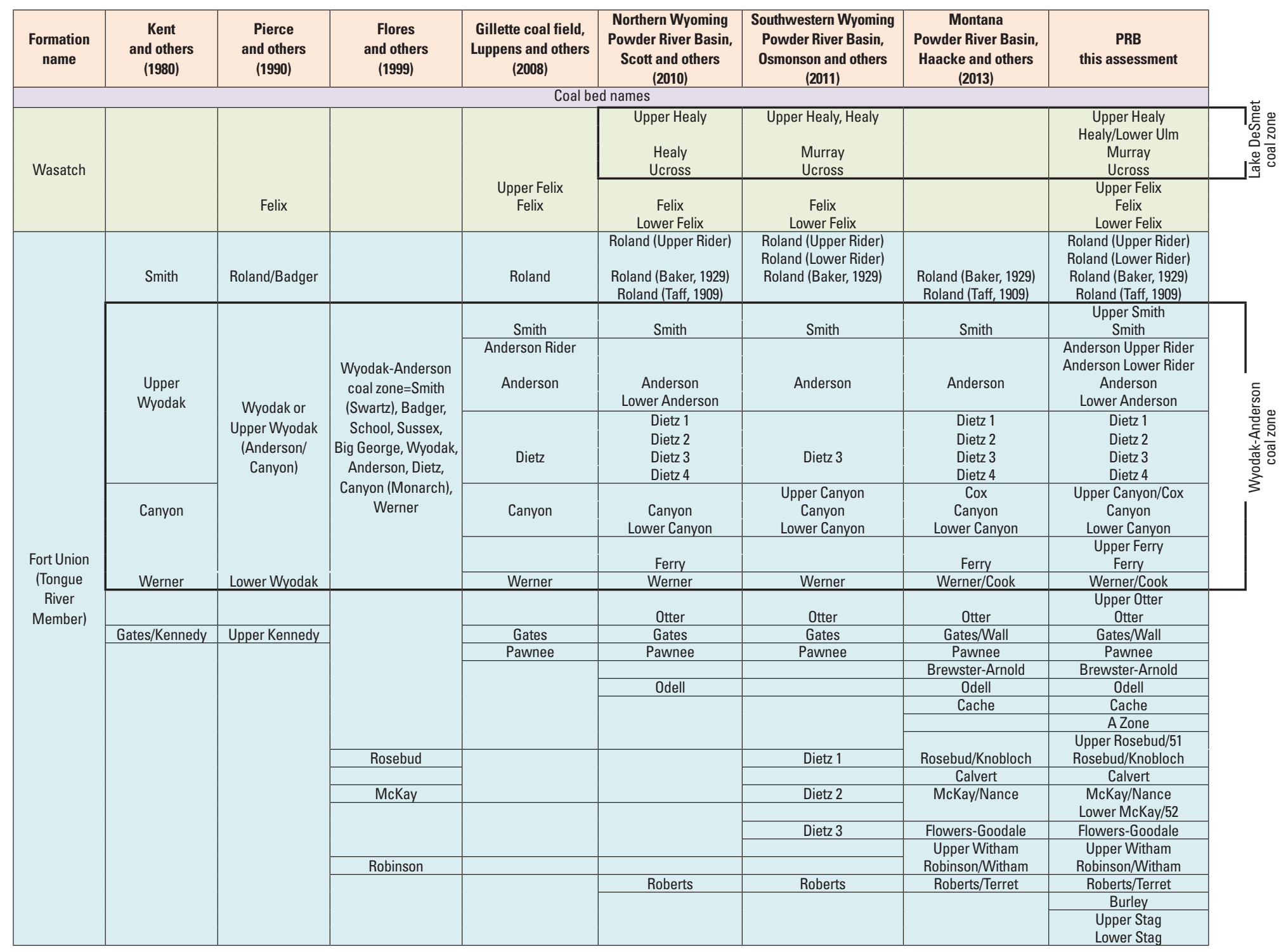

Figure 13. Coal bed and coal zone names used in this assessment and previous publications in the Powder River Basin, Wyoming and Montana. 


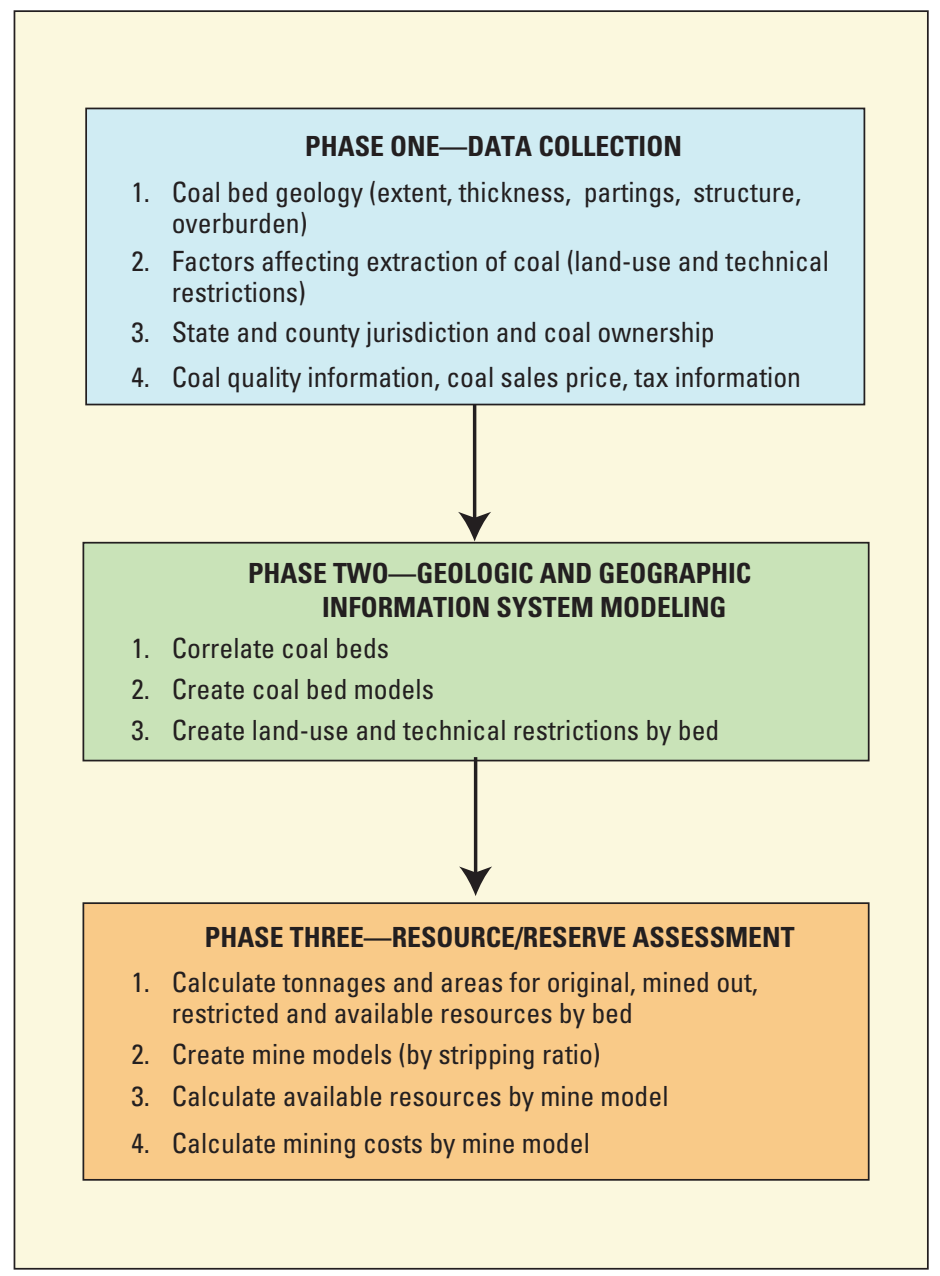

Figure 14. Flow chart showing generalized U.S. Geological Survey methodology used for coal resource and reserve assessment. 


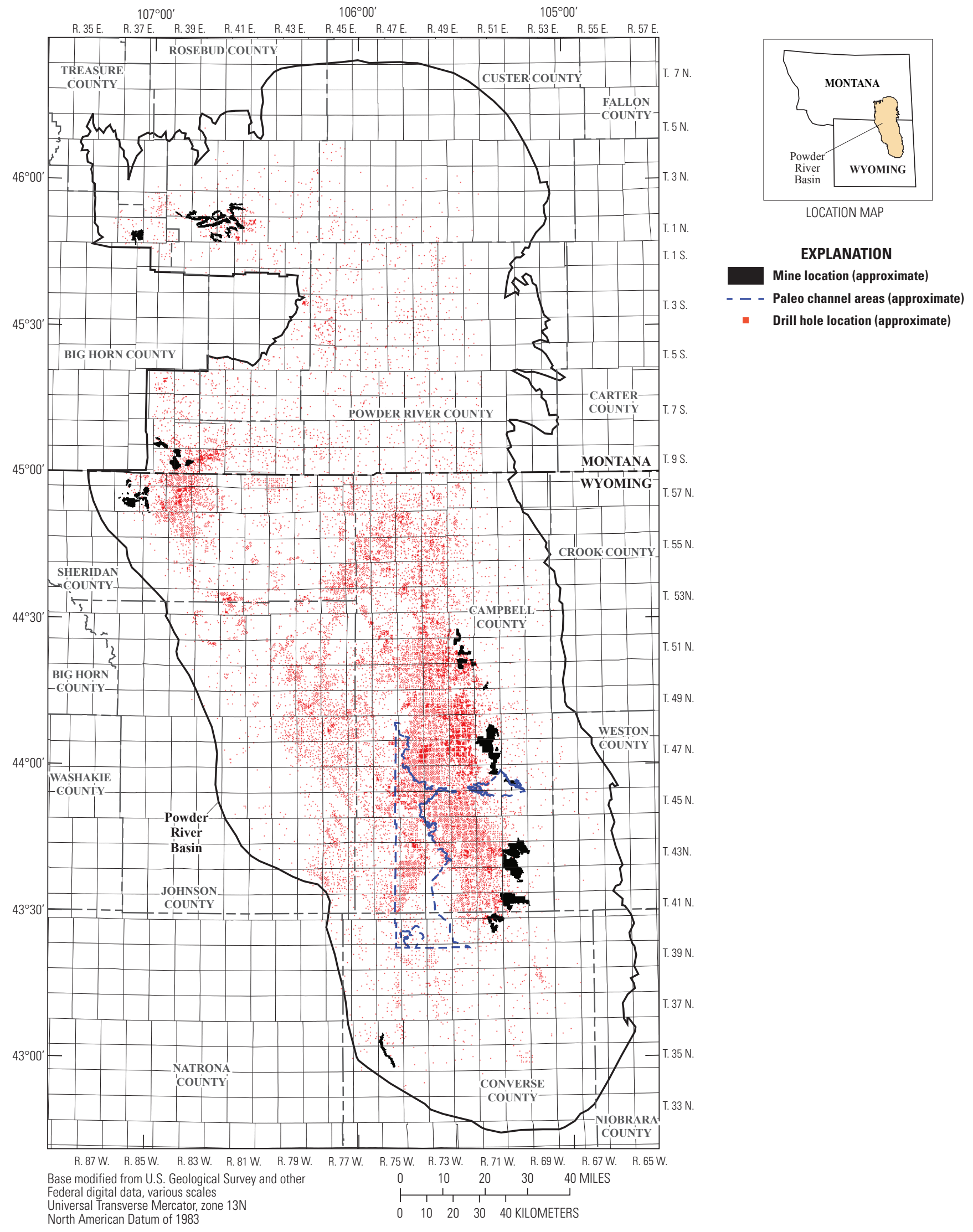

Figure 15. Map showing mines and nonproprietary drill holes and paleochannels within the Anderson coal bed in the Powder River Basin, Wyoming and Montana. 


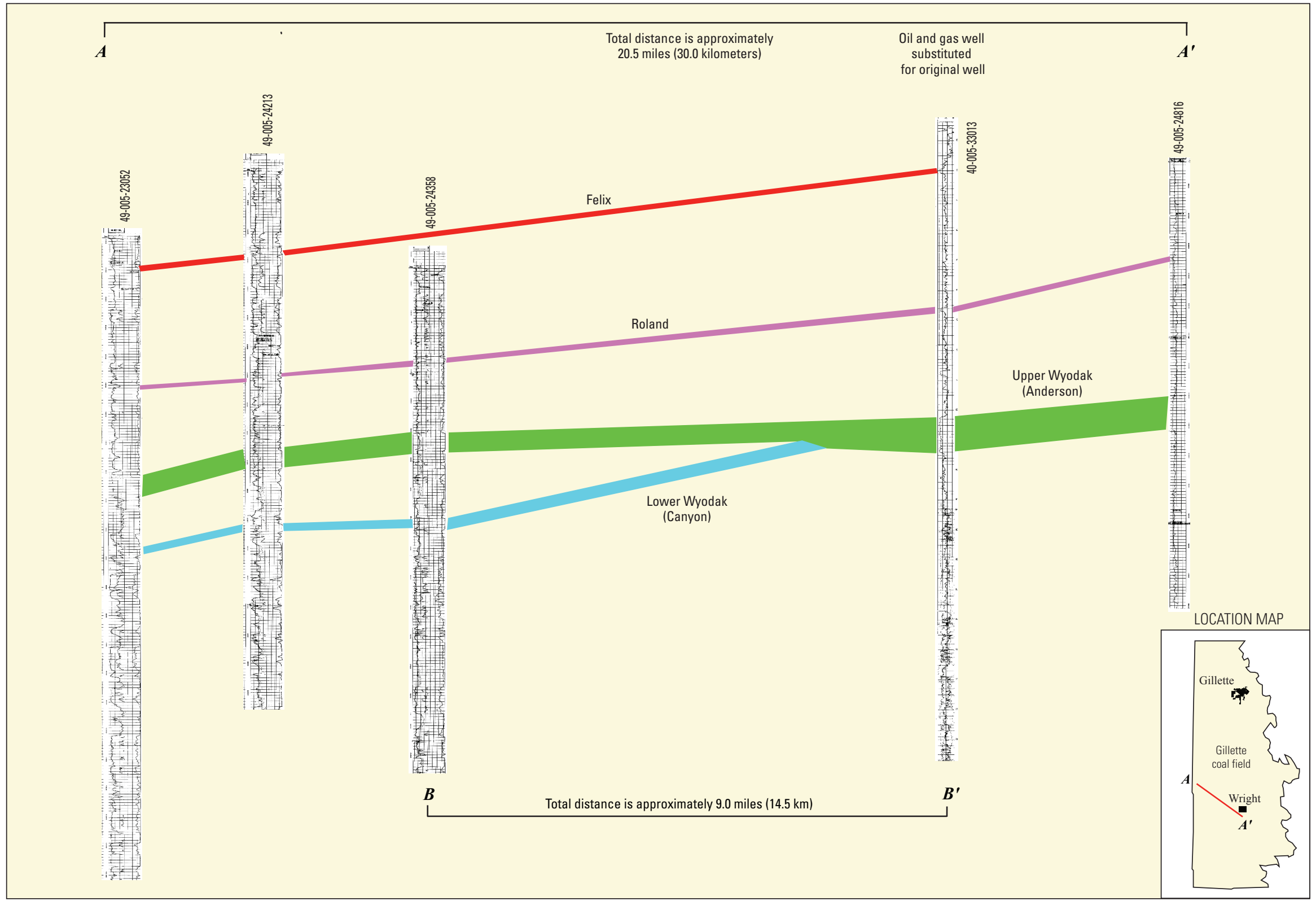

Figure 16. Cross section A- $A^{\prime}$ showing correlations used in the U.S. Geological Survey Miscellaneous Investigations Series Map I-1959-D by Molnia and Pierce (1992). 


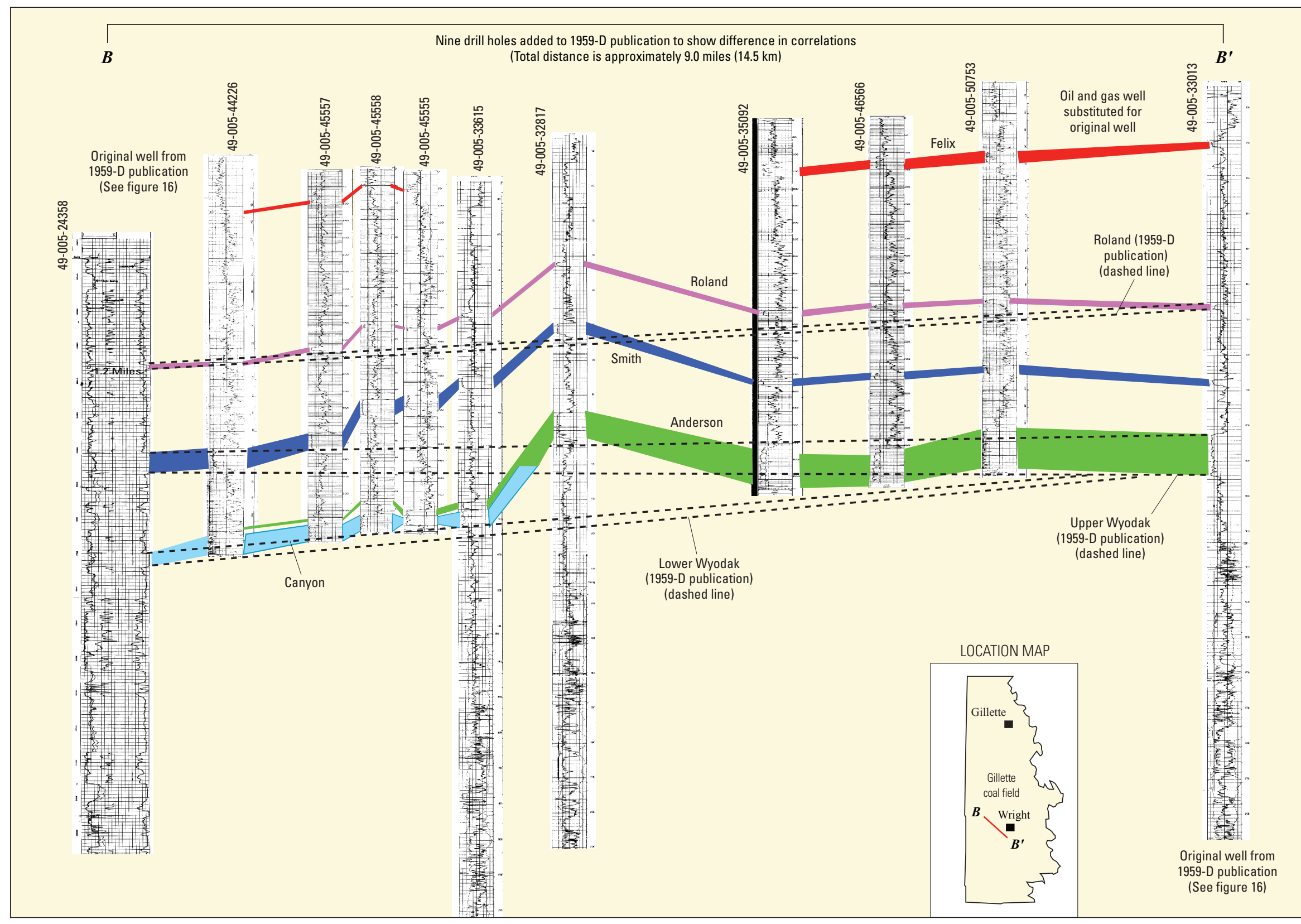

Figure 17. Cross section $B-B^{\prime}$ showing comparison of coal bed correlations made in the Gillette coal field report to the U.S. Geological Survey Miscellaneous Investigations Series Map I-1959-D by Molnia and Pierce (1992). 


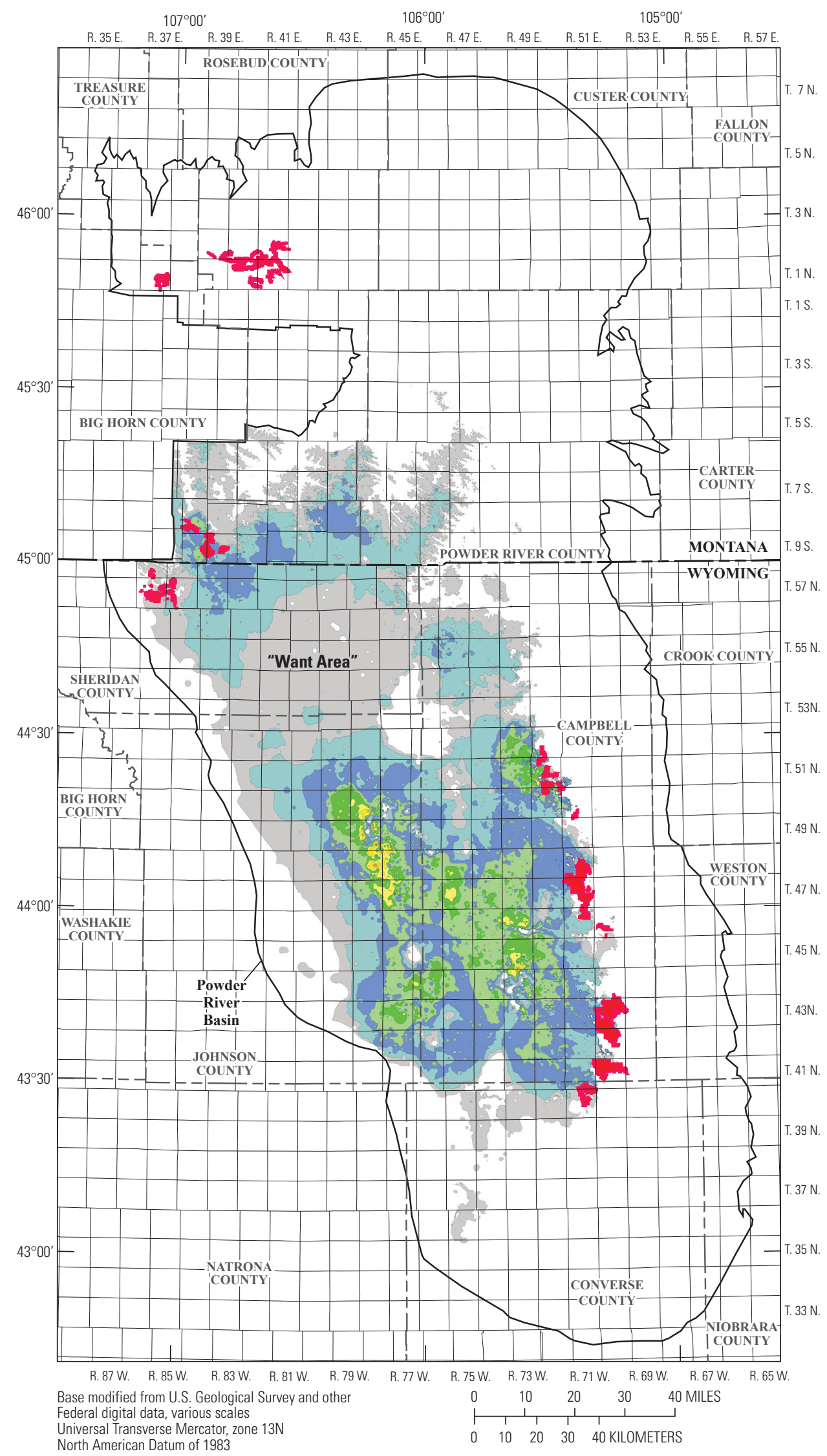

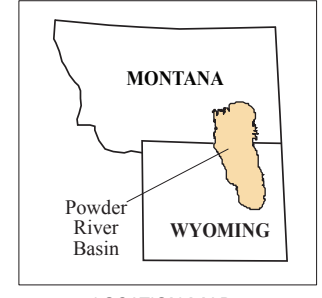

LOCATION MAP

EXPLANATION

Thickness (feet)

300 and greater

250

200

150

125

100

75

50

25

5

Mine area

Figure 18. Isopach map showing combined thickness of the Smith, Anderson, and Canyon coal beds and areas of thin or absent coal ("want area" after Flores and others, 2010) within the Powder River Basin, Wyoming and Montana. 


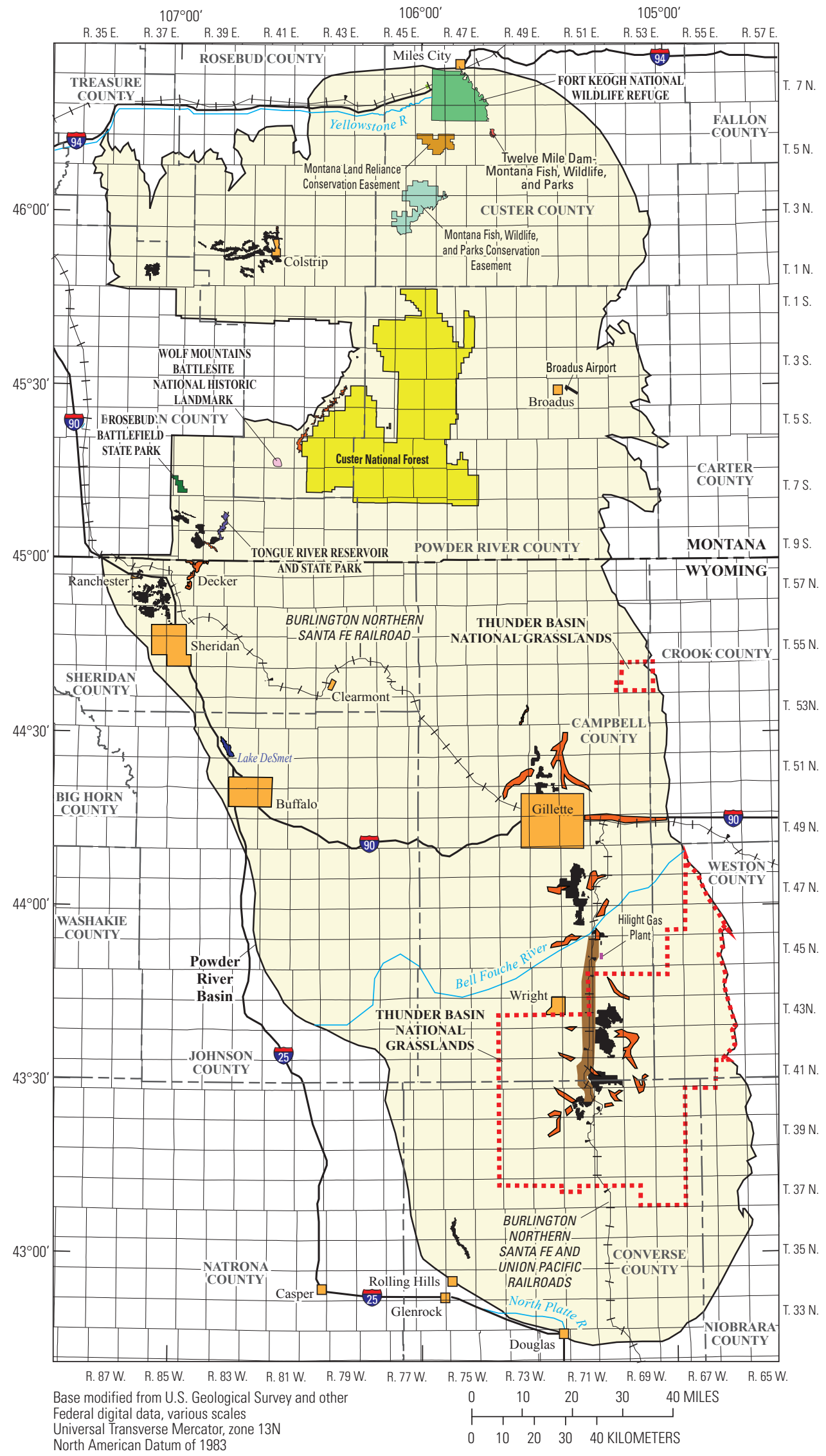

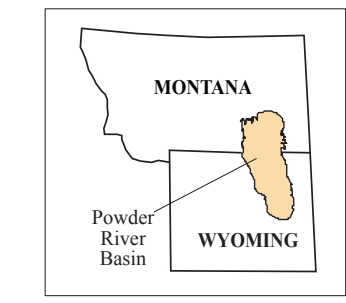

LOCATION MAP

EXPLANATION

Area of joint line box cut offset

Alluvial valley floor

Mine area

Figure 19. Map showing land-use restrictions in the Powder River, Wyoming and Montana. 


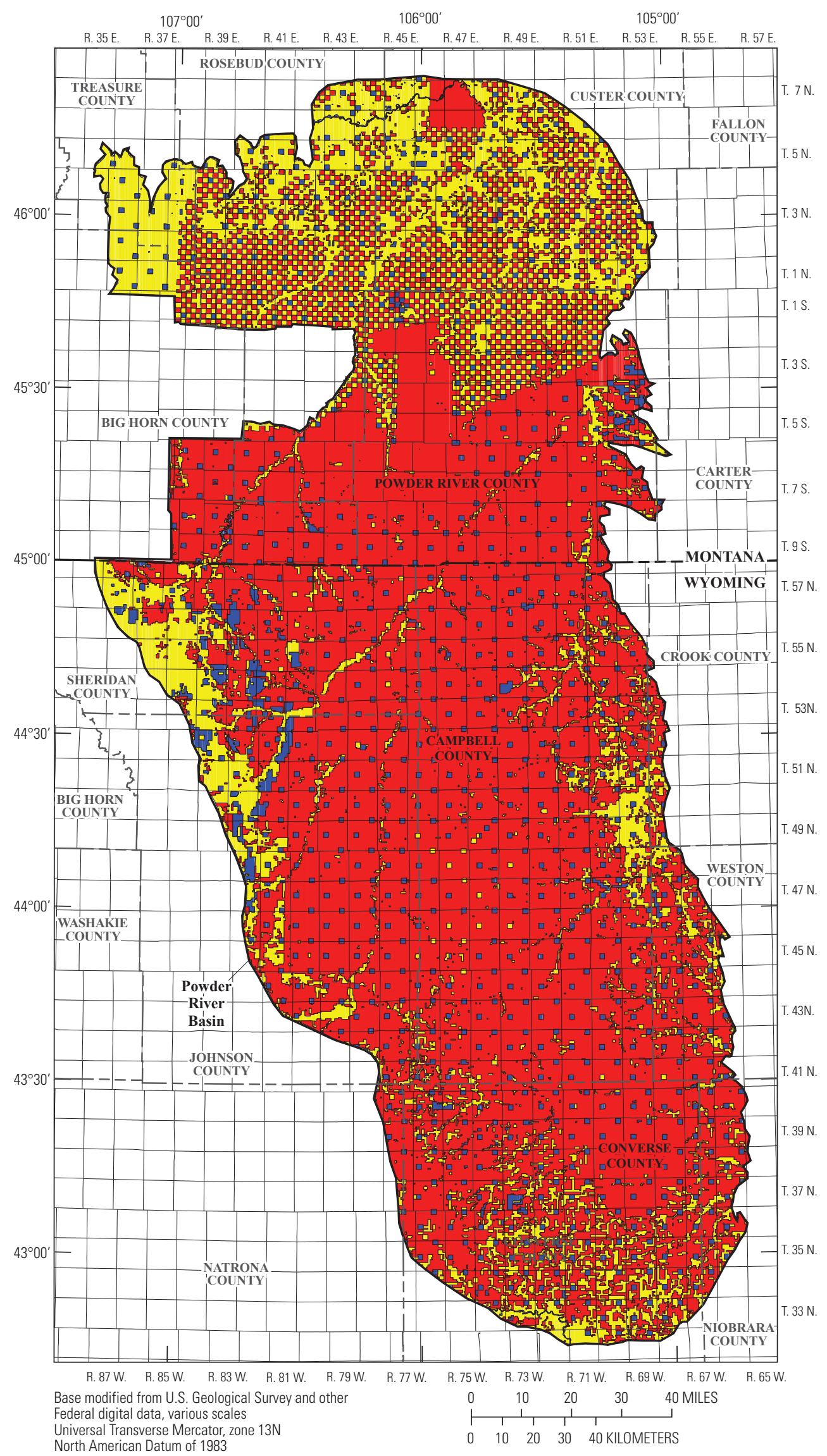

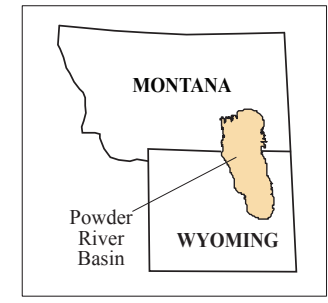

LOCATION MAP

EXPLANATION

Federal coal

State coal

Private coal

Figure 20. Map showing coal mineral estate ownership in the Powder River Basin, Wyoming and Montana. 


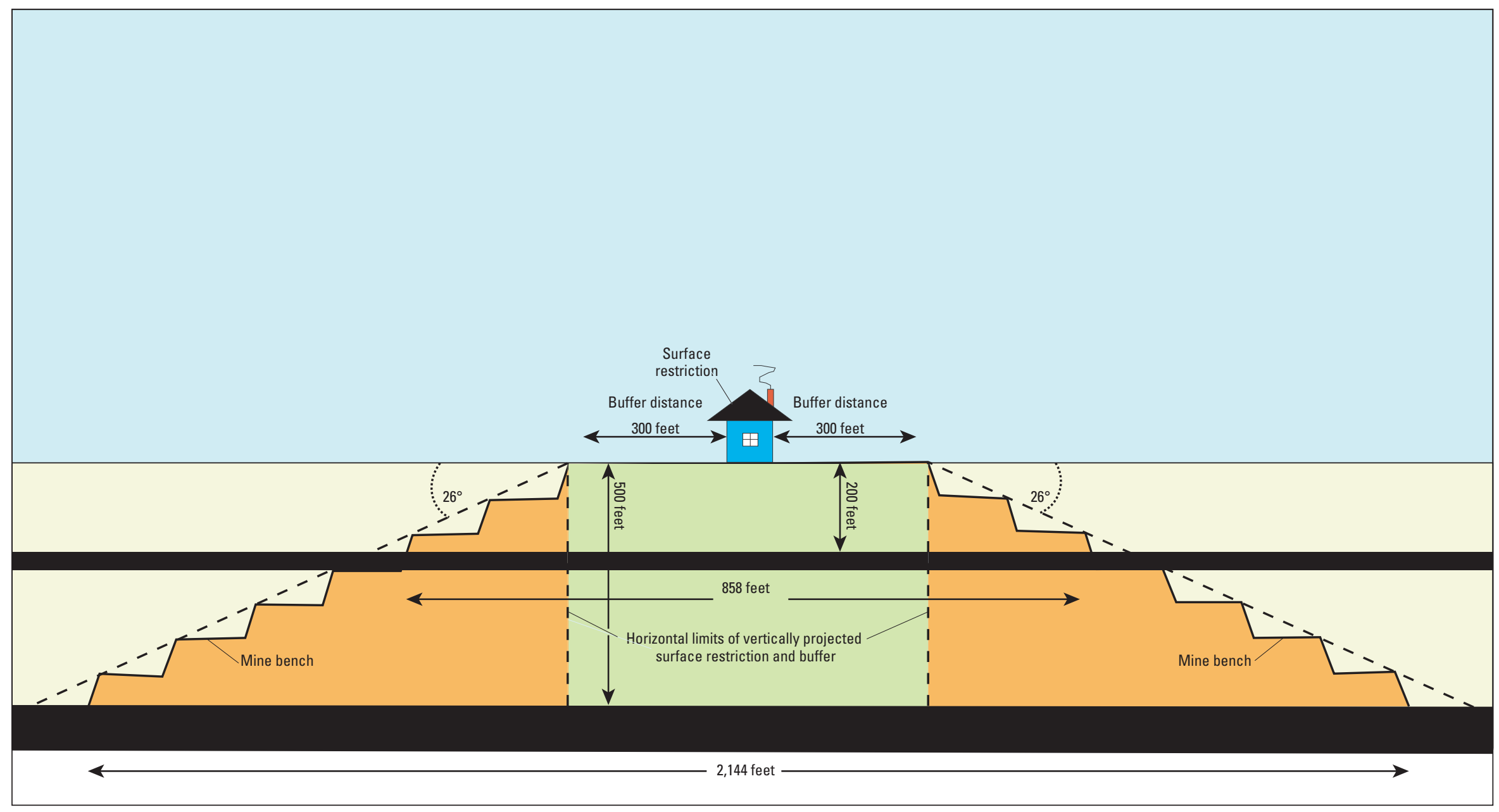

\section{EXPLANATION}

Coal bed

Mine accessible coal-bearing rock

Surface restriction and buffer projected

downward (coal unavailable for mining)

Additional restriction due to required mine

pit highwall angle (coal unavailable

for mining)

Restriction to mining

Figure 21. Illustration showing the effect of coal-bed depth upon restricted resource because of mine-pit highwall setback requirements. 


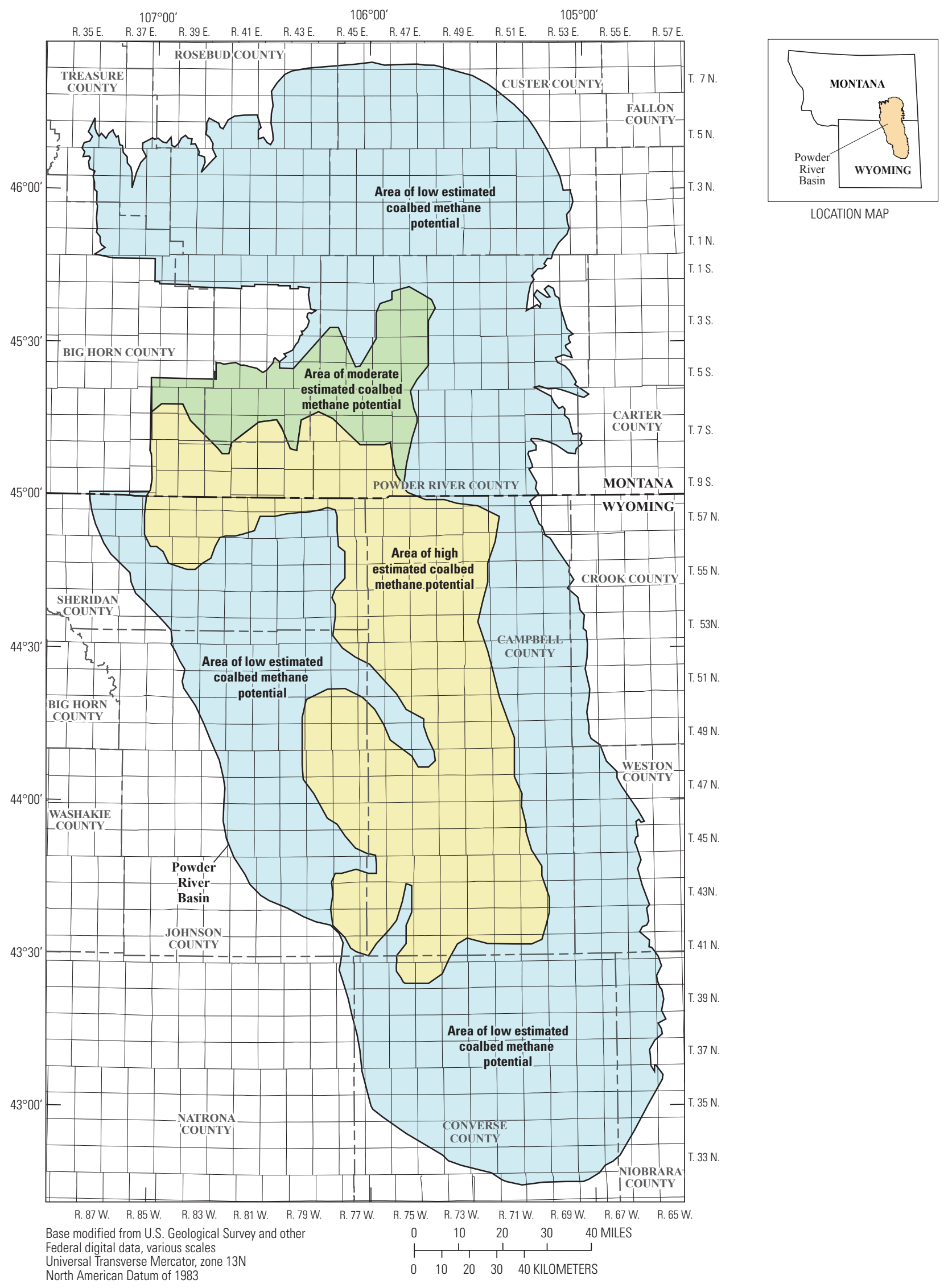

Figure 22. Map showing location of areas of low, moderate, and high coalbed methane potential in the Powder River Basin, Wyoming and Montana. 


\begin{tabular}{|c|c|c|c|c|c|c|}
\hline \multicolumn{6}{|c|}{ Coal bed stratigraphy, original and available resources, and thickness } & \multirow{50}{*}{ 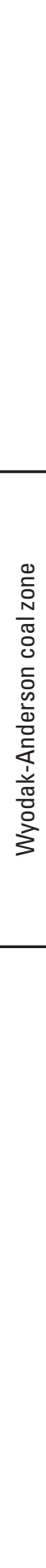 } \\
\hline $\begin{array}{c}\text { Formation } \\
\text { name }\end{array}$ & $\begin{array}{c}\text { Coal beds } \\
\text { identified in } \\
\text { this assessment }\end{array}$ & $\begin{array}{l}\text { Original } \\
\text { resources } \\
\text { calculate } \\
\text { (millions of tons) }\end{array}$ & $\begin{array}{l}\text { Available } \\
\text { resources } \\
\text { calculated } \\
\text { (millions of tons) }\end{array}$ & $\begin{array}{l}\text { Maximum } \\
\text { thickness } \\
\text { (feet) }\end{array}$ & $\begin{array}{c}\text { Average } \\
\text { thickness } \\
\text { (feet) }\end{array}$ & \\
\hline \multirow{7}{*}{ Wasatch } & Upper Healy & 6,863 & 5,327 & 17 & 12 & \\
\hline & Healy/Lower Ulm & 13,004 & 10,738 & 83 & 14 & \\
\hline & Murray & 2,664 & 599 & 14 & 3 & \\
\hline & Ucross & 6,808 & 4,492 & 40 & 7 & \\
\hline & Upper Felix & 2,122 & 1,205 & 19 & 4 & \\
\hline & Felix & 18,759 & 16,784 & 55 & 12 & \\
\hline & Lower Felix & 19,385 & 14,929 & 53 & 7 & \\
\hline \multirow{41}{*}{$\begin{array}{c}\text { Fort Union } \\
\text { (Tongue River } \\
\text { Member) }\end{array}$} & Roland Upper Rider & 13,506 & 8,304 & 32 & 4 & \\
\hline & Roland Lower Rider & 3,257 & 1,693 & 20 & 4 & \\
\hline & Roland (Baker, 1929) & 47,774 & 43,336 & 40 & 10 & \\
\hline & Roland (Taff, 1909) & 3,403 & 1,290 & 27 & 3 & \\
\hline & Upper Smith & 1,036 & 430 & 36 & 3 & \\
\hline & Smith & 126,433 & 122,868 & 278 & 24 & \\
\hline & Anderson Upper Rider & 272 & 44 & 18 & 3 & \\
\hline & Anderson Lower Rider & 755 & 480 & 20 & 8 & \\
\hline & Anderson & 125,481 & 101,825 & 225 & 24 & \\
\hline & Lower Anderson & 3,382 & 2,039 & 44 & 4 & \\
\hline & Dietz 1 & 1,138 & 495 & 29 & 4 & \\
\hline & Dietz 2 & 2,992 & 2,032 & 37 & 6 & \\
\hline & Dietz 3 & 50,880 & 45,063 & 119 & 13 & \\
\hline & Dietz 4 & 1,765 & 807 & 20 & 3 & \\
\hline & Upper Canyon/Cox & 5,968 & 4,711 & 31 & 7 & \\
\hline & Canyon & 147,450 & 135,454 & 183 & 21 & \\
\hline & Lower Canyon & 59,528 & 52,056 & 85 & 11 & \\
\hline & Upper Ferry & 814 & 464 & 10 & 4 & \\
\hline & Ferry & 6,396 & 4,277 & 28 & 5 & \\
\hline & Werner/Cook & 73,986 & 63,353 & 90 & 13 & \\
\hline & Upper Otter & 919 & 604 & 21 & 4 & \\
\hline & Otter & 71,021 & 64,310 & 170 & 14 & \\
\hline & Gates/Wall & 66,426 & 57,851 & 125 & 9 & \\
\hline & Pawnee & 24,498 & 16,964 & 34 & 7 & \\
\hline & Brewster-Arnold & 1,968 & 475 & 19 & 5 & \\
\hline & Odell & 11,676 & 6,581 & 26 & 4 & \\
\hline & Cache & 3,303 & 809 & 26 & 3 & \\
\hline & A Zone & 111 & 15 & 9 & 3 & \\
\hline & Upper Rosebud/S1 & 209 & 54 & 15 & 3 & \\
\hline & Rosebud/Knobloch & 64,401 & 47,091 & 73 & 12 & \\
\hline & Calvert & 1,162 & 196 & 18 & 3 & \\
\hline & McKay/Nance & 33,289 & 22,614 & 36 & 5 & \\
\hline & Lower McKay/S2 & 190 & 1 & 7 & 3 & \\
\hline & Flowers-Goodale & 60,544 & 51,064 & 40 & 8 & \\
\hline & Upper Witham & 117 & 68 & 29 & 4 & \\
\hline & Robinson/Witham & 20,677 & 15,007 & 41 & 7 & \\
\hline & Roberts/Terret & 51,866 & 44,467 & 42 & 8 & \\
\hline & Burley & 1,632 & 684 & 10 & 3 & \\
\hline & Upper Stag & 1,870 & 790 & 13 & 3 & \\
\hline & Lower Stag & 151 & 11 & 6 & 3 & \\
\hline & TOTAL TONS & $1,161,851$ & 974,751 & & & \\
\hline
\end{tabular}

Figure 23. Coal bed stratigraphy, original and available resources, and maximum and average thicknesses for coal beds in the Powder River Basin, Wyoming and Montana. 


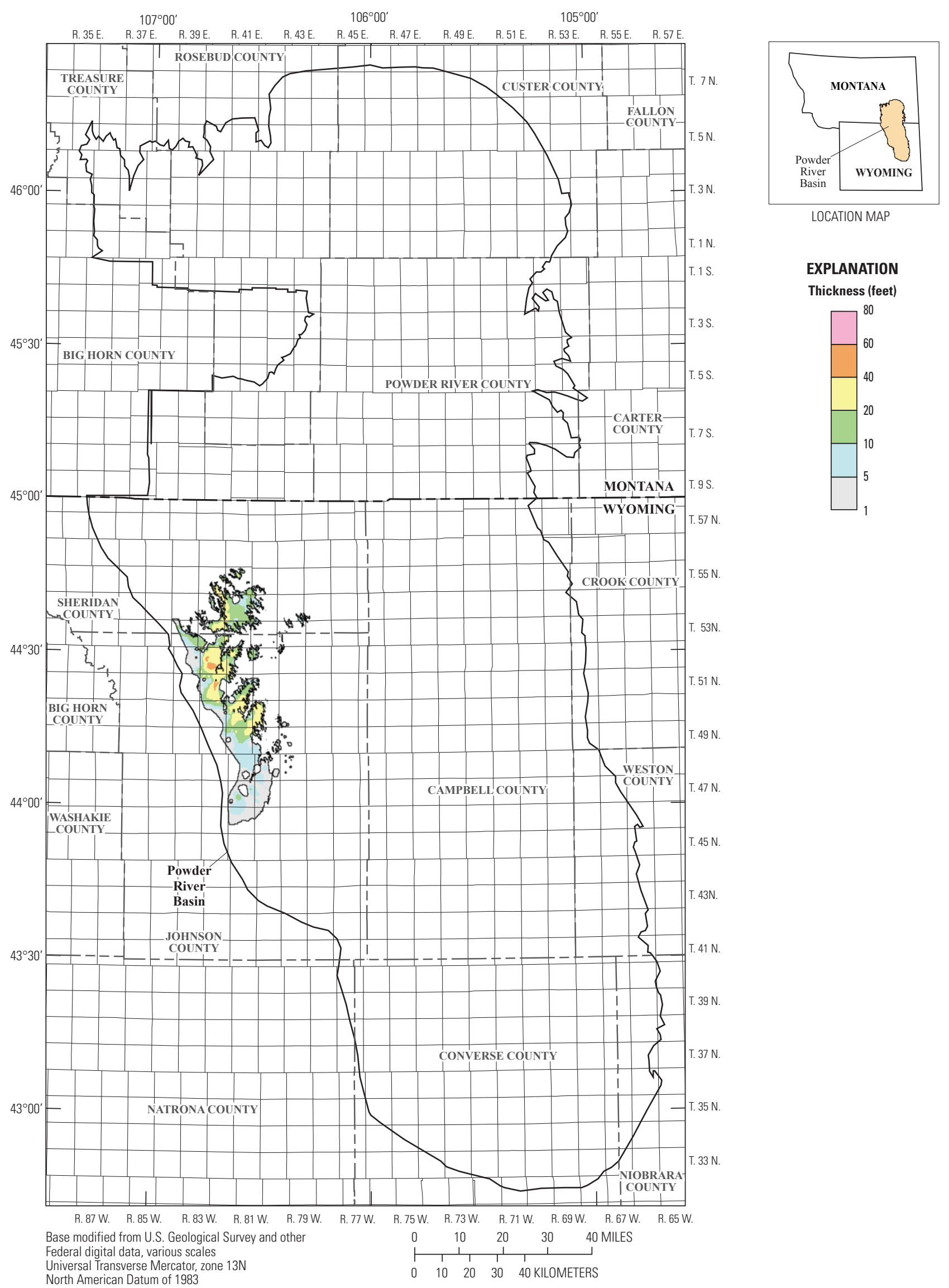

Figure 24. Isopach map of the Upper Healy coal bed showing extent of coal at least 1.0 foot thick within the Powder River Basin. 


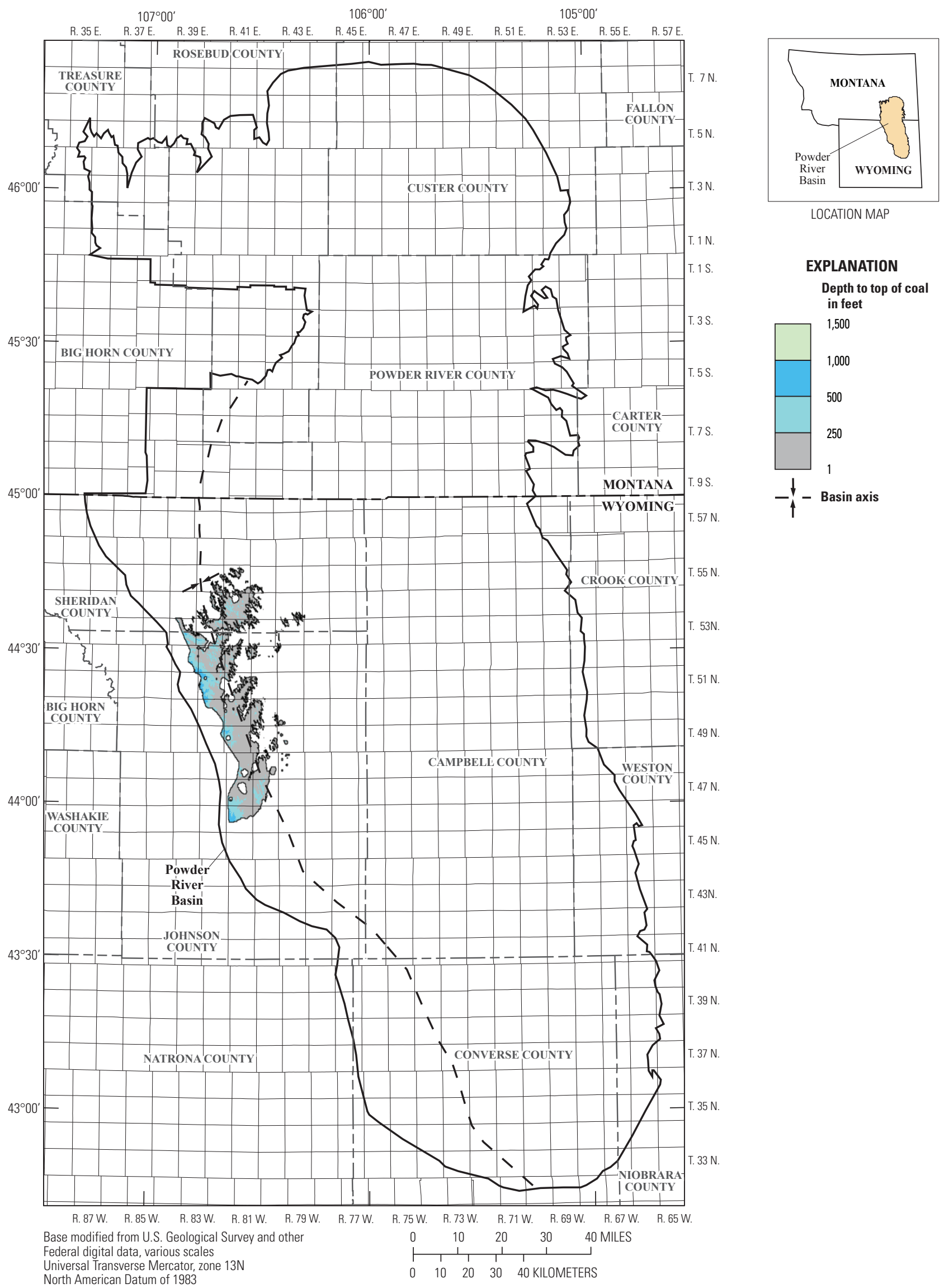

Figure 25. Map showing depth to the top of the Upper Healy coal bed within the Powder River Basin. 


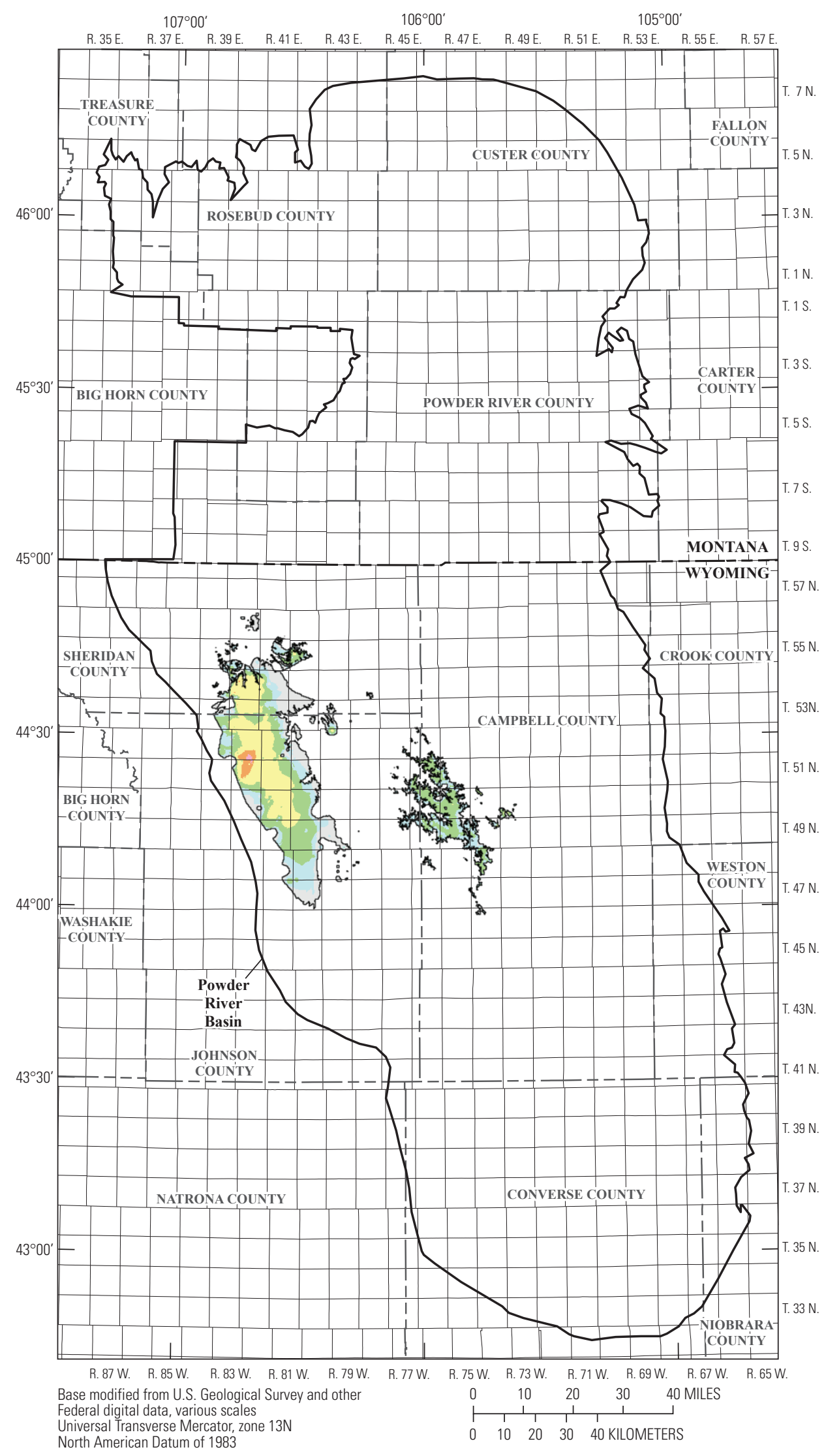

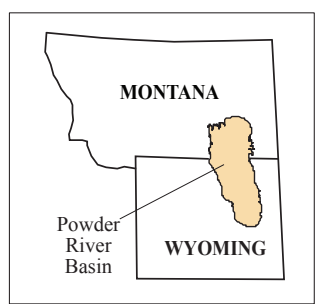

LOCATION MAP

EXPLANATION

Thickness in feet

100

80

60

40

20

10

5

Figure 26. Isopach map of the Healy/Lower Ulm coal bed showing extent of coal at least 1.0 foot thick within the Powder River Basin. 


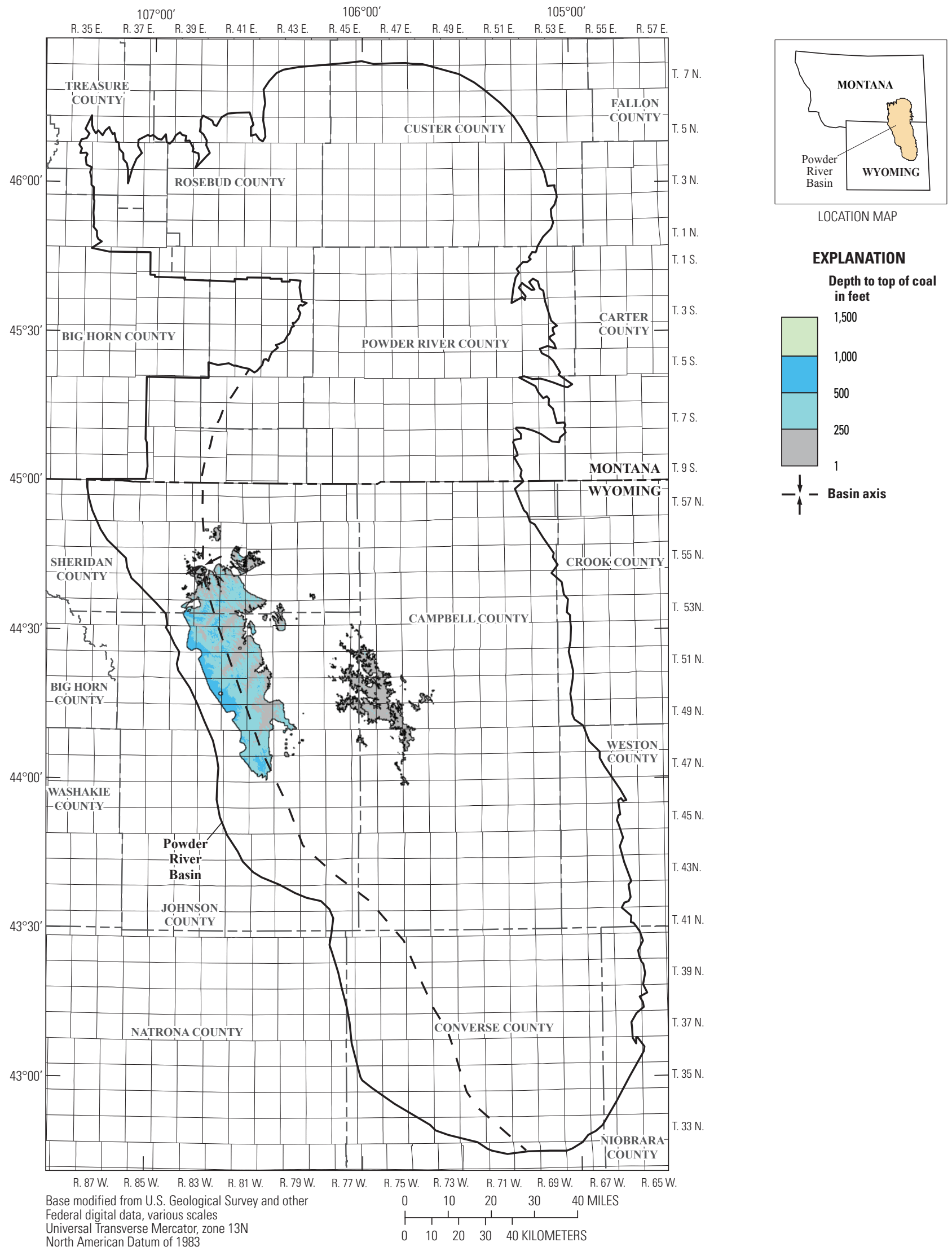

Figure 27. Map showing depth to the top of the Healy/Lower Ulm coal bed within the Powder River Basin. 


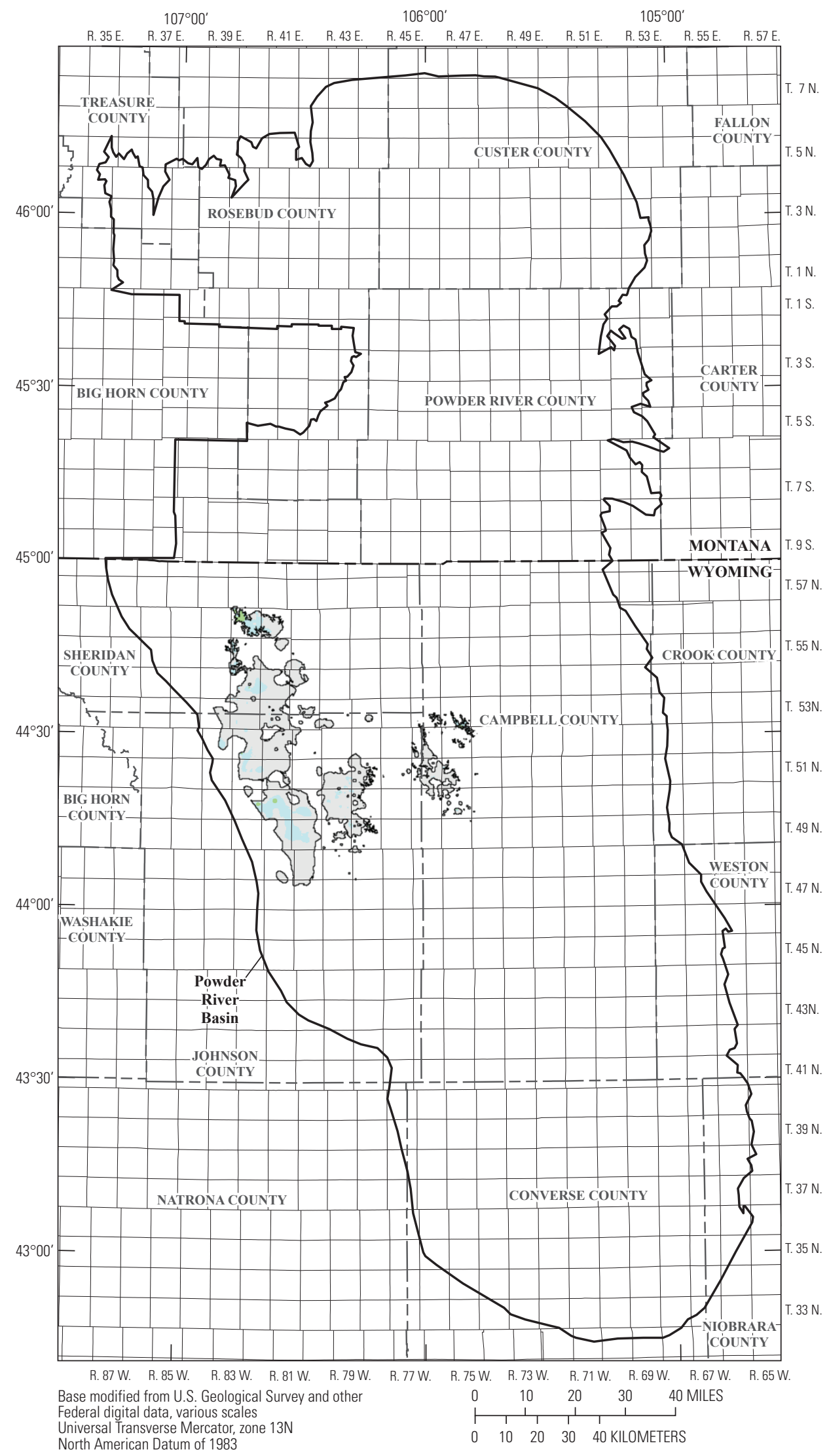

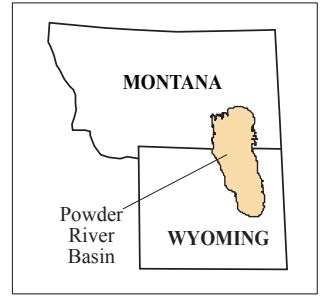

LOCATION MAP

EXPLANATION

Thickness in feet

20

10

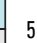

Figure 28. Isopach map of the Murray coal bed showing extent of coal at least 1.0 foot thick within the Powder River Basin. 

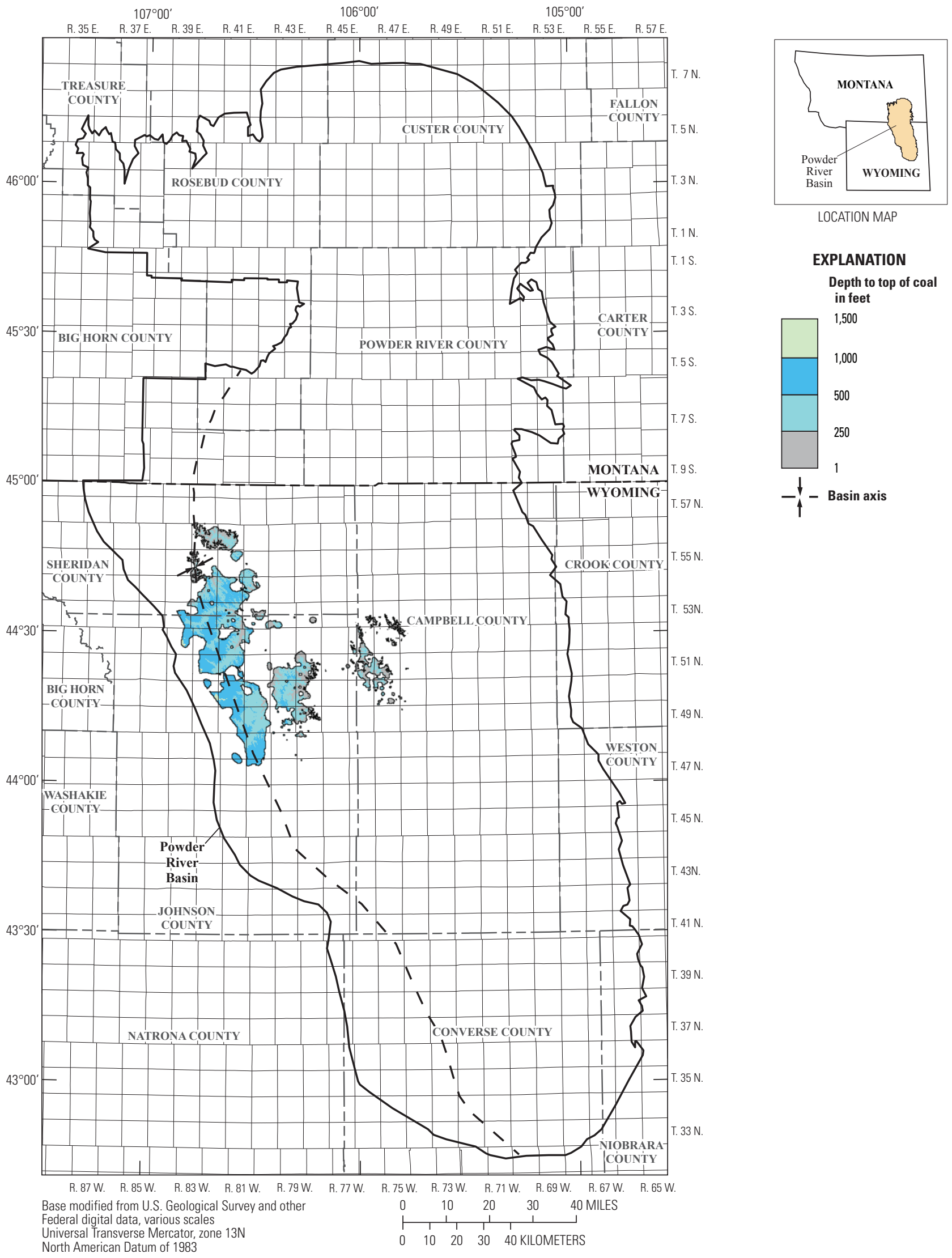

Figure 29. Map showing depth to the top of the Murray coal bed within the Powder River Basin. 


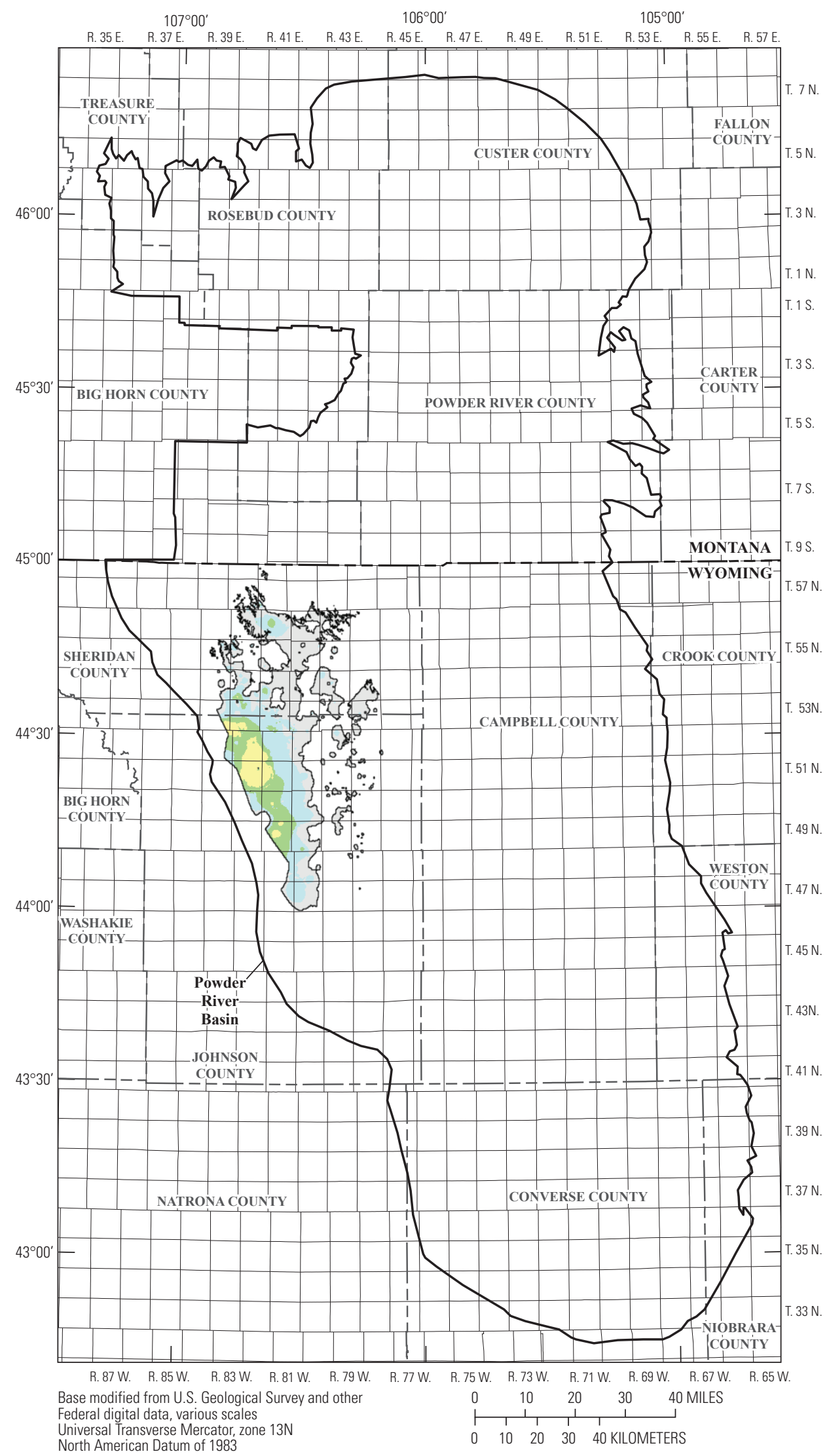

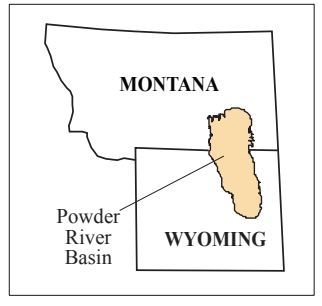

LOCATION MAP

EXPLANATION

Thickness in feet

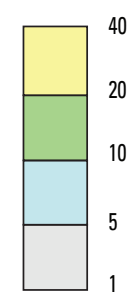

Figure 30. Isopach map of the Ucross coal bed showing extent of coal at least 1.0 foot thick within the Powder River Basin. 

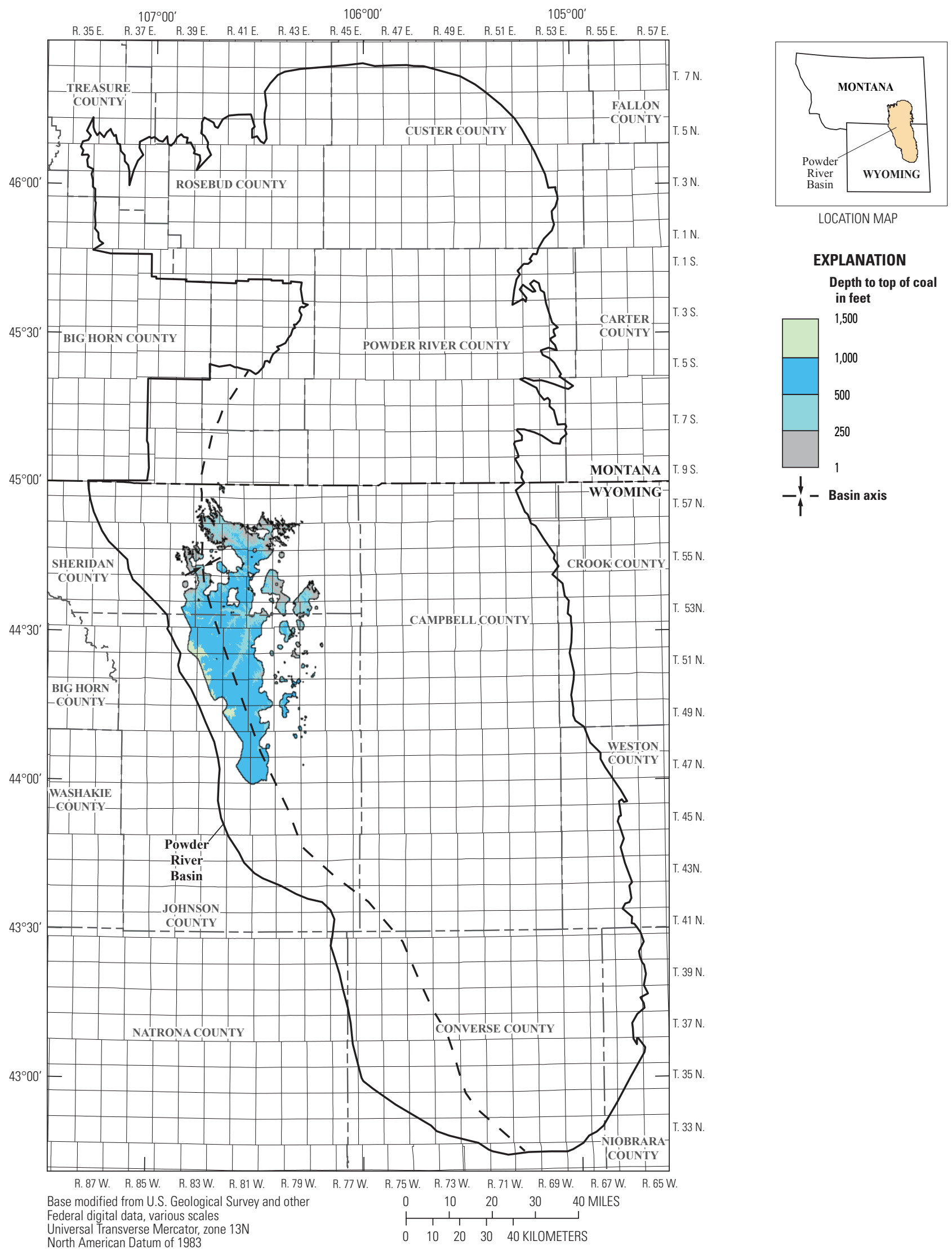

Figure 31. Map showing depth to the top of the Ucross coal bed within the Powder River Basin. 

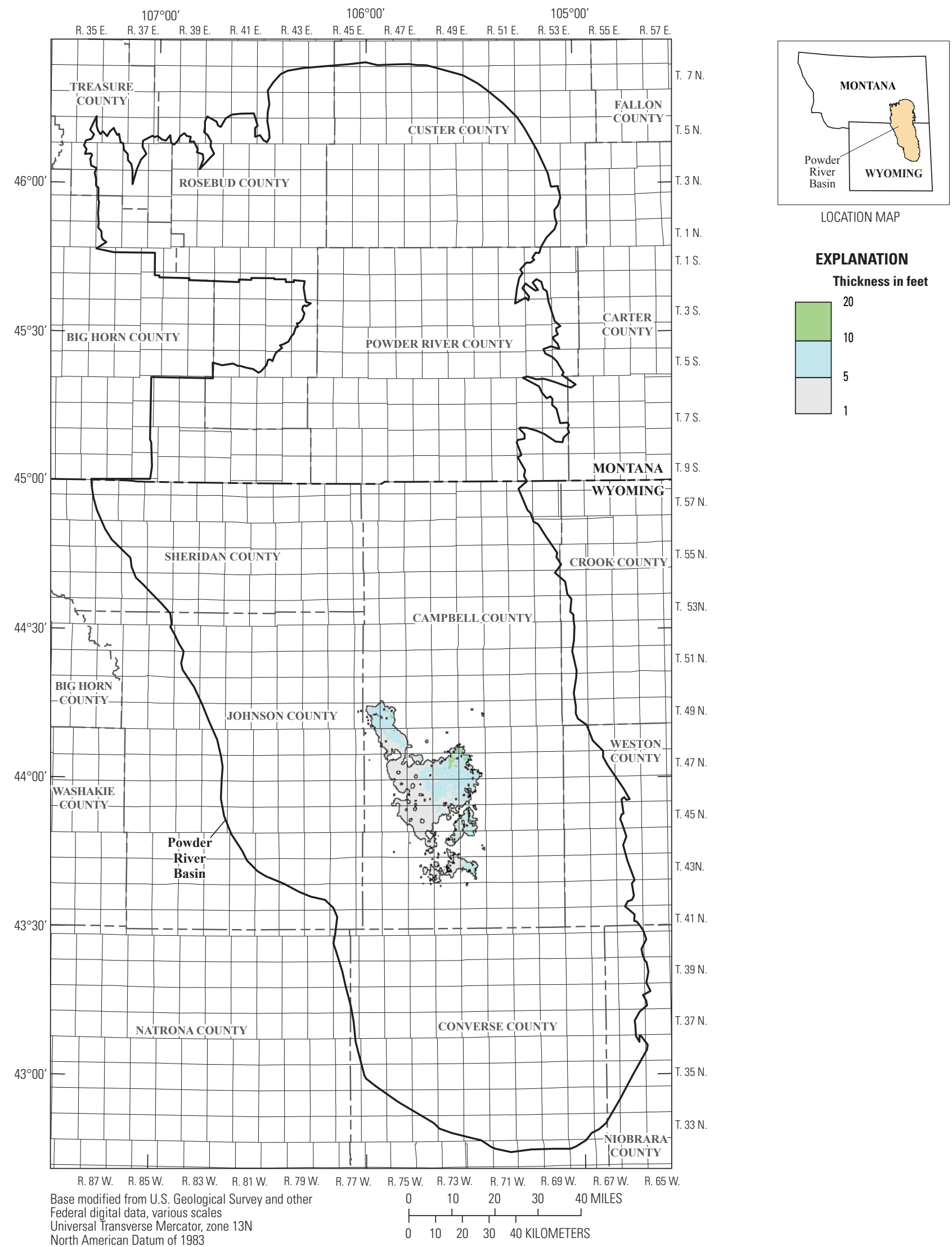

Figure 32. Isopach map of the Upper Felix coal bed showing extent of coal at least 1.0 foot thick within the Powder River Basin. 

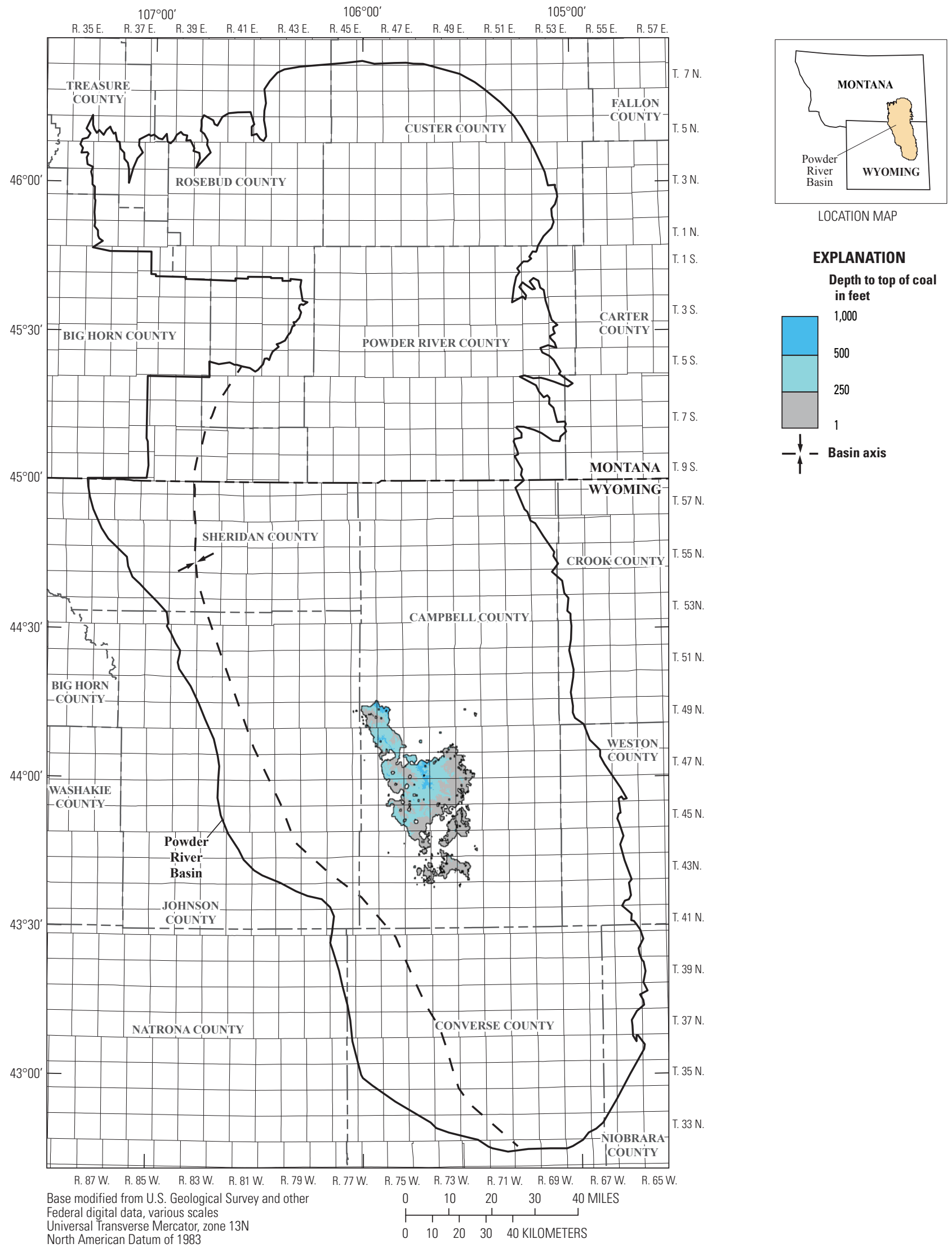

Figure 33. Map showing depth to the top of the Upper Felix coal bed within the Powder River Basin. 


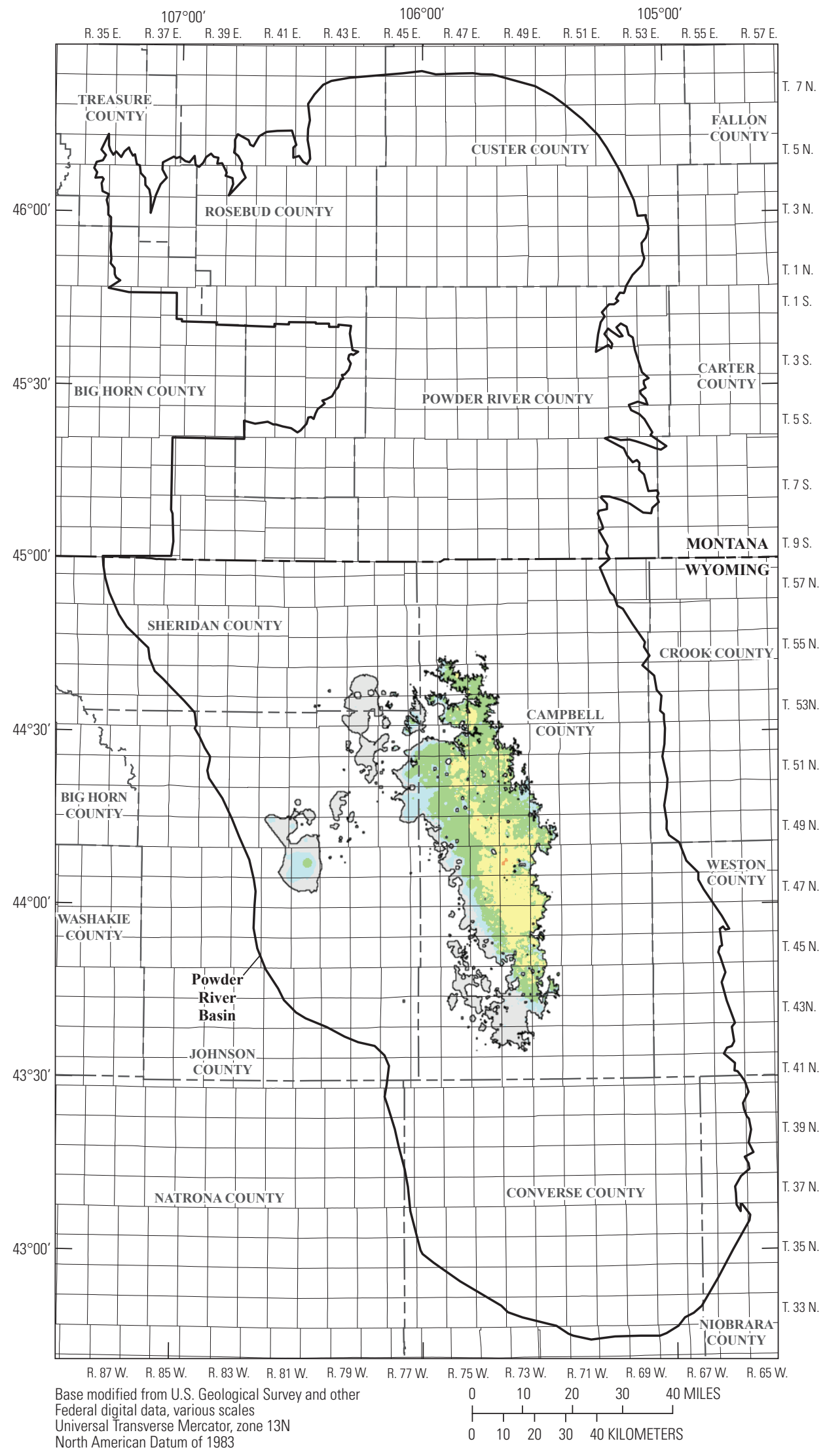

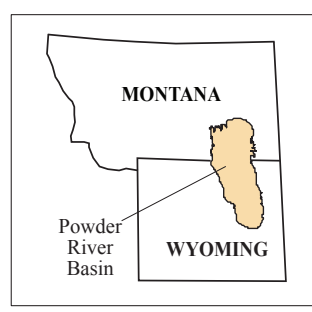

LOCATION MAP

EXPLANATION

Thickness in feet

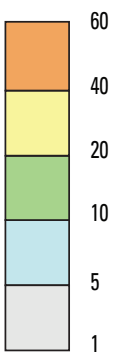

Figure 34. Isopach map of the Felix coal bed showing extent of coal at least 1.0 foot thick within the Powder River Basin. 

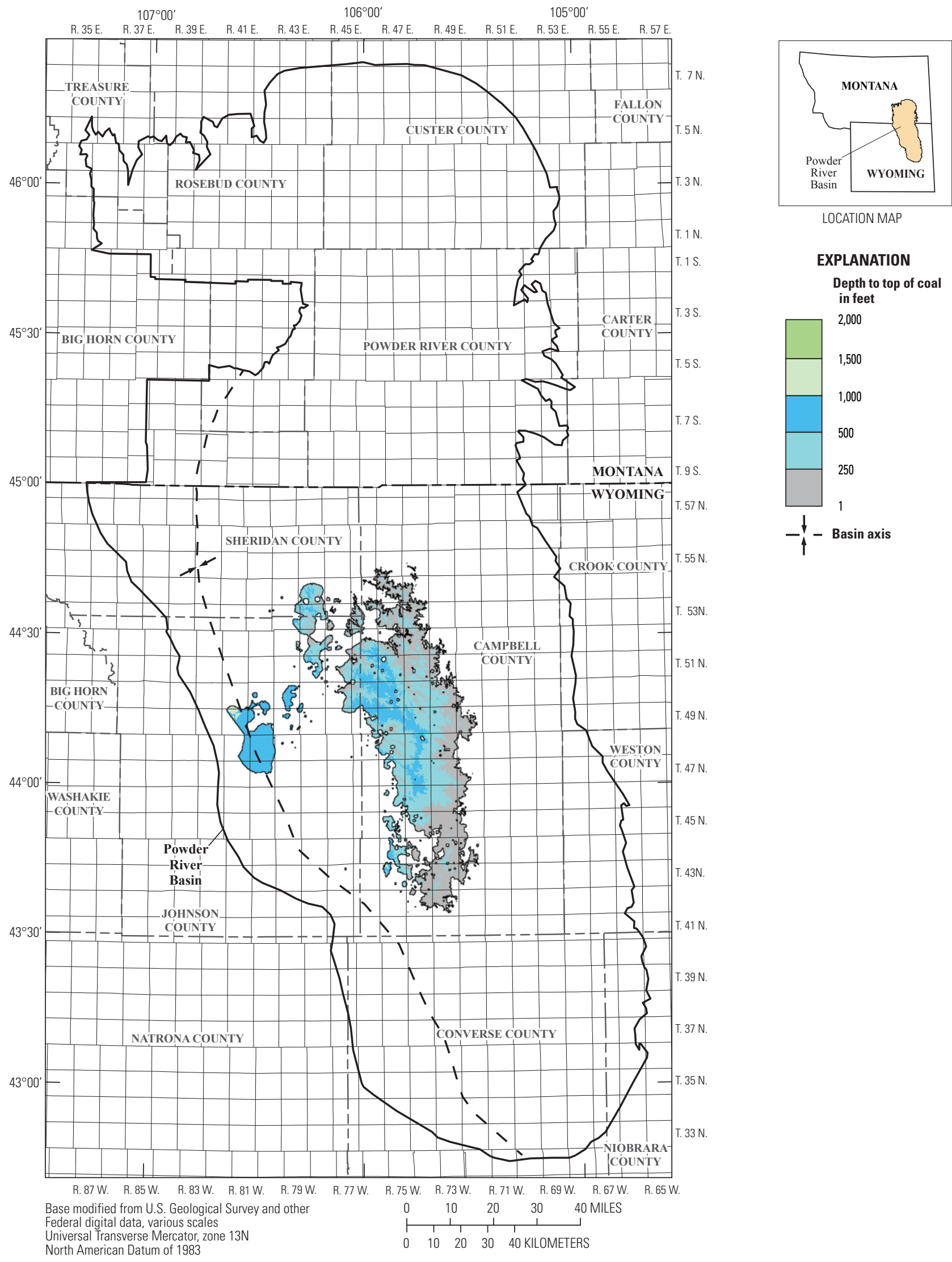

Figure 35. Map showing depth to the top of the Felix coal bed within the Powder River Basin. 


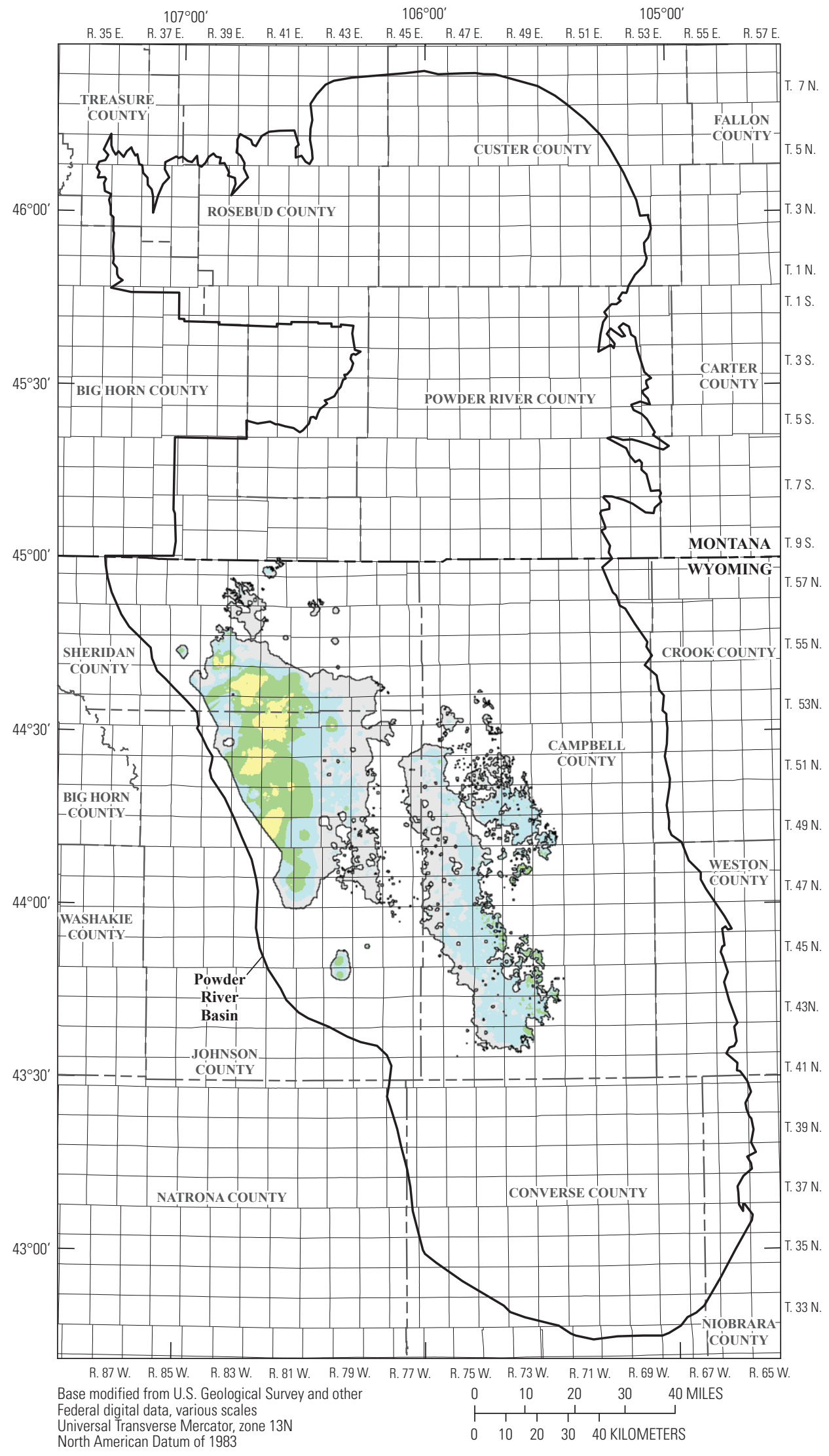

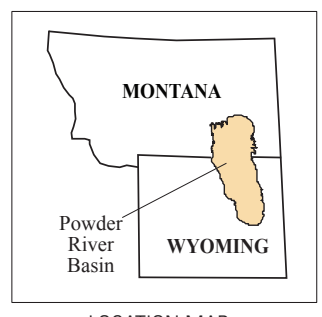

LOCATION MAP

EXPLANATION

Thickness in feet

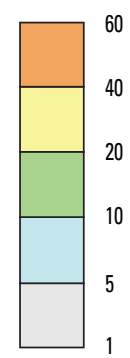

Figure 36. Isopach map of the Lower Felix coal bed showing extent of coal at least 1.0 foot thick within the Powder River Basin. 


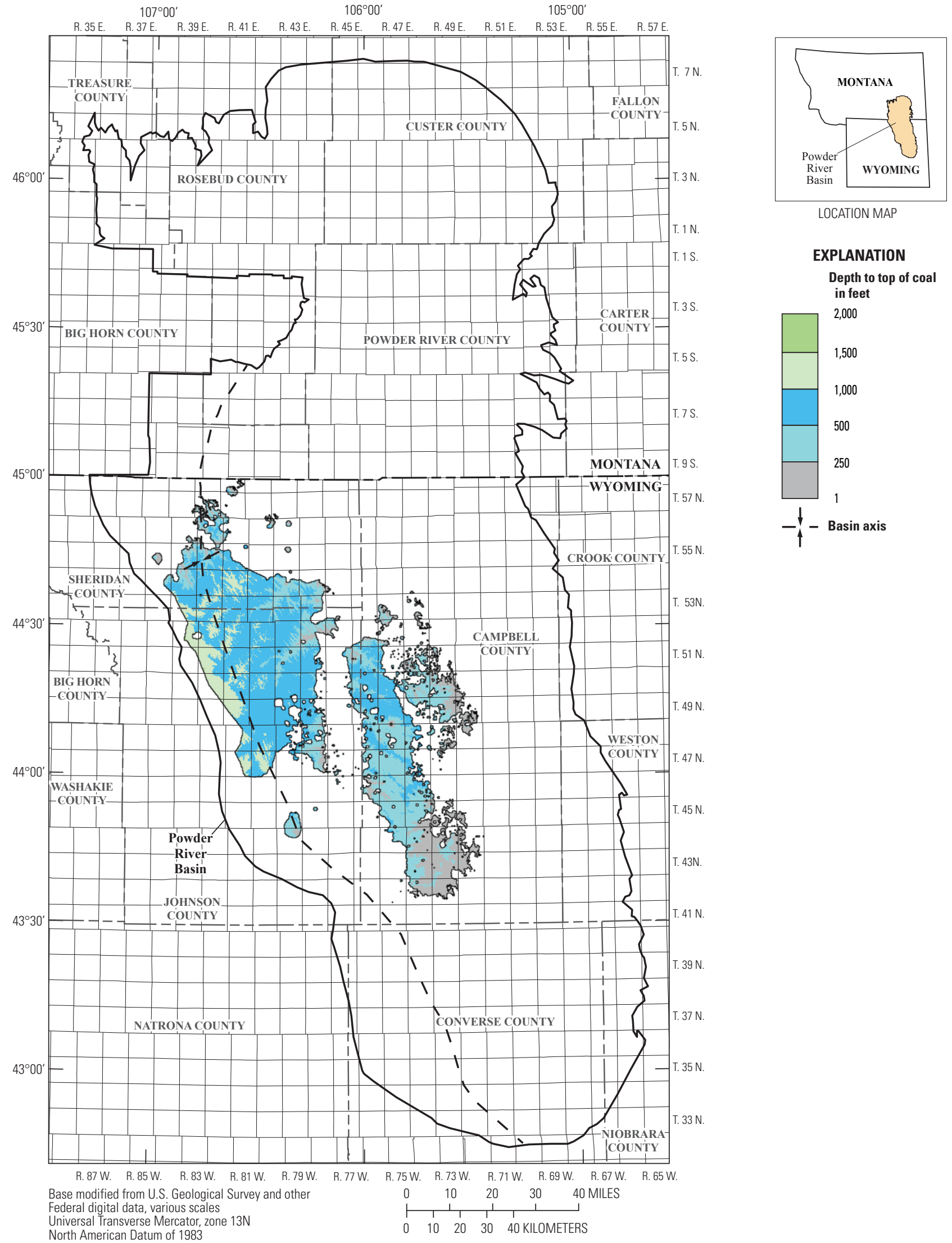

Figure 37. Map showing depth to the top of the Lower Felix coal bed within the Powder River Basin. 


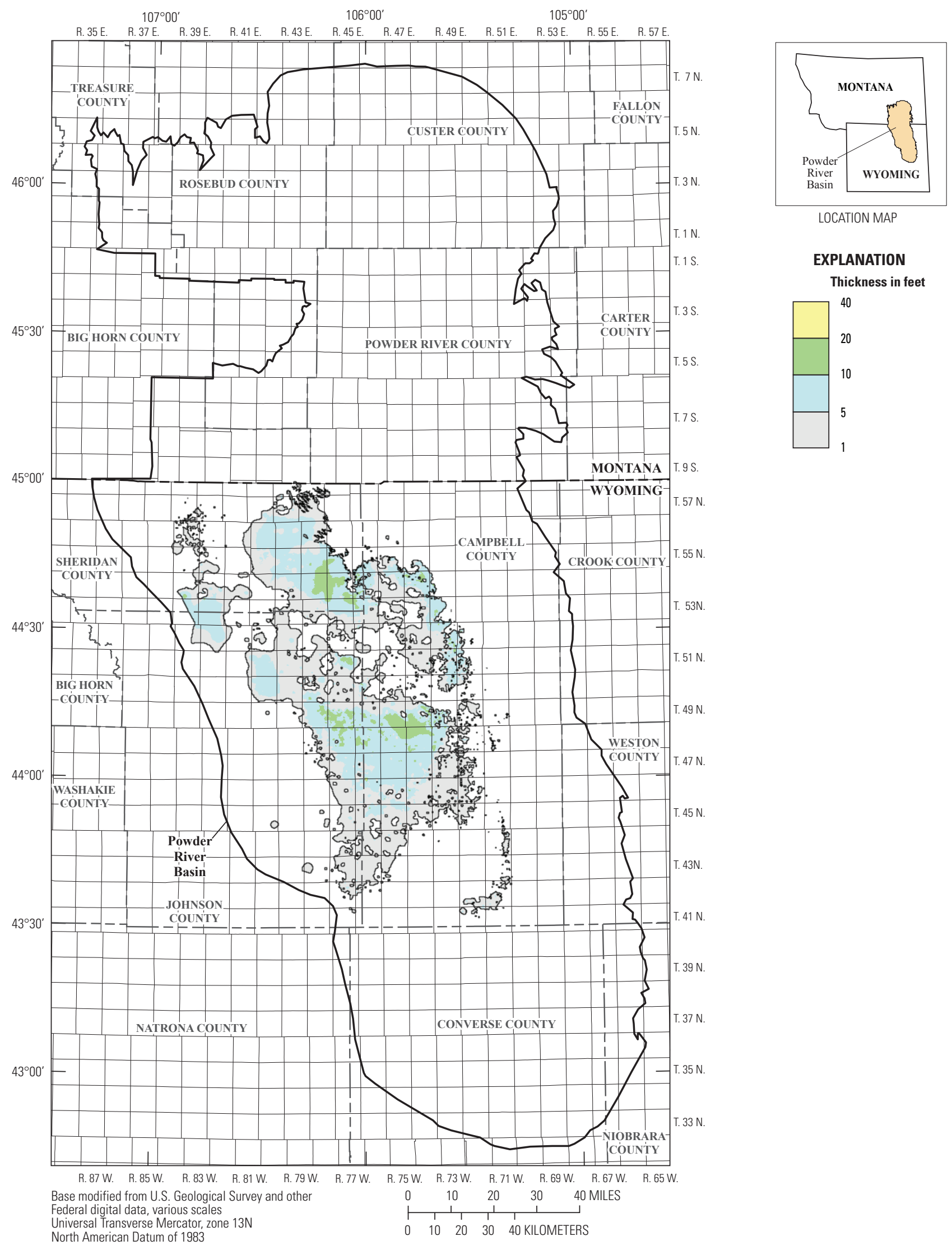

Figure 38. Isopach map of the Roland (Upper Rider) coal bed showing extent of coal at least 1.0 foot thick within the Powder River Basin. 


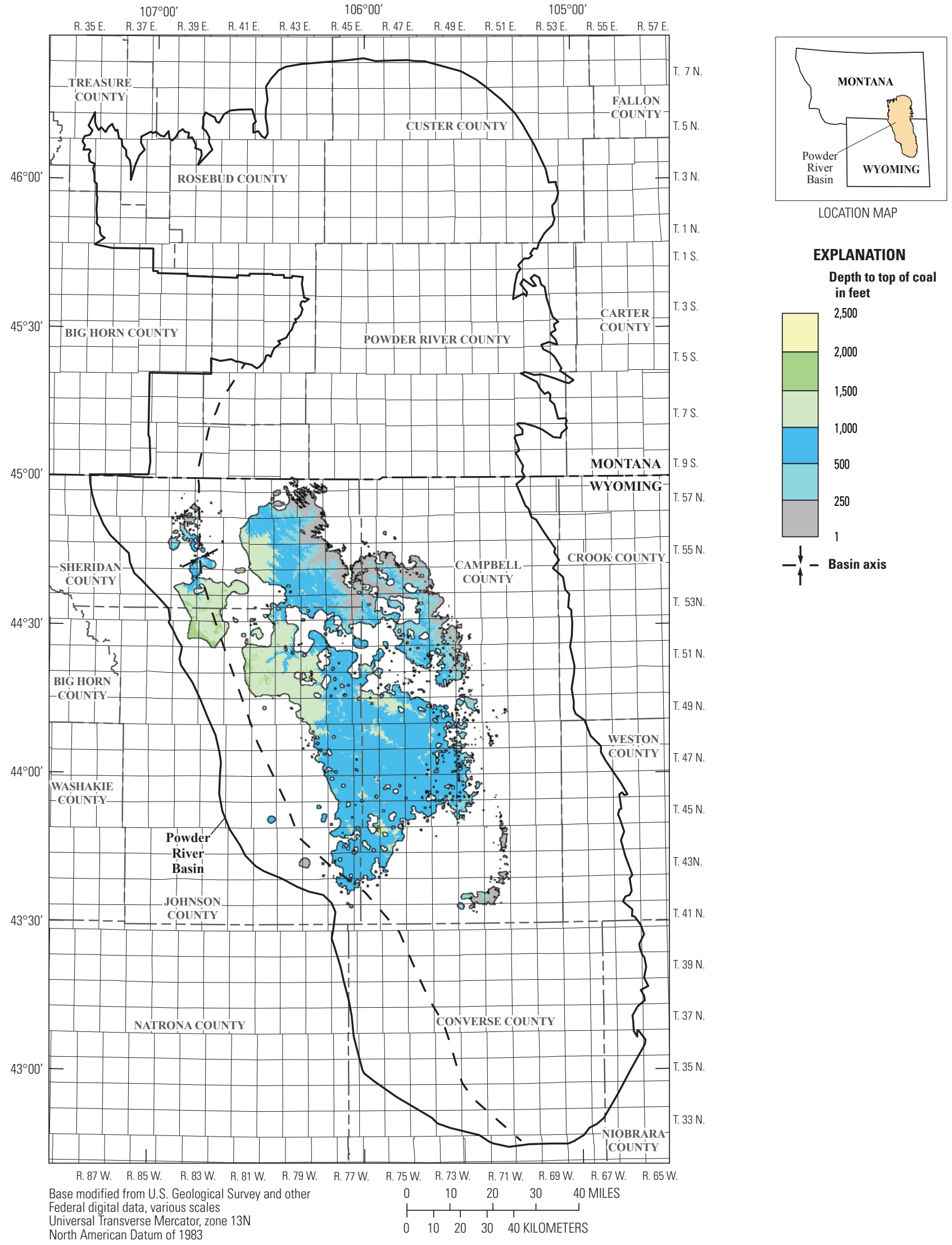

Figure 39. Map showing depth to the top of the Roland (Upper Rider) coal bed within the Powder River Basin. 


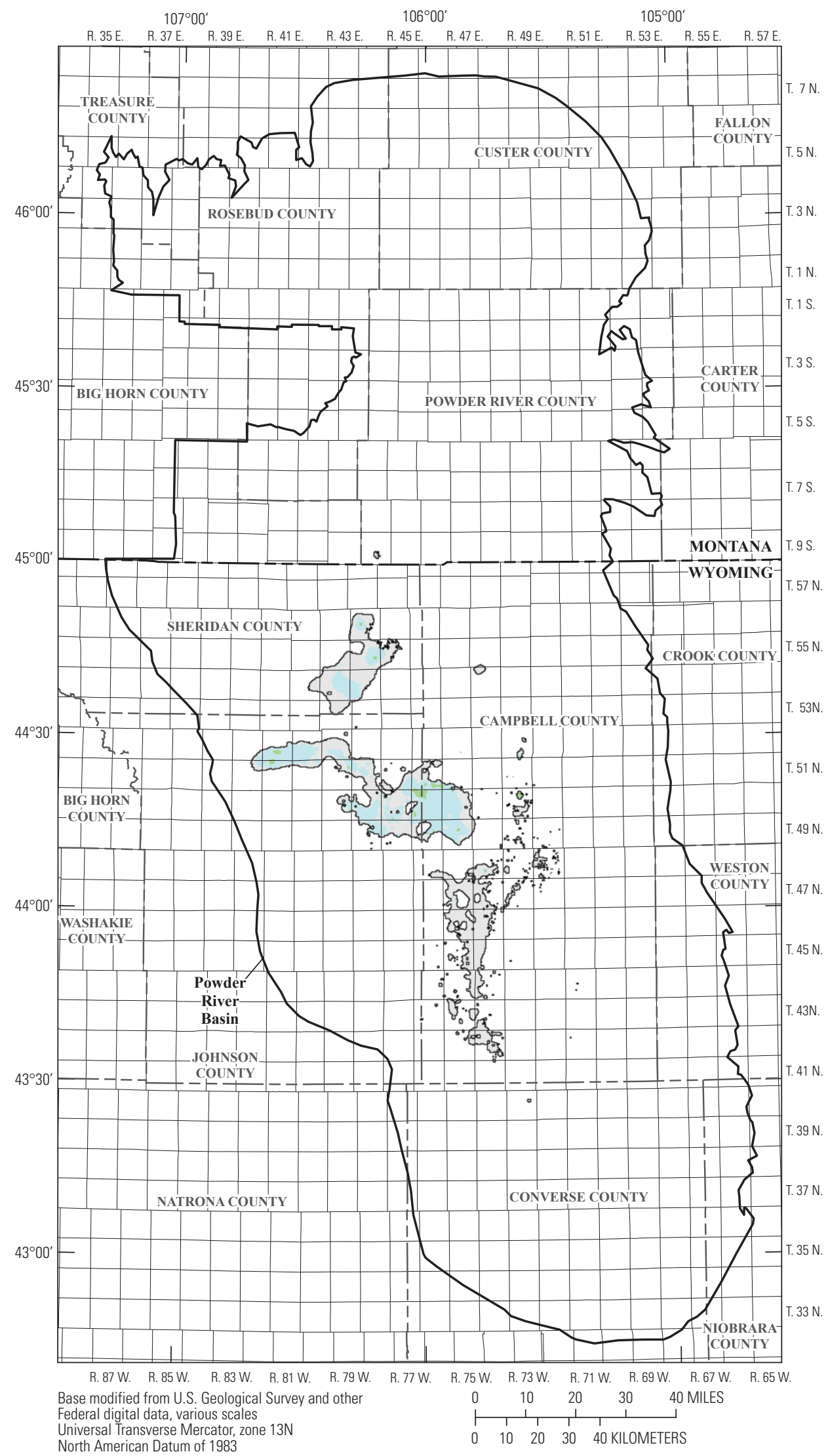

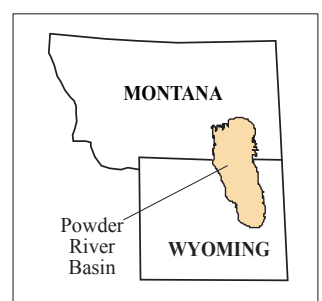

LOCATION MAP

EXPLANATION

Thickness in feet

20

10

5

Figure 40. Isopach map of the Roland (Lower Rider) coal bed showing extent of coal at least 1.0 foot thick within the Powder River Basin. 


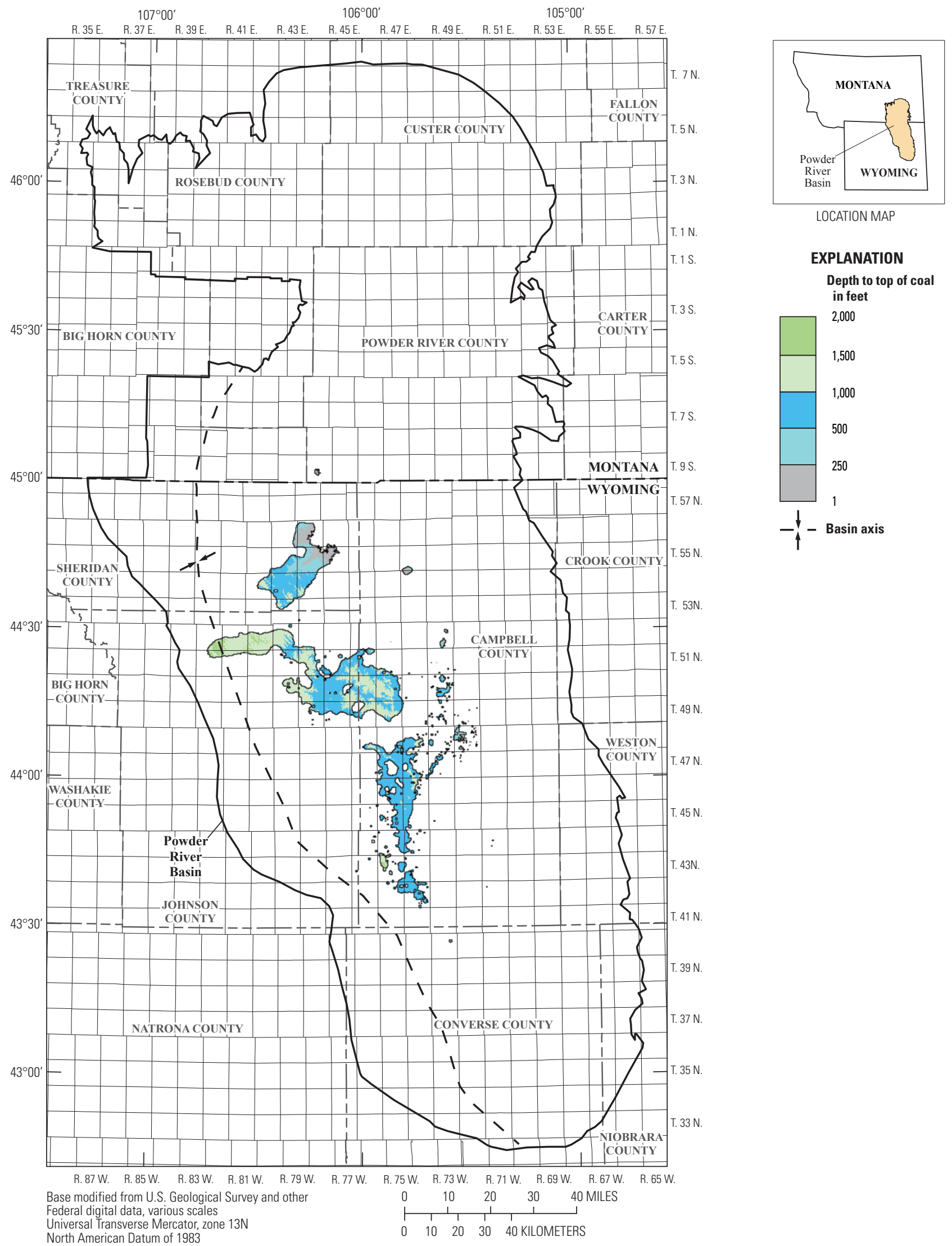

Figure 41. Map showing depth to the top of the Roland (Lower Rider) coal bed within the Powder River Basin. 


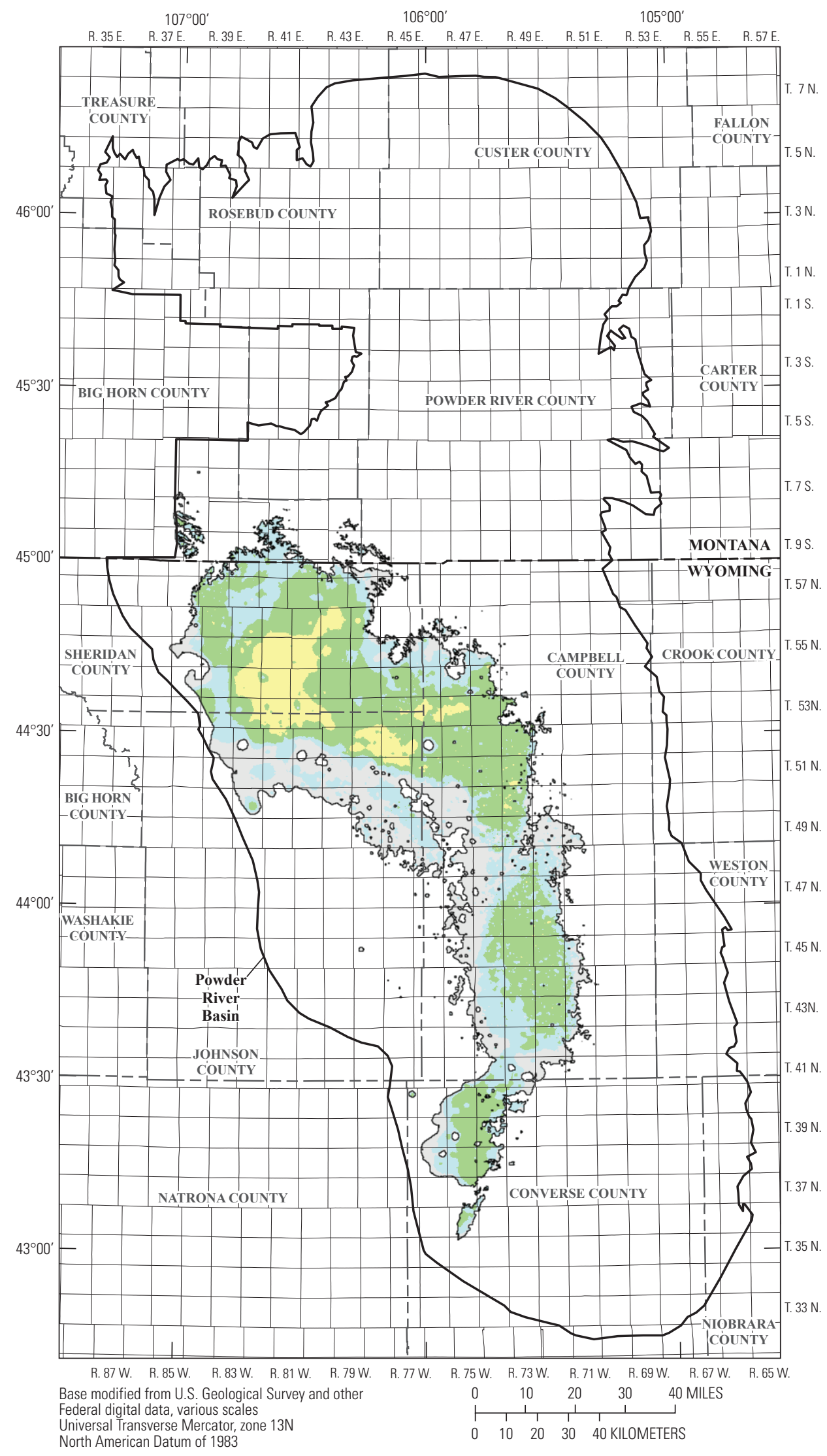

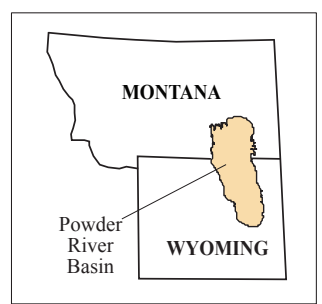

LOCATION MAP

EXPLANATION

Thickness in feet

40

20

10

5

Figure 42. Isopach map of the Roland (Baker) coal bed showing extent of coal at least 1.0 foot thick within the Powder River Basin. 

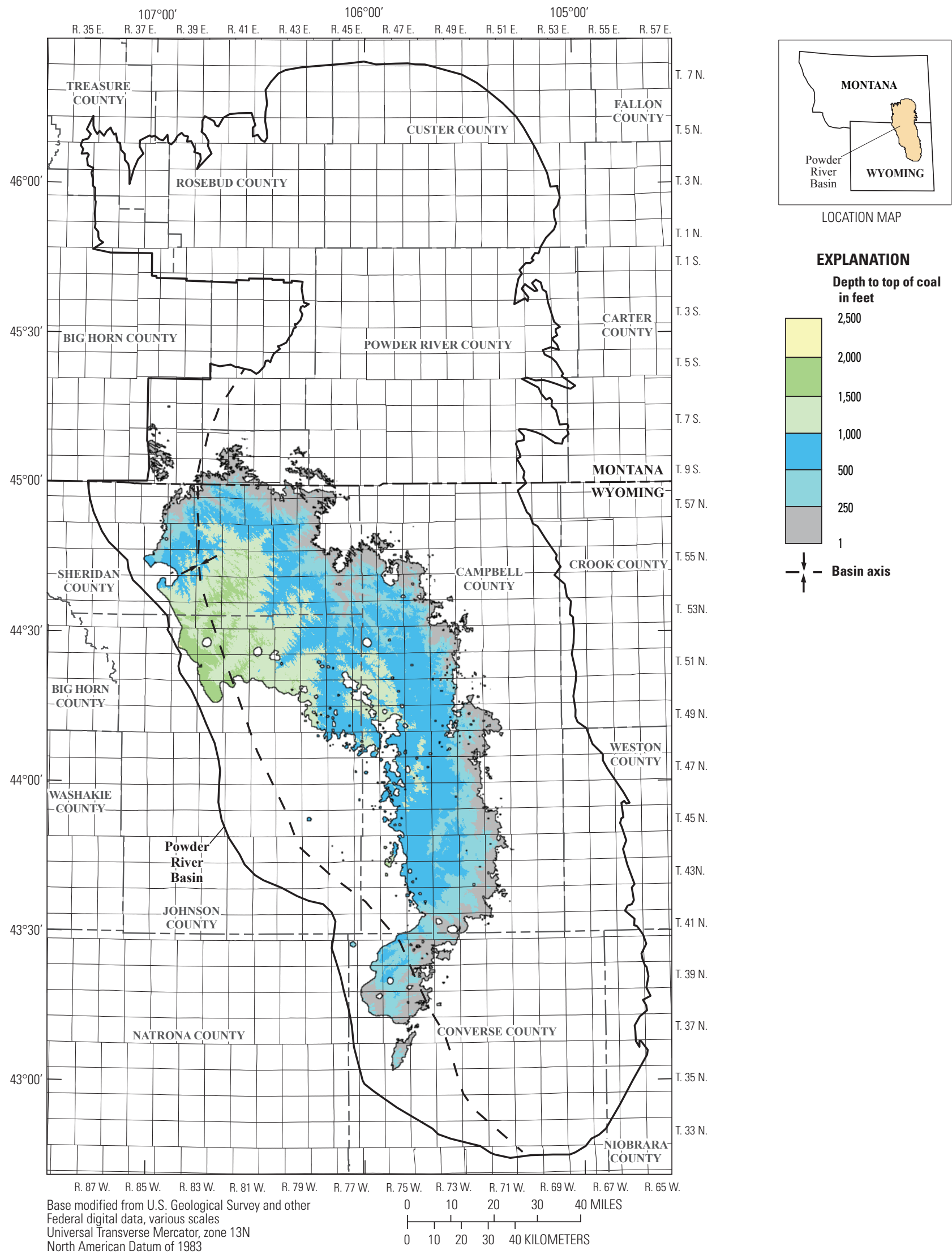

Figure 43. Map showing depth to the top of the Roland (Baker) coal bed within the Powder River Basin. 


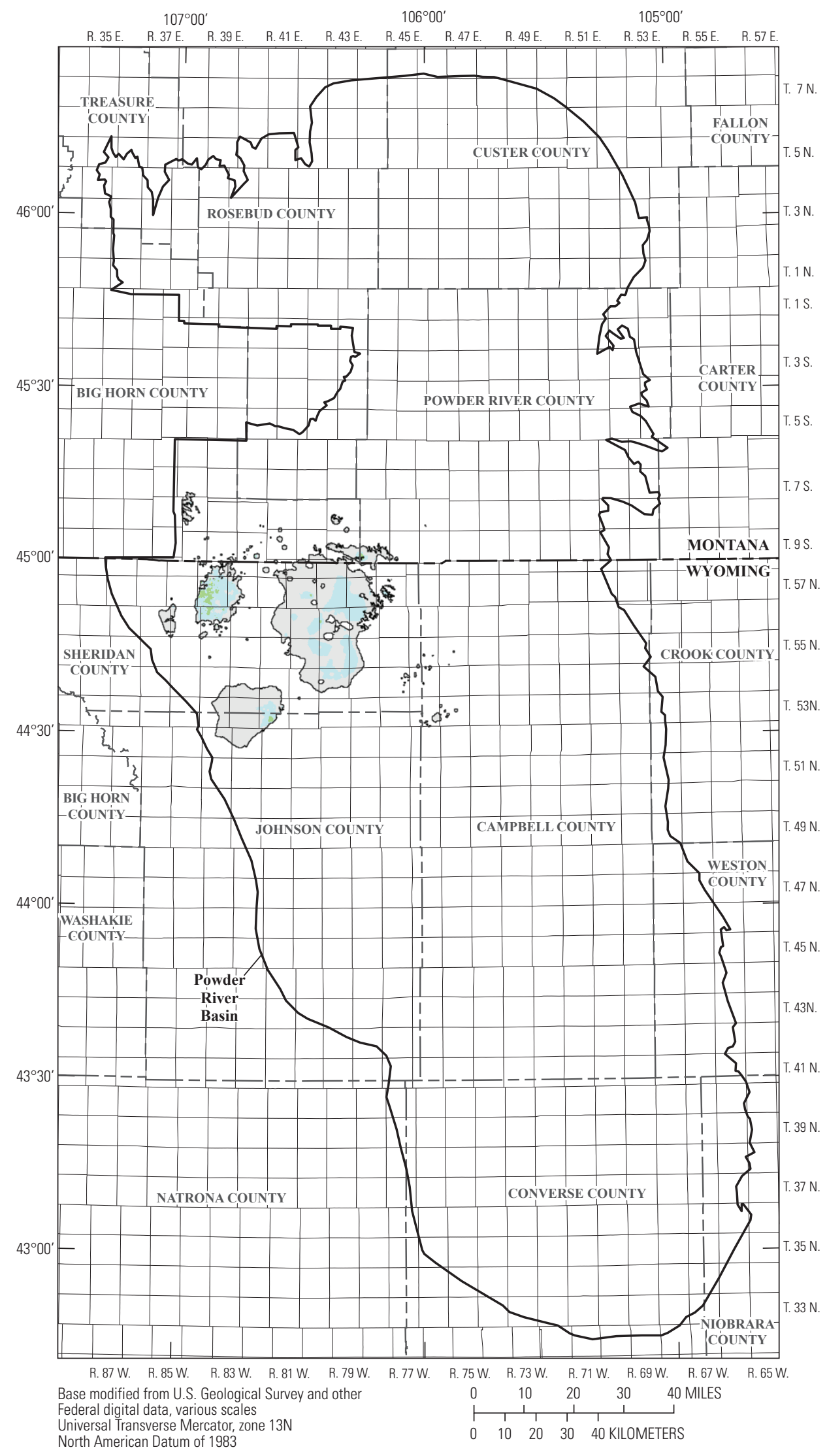

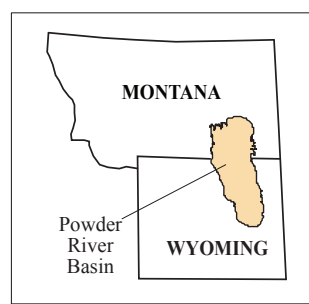

LOCATION MAP

EXPLANATION

Thickness in feet

40

20

10

5

Figure 44. Isopach map of the Roland (Taff) coal bed showing extent of coal at least 1.0 foot thick within the Powder River Basin. 


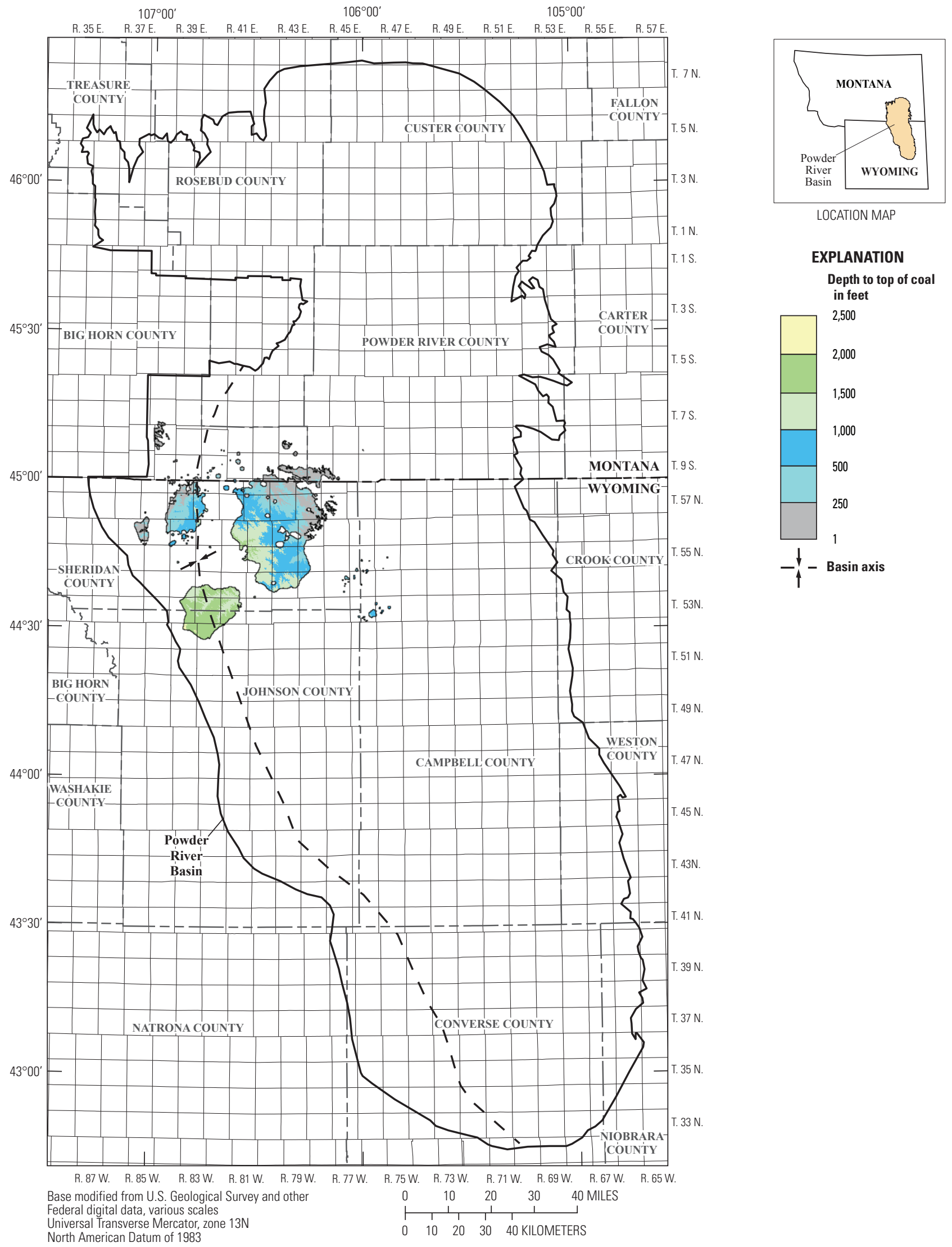

Figure 45. Map showing depth to the top of the Roland (Taff) coal bed within the Powder River Basin. 


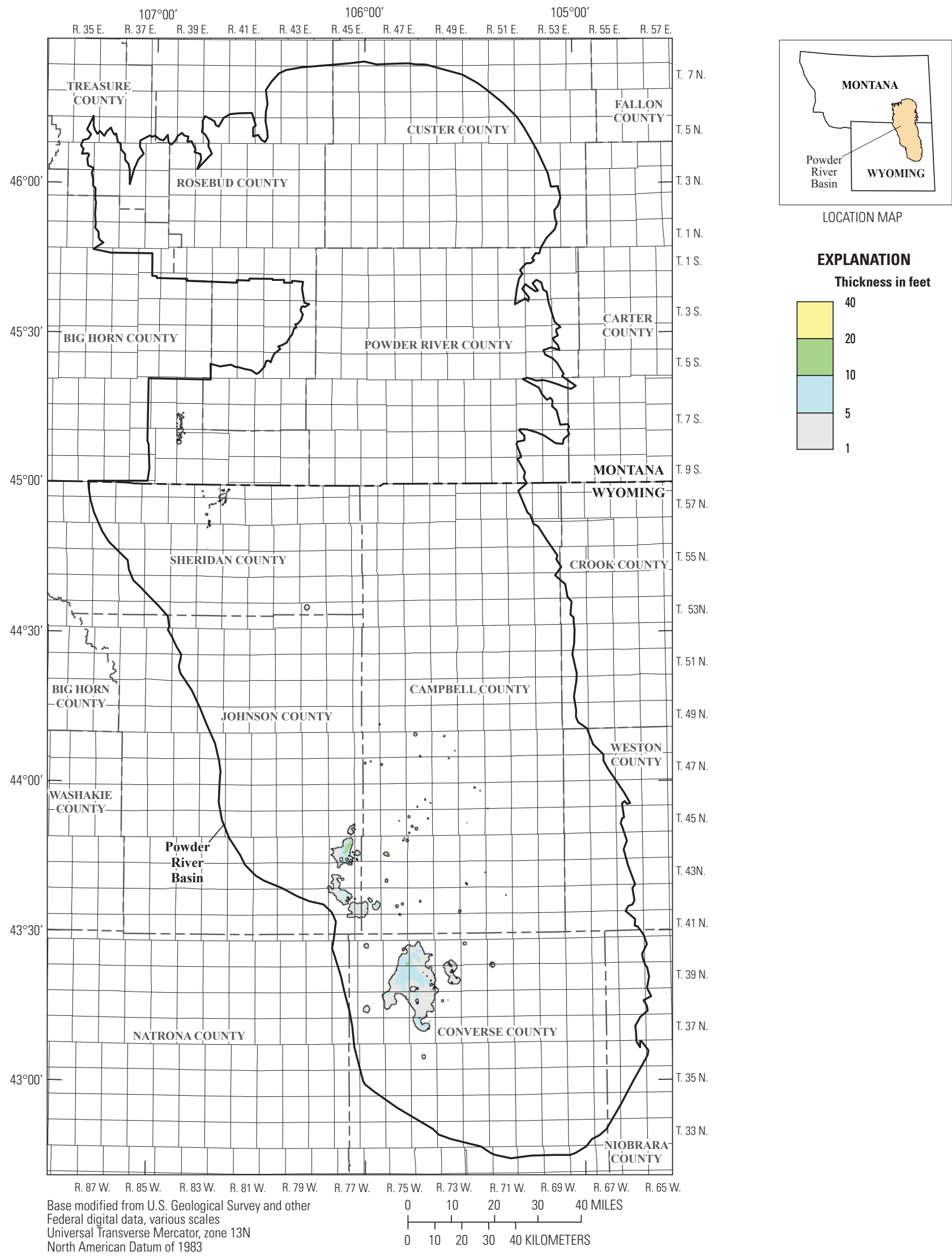

Figure 46. Isopach map of the Upper Smith coal bed showing extent of coal at least 1.0 foot thick within the Powder River Basin. 


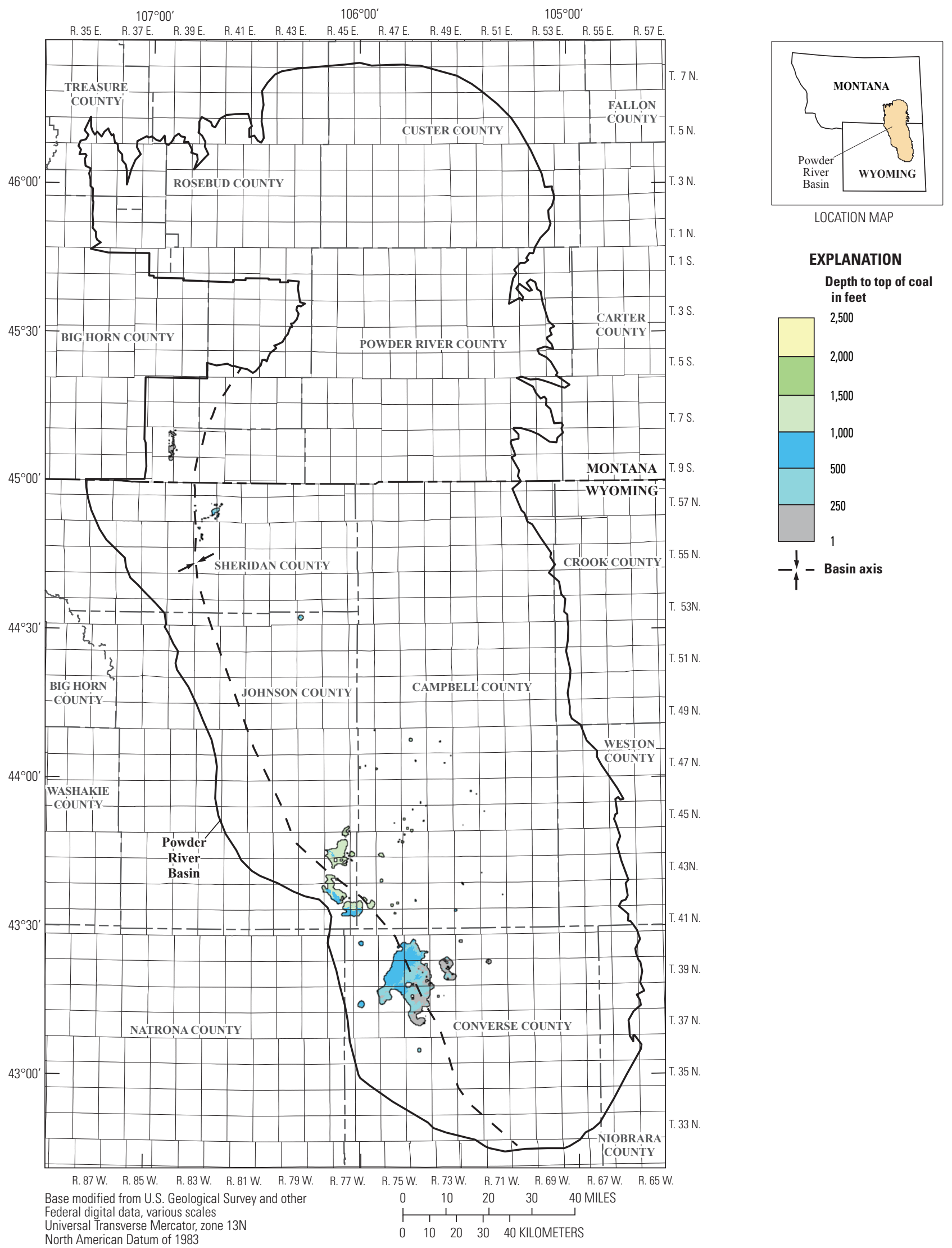

Figure 47. Map showing depth to the top of the Upper Smith coal bed within the Powder River Basin. 


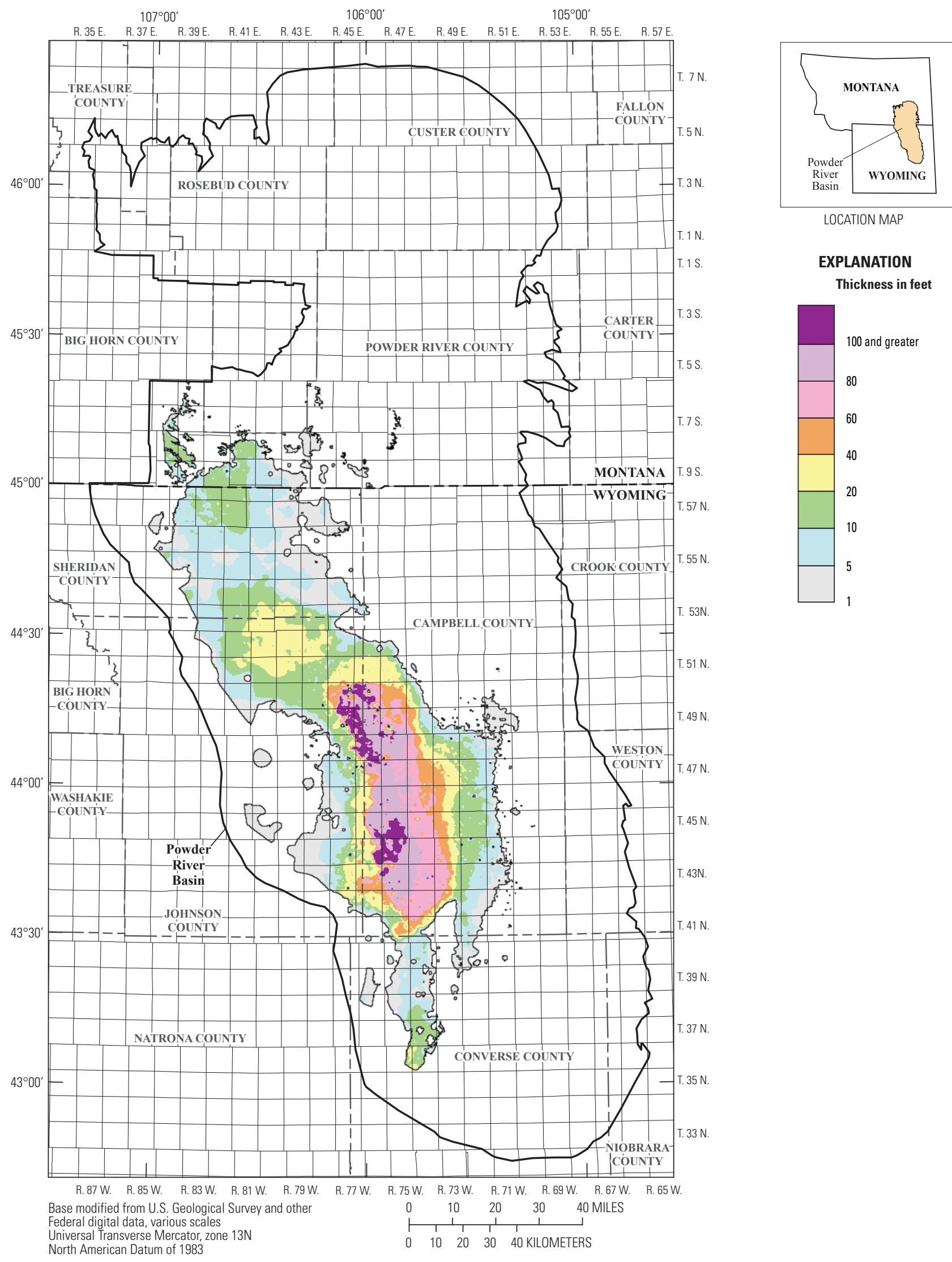

Figure 48. Isopach map of the Smith coal bed showing extent of coal at least 1.0 foot thick within the Powder River Basin. 

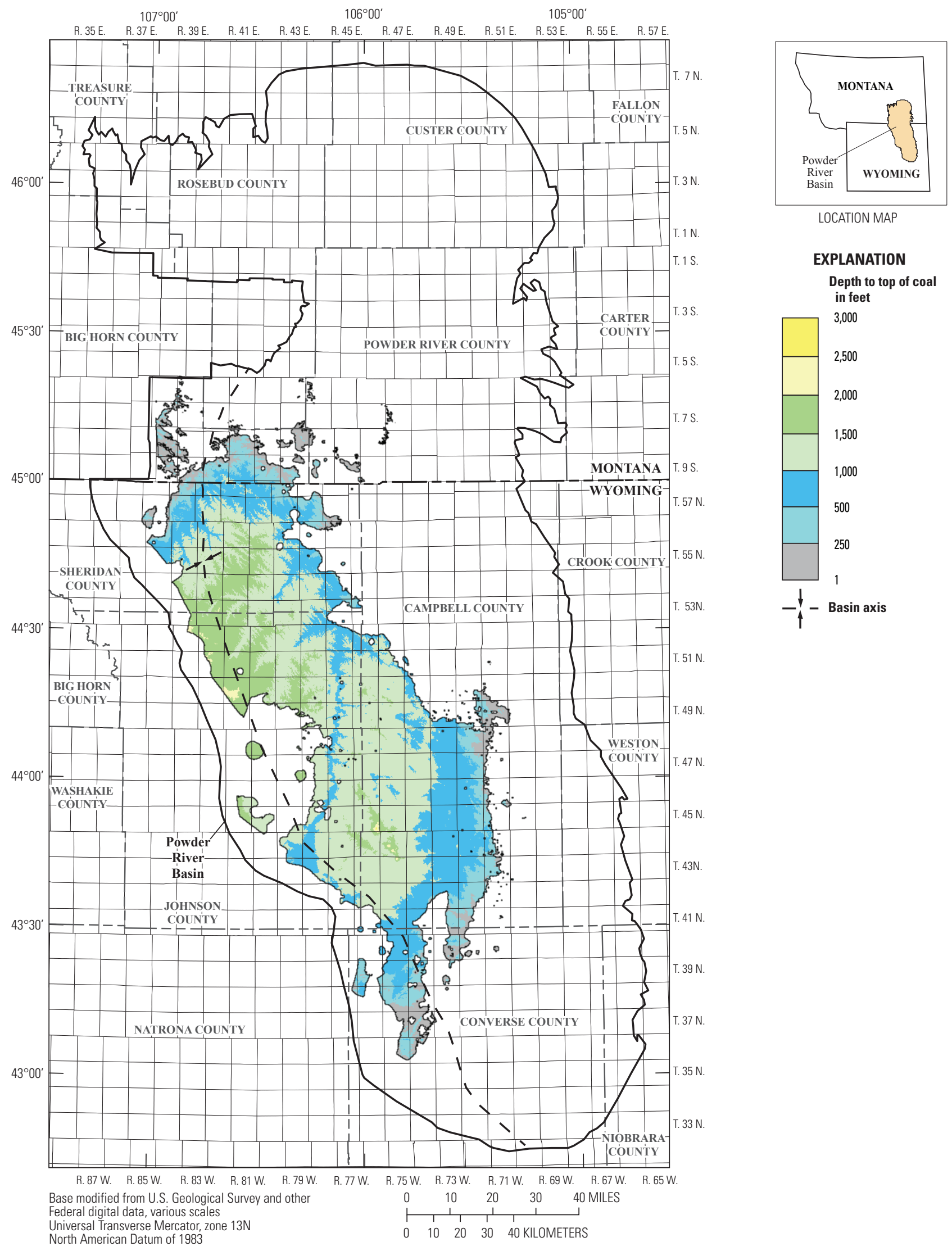

Figure 49. Map showing depth to the top of the Smith coal bed within the Powder River Basin. 


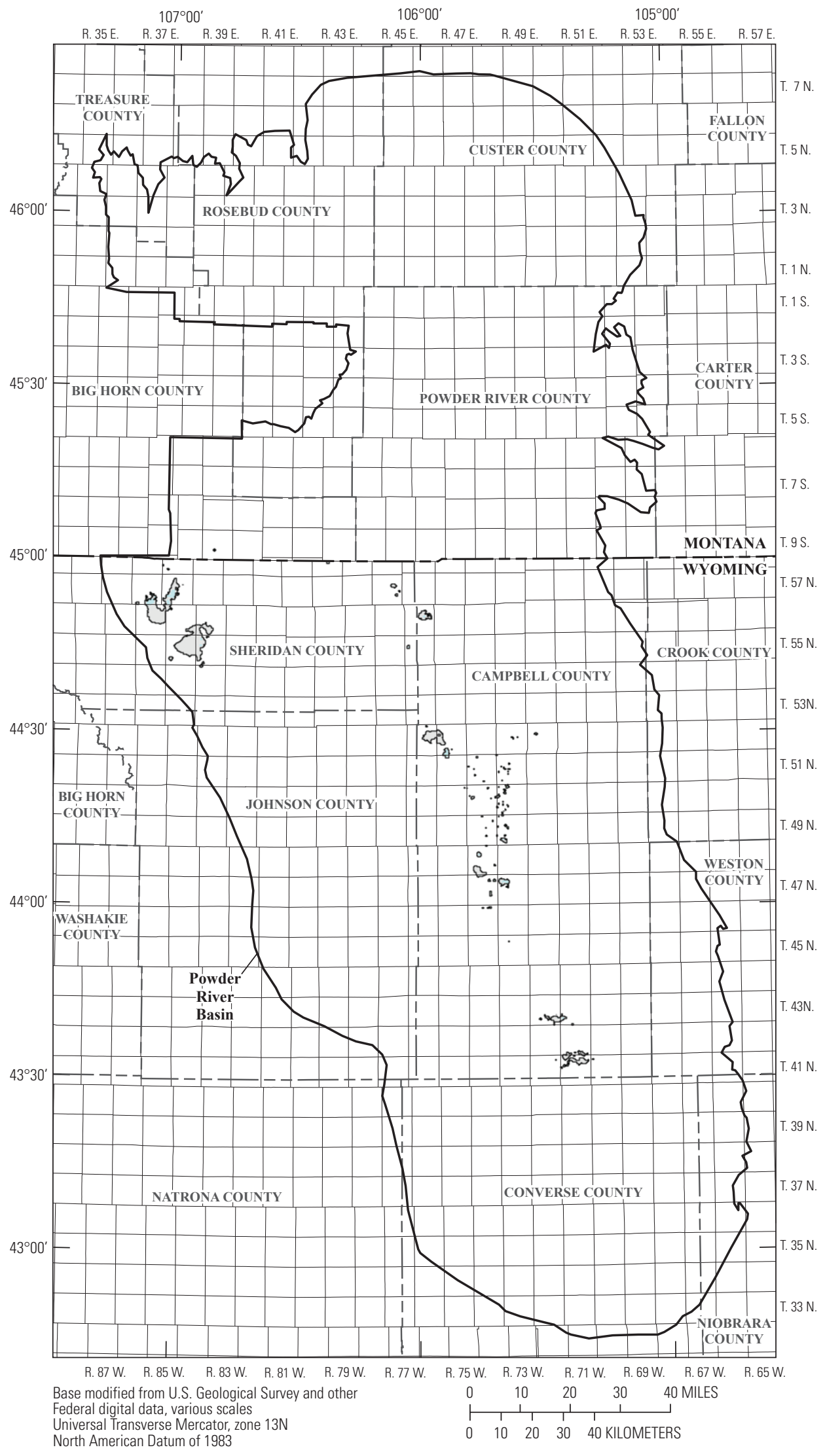

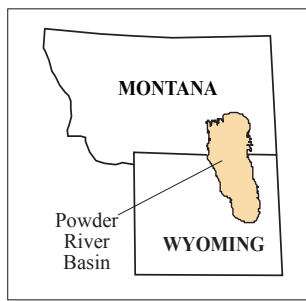

LOCATION MAP

EXPLANATION

Thickness in feet

20

10

5

Figure 50. Isopach map of the Anderson Upper Rider coal bed showing extent of coal at least 1.0 foot thick within the Powder River Basin. 


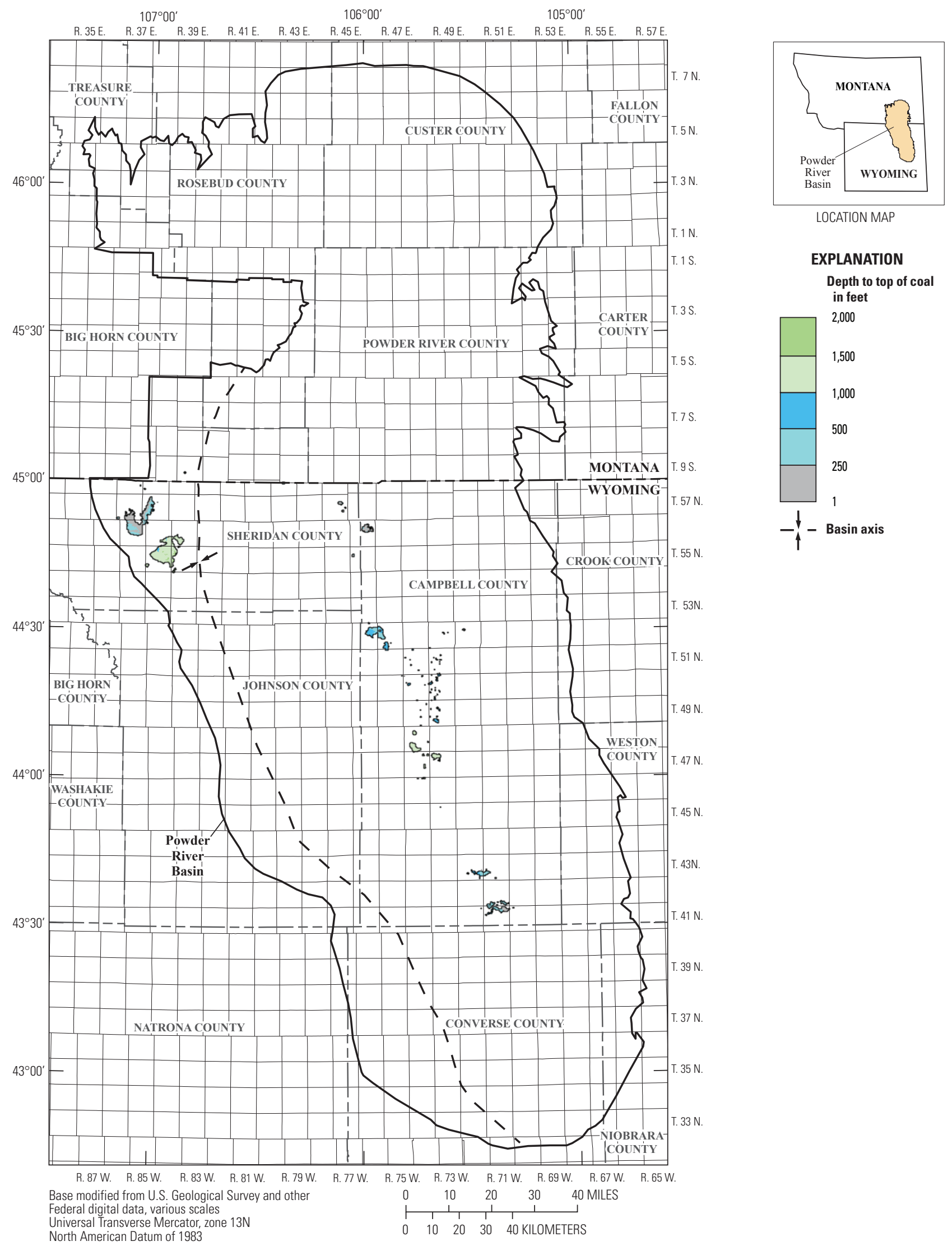

Figure 51. Map showing depth to the top of the Anderson Upper Rider coal bed within the Powder River Basin. 


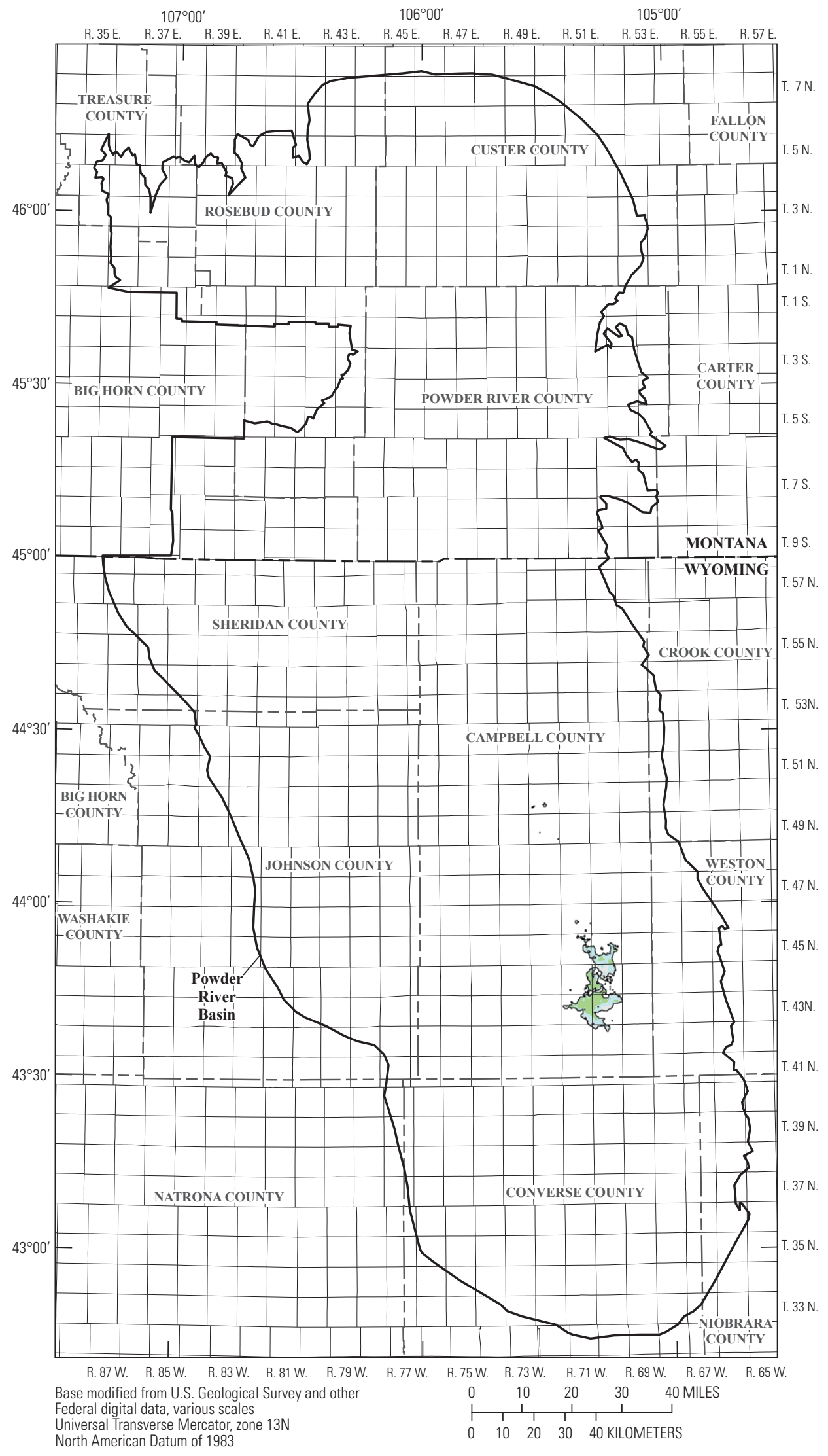

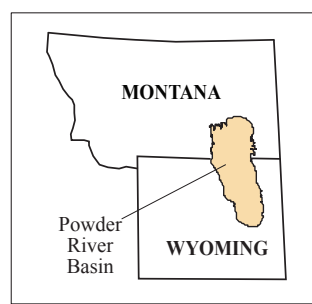

LOCATION MAP

EXPLANATION

Thickness in feet

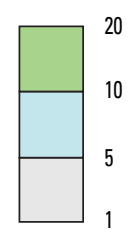

Figure 52. Isopach map of the Anderson Lower Rider coal bed showing extent of coal at least 1.0 foot thick within the Powder River Basin. 


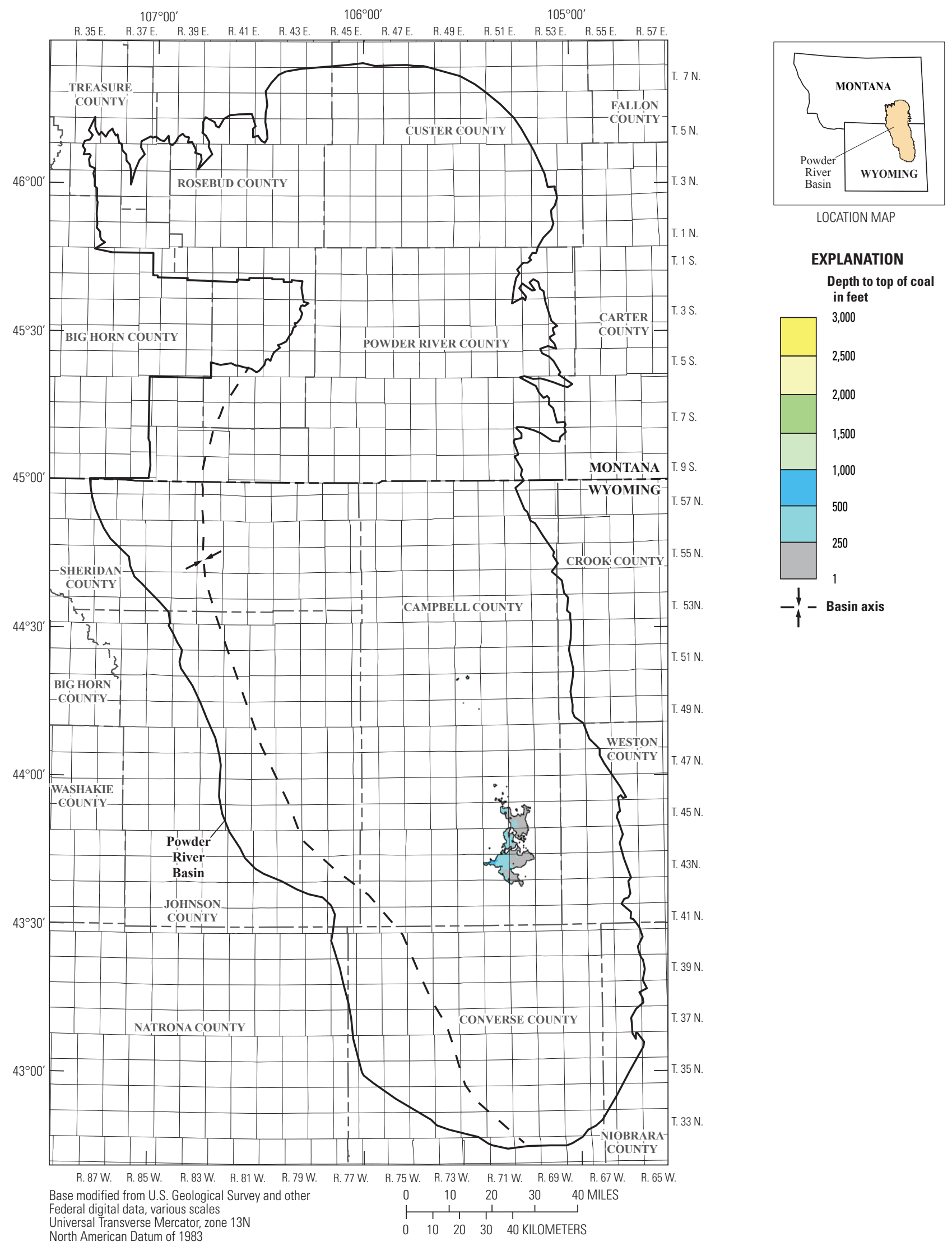

Figure 53. Map showing depth to the top of the Anderson Lower Rider coal bed within the Powder River Basin. 


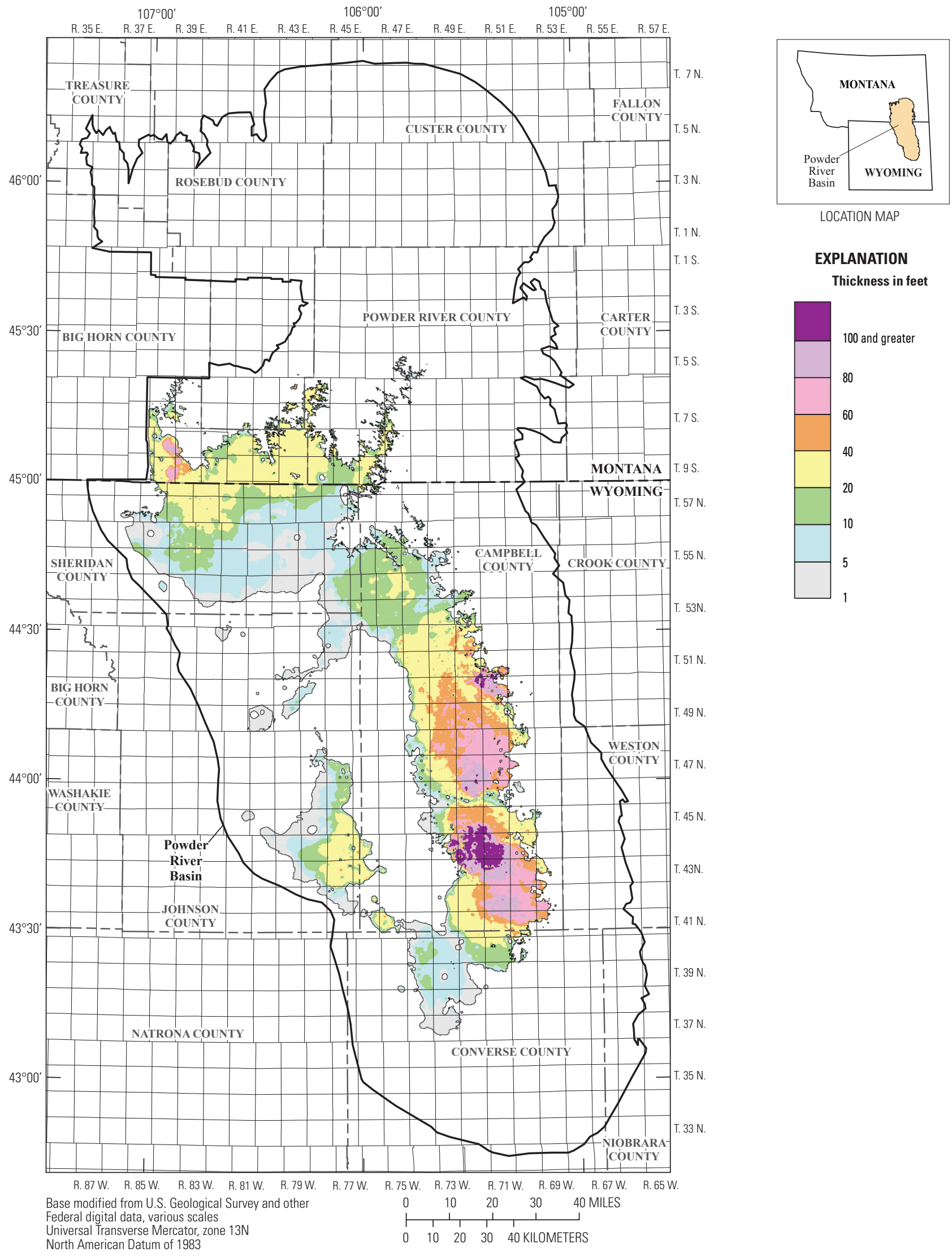

Figure 54. Isopach map of the Anderson coal bed showing extent of coal at least 1.0 foot thick within the Powder River Basin. 

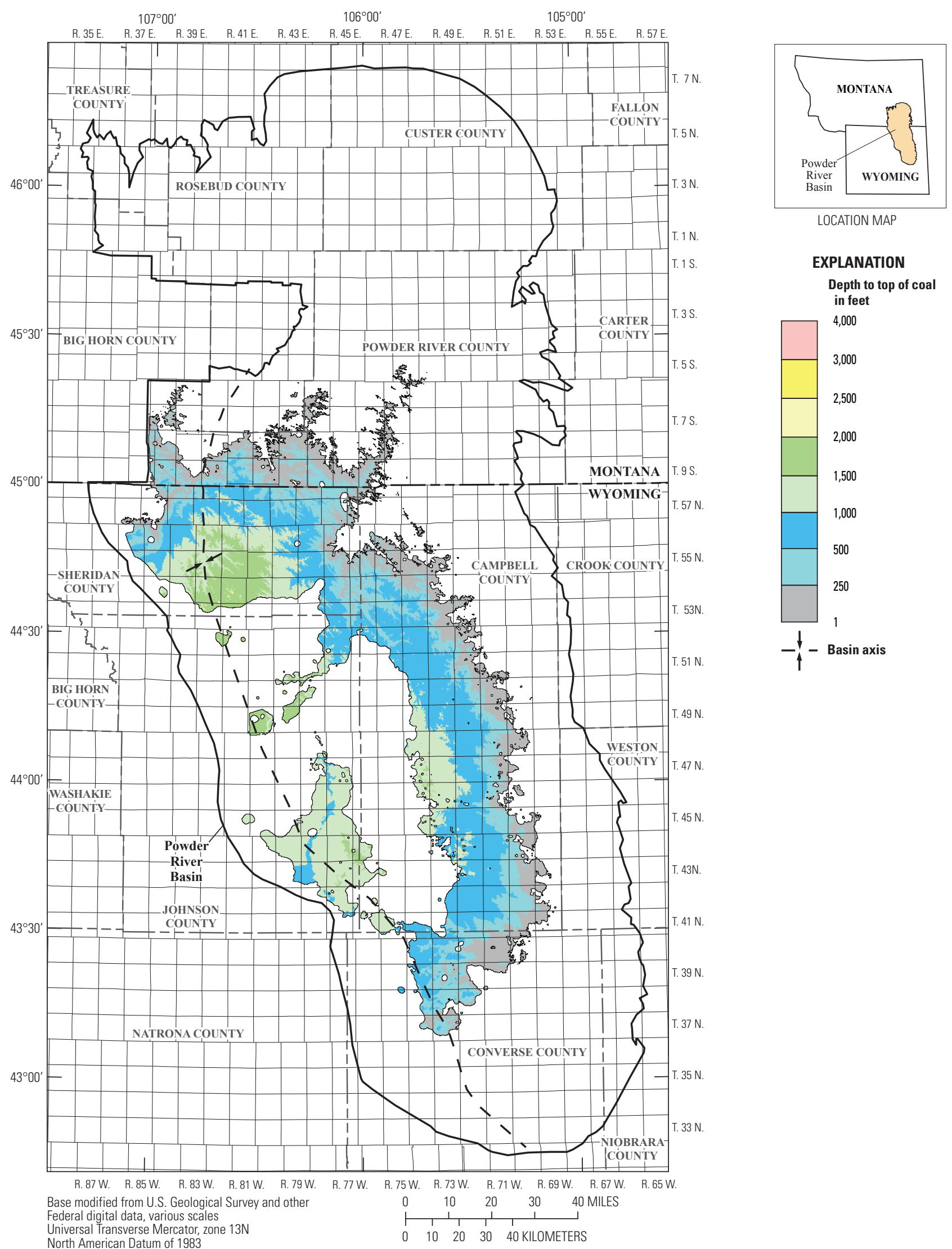

Figure 55. Map showing depth to the top of the Anderson coal bed within the Powder River Basin. 


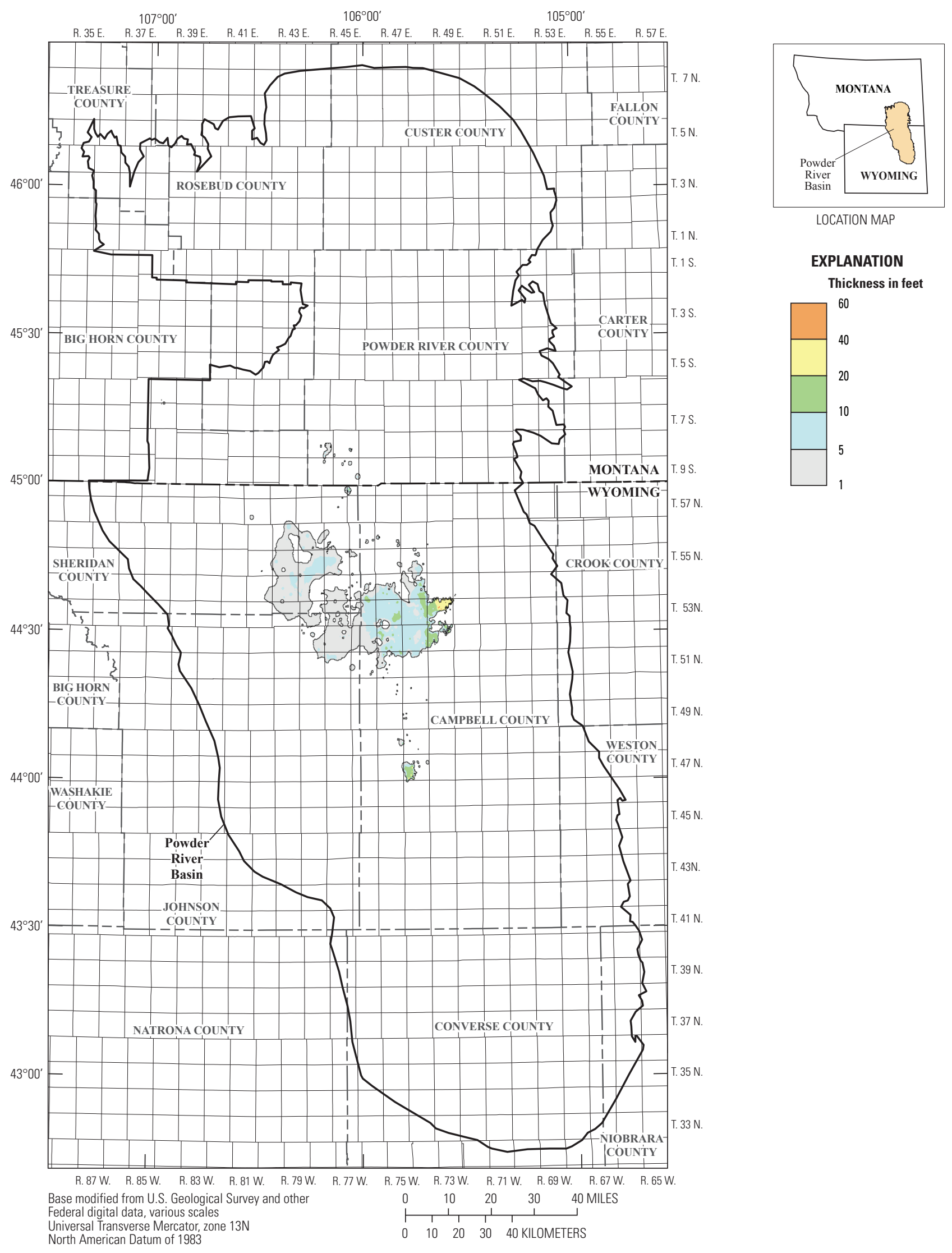

Figure 56. Isopach map of the Lower Anderson coal bed showing extent of coal at least 1.0 foot thick within the Powder River Basin. 


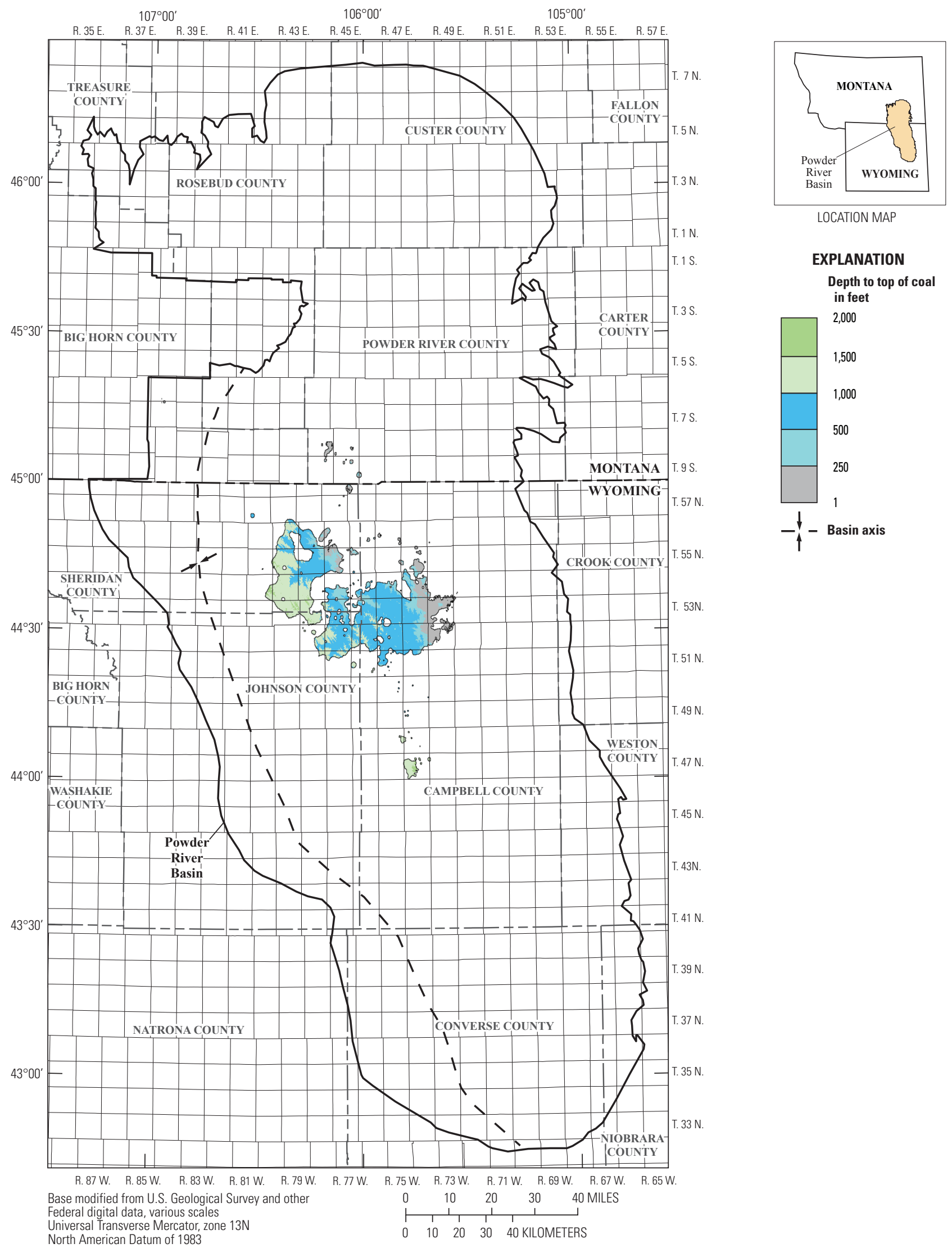

Figure 57. Map showing depth to the top of the Lower Anderson coal bed within the Powder River Basin. 


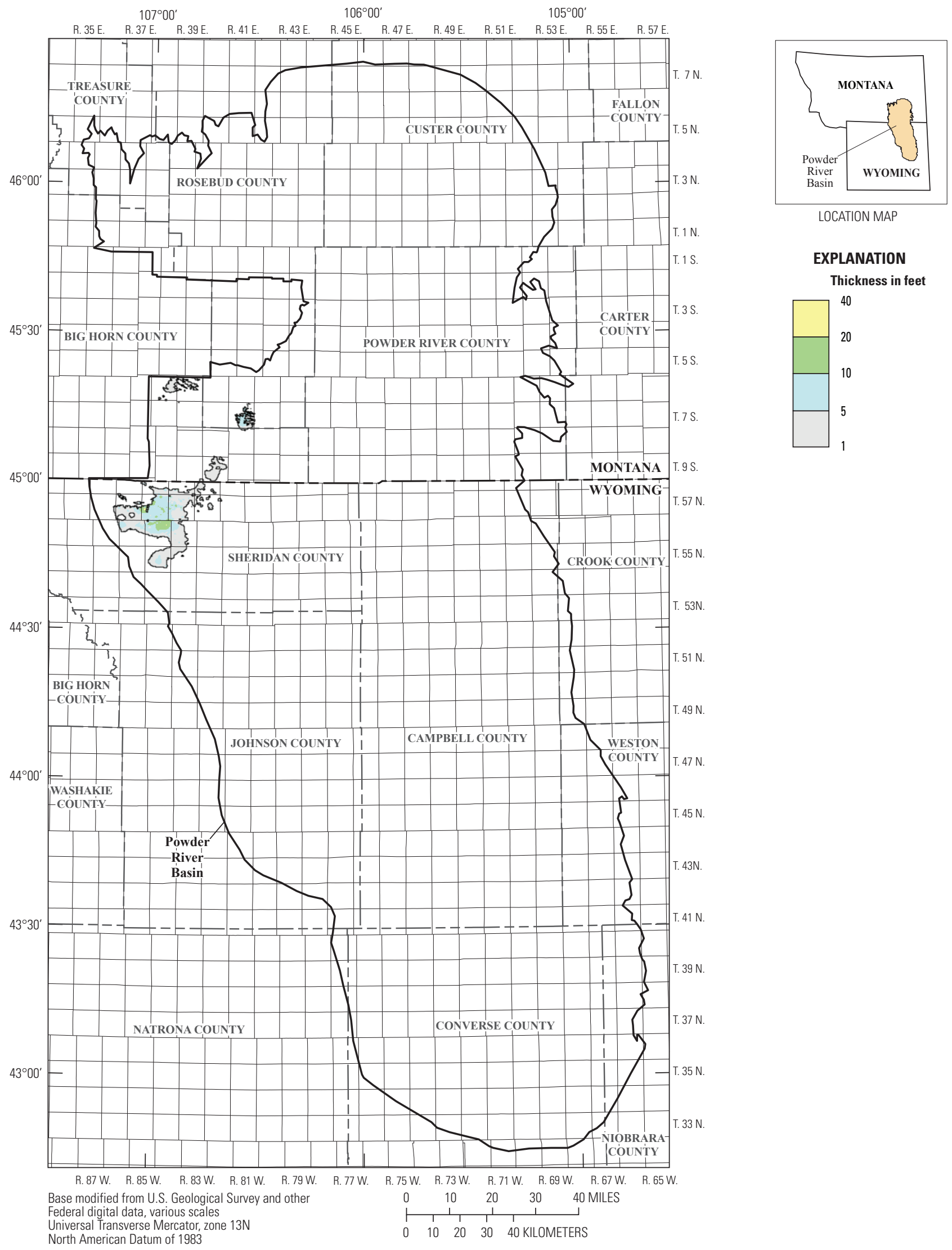

Figure 58. Isopach map of the Dietz 1 coal bed showing extent of coal at least 1.0 foot thick within the Powder River Basin. 


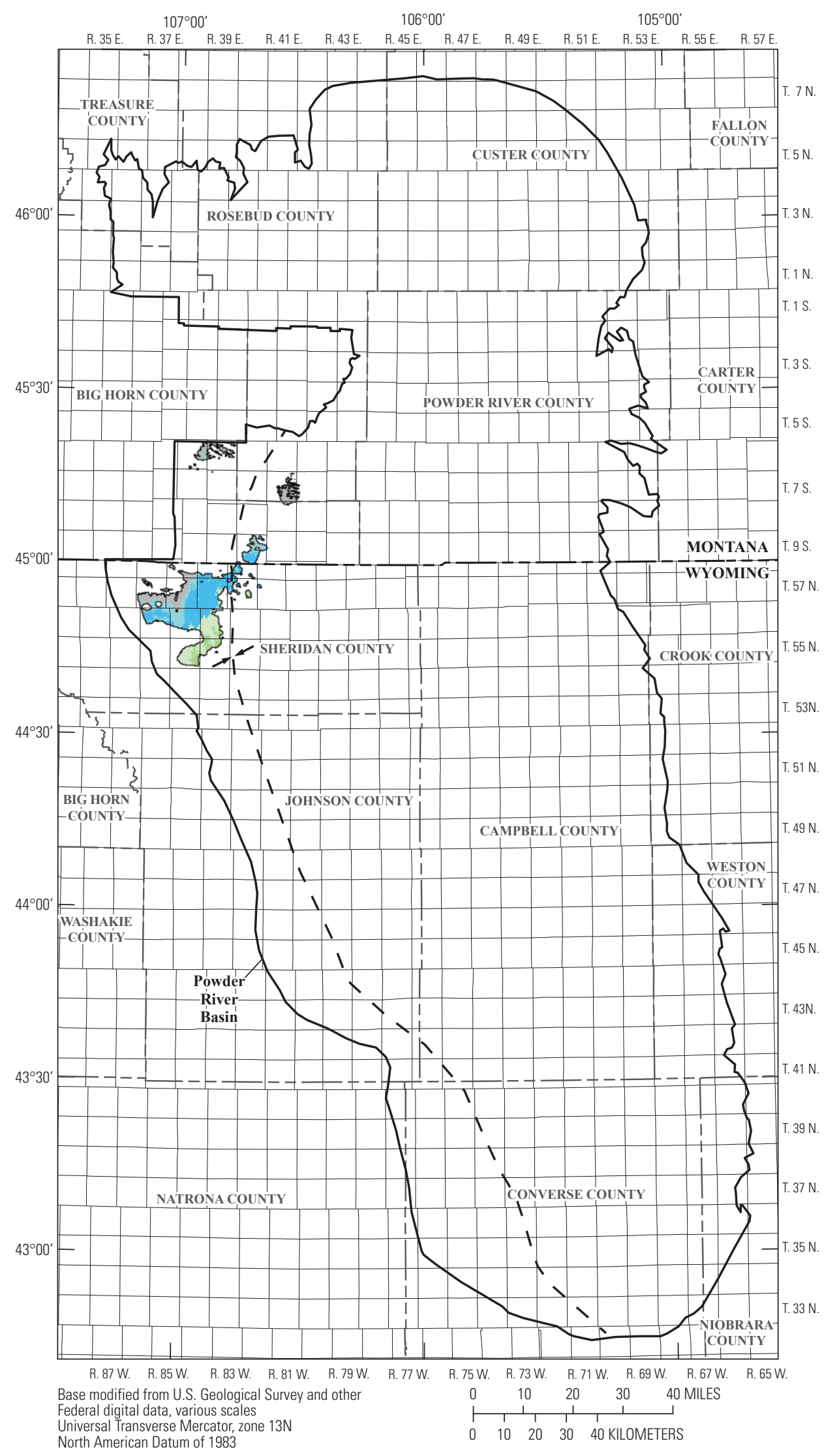

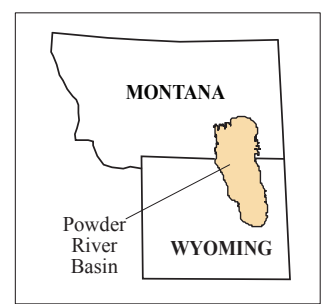

LOCATION MAP

EXPLANATION

Depth to top of coa in feet

2,500

2,000

1,500

1,000

500

250

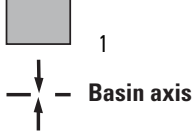

Figure 59. Map showing depth to the top of the Dietz 1 coal bed within the Powder River Basin. 


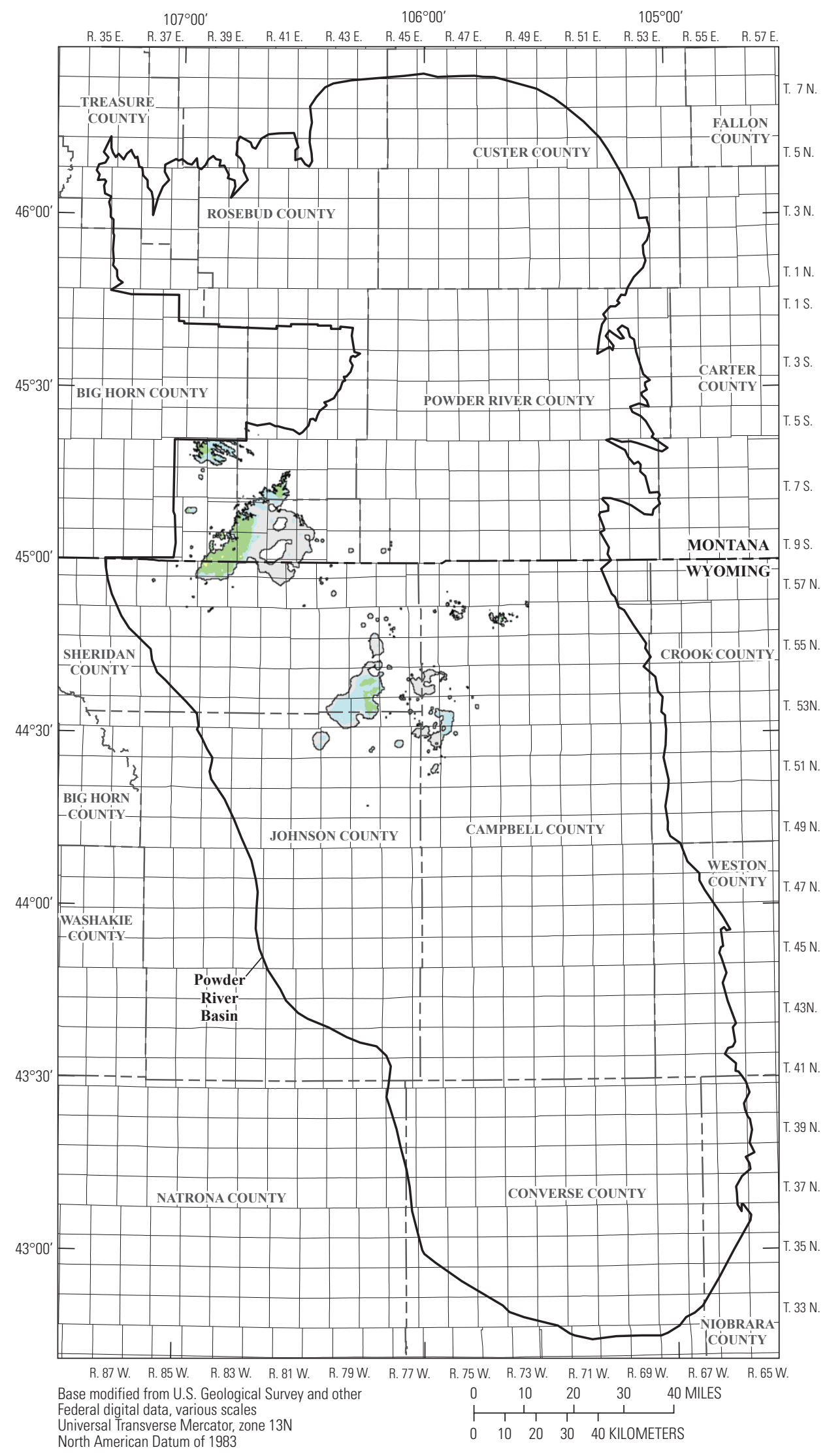

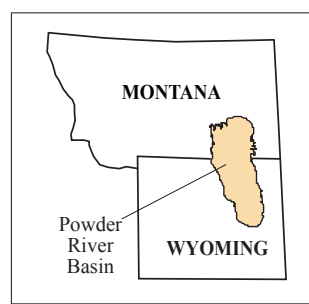

LOCATION MAP

EXPLANATION

Thickness in feet

40

20

10

5

Figure 60. Isopach map of the Dietz 2 coal bed showing extent of coal at least 1.0 foot thick within the Powder River Basin. 

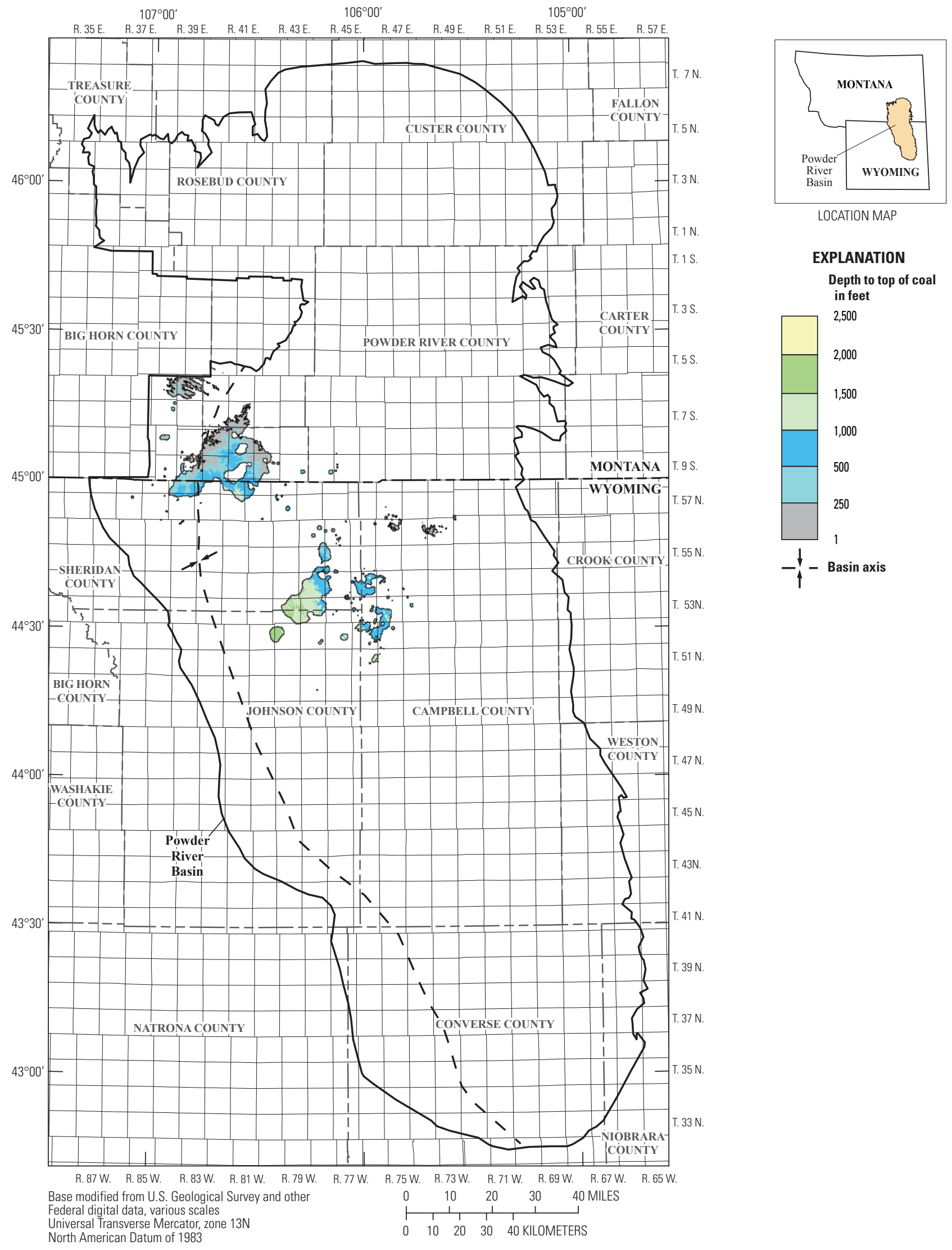

Figure 61. Map showing depth to the top of the Dietz 2 coal bed within the Powder River Basin. 


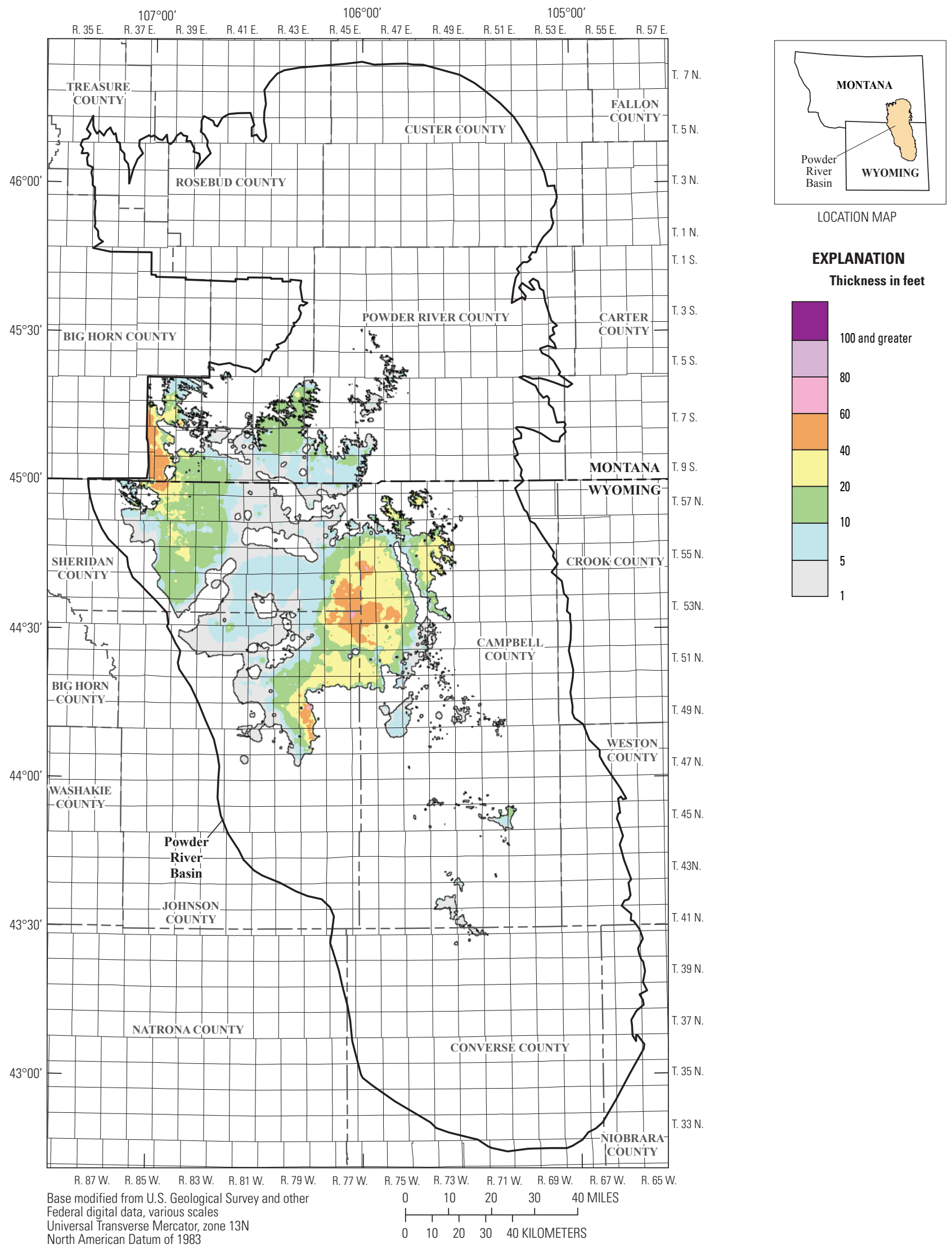

Figure 62. Isopach map of the Dietz 3 coal bed showing extent of coal at least 1.0 foot thick within the Powder River Basin. 

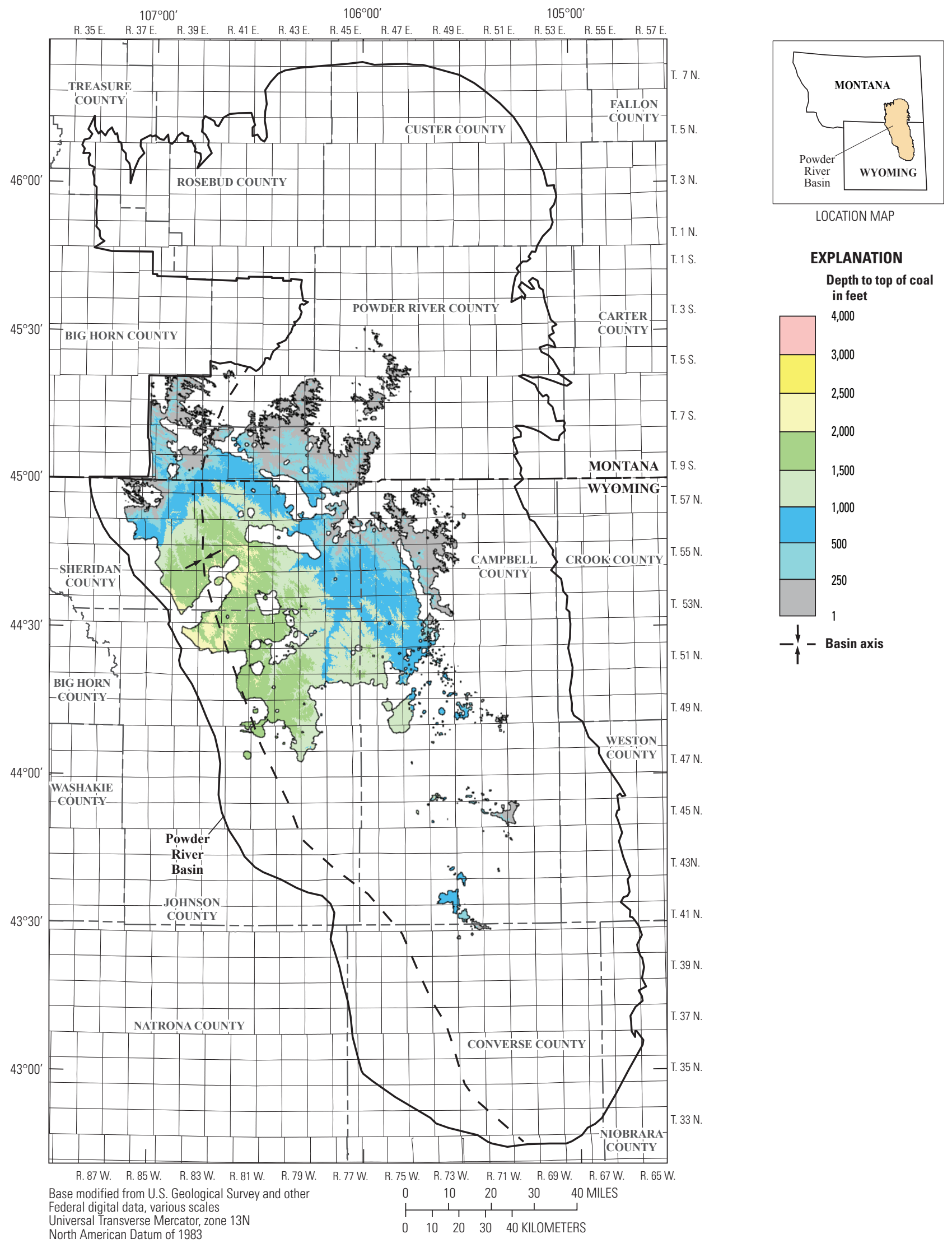

Figure 63. Map showing depth to the top of the Dietz 3 coal bed within the Powder River Basin. 


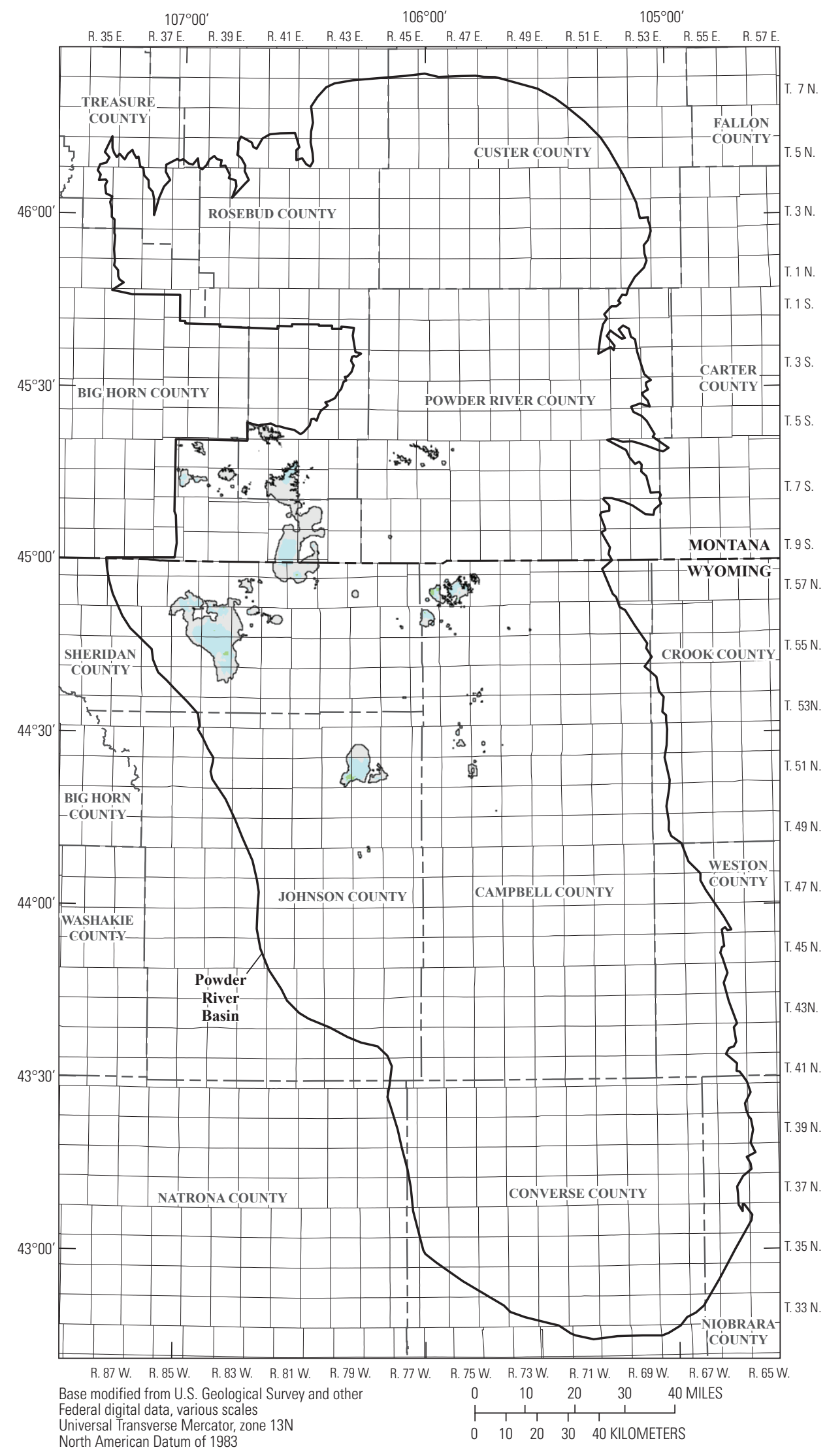

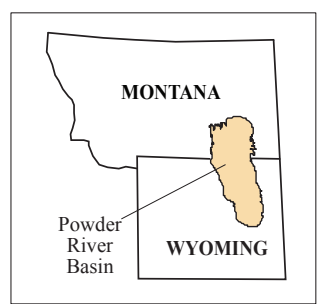

LOCATION MAP

EXPLANATION

Thickness in feet

20

10

5

Figure 64. Isopach map of the Dietz 4 coal bed showing extent of coal at least 1.0 foot thick within the Powder River Basin. 

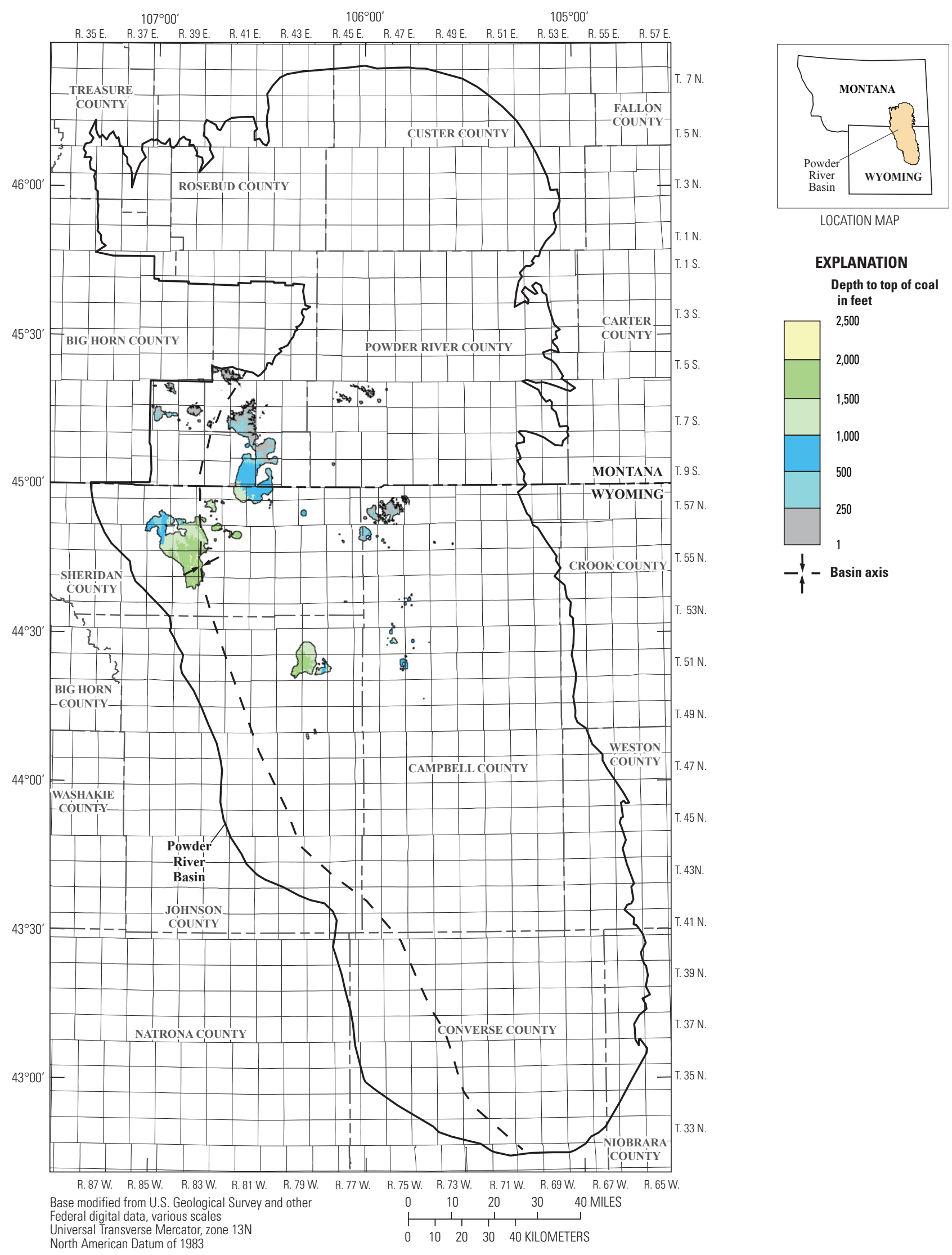

Figure 65. Map showing depth to the top of the Dietz 4 coal bed within the Powder River Basin. 


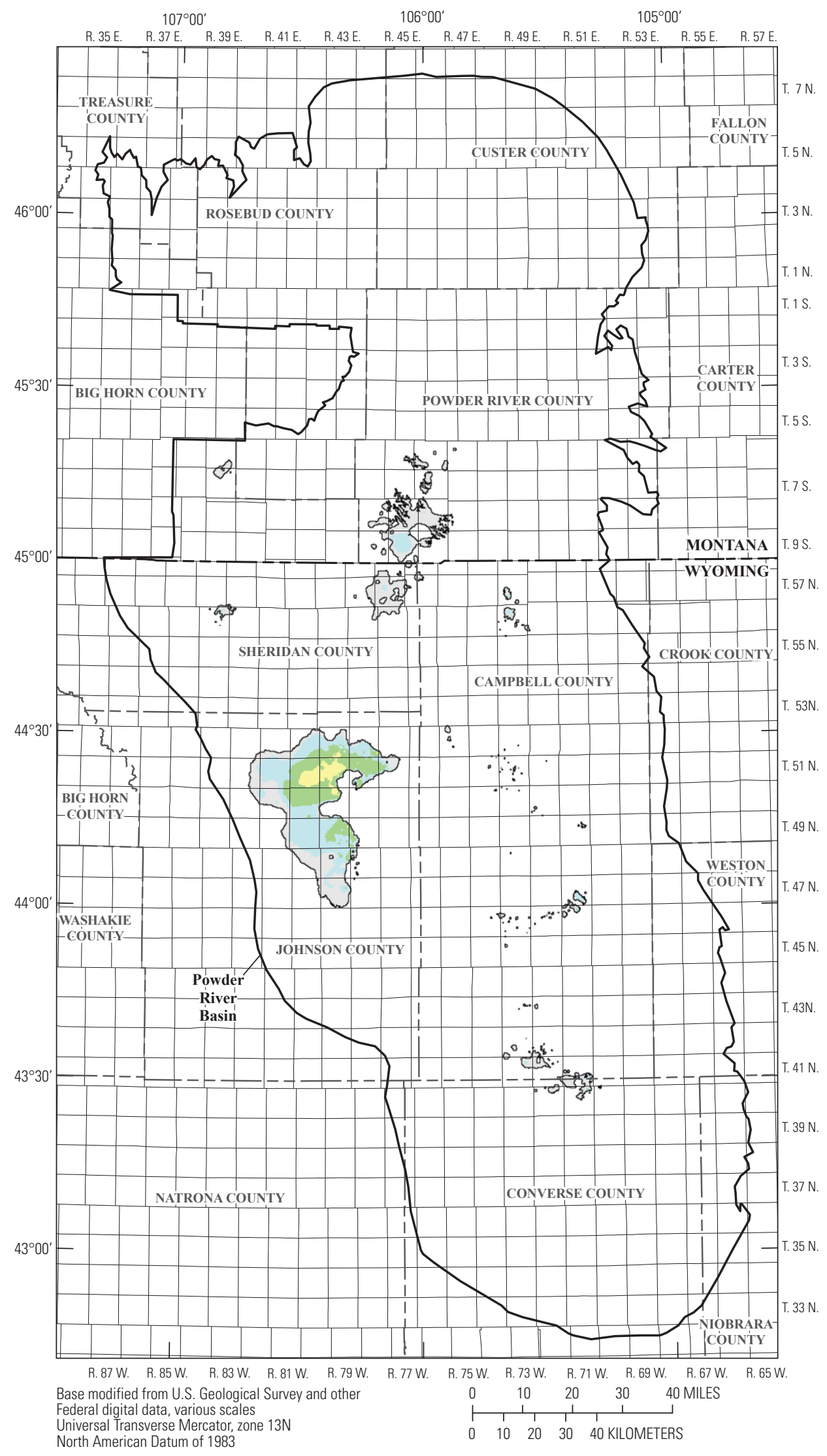

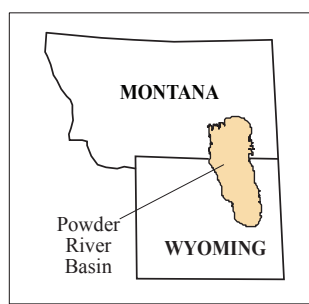

LOCATION MAP

EXPLANATION

Thickness in feet

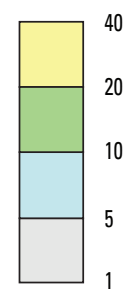

Figure 66. Isopach map of the Upper Canyon (Cox) coal bed showing extent of coal at least 1.0 foot thick within the Powder River Basin. 


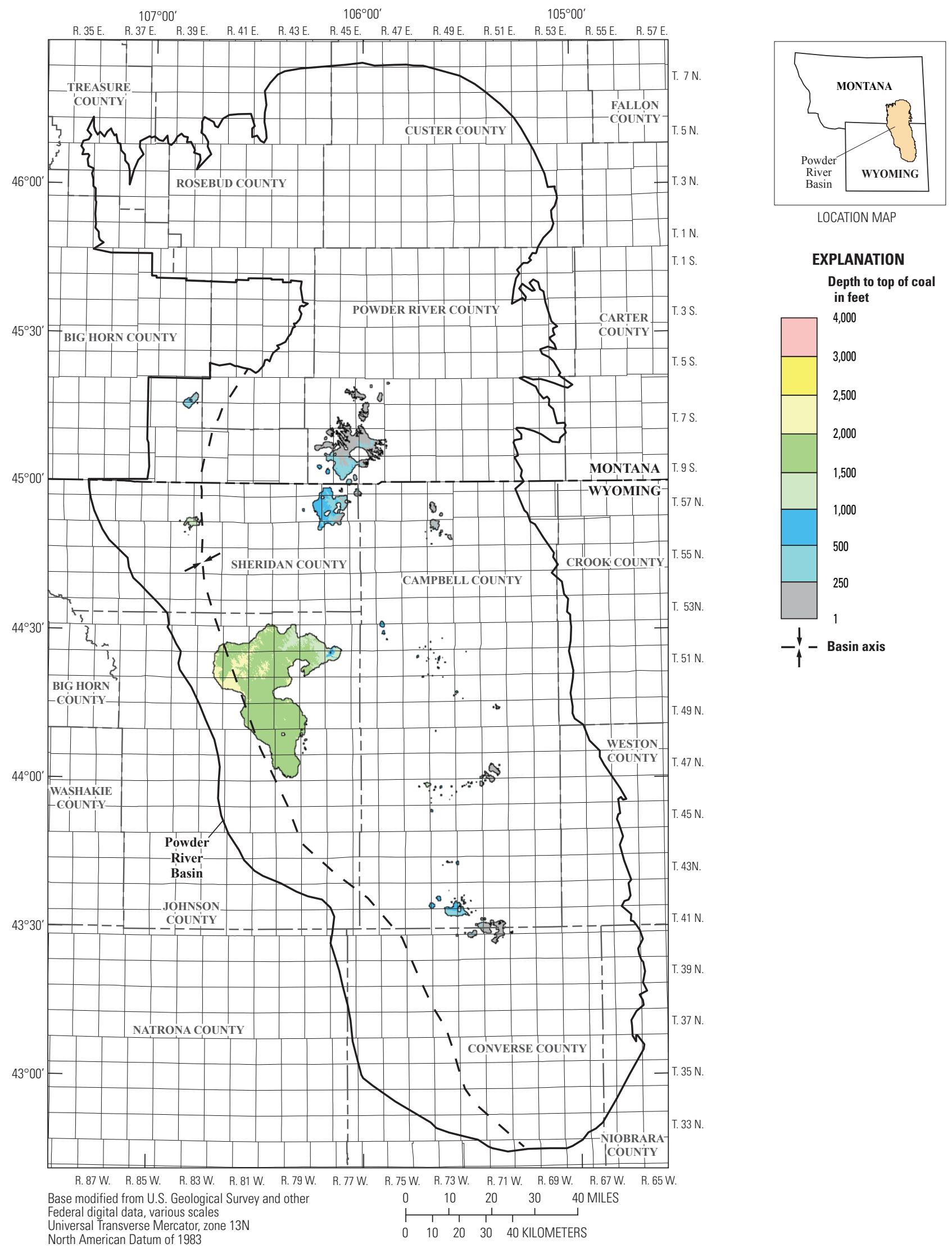

Figure 67. Map showing depth to the top of the Upper Canyon (Cox) coal bed within the Powder River Basin. 




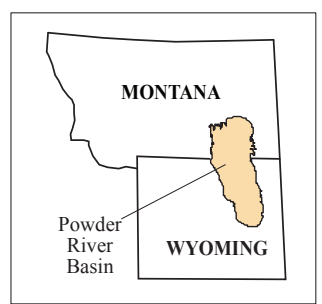

LOCATION MAP

EXPLANATION

Thickness in feet

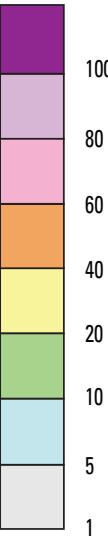

Figure 68. Isopach map of the Canyon coal bed showing extent of coal at least 1.0 foot thick within the Powder River Basin. 

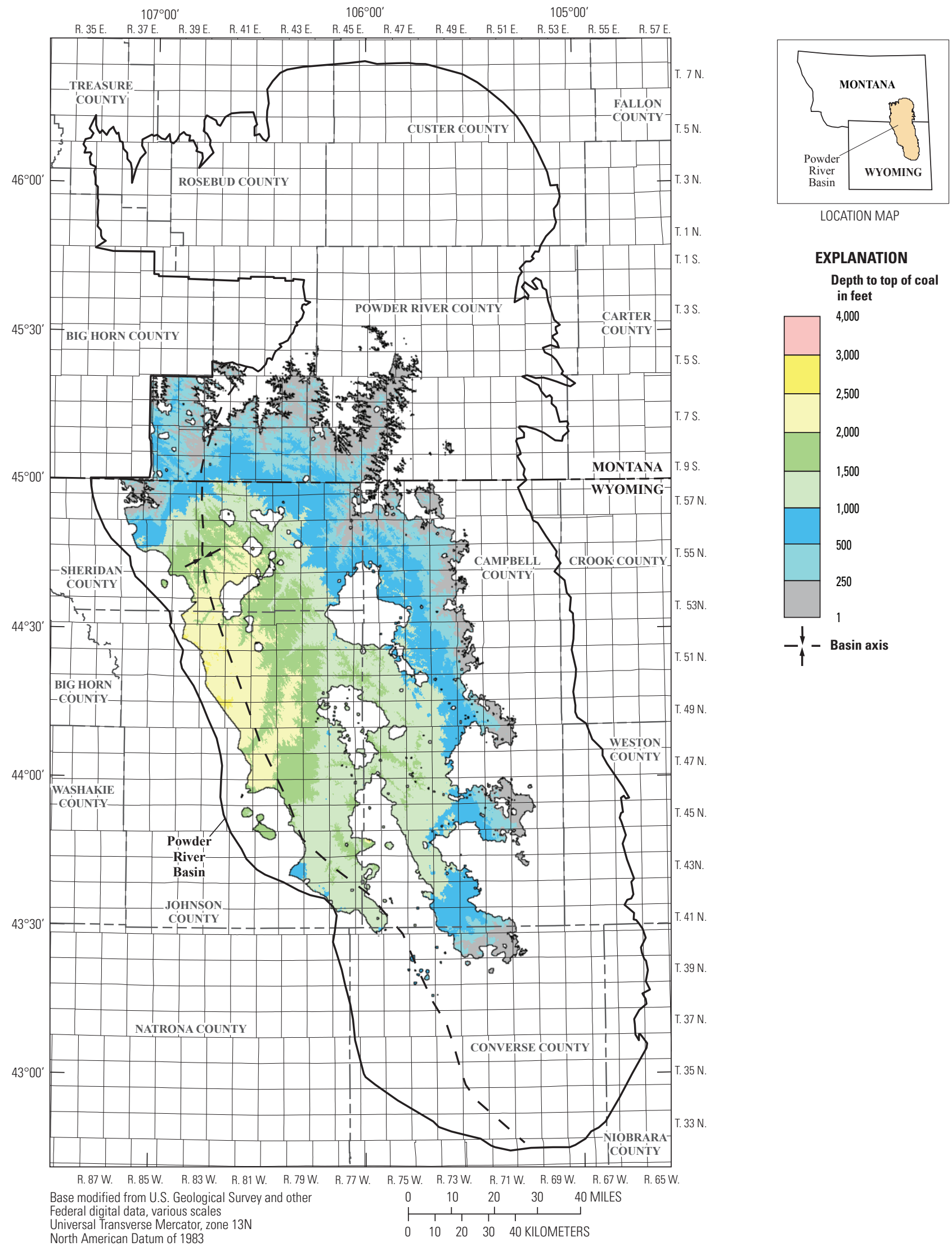

Figure 69. Map showing depth to the top of the Canyon coal bed within the Powder River Basin. 


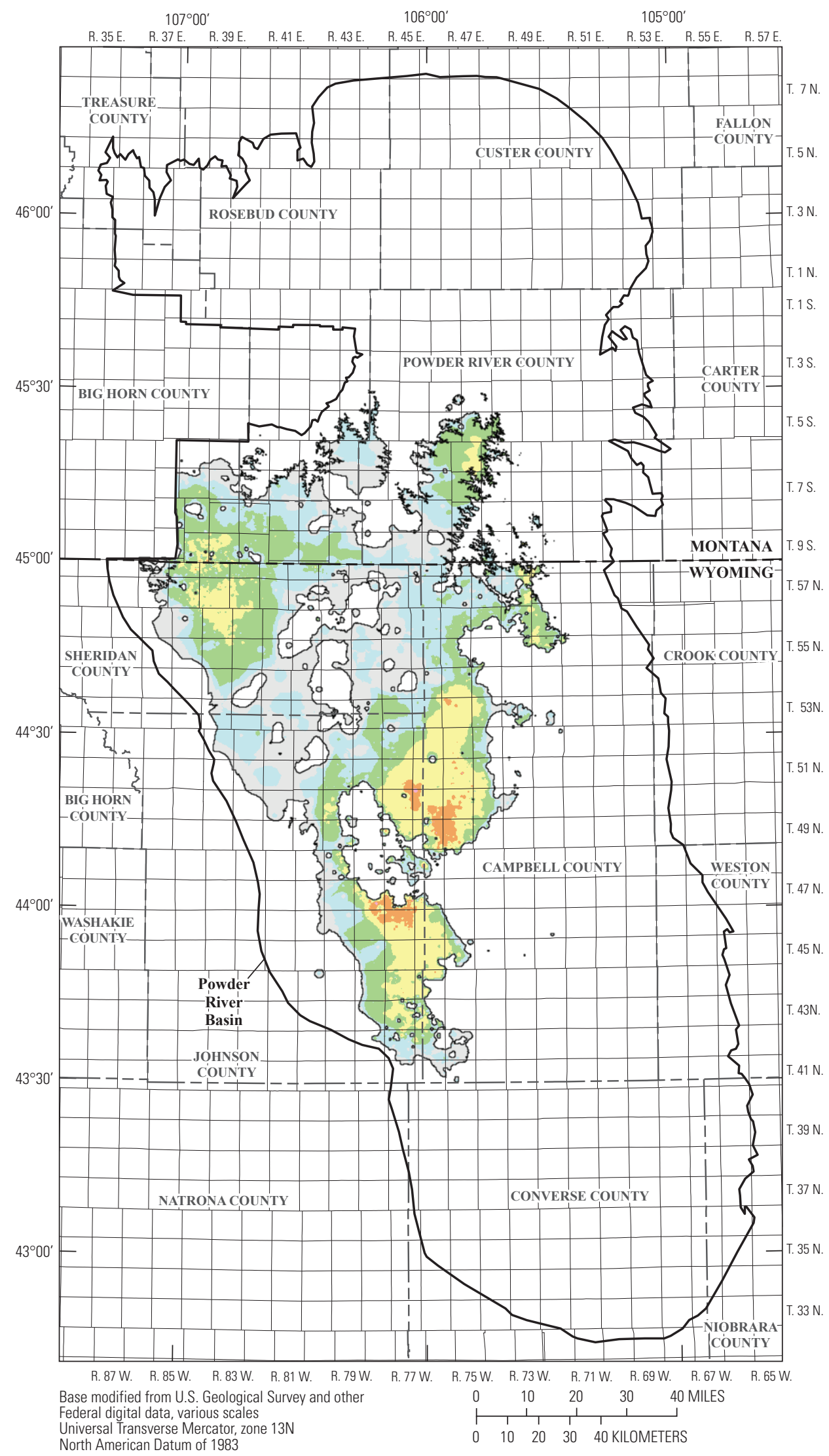

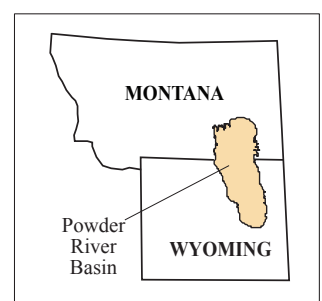

LOCATION MAP

EXPLANATION

Thickness in feet

100

80

60

40

20

10

5

Figure 70. Isopach map of the Lower Canyon coal bed showing extent of coal at least 1.0 foot thick within the Powder River Basin. 

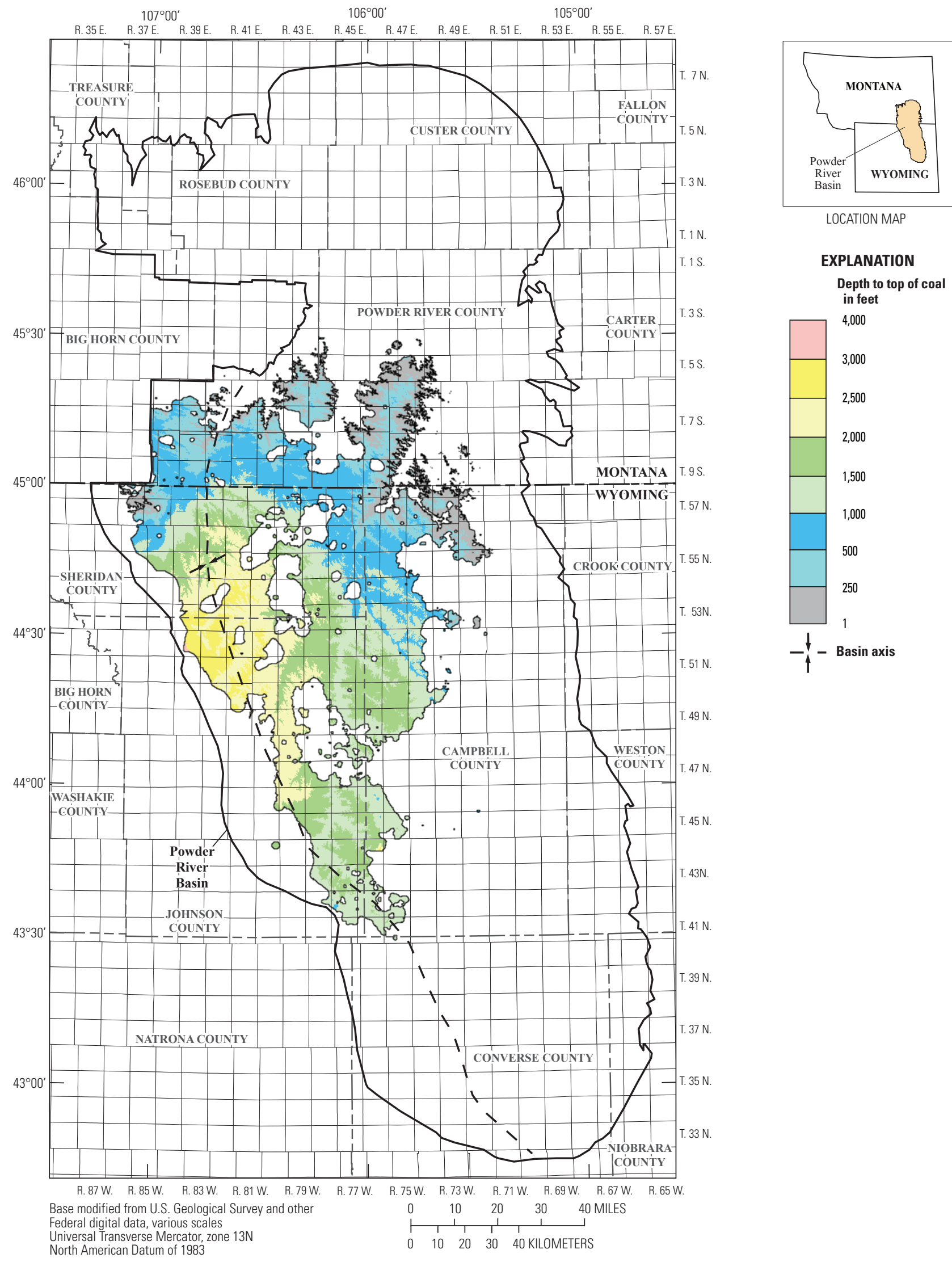

LOCATION MAP

EXPLANATION

Depth to top of coal

in feet

4,000

3,000

2,500

2,000

1,500

1,000

500

250

1

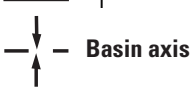

Figure 71. Map showing depth to the top of the Lower Canyon coal bed within the Powder River Basin. 


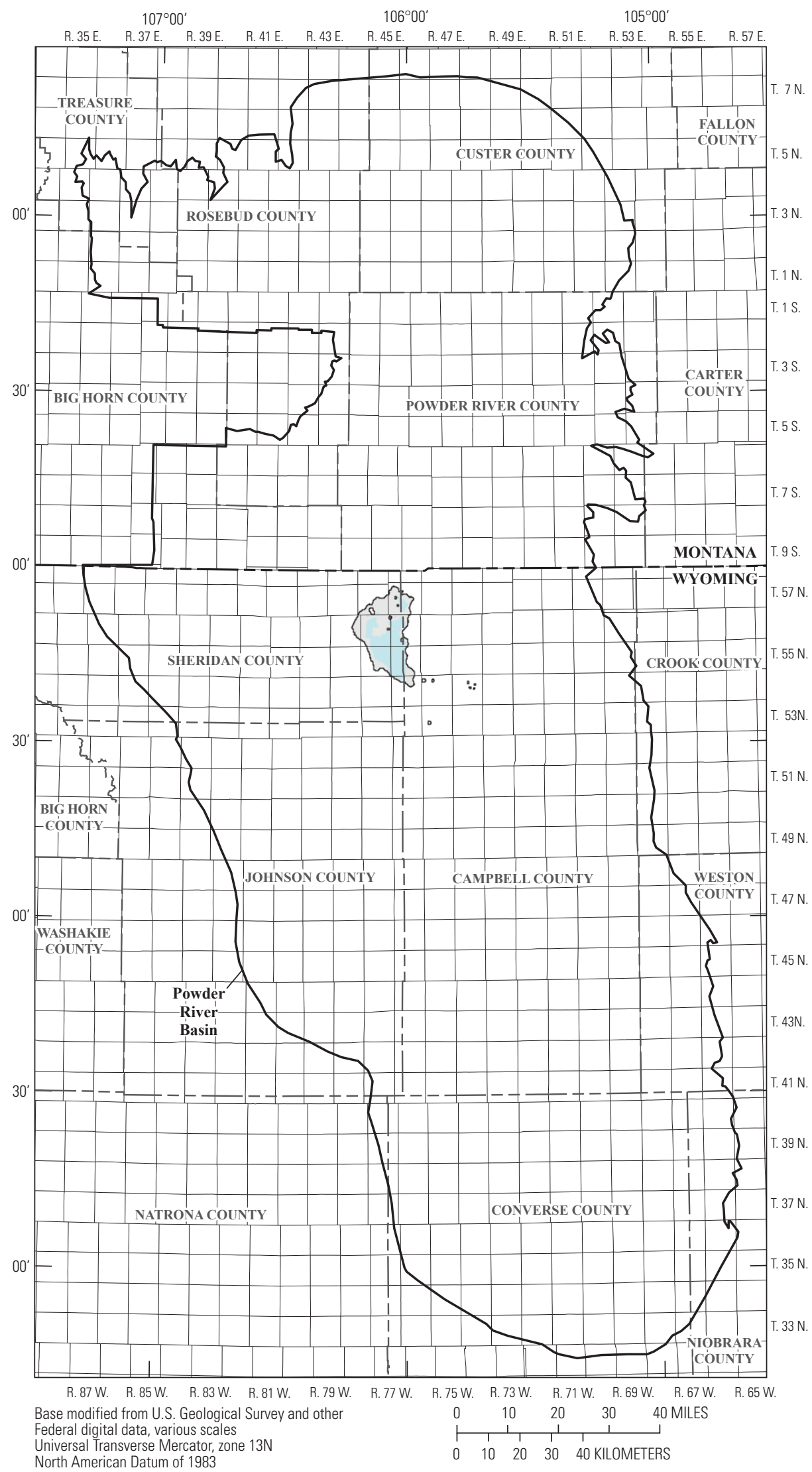

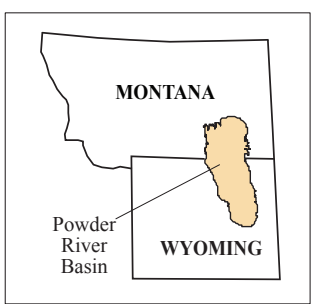

LOCATION MAP

EXPLANATION

Thickness in feet

10

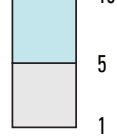

Figure 72. Isopach map of the Upper Ferry coal bed showing extent of coal at least 1.0 foot thick within the Powder River Basin. 


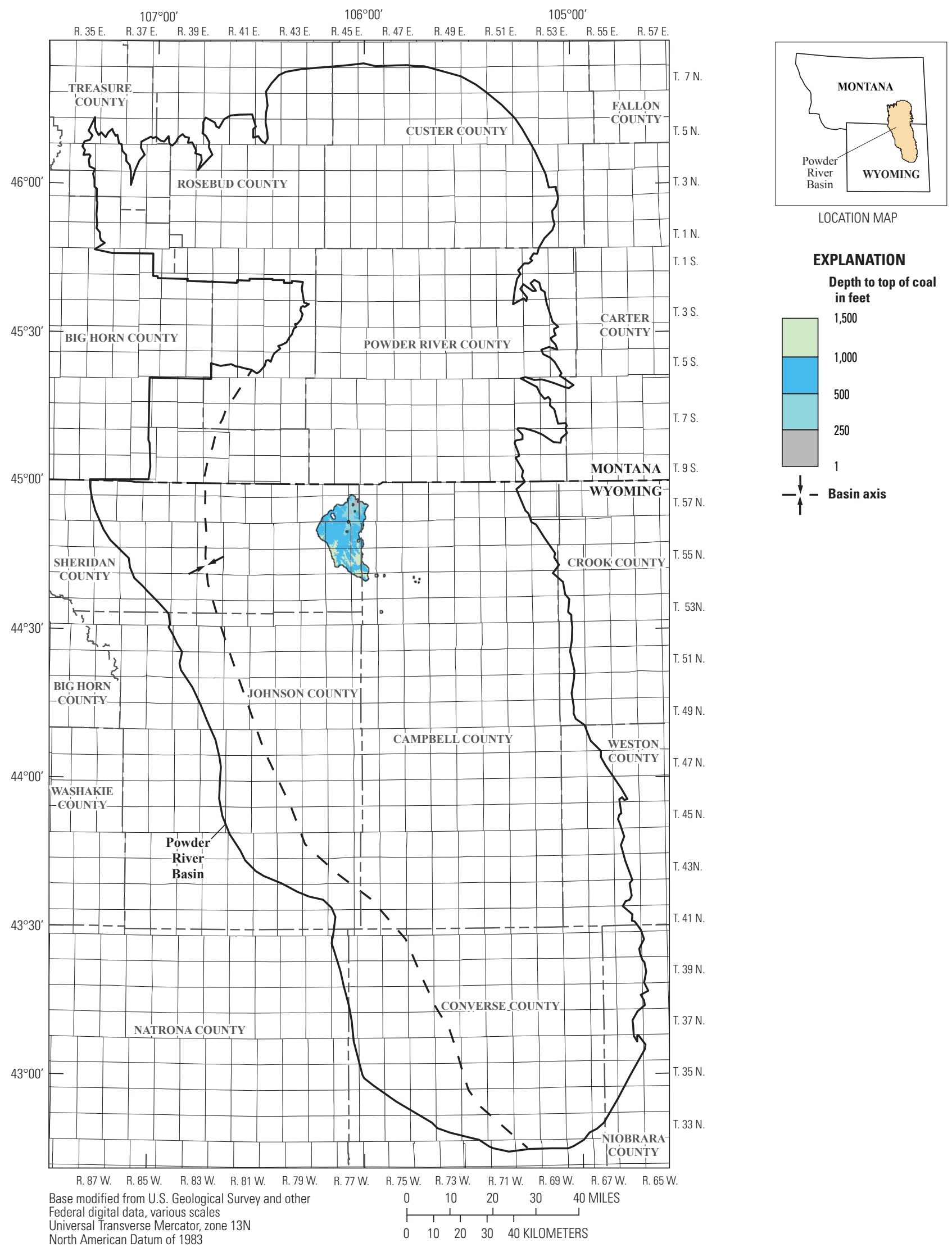

Figure 73. Map showing depth to the top of the Upper Ferry coal bed within the Powder River Basin. 


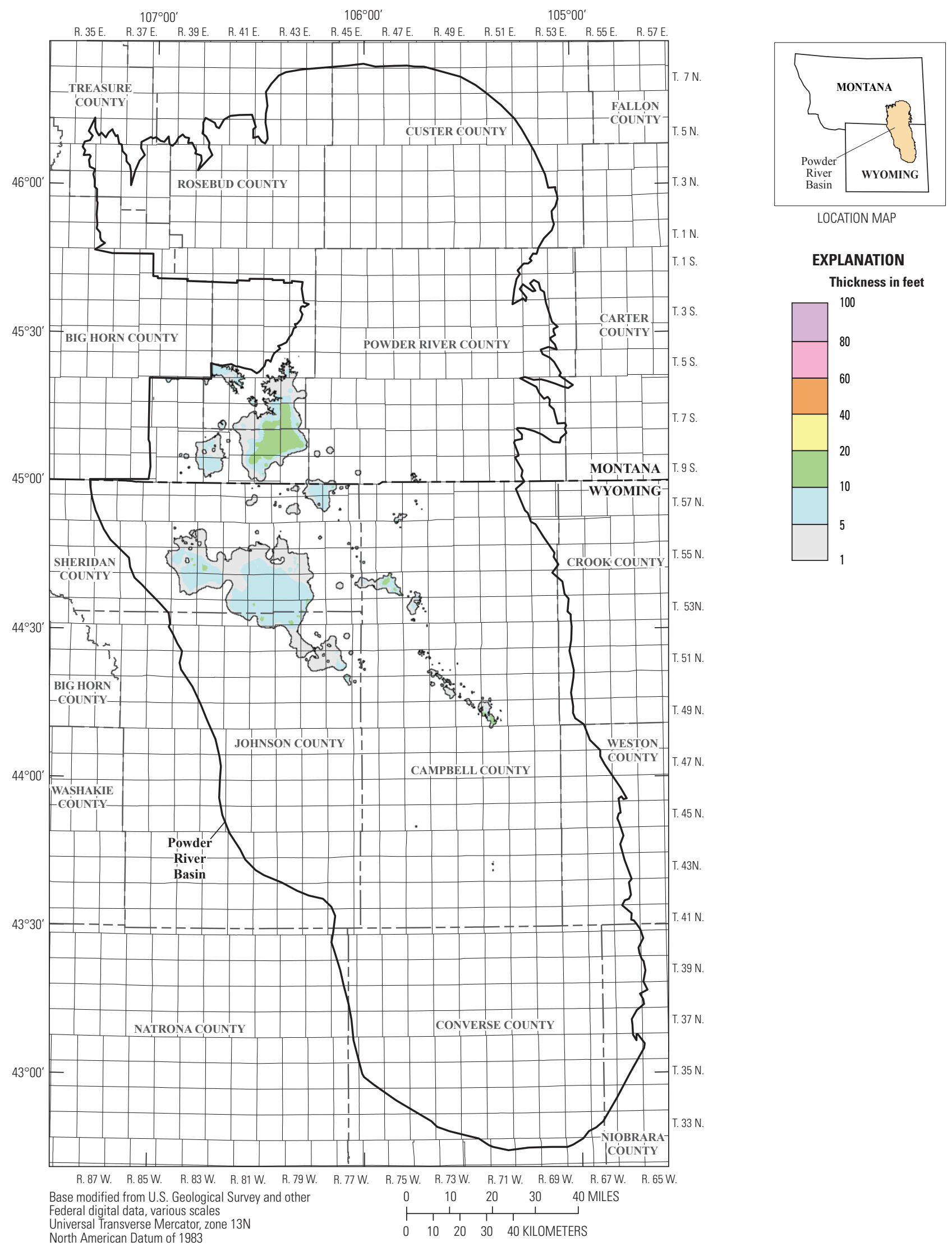

Figure 74. Isopach map of the Ferry coal bed showing extent of coal at least 1.0 foot thick within the Powder River Basin. 

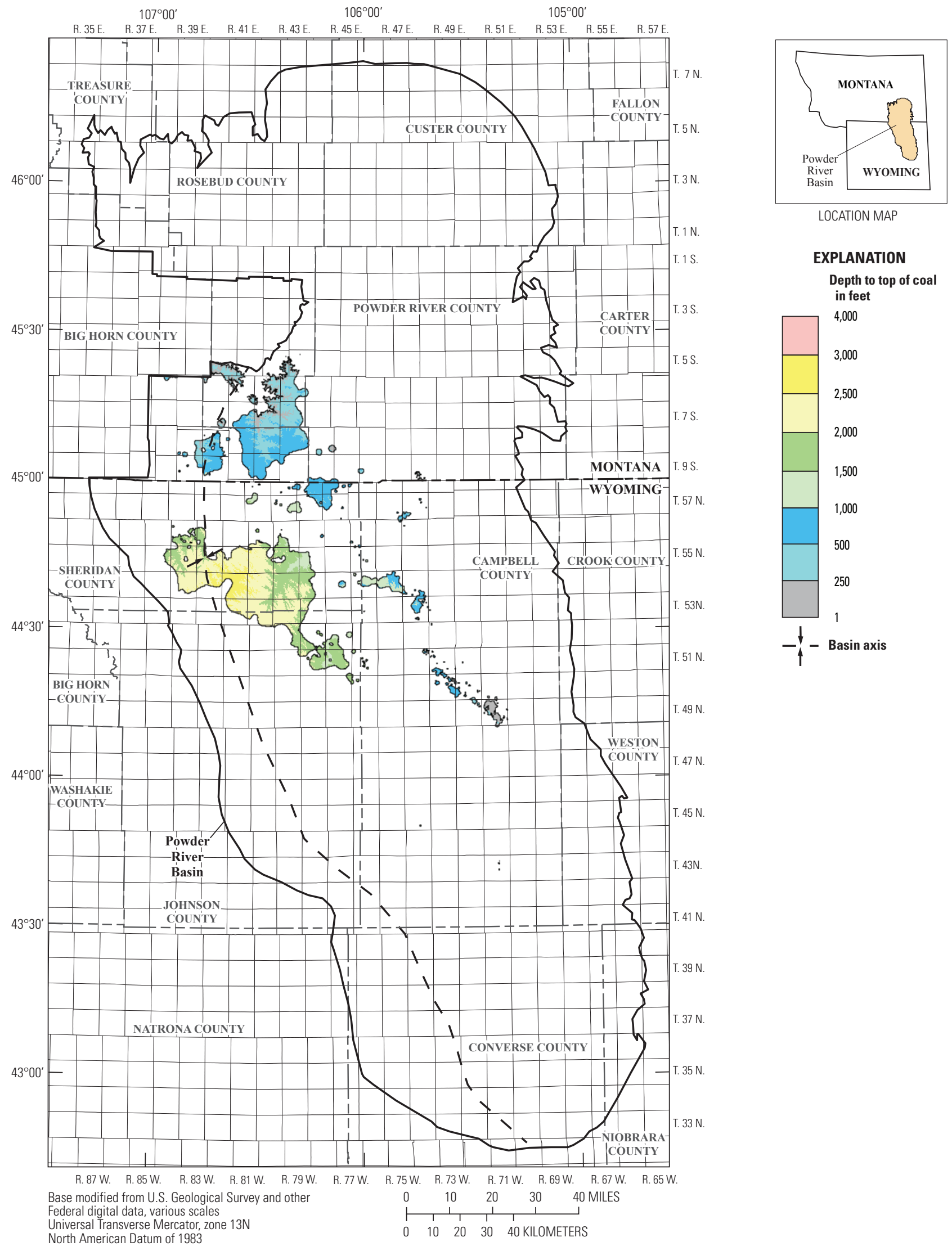

Figure 75. Map showing depth to the top of the Ferry coal bed within the Powder River Basin. 


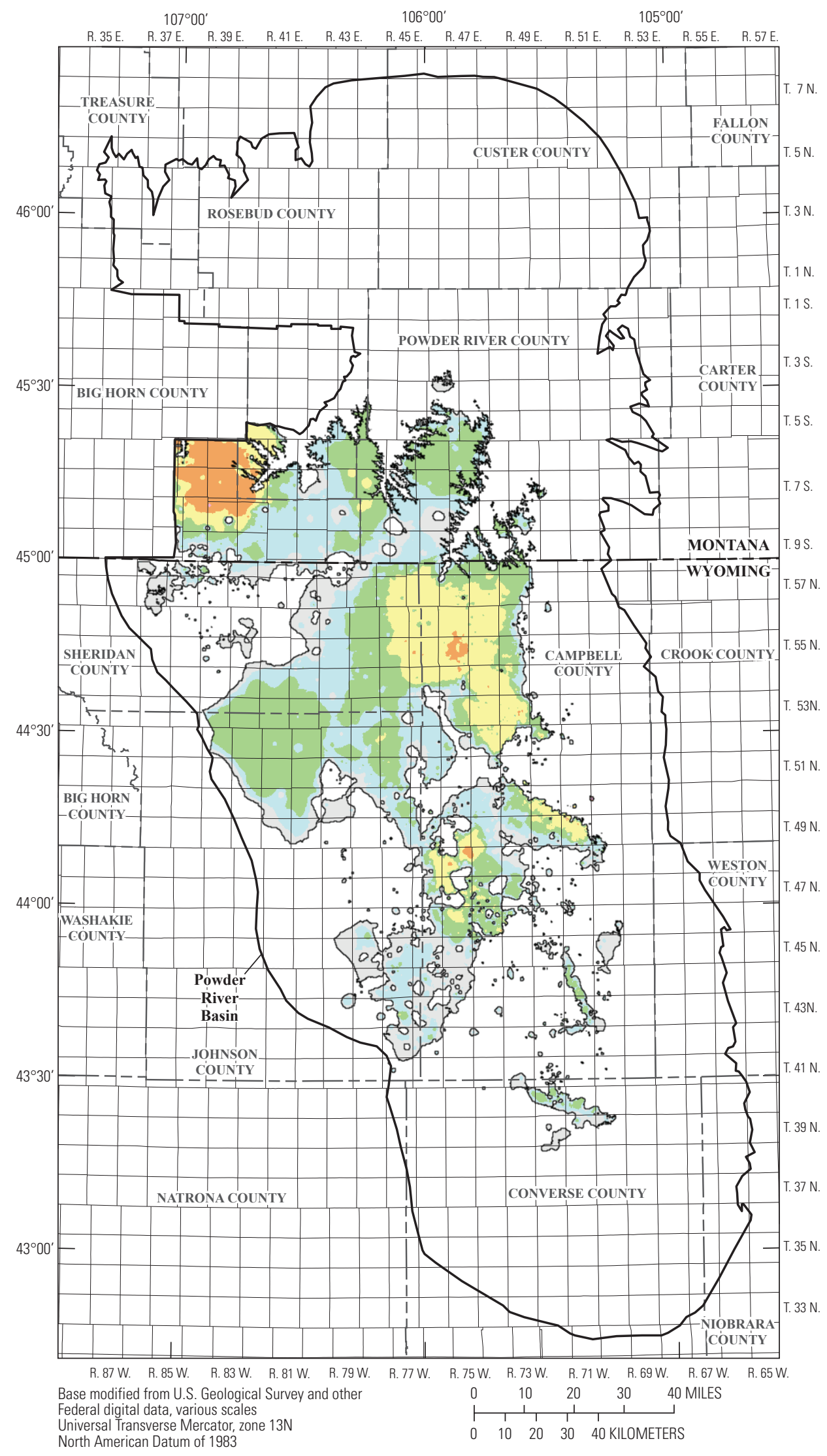

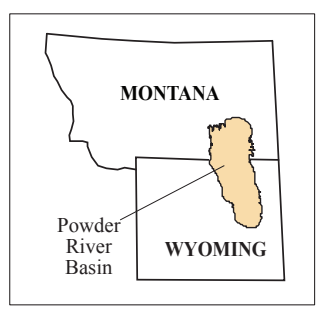

LOCATION MAP

EXPLANATION

Thickness in feet

100 and greater

80

60

40

20

10

5

Figure 76. Isopach map of the Werner/Cook coal bed showing extent of coal at least 1.0 foot thick within the Powder River Basin. 


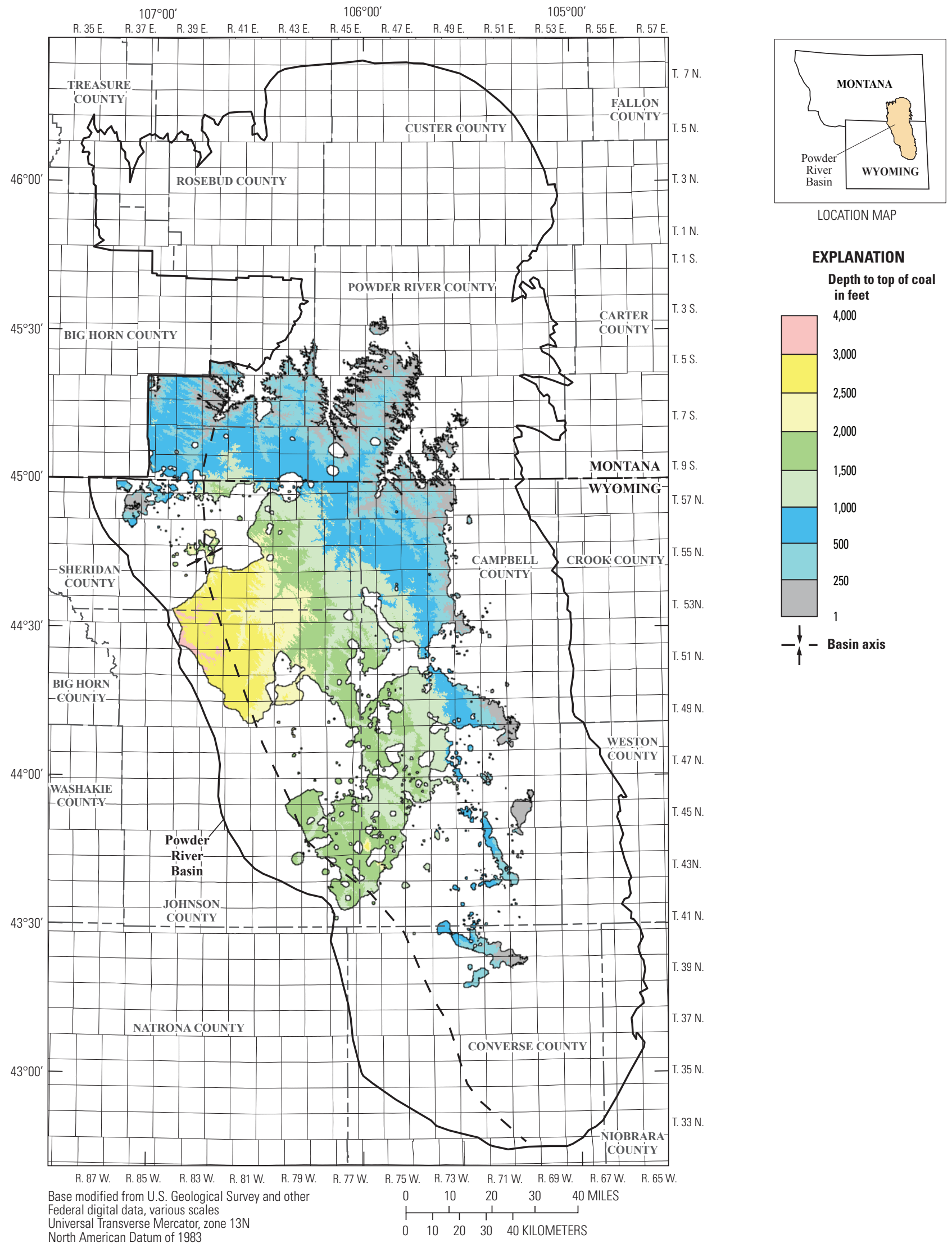

Figure 77. Map showing depth to the top of the Werner/Cook coal bed within the Powder River Basin. 


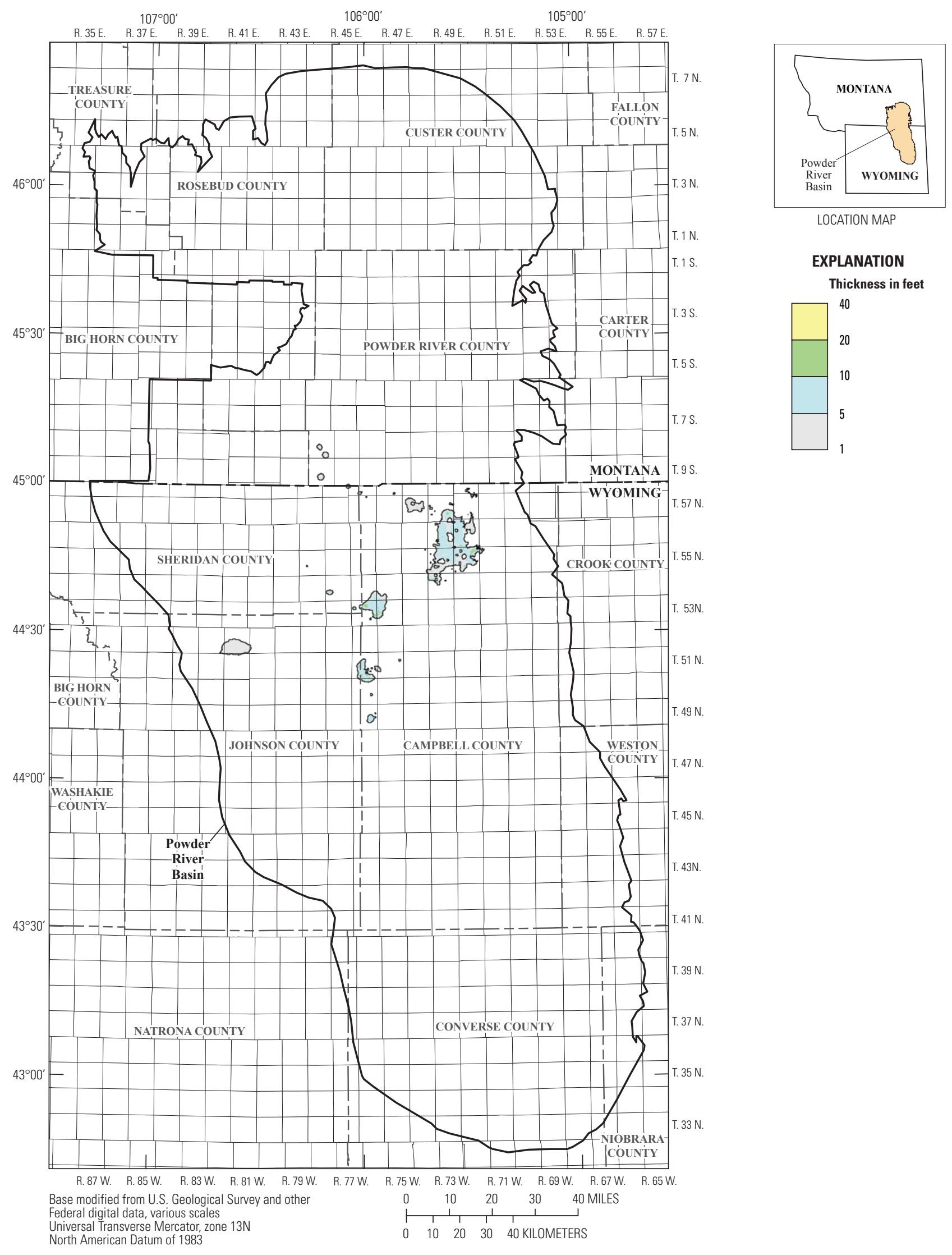

Figure 78. Isopach map of the Upper Otter coal bed showing extent of coal at least 1.0 foot thick within the Powder River Basin. 


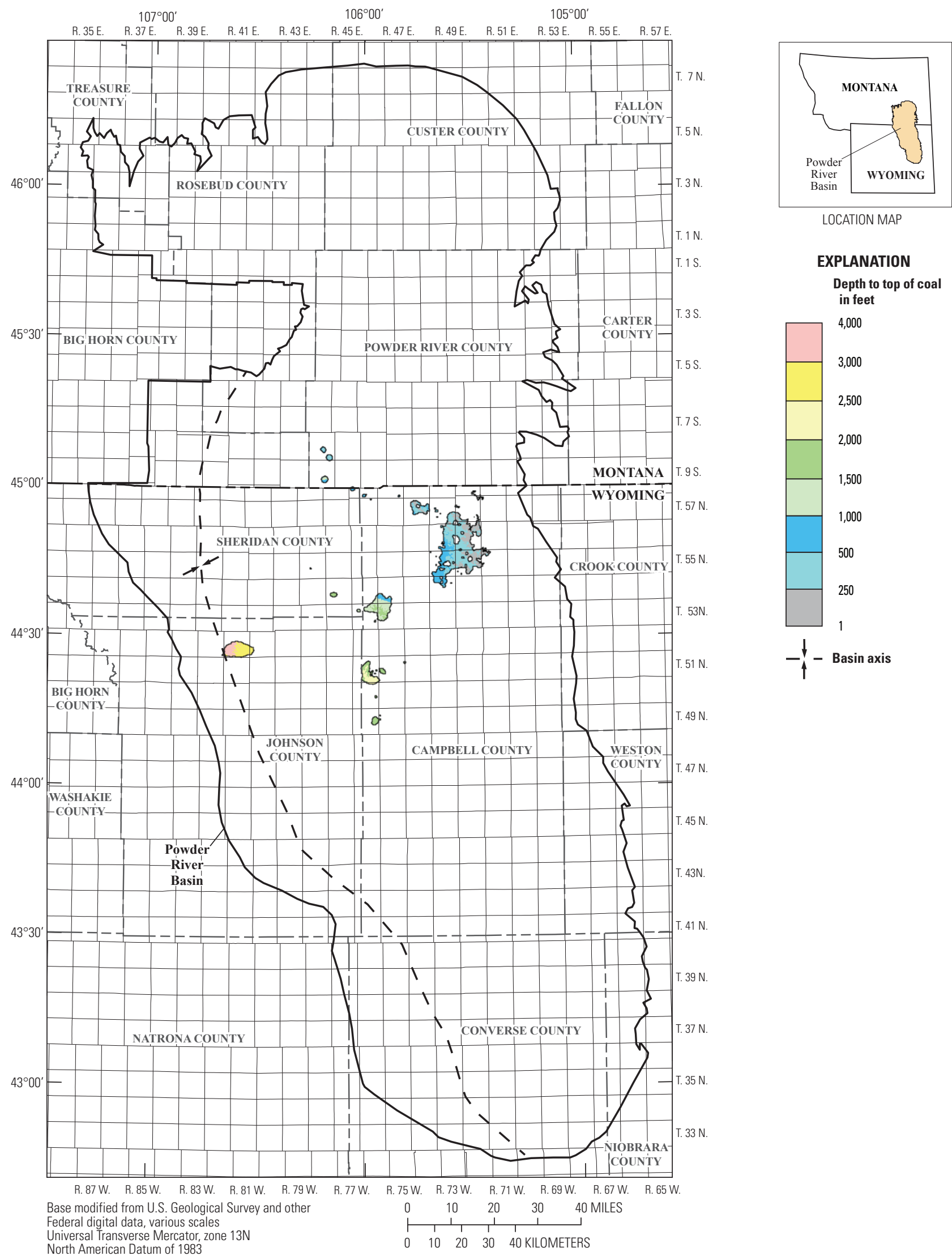

Figure 79. Map showing depth to the top of the Upper Otter coal bed within the Powder River Basin. 


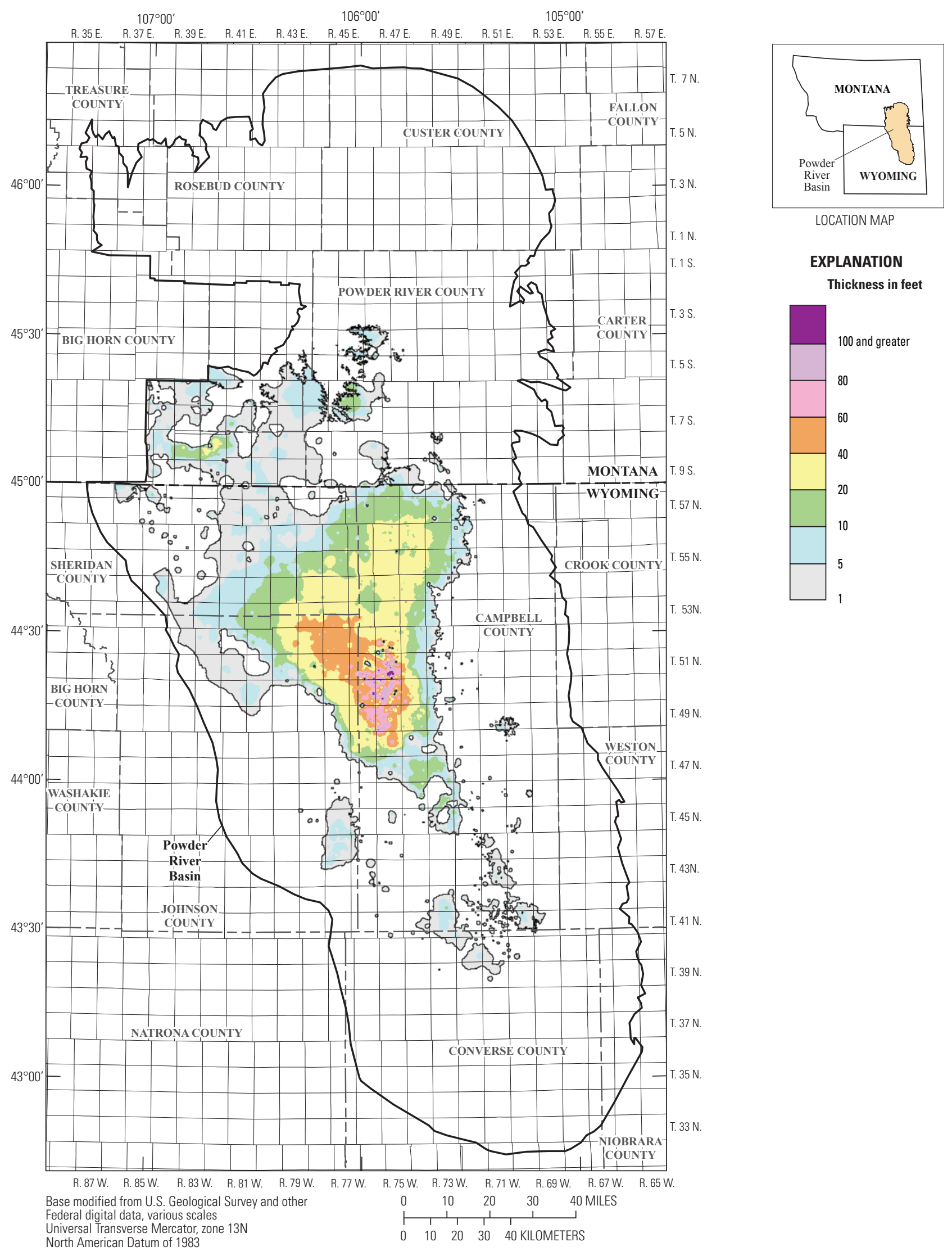

Figure 80. Isopach map of the Otter coal bed showing extent of coal at least 1.0 foot thick within the Powder River Basin. 

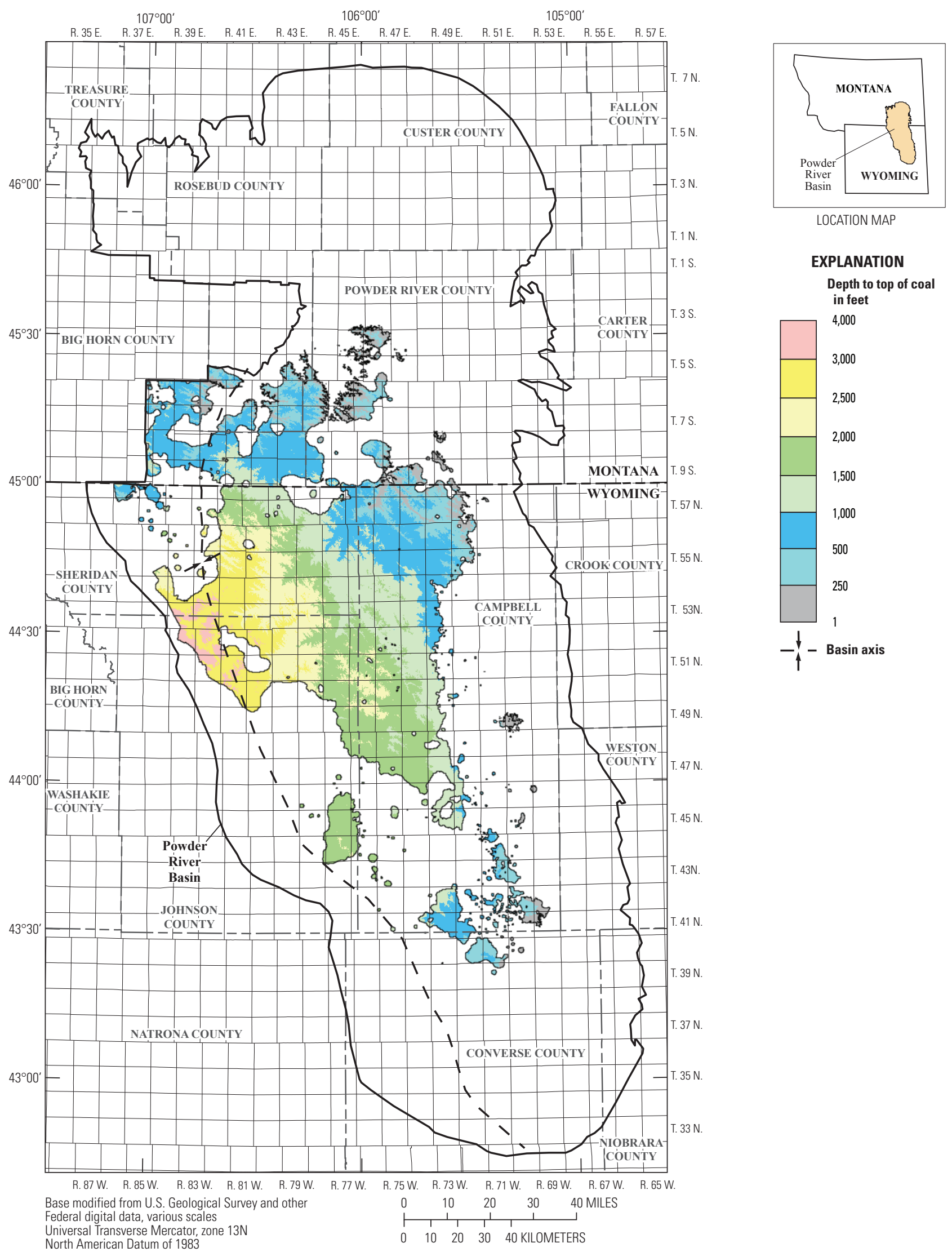

Figure 81. Map showing depth to the top of the Otter coal bed within the Powder River Basin. 


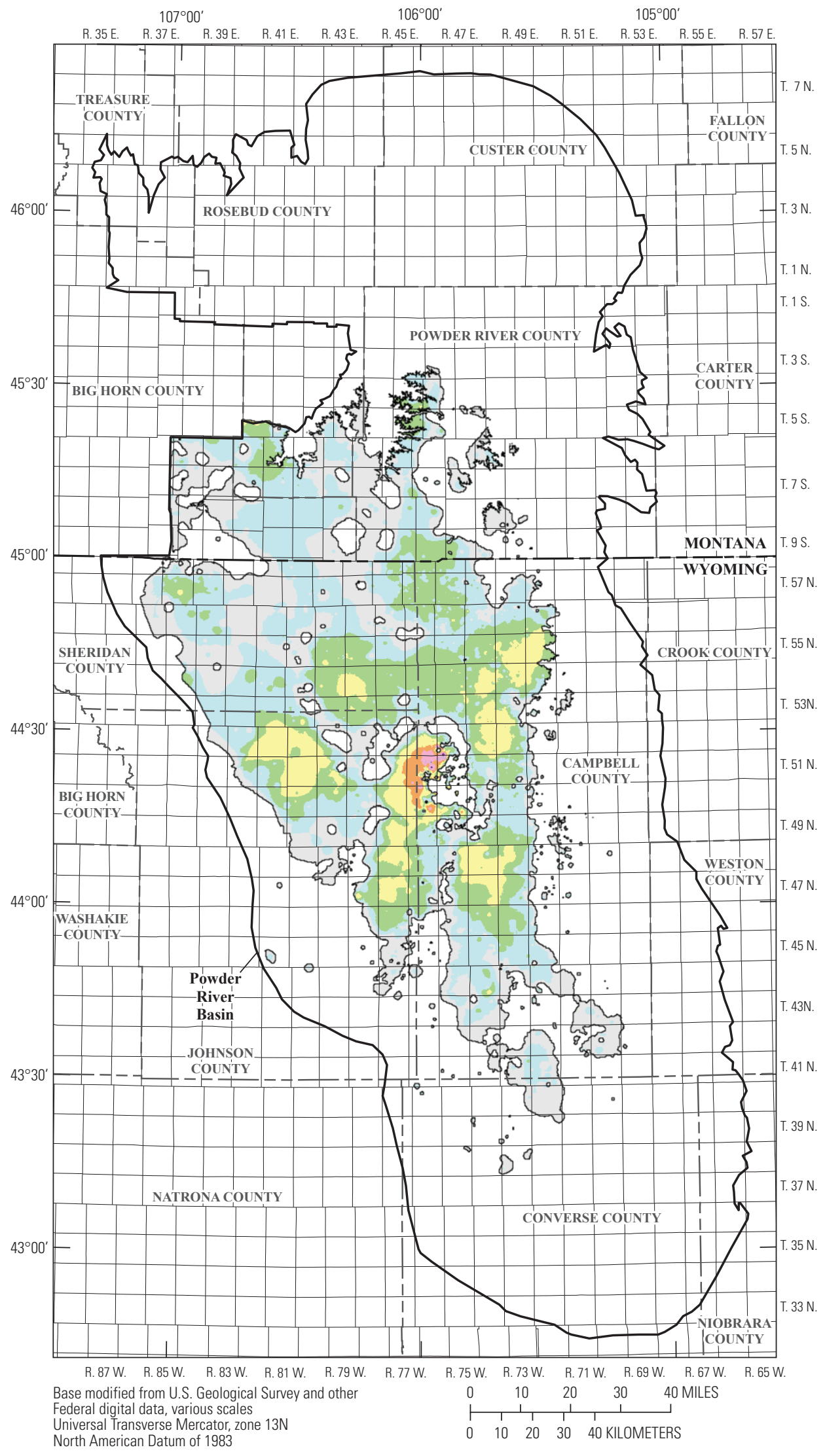

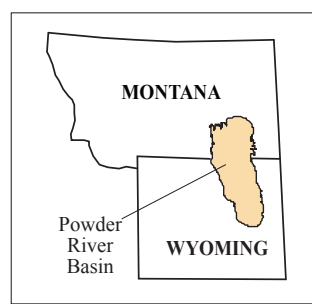

LOCATION MAP

EXPLANATION

Thickness in feet

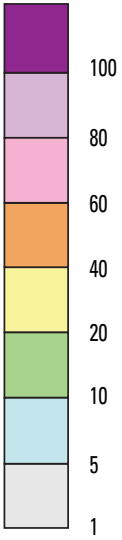

Figure 82. Isopach map of the Gates/Wall coal bed showing extent of coal at least 1.0 foot thick within the Powder River Basin. 

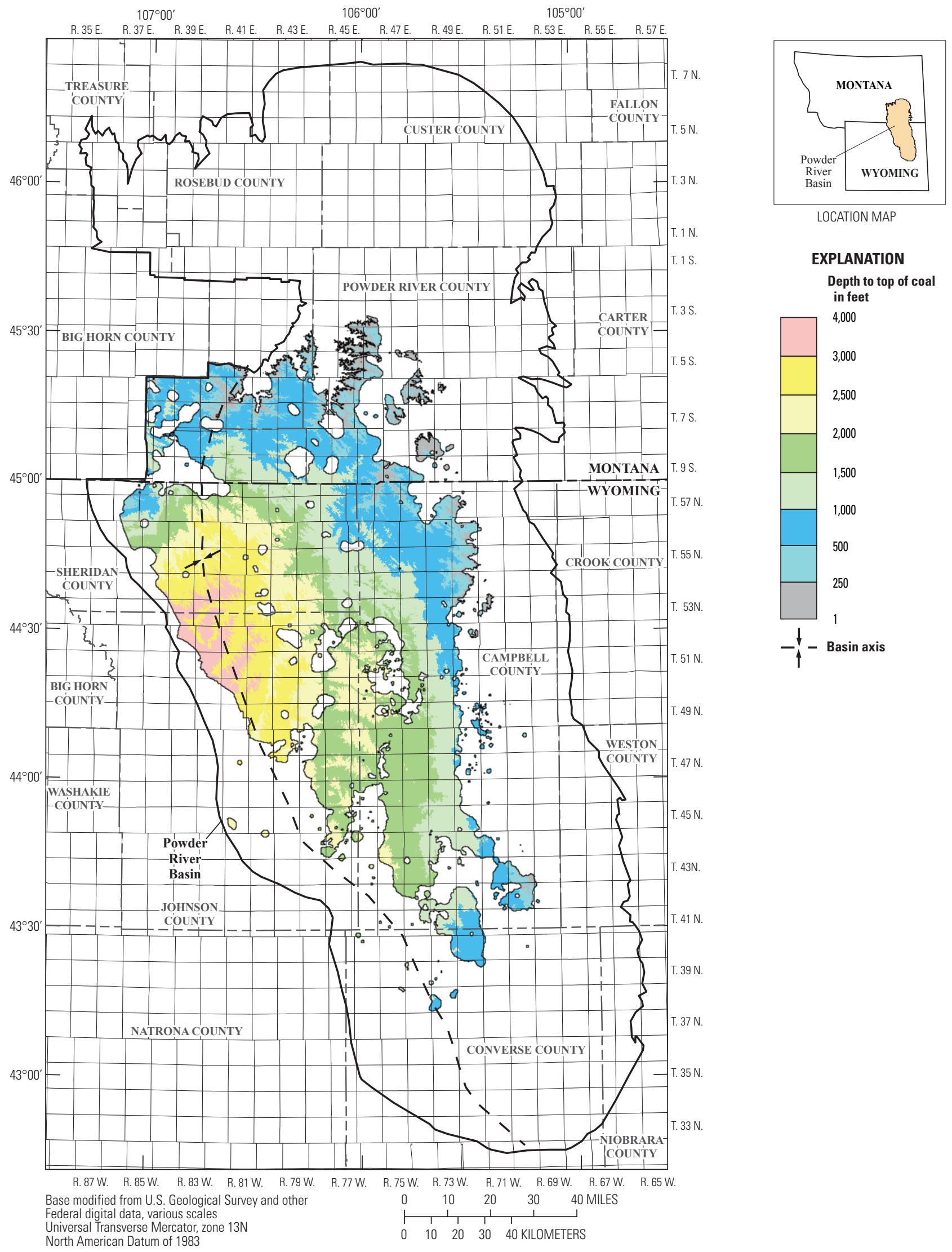

Figure 83. Map showing depth to the top of the Gates/Wall coal bed within the Powder River Basin. 


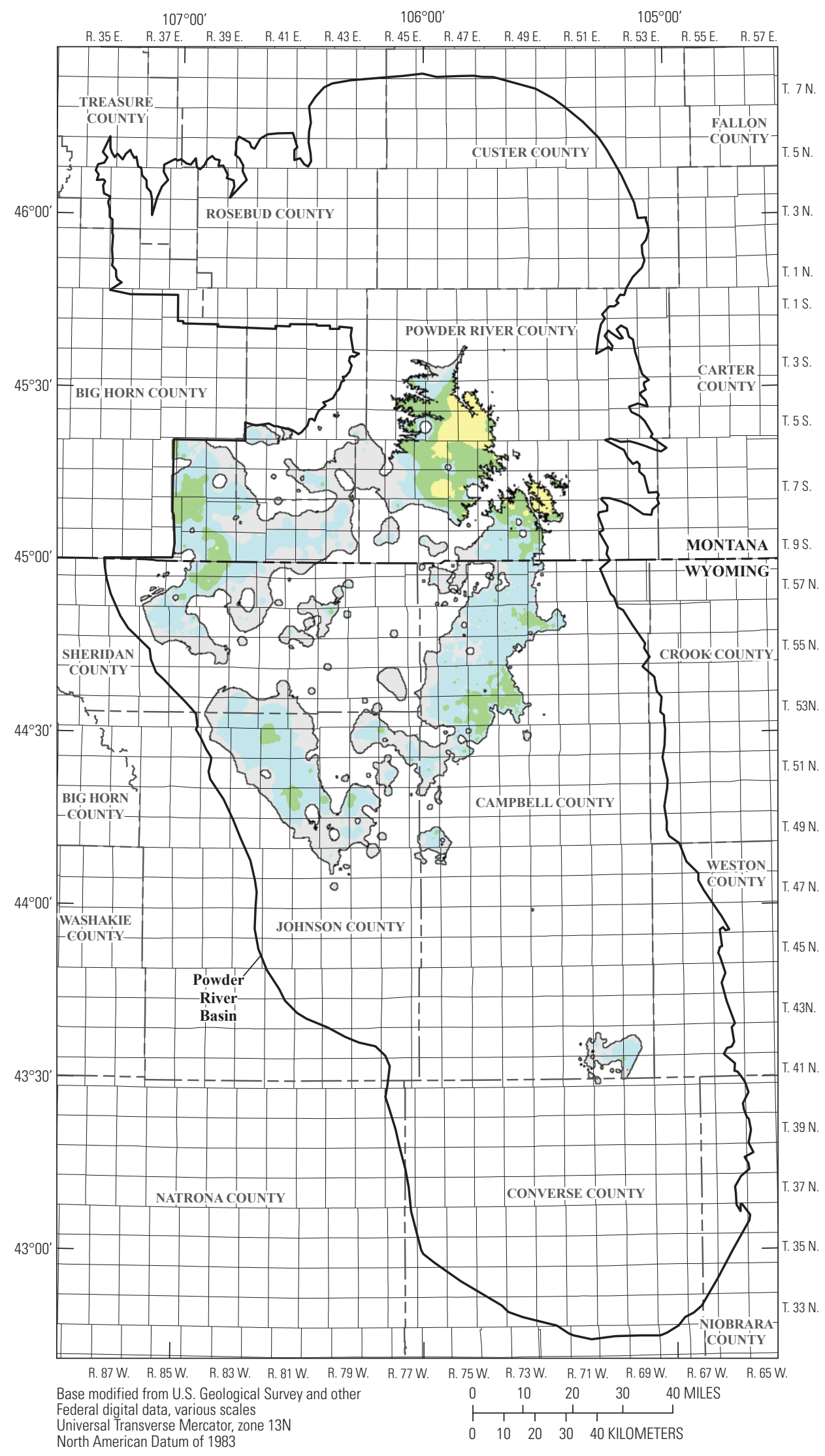

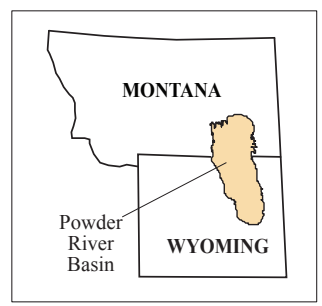

LOCATION MAP

EXPLANATION

Thickness in feet

40

20

10

5

Figure 84. Isopach map of the Pawnee coal bed showing extent of coal at least 1.0 foot thick within the Powder River Basin. 

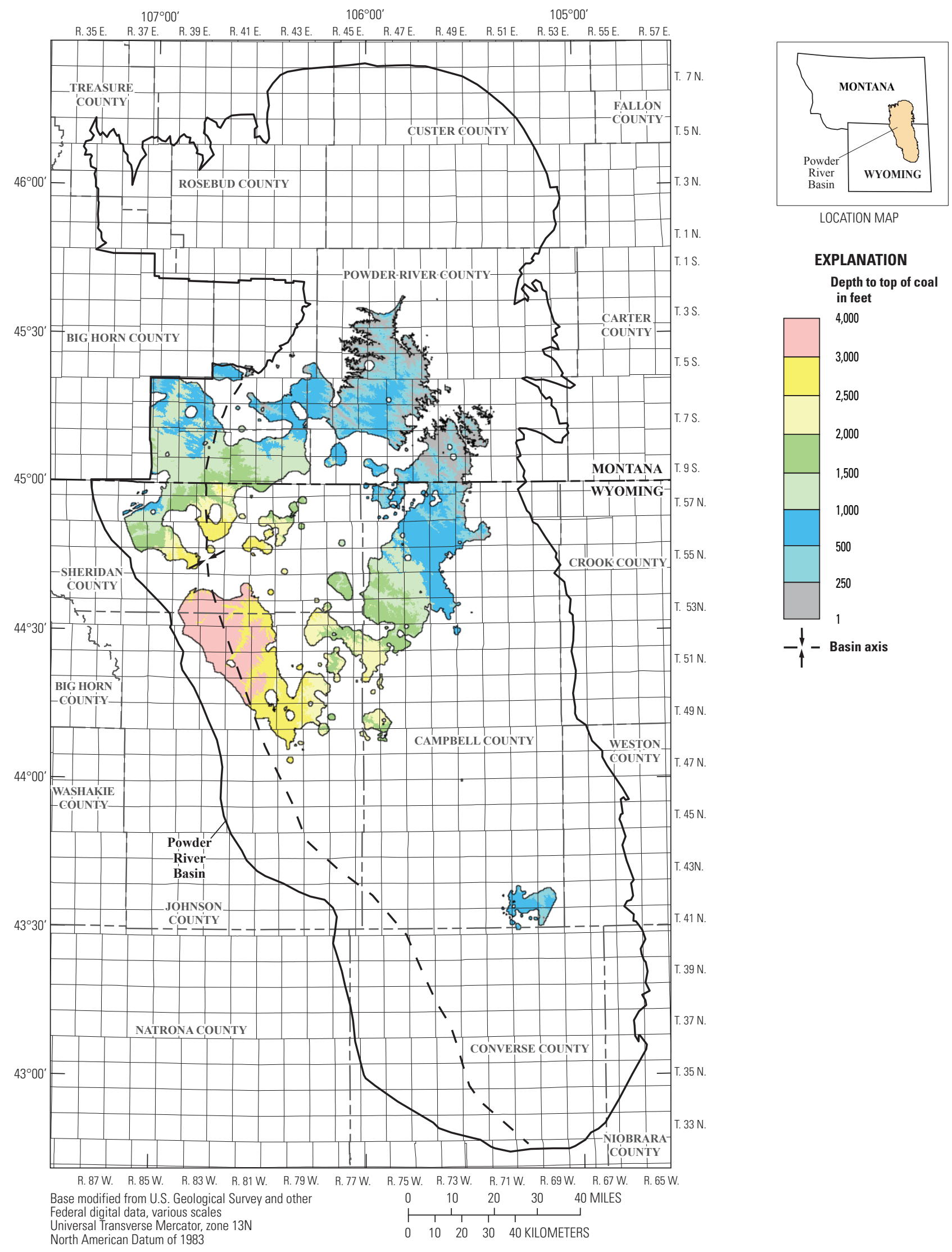

Figure 85. Map showing depth to the top of the Pawnee coal bed within the Powder River Basin. 


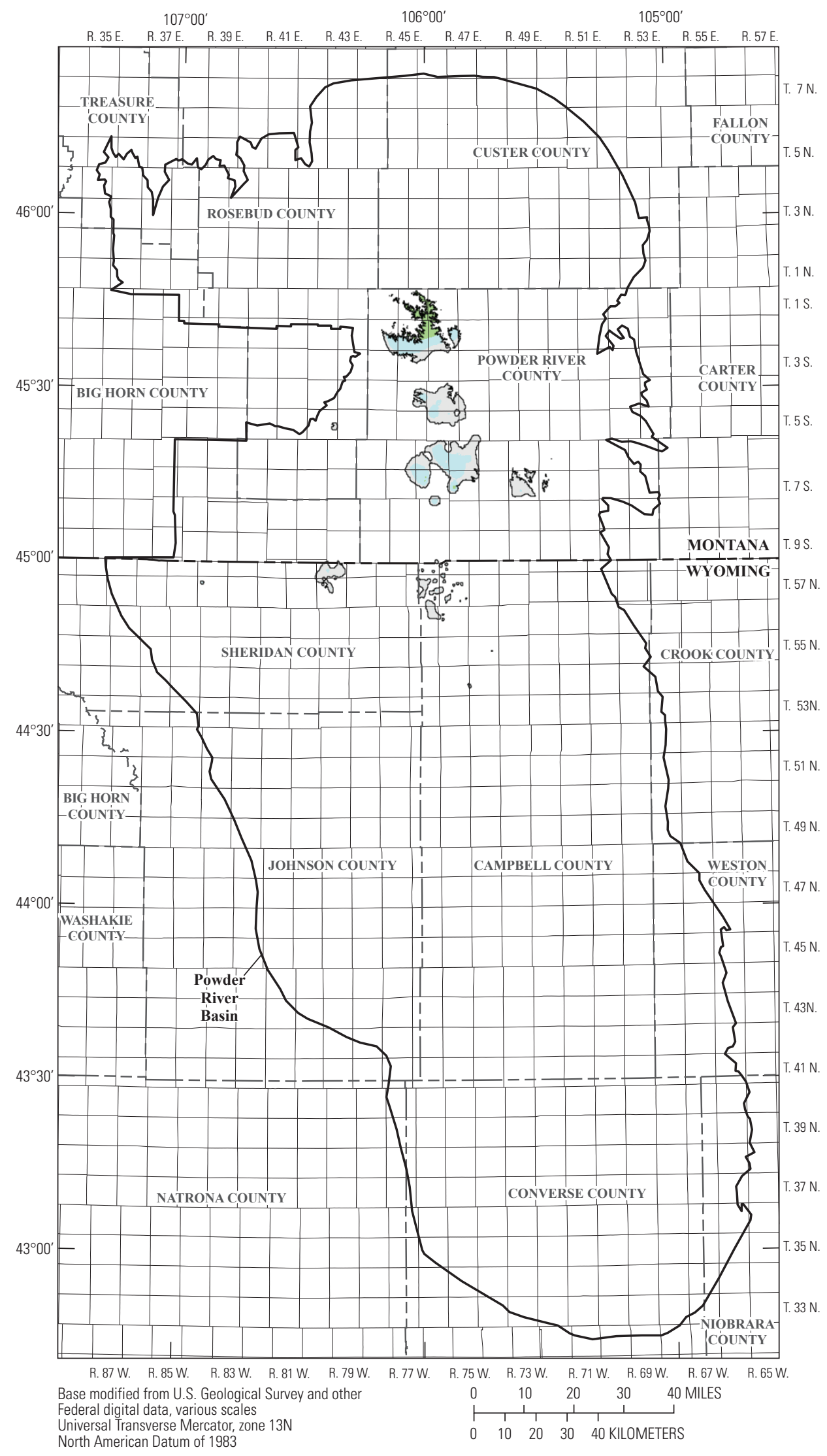

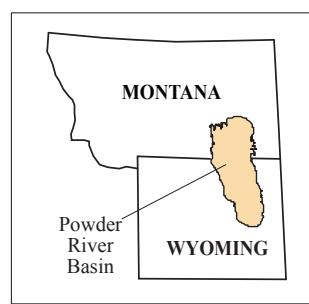

LOCATION MAP

EXPLANATION Thickness in feet 20 10 5

Figure 86. Isopach map of the Brewster-Arnold coal bed showing extent of coal at least 1.0 foot thick within the Powder River Basin. 


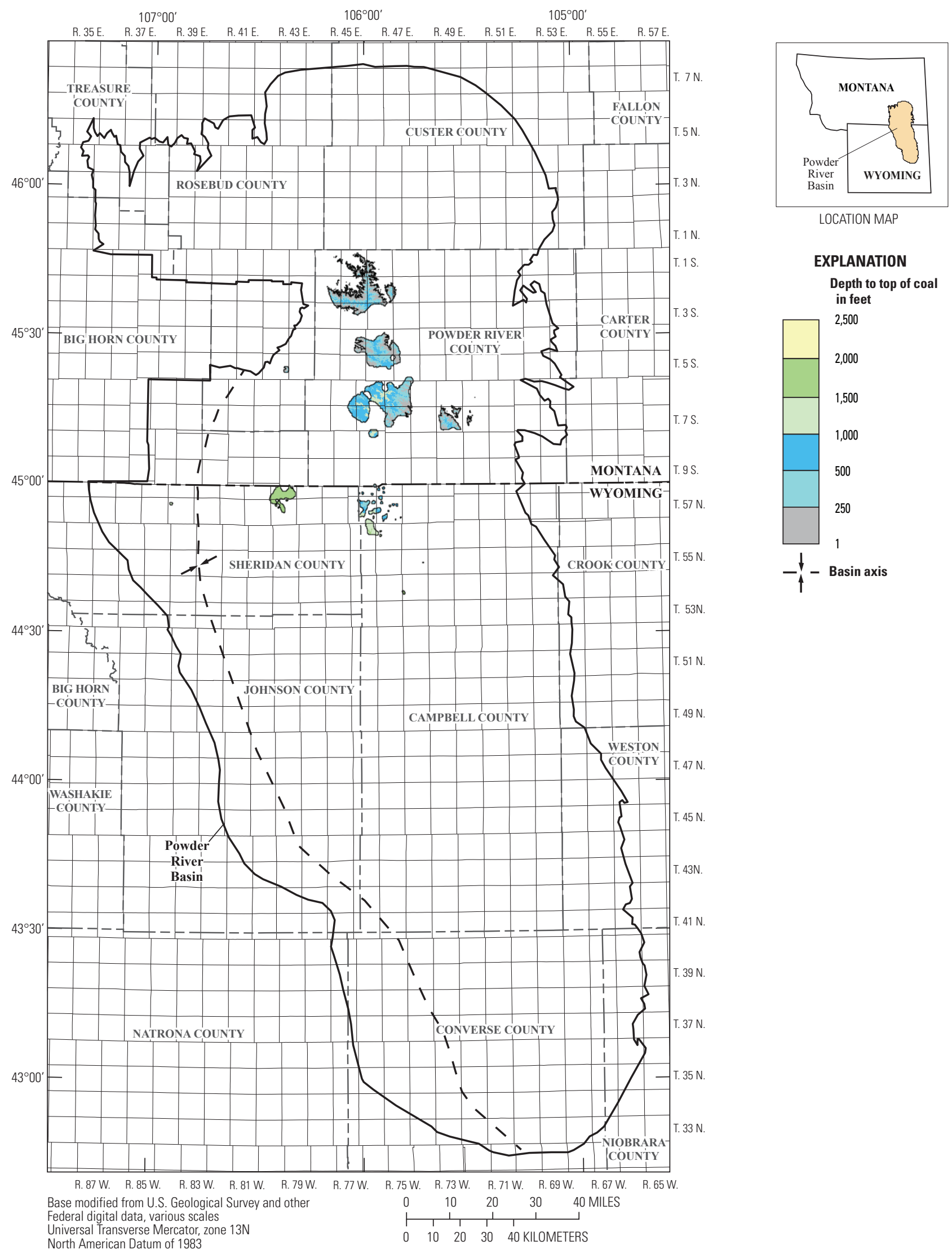

Figure 87. Map showing depth to the top of the Brewster-Arnold coal bed within the Powder River Basin. 


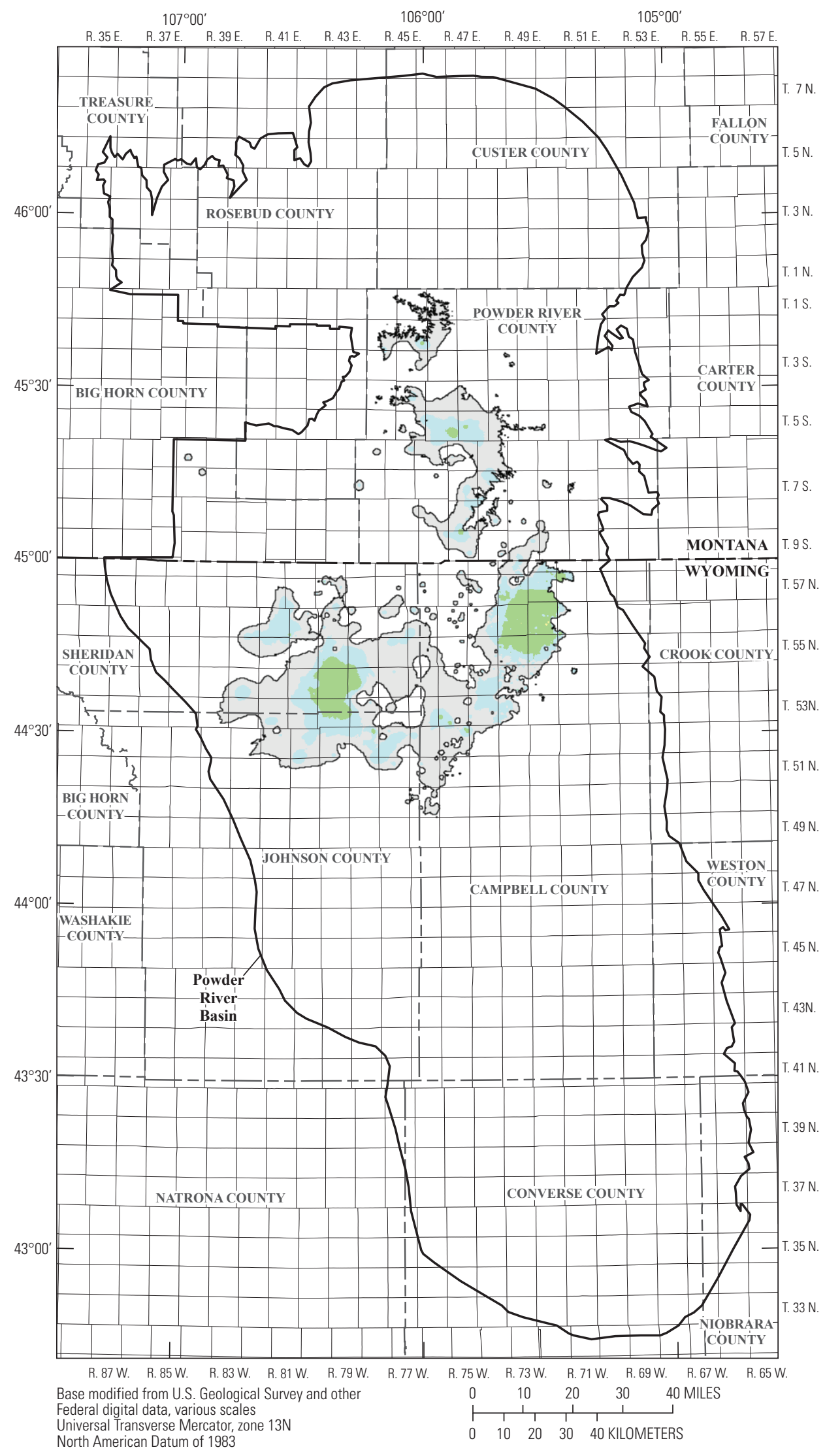

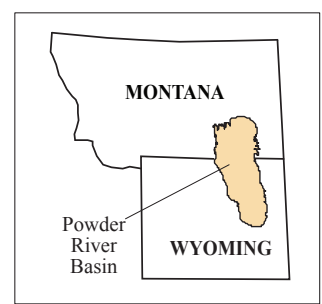

LOCATION MAP

EXPLANATION

Thickness in feet

40

20

10

5

Figure 88. Isopach map of the Odell coal bed showing extent of coal at least 1.0 foot thick within the Powder River Basin. 


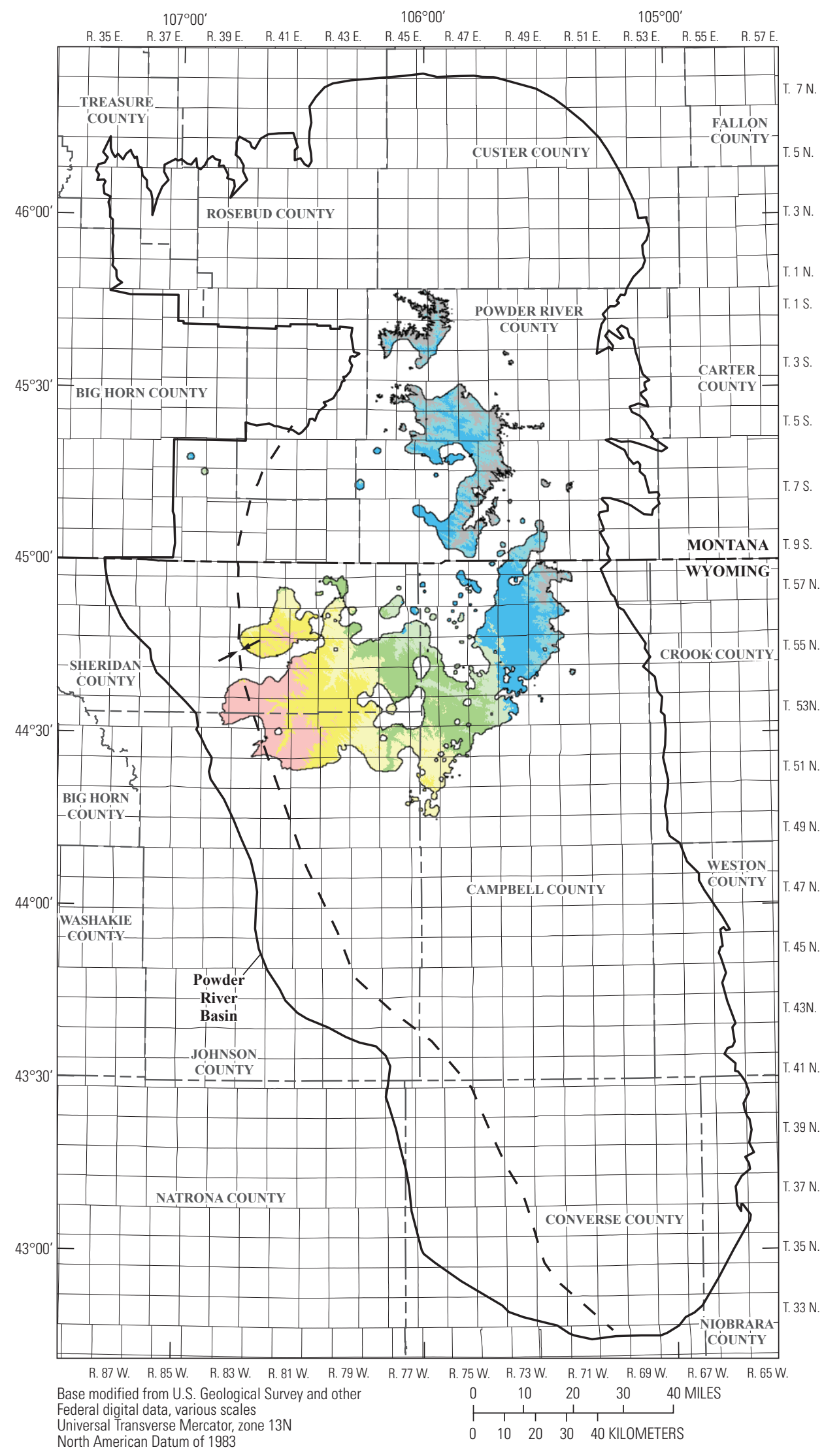

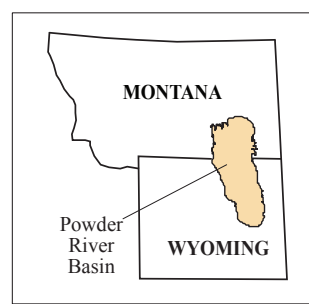

LOCATION MAP

EXPLANATION

Depth to top of coal

in feet

4,000

3,000

2,500

2,000

1,500

1,000

500

250

1

$-\downarrow-$ Basin axis

Figure 89. Map showing depth to the top of the Odell coal bed within the Powder River Basin. 


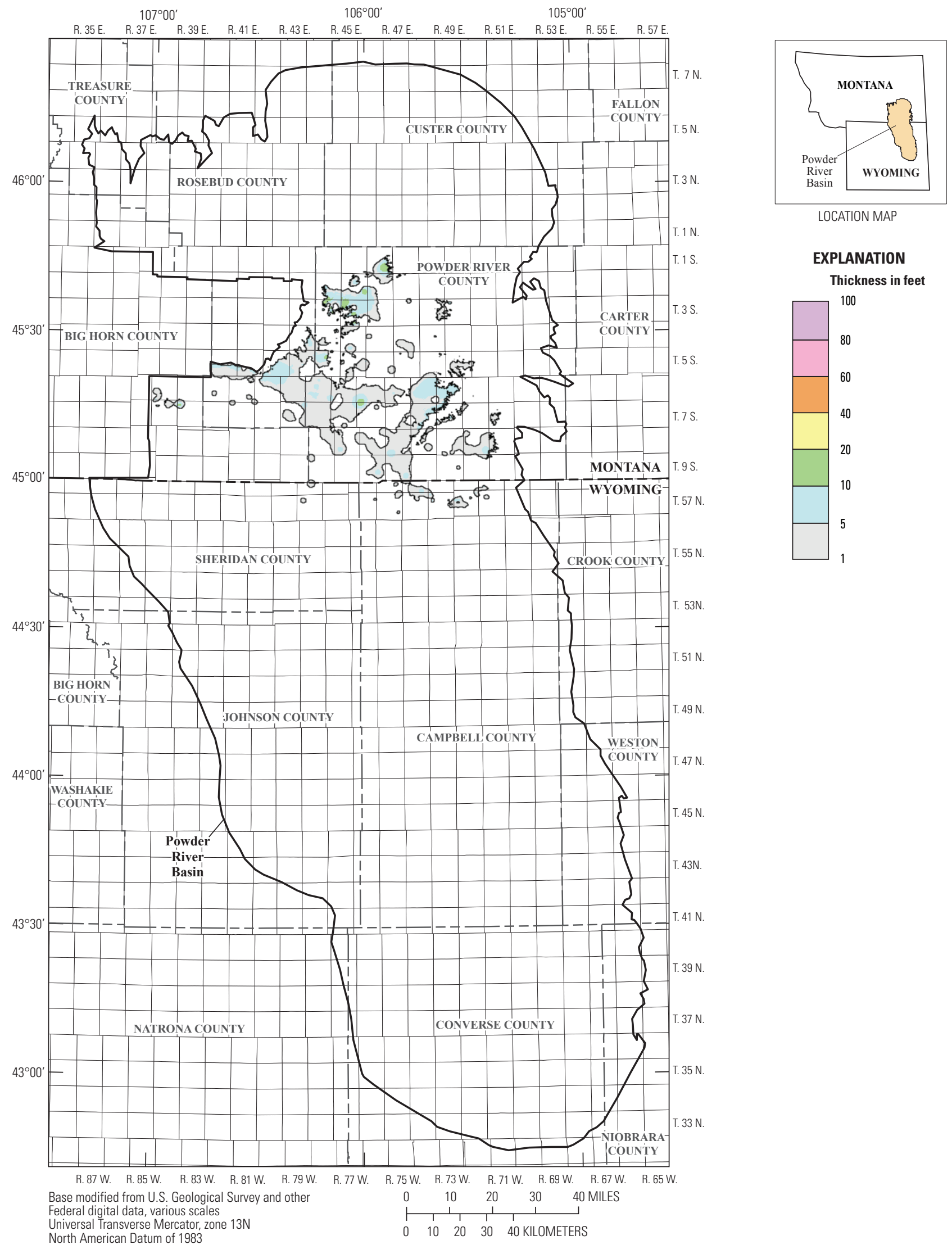

Figure 90. Isopach map of the Cache coal bed showing extent of coal at least 1.0 foot thick within the Powder River Basin. 

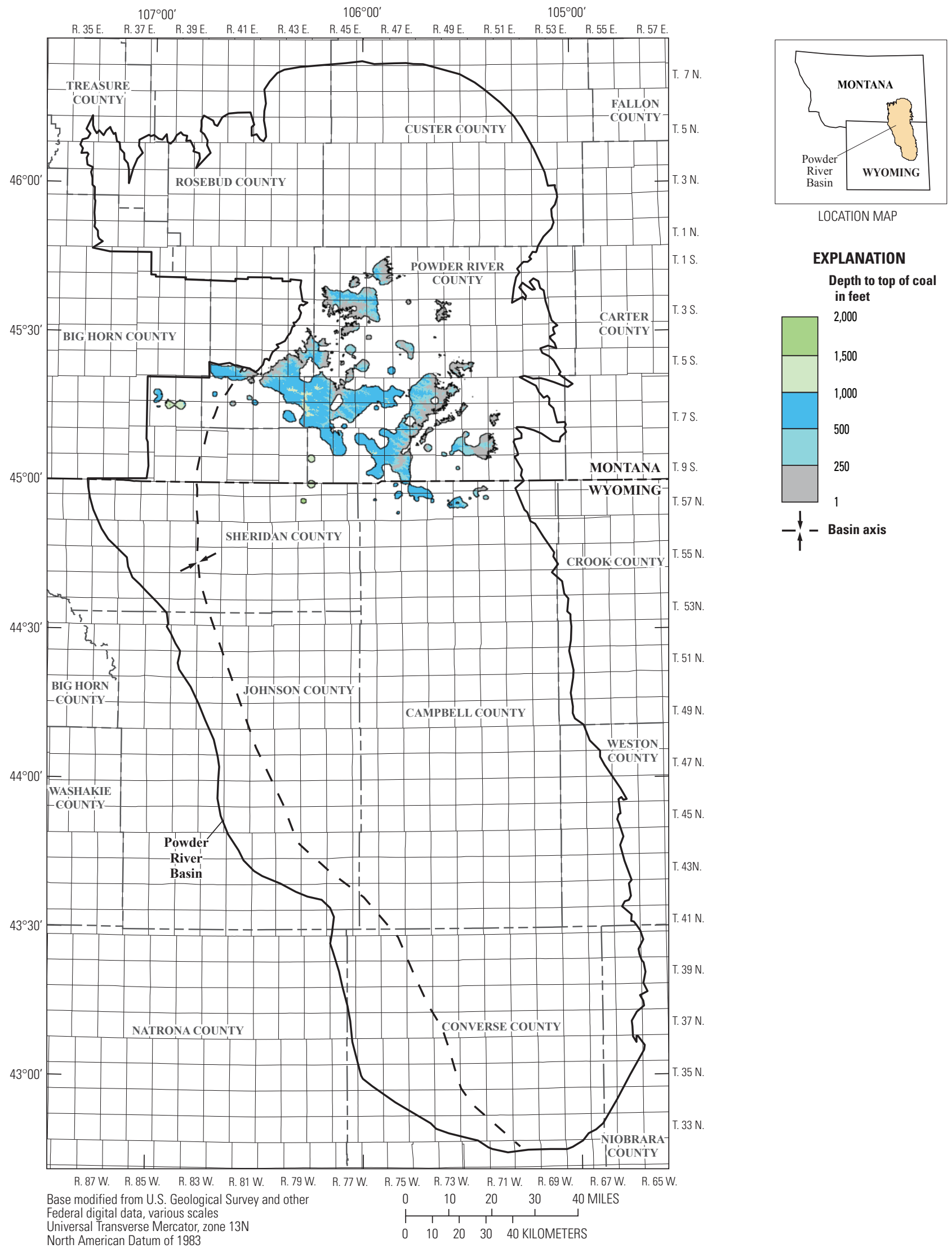

Figure 91. Map showing depth to the top of the Cache coal bed within the Powder River Basin. 


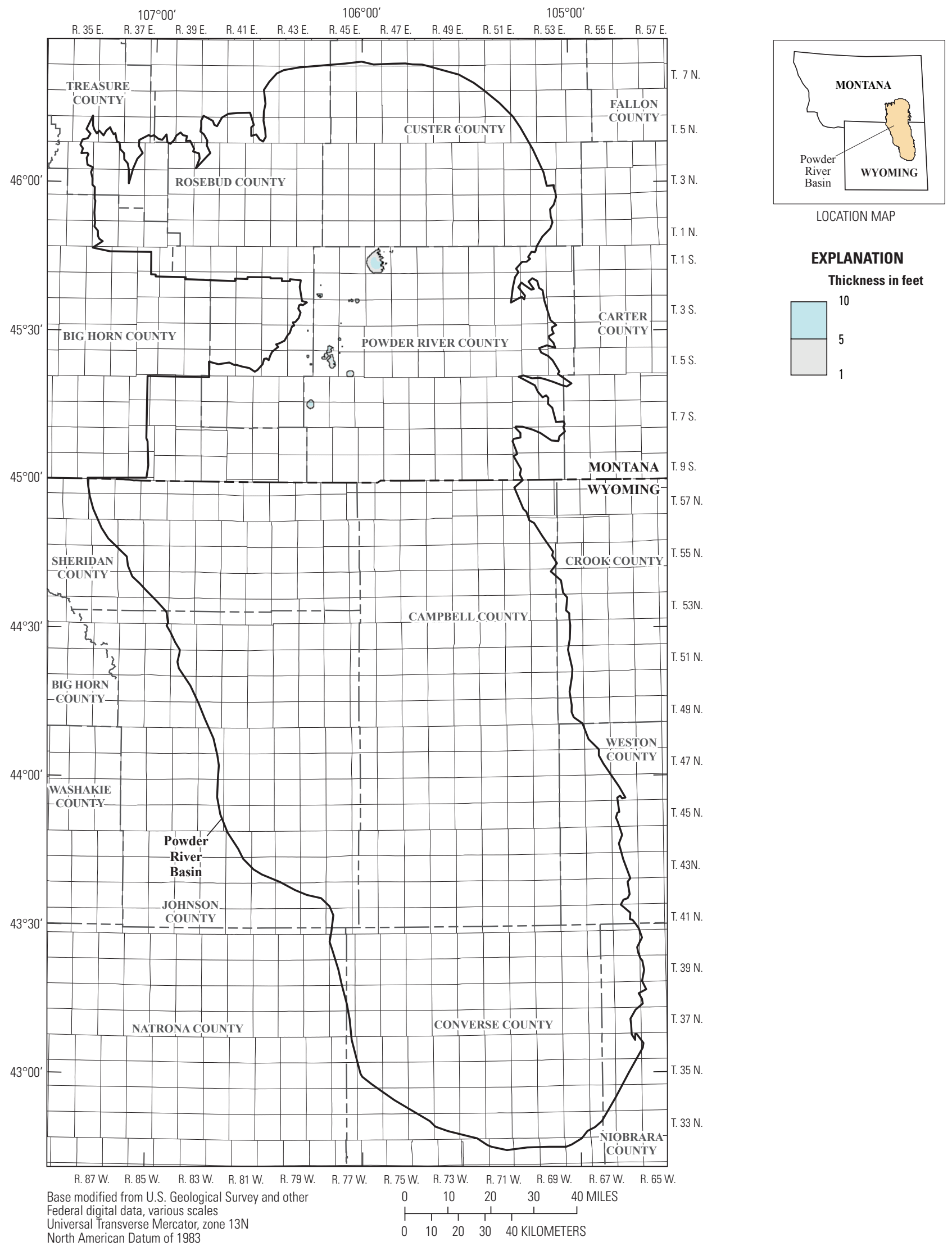

Figure 92. Isopach map of the A Zone coal bed showing extent of coal at least 1.0 foot thick within the Powder River Basin. 

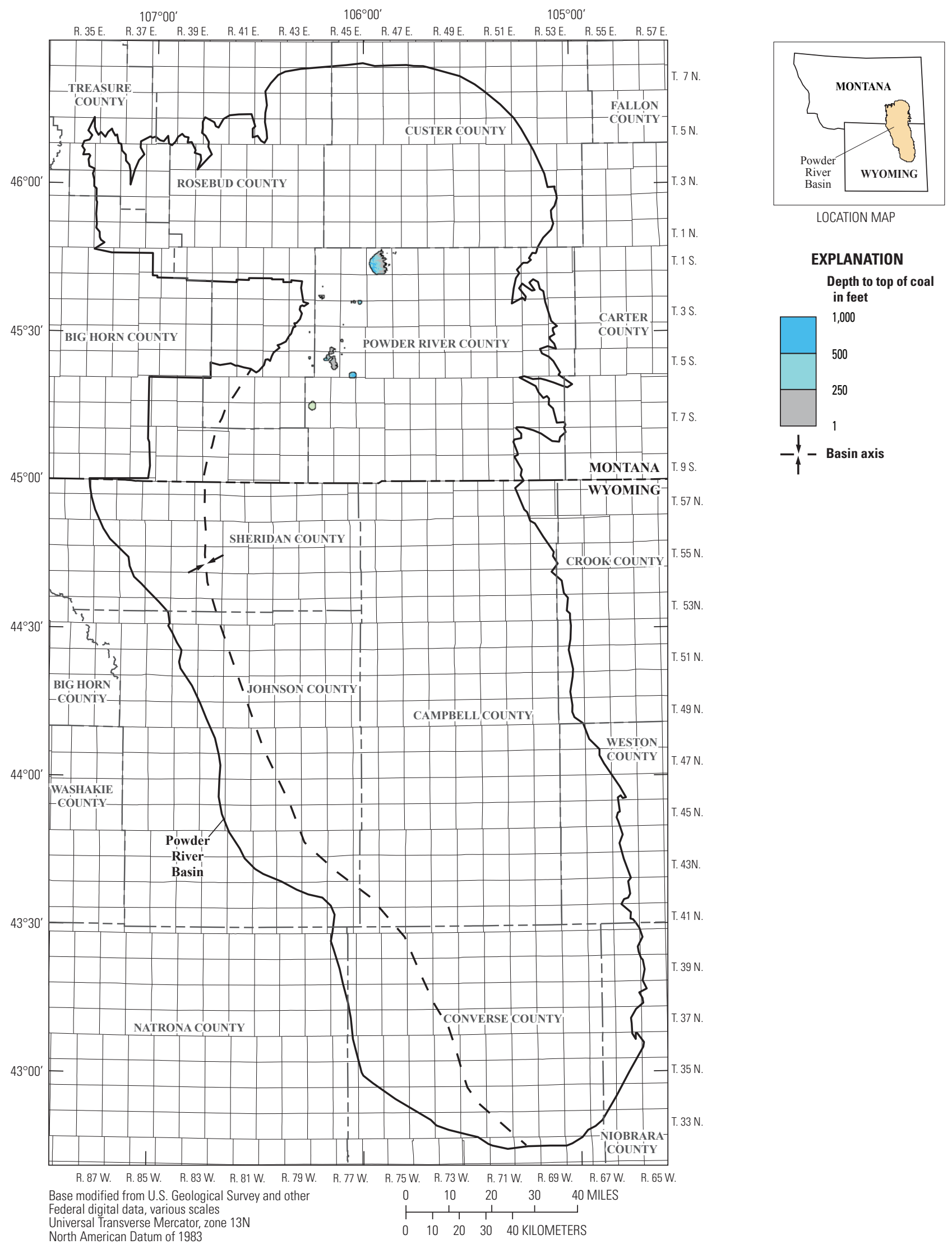

Figure 93. Map showing depth to the top of the A Zone coal bed within the Powder River Basin. 


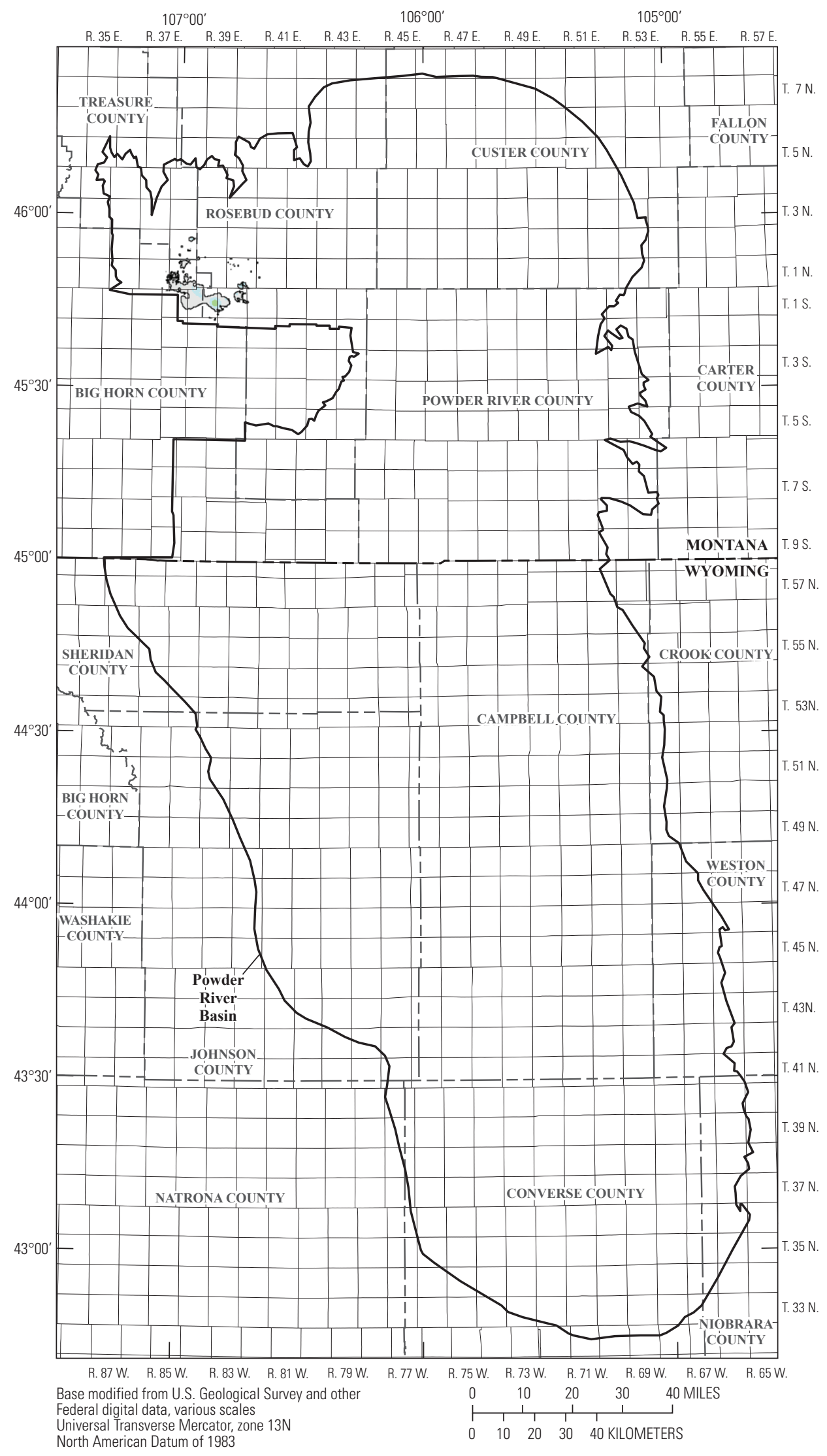

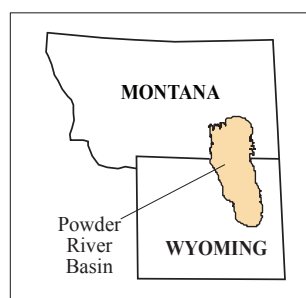

LOCATION MAP

EXPLANATION

Thickness in feet

20

10

5 $57 \mathrm{~N}$. 


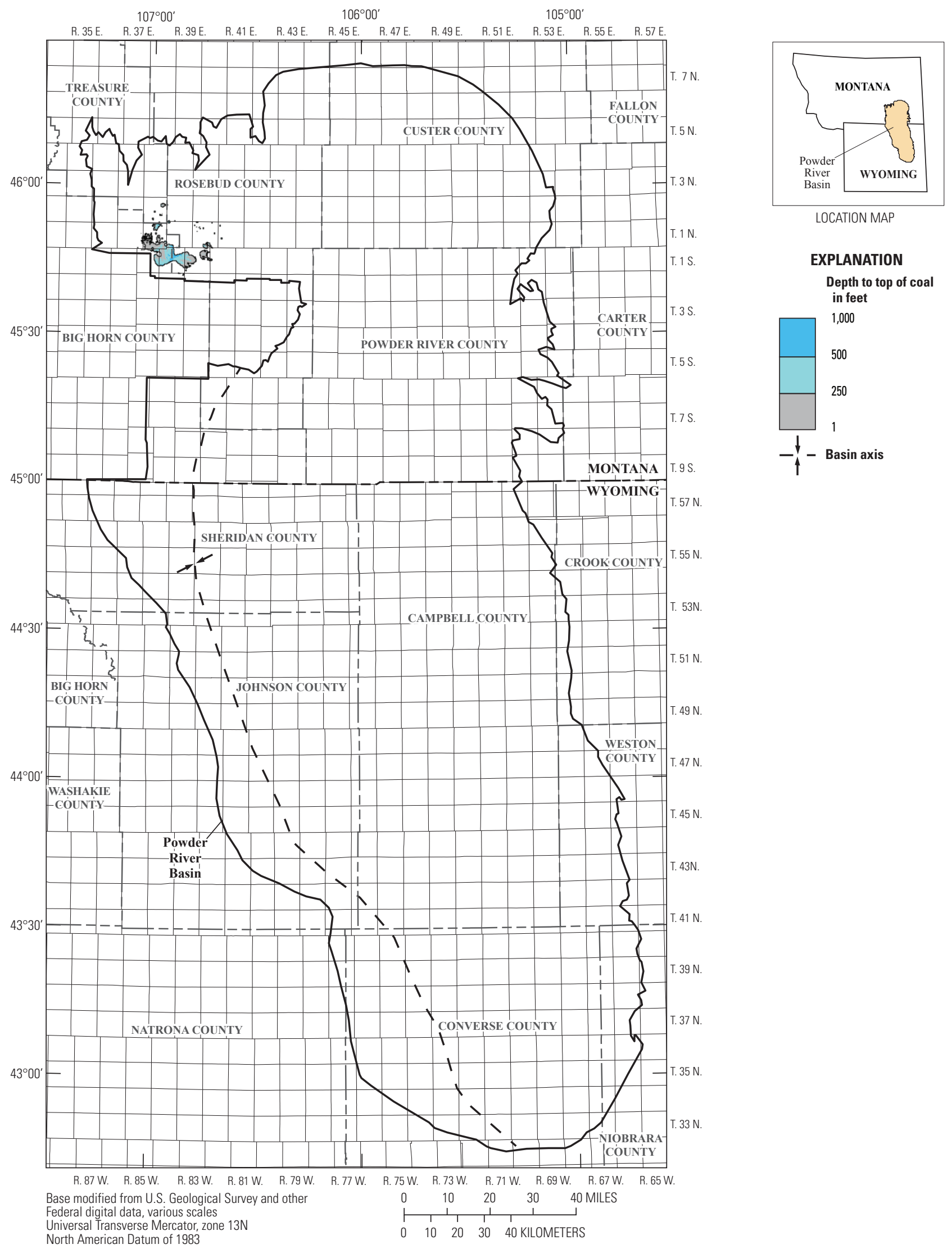

Figure 95. Map showing depth to the top of the Upper Rosebud coal bed within the Powder River Basin. 


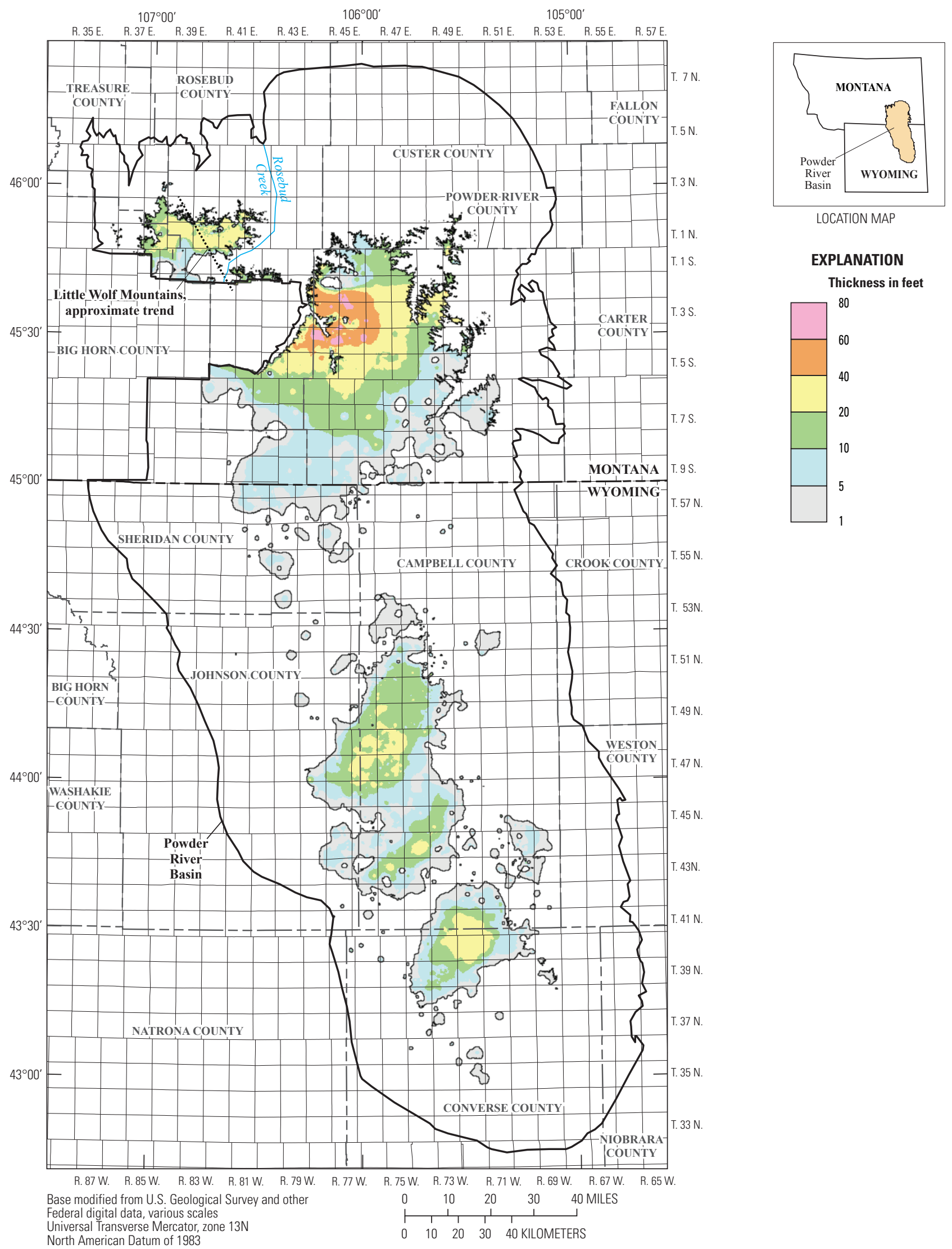

Figure 96. Isopach map of the Rosebud/Knobloch coal bed showing extent of coal at least 1.0 foot thick within the Powder River Basin. 


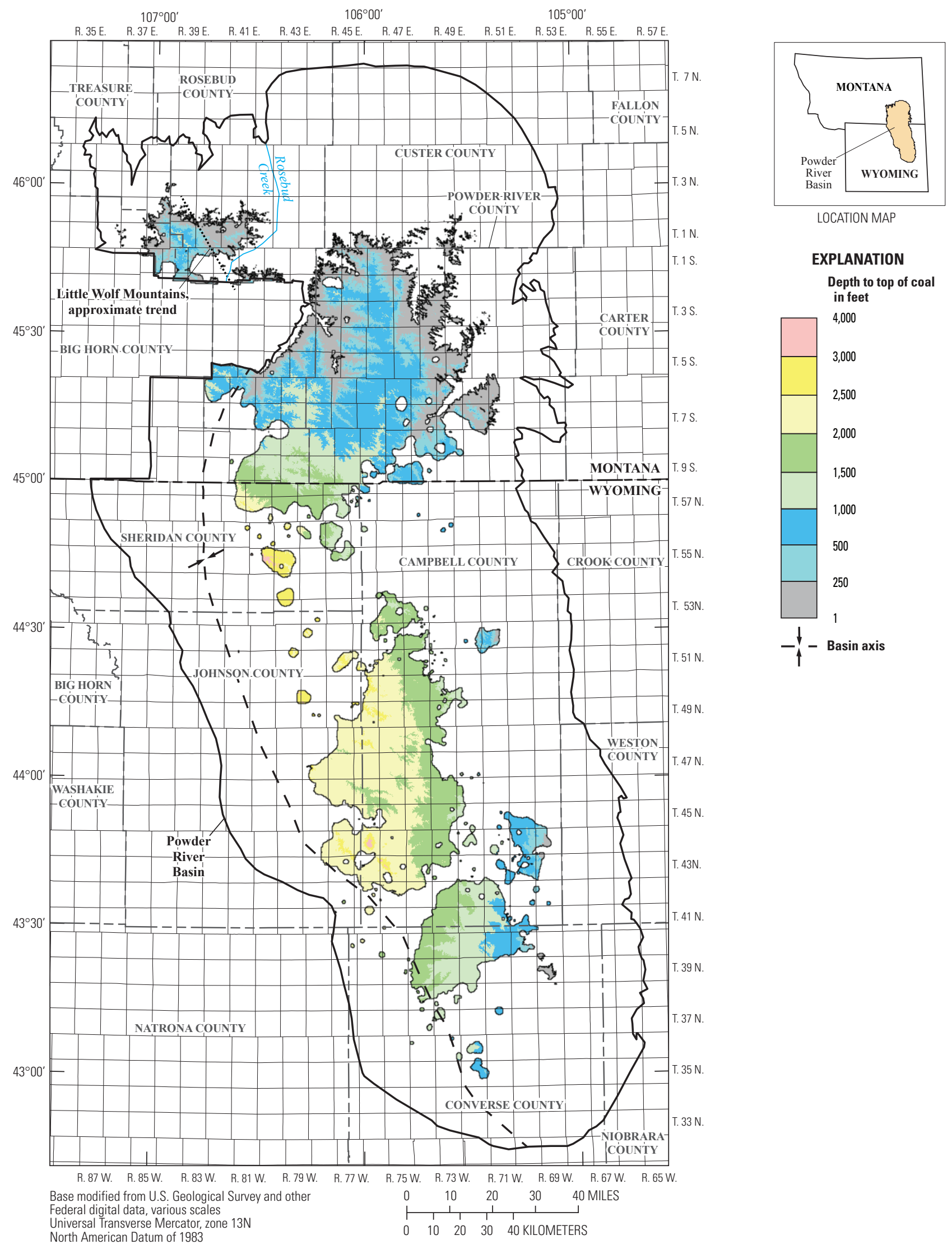

Figure 97. Map showing depth to the top of the Rosebud/Knobloch coal bed within the Powder River Basin. 


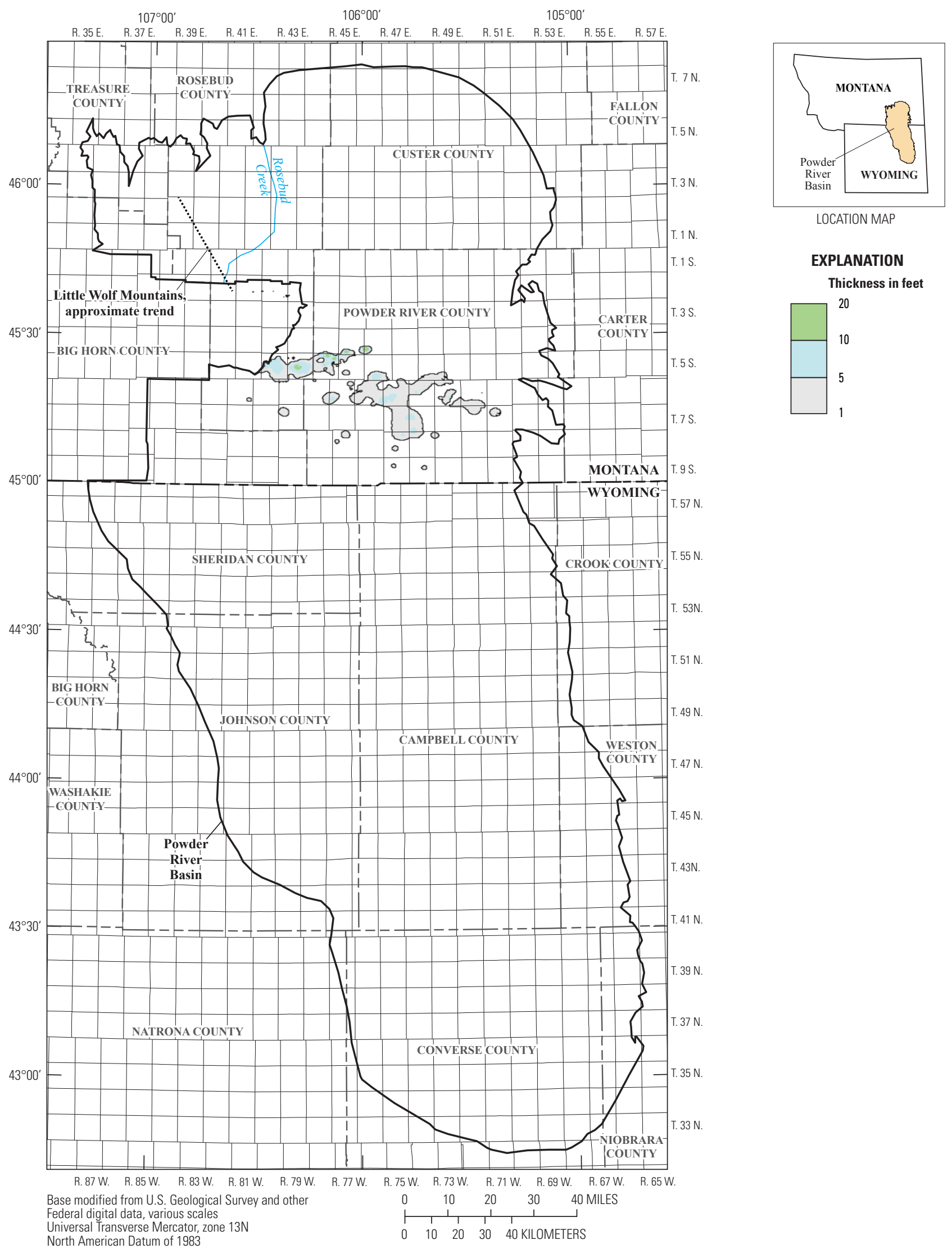

Figure 98. Isopach map of the Calvert coal bed showing extent of coal at least 1.0 foot thick within the Powder River Basin. 

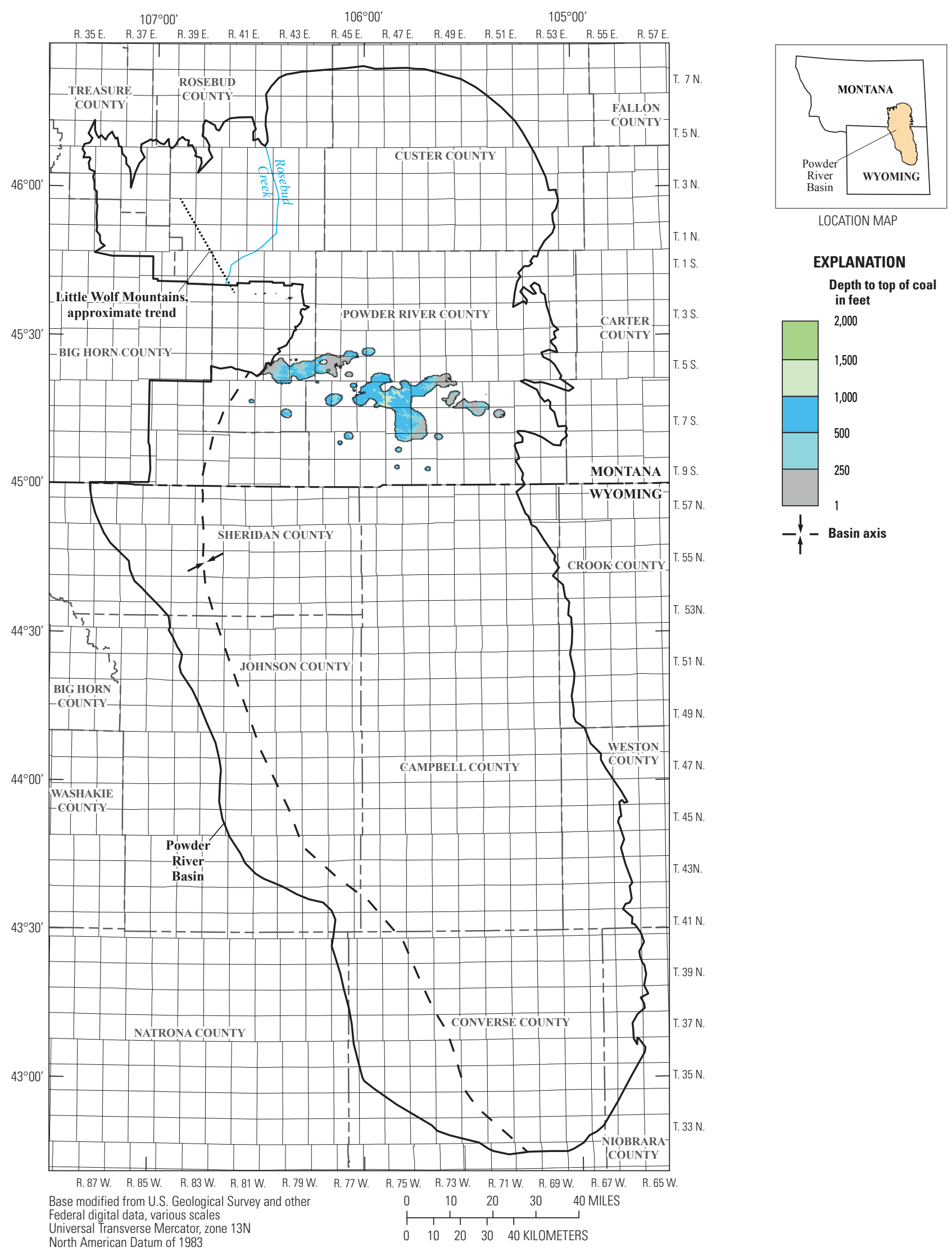

Figure 99. Map showing depth to the top of the Calvert coal bed within the Powder River Basin. 


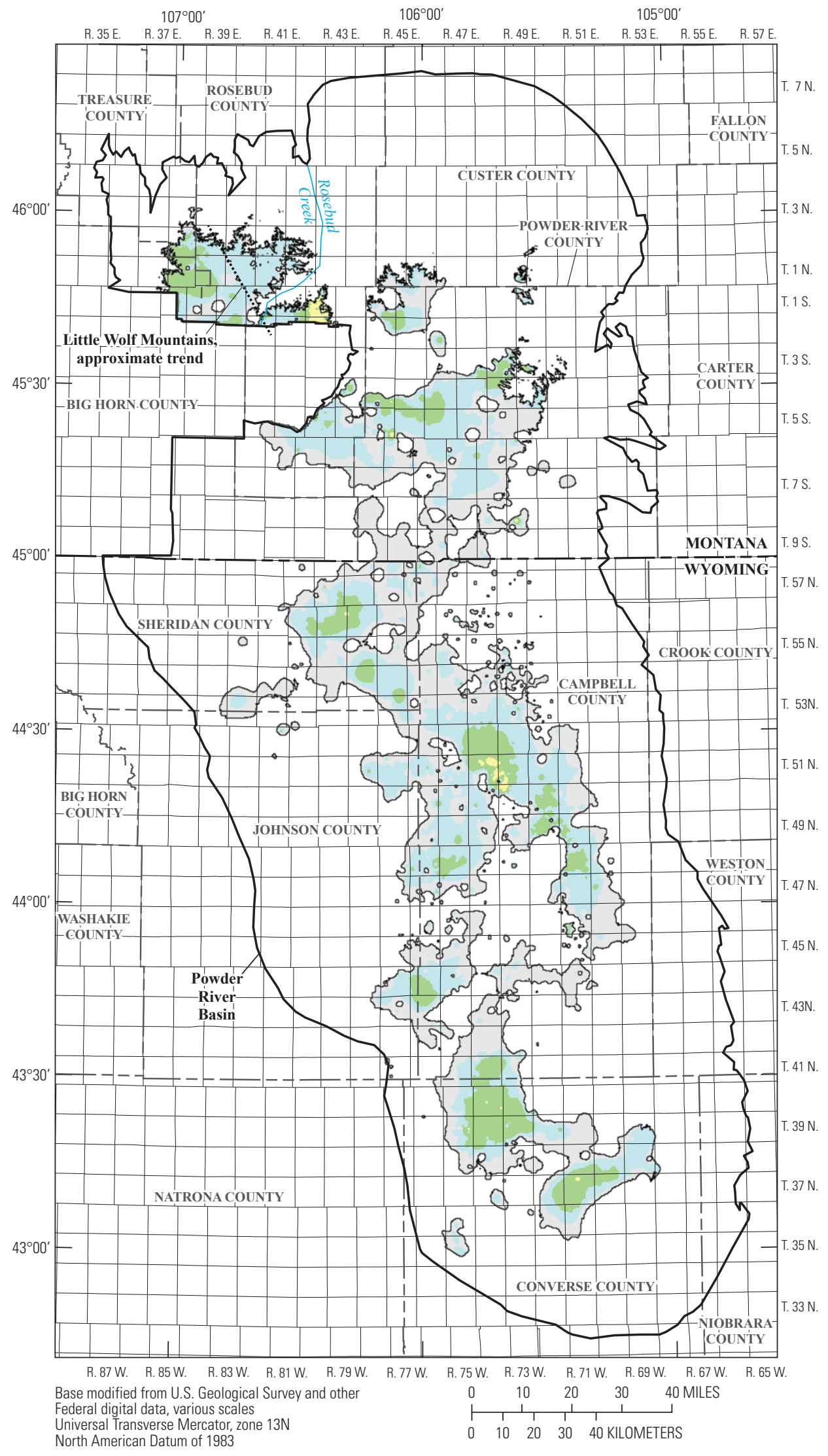

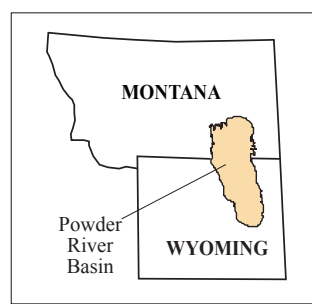

LOCATION MAP

EXPLANATION

Thickness in feet

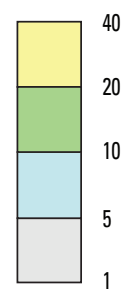

Figure 100. Isopach map of the McKay/Nance coal bed showing extent of coal at least 1.0 foot thick within the Powder River Basin. 


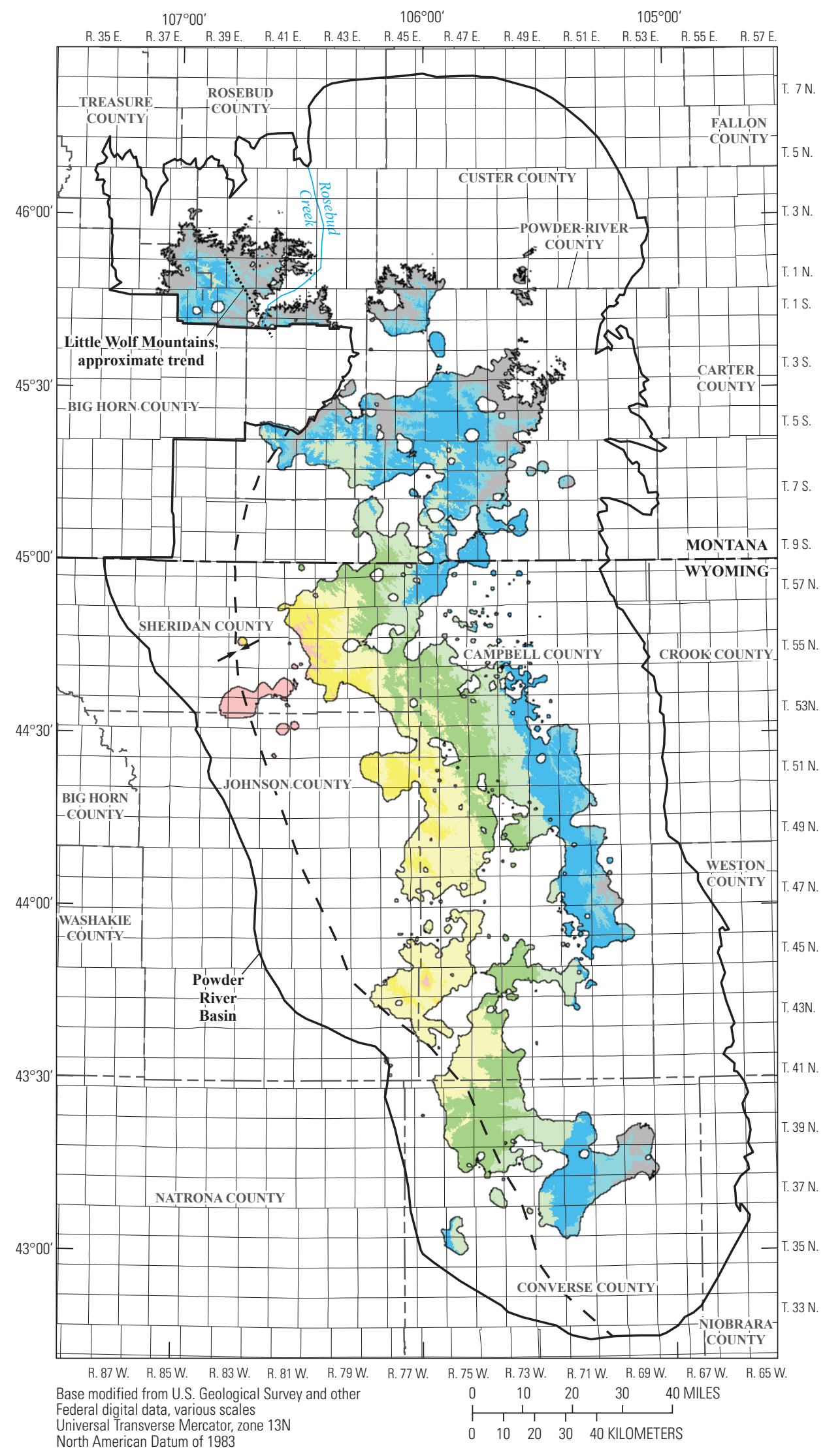

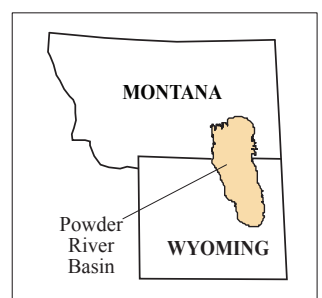

LOCATION MAP

EXPLANATION

Depth to top of coal

in feet

4,000

3,000

2,500

2,000

1,500

1,000

500

250

1

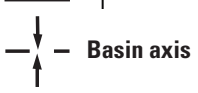

Figure 101. Map showing depth to the top of the McKay/Nance coal bed within the Powder River Basin. 


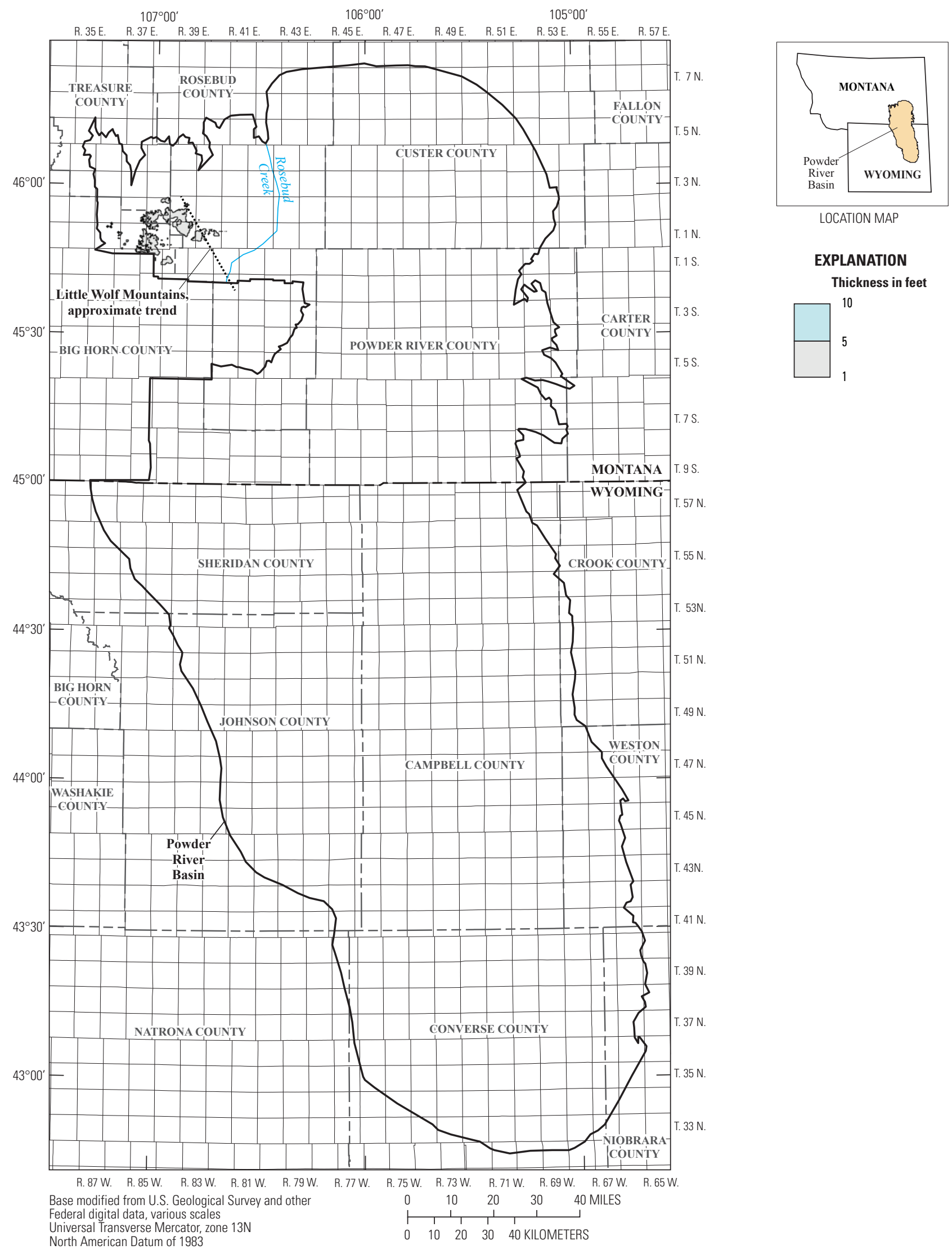

Figure 102. Isopach map of the Lower McKay coal bed showing extent of coal at least 1.0 foot thick within the Powder River Basin. 


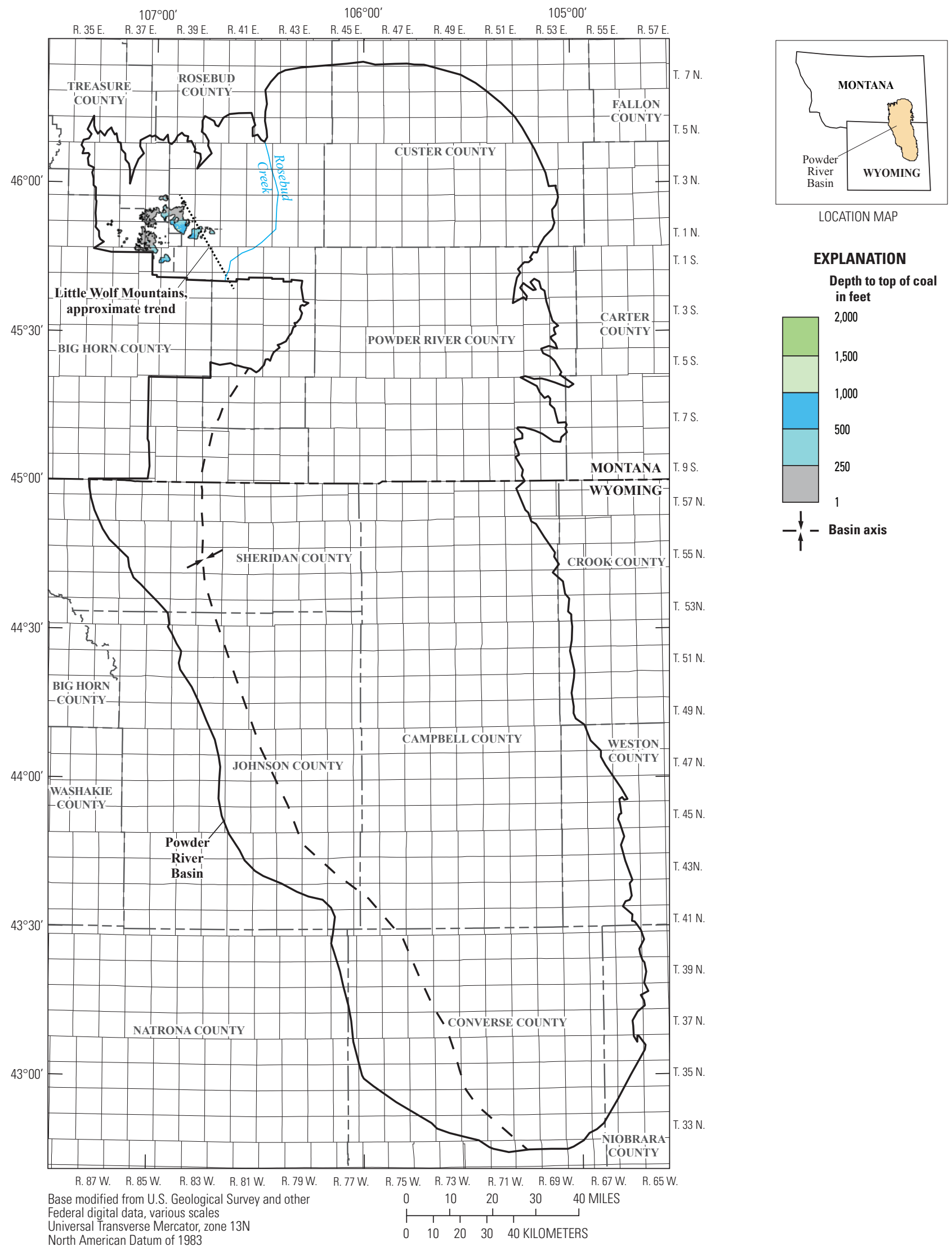

Figure 103. Map showing depth to the top of the Lower McKay coal bed within the Powder River Basin. 


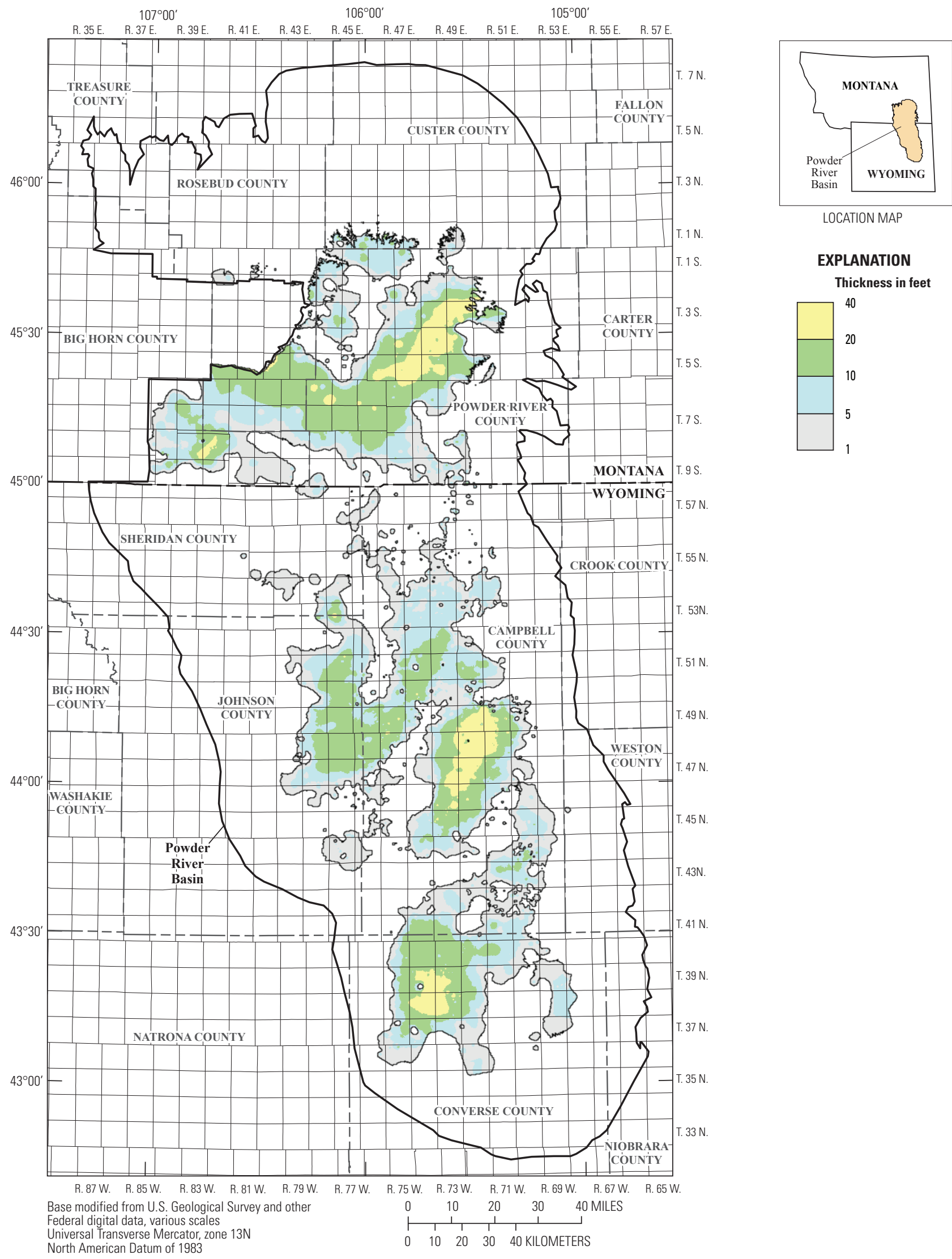

Figure 104. Isopach map of the Flowers-Goodale coal bed showing extent of coal at least 1.0 foot thick within the Powder River Basin. 




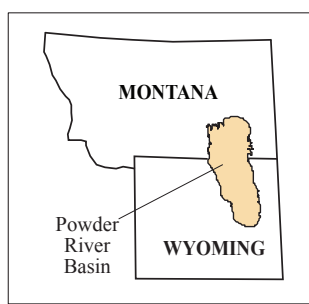

LOCATION MAP

EXPLANATION

Depth to top of coal in feet

4,000

3,000

2,500

2,000

1,500

1,000

500

250

1

$-\downarrow-$ Basin axis

Figure 105. Map showing depth to the top of the Flowers-Goodale coal bed within the Powder River Basin. 


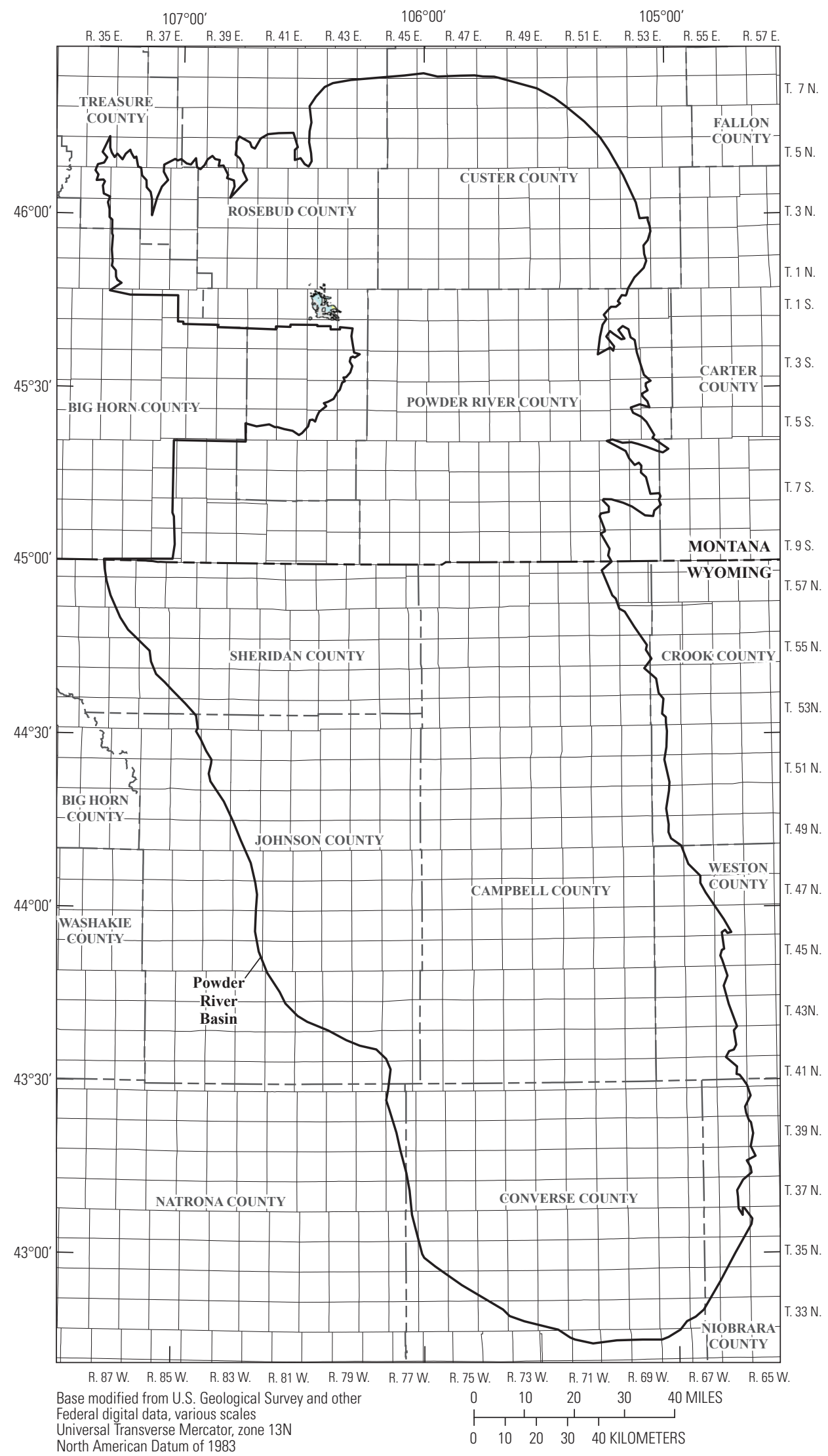

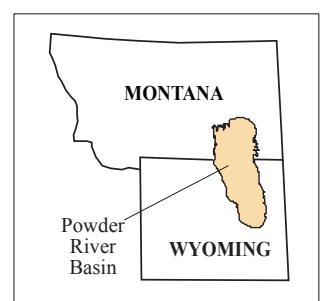

LOCATION MAP

EXPLANATION

Thickness in feet

40

20

10

5

Figure 106. Isopach map of the Upper Witham coal bed showing extent of coal at least 1.0 foot thick within the Powder River Basin. 


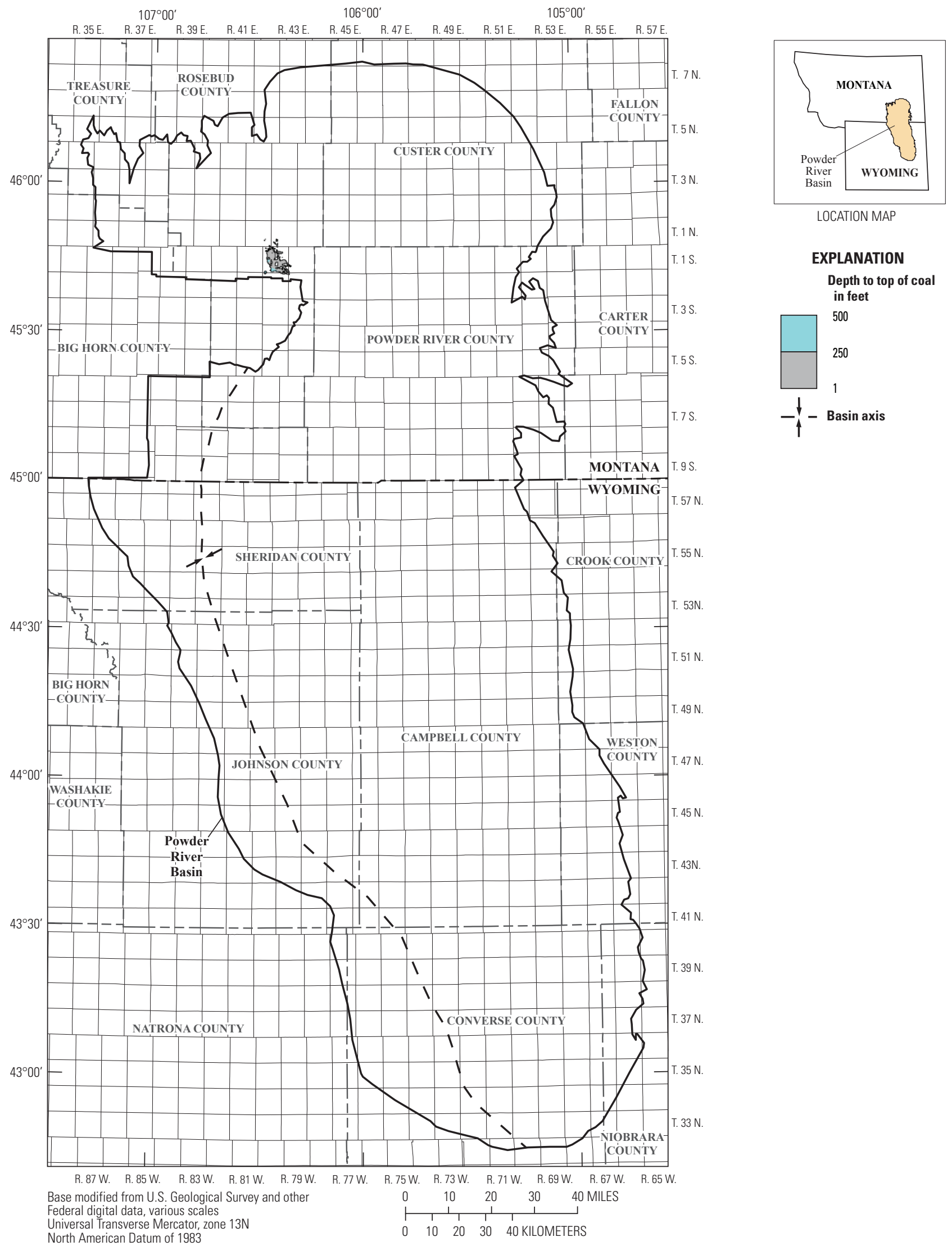

Figure 107. Map showing depth to the top of the Upper Witham coal bed within the Powder River Basin. 


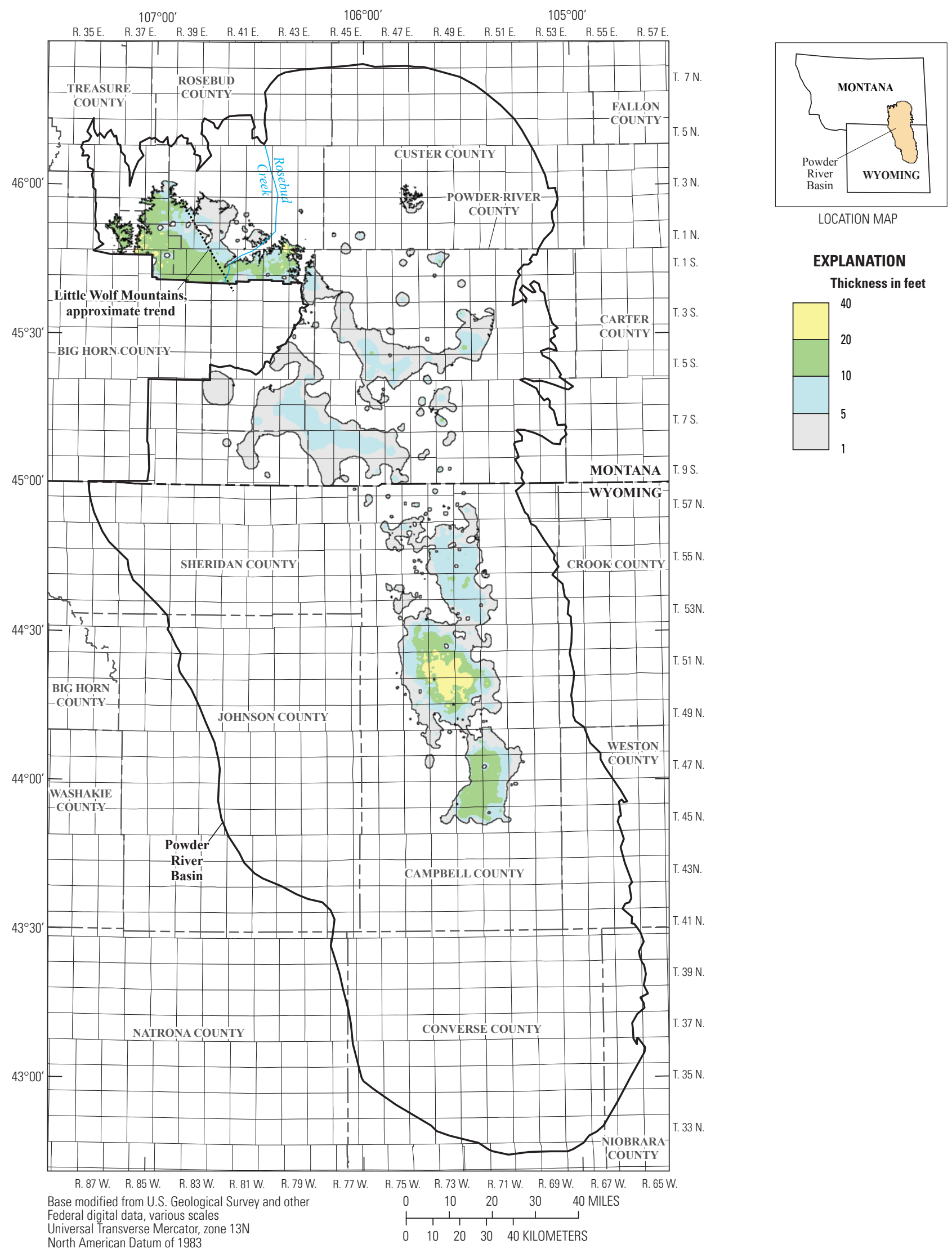

Figure 108. Isopach map of the Robinson/Witham coal bed showing extent of coal at least 1.0 foot thick within the Powder River Basin. 


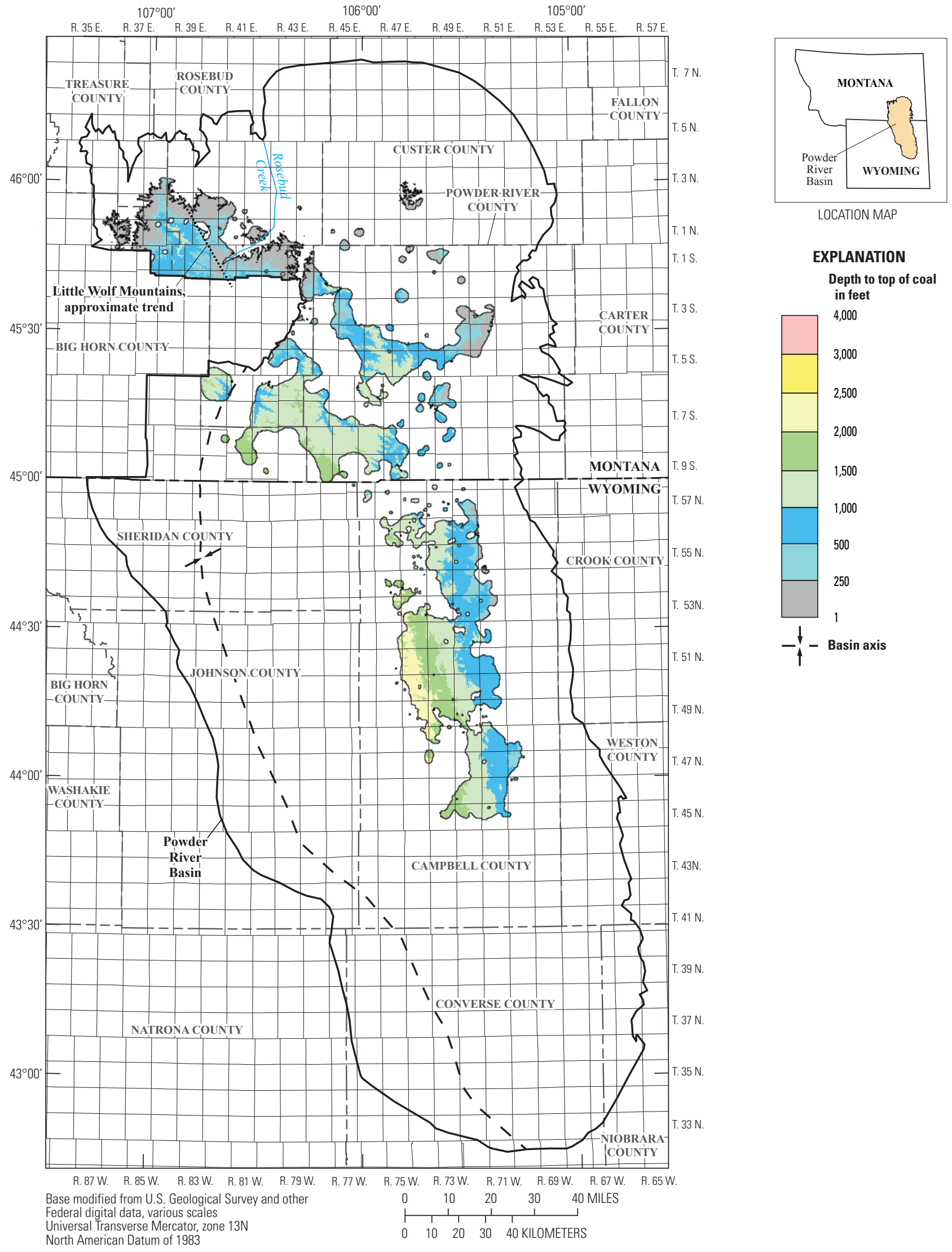

Figure 109. Map showing depth to the top of the Robinson/Witham coal bed within the Powder River Basin. 


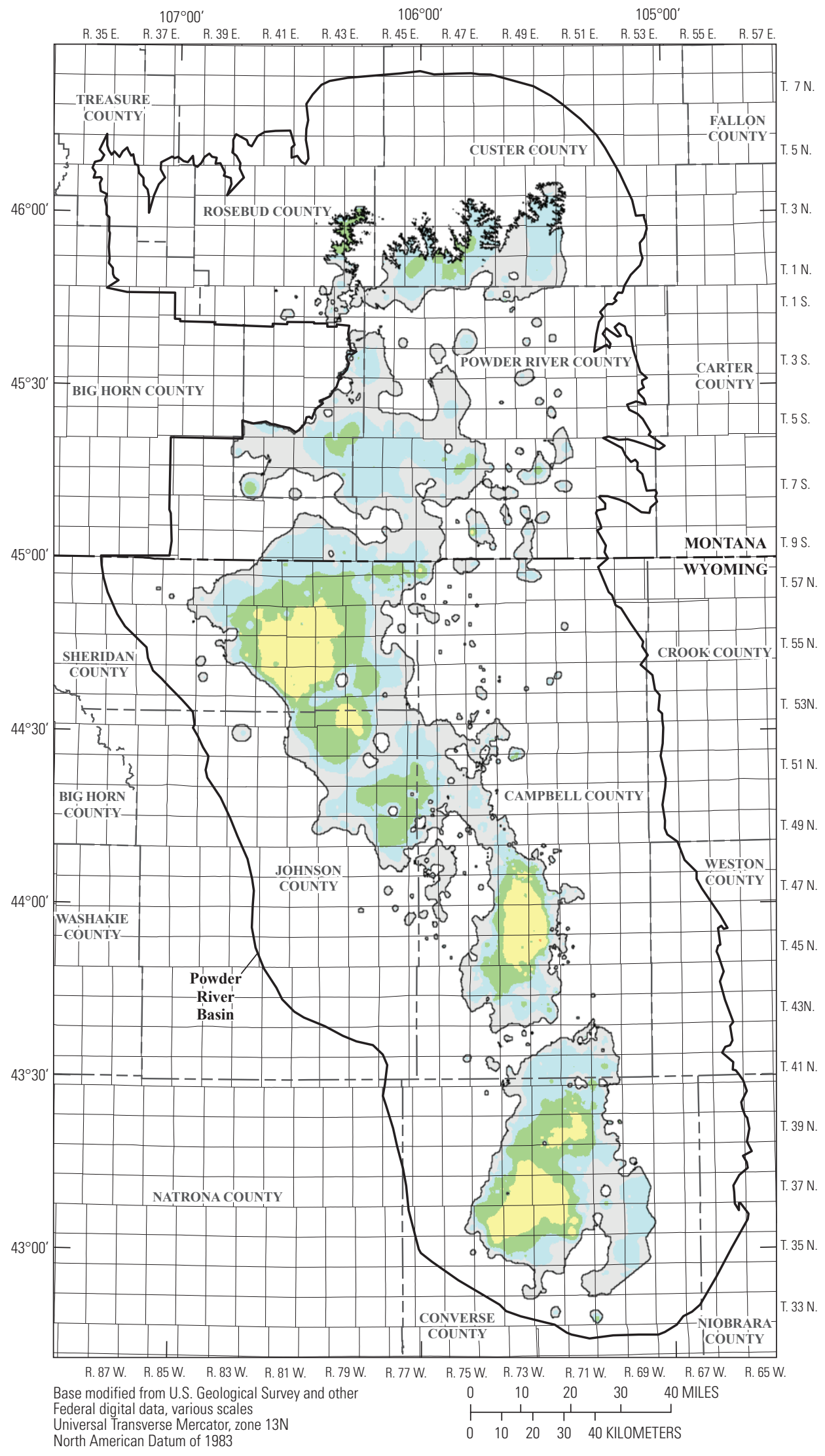

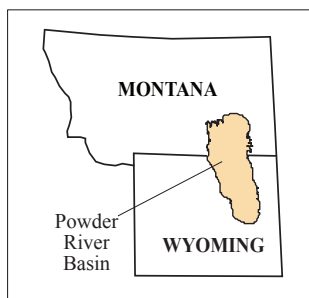

LOCATION MAP

EXPLANATION

Thickness in feet

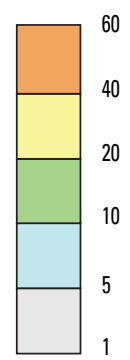

Figure 110. Isopach map of the Roberts/Terret coal bed showing extent of coal at least 1.0 foot thick within the Powder River Basin. 


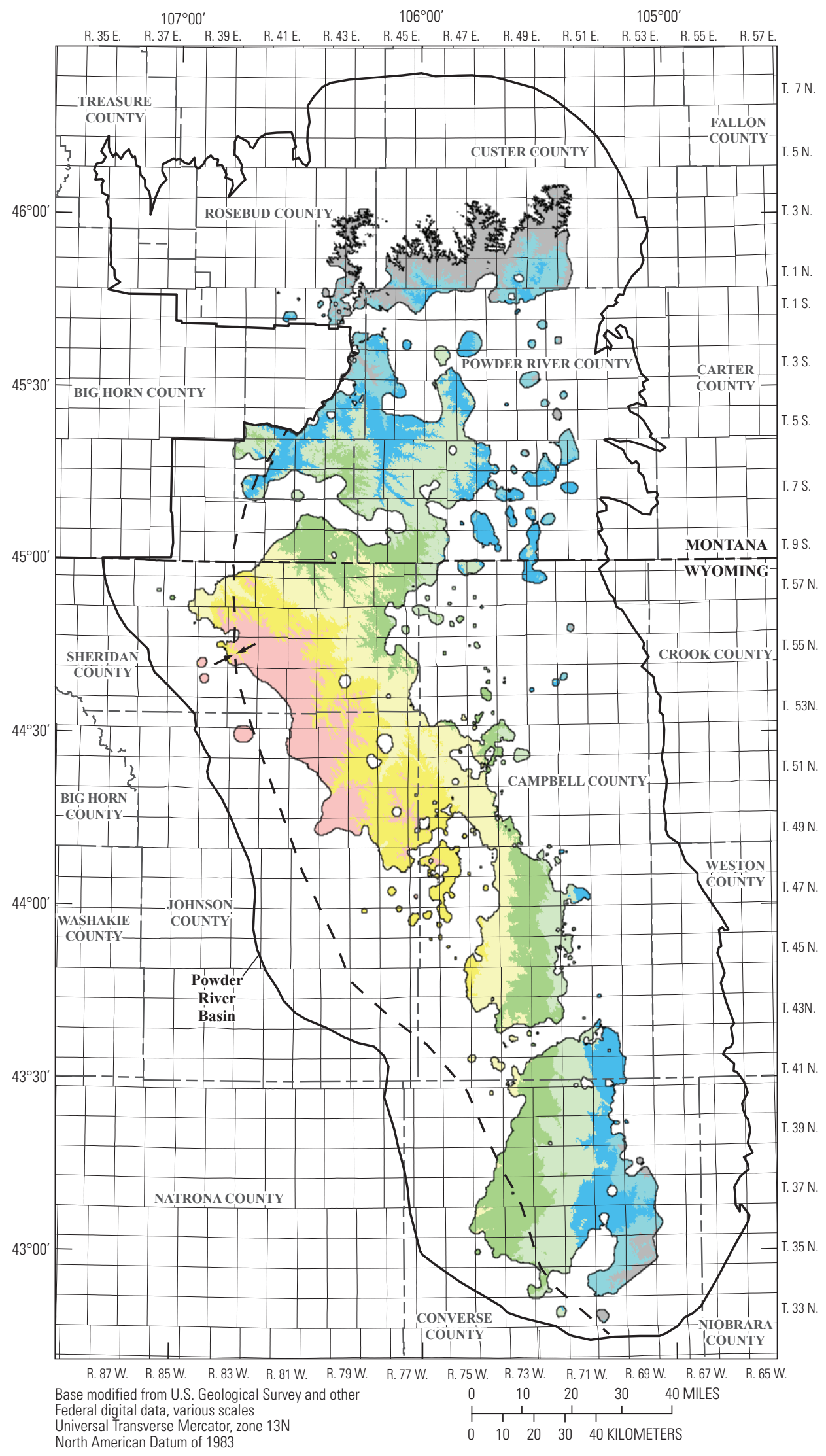

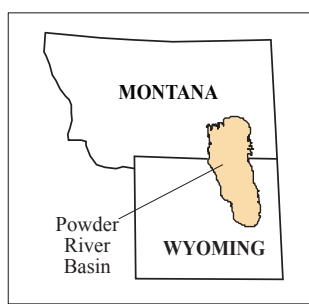

LOCATION MAP

EXPLANATION

Depth to top of coal in feet

4,000

3,000

2,500

2,000

1,500

1,000

500

250

1

$-\downarrow-$ Basin axis

Figure 111. Map showing depth to the top of the Roberts/Terret coal bed within the Powder River Basin. 


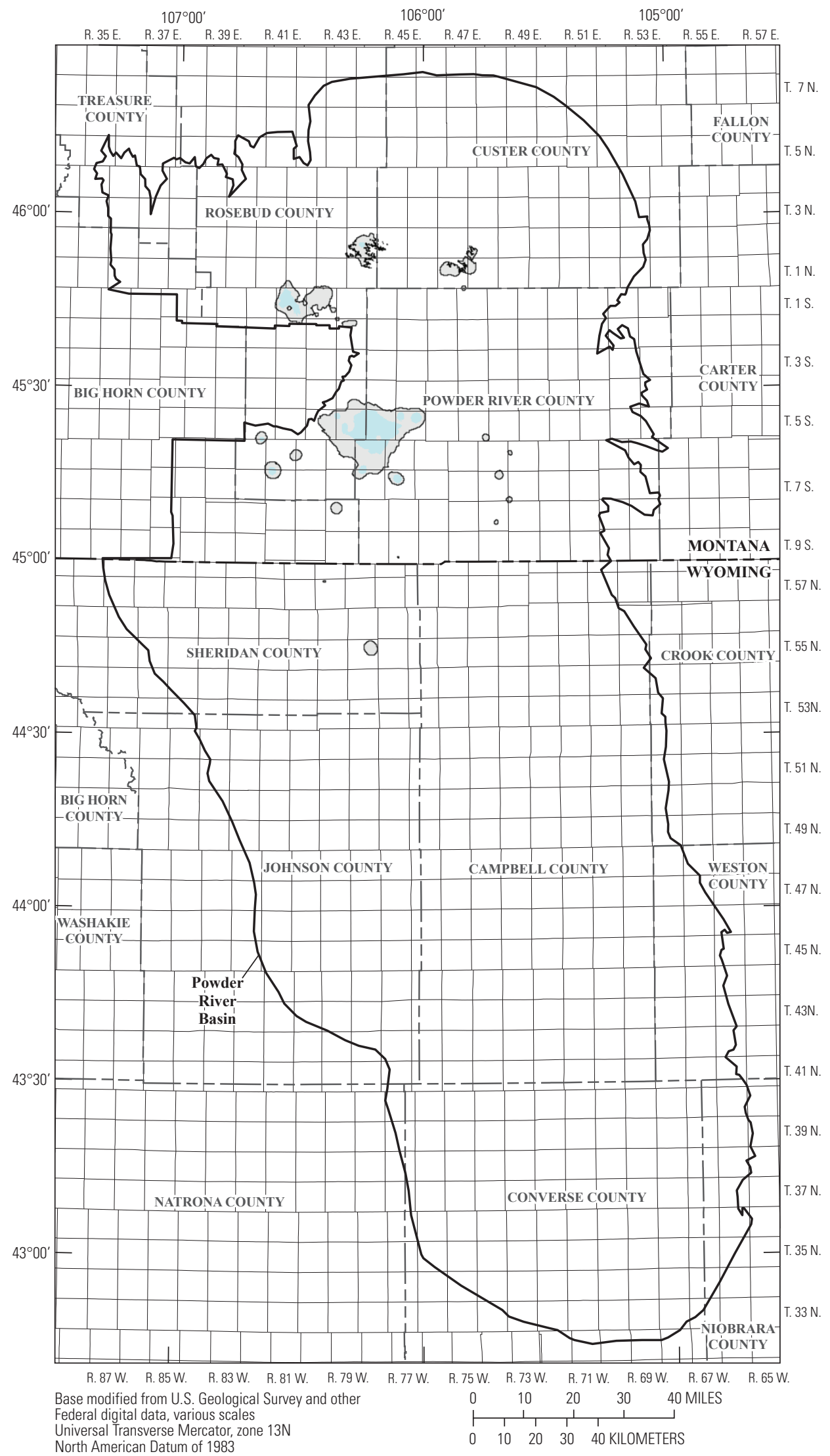

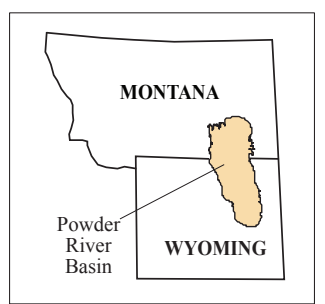

LOCATION MAP

EXPLANATION

Thickness in feet

10

5

Figure 112. Isopach map of the Burley coal bed showing extent of coal at least 1.0 foot thick within the Powder River Basin. 

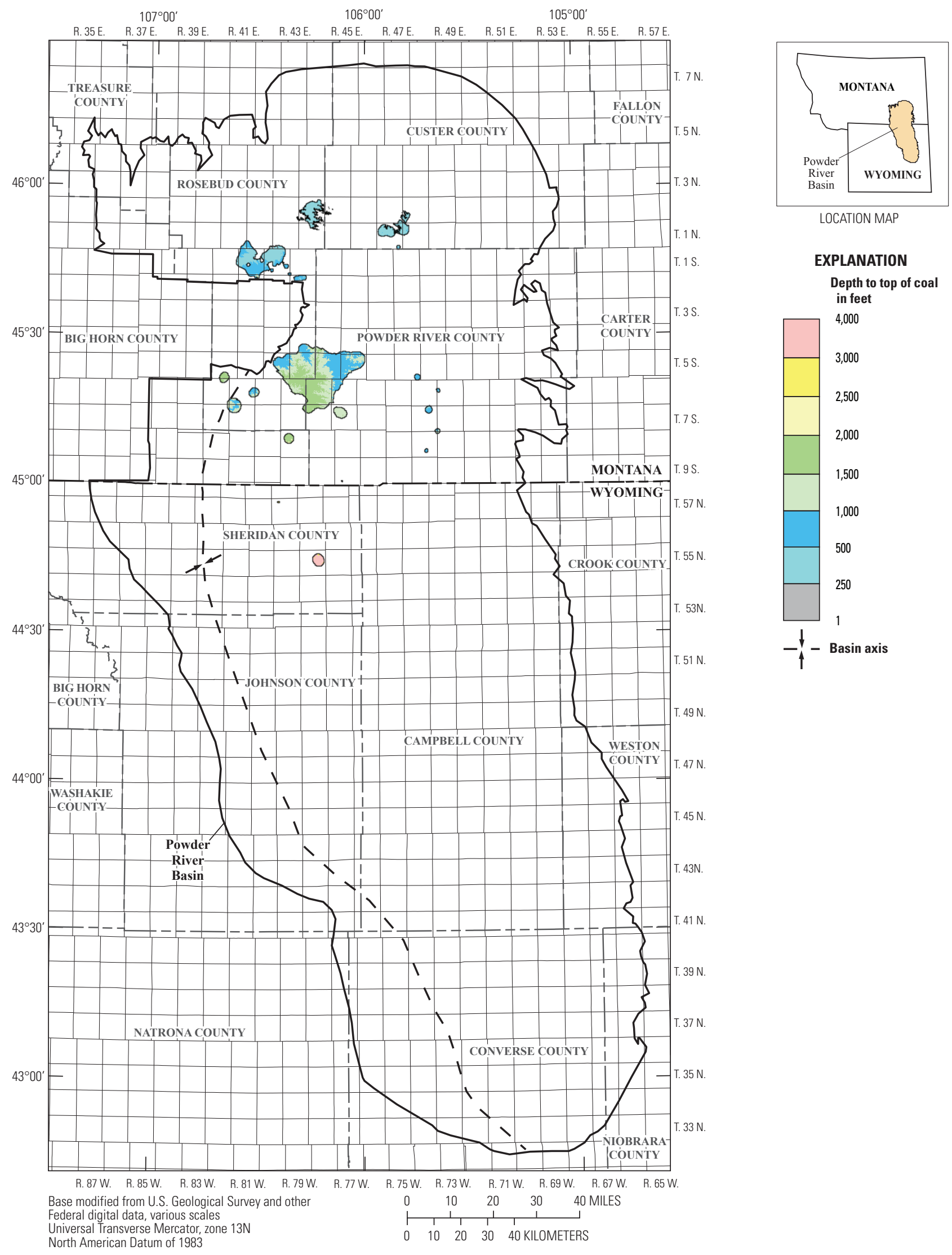

Figure 113. Map showing depth to the top of the Burley coal bed within the Powder River Basin. 


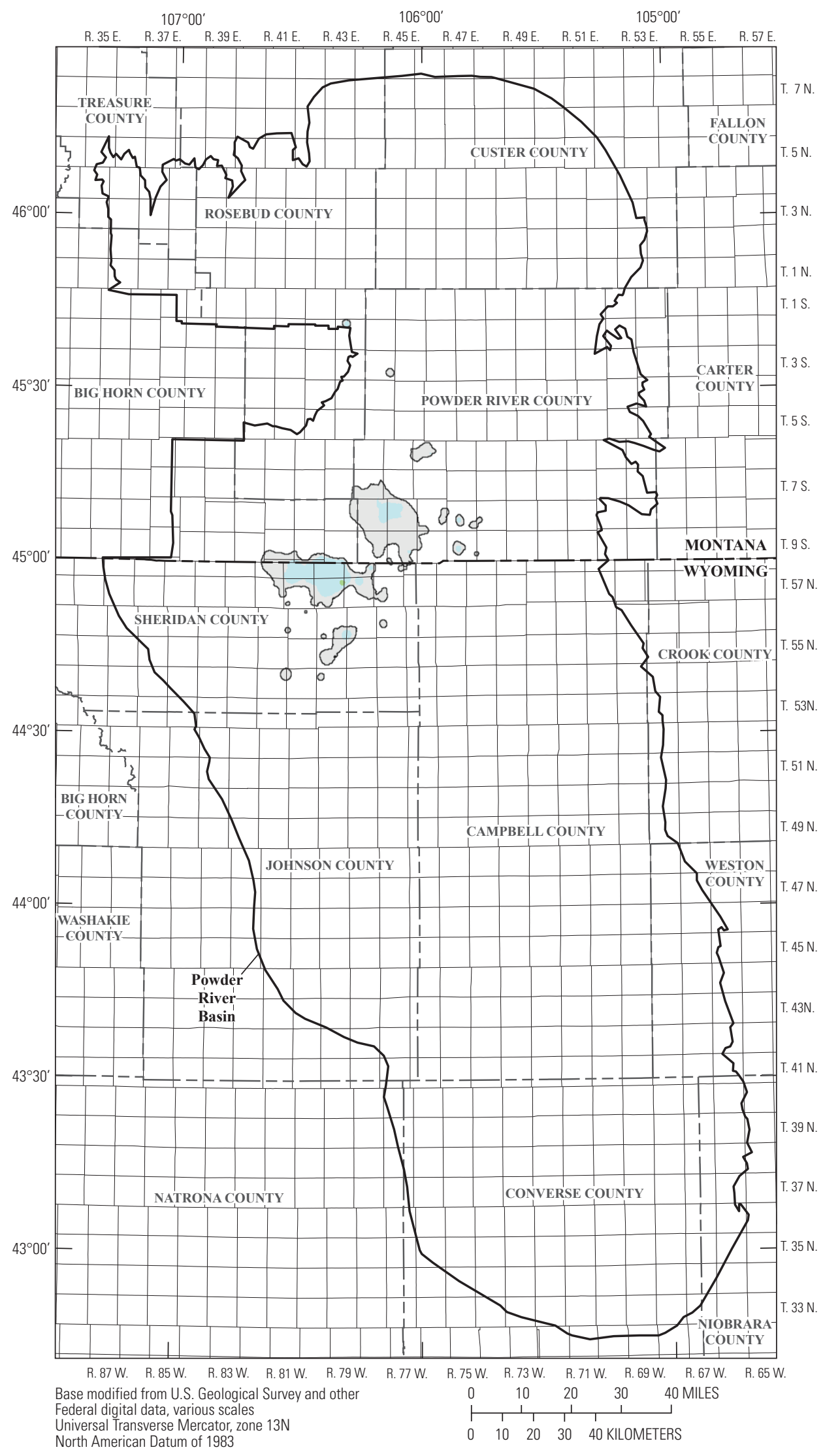

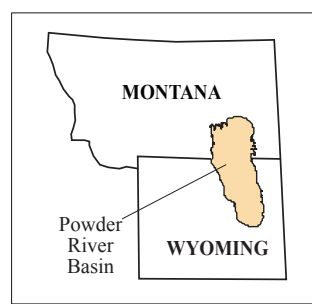

LOCATION MAP

EXPLANATION

Thickness in feet

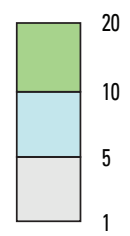

Figure 114. Isopach map of the Upper Stag coal bed showing extent of coal at least 1.0 foot thick within the Powder River Basin. 

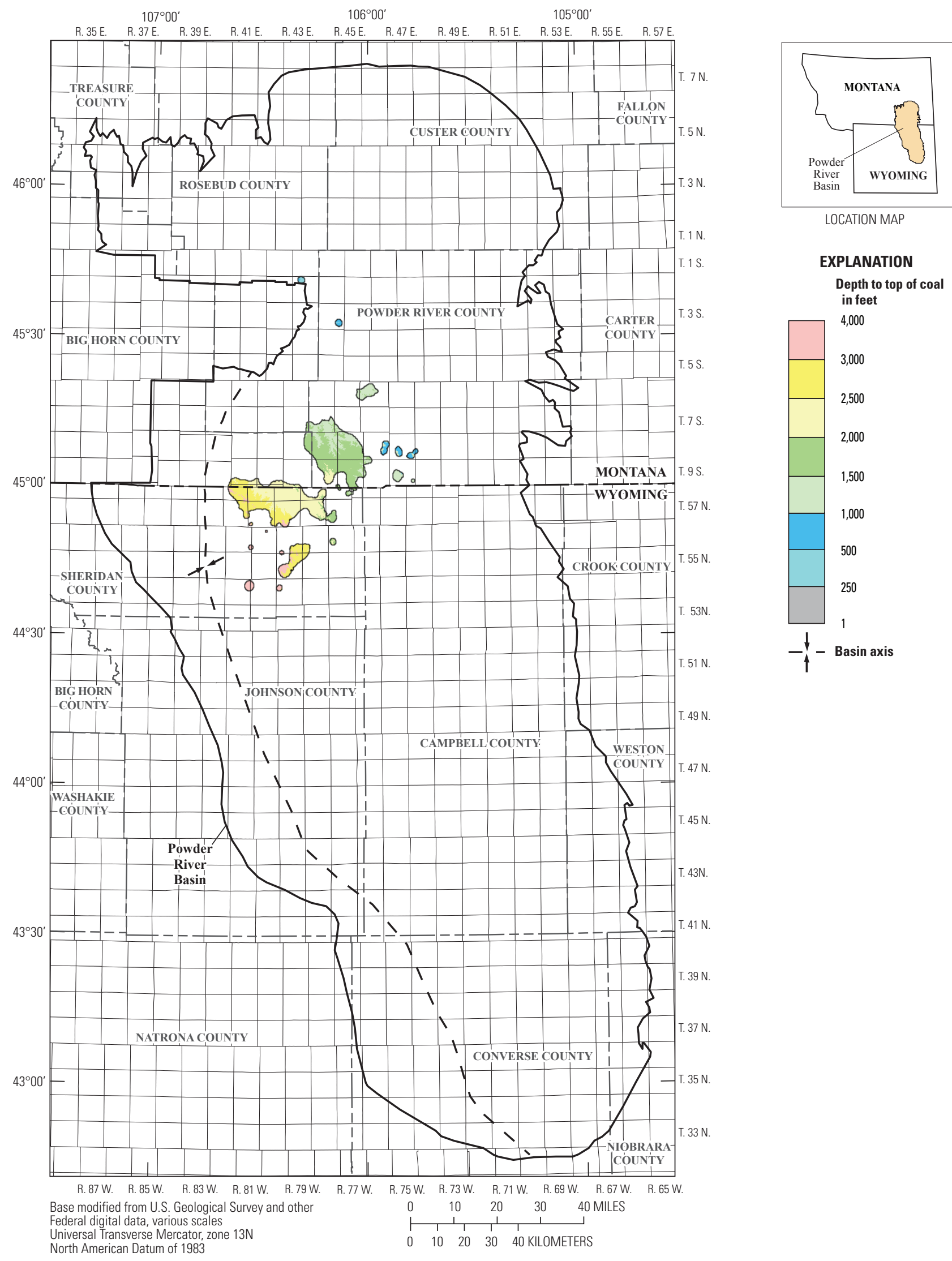

LOCATION MAP

EXPLANATION

Depth to top of coal

in feet

4,000

3,000

2,500

2,000

1,500

1,000

500

250

1

$-\downarrow-$ Basin axis

Figure 115. Map showing depth to the top of the Upper Stag coal bed within the Powder River Basin. 


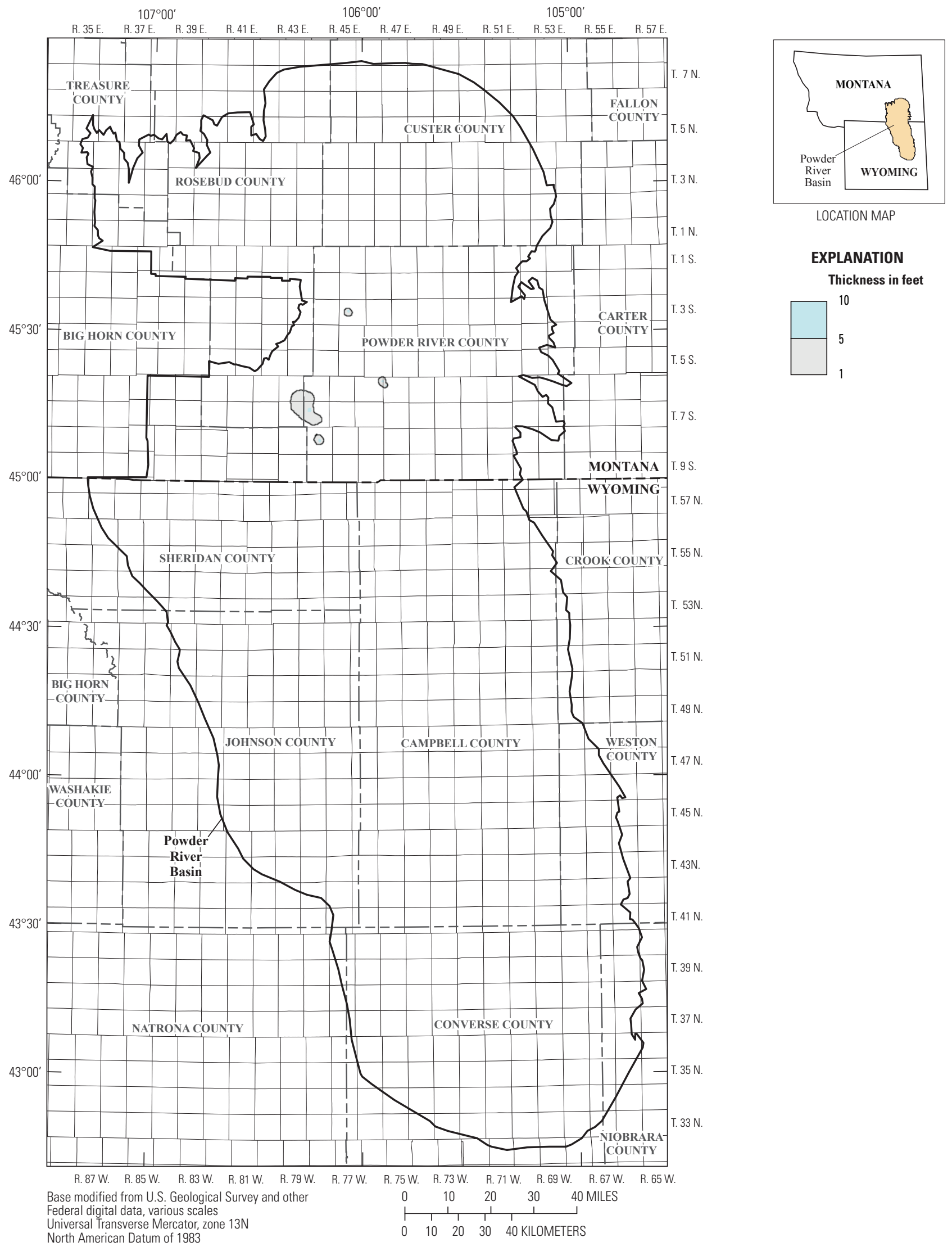

Figure 116. Isopach map of the Lower Stag coal bed showing extent of coal at least 1.0 foot thick within the Powder River Basin. 


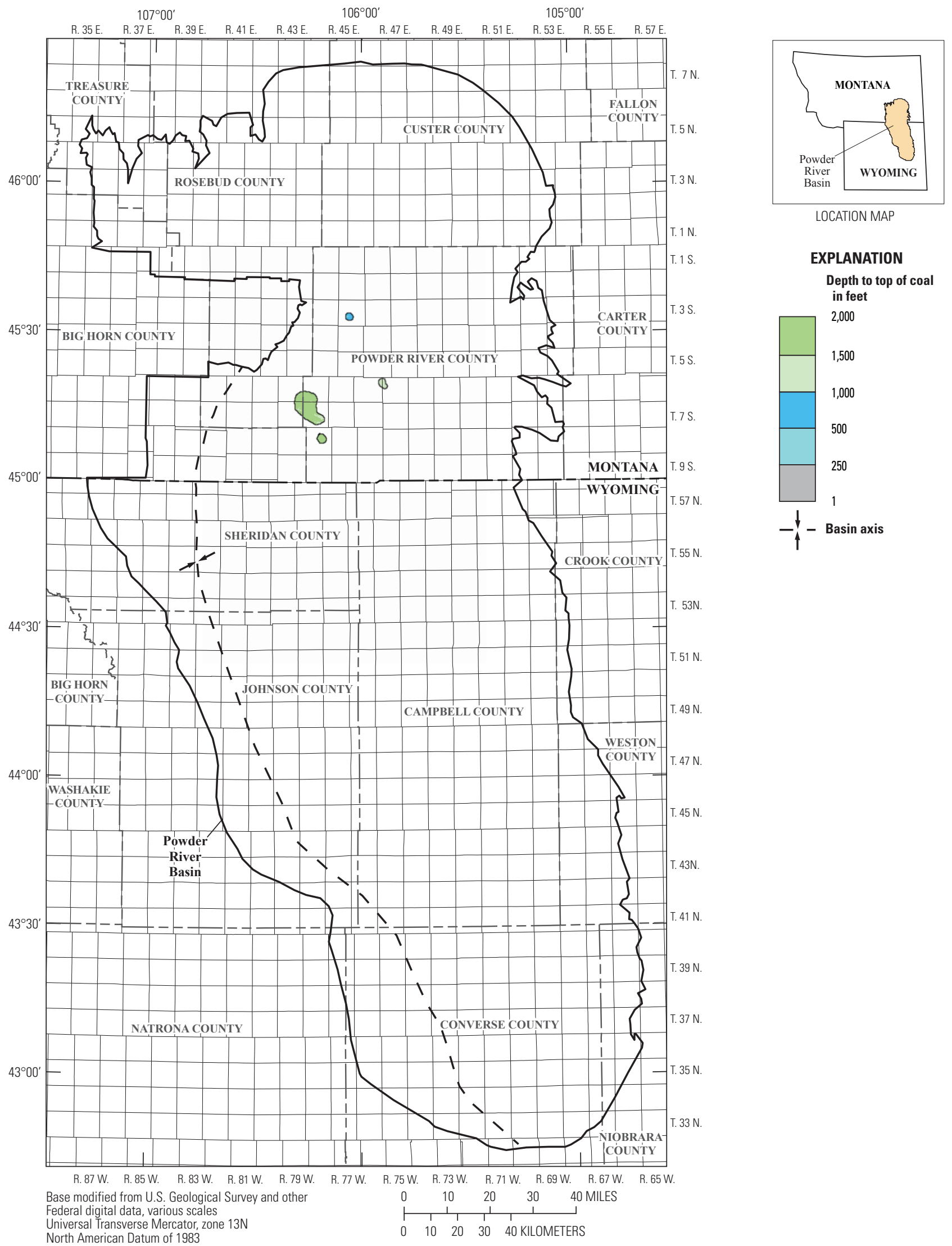

Figure 117. Map showing depth to the top of the Lower Stag coal bed within the Powder River Basin. 


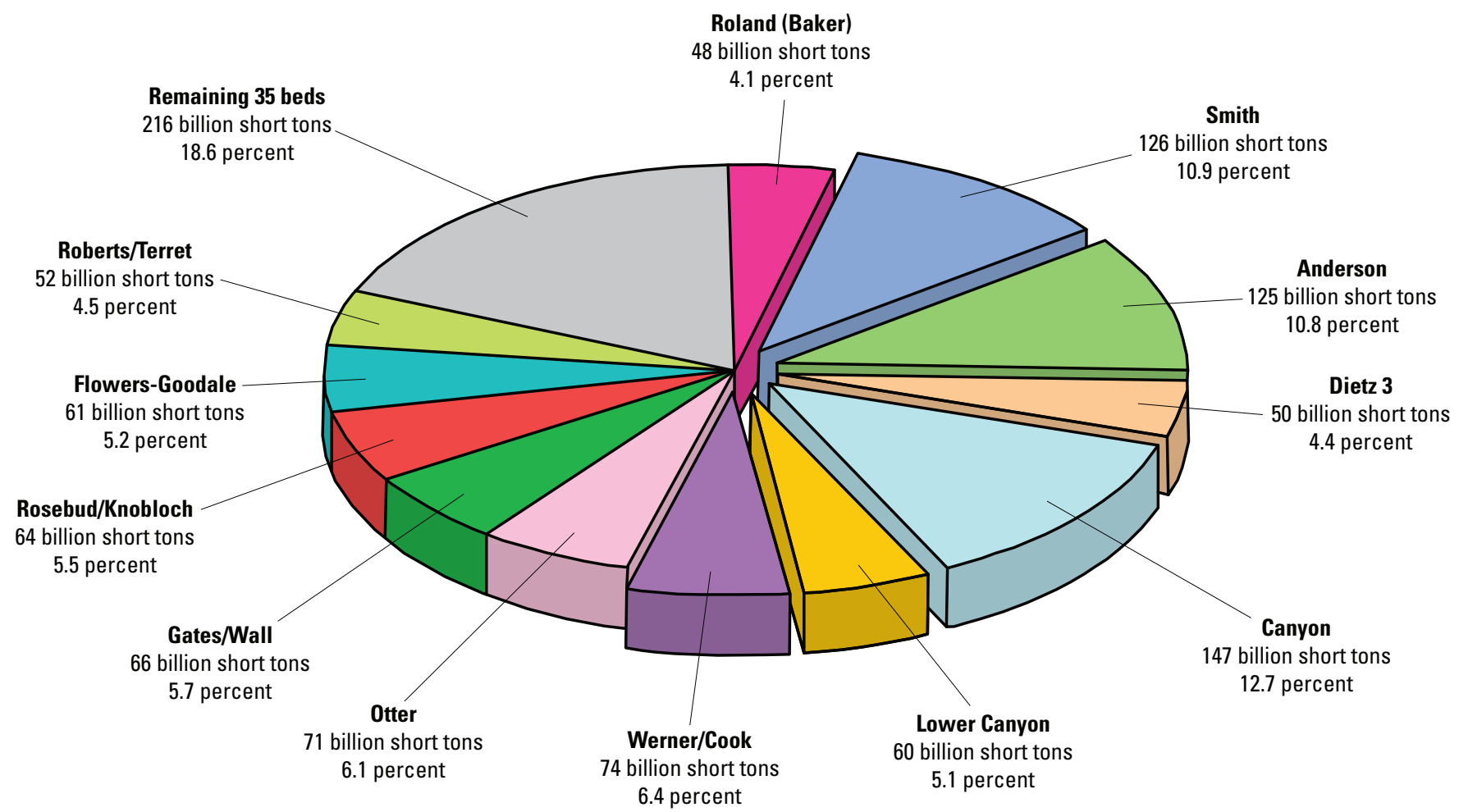

Figure 118. Pie diagram showing tonnages and percentages of individual coal beds in relation to the total 1.16 trillion short tons of original resources in the Powder River Basin, Wyoming and Montana. 




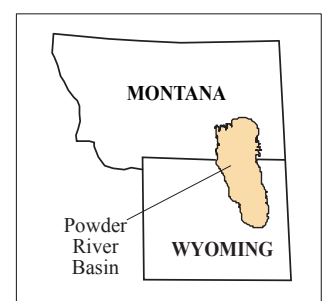

LOCATION MAP

EXPLANATION

Thickness in feet

40

20

10

5

1

-Rozet- Lineament and identifie

Lineament data modified from Jones (2010a)

Figure 119. Isopach map of the Flowers-Goodale coal bed showing extent of resources at least 1.0 foot thick and location of lineaments described by Jones, 2010a, in the Powder River Basin, Wyoming and Montana. 


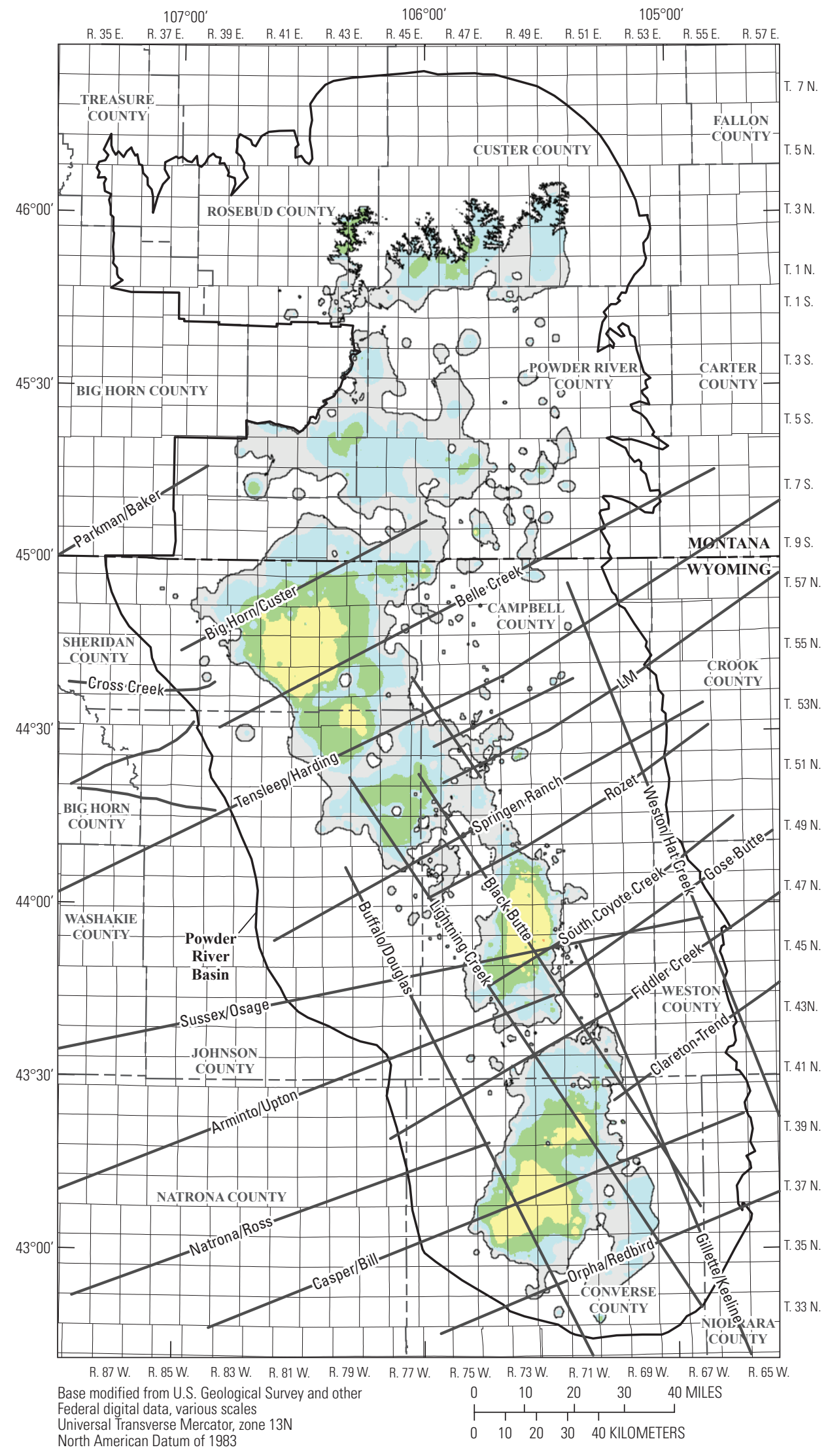

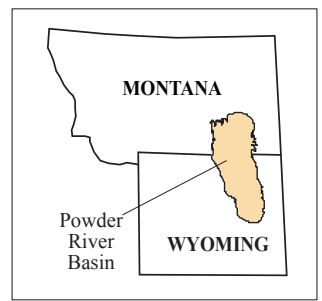

LOCATION MAP

EXPLANATION

Thickness in feet

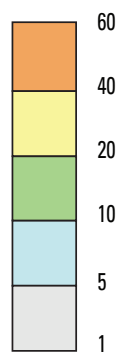

-Rozet- Lineament and identifier

Lineament data modified from Jones (2010a)

Figure 120. Isopach map of the Roberts/Terret coal bed showing extent of resources at least 1.0 foot thick and location of lineaments described by Jones, 2010a, in the Powder River Basin, Wyoming and Montana. 


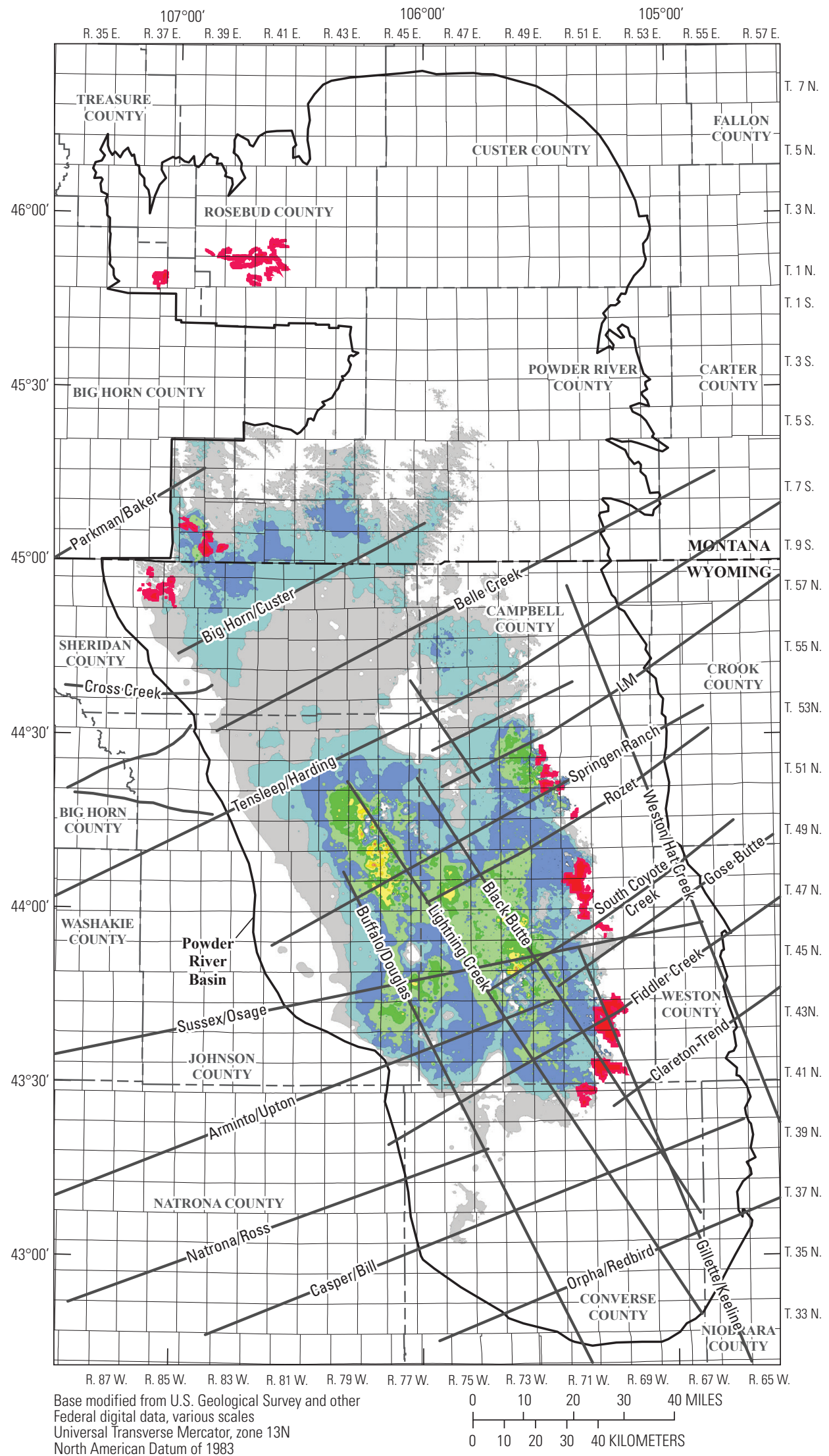

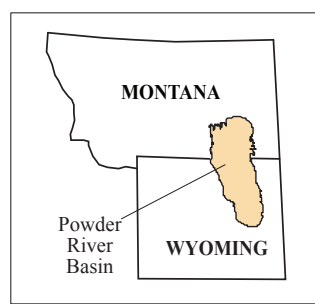

LOCATION MAP

EXPLANATION

Thickness in feet

300 and greater

250

200

150

125

100

75

50

25

5

$\square$ Mine area

-Rozet- Lineament and identifier

Lineament data modified from Jones (2010a)

Figure 121. Isopach map of the Smith, Anderson, and Canyon coal beds showing extent of resources at least 5 feet thick and location of lineaments described by Jones, 2010a in the Powder River Basin, Wyoming and Montana. 


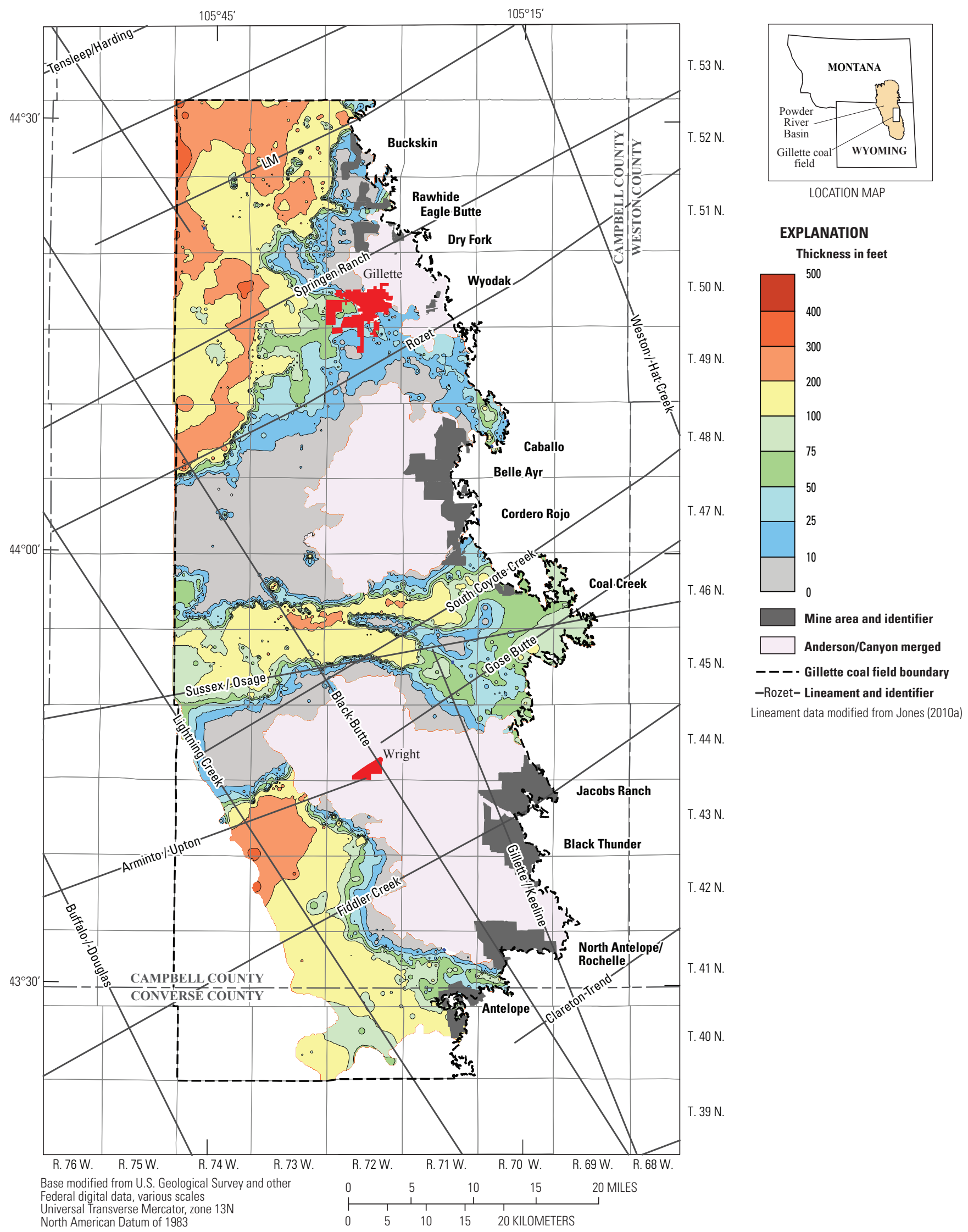

Figure 122. Isopach map showing interburden thickness between the Anderson and Canyon coal beds in the Gillette coal field and location of lineaments described by Jones, 2010a in the Powder River Basin, Wyoming. 


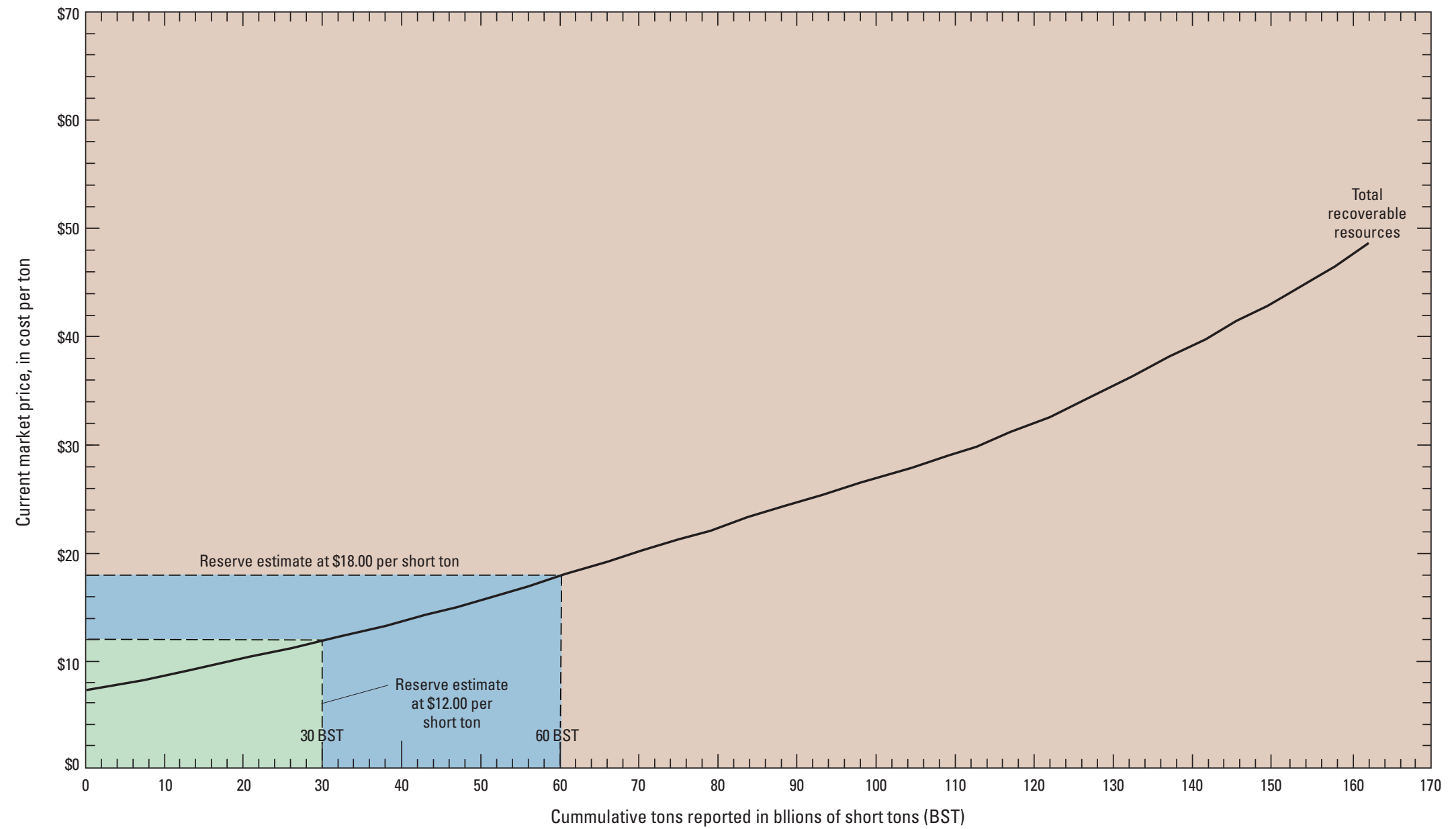

Figure 123. Generic cost curve showing 12.8 billion short tons (BST) reserve estimate at $\$ 13.20$ per ton for the Powder River Basin, Wyoming and Montana. 


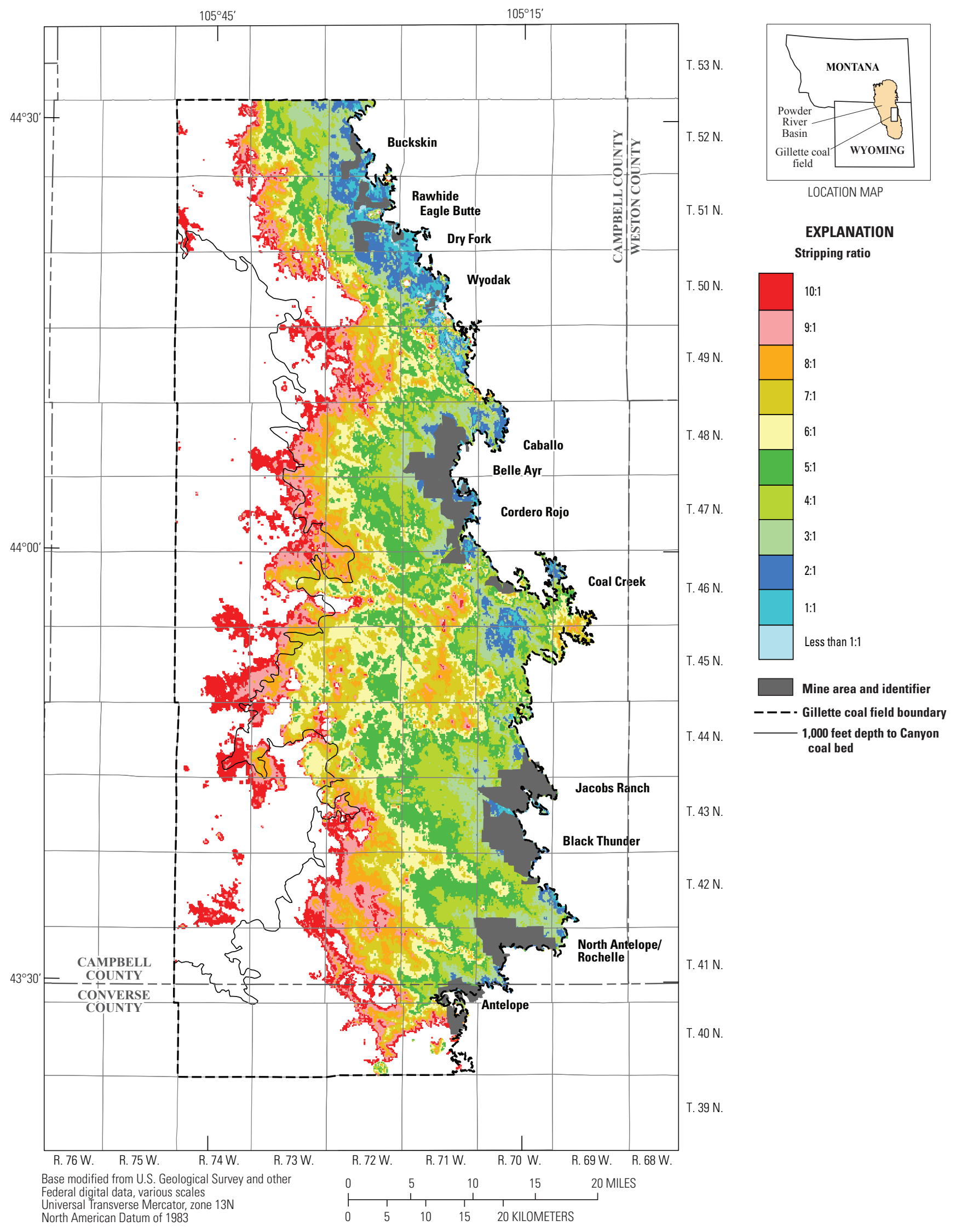

Figure 124. Map showing areal extent for the composite stripping ratio of the Roland (Baker), Smith, Upper Anderson, Anderson, Dietz, and Canyon coal beds in the Gillette coal field, Wyoming Powder River Basin. 


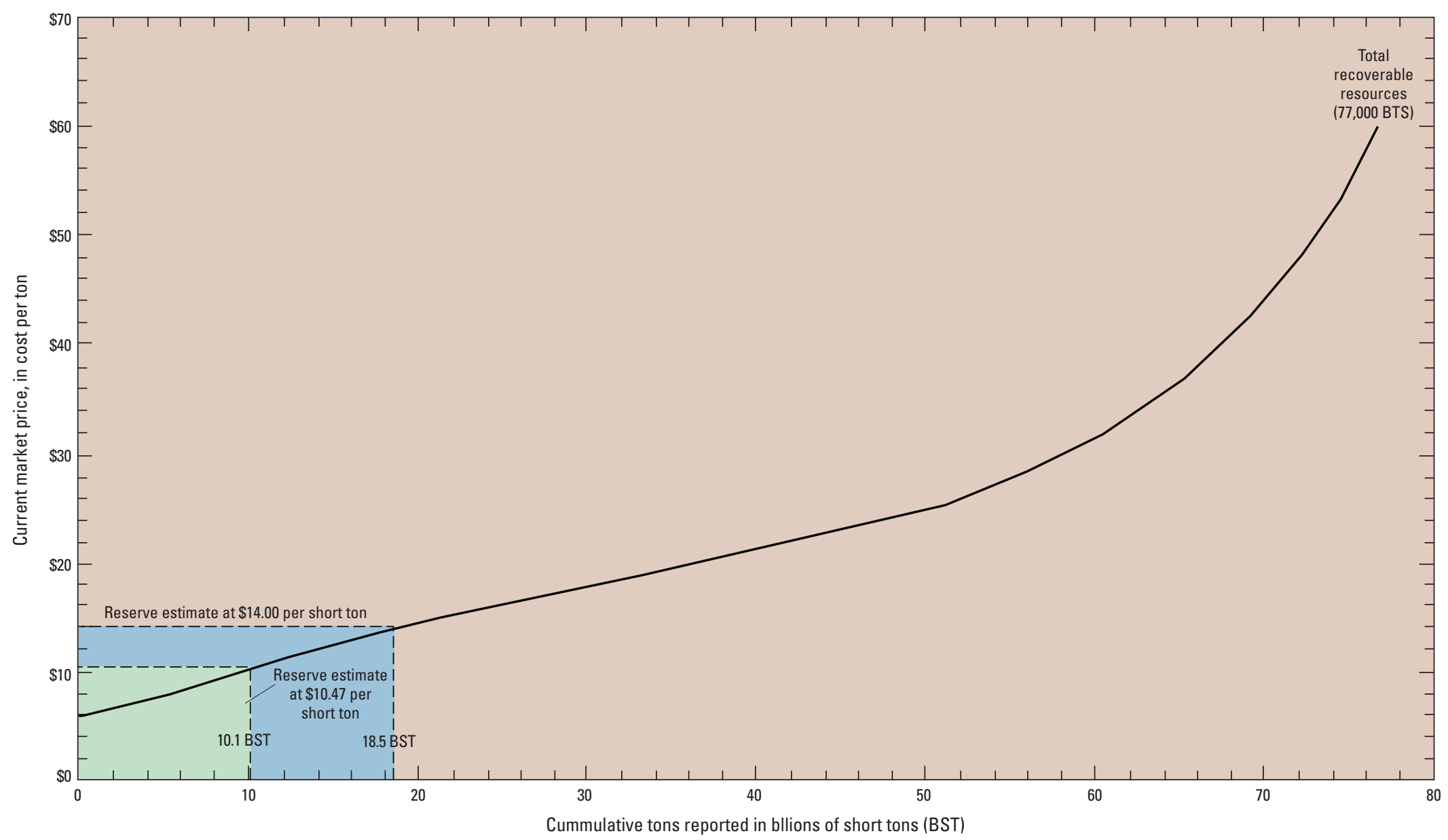

Figure 125. Cost curve showing reserve estimates at $\$ 10.47$ per short ton (as of January 2007) and $\$ 14.00$ per short ton (as of March 2008) for the Gillette coal field, Wyoming. 


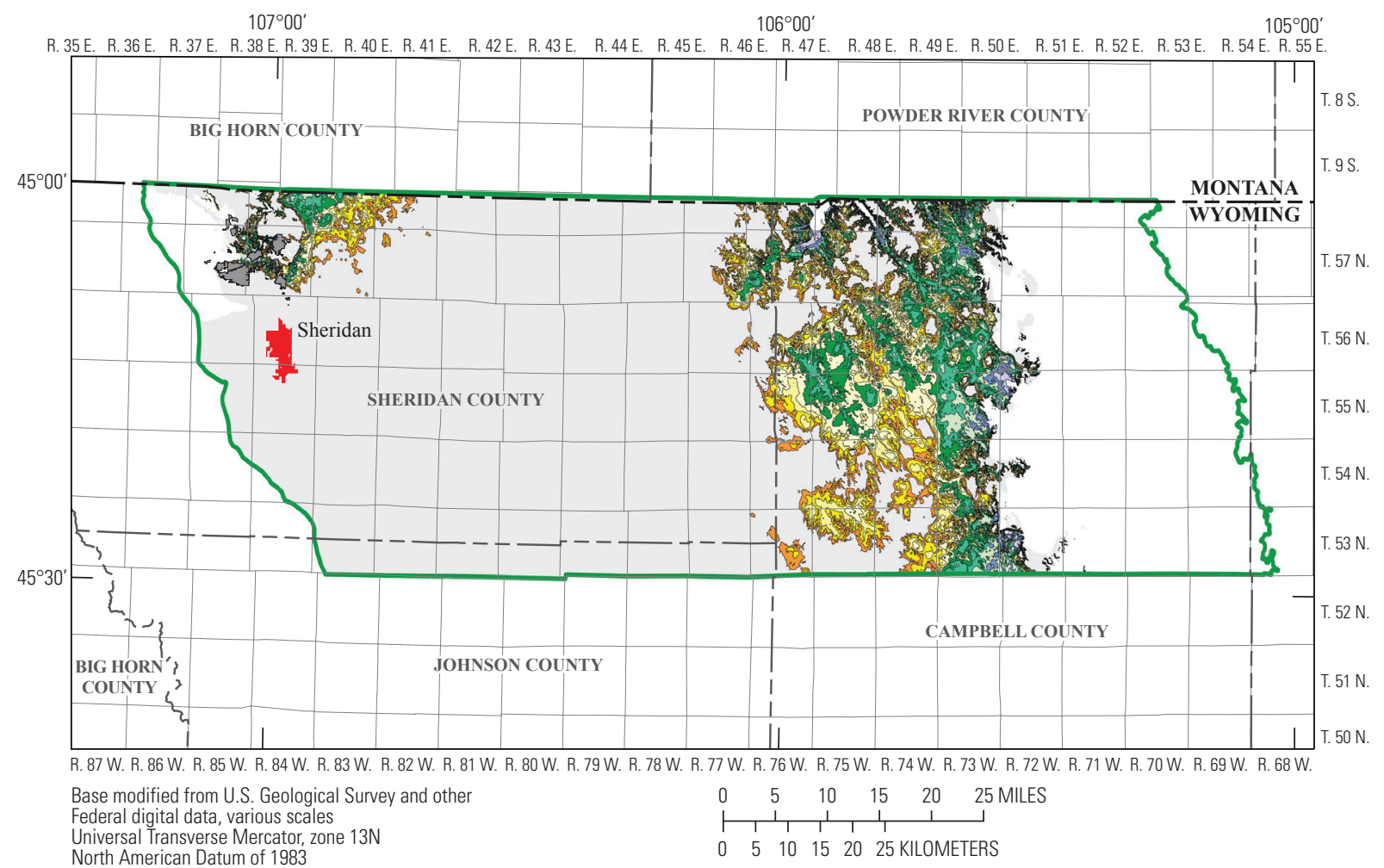

EXPLANATION

Stripping ratio

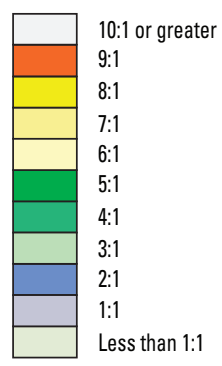

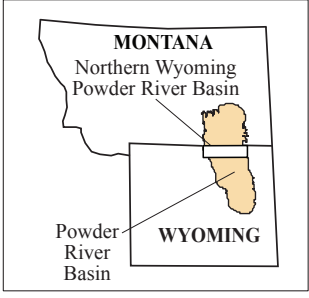

LOCATION MAP

Mine area

Northern Wyoming Powder

River Basin assessment

area boundary

Figure 126. Map showing areal extent for the composite stripping ratio of the Roland (Baker), Smith, Anderson, Dietz 3 , Canyon, Lower Canyon, and Werner/Cook coal beds where the stripping ratios are from 1:1 to 10:1, thicknesses are equal to at least 5.0 feet, and the overburden is less than or equal to 500 feet thick, in the Wyoming Powder River Basin. 


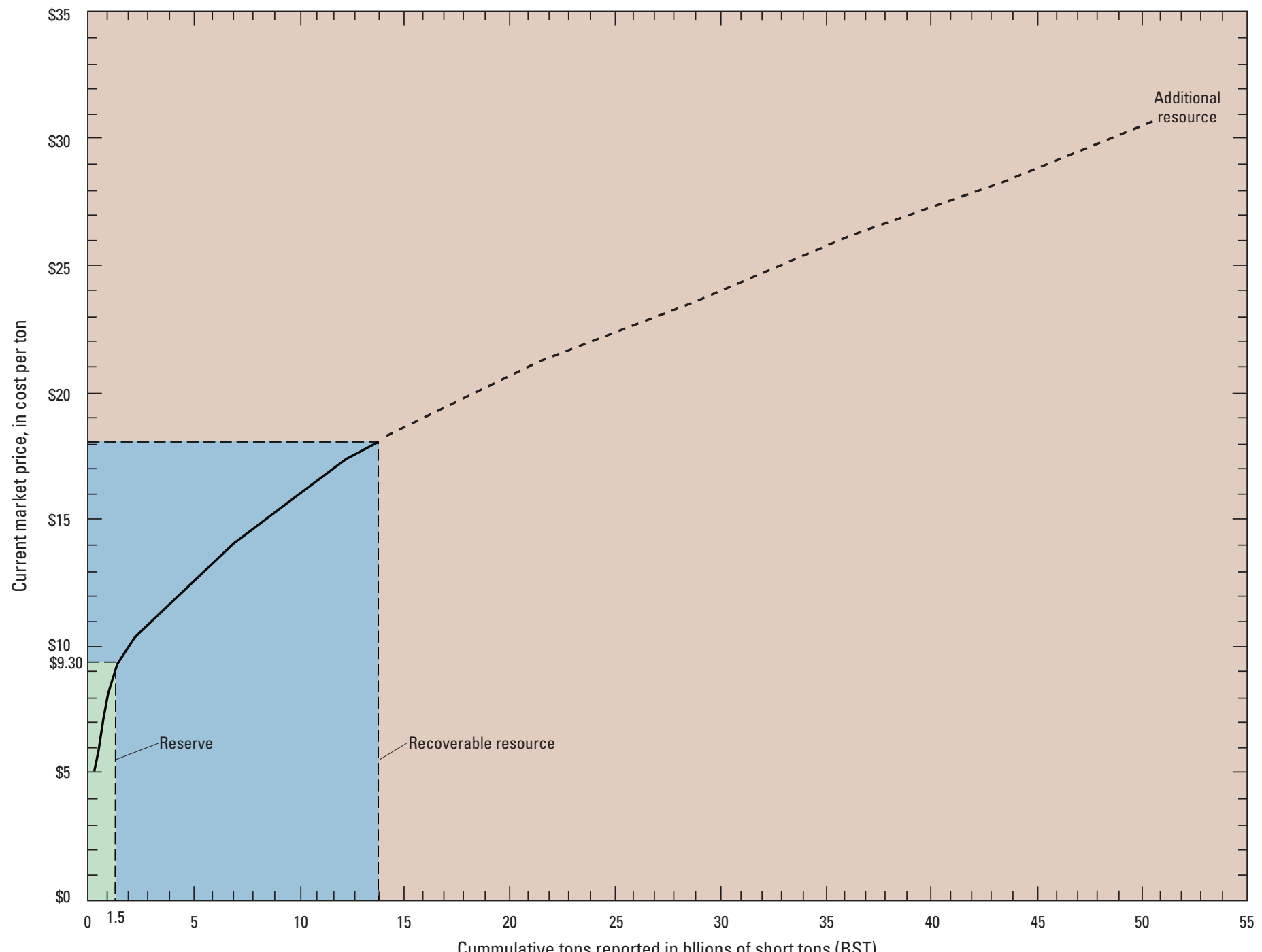

Figure 127. Cost curve showing 1.5 billion ton reserve estimate at $\$ 9.30$ per short ton (as of February 2010) for the Northern Wyoming Powder River Basin assessment area. 


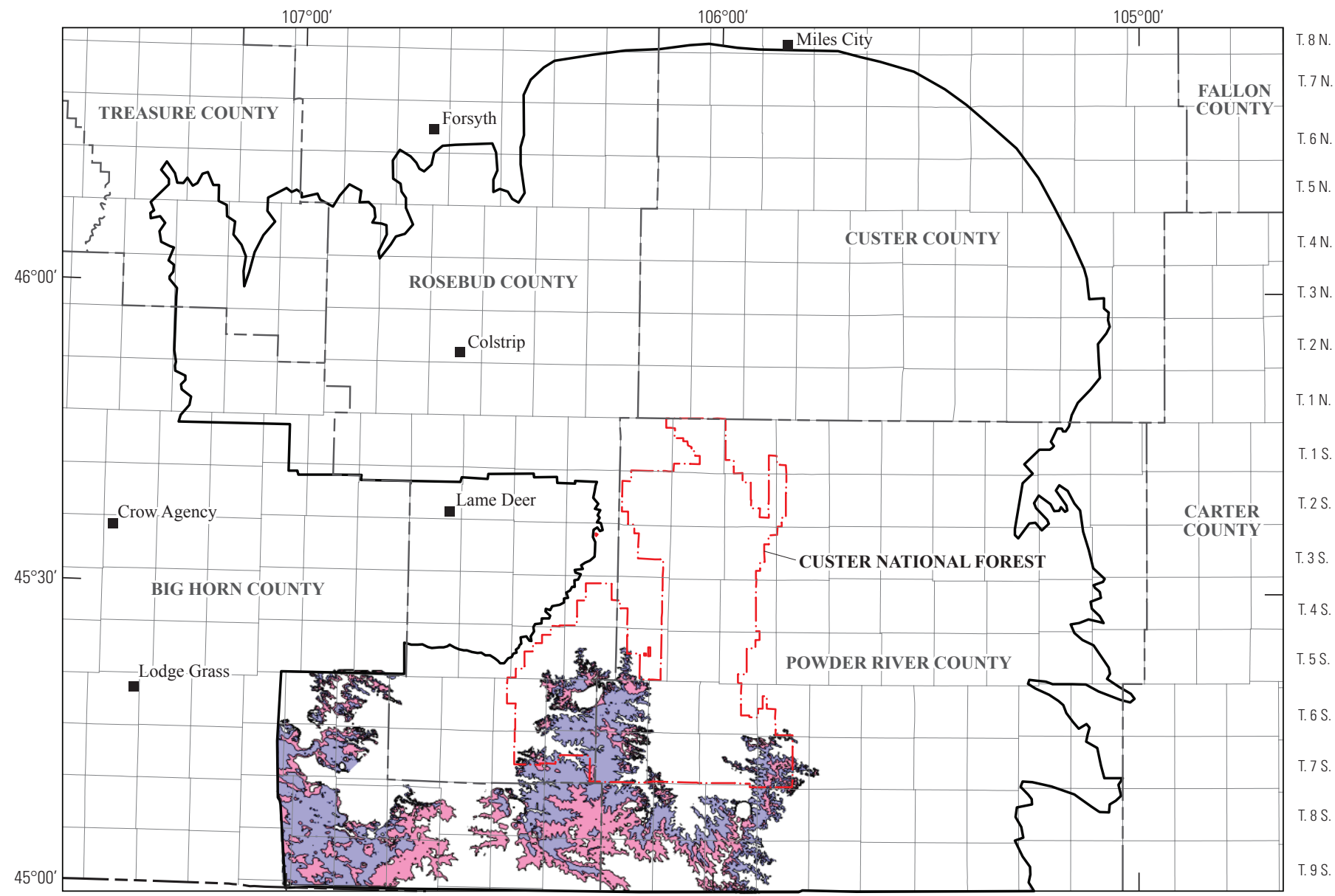

R. 35 E. R. 36 E. R. 37 E. R. 38 E. R. 39 E. R. 40 E. R. 41 E. R. 42 E. R. 43 E. R. 44 E. R. 45 E. R. 46 E. R. 47 E. R. 48 E. R. 49 E. R. 50 E. R. 51 E. R. 52 E. R. 53 E. R. 54 E. R. 55 E. R. 56 E. R. 57 E. Base modified from U.S. Geological Survey and other Federal digital data, various scales

Universal Transverse Mercator, zone 13N

North American Datum of 1983
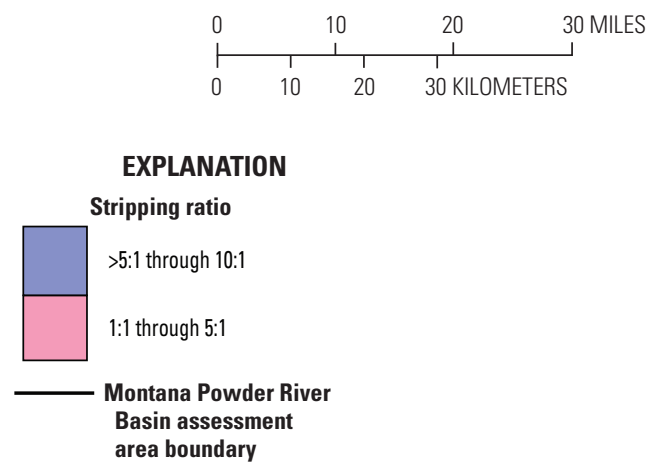

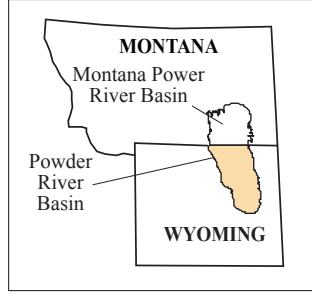

LOCATION MAP

Figure 128. Map showing areal extent for the composite stripping ratio of the Roland (Baker), Smith, Anderson, Dietz 2, and Dietz 3 coal beds where the stripping ratios are from 1:1 to 10:1, thicknesses are equal to at least 5.0 feet, and the overburden is less than or equal to 500 feet thick, in the Montana Powder River Basin. 


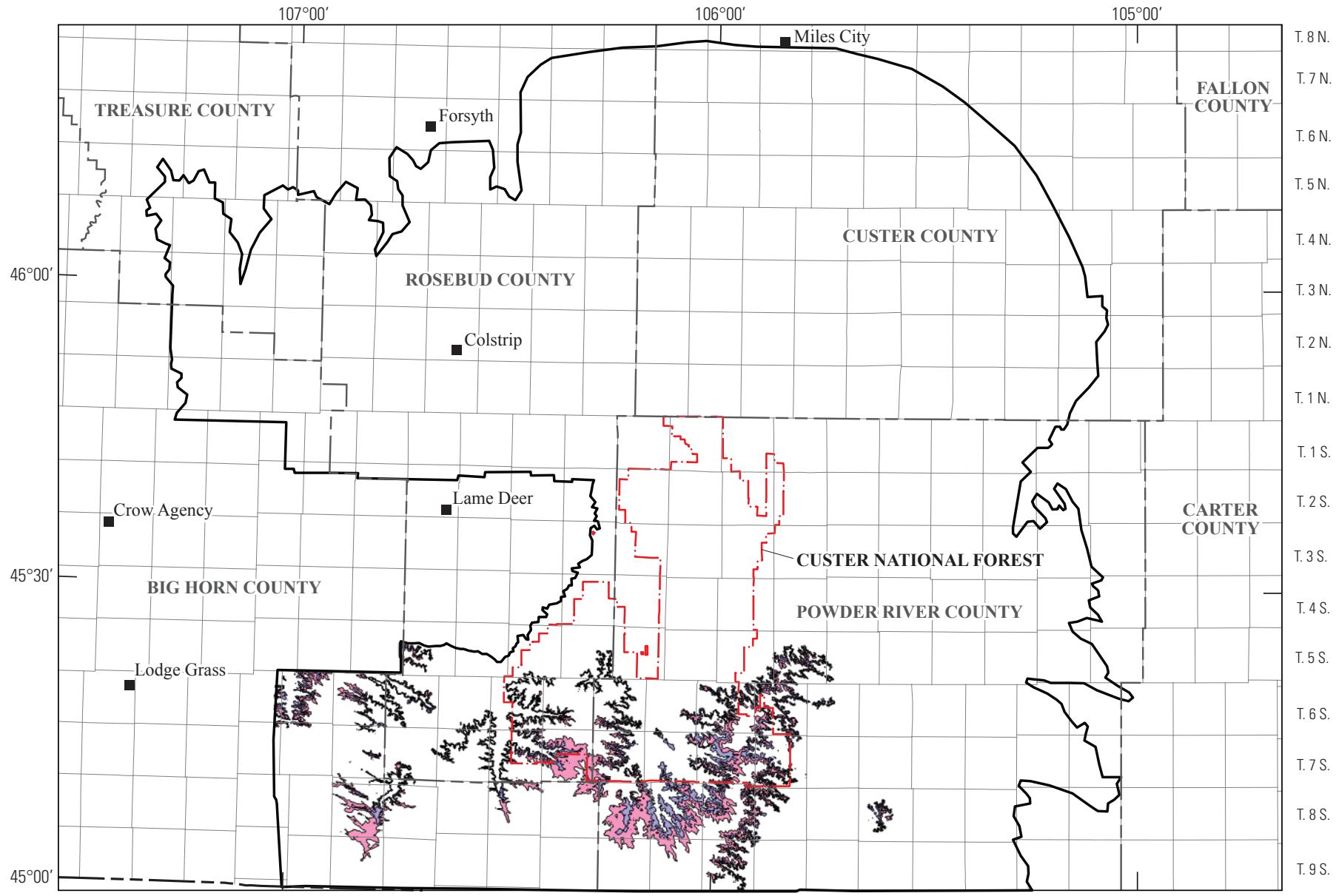

R. 35 E. R. 36 E. R. 37 E. R. 38 E. R. 39 E. R. 40 E. R. 41 E. R. 42 E. R. 43 E. R. 44 E. R. 45 E. R. 46 E. R. 47 E. R. 48 E. R. 49 E. R. 50 E. R. 51 E. R. 52 E. R. 53 E. R. 54 E. R. 55 E. R. 56 E. R. 57 E Base modified from U.S. Geological Survey and other

Base modified from U.S. Geological Survey a
Federal digital data, various scales
Universal Transverse Mercator, zone $13 \mathrm{~N}$

North American Datum of 1983
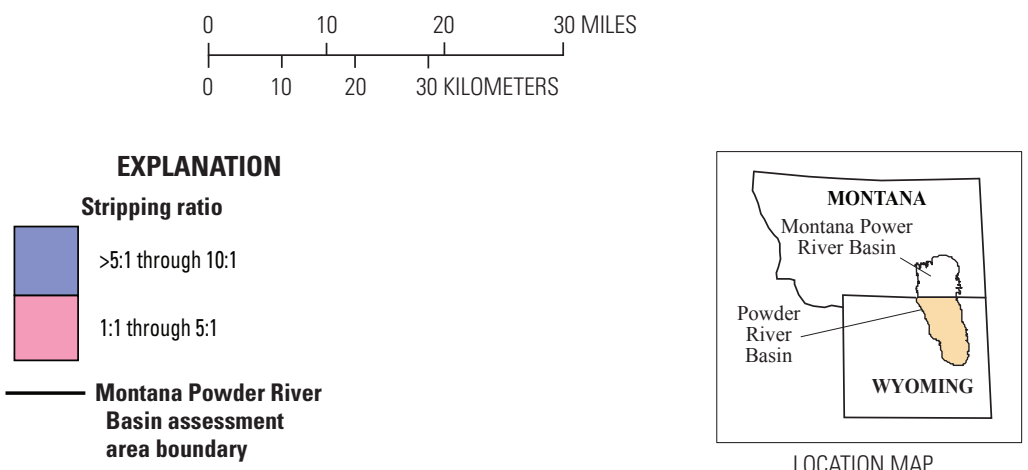

Figure 129. Map showing areal extent for the stripping ratio of the Canyon coal bed where the stripping ratios are from 1:1 to 10:1, thicknesses are equal to at least 5.0 feet, and the overburden is less than or equal to 500 feet thick, in the Montana Powder River Basin. 


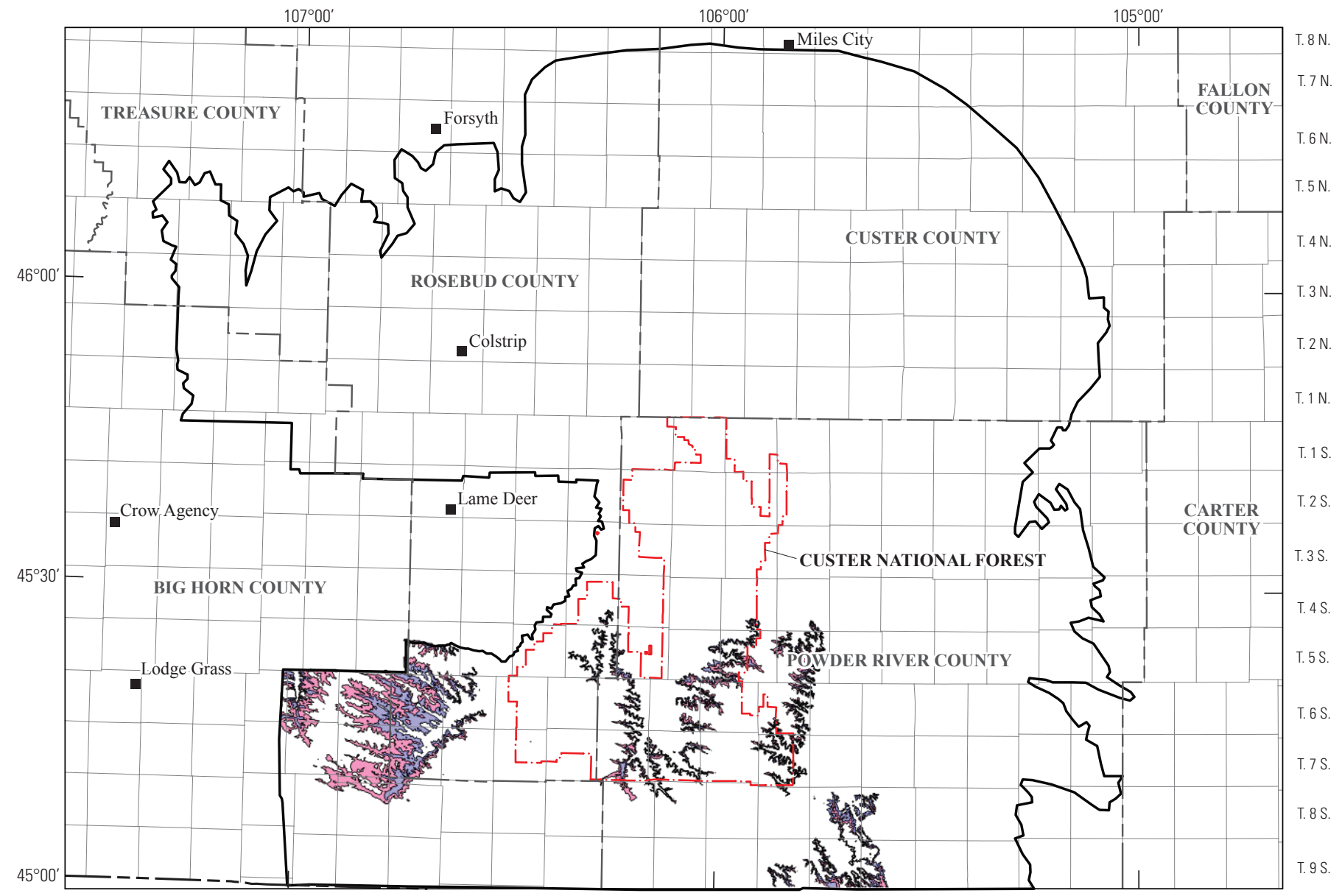

R. 35 E. R. 36 E. R. 37 E. R. 38 E. R. 39 E. R. 40 E. R. 41 E. R. 42 E. R. 43 E. R. 44 E. R. 45 E. R. 46 E. R. 47 E. R. 48 E. R. 49 E. R. 50 E. R. 51 E. R. 52 E. R. 53 E. R. 54 E. R. 55 E. R. 56 E. R. 57 E. Base modified from U.S. Geological Survey and other Federal digital data, various scales Universal Transverse Mercator, zone 13N North American Datum of 1983
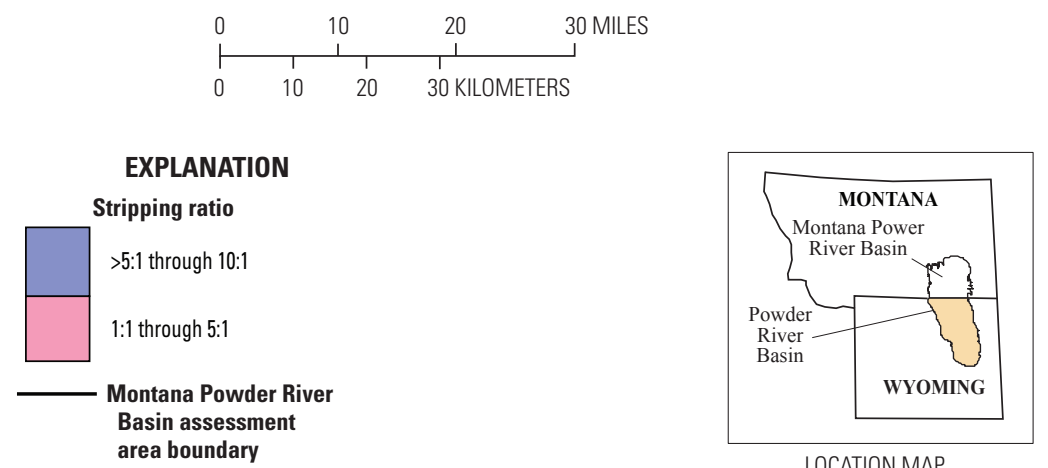

Figure 130. Map showing areal extent for the stripping ratio of the Werner/Cook coal bed where the stripping ratios are from 1:1 to 10:1, thicknesses are equal to at least 5.0 feet, and the overburden is less than or equal to 500 feet thick, in the Montana Powder River Basin. 


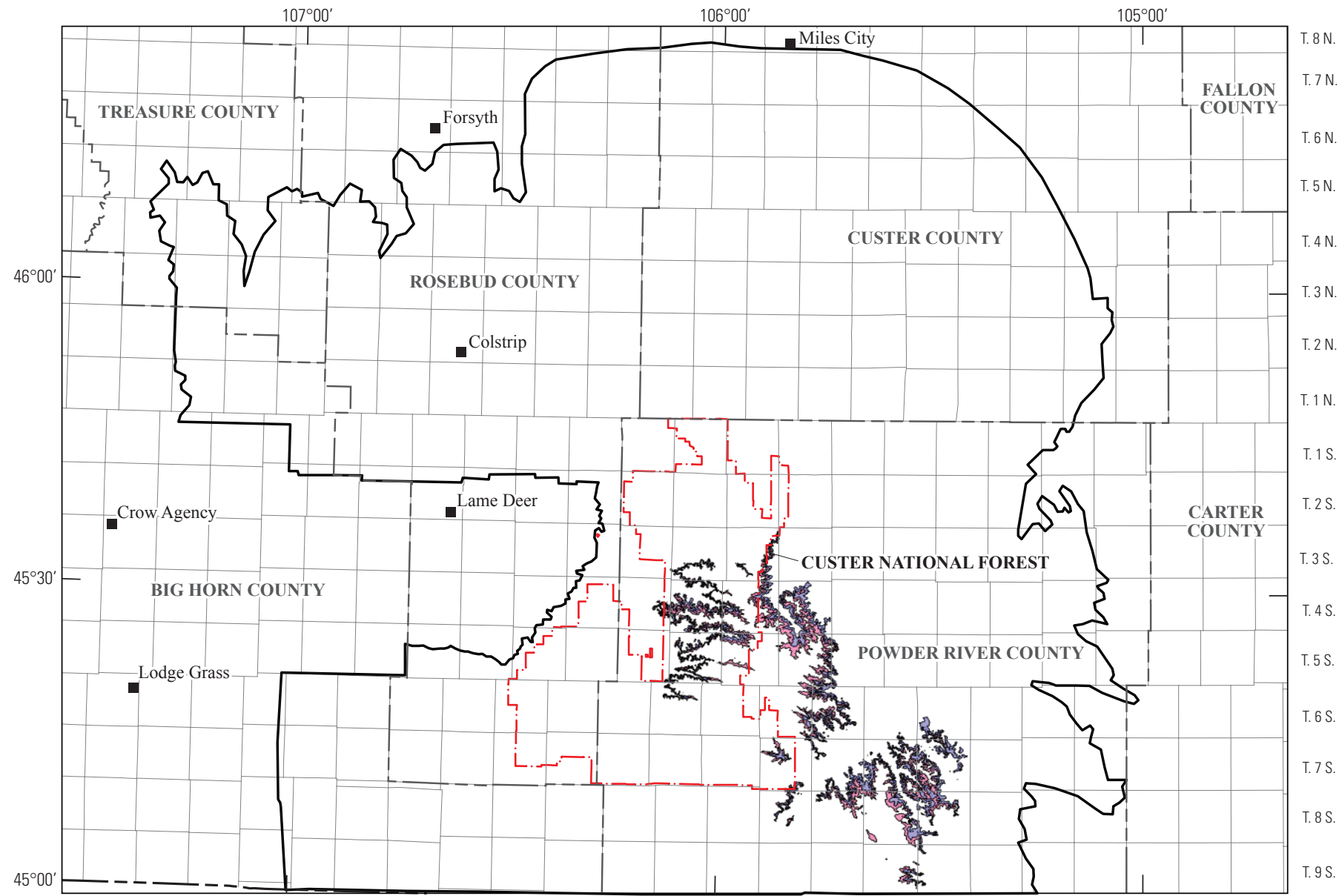

R. 35 E. R. 36 E. R. 37 E. R. 38 E. R. 39 E. R. 40 E. R. 41 E. R. 42 E. R. 43 E. R. 44 E. R. 45 E. R. 46 E. R. 47 E. R. 48 E. R. 49 E. R. 50 E. R. 51 E. R. 52 E. R. 53 E. R. 54 E. R. 55 E. R. 56 E. R. 57 E. Base modified from U.S. Geological Survey and other Federal digital data, various scales

Universal Transverse Mercator, zone 13N

North American Datum of 1983
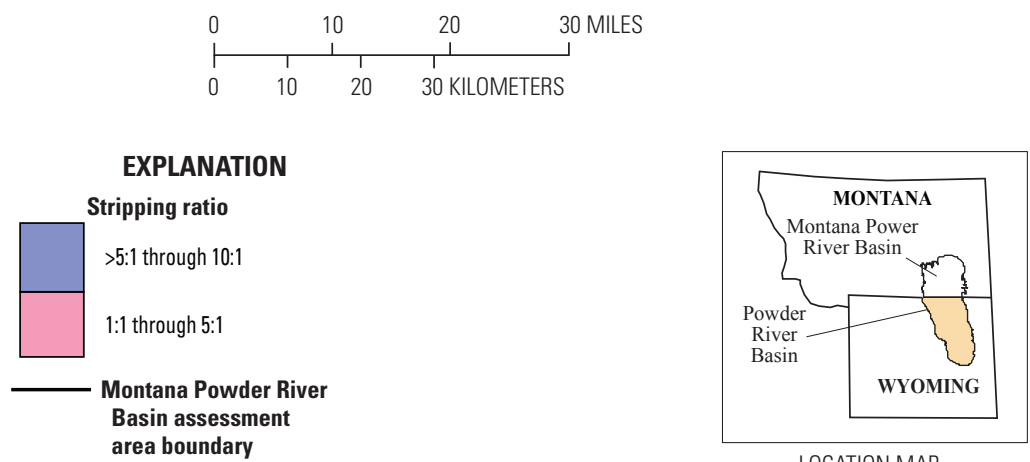

Figure 131. Map showing areal extent for the stripping ratio of the Pawnee coal bed where the stripping ratios are from 1:1 to 10:1, thicknesses are equal to at least 5.0 feet, and the overburden is less than or equal to 500 feet thick, in the Montana Powder River Basin. 


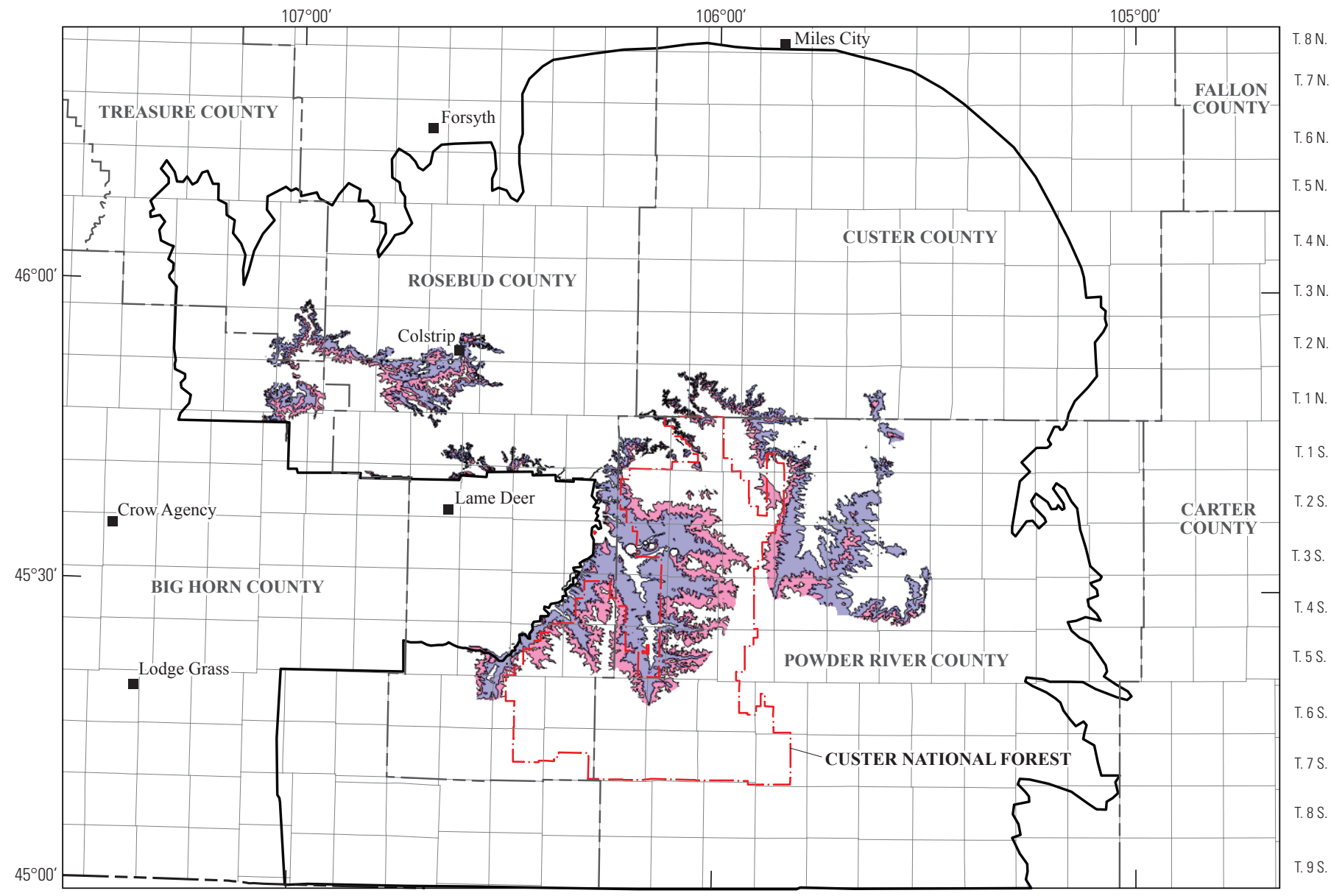

R. 35 E. R. 36 E. R. 37 E. R. 38 E. R. 39 E. R. 40 E. R. 41 E. R. 42 E. R. 43 E. R. 44 E. R. 45 E. R. 46 E. R. 47 E. R. 48 E. R. 49 E. R. 50 E. R. 51 E. R. 52 E. R. 53 E. R. 54 E. R. 55 E. R. 56 E. R. 57 E. Base modified from U.S. Geological Survey and other Federal digital data, various scales

Universal Transverse Mercator, zone 13N

North American Datum of 1983

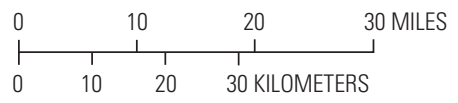

\section{EXPLANATION}

Stripping ratio

$>5: 1$ through $10: 1$

$1: 1$ through $5: 1$

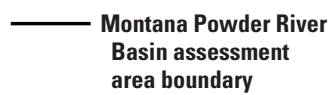

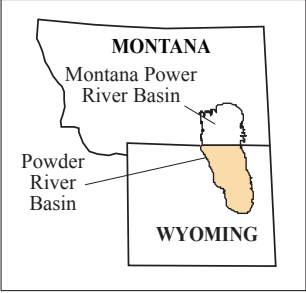

LOCATION MAP

Figure 132. Map showing areal extent for the stripping ratio of the Rosebud/Knobloch coal bed where the stripping ratios are from 1:1 to 10:1, thicknesses are equal to at least 5.0 feet, and the overburden is less than or equal to 500 feet thick, in the Montana Powder River Basin. 


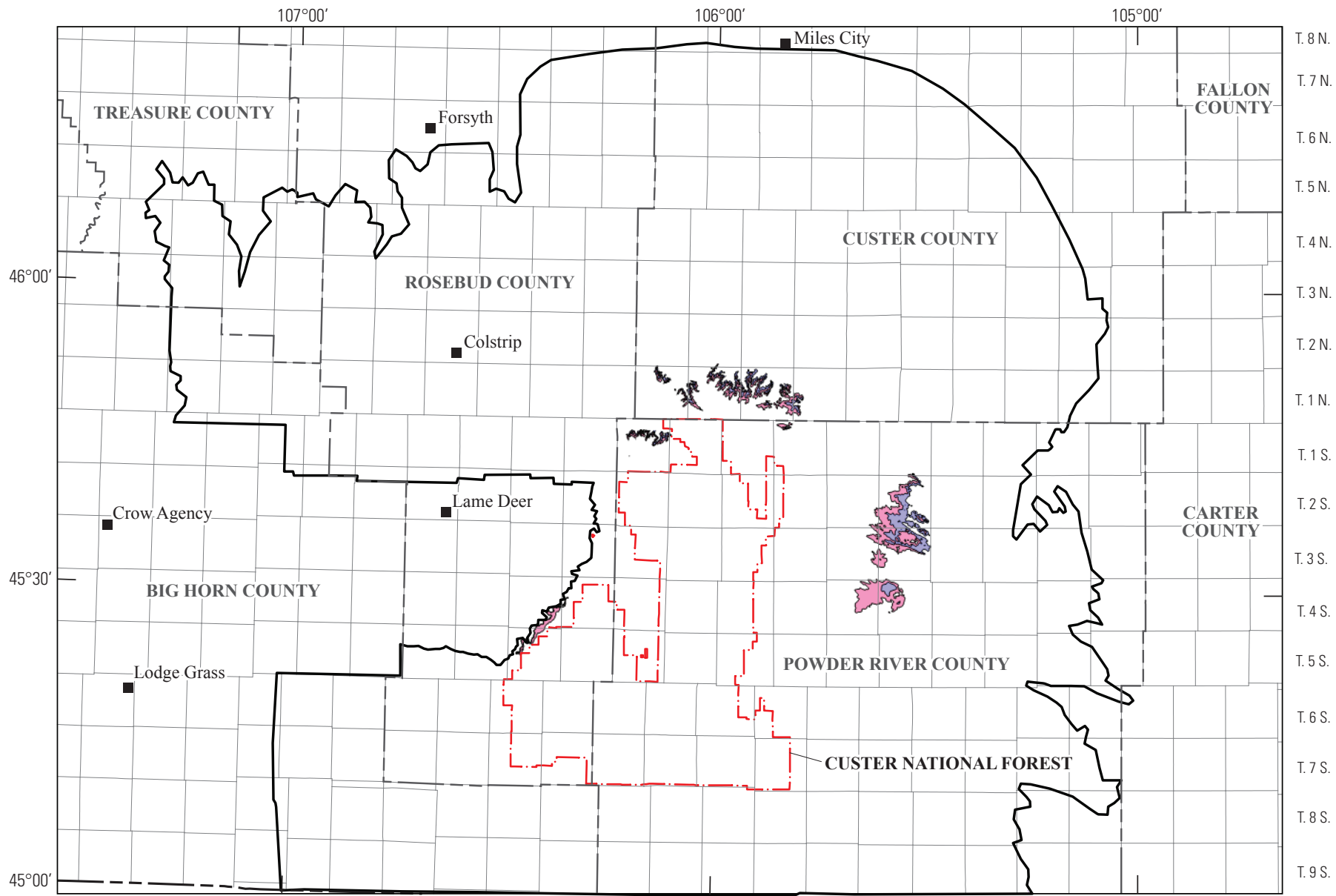

R. 35 E. R. 36 E. R. 37 E. R. 38 E. R. 39 E. R. 40 E. R. 41 E. R. 42 E. R. 43 E. R. 44 E. R. 45 E. R. 46 E. R. 47 E. R. 48 E. R. 49 E. R. 50 E. R. 51 E. R. 52 E. R. 53 E. R. 54 E. R. 55 E. R. 56 E. R. 57 E. Base modified from U.S. Geological Survey and other Federal digital data, various scales

Universal Transverse Mercator, zone 13N

North American Datum of 1983

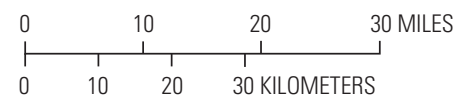

EXPLANATION

Stripping ratio

$>5: 1$ through 10:1

1:1 through 5:1

Montana Powder River

Basin assessment

area boundary

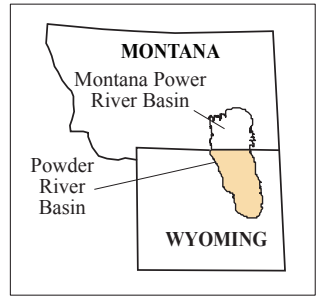

LOCATION MAP

Figure 133. Map showing areal extent for the stripping ratio of the Flowers-Goodale coal bed where the stripping ratios are from 1:1 to 10:1, thicknesses are equal to at least 5.0 feet, and the overburden is less than or equal to 500 feet thick, in the Montana Powder River Basin. 


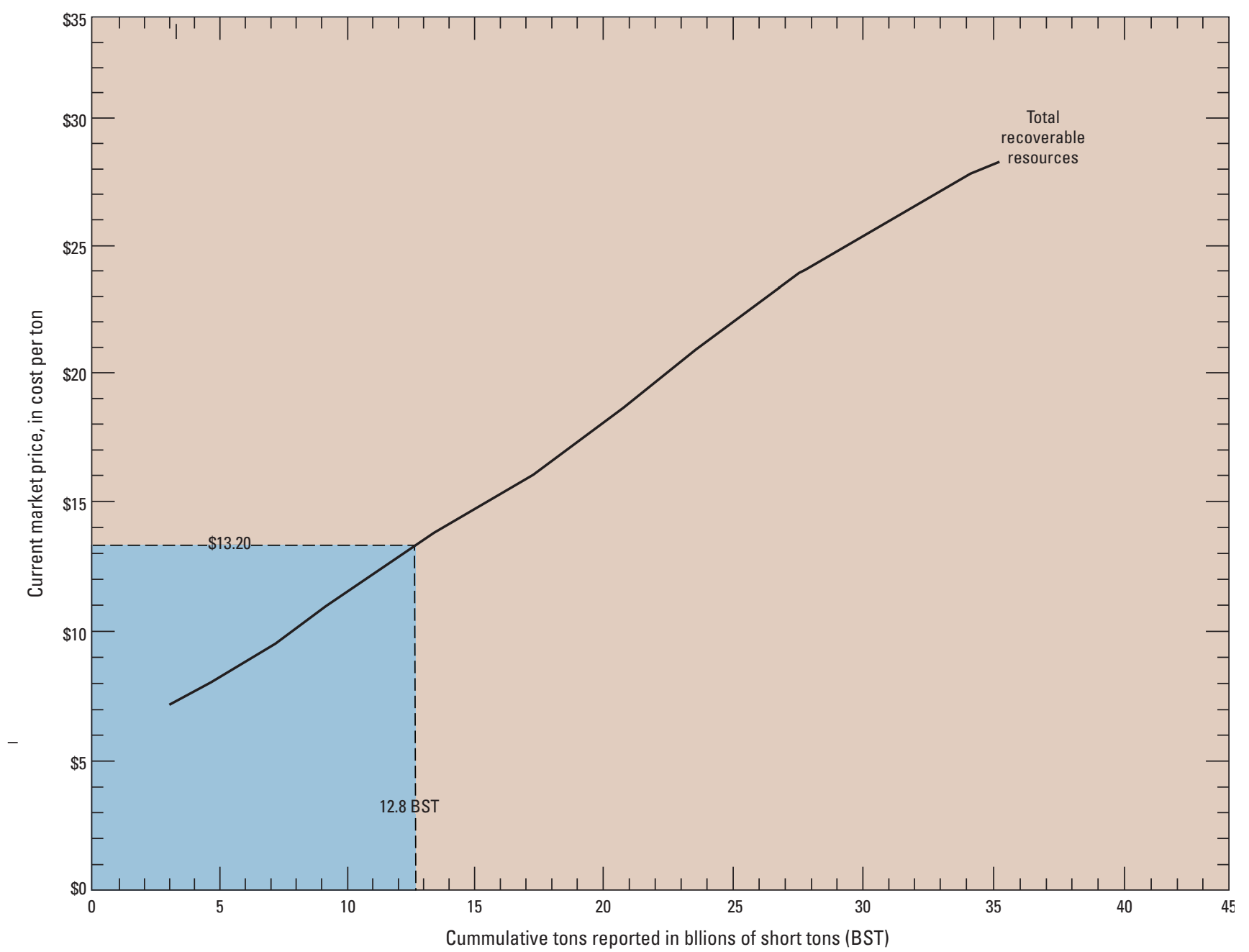

Figure 134. Graph showing cost curve for the Montana Powder River Basin assessment area showing estimated recoverable coal resources compared to sales price per ton of coal. 


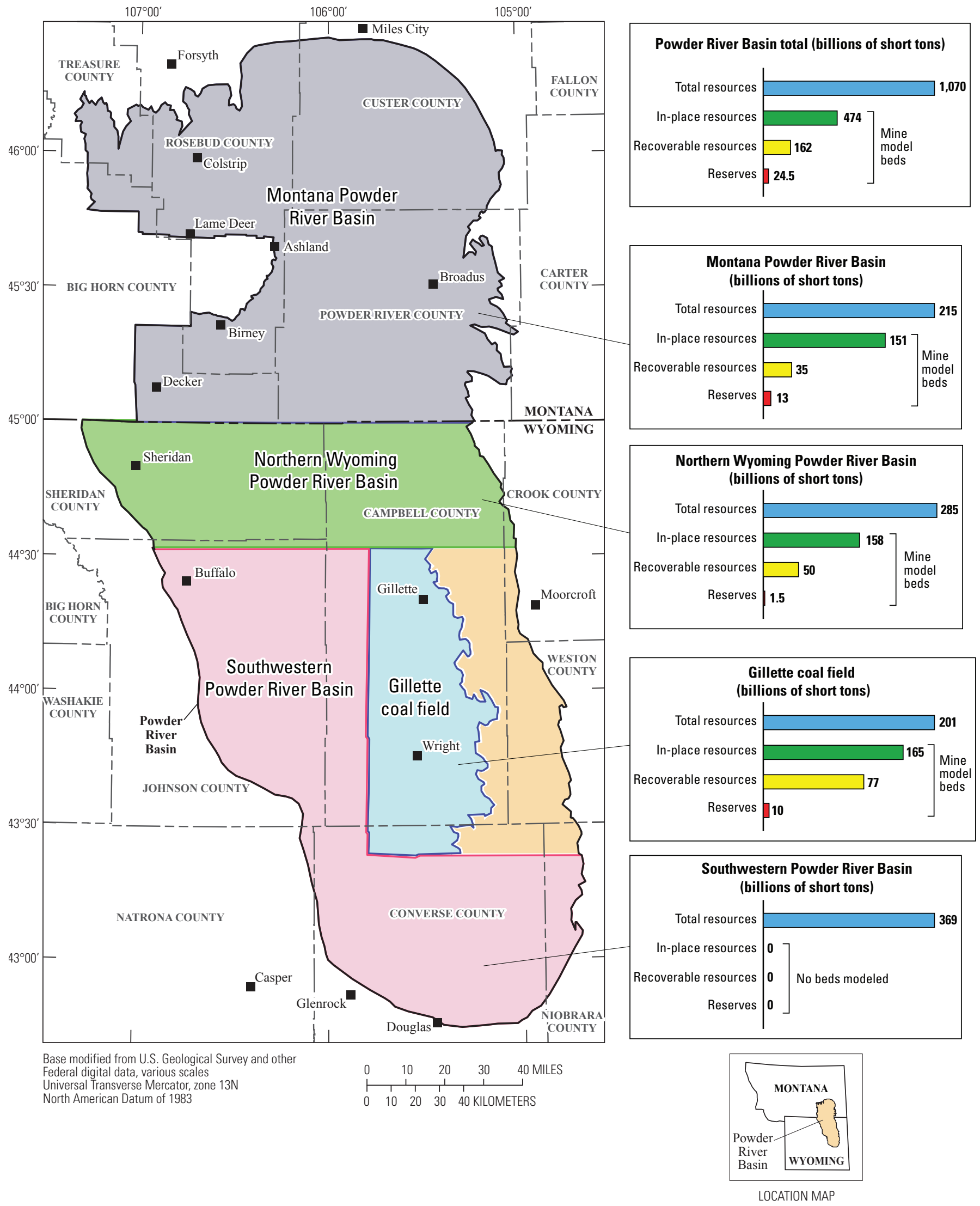

Figure 135. Bar graph showing resource and reserve summary in the Powder River Basin, Wyoming and Montana. 


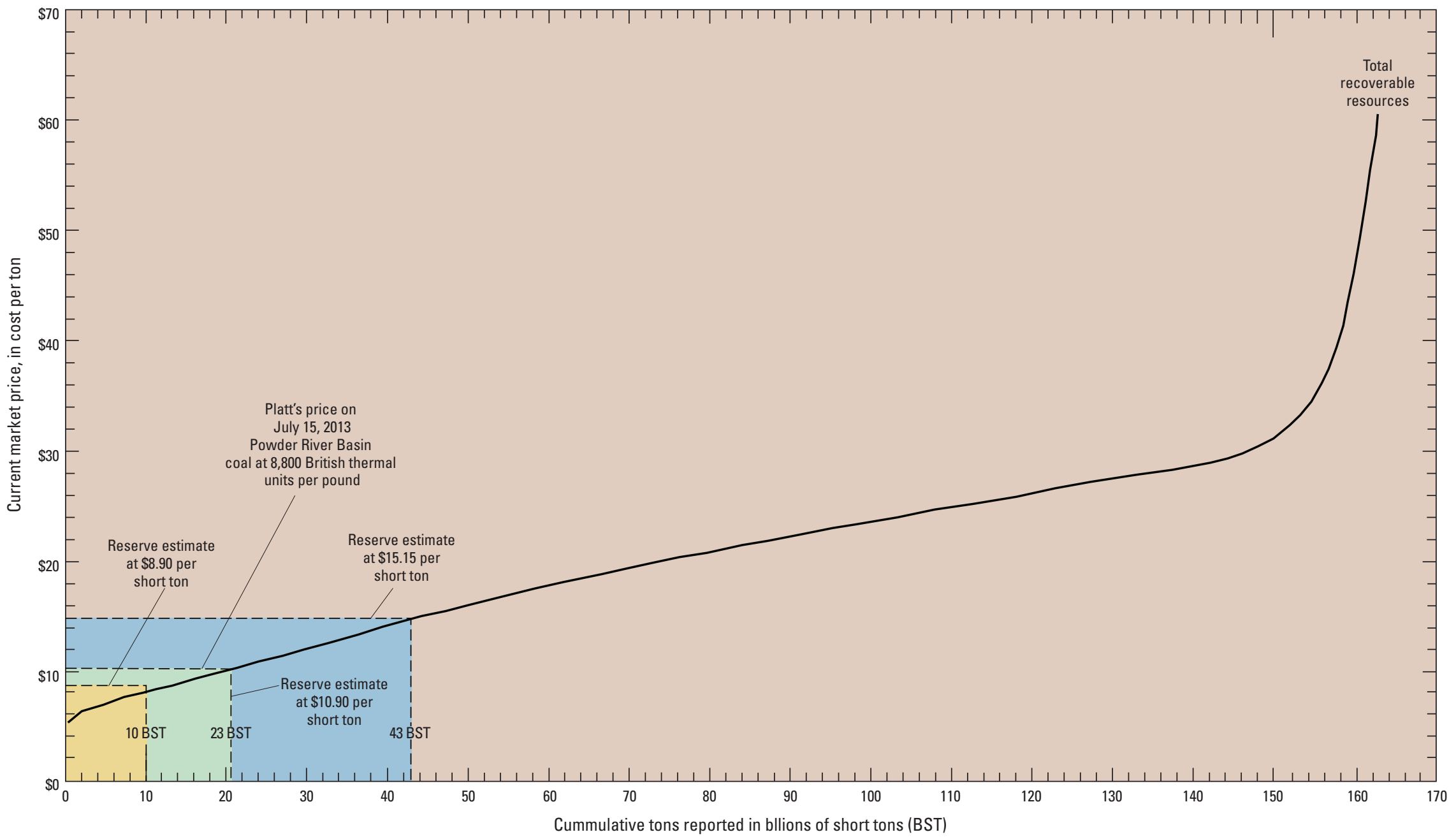

Figure 136. Graph showing cumulative cost curve for the Powder River Basin, Wyoming and Montana (Gillette coal field, Northern Wyoming Powder River Basin, and Montana Powder River Basin assessment areas). 
Tables 

Table 1. 2012 and cumulative coal production from the Powder River Basin, Wyoming and Montana (reported in short tons).

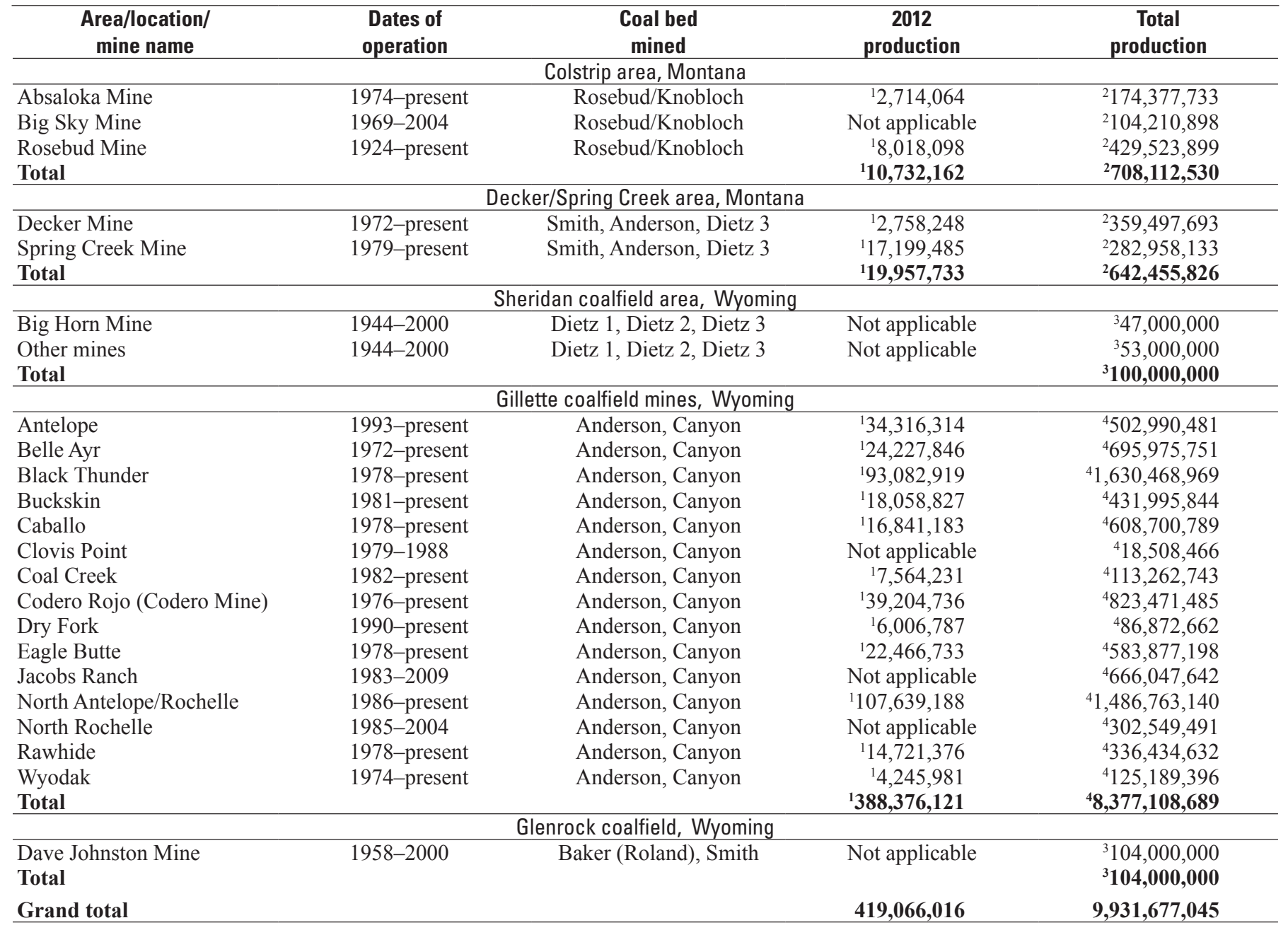

${ }^{1}$ Mine Safety and Health Administration (MSHA), Mine Yearly Production Information (www.msha.gov/drs/ASP/Mine).

${ }^{2}$ Department of Labor and Industry Safety and Health Bureau, State of Montana, P.O. Box 1728, Helena, MT, 59624.

${ }^{3}$ Wyoming Geological Survey, written commun., 2009.

${ }^{4}$ Keystone Coal Industry Manual, years (1969-2000) and Mine Safety and Health Administration (MSHA), Mine Yearly Production Information (www.msha.gov/drs/ASP/Mine Action). 
Table 2. Typical proximate analysis on an as-received basis of coal from mines in the Powder River Basin, Wyoming and Montana.

\begin{tabular}{|c|c|c|c|c|c|}
\hline $\begin{array}{l}\text { Area/location/ } \\
\text { mine name }\end{array}$ & Owner & Coal bed name & $\begin{array}{l}\text { Calorific value } \\
\text { (British thermal } \\
\text { unit per pound) }\end{array}$ & $\begin{array}{c}\text { Sulfur } \\
\text { (percent) }\end{array}$ & $\begin{array}{c}\text { Ash } \\
\text { (percent) }\end{array}$ \\
\hline \multicolumn{6}{|c|}{ Colstrip area, Montana } \\
\hline Big Sky Mine ${ }^{2}$ & Peabody Energy/abandoned & Rosebud/Knobloch & 8,750 & 0.75 & 8.80 \\
\hline Rosebud Mine $^{1}$ & Westmoreland Coal Co. & Rosebud/Knobloch & 8,750 & 0.80 & 8.50 \\
\hline Otter Creek area (Arch lease) $)^{3}$ & Arch Coal Inc. & Rosebud/Knobloch & 8,497 & 0.19 & 6.21 \\
\hline Spring Creek Mine ${ }^{1}$ & Cloud Peak Energy & Smith, Anderson, Dietz 3 & 9,350 & 0.38 & 4.10 \\
\hline \multicolumn{6}{|c|}{ Sheridan coalfield area, Wyoming } \\
\hline Big Horn Mine $^{2}$ & Kiewit Mining Group/abandoned & Dietz 1, Dietz 2, Dietz 3 & 9,300 & 0.60 & 5.70 \\
\hline Lake DeSmet area ${ }^{4}$ (estimated) & Not applicable & Lake DeSmet zone & 7,559 & 0.7 & 7.7 \\
\hline \multicolumn{6}{|c|}{ Gillette coalfield area Wyoming } \\
\hline Antelope $^{1}$ & Cloud Peak Energy & Anderson, Canyon & 8,800 & 0.24 & 5.25 \\
\hline Clovis Point ${ }^{2}$ & Kerr-McGee/abandoned & Anderson, Canyon & 8,050 & 0.40 & 6.00 \\
\hline Coal Creek ${ }^{1}$ & Arch Coal & Anderson, Canyon & 8,325 & 0.30 & 6.00 \\
\hline Codero Rojo ${ }^{1}$ & Cloud Peak Energy & Anderson, Canyon & 8,400 & 0.34 & 5.40 \\
\hline Dry Fork ${ }^{1}$ & Western Fuels & Anderson, Canyon & 8,100 & 0.34 & 4.60 \\
\hline Eagle Butte $^{1}$ & Alpha Natural Resources & Anderson, Canyon & 8,400 & 0.34 & 4.50 \\
\hline Jacobs Ranch ${ }^{2}$ & Arch Coal-combined/Black Thunder & Anderson, Canyon & 8,800 & 0.45 & 5.40 \\
\hline North Antelope/Rochelle ${ }^{1}$ & Peabody Energy & Anderson, Canyon & 8,800 & 0.21 & 4.60 \\
\hline North Rochelle ${ }^{2}$ & Triton Coal/abandoned & Anderson, Canyon & 8,673 & 0.24 & 8.00 \\
\hline Rawhide $^{1}$ & Peabody Energy & Anderson, Canyon & 8,300 & 0.37 & 5.40 \\
\hline Wyodak $^{1}$ & Wyodak Resources & Anderson, Canyon & 8,050 & 0.40 & 6.00 \\
\hline \multicolumn{6}{|c|}{ Glenrock coalfield, Wyoming } \\
\hline Dave Johnston Mine $^{2}$ & Glenrock Coal Co./abandoned & Baker (Roland), Smith & 7,581 & 0.45 & 12.1 \\
\hline
\end{tabular}

${ }^{1}$ Guide to Coal Mines, April 21, 2010.

${ }^{2}$ Keystone Coal Industry Manuals, 1998-2000.

${ }^{3}$ Minerals Management Service Memorandum July 22, 1982.

${ }^{4}$ Luppens, 2011. 
Table 3. Typical proximate analysis on an as-received basis of coal beds reporting sodium as percent of ash, percent sulfur, percent ash, and calorific value, in coal beds in the Wyoming Powder River Basin compared to the Montana Powder River Basin.

[All data from Guide to Coal Mines, April 21, 2010]

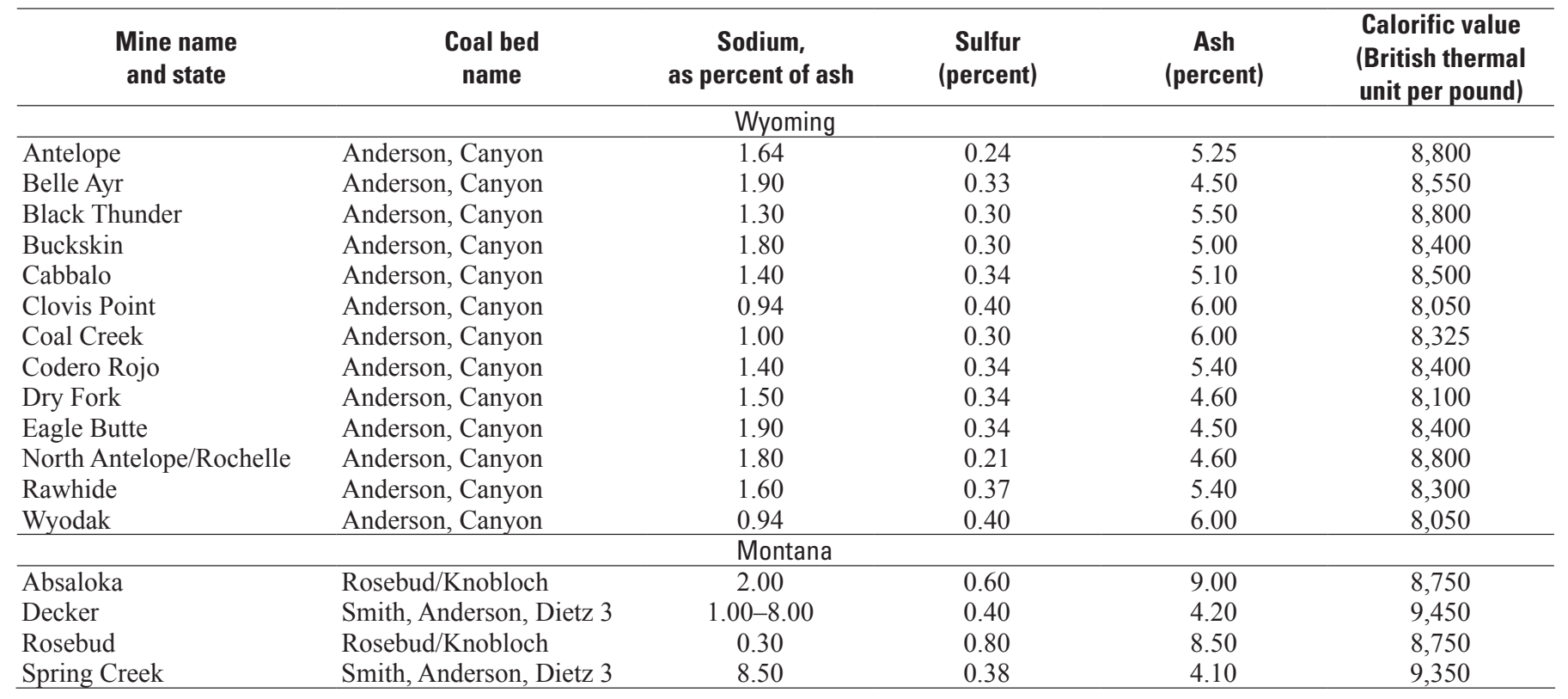


Table 4. Coal resources and restrictions for 47 beds greater than or equal to 2.5 feet thick, reported in millions of short tons by reliability category for the Powder River Basin, Wyoming and Montana. Reliability categories are based on distance from nearest data point. Measured: less than 0.25 mile; Indicated: 0.25-0.75 mile; Inferred: 0.75-3 miles; Hypothetical: greater than 3 miles. Totals may not sum exactly because of to rounding.

\begin{tabular}{|c|c|c|c|c|c|c|c|c|}
\hline $\begin{array}{c}\text { Coal bed } \\
\text { name }\end{array}$ & $\begin{array}{l}\text { Reliability } \\
\text { category }\end{array}$ & $\begin{array}{l}\text { Original } \\
\text { resources }\end{array}$ & $\begin{array}{c}\text { Burned } \\
\text { coal }\end{array}$ & $\begin{array}{l}\text { Mined } \\
\text { coal }\end{array}$ & $\begin{array}{l}\text { Remaining } \\
\text { resources }\end{array}$ & $\begin{array}{l}\text { Land-use } \\
\text { restrictions }\end{array}$ & $\begin{array}{l}\text { Technical } \\
\text { restrictions }\end{array}$ & $\begin{array}{l}\text { Available } \\
\text { resources }\end{array}$ \\
\hline \multirow{4}{*}{ Upper Healy } & Indicated & 2,212 & 83 & 0 & 2,129 & 170 & 73 & 1,885 \\
\hline & Inferred & 3,672 & 95 & 0 & 3,577 & 617 & 277 & 2,683 \\
\hline & Hypothetical & 303 & 0 & 0 & 303 & 55 & 81 & 167 \\
\hline & Total & 6,863 & 206 & 0 & 6,657 & 878 & 452 & 5,327 \\
\hline \multirow[t]{3}{*}{ Healy/ Lower Ulm } & Measured & 1,677 & 4 & 0 & 1,673 & 76 & 58 & 1,539 \\
\hline & Indicated & 4,794 & 8 & 0 & 4,786 & 370 & 155 & 4,260 \\
\hline & Total & 13,004 & 26 & $\mathbf{0}$ & 12,977 & 1,652 & 588 & 10,738 \\
\hline \multirow[t]{5}{*}{ Murray } & Measured & 471 & 0 & 0 & 471 & 3 & 343 & 125 \\
\hline & Indicated & 980 & 0 & 0 & 980 & 9 & 699 & 271 \\
\hline & Inferred & 1,144 & 0 & 0 & 1,144 & 13 & 948 & 184 \\
\hline & Hypothetical & 68 & 0 & 0 & 68 & 2 & 47 & 19 \\
\hline & Total & 2,664 & 0 & $\mathbf{0}$ & 2,664 & 27 & 2,036 & 599 \\
\hline Ucross & Total & 6,808 & 0 & $\mathbf{0}$ & 6,808 & 944 & 1,371 & 4,492 \\
\hline \multirow{5}{*}{ Upper Felix } & Measured & 1,455 & 0 & 0 & 1,455 & 4 & 496 & 955 \\
\hline & Indicated & 625 & 0 & 0 & 625 & 3 & 377 & 243 \\
\hline & Inferred & 41 & 0 & 0 & 41 & 0 & 35 & 6 \\
\hline & Hypothetical & 0 & 0 & 0 & 0 & 0 & 0 & 0 \\
\hline & Total & 2,122 & 0 & 0 & 2,122 & 7 & 909 & 1,205 \\
\hline \multirow[t]{5}{*}{ Felix } & Measured & 9,838 & 5 & 0 & 9,833 & 482 & 322 & 9,028 \\
\hline & Indicated & 6,801 & 3 & 0 & 6,798 & 213 & 463 & 6,123 \\
\hline & Inferred & 2,046 & 1 & 0 & 2,046 & 19 & 400 & 1,626 \\
\hline & Hypothetical & 73 & 0 & 0 & 73 & 6 & 60 & 7 \\
\hline & Total & 18,759 & 9 & $\mathbf{0}$ & 18,750 & 720 & 1,246 & 16,784 \\
\hline \multirow[t]{2}{*}{ Lower Felix } & Measured & 4,376 & 1 & 0 & 4,375 & 232 & 948 & 3,196 \\
\hline & Indicated & 6,350 & 0 & 0 & 6,350 & 171 & 1,518 & 4,661 \\
\hline \multirow[t]{5}{*}{ Roland Lower Rider } & Measured & 1,014 & 0 & 0 & 1,014 & 4 & 509 & 501 \\
\hline & Indicated & 1,473 & 0 & 0 & 1,473 & 0 & 619 & 854 \\
\hline & Inferred & 770 & 0 & 0 & 770 & 4 & 429 & 338 \\
\hline & Hypothetical & 0 & 0 & 0 & 0 & 0 & 0 & 0 \\
\hline & Total & 3,257 & 0 & 0 & 3,257 & 8 & 1,555 & 1,693 \\
\hline \multirow[t]{5}{*}{ Roland (Baker) } & Measured & 14,647 & 3 & 0 & 14,646 & 529 & 1,171 & 12,947 \\
\hline & Indicated & 17,532 & 7 & 0 & 17,525 & 302 & 1,336 & 15,888 \\
\hline & Inferred & 15,475 & 2 & 0 & 15,472 & 123 & 890 & 14,460 \\
\hline & Hypothetical & 117 & 1 & 0 & 117 & 1 & 74 & 42 \\
\hline & Total & 47,774 & 13 & 0 & 47,761 & 954 & 3,471 & 43,336 \\
\hline \multirow[t]{5}{*}{ Roland (Taff) } & Measured & 776 & 0 & 0 & 776 & 12 & 263 & 501 \\
\hline & Indicated & 1,017 & 0 & 0 & 1,017 & 15 & 620 & 383 \\
\hline & Inferred & 1,574 & 0 & 0 & 1,574 & 6 & 1,161 & 407 \\
\hline & Hypothetical & 37 & 0 & 0 & 37 & 0 & 37 & 0 \\
\hline & Total & 3,403 & 0 & 0 & 3,403 & 33 & 2,079 & 1,290 \\
\hline \multirow[t]{5}{*}{ Upper Smith } & Measured & 260 & 0 & 0 & 260 & 0 & 114 & 145 \\
\hline & Indicated & 517 & 0 & 0 & 517 & 0 & 309 & 208 \\
\hline & Inferred & 259 & 0 & 0 & 259 & 0 & 183 & 76 \\
\hline & Hypothetical & 0 & 0 & 0 & 0 & 0 & 0 & 0 \\
\hline & Total & 1,036 & 0 & 0 & 1,036 & 0 & 607 & 430 \\
\hline
\end{tabular}


Table 4. Coal resources and restrictions for 47 beds greater than or equal to 2.5 feet thick, reported in millions of short tons by reliability category for the Powder River Basin, Wyoming and Montana. Reliability categories are based on distance from nearest data point. Measured: less than 0.25 mile; Indicated: 0.25-0.75 mile; Inferred: 0.75-3 miles; Hypothetical: greater than 3 miles. Totals may not sum exactly because of to rounding.-Continued

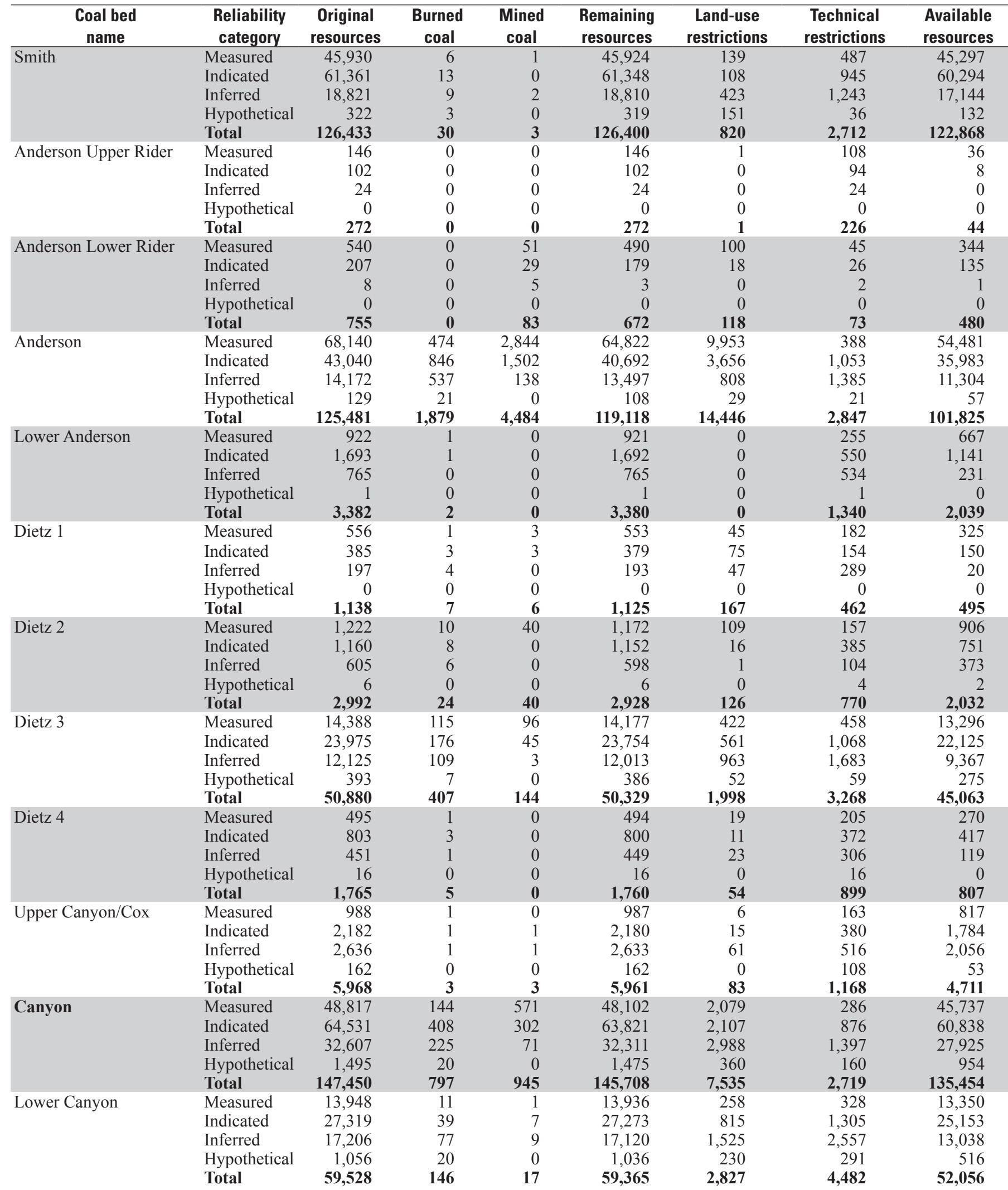


Table 4. Coal resources and restrictions for 47 beds greater than or equal to 2.5 feet thick, reported in millions of short tons by reliability category for the Powder River Basin, Wyoming and Montana. Reliability categories are based on distance from nearest data point. Measured: less than 0.25 mile; Indic ated: $0.25-0.75$ mile; Inferred: $0.75-3$ miles; Hypothetical: greater than 3 miles. Totals may not sum exactly because of to rounding.-Continued

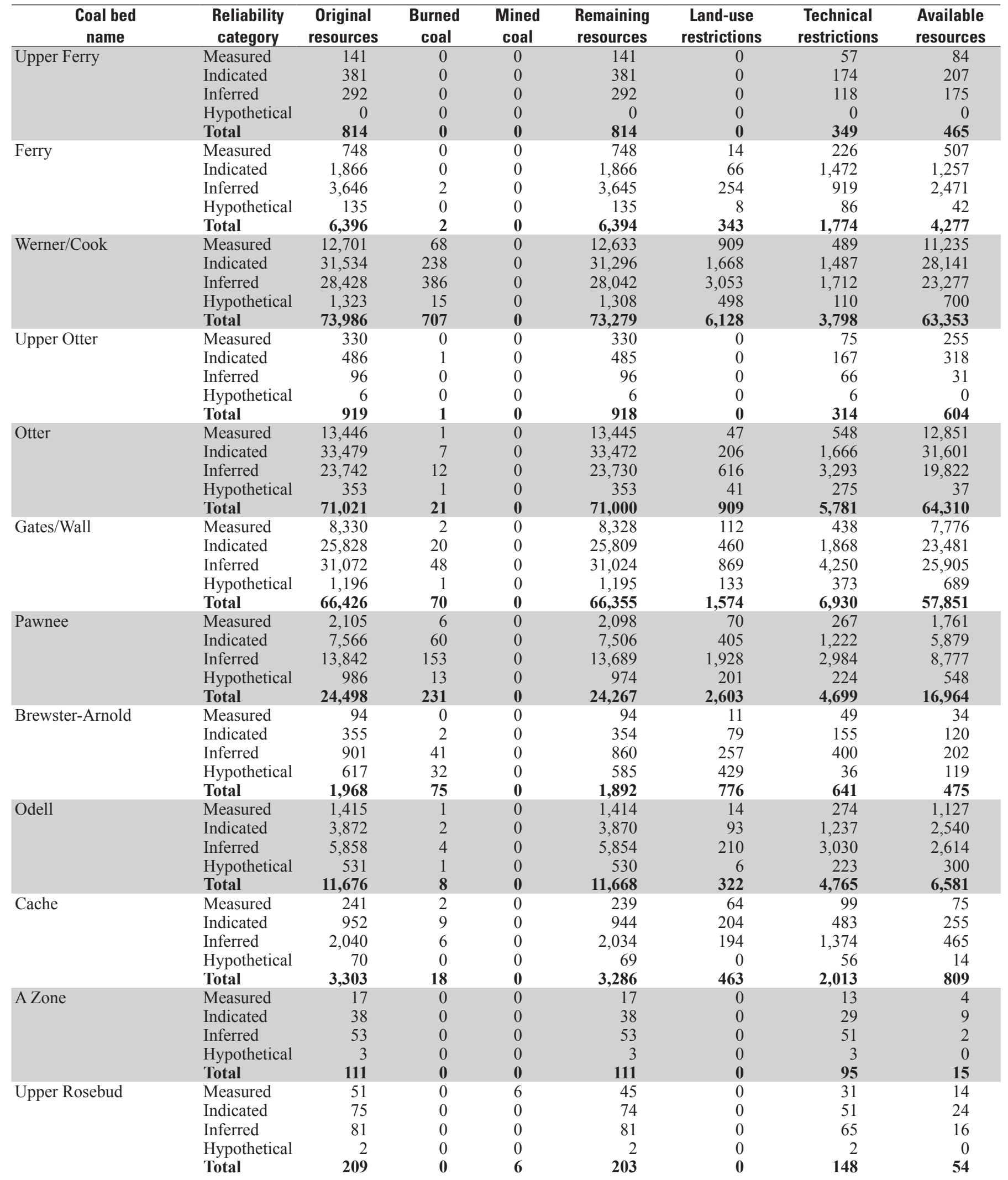


Table 4. Coal resources and restrictions for 47 beds greater than or equal to 2.5 feet thick, reported in millions of short tons by reliability category for the Powder River Basin, Wyoming and Montana. Reliability categories are based on distance from nearest data point. Measured: less than 0.25 mile; Indic ated: $0.25-0.75$ mile; Inferred: $0.75-3$ miles; Hypothetical: greater than 3 miles. Totals may not sum exactly because of to rounding.-Continued

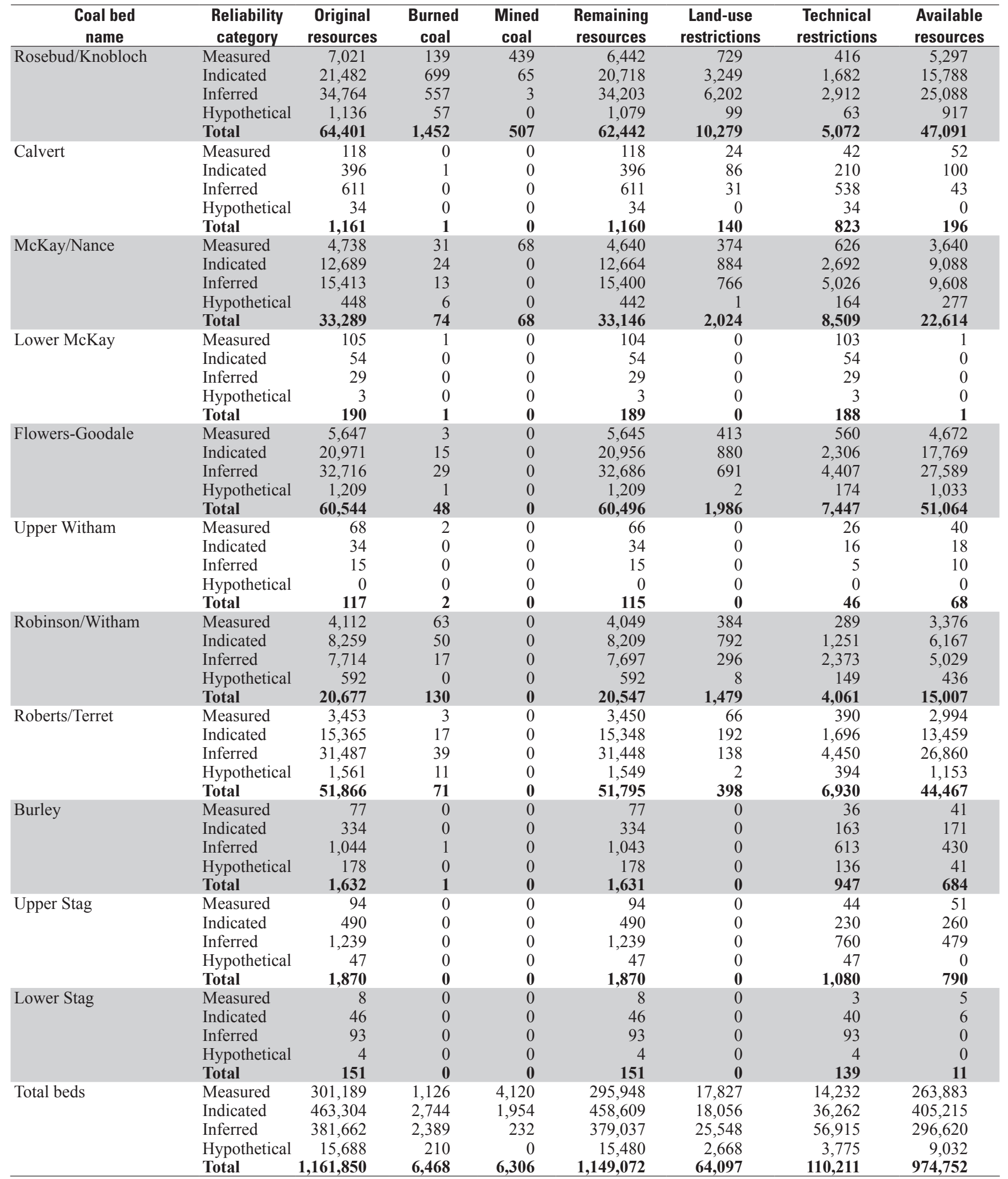


Table 5. Coal resources and restrictions for 47 beds greater than or equal to 2.5 feet thick, reported in millions of short tons by overburden depth for the Powder River Basin, Wyoming and Montana. Resource includes coal plus partings. Totals may not sum exactly because of rounding.

\begin{tabular}{|c|c|c|c|c|c|c|c|c|}
\hline $\begin{array}{l}\text { Coal bed } \\
\text { name }\end{array}$ & $\begin{array}{c}\text { Overburden } \\
\text { thickness } \\
\text { (feet) }\end{array}$ & $\begin{array}{l}\text { Original } \\
\text { resources }\end{array}$ & $\begin{array}{c}\text { Burned } \\
\text { coal }\end{array}$ & $\begin{array}{c}\text { Mined } \\
\text { coal }\end{array}$ & $\begin{array}{c}\text { Remaining } \\
\text { resources }\end{array}$ & $\begin{array}{l}\text { Land-use } \\
\text { restrictions }\end{array}$ & $\begin{array}{c}\text { Technical } \\
\text { restrictions }\end{array}$ & $\begin{array}{l}\text { Available } \\
\text { resources }\end{array}$ \\
\hline \multirow[t]{5}{*}{ Upper Healy } & $0-500$ & 6,681 & 206 & 0 & 6,475 & 815 & 435 & 5,225 \\
\hline & $1,000-2,000$ & 0 & 0 & 0 & 0 & 0 & 0 & 0 \\
\hline & $2,000-3,000$ & 0 & 0 & 0 & 0 & 0 & 0 & 0 \\
\hline & Greater than 3,000 & 0 & 0 & 0 & 0 & 0 & 0 & 0 \\
\hline & Total & 6,863 & 206 & $\mathbf{0}$ & 6,657 & 878 & 452 & 5,327 \\
\hline \multirow{5}{*}{ Healy/Lower Ulm } & $500-1,000$ & 1,774 & 0 & 0 & 1,774 & 318 & 74 & 1,381 \\
\hline & $1,000-2,000$ & 1 & 0 & 0 & 1 & 0 & 0 & 1 \\
\hline & $2,000-3,000$ & 0 & 0 & 0 & 0 & 0 & 0 & 0 \\
\hline & Greater than 3,000 & 0 & 0 & 0 & 0 & 0 & 0 & 0 \\
\hline & Total & 13,004 & 26 & $\mathbf{0}$ & 12,977 & 1,652 & 588 & 10,738 \\
\hline \multirow[t]{2}{*}{ Murray } & $0-500$ & 1,681 & 0 & 0 & 1,681 & 16 & 1,292 & 372 \\
\hline & $500-1,000$ & 960 & 0 & 0 & 960 & 11 & 744 & 206 \\
\hline \multirow[t]{6}{*}{ Ucross } & $0-500$ & 1,187 & 0 & 0 & 1,187 & 49 & 732 & 405 \\
\hline & $500-1,000$ & 5,195 & 0 & 0 & 5,195 & 809 & 638 & 3,749 \\
\hline & $1,000-2,000$ & 425 & 0 & 0 & 425 & 85 & 2 & 338 \\
\hline & $2,000-3,000$ & 0 & 0 & 0 & 0 & 0 & 0 & 0 \\
\hline & Greater than 3,000 & 0 & 0 & 0 & 0 & 0 & 0 & 0 \\
\hline & Total & 6,808 & $\mathbf{0}$ & $\mathbf{0}$ & 6,808 & 944 & 1,371 & 4,492 \\
\hline \multirow[t]{6}{*}{ Upper Felix } & $0-500$ & 2,033 & 0 & 0 & 2,033 & 7 & 879 & 1,147 \\
\hline & $500-1,000$ & 87 & 0 & 0 & 87 & 0 & 31 & 57 \\
\hline & $1,000-2,000$ & 1 & 0 & 0 & 1 & 0 & 0 & 0 \\
\hline & $2,000-3,000$ & 0 & 0 & 0 & 0 & 0 & 0 & 0 \\
\hline & Greater than 3,000 & 0 & 0 & 0 & 0 & 0 & 0 & 0 \\
\hline & Total & 2,122 & $\mathbf{0}$ & $\mathbf{0}$ & 2,122 & 7 & 909 & 1,205 \\
\hline \multirow{4}{*}{ Lower Felix } & $1,000-2,000$ & 3,215 & 0 & 0 & 3,215 & 294 & 111 & 2,811 \\
\hline & $2,000-3,000$ & 0 & 0 & 0 & 0 & 0 & 0 & 0 \\
\hline & Greater than 3,000 & 0 & 0 & 0 & 0 & 0 & 0 & 0 \\
\hline & Total & 19,385 & 1 & $\mathbf{0}$ & 19,384 & 1,094 & 3,361 & 14,929 \\
\hline \multirow[t]{6}{*}{ Roland Upper Rider } & $0-500$ & 4,115 & 0 & 0 & 4,115 & 152 & 1,462 & 2,502 \\
\hline & $500-1,000$ & 6,956 & 0 & 0 & 6,956 & 8 & 2,357 & 4,591 \\
\hline & $1,000-2,000$ & 2,434 & 0 & 0 & 2,434 & 22 & 1,202 & 1,210 \\
\hline & $2,000-3,000$ & 1 & 0 & 0 & 1 & 0 & 1 & 0 \\
\hline & Greater than 3,000 & 0 & 0 & 0 & 0 & 0 & 0 & 0 \\
\hline & Total & 13,506 & $\mathbf{0}$ & $\mathbf{0}$ & 13,506 & 181 & 5,021 & 8,304 \\
\hline \multirow[t]{6}{*}{ Roland Lower Rider } & $0-500$ & 365 & 0 & 0 & 365 & 8 & 244 & 113 \\
\hline & $500-1,000$ & 1,960 & 0 & 0 & 1,960 & 0 & 994 & 966 \\
\hline & $1,000-2,000$ & 932 & 0 & 0 & 932 & 0 & 318 & 613 \\
\hline & $2,000-3,000$ & 0 & 0 & 0 & 0 & 0 & 0 & 0 \\
\hline & Greater than 3,000 & 0 & 0 & 0 & 0 & 0 & 0 & 0 \\
\hline & Total & 3,257 & 0 & 0 & 3,257 & 8 & 1,555 & 1,693 \\
\hline
\end{tabular}


Table 5. Coal resources and restrictions for 47 beds greater than or equal to 2.5 feet thick, reported in millions of short tons by overburden depth for the Powder River Basin, Wyoming and Montana. Resource includes coal plus partings. Totals may not sum exactly because of rounding.-Continued

\begin{tabular}{|c|c|c|c|c|c|c|c|c|}
\hline $\begin{array}{l}\text { Coal bed } \\
\text { name }\end{array}$ & $\begin{array}{c}\text { Overburden } \\
\text { thickness } \\
\text { (feet) }\end{array}$ & $\begin{array}{c}\text { Original } \\
\text { resources }\end{array}$ & $\begin{array}{c}\text { Burned } \\
\text { coal }\end{array}$ & $\begin{array}{c}\text { Mined } \\
\text { coal }\end{array}$ & $\begin{array}{c}\text { Remaining } \\
\text { resources }\end{array}$ & $\begin{array}{l}\text { Land-use } \\
\text { restrictions }\end{array}$ & $\begin{array}{l}\text { Technical } \\
\text { restrictions }\end{array}$ & $\begin{array}{l}\text { Available } \\
\text { resources }\end{array}$ \\
\hline \multirow[t]{4}{*}{ Roland (Baker) } & $0-500$ & 16,907 & 13 & 0 & 16,894 & 796 & 1,108 & 14,990 \\
\hline & $1,000-2,000$ & 12,848 & 0 & 0 & 12,848 & 64 & 1,089 & 11,695 \\
\hline & $2,000-3,000$ & 26 & 0 & 0 & 26 & 0 & 1 & 25 \\
\hline & Greater than 3,000 & 0 & 0 & 0 & 0 & 0 & 0 & 0 \\
\hline \multirow{5}{*}{ Roland (Taff) } & $500-1,000$ & 939 & 0 & 0 & 939 & 0 & 536 & 403 \\
\hline & $1,000-2,000$ & 1,018 & 0 & 0 & 1,018 & 0 & 805 & 214 \\
\hline & $2,000-3,000$ & 1 & 0 & 0 & 1 & 0 & 1 & 0 \\
\hline & Greater than 3,000 & 0 & 0 & 0 & 0 & 0 & 0 & 0 \\
\hline & Total & 3,403 & $\mathbf{0}$ & $\mathbf{0}$ & 3,403 & 33 & 2,079 & 1,290 \\
\hline Upper Smith & $0-500$ & 584 & 0 & 0 & 584 & 0 & 385 & 199 \\
\hline \multirow[t]{6}{*}{ Smith } & $0-500$ & 6,583 & 30 & 3 & 6,550 & 151 & 999 & 5,400 \\
\hline & $500-1,000$ & 41,135 & 0 & 0 & 41,135 & 149 & 892 & 40,094 \\
\hline & $1,000-2,000$ & 78,389 & 0 & 0 & 78,389 & 518 & 818 & 77,053 \\
\hline & $2,000-3,000$ & 320 & 0 & 0 & 320 & 3 & 2 & 315 \\
\hline & Greater than 3,000 & 6 & 0 & 0 & 6 & 0 & 0 & 6 \\
\hline & Total & 126,433 & 30 & 3 & 126,400 & 820 & 2,712 & 122,868 \\
\hline \multirow[t]{6}{*}{ Anderson Upper Rider } & $0-500$ & 127 & 0 & 0 & 127 & 1 & 99 & 26 \\
\hline & $500-1,000$ & 46 & 0 & 0 & 46 & 0 & 33 & 12 \\
\hline & $1,000-2,000$ & 99 & 0 & 0 & 99 & 0 & 92 & 6 \\
\hline & $2,000-3,000$ & 0 & 0 & 0 & 0 & 0 & 0 & 0 \\
\hline & Greater than 3,000 & 0 & 0 & 0 & 0 & 0 & 0 & 0 \\
\hline & Total & 272 & $\mathbf{0}$ & $\mathbf{0}$ & 272 & 1 & 226 & 44 \\
\hline \multirow{4}{*}{ Anderson } & $1,000-2,000$ & 19,152 & 0 & 141 & 19,011 & 272 & 543 & 17,531 \\
\hline & $2,000-3,000$ & 271 & 0 & 39 & 233 & 55 & 258 & 177 \\
\hline & Greater than 3,000 & 8 & 0 & 2 & 6 & 2 & 0 & 5 \\
\hline & Total & 125,481 & 1,879 & 4,484 & 119,118 & 14,446 & 2,847 & 101,825 \\
\hline \multirow[t]{6}{*}{ Lower Anderson } & $0-500$ & 1,147 & 2 & 0 & 1,145 & 0 & 292 & 854 \\
\hline & $500-1,000$ & 1,640 & 0 & 0 & 1,640 & 0 & 598 & 1,041 \\
\hline & $1,000-2,000$ & 591 & 0 & 0 & 591 & 0 & 449 & 141 \\
\hline & $2,000-3,000$ & 3 & 0 & 0 & 3 & 0 & 0 & 3 \\
\hline & Greater than 3,000 & 0 & 0 & 0 & 0 & 0 & 0 & 0 \\
\hline & Total & 3,382 & 2 & 0 & 3,380 & 0 & 1,340 & 2,039 \\
\hline \multirow[t]{6}{*}{ Dietz 1} & $0-500$ & 464 & 7 & 6 & 451 & 119 & 163 & 168 \\
\hline & $500-1,000$ & 485 & 0 & 0 & 485 & 46 & 152 & 287 \\
\hline & $1,000-2,000$ & 189 & 0 & 0 & 189 & 2 & 146 & 40 \\
\hline & $2,000-3,000$ & 0 & 0 & 0 & 0 & 0 & 0 & 0 \\
\hline & Greater than 3,000 & 0 & 0 & 0 & 0 & 0 & 0 & 0 \\
\hline & Total & 1,138 & 7 & 6 & 1,125 & 167 & 462 & 495 \\
\hline
\end{tabular}


Table 5. Coal resources and restrictions for 47 beds greater than or equal to 2.5 feet thick, reported in millions of short tons by overburden depth for the Powder River Basin, Wyoming and Montana. Resource includes coal plus partings. Totals may not sum exactly because of rounding.-Continued

\begin{tabular}{|c|c|c|c|c|c|c|c|c|}
\hline $\begin{array}{l}\text { Coal bed } \\
\text { name }\end{array}$ & $\begin{array}{c}\begin{array}{c}\text { Overburden } \\
\text { thickness } \\
\text { (feet) }\end{array} \\
\end{array}$ & $\begin{array}{c}\text { Original } \\
\text { resources }\end{array}$ & $\begin{array}{l}\text { Burned } \\
\text { coal }\end{array}$ & $\begin{array}{l}\text { Mined } \\
\text { coal }\end{array}$ & $\begin{array}{l}\text { Remaining } \\
\text { resources }\end{array}$ & $\begin{array}{l}\text { Land-use } \\
\text { restrictions }\end{array}$ & $\begin{array}{l}\text { Technical } \\
\text { restrictions }\end{array}$ & $\begin{array}{l}\text { Available } \\
\text { resources }\end{array}$ \\
\hline \multirow[t]{6}{*}{ Dietz 2} & $0-500$ & 1,677 & 24 & 40 & 1,612 & 126 & 334 & 1,153 \\
\hline & $500-1,000$ & 846 & 0 & 0 & 846 & 0 & 315 & 530 \\
\hline & $1,000-2,000$ & 470 & 0 & 0 & 470 & 0 & 121 & 349 \\
\hline & $2,000-3,000$ & 0 & 0 & 0 & 0 & 0 & 0 & 0 \\
\hline & Greater than 3,000 & 0 & 0 & 0 & 0 & 0 & 0 & 0 \\
\hline & Total & 2,992 & 24 & 40 & 2,928 & 126 & 770 & 2,032 \\
\hline \multirow[t]{6}{*}{ Dietz 3} & $0-500$ & 15,437 & 407 & 144 & 14,887 & 1,636 & 963 & 12,287 \\
\hline & $500-1,000$ & 16,330 & 0 & 0 & 16,329 & 77 & 720 & 15,532 \\
\hline & $1,000-2,000$ & 18,558 & 0 & 0 & 18,558 & 286 & 1,427 & 16,844 \\
\hline & $2,000-3,000$ & 556 & 0 & 0 & 556 & 0 & 157 & 399 \\
\hline & Greater than 3,000 & 0 & 0 & 0 & 0 & 0 & 0 & 0 \\
\hline & Total & 50,880 & 407 & 144 & 50,329 & 1,998 & 3,268 & 45,063 \\
\hline \multirow[t]{6}{*}{ Dietz 4} & $0-500$ & 521 & 5 & 0 & 516 & 26 & 342 & 148 \\
\hline & $500-1,000$ & 344 & 0 & 0 & 344 & 0 & 208 & 136 \\
\hline & $1,000-2,000$ & 882 & 0 & 0 & 882 & 28 & 343 & 512 \\
\hline & $2,000-3,000$ & 17 & 0 & 0 & 17 & 0 & 6 & 10 \\
\hline & Greater than 3,000 & 0 & 0 & 0 & 0 & 0 & 0 & 0 \\
\hline & Total & 1,765 & 5 & 0 & 1,760 & 54 & 899 & 807 \\
\hline \multirow[t]{6}{*}{ Upper Canyon/Cox } & $0-500$ & 555 & 3 & 3 & 549 & 7 & 432 & 110 \\
\hline & $500-1,000$ & 132 & 0 & 0 & 132 & 0 & 118 & 14 \\
\hline & $1,000-2,000$ & 4,226 & 0 & 0 & 4,226 & 40 & 420 & 3,766 \\
\hline & $2,000-3,000$ & 1,055 & 0 & 0 & 1,055 & 37 & 197 & 821 \\
\hline & Greater than 3,000 & 0 & 0 & 0 & 0 & 0 & 0 & 0 \\
\hline & Total & 5,968 & 3 & 3 & 5,961 & 83 & 1,168 & 4,711 \\
\hline \multirow[t]{6}{*}{ Canyon } & $0-500$ & 34,020 & 797 & 915 & 32,307 & 5,710 & 650 & 25,947 \\
\hline & $500-1,000$ & 24,725 & 0 & 23 & 24,701 & 981 & 268 & 23,452 \\
\hline & $1,000-2,000$ & 76,241 & 0 & 6 & 76,235 & 425 & 1,088 & 74,722 \\
\hline & $2,000-3,000$ & 12,459 & 0 & 0 & 12,458 & 419 & 712 & 11,328 \\
\hline & Greater than 3,000 & 6 & 0 & 0 & 6 & 0 & 0 & 6 \\
\hline & Total & 147,450 & 797 & 945 & 145,7 & 7,535 & 2,719 & 135,454 \\
\hline \multirow[t]{6}{*}{ Lower Canyon } & $0-500$ & 10,111 & 146 & 14 & 9,951 & 2,434 & 1,133 & 6,384 \\
\hline & $500-1,000$ & 8,709 & 0 & 3 & 8,706 & 39 & 920 & 7,747 \\
\hline & $1,000-2,000$ & 35,317 & 0 & 0 & 35,317 & 264 & 1,072 & 33,981 \\
\hline & $2,000-3,000$ & 5,371 & 0 & 0 & 5,371 & 90 & 1,340 & 3,941 \\
\hline & Greater than 3,000 & 20 & 0 & 0 & 20 & 0 & 17 & 23 \\
\hline & Total & 59,528 & 146 & 17 & 59,365 & 2,827 & 4,482 & 52,056 \\
\hline \multirow[t]{6}{*}{ Upper Ferry } & $0-500$ & 124 & 0 & 0 & 124 & 0 & 99 & 26 \\
\hline & $500-1,000$ & 574 & 0 & 0 & 574 & 0 & 212 & 362 \\
\hline & $1,000-2,000$ & 115 & 0 & 0 & 115 & 0 & 39 & 77 \\
\hline & $2,000-3,000$ & 0 & 0 & 0 & 0 & 0 & 0 & 0 \\
\hline & Greater than 3,000 & 0 & 0 & 0 & 0 & 0 & 0 & 0 \\
\hline & Total & 814 & 0 & 0 & 814 & 0 & 349 & 464 \\
\hline \multirow[t]{6}{*}{ Ferry } & $0-500$ & 1,449 & 2 & 0 & 1,446 & 327 & 403 & 717 \\
\hline & $500-1,000$ & 1,568 & 0 & 0 & 1,568 & 3 & 363 & 1,202 \\
\hline & $1,000-2,000$ & 1,197 & 0 & 0 & 1,197 & 11 & 593 & 594 \\
\hline & $2,000-3,000$ & 2,182 & 0 & 0 & 2,182 & 2 & 416 & 1,764 \\
\hline & Greater than 3,000 & 0 & 0 & 0 & 0 & 0 & 0 & 0 \\
\hline & Total & 6,396 & 2 & 0 & 6,394 & 343 & 1,774 & 4,277 \\
\hline \multirow[t]{6}{*}{ Werner/Cook } & $0-500$ & 22,968 & 707 & 0 & 22,261 & 4,888 & 824 & 16,549 \\
\hline & $500-1,000$ & 23,553 & 0 & 0 & 23,553 & 666 & 482 & 22,406 \\
\hline & $1,000-2,000$ & 18,304 & 0 & 0 & 18,304 & 193 & 1,929 & 16,181 \\
\hline & $2,000-3,000$ & 8,710 & 0 & 0 & 8,710 & 354 & 539 & 7,818 \\
\hline & Greater than 3,000 & 450 & 0 & 0 & 450 & 27 & 24 & 399 \\
\hline & Total & 73,986 & 707 & 0 & 73,279 & 6,128 & 3,798 & 63,353 \\
\hline
\end{tabular}


Table 5. Coal resources and restrictions for 47 beds greater than or equal to 2.5 feet thick, reported in millions of short tons by overburden depth for the Powder River Basin, Wyoming and Montana. Resource includes coal plus partings. Totals may not sum exactly because of rounding.-Continued

\begin{tabular}{|c|c|c|c|c|c|c|c|c|}
\hline $\begin{array}{l}\text { Coal bed } \\
\text { name }\end{array}$ & $\begin{array}{c}\text { Overburden } \\
\text { thickness } \\
\text { (feet) }\end{array}$ & $\begin{array}{l}\text { Original } \\
\text { resources }\end{array}$ & $\begin{array}{c}\text { Burned } \\
\text { coal }\end{array}$ & $\begin{array}{l}\text { Mined } \\
\text { coal }\end{array}$ & $\begin{array}{l}\text { Remaining } \\
\text { resources }\end{array}$ & $\begin{array}{l}\text { Land-use } \\
\text { restrictions }\end{array}$ & $\begin{array}{c}\text { Technical } \\
\text { restrictions }\end{array}$ & $\begin{array}{l}\text { Available } \\
\text { resources }\end{array}$ \\
\hline \multirow[t]{6}{*}{ Upper Otter } & $0-500$ & 530 & 0 & 0 & 529 & 0 & 176 & 353 \\
\hline & $500-1,000$ & 101 & 0 & 0 & 101 & 0 & 55 & 46 \\
\hline & $1,000-2,000$ & 201 & 0 & 0 & 201 & 0 & 41 & 159 \\
\hline & $2,000-3,000$ & 83 & 0 & 0 & 83 & 0 & 37 & 45 \\
\hline & Greater than 3,000 & 4 & 0 & 0 & 4 & 0 & 4 & 0 \\
\hline & Total & 919 & $\mathbf{0}$ & $\mathbf{0}$ & 918 & $\mathbf{0}$ & 314 & 604 \\
\hline \multirow[t]{6}{*}{ Otter } & $0-500$ & 5,503 & 21 & 0 & 5,482 & 864 & 1,100 & 3,518 \\
\hline & $500-1,000$ & 10,143 & 0 & 0 & 10,143 & 29 & 1,649 & 8,465 \\
\hline & $1,000-2,000$ & 38,786 & 0 & 0 & 38,786 & 6 & 1,600 & 37,182 \\
\hline & $2,000-3,000$ & 16,297 & 0 & 0 & 16,297 & 10 & 1,212 & 15,075 \\
\hline & Greater than 3,000 & 292 & 0 & 0 & 292 & 0 & 222 & 70 \\
\hline & Total & 71,021 & 21 & $\mathbf{0}$ & 71,000 & 909 & 5,781 & 64,310 \\
\hline \multirow{6}{*}{ Gates/Wall } & $0-500$ & 6,441 & 70 & 0 & 6,371 & 859 & 1,039 & 4,473 \\
\hline & $500-1,000$ & 10,771 & 0 & 0 & 10,771 & 32 & 1,552 & 9,187 \\
\hline & $1,000-2,000$ & 26,324 & 0 & 0 & 26,324 & 428 & 2,248 & 23,647 \\
\hline & $2,000-3,000$ & 192 & 0 & 0 & 192 & 129 & 2,008 & 18,512 \\
\hline & Greater than 3,000 & 2,240 & 0 & 0 & 2,240 & 126 & 82 & 2,032 \\
\hline & Total & 66,426 & 70 & $\mathbf{0}$ & 66,355 & 1,574 & 6,930 & 57,851 \\
\hline \multirow[t]{6}{*}{ Pawnee } & $0-500$ & 9,110 & 231 & 0 & 8,878 & 2,562 & 573 & 5,743 \\
\hline & $500-1,000$ & 5,215 & 0 & 0 & 5,215 & 8 & 1,139 & 4,068 \\
\hline & $1,000-2,000$ & 5,704 & 0 & 0 & 5,704 & 23 & 1,512 & 4,170 \\
\hline & $2,000-3,000$ & 2,920 & 0 & 0 & 2,920 & 6 & 1,262 & 1,652 \\
\hline & Greater than 3,000 & 1,549 & 0 & 0 & 1,549 & 5 & 213 & 1,331 \\
\hline & Total & 24,498 & 231 & $\mathbf{0}$ & 24,267 & 2,603 & 4,699 & 16,964 \\
\hline \multirow[t]{6}{*}{ Brewster-Arnold } & $0-500$ & 1,490 & 75 & 0 & 1,415 & 776 & 416 & 223 \\
\hline & $500-1,000$ & 417 & 0 & 0 & 417 & 0 & 168 & 250 \\
\hline & $1,000-2,000$ & 61 & 0 & 0 & 61 & 0 & 59 & 2 \\
\hline & $2,000-3,000$ & 0 & 0 & 0 & 0 & 0 & 0 & 0 \\
\hline & Greater than 3,000 & 0 & 0 & 0 & 0 & 0 & 0 & 0 \\
\hline & Total & 1,968 & 75 & $\mathbf{0}$ & 1,892 & 776 & 641 & 475 \\
\hline \multirow[t]{6}{*}{ Odell } & $0-500$ & 2,870 & 8 & 0 & 2,862 & 318 & 1,181 & 1,363 \\
\hline & $500-1,000$ & 2,352 & 0 & 0 & 2,352 & 0 & 552 & 1,801 \\
\hline & $1,000-2,000$ & 1,684 & 0 & 0 & 1,684 & 0 & 1,129 & 555 \\
\hline & $2,000-3,000$ & 3,646 & 0 & 0 & 3,646 & 4 & 1,193 & 2,449 \\
\hline & Greater than 3,000 & 1,124 & 0 & 0 & 1,124 & 0 & 711 & 413 \\
\hline & Total & 11,676 & 8 & $\mathbf{0}$ & 11,668 & 322 & 4,765 & 6,581 \\
\hline \multirow[t]{6}{*}{ Cache } & $0-500$ & 1,927 & 18 & 0 & 1,910 & 463 & 959 & 488 \\
\hline & $500-1,000$ & 1,198 & 0 & 0 & 1,198 & 0 & 903 & 295 \\
\hline & $1,000-2,000$ & 178 & 0 & 0 & 178 & 0 & 152 & 26 \\
\hline & $2,000-3,000$ & 0 & 0 & 0 & 0 & 0 & 0 & 0 \\
\hline & Greater than 3,000 & 0 & 0 & 0 & 0 & 0 & 0 & 0 \\
\hline & Total & 3,303 & 18 & 0 & 3,286 & 463 & 2,013 & 809 \\
\hline \multirow[t]{6}{*}{ A Zone } & $0-500$ & 90 & 0 & 0 & 90 & 0 & 77 & 13 \\
\hline & $500-1,000$ & 12 & 0 & 0 & 12 & 0 & 12 & 0 \\
\hline & $1,000-2,000$ & 9 & 0 & 0 & 9 & 0 & 7 & 2 \\
\hline & $2,000-3,000$ & 0 & 0 & 0 & 0 & 0 & 0 & 0 \\
\hline & Greater than 3,000 & 0 & 0 & 0 & 0 & 0 & 0 & 0 \\
\hline & Total & 111 & $\mathbf{0}$ & $\mathbf{0}$ & 111 & $\mathbf{0}$ & 95 & 15 \\
\hline \multirow[t]{6}{*}{ Upper Rosebud } & $0-500$ & 159 & 0 & 4 & 155 & 0 & 118 & 37 \\
\hline & $500-1,000$ & 28 & 0 & 1 & 27 & 0 & 16 & 12 \\
\hline & $1,000-2,000$ & 18 & 0 & 1 & 17 & 0 & 12 & 5 \\
\hline & $2,000-3,000$ & 3 & 0 & 0 & 3 & 0 & 3 & 0 \\
\hline & Greater than 3,000 & 0 & 0 & 0 & 0 & 0 & 0 & 0 \\
\hline & Total & 209 & 0 & 6 & 203 & $\mathbf{0}$ & 148 & 54 \\
\hline
\end{tabular}


Table 5. Coal resources and restrictions for 47 beds greater than or equal to 2.5 feet thick, reported in millions of short tons by overburden depth for the Powder River Basin, Wyoming and Montana. Resource includes coal plus partings. Totals may not sum exactly because of rounding.-Continued

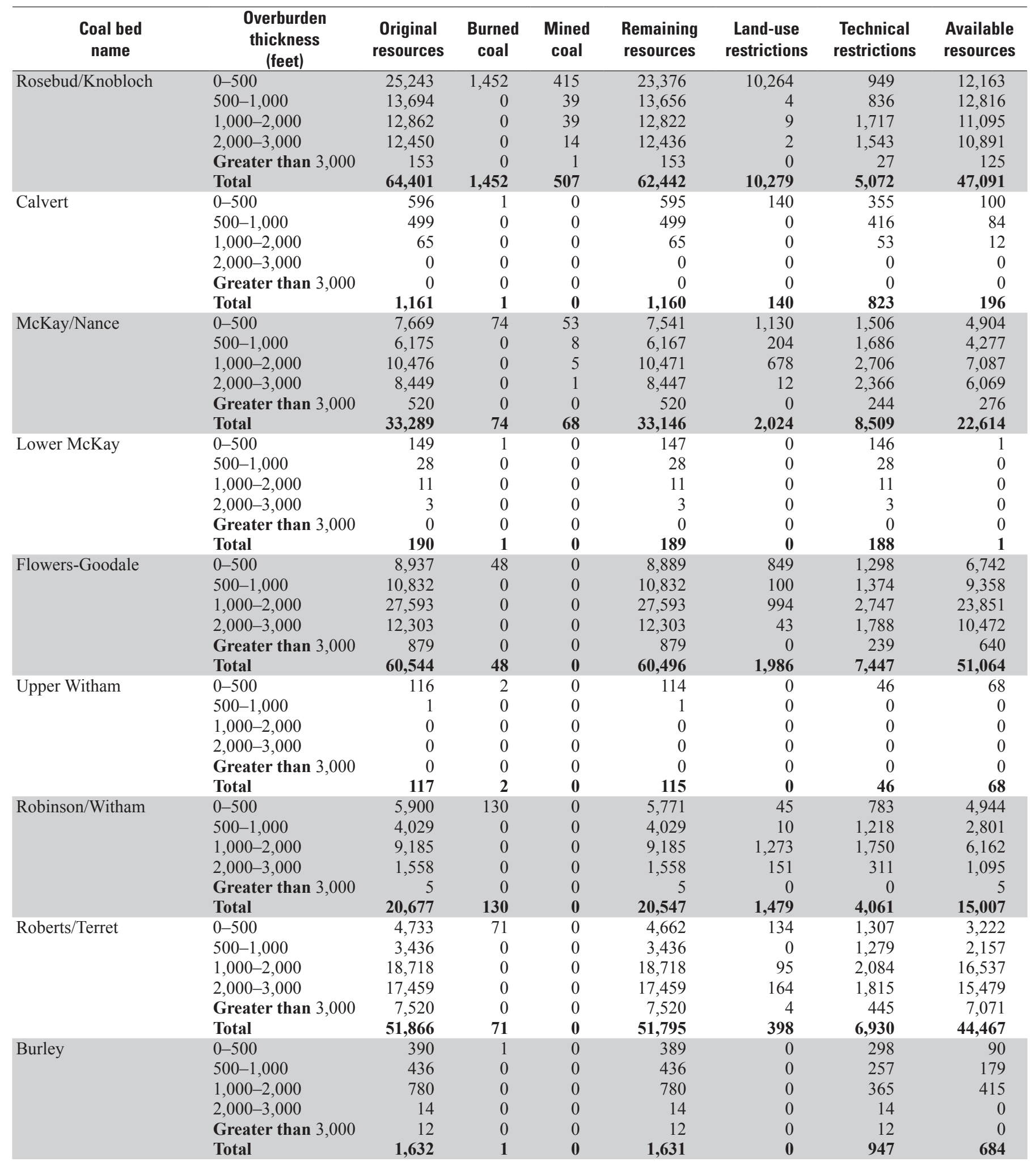


Table 5. Coal resources and restrictions for 47 beds greater than or equal to 2.5 feet thick, reported in millions of short tons by overburden depth for the Powder River Basin, Wyoming and Montana. Resource includes coal plus partings. Totals may not sum exactly because of rounding.-Continued

\begin{tabular}{|c|c|c|c|c|c|c|c|c|}
\hline $\begin{array}{l}\text { Coal bed } \\
\text { name }\end{array}$ & $\begin{array}{c}\text { Overburden } \\
\text { thickness } \\
\text { (feet) }\end{array}$ & $\begin{array}{l}\text { Original } \\
\text { resources }\end{array}$ & $\begin{array}{c}\text { Burned } \\
\text { coal }\end{array}$ & $\begin{array}{l}\text { Mined } \\
\text { coal }\end{array}$ & $\begin{array}{l}\text { Remaining } \\
\text { resources }\end{array}$ & $\begin{array}{l}\text { Land-use } \\
\text { restrictions }\end{array}$ & $\begin{array}{l}\text { Technical } \\
\text { restrictions }\end{array}$ & $\begin{array}{l}\text { Available } \\
\text { resources }\end{array}$ \\
\hline \multirow[t]{4}{*}{ Upper Stag } & $0-500$ & 11 & 0 & 0 & 11 & 0 & 4 & 7 \\
\hline & $1,000-2,000$ & 717 & 0 & 0 & 717 & 0 & 611 & 107 \\
\hline & $2,000-3,000$ & 1,027 & 0 & 0 & 1,027 & 0 & 358 & 669 \\
\hline & Greater than 3,000 & 83 & 0 & 0 & 83 & 0 & 79 & 3 \\
\hline \multirow{5}{*}{ Lower Stag } & $500-1,000$ & 9 & 0 & 0 & 9 & 0 & 8 & 2 \\
\hline & $1,000-2,000$ & 141 & 0 & 0 & 141 & 0 & 132 & 9 \\
\hline & $2,000-3,000$ & 0 & 0 & 0 & 0 & 0 & 0 & 0 \\
\hline & Greater than 3,000 & 0 & 0 & 0 & 0 & 0 & 0 & 0 \\
\hline & Total & 151 & 0 & 0 & 151 & 0 & 139 & 11 \\
\hline \multirow[t]{2}{*}{ Total beds } & $0-500$ & 304,254 & 6,467 & 5,712 & 292,073 & 49,000 & 30,633 & 212,439 \\
\hline & Total & $1,161,850$ & 6,468 & 6,306 & $1,149,072$ & 64,097 & 110,211 & 974,752 \\
\hline
\end{tabular}


Table 6. Coal resources and restrictions for 47 beds greater than or equal to 2.5 feet thick, reported in millions of short tons, by coal ownership categories for the Powder River Basin, Wyoming and Montana. Resource includes coal plus partings. Totals may not sum exactly because of rounding.

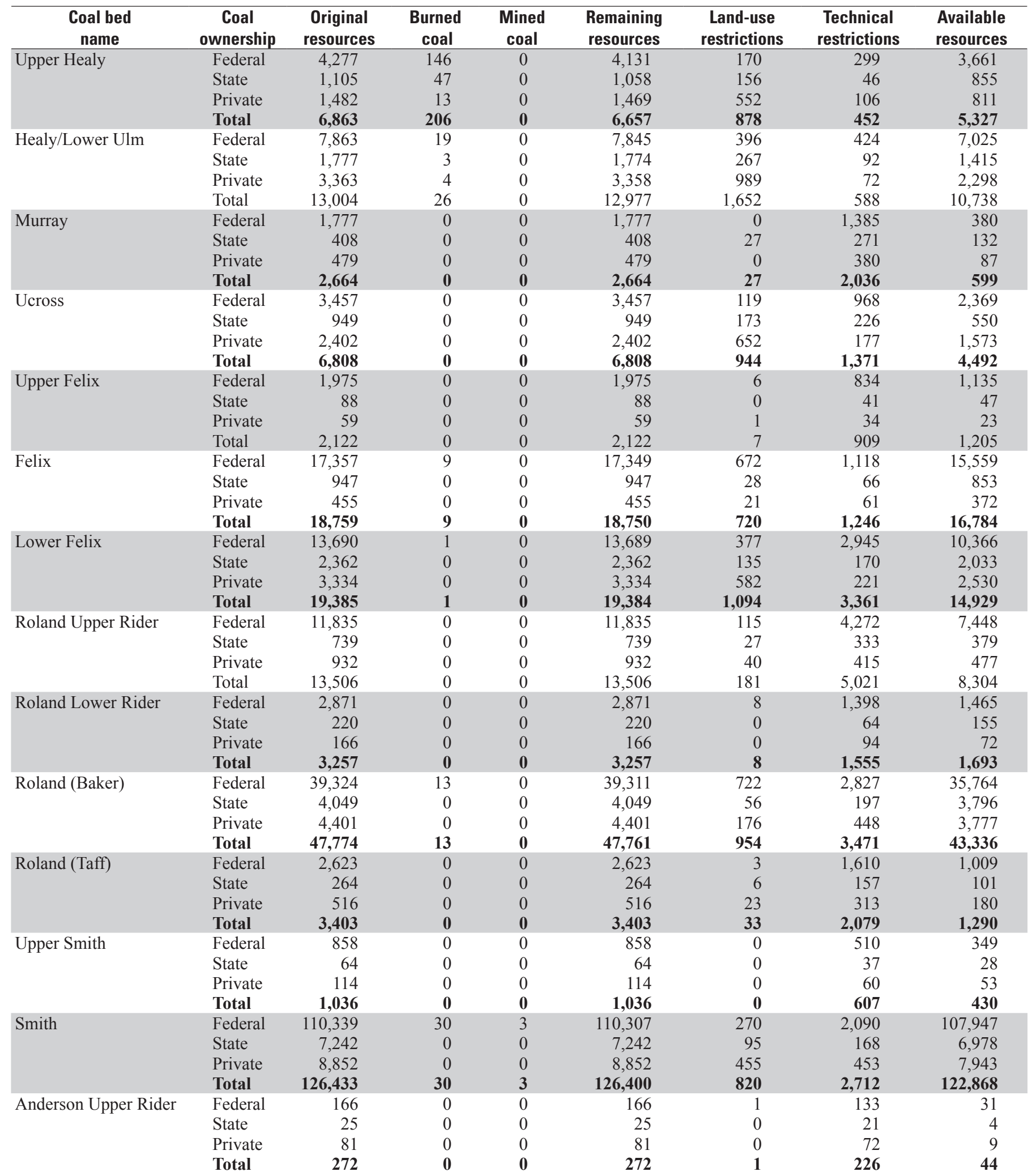


Table 6. Coal resources and restrictions for 47 beds greater than or equal to 2.5 feet thick, reported in millions of short tons, by coal ownership categories for the Powder River Basin, Wyoming and Montana. Resource includes coal plus partings. Totals may not sum exactly because of rounding.-Continued

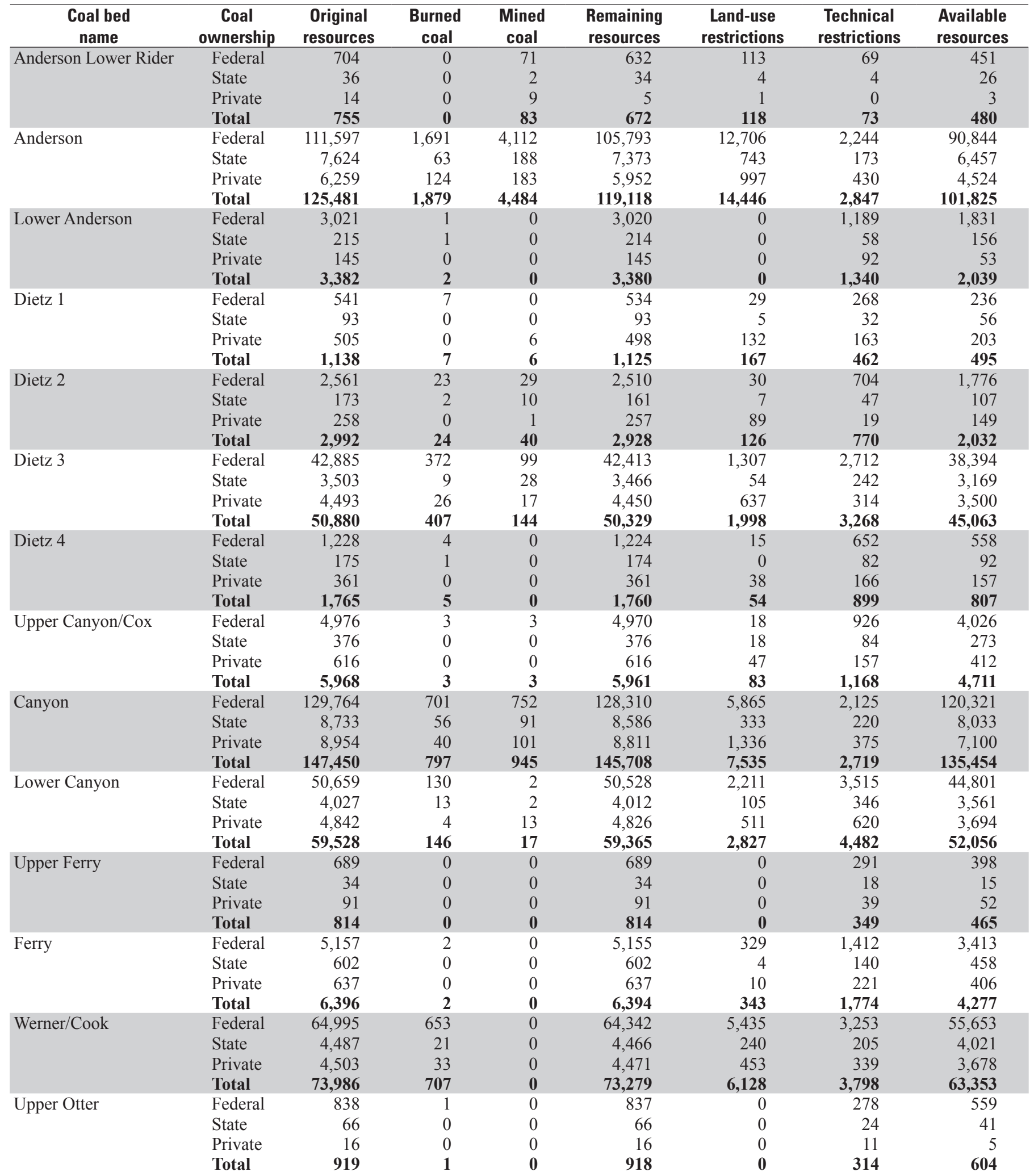


Table 6. Coal resources and restrictions for 47 beds greater than or equal to 2.5 feet thick, reported in millions of short tons, by coal ownership categories for the Powder River Basin, Wyoming and Montana. Resource includes coal plus partings. Totals may not sum exactly because of rounding.-Continued

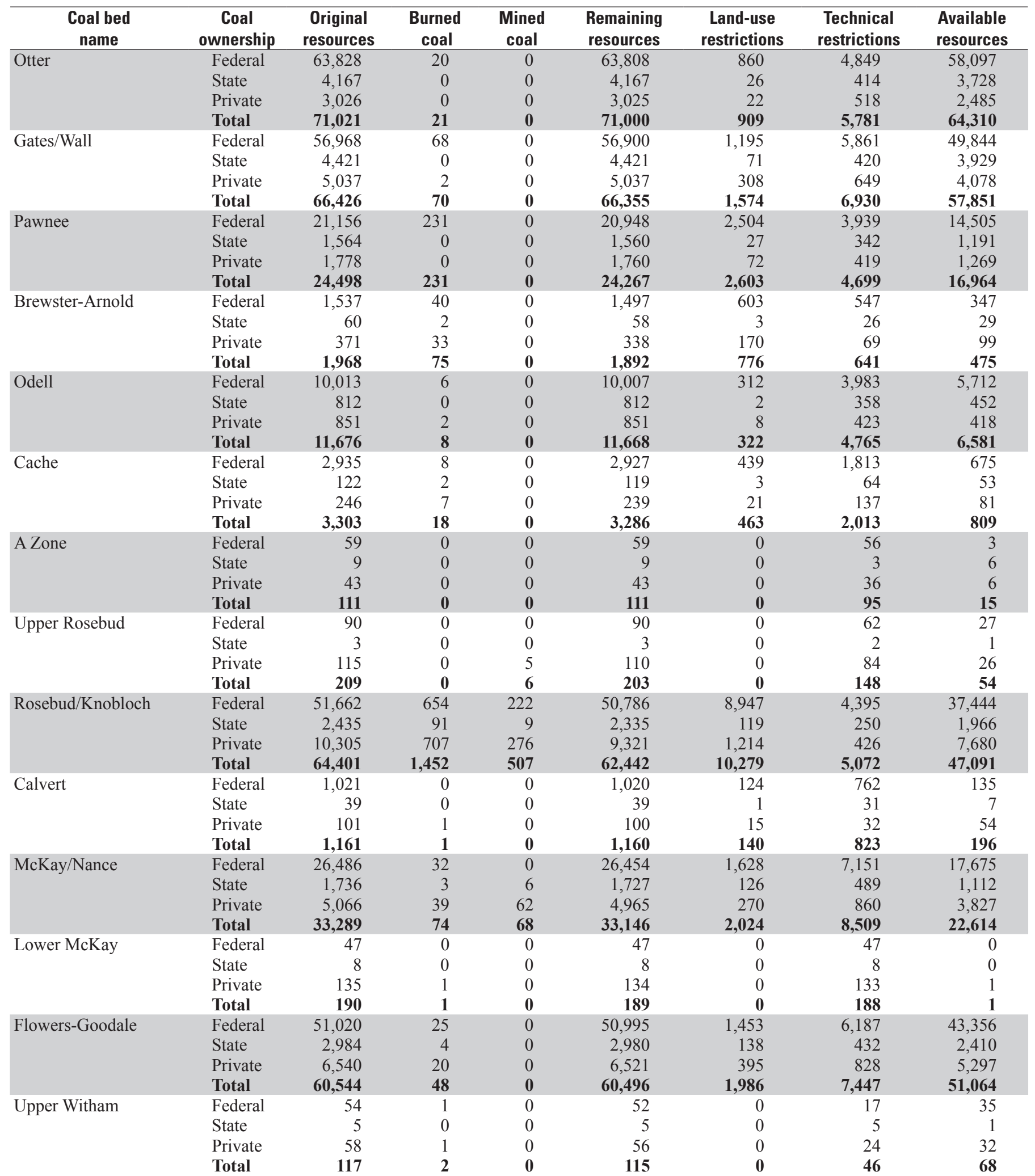


Table 6. Coal resources and restrictions for 47 beds greater than or equal to 2.5 feet thick, reported in millions of short tons, by coal ownership categories for the Powder River Basin, Wyoming and Montana. Resource includes coal plus partings. Totals may not sum exactly because of rounding.-Continued

\begin{tabular}{|c|c|c|c|c|c|c|c|c|}
\hline $\begin{array}{c}\text { Coal bed } \\
\text { name }\end{array}$ & $\begin{array}{c}\text { Coal } \\
\text { ownership }\end{array}$ & $\begin{array}{c}\text { Original } \\
\text { resources }\end{array}$ & $\begin{array}{c}\text { Burned } \\
\text { coal }\end{array}$ & $\begin{array}{c}\text { Mined } \\
\text { coal }\end{array}$ & $\begin{array}{l}\text { Remaining } \\
\text { resources }\end{array}$ & $\begin{array}{l}\text { Land-use } \\
\text { restrictions }\end{array}$ & $\begin{array}{l}\text { Technical } \\
\text { restrictions }\end{array}$ & $\begin{array}{l}\text { Available } \\
\text { resources }\end{array}$ \\
\hline \multirow{2}{*}{ Robinson/Witham } & State & 1,008 & 5 & 0 & 1,002 & 97 & 192 & 713 \\
\hline & Total & 20,677 & 130 & $\mathbf{0}$ & 20,547 & 1,479 & 4,061 & 15,007 \\
\hline \multirow[t]{2}{*}{ Roberts/Terret } & Federal & 43,088 & 34 & 0 & 43,055 & 293 & 5,616 & 37,146 \\
\hline & State & 2,876 & 1 & 0 & 2,875 & 21 & 352 & 2,501 \\
\hline \multirow[t]{4}{*}{ Burley } & Federal & 1,314 & 0 & 0 & 1,313 & 0 & 723 & 590 \\
\hline & State & 31 & 0 & 0 & 31 & 0 & 25 & 5 \\
\hline & Private & 287 & 1 & 0 & 287 & 0 & 198 & 88 \\
\hline & Total & 1,632 & 1 & $\mathbf{0}$ & 1,631 & $\mathbf{0}$ & 947 & 684 \\
\hline \multirow[t]{2}{*}{ Upper Stag } & Federal & 1,634 & 0 & 0 & 1,634 & 0 & 998 & 637 \\
\hline & State & 77 & 0 & 0 & 77 & 0 & 42 & 35 \\
\hline \multirow{2}{*}{ Lower Stag } & Private & 2 & 0 & 0 & 2 & 0 & 2 & 0 \\
\hline & Total & 151 & 0 & $\mathbf{0}$ & 151 & $\mathbf{0}$ & 139 & 11 \\
\hline \multirow[t]{4}{*}{ Total beds } & Federal & 985,692 & 4,941 & 5,293 & 975,480 & 50,607 & 90,959 & 833,900 \\
\hline & State & 72,742 & 324 & 336 & 72,076 & 3,117 & 7,021 & 61,930 \\
\hline & Private & 103,415 & 1,203 & 673 & 101,523 & 10,372 & 12,195 & 78,922 \\
\hline & Total & $1,161,850$ & 6,468 & 6,306 & $1,149,072$ & 64,097 & 110,211 & 974,752 \\
\hline
\end{tabular}


Table 7. Coal resources and restrictions for 47 beds greater than or equal to 2.5 feet thick, reported in millions of short tons by assessment area.

[MTPRB. Montana Powder River Basin; NWPRB, Northern Wyoming Powder River Basin; SWPRB, Southwestern Powder River Basin; GILLETTE, Gillette coal field; East Gillette (area east of the Gillette coal field)]

\begin{tabular}{|c|c|c|c|c|c|c|c|c|}
\hline $\begin{array}{c}\text { Coal bed } \\
\text { name }\end{array}$ & $\begin{array}{c}\text { Assessment } \\
\text { area name }\end{array}$ & $\begin{array}{c}\text { Original } \\
\text { resources }\end{array}$ & $\begin{array}{c}\text { Burned } \\
\text { coal }\end{array}$ & $\begin{array}{c}\text { Mined } \\
\text { coal }\end{array}$ & $\begin{array}{l}\text { Remaining } \\
\text { resources }\end{array}$ & $\begin{array}{c}\text { Land-use } \\
\text { restrictions }\end{array}$ & $\begin{array}{c}\text { Technical } \\
\text { restrictions }\end{array}$ & $\begin{array}{l}\text { Available } \\
\text { resources }\end{array}$ \\
\hline \multirow{6}{*}{ Upper Healy } & MTPRB & 0 & 0 & 0 & 0 & 0 & 0 & 0 \\
\hline & NWPRB & 1,889 & 45 & 0 & 1,845 & 34 & 55 & 1,755 \\
\hline & SWPRB & 4,974 & 161 & 0 & 4,813 & 843 & 398 & 3,572 \\
\hline & GILLETTE & 0 & 0 & 0 & 0 & 0 & 0 & 0 \\
\hline & EAST GILLETTE & 0 & 0 & 0 & 0 & 0 & 0 & 0 \\
\hline & Total & 6,863 & 206 & $\mathbf{0}$ & 6,657 & 878 & 452 & 5,327 \\
\hline \multirow[t]{6}{*}{ Healy/Lower Ulm } & MTPRB & 0 & 0 & 0 & 0 & 0 & 0 & 0 \\
\hline & NWPRB & 3,669 & 17 & 0 & 3,652 & 45 & 258 & 3,349 \\
\hline & SWPRB & 9,026 & 6 & 0 & 9,020 & 1,592 & 1,672 & 7,118 \\
\hline & GILLETTE & 308 & 3 & 0 & 305 & 15 & 20 & 270 \\
\hline & EAST GILLETTE & 0 & 0 & 0 & 0 & 0 & 0 & 0 \\
\hline & Total & 13,004 & 26 & $\mathbf{0}$ & 12,977 & 1,652 & 588 & 10,738 \\
\hline \multirow[t]{6}{*}{ Murray } & MTPRB & 0 & 0 & 0 & 0 & 0 & 0 & 0 \\
\hline & NWPRB & 926 & 0 & 0 & 926 & 0 & 673 & 252 \\
\hline & SWPRB & 1,718 & 0 & 0 & 1,718 & 27 & 1,356 & 335 \\
\hline & GILLETTE & 20 & 0 & 0 & 20 & 0 & 9 & 12 \\
\hline & EAST GILLETTE & 0 & 0 & 0 & 0 & 0 & 0 & 0 \\
\hline & Total & 2,664 & 0 & 0 & 2,664 & 27 & 2,036 & 599 \\
\hline \multirow[t]{6}{*}{ Ucross } & MTPRB & 0 & 0 & 0 & 0 & 0 & 0 & 0 \\
\hline & NWPRB & 2,205 & 0 & 0 & 2,205 & 11 & 933 & 1,261 \\
\hline & SWPRB & 4,602 & 0 & 0 & 4,602 & 933 & 438 & 3,231 \\
\hline & GILLETTE & 0 & 0 & 0 & 0 & 0 & 0 & 0 \\
\hline & EAST GILLETTE & 0 & 0 & 0 & 0 & 0 & 0 & 0 \\
\hline & Total & 6,808 & $\mathbf{0}$ & $\mathbf{0}$ & 6,808 & 944 & 1,371 & 4,492 \\
\hline \multirow[t]{6}{*}{ Upper Felix } & MTPRB & 0 & 0 & 0 & 0 & 0 & 0 & 0 \\
\hline & NWPRB & 0 & 0 & 0 & 0 & 0 & 0 & 0 \\
\hline & SWPRB & 626 & 0 & 0 & 626 & 6 & 367 & 253 \\
\hline & GILLETTE & 1,496 & 0 & 0 & 1,496 & 1 & 542 & 952 \\
\hline & EAST GILLETTE & 0 & 0 & 0 & 0 & 0 & 0 & 0 \\
\hline & Total & 2,122 & $\mathbf{0}$ & 0 & 2,122 & 7 & 909 & 1,205 \\
\hline \multirow[t]{6}{*}{ Felix } & MTPRB & 0 & 0 & 0 & 0 & 0 & 0 & 0 \\
\hline & NWPRB & 1,508 & 1 & 0 & 1,507 & 1 & 220 & 1,287 \\
\hline & SWPRB & 4,466 & 0 & 0 & 4,465 & 36 & 626 & 3,803 \\
\hline & GILLETTE & 12,786 & 8 & 0 & 12,777 & 683 & 400 & 11,695 \\
\hline & EAST GILLETTE & 0 & 0 & 0 & 0 & 0 & 0 & 0 \\
\hline & Total & 18,759 & 9 & $\mathbf{0}$ & 18,750 & 720 & 1,246 & 16,784 \\
\hline \multirow[t]{6}{*}{ Lower Felix } & MTPRB & 3 & 0 & 0 & 3 & 0 & 2 & 1 \\
\hline & NWPRB & 5,951 & 0 & 0 & 5,951 & 28 & 782 & 5,141 \\
\hline & SWPRB & 10,242 & 0 & 0 & 10,242 & 780 & 2,023 & 7,439 \\
\hline & GILLETTE & 3,189 & 1 & 0 & 3,188 & 286 & 555 & 2,347 \\
\hline & EAST GILLETTE & 0 & 0 & 0 & 0 & 0 & 0 & 0 \\
\hline & Total & 19,385 & 1 & 0 & 19,384 & 1,094 & 3,361 & 14,929 \\
\hline \multirow[t]{6}{*}{ Roland Upper Rider } & MTPRB & 1 & 0 & 0 & 1 & 0 & 1 & 0 \\
\hline & NWPRB & 4,799 & 0 & 0 & 4,799 & 94 & 1,480 & 3,225 \\
\hline & SWPRB & 6,681 & 0 & 0 & 6,681 & 56 & 2,609 & 4,016 \\
\hline & GILLETTE & 2,025 & 0 & 0 & 2,025 & 31 & 930 & 1,063 \\
\hline & EAST GILLETTE & 0 & 0 & 0 & 0 & 0 & 0 & 0 \\
\hline & Total & 13,506 & $\mathbf{0}$ & $\mathbf{0}$ & 13,506 & 181 & 5,021 & 8,304 \\
\hline \multirow[t]{6}{*}{ Roland Lower Rider } & MTPRB & 4 & 0 & 0 & 4 & 0 & 3 & 1 \\
\hline & NWPRB & 580 & 0 & 0 & 580 & 4 & 370 & 206 \\
\hline & SWPRB & 2,284 & 0 & 0 & 2,284 & 0 & 820 & 1,464 \\
\hline & GILLETTE & 389 & 0 & 0 & 389 & 4 & 362 & 23 \\
\hline & EAST GILLETTE & 0 & 0 & 0 & 0 & 0 & 0 & 0 \\
\hline & Total & 3,257 & $\mathbf{0}$ & $\mathbf{0}$ & 3,257 & 8 & 1,555 & 1,693 \\
\hline
\end{tabular}


Table 7. Coal resources and restrictions for 47 beds greater than or equal to 2.5 feet thick, reported in millions of short tons by assessment area.-Continued

[MTPRB. Montana Powder River Basin; NWPRB, Northern Wyoming Powder River Basin; SWPRB, Southwestern Powder River Basin; GILLETTE, Gillette coal field; East Gillette (area east of the Gillette coal field)]

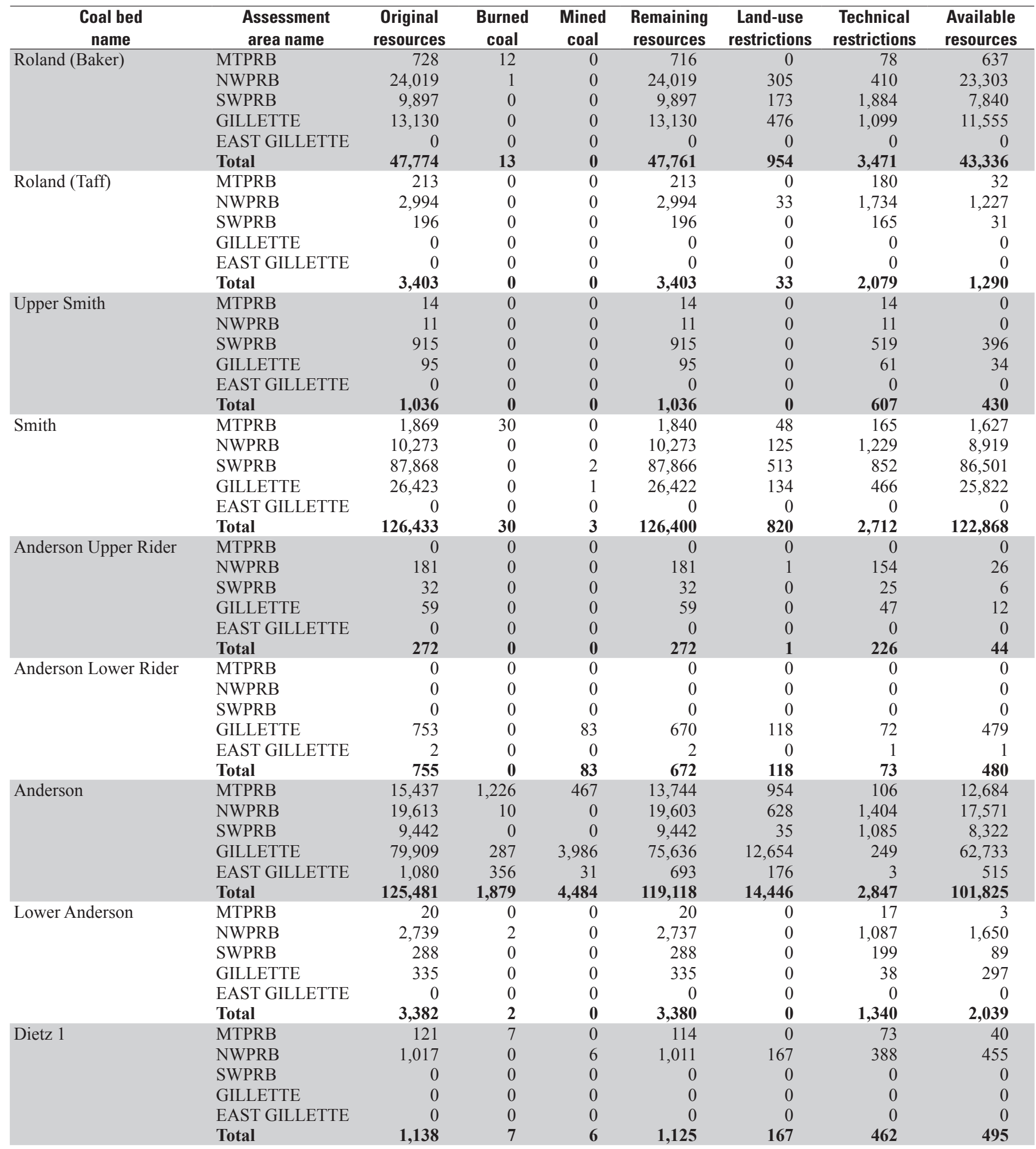


Table 7. Coal resources and restrictions for 47 beds greater than or equal to 2.5 feet thick, reported in millions of short tons by assessment area.-Continued

[MTPRB. Montana Powder River Basin; NWPRB, Northern Wyoming Powder River Basin; SWPRB, Southwestern Powder River Basin; GILLETTE, Gillette coal field; East Gillette (area east of the Gillette coal field)]

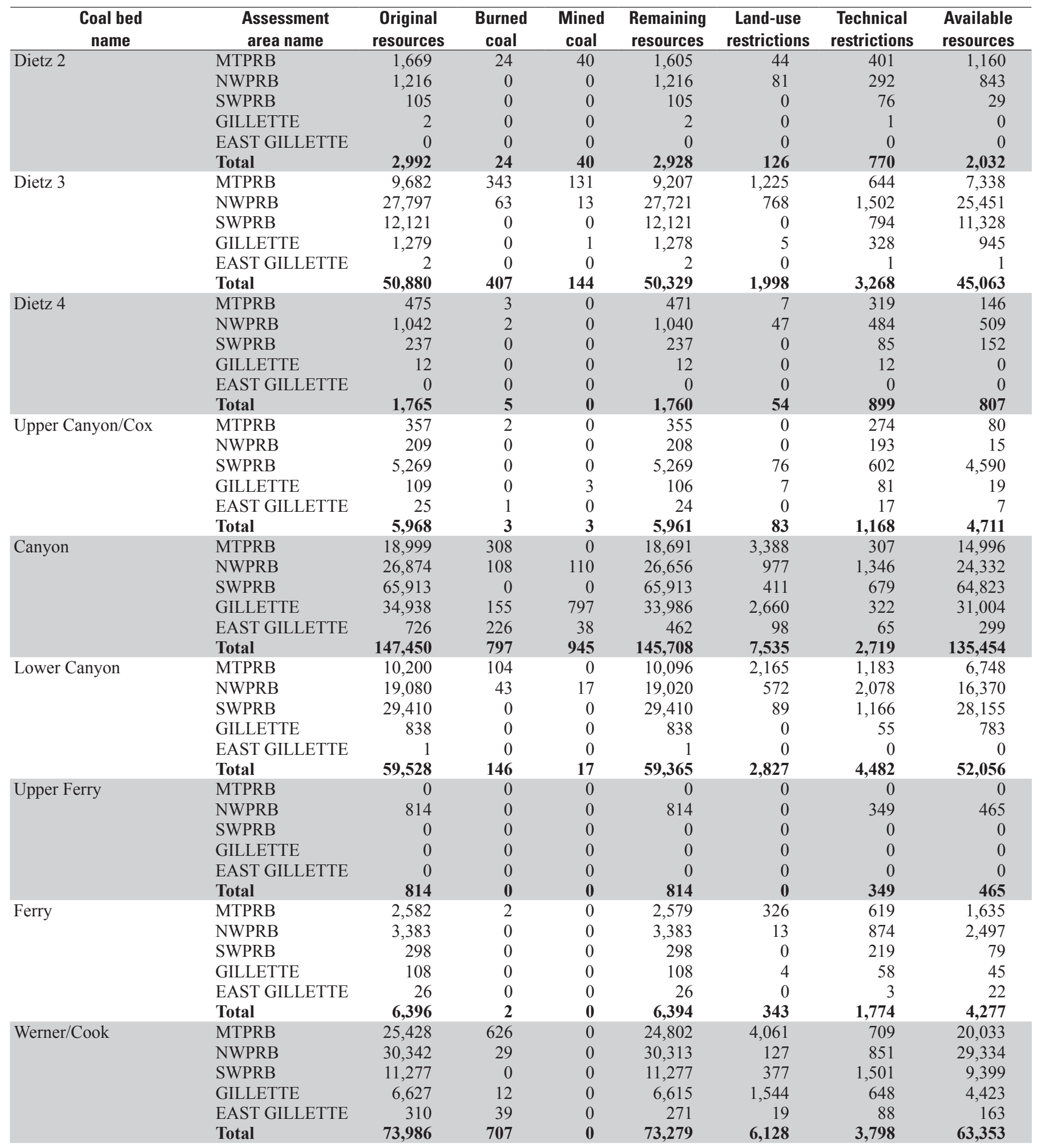


Table 7. Coal resources and restrictions for 47 beds greater than or equal to 2.5 feet thick, reported in millions of short tons by assessment area.-Continued

[MTPRB. Montana Powder River Basin; NWPRB, Northern Wyoming Powder River Basin; SWPRB, Southwestern Powder River Basin; GILLETTE, Gillette coal field; East Gillette (area east of the Gillette coal field)]

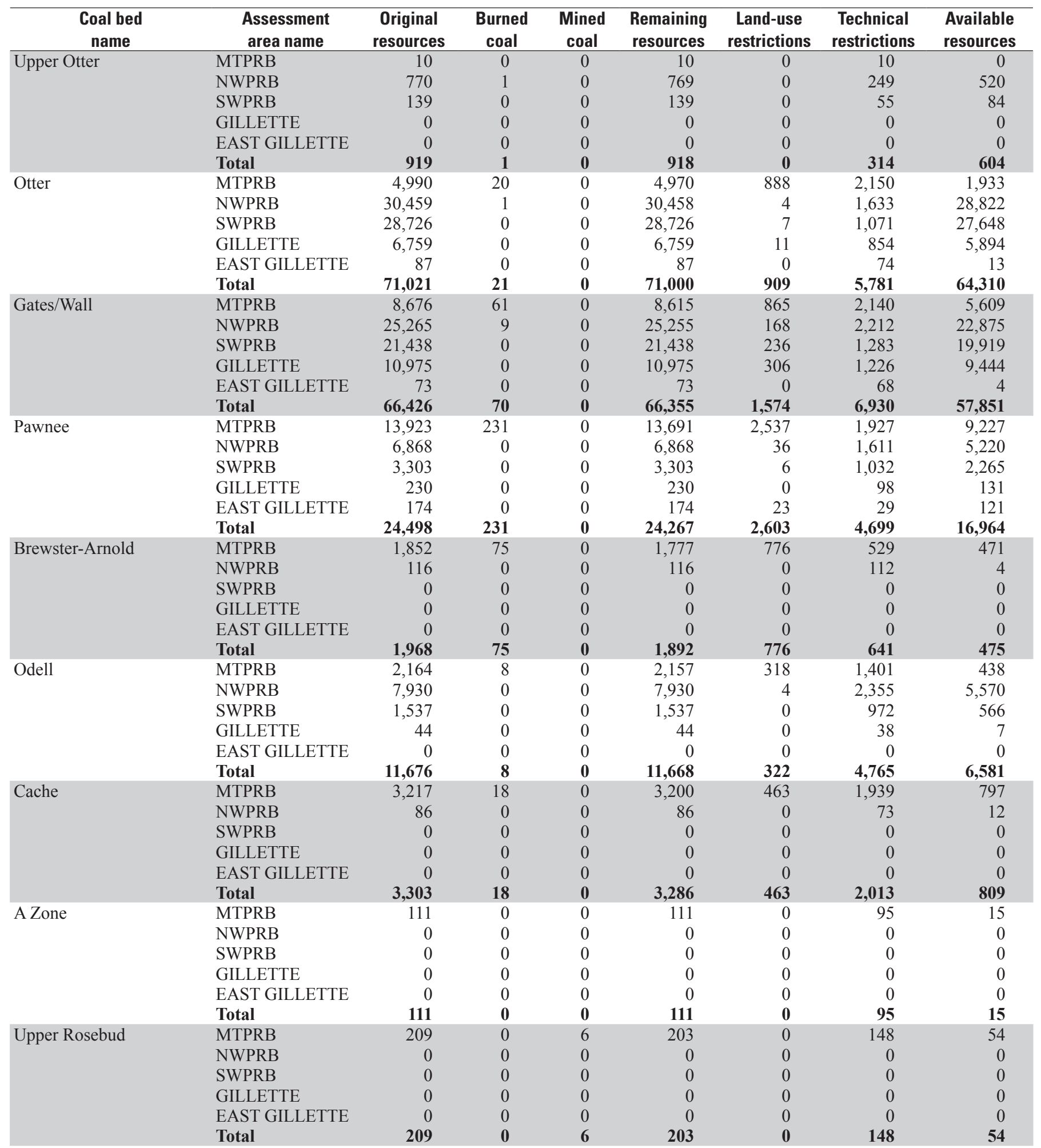


Table 7. Coal resources and restrictions for 47 beds greater than or equal to 2.5 feet thick, reported in millions of short tons by assessment area.-Continued

[MTPRB. Montana Powder River Basin; NWPRB, Northern Wyoming Powder River Basin; SWPRB, Southwestern Powder River Basin; GILLETTE, Gillette coal field; East Gillette (area east of the Gillette coal field)]

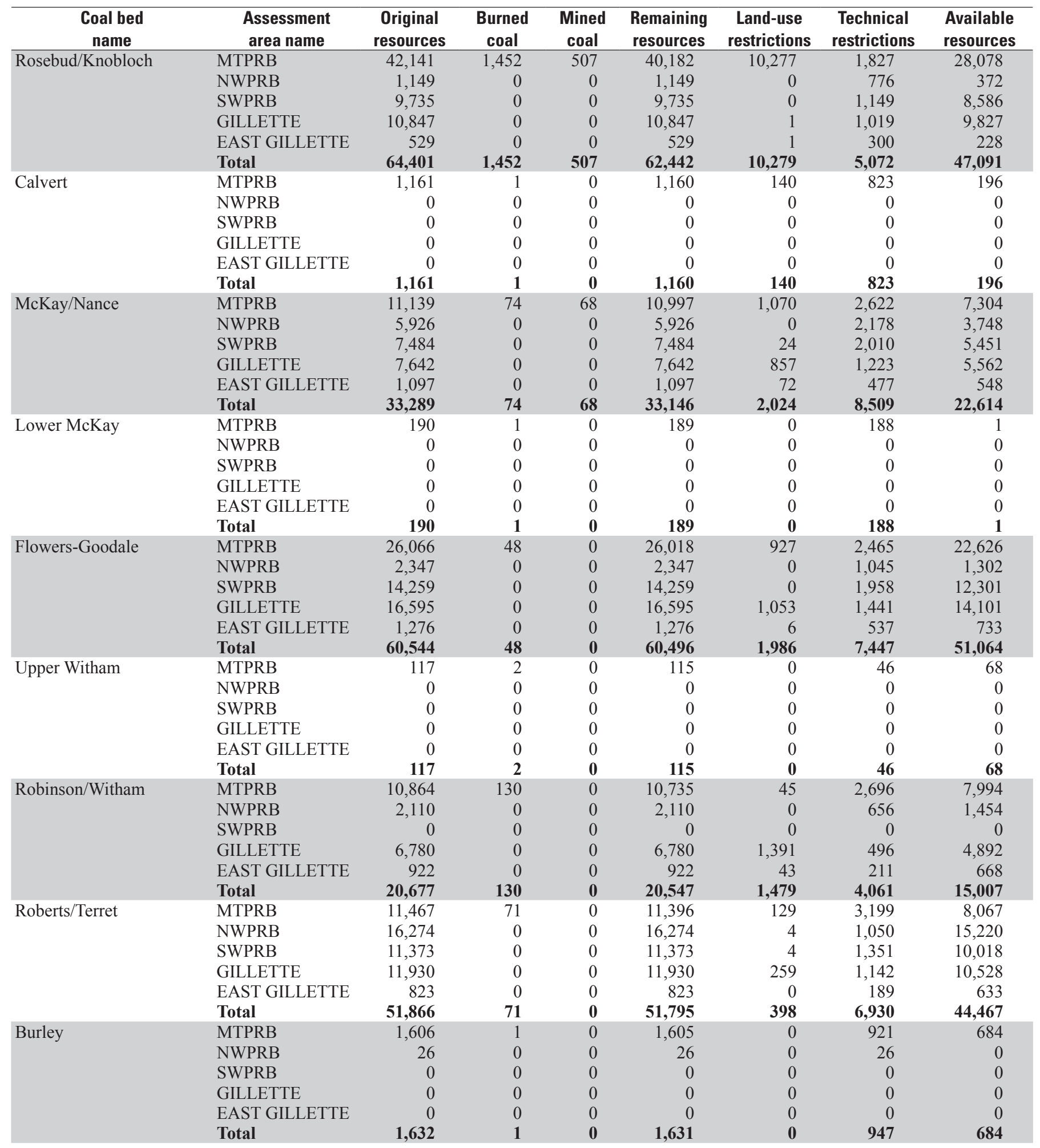


Table 7. Coal resources and restrictions for 47 beds greater than or equal to 2.5 feet thick, reported in millions of short tons by assessment area.-Continued

[MTPRB. Montana Powder River Basin; NWPRB, Northern Wyoming Powder River Basin; SWPRB, Southwestern Powder River Basin; GILLETTE, Gillette coal field; East Gillette (area east of the Gillette coal field)]

\begin{tabular}{|c|c|c|c|c|c|c|c|c|}
\hline $\begin{array}{c}\text { Coal bed } \\
\text { name }\end{array}$ & $\begin{array}{c}\text { Assessment } \\
\text { area name }\end{array}$ & $\begin{array}{l}\text { Original } \\
\text { resources }\end{array}$ & $\begin{array}{c}\text { Burned } \\
\text { coal }\end{array}$ & $\begin{array}{l}\text { Mined } \\
\text { coal }\end{array}$ & $\begin{array}{l}\text { Remaining } \\
\text { resources }\end{array}$ & $\begin{array}{l}\text { Land-use } \\
\text { restrictions }\end{array}$ & $\begin{array}{c}\text { Technical } \\
\text { restrictions }\end{array}$ & $\begin{array}{l}\text { Available } \\
\text { resources }\end{array}$ \\
\hline \multirow{4}{*}{ Upper Stag } & NWPRB & 1,084 & 0 & 0 & 1,084 & 0 & 408 & 676 \\
\hline & GILLETTE & 0 & 0 & 0 & 0 & 0 & 0 & 0 \\
\hline & EAST GILLETTE & 0 & 0 & 0 & 0 & 0 & 0 & 0 \\
\hline & Total & 1,870 & $\mathbf{0}$ & $\mathbf{0}$ & 1,870 & $\mathbf{0}$ & 1,080 & 790 \\
\hline \multirow{4}{*}{ Lower Stag } & SWPRB & 0 & 0 & 0 & 0 & 0 & 0 & 0 \\
\hline & GILLETTE & 0 & 0 & 0 & 0 & 0 & 0 & 0 \\
\hline & EAST GILLETTE & 0 & 0 & 0 & 0 & 0 & 0 & 0 \\
\hline & Total & 151 & $\mathbf{0}$ & $\mathbf{0}$ & 151 & 0 & 139 & 11 \\
\hline \multirow[t]{2}{*}{ Total beds } & MTPRB & 228,542 & 4,880 & 1,219 & 222,543 & 30,653 & 31,031 & 160,848 \\
\hline & NWPRB & 293,541 & 332 & 146 & 293,063 & 4,277 & 33,541 & 255,238 \\
\hline
\end{tabular}


Table 8. Summary of coal resources by reliability, depth, ownership, and assessment area categories in the Powder River Basin, Wyoming and Montana.

[MTPRB. Montana Powder River Basin; NWPRB, Northern Wyoming Powder River Basin; SWPRB, Southwestern Powder River Basin; GILLETTE, Gillette coal field; East Gillette (area east of the Gillette coal field)]

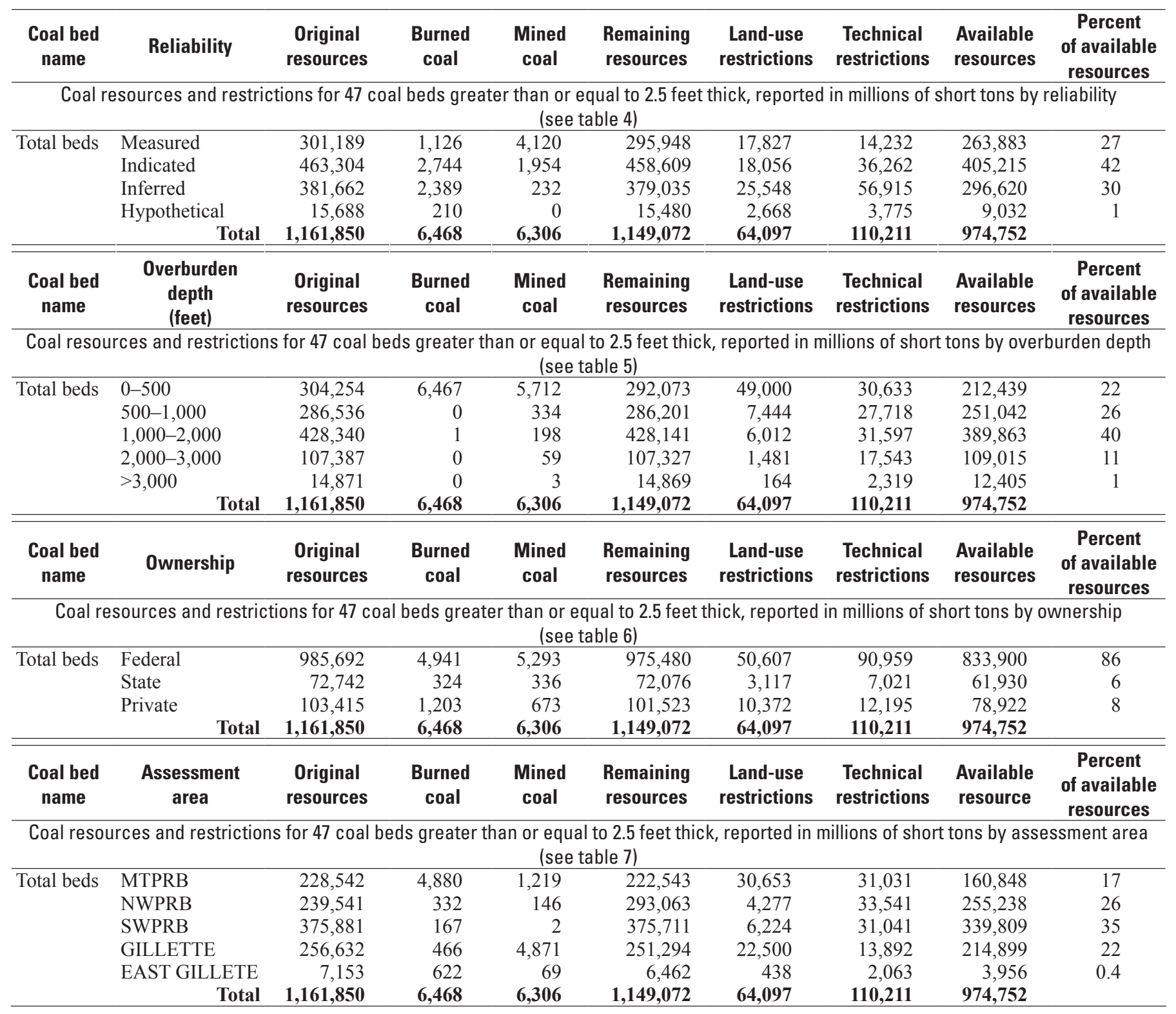


Table 9. Summary of resources by reliability categories for all $47 \mathrm{coal}$ beds assessed in the Powder River Basin and comparison of reliability of previous assessment of the Wyodak-Anderson zone in the Gillette coal field (Ellis and others, 1999) to the current Powder River Basin assessment.

\begin{tabular}{|c|c|c|c|c|c|}
\hline Reliability category & Measured & Indicated & Inferred & Hypothetical & Total \\
\hline \multicolumn{6}{|c|}{ Reliability of 47 coal beds assessed in the Powder River Basin } \\
\hline Percent of total & 26 & 40 & 33 & 1 & 100 \\
\hline \multicolumn{6}{|c|}{ Powder River Basin Assessment } \\
\hline Tons (billions of short tons) & 206,945 & 255,974 & 128,258 & 4,875 & 596,052 \\
\hline Percent of total & 35 & 43 & 22 & 1 & 100 \\
\hline Tons (billions of short tons) & 43,670 & 167,700 & 303,700 & 35,610 & 550,700 \\
\hline Percent of total & 8 & 30 & 55 & 6 & 100 \\
\hline \multicolumn{6}{|c|}{ Reliability of coal beds in the Wyodak-Anderson coal zone assessed in the Gillette coal field } \\
\hline \multicolumn{6}{|c|}{ Powder River Basin Assessment } \\
\hline Tons (billions of short tons) & 94,433 & 51,950 & 10,769 & 214 & 157,366 \\
\hline Percent of total & 60 & 33 & 7 & 0 & 100 \\
\hline \multicolumn{6}{|c|}{$\begin{array}{l}\text { Ellis and others, 1999, Gillette coal field, Powder River Basin: } \\
\text { Geology, coal quality, and coal resources, in U.S. Geological Survey Professional Paper 1625-A }\end{array}$} \\
\hline
\end{tabular}

Table 10. Example of a regional mine model stratigraphic sequence used in the economic evaluation of the Northern Wyoming Powder River Basin assessment area, River Wyoming.

\begin{tabular}{|c|c|c|c|c|c|c|c|c|c|c|c|}
\hline \multirow{2}{*}{$\begin{array}{c}\text { Coal bed } \\
\text { name }\end{array}$} & \multirow{2}{*}{$\begin{array}{c}\text { Interburden/overburden } \\
\text { (feet) }\end{array}$} & \multicolumn{10}{|c|}{ Stripping ratio } \\
\hline & & 1:1 & 2:1 & 3:1 & 4:1 & 5:1 & 6:1 & 7:1 & 8:1 & 9:1 & 10:1 \\
\hline Bed 6 & Average thickness & & & & & 11 & 11 & 11 & 11 & 11 & 11 \\
\hline Bed 5 & Average thickness & & & & 15 & 15 & 15 & 15 & 15 & 15 & 15 \\
\hline \multirow[t]{2}{*}{ Bed 4} & Average overburden/interburden thickness & & & 51 & 95 & 95 & 95 & 95 & 95 & 95 & 95 \\
\hline & Average thickness & & & 22 & 22 & 22 & 22 & 22 & 22 & 22 & 22 \\
\hline \multirow[t]{2}{*}{ Bed 2} & Average overburden/interburden thickness & & 26 & 55 & 55 & 55 & 55 & 55 & 55 & 55 & 55 \\
\hline & Average thickness & & 16 & 16 & 16 & 16 & 16 & 16 & 16 & 16 & 16 \\
\hline \multirow[t]{4}{*}{ Bed 1} & Average overburden/interburden thickness & 26 & 60 & 60 & 60 & 60 & 60 & 60 & 60 & 60 & 60 \\
\hline & Average thickness & 24 & 24 & 24 & 24 & 24 & 24 & 24 & 24 & 24 & 24 \\
\hline & Total coal & 24 & 40 & 80 & 98 & 109 & 109 & 109 & 109 & 109 & 109 \\
\hline & Total burden & 26 & 86 & 268 & 421 & 586 & 703 & 820 & 938 & 1,055 & 1,172 \\
\hline
\end{tabular}



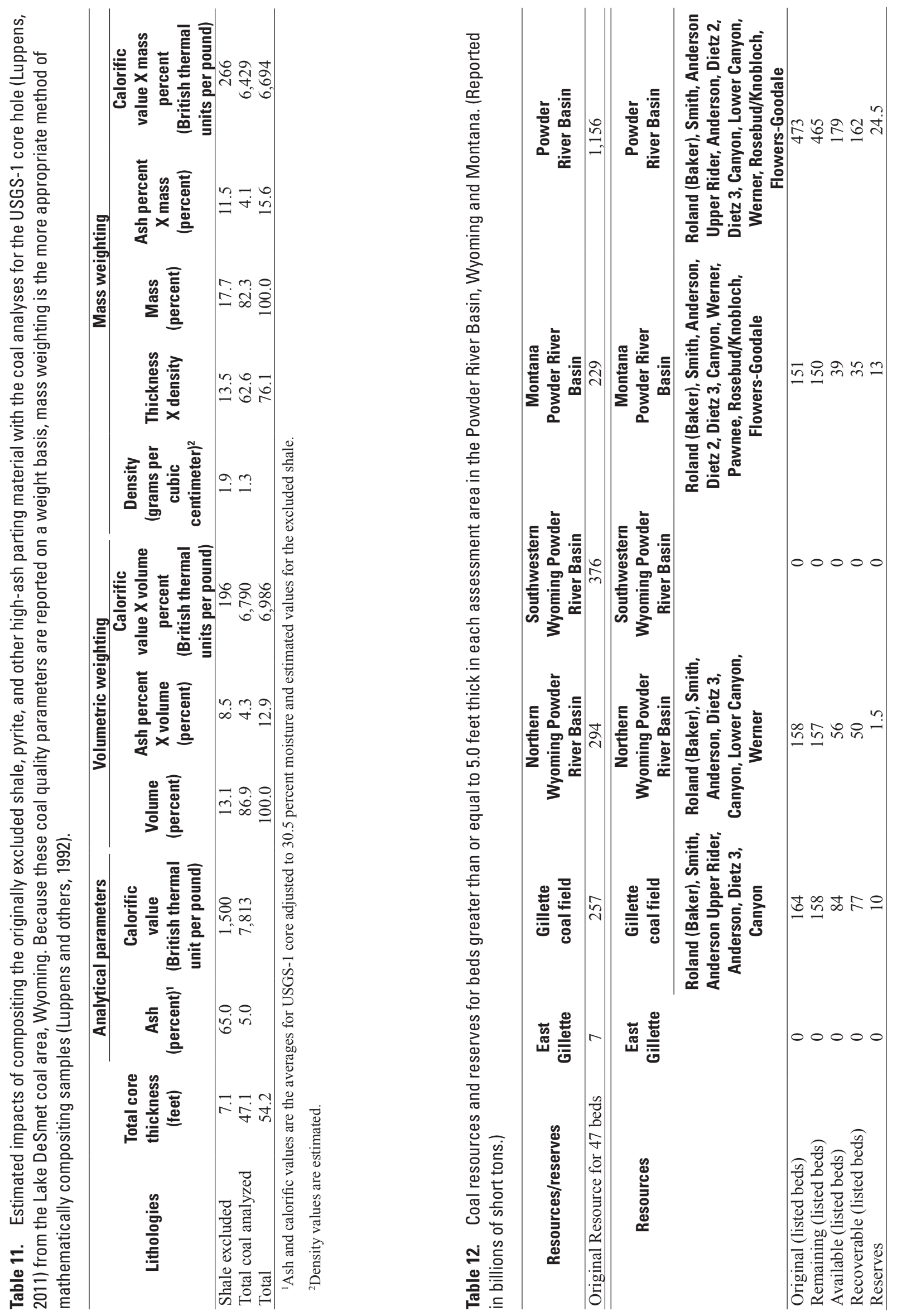
Table 13. Underground resources for coal beds 10-20 feet thick and greater than 500 feet deep in the Powder River Basin, Wyoming and Montana (reported in millions of short tons). Columns may not sum exactly because of rounding.

\begin{tabular}{|c|c|c|c|c|c|c|}
\hline $\begin{array}{l}\text { Coal bed } \\
\text { name }\end{array}$ & $\begin{array}{l}\text { Depth } \\
\text { (feet) }\end{array}$ & $\begin{array}{c}\text { Northern } \\
\text { Wyoming Powder } \\
\text { River Basin }\end{array}$ & $\begin{array}{l}\text { Southwestern } \\
\text { Powder } \\
\text { River Basin }\end{array}$ & $\begin{array}{l}\text { Montana Powder } \\
\text { River Basin }\end{array}$ & $\begin{array}{l}\text { Total short } \\
\text { tons by bed }\end{array}$ & $\begin{array}{l}\text { Percent of total } \\
\text { underground } \\
\text { resource }\end{array}$ \\
\hline \multirow[t]{6}{*}{ Roland (Baker) } & $500-1,000$ & 6,254 & 0 & 0 & 6,254 & \\
\hline & $500-1,500$ & 0 & 4,187 & 0 & 4,187 & \\
\hline & $1,000-2,000$ & 9,308 & 0 & 0 & 9,308 & \\
\hline & $1,500-2,000$ & 0 & 158 & 0 & 158 & \\
\hline & Greater than 2,000 & 109 & 0 & 0 & 109 & \\
\hline & Total & 15,672 & 4,345 & $\mathbf{0}$ & 20,017 & 7 \\
\hline \multirow[t]{6}{*}{ Smith } & $500-1,000$ & 831 & 0 & 0 & 831 & \\
\hline & $500-1,500$ & 0 & 75,957 & 0 & 75,957 & \\
\hline & $1,000-2,000$ & 3,447 & 0 & 0 & 3,447 & \\
\hline & $1,500-2,000$ & 0 & 5,945 & 0 & 5,945 & \\
\hline & Greater than 2,000 & 67 & 0 & 0 & 67 & \\
\hline & Total & 4,346 & 81,902 & $\mathbf{0}$ & 86,248 & 28 \\
\hline \multirow[t]{6}{*}{ Anderson } & $500-1,000$ & 3,540 & 0 & 897 & 4,437 & \\
\hline & $500-1,500$ & 0 & 6,420 & 0 & 6,420 & \\
\hline & $1,000-2,000$ & 2,547 & 0 & 0 & 2,547 & \\
\hline & $1,500-2,000$ & 0 & 53 & 0 & 53 & \\
\hline & Greater than 2,000 & 0 & 0 & 0 & 0 & \\
\hline & Total & 6,087 & 6,473 & 897 & 13,457 & 4 \\
\hline \multirow[t]{6}{*}{ Dietz 3} & $500-1,000$ & 5,610 & 0 & 754 & 6,364 & \\
\hline & $500-1,500$ & 0 & 8,303 & 0 & 8,303 & \\
\hline & $1,000-2,000$ & 5,322 & 0 & 6 & 5,328 & \\
\hline & $1,500-2,000$ & 0 & 1,980 & 0 & 1,980 & \\
\hline & Greater than 2,000 & 39 & 0 & 0 & 39 & \\
\hline & Total & 10,972 & 10,283 & 760 & 22,015 & 7 \\
\hline \multirow[t]{6}{*}{ Canyon } & $500-1,000$ & 3,334 & 0 & 4,163 & 7,497 & \\
\hline & $500-1,500$ & 0 & 28,846 & 0 & 28,846 & \\
\hline & $1,000-2,000$ & 3,319 & 0 & 70 & 3,389 & \\
\hline & $1,500-2,000$ & 0 & 22,767 & 0 & 22,767 & \\
\hline & Greater than 2,000 & 124 & 0 & 0 & 124 & \\
\hline & Total & 6,777 & 51,613 & 4,233 & 62,623 & 21 \\
\hline \multirow[t]{6}{*}{ Lower Canyon } & $500-1,000$ & 401 & 0 & 2,408 & 2,809 & \\
\hline & $500-1,500$ & 0 & 10,497 & 0 & 10,497 & \\
\hline & $1,000-2,000$ & 6,125 & 0 & 119 & 6,244 & \\
\hline & $1,500-2,000$ & 0 & 13,849 & 0 & 13,849 & \\
\hline & Greater than 2,000 & 954 & 0 & 0 & 954 & \\
\hline & Total & 7,481 & 24,346 & 2,527 & 34,354 & 11 \\
\hline \multirow[t]{6}{*}{ Werner/Cook } & $500-1,000$ & 2,871 & 0 & 6,963 & 9,834 & \\
\hline & $500-1,500$ & 0 & 934 & 0 & 934 & \\
\hline & $1,000-2,000$ & 4,282 & 0 & 39 & 4,321 & \\
\hline & $1,500-2,000$ & 0 & 2,386 & 0 & 2,386 & \\
\hline & Greater than 2,000 & 3,204 & 0 & 0 & 3,204 & \\
\hline & Total & 10,358 & 3,320 & 7,002 & 20,680 & 7 \\
\hline \multirow[t]{6}{*}{ Otter } & $500-1,000$ & 0 & 0 & 0 & 0 & \\
\hline & $500-1,500$ & 0 & 1,972 & 0 & 1,972 & \\
\hline & $1,000-2,000$ & 0 & 0 & 0 & 0 & \\
\hline & $1,500-2,000$ & 0 & 16,596 & 0 & 16,596 & \\
\hline & Greater than 2,000 & 0 & 0 & 0 & 0 & \\
\hline & Total & $\mathbf{0}$ & 18,568 & $\mathbf{0}$ & 18,568 & 6 \\
\hline \multirow[t]{6}{*}{ Pawnee } & $500-1,000$ & 0 & 0 & 1,855 & 1,855 & \\
\hline & $500-1,500$ & 0 & 0 & 0 & 0 & \\
\hline & $1,000-2,000$ & 0 & 0 & 639 & 639 & \\
\hline & $1,500-2,000$ & 0 & 0 & 0 & 0 & \\
\hline & Greater than 2,000 & 0 & 0 & 0 & 0 & \\
\hline & Total & $\mathbf{0}$ & 0 & 2,494 & 2,494 & 1 \\
\hline
\end{tabular}


Table 13. Underground resources for coal beds 10-20 feet thick and greater than 500 feet deep in the Powder River Basin, Wyoming and Montana (reported in millions of short tons). Columns may not sum exactly because of rounding.-Continued

\begin{tabular}{|c|c|c|c|c|c|c|}
\hline $\begin{array}{c}\text { Coal bed } \\
\text { name }\end{array}$ & $\begin{array}{l}\text { Depth } \\
\text { (feet) }\end{array}$ & $\begin{array}{c}\text { Northern } \\
\text { Wyoming Powder } \\
\text { River Basin }\end{array}$ & $\begin{array}{l}\text { Southwestern } \\
\text { Powder } \\
\text { River Basin }\end{array}$ & $\begin{array}{l}\text { Montana Powder } \\
\text { River Basin }\end{array}$ & $\begin{array}{l}\text { Total short } \\
\text { tons by bed }\end{array}$ & $\begin{array}{l}\text { Percent of total } \\
\text { underground } \\
\text { resource }\end{array}$ \\
\hline \multirow[t]{6}{*}{ Rosebud/Knobloch } & $500-1,000$ & 0 & 0 & 10,271 & 10,271 & \\
\hline & $500-1,500$ & 0 & 0 & 0 & 0 & \\
\hline & $1,000-2,000$ & 0 & 0 & 1,251 & 1,251 & \\
\hline & $1,500-2,000$ & 0 & 0 & 0 & 0 & \\
\hline & Greater than 2,000 & 0 & 0 & 0 & 0 & \\
\hline & Total & 0 & $\mathbf{0}$ & 11,522 & 11,522 & 4 \\
\hline \multirow[t]{6}{*}{ Flowers-Goodale } & $500-1,000$ & 0 & 0 & 6,468 & 6,468 & \\
\hline & $500-1,500$ & 0 & 0 & 0 & 0 & \\
\hline & $1,000-2,000$ & 0 & 0 & 5,854 & 5,854 & \\
\hline & $1,500-2,000$ & 0 & 0 & 0 & 0 & \\
\hline & Greater than 2,000 & 0 & 0 & 3 & 3 & \\
\hline & Total & 0 & $\mathbf{0}$ & 12,325 & 12,325 & 4 \\
\hline \multirow[t]{6}{*}{ Total } & $500-1,000$ & 22,841 & & & 56,620 & 19 \\
\hline & $500-1,500$ & & 137,116 & 33,902 & 137,116 & 45 \\
\hline & $1,000-2,000$ & 34,350 & & & 42,328 & 14 \\
\hline & $1,500-2,000$ & & 61,348 & 7,978 & 65,706 & 21 \\
\hline & Greater than 2,000 & 4,497 & & 41,880 & 4,500 & 1 \\
\hline & Total & 61,688 & 198,464 & 3 & 304,303 & \\
\hline \multicolumn{2}{|c|}{$\begin{array}{l}\text { Percent of total underground resource } \\
\text { by assessment area }\end{array}$} & 20 & 66 & 14 & & \\
\hline
\end{tabular}

Publishing support provided by:

Denver Publishing Service Center, Denver, Colorado

For more information concerning this publication, contact:

Center Director, USGS Central Energy Resources Science Center

Box 25046, Mail Stop 939

Denver, C0 80225

(303) 236-1647

Or visit the Central Energy Resources Science Center Web site at:

http://energy.usgs.gov/

This publication is available online at:

http://dx.doi.org/10.3133/pp1809 

I SBN $978-1-4113-3875-3$ 